\title{
WRR
}

WETENSCHAPPELIJKE RAAD VOOR HET REGERINGSBELEID

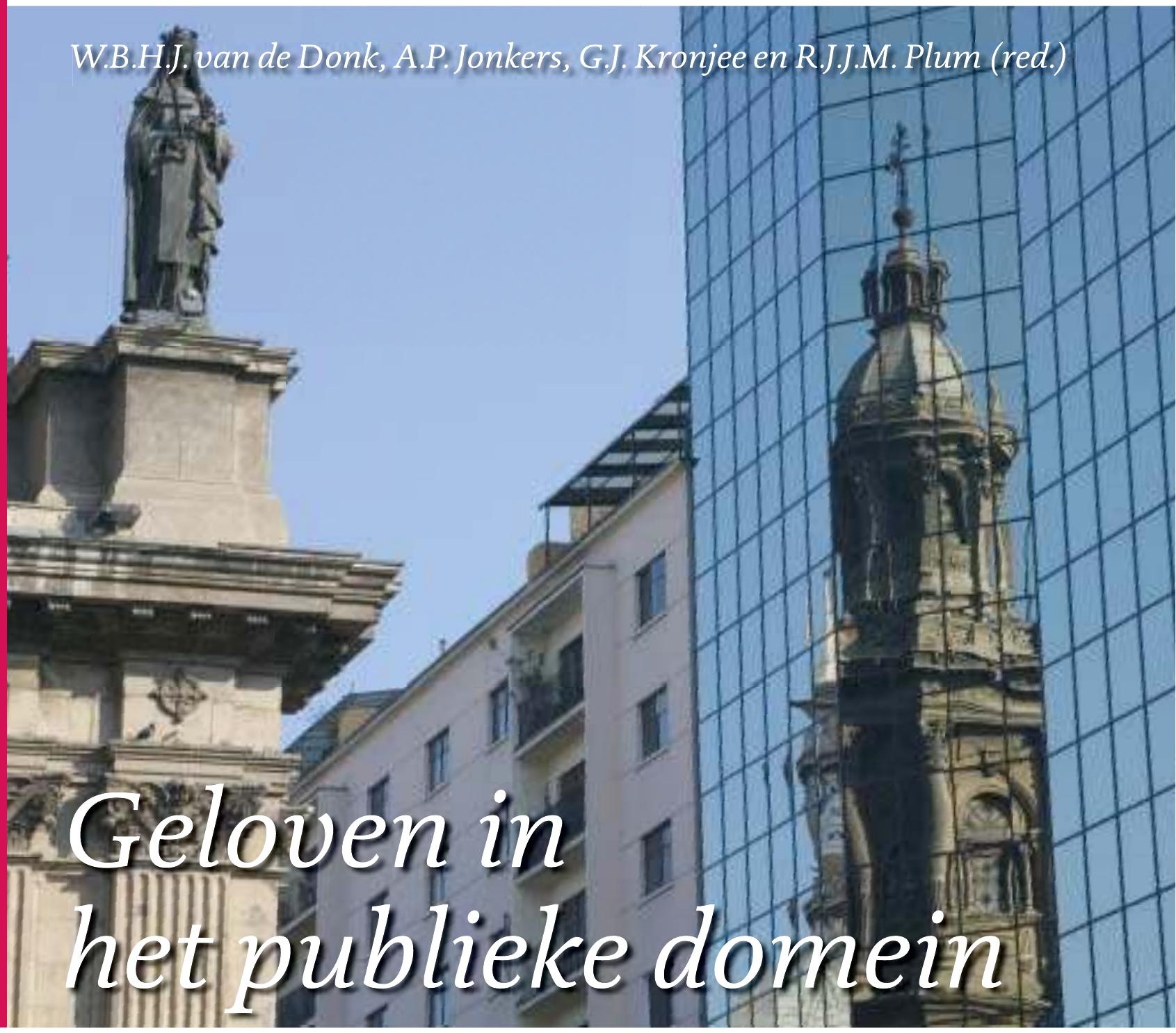

VERKEN NINGEN VAN EEN DUBBELE TRA NSFORM ATIE 
Geloven in het publieke domein 
De serie 'Verkenningen' omvat studies die in het kader van de werkzaamheden van de WRR tot stand zijn gekomen en naar zijn oordeel van zodanige kwaliteit en betekenis zijn dat publicatie gewenst is. De verantwoordelijkheid voor de inhoud en de ingenomen standpunten berust bij de auteurs.

Wetenschappelijke Raad voor het Regeringsbeleid

De WRR is gevestigd:

Lange Vijverberg 4-5

Postbus 20004

2500 EA 's-Gravenhage

Telefoon 070-356 46 oo

Telefax 070-356 4685

E-mail info@wrr.nl

Website http://www.wrr.nl 


\section{Geloven in het publieke domein}

VERKENNINGEN VAN EEN DUBBELE TRANSFORMATIE

W.B.H.J. van de Donk, A.P. Jonkers, G.J. Kronjee en R.J.J.M. Plum (red.) 
Omslagfoto: ‘Cathedral Reflection', Santiago, Chili (c) Keren Su/corbis

Omslagontwerp: Studio Daniëls, Den Haag

Vormgeving binnenwerk: Het Steen Typografie, Maarssen

ISBN-13 9789053569368

ISBN-10 9053569367

NUR $\quad 754$

(C) WRR/Amsterdam University Press, Den Haag / Amsterdam 2006

Alle rechten voorbehouden. Niets uit deze uitgave mag worden verveelvoudigd, opgeslagen in een geautomatiseerd gegevensbestand, of openbaar gemaakt, in enige vorm of op enige wijze, hetzij elektronisch, mechanisch, door fotokopieën, opnamen of enige andere manier, zonder voorafgaande schriftelijke toestemming van de uitgever.

Voor zover het maken van kopieën uit deze uitgave is toegestaan op grond van artikel 16B Auteurswet $1912 j^{\circ}$ het Besluit van 20 juni 1974, Stb. 351, zoals gewijzigd bij het Besluit van 23 augustus 1985, Stb. 471 en artikel 17 Auteurswet 1912, dient men de daarvoor wettelijk verschuldigde vergoedingen te voldoen aan de Stichting Reprorecht (Postbus 3051, $2130 \mathrm{~KB}$ Hoofddorp). Voor het overnemen van gedeelte(n) uit deze uitgave in bloemlezingen, readers en andere compilatiewerken (artikel 16 Auteurswet 1912) dient men zich tot de uitgever te wenden. 


\section{INHOUDSOPGAVE}

Ten geleide

Geloven in het publieke domein: een introductie van deze verkenning

Wim van de Donk en Petra Jonkers

LUIK 1 BEGRIPPEN, THEORIEËN EN DISCIPLINAIRE BENADERINGEN

$1 \quad$ Begripsverkenning

Wim van de Donk en Rob Plum

1.1 Secularisering en terugkeer van religie

1.2 Kritiek op de seculariseringsthese

1.3 Religie

1.4 Religie in het publieke domein

1.5 Slot

2 Religion in the age of contingency

Hans Joas

3 De religieuze transformatie en de sociale cohesie

Gerrit Kronjee

3.1 Inleiding

3.2 Toelichting op de hoofdstukken in het empirische luik

68

3.3 Vergelijking tussen landen van de band met religie

69

3.4 De leefstijlmaatschappij 74

3.5 De toekomst van religie en sociale cohesie in een leefstijlmaatschappij $\quad 80$

$4 \quad$ Een religieuze atlas van Nederland $\quad 89$

Ton Bernts, Gert de Jong en Hasan Yar

4.1 Inleiding

4.1.1 Doel van deze religieuze atlas $\quad 89$

4.1.2 Religies in Nederland 90

4.1.3 Verantwoording 90

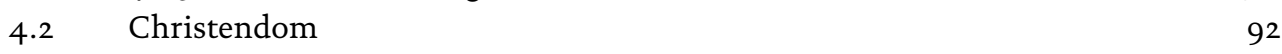

4.2.1 Rooms-Katholieke Kerk 92

4.2.2 Protestantse Kerk in Nederland 95

4.2.3 Orthodox gereformeerde kerken 99

$\begin{array}{ll}\text { 4.2.4 Bevindelijk gereformeerden } & 103\end{array}$

4.2.5 Evangelische en pinksterkerken 105

$\begin{array}{lll}4.2 .6 & \text { Vrijzinnig } & 108\end{array}$

4.2.7 Overige christelijke kerken 111 
4.3 Islam 113

4.3.1 Aantal moslims 113

4.3.2 Belangrijke islamitische richtingen 116

4.3.3 De organisatie van moslimgroepen in Nederland $\quad 118$

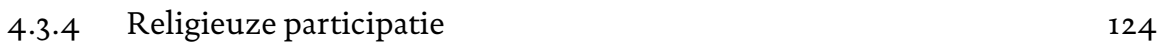

4.3.5 De maatschappelijke rol van moskeeën $\quad 125$

$\begin{array}{lll}4.4 & \text { Overige religies } & 126\end{array}$

4.4.1 Hindoeïsme $\quad 126$

4.4.2 Jodendom 131

$\begin{array}{ll}4.4 .3 \text { Boeddhisme } & 133\end{array}$

$5 \quad$ Kerken in de Nederlandse civil society: institutionele grondslag en $\begin{array}{ll}\text { individuele inspiratiebron } & 139\end{array}$

Joep de Hart en Paul Dekker

5.1 Inleiding 139

$\begin{array}{ll}5.2 & \text { De civil society en de kerken } \\ 5.340\end{array}$

5.3 Opvattingen over de plaats van religie in de civil society $\quad 142$

$\begin{array}{lll}5.4 & \text { Vertrouwen in de kerken } & 147\end{array}$

5.5 Kerkelijke achtergronden van individueel engagement $\quad 150$

$\begin{array}{ll}\text { 5.6 Alternatieven voor de traditionele christelijke kerken } & 154\end{array}$

$\begin{array}{lll}5.7 & \text { Conclusies } & 158\end{array}$

$\begin{array}{lll}5.8 & \text { Slotoverwegingen } & 161\end{array}$

$6 \quad$ Leefstijlen in zingeving $\quad 171$

Gerrit Kronjee en Martijn Lampert

$\begin{array}{lll}6.1 & \text { Inleiding } & 171\end{array}$

6.2 Achtergrond: veranderingen in de maatschappelijke betekenis van religie $\quad 172$

6.3 Geloof, ongeloof en de zingeving 176

$\begin{array}{lll}6.4 & \text { De niet-religieuze categorieën } & 180\end{array}$

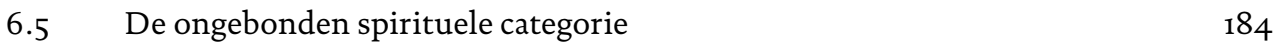

6.6 De religieuze categorieën 186

$\begin{array}{ll}6.7 & \text { Religie en burgerschap } \\ 6.899\end{array}$

$\begin{array}{lll}6.8 & \text { Tot slot } & 192\end{array}$

6.9 Conclusies 194

Bijlage Enkele kerngegevens van de levensbeschouwelijke profielen 195

$7 \quad$ An introduction to American religious practice 209

Alan Wolfe

$\begin{array}{lll}7.1 & \text { Belief and practice } & 209\end{array}$

$\begin{array}{lll}7.2 & \text { Worship } & 209\end{array}$

$\begin{array}{lll}7.3 & \text { Tradition } & 212\end{array}$

$\begin{array}{lll}7.4 & \text { Fellowship } & 216\end{array}$

$\begin{array}{lll}7.5 & \text { Doctrine } & 216\end{array}$

$\begin{array}{lll}7.6 & \text { Sin } & 218\end{array}$

$\begin{array}{lll}7.7 & \text { Witness } & 220\end{array}$

7.8 Conclusion 222 
8 Scheiding van kerk en staat: een klassieke norm in een moderne tijd

Sophie van Bijsterveld

$\begin{array}{lll}8.1 \quad \text { Inleiding } & 227\end{array}$

$\begin{array}{lll}8.2 & \text { Vooronderstellingen } & 229\end{array}$

8.3 Groeiende onzekerheid 233

$\begin{array}{ll}8.4 & \text { Ontvlechting en accommodatie } 238\end{array}$

$\begin{array}{ll}8.5 & \text { Andere overheid } \\ 8.6 & 240\end{array}$

8.6 Andere godsdienst 243

$\begin{array}{lll}8.7 & \text { Een blik over de grens } & 245\end{array}$

8.8 Waar gaat het uiteindelijk om? $\quad 247$

8.9 Slot 250

Bijlage Europa: de EU en het EVRM $\quad 252$

8a Intermezzo: Stappen in de tijd $\quad 261$

Ben Koolen

$9 \quad$ Laïcité in het licht van de geschiedenis van de Franse assimilatie- $\quad 275$ politiek

Yolande Jansen

9.1 Laïcité, een juridisch begrip met een culturele lading 276

9.2 Laïcité in de Derde Republiek 279

$9.3 \quad$ Laïcité en assimilatiepolitiek $\quad 282$

9.4 Assimilatie als herinnering voor een hedendaags secularisme 286

10 'Church'-State relations in the public square: French laicism and Canadian multiculturalism 293

Hendrik M. Vroom

10.1 Introduction 293

$\begin{array}{lll}10.2 & \text { Laïcité/ Laicism } & 294\end{array}$

10.2.1 The law 294

10.2.2 Historical Background 296

10.2.3 Reality under Laicism $\quad 297$

$\begin{array}{ll}\text { 10.2.4 Discussions } & 298\end{array}$

10.3 A Shari'ah Court in Toronto? 299

10.3.1 Arbitration 300

10.3.2 The Background: Islam in the West 301

$\begin{array}{ll}\text { 10.3.3 The main Objections } & 302\end{array}$

$\begin{array}{lll}10.3 .4 & \text { Reasons and advice } & 303\end{array}$

10.3.5 Revision of the Ontario Laws $\quad 304$

$\begin{array}{lll}\text { 10.3.6 Conclusion } & 305\end{array}$

$\begin{array}{lll}10.4 & \text { Comparison and Observations } & 306\end{array}$ 
II De onlosmakelijke verbondenheid van religie en publiek domein: pleidooi voor een 'omgekeerde doorbraak'

Erik Borgman

11.1 Inleiding

11.2 De 'terugkeer' van religie - Max Weber

11.3 De 'terugkeer' van religie aan het einde van de negentiende eeuw 318

11.4 Religie in het publiek domein - Jürgen Habermas 321

11.5 Het maatschappelijke belang van 'waarde- en geloofsoordelen' 325

11.6 De presentie van religie in de hedendaagse samenleving - een voorbeeld 329

11.7 Pleidooi voor een 'omgekeerde doorbraak' - conclusie 332

12 Religious pluralism and the Dutch state: reflections on the future of Article 23

James Kennedy en Markha Valenta

12.1 Introduction

12.2 Religion in the Dutch Public Sphere: The Legacy of Pillarization and

Depillarization

12.3 Religion in the Dutch Public Sphere: The Colonial Legacy 342

12.4 A New Church-State Relationship for the Netherlands?

13 Een schets en evaluatie van de kritiek op de overheidsfinanciering van het bijzonder onderwijs

Ben Vermeulen

13. 1 Inleiding

13.2 Onderwijsstelsels 353

13.3 Scheiding van kerk en staat 354

13.4 Vervaging van het onderscheid tussen openbaar en bijzonder onderwijs $\quad 356$

13.5 'Witte' en 'zwarte' scholen: etnische segregatie 358

13.6 Islamitische scholen $\quad 359$

$\begin{array}{ll}13.7 & \text { Ideologische segregatie } 360\end{array}$

13.8 Aantasting van de autonomie van het kind 363

$\begin{array}{ll}13.9 & \text { Afrondende beschouwingen } \\ \end{array}$

14 Horizontale transcendentie en normatieve professionalisering: de casus geestelijke verzorging

Harry Kunneman

$\begin{array}{ll}14.1 & \text { Inleiding }\end{array}$

$\begin{array}{lll}14.2 & \text { Historische context } & 371\end{array}$

$\begin{array}{lll}\text { 14.3 Levensbeschouwelijke individualisering } & 374\end{array}$

14.4 Verstrengeling en omvorming $\quad 377$

$\begin{array}{ll}\text { 14.4.1 Verstrengeling } & 377\end{array}$

$\begin{array}{ll}\text { 14.4.2 Omvorming } & 379\end{array}$

\begin{tabular}{ll}
14.5 & Normatieve professionalisering \\
\hline 82
\end{tabular} 
15 Religie en zorg in het publieke domein

Hans Schilderman

15.1 Probleemstelling

395

15.2 Maatschappelijke functies van religie 395

15.3 Ontvlechting van religie en zorg 400

15.4 Professionele zorg voor religieuze overtuigingen 404

15.5 Scenario's van geestelijke verzorging 408

16 De migratie van het goddelijke. Over geloof en kerk in de moderne maatschappij

Gabriël van den Brink

16.1 Twee grondbegrippen

16.2 Een meervoudige crisis

\begin{tabular}{ll}
16.3 & Drie mogelijke houdingen \\
\hline 6.422
\end{tabular}

16.4 Een andere oplossing? $\quad 425$

$\begin{array}{ll}16.5 & \text { De werking van het ideaal }\end{array}$

$17 \quad$ Religie en het morele dispuut 435

Jean-Pierre Wils

$\begin{array}{ll}\text { 17.1 Religie en haar dubbelzinnigheid } & 435\end{array}$

17.2 Tegen de metafysica van 'goed' en 'kwaad' 438

17.3 De prioriteit van het 'juiste' over het 'goede' - een moderne uitvinding 441

$\begin{array}{ll}17.4 & \text { In het publieke domein }\end{array}$

18 Religion and media: a political theological problem 447

Hent de Vries

18.1 Introduction: understanding ambivalent (public) religions in a global era 447

18.2 The dynamic relationship between the 'theological' and the 'political':

the need for new concepts and methodologies

18.3 In search of adequate strategies: how to confront the manifestations and ambiguities of religion in a post-secular age

18.4 Beyond fundamentalism: is violent jihadism a mere political product of globalization and societal alienation?

18.5 The importance of (new) media for the (re)emergence of religious identities

18.6 Markets, electronic networks and civil society: new domains for the theologico-political

18.7 New challenges for political theology in a digital age

19 Hoe zal de rechter dat oplossen? Lastige kwesties rond godsdienst

19.1 Inleiding

19.2 Institutionalisering en horizontale werking van grondrechten 475

$\begin{array}{ll}19.3 & \text { Beschrijving jurisprudentie en toetsingskader }\end{array} 479$

$\begin{array}{ll}\text { 19.3.1 Jurisprudentie EHRM } & 479\end{array}$

19.3.2 Jurisprudentie van de Nederlandse rechter 483 
19.3.3 "Jurisprudentie" (oordelenpraktijk) van de CGB

19.4 Lastige kwesties en nieuwe vragen

493

19.5 Slotreflectie

496

Over de auteurs 


\section{TEN GELEIDE}

De voor $\mathrm{u}$ liggende bundel opstellen is een eerste product van een kleine projectgroep binnen de WRR die zich ten doel heeft gesteld een al even brede als onbevangen verkenning te verrichten naar zowel fundamentele, theoretische als empirische vragen met betrekking tot - ontwikkelingen in - de verhouding tussen religie en publiek domein.

De redactie van deze bundel hecht er aan alle auteurs zeer te danken voor de inspirerende discussies die we over versies-in-wording hebben kunnen voeren. Naast de bijdrage van de leden van de projectgroep en medeauteurs van deze bundel is aan die verkenning een belangrijke bijdrage geleverd door een groot aantal gesprekspartners. Zij voerden gesprekken met leden van de projectgroep of namen deel aan een of meer auteursconferenties. De projectgroep is hen voor de inspirerende gesprekken en opmerkingen bij een of meer hoofdstukken van deze bundel zeer erkentelijk. Met name gaat onze dank uit naar Job Cohen, Wim Deetman, Herman Philipse, Pieter-Anton van Gennip, André Rouvoet, Dick Pels, Thijs Wöltgens, Abraham Soetendorp, Peter van der Veer, Theo de Wit, Peter van Rooden, Anton van Harskamp, Andre Droogers, Jan Bremmer, Meerten ter Borg, mevrouw Saskia Wendel, Hans Alma, mevrouw Maria Quartas y de Machena, Haci Karacaer, Paul Cobben, Donald Loose, Ad Verbrugge, Henk Witte en Cees de Groot. Ook willen wij dank zeggen aan de heren Ben Koolen, Paul Sasse van IJsselt, Tjandersigher Bissessur en mevrouw Ineke Bakker. Hent de Vries was als adviseur van de projecgroep een belangrijke schakel met de wetenschappers die werkzaam zijn in het Nwo-programma 'The Future of the Religious Past'. Hans Huyssoon danken wij voor de interessante excursie die hij voor ons organiseerde in Amsterdam.

Binnen de WRR is dank verschuldigd aan Frans Hoefnagel, Huub Dijstelbloem en in het bijzonder aan Silke Vermeulen. Zij heeft de projectgroep en de redacteuren van deze bundel als stagiaire van de Universiteit voor Humanistiek bij de WRR werkzaam, en later als projectassistente steeds adequaat ondersteund.

Mirjan van Leijenhorst, Yvonne de Graaf, Leny Tupan en Alinda Lamein zijn wij dank verschuldigd voor hun belangrijke ondersteuning bij de productie van deze bundel. Dennis McLeod verdient lof voor de wijze waarop hij de vele bijeenkomsten en vergaderingen op een meer materiële wijze ondersteunde, waarbij hij telkens een scherp oog had voor de timing van de noodzakelijke onderbrekingen van discussies die soms de neiging hadden eeuwig te duren.

Kinnema van Eik en Sietske Bom waren als vanouds voortreffelijke ondersteuners bij het zoeken en ordenen van de vele publicaties die voor het werk aan deze bundel werden opgevraagd en geraadpleegd. 


\title{
GELOVEN IN HET PUBLIEKE DOMEIN: EEN INTRODUCTIE VAN DEZE VERKENNING
}

\author{
Wim van de Donk en Petra Jonkers
}

Een van de vele boeken die de afgelopen jaren over 'het fenomeen religie' verschenen spreekt van 'une instance mal dans son siècle' (Magnard 2006). Daarmee lijkt dan overigens vooral de verlegenheid van de institutionele religie met de moderniteit van de twintigste eeuw te worden uitgedrukt. 'Religie' lijkt, aan het begin van de eenentwintigste eeuw, immers bezig met een inmiddels veelbesproken terugkeer. Een 'terugkeer' die overigens nog meer vragen dan antwoorden oproept; vragen die vooral ook de aard van het fenomeen religie zelf lijken te betreffen. Duidelijk is wel dat die terugkeer door velen als een 'maatschappelijke verrassing' wordt beleefd: de dominante these was dat het geloven uit zou doven in het volle licht van de moderniteit. Duidelijk is ook dat die terugkeer, zeker in het Westen, niet de vooral traditionele en institutionele manifestaties van religie betreft waarnaar Magnard in zijn citaat verwijst.

Aan de wetenschappelijke aandacht voor religie en (traditionele) religieuze instituties aan het begin van de twintigste eeuw kan dat niet gelegen hebben. De Amerikaanse godsdienstsocioloog Alan Wolfe laat in een beschouwing over de relatie tussen religie en sociale wetenschap zien hoezeer de drie founding fathers van de moderne sociale wetenschappen (Marx, Weber en Durkheim) religie als centraal onderwerp van hun onderzoek beschouwden. Vooral de laatste twee lieten volgens hem zien dat een goed begrip van samenlevingen onmogelijk was zonder grondige kennis en begrip van het fenomeen religie. Maar, zo constateert hij, van die opvatting is weinig meer terug te vinden aan het einde van de twintigste eeuw; religie werd door sociale wetenschappers steeds minder bestudeerd, om niet te zeggen: verwaarloosd.

Een belangrijke verklaring daarvoor ziet hij in de ontwikkeling van de sociale wetenschappen zelf. Die droegen in belangrijke mate bij aan de door Max Weber zelf zo genoemde samenhang tussen de 'onttovering' en de 'modernisering' van de samenleving. Modernisering en rationalisering van samenlevingen, zo luidde de seculariseringsthese ${ }^{1}$, verdragen zich niet met een grote rol van religie. ${ }^{2}$ Religie zou volgens de verwachting op termijn vanzelf verdwijnen, hoogstens nog een tijdje stand houdend in de privésfeer. Bovendien was dat ook de plaats waar religie, zeker in normatieve zin, volgens velen thuishoorde. Mogelijk was dat ook de reden, gecombineerd met opvattingen over het formele beginsel van scheiding tussen kerk en staat, die leidde tot geringere aandacht voor religie in overheidsbeleid en in de publieke sfeer.

Zowel in wetenschap als in het publieke domein is er de afgelopen jaren echter sprake van een al even opmerkelijke als verbazingwekkende 'comeback'. Vooraanstaande wetenschappelijke tijdschriften en instituties besteedden er de afge- 
lopen jaren opvallend veel aandacht aan. En ook in het publieke debat is religie en niet alleen door de opkomst van de islam in westerse samenlevingen - volop terug als onderwerp van gesprek. Voor de socioloog Jacques van Doorn (2005) was het onlangs reden om te spreken van de kennelijke 'onverwoestbaarheid van religie'. Sommigen spreken zelfs van een 'terugkeer' van religie en in verband daarmee van post- of desecularisatie.

Alan Wolfe (zie verderop in deze bundel zijn bijdrage in het empirische luik) wijst erop dat ook dit beeld waarschijnlijk te simpel is, en spreekt liever over een transformatie van religie: áls er al sprake is van een terugkeer van religie, dan wel in verschijningsvormen die soms in weinig meer doen denken aan de religie die wij kenden: een vooral institutioneel gebonden vorm, die zich in een tamelijk overzichtelijk schema liet vangen. De getransformeerde religie is fundamenteel van gedaante veranderd en ontwikkelt zich volgens sommige godsdienstsociologen zelfs als een aan traditionele religie tegengestelde vorm. Borgman spreekt van een metamorfose, Van den Brink heeft het, ook in deze bundel, over de migratie van het goddelijke. Het zijn, kortom, niet de oude instituties die weer opleven. De filosoof Anton van Harskamp noemt sommige verschijningsvormen van de nieuwe religie zelfs antitheïstische religie en bovendien sterk gekeerd tegen het idee dat er in de wereld of in een mensenleven 'verlossing' nodig zou zijn. Veel vormen van nieuwe religie of spiritualiteit lijken inderdaad niet gericht op het opheffen van menselijk tekort, maar op de vervulling van het zelf. Dergelijke vormen van 'nieuwe religie' kenmerken zich ook niet door 'dwang van bovenaf', maar bieden veeleer een niet-verplichtende keuzemogelijkheid. In het onderzoek van Kronjee en Lampert (hoofdstuk 6) naar nieuwe religie ligt dan ook sterk de nadruk op zingeving door onderscheiden leefstijlen. Voor sommigen heeft het op zoek zijn naar en het vormgeven van de eigen levensstijl een religieuze dimensie die ook kaders biedt bij het maken van allerhande keuzes. ${ }^{3}$

De ingrijpende transformatie maakt het tegelijkertijd ook lastig om de al genoemde secularisatiethese zonder meer als achterhaald te beschouwen. Immers, het feit dat we de secularisatiethese kunnen weerspreken, lijkt voor een belangrijk deel bepaald door het feit dat we religie op een nieuwe manier zijn gaan verstaan en definiëren. De traditionele religies zijn, zeker in de meeste Europese landen, in hun instituties, gezag en ledental wel degelijk sterk ondermijnd geraakt (SCP 2006). Er is, kortom, sprake van een veel meer heterogeen religieus landschap dat forse invloed heeft ondergaan van ontwikkelingen van de-institutionalisering en individualisering. Dergelijke ontwikkelingen maken het intussen nog moeilijker dan het al was om het fenomeen religie precies te duiden.

Zowel een vermeende 'terugkeer' als 'transformatie' van religie heeft mogelijk belangrijke implicaties voor de wijze waarop deze zich in het publieke domein manifesteert. De manifestaties van religieuze overtuigingen en gedragingen beperken zich daarbij niet tot de privésfeer. En zelfs wanneer dat zo is, zullen er publieke discussies zijn over de mate waarin bepaalde gedragingen daarin kunnen worden getolereerd. De reikwijdte van de privésfeer lijkt immers in ieder 
geval zelf ook telkens onderwerp van publiek debat. Maar ook een meer publieke rol van religie leidt tot allerlei vragen.

Hierbij is cruciaal dat niet alleen de manifestatie van religie verandert, maar dat ook door verdergaande personalisering (Pessers 2002), internationalisering en virtualisering het publieke domein grondig verandert. De internationale ophef na de publicatie van de Deense cartoons verbeeldt dit (zie ook de bijdrage van Hent de Vries in deze bundel). Welke verhoudingen zijn überhaupt mogelijk ten opzichte van religie in cyberspace? Reflectie over het belang van het beginsel van scheiding tussen kerk en staat biedt te weinig soelaas voor de omgang met conflicten rond religie, in een tijd waarin de grenzen van de staat onduidelijk zijn geworden of juist overduidelijk kunnen worden overschreden. Eenzelfde reflectie kan worden gegeven inzake de transnationale informatie- en geldstromen, die zich minder dan voorheen lijken te storen aan statelijke grenzen. Religie manifesteert zich bovendien op plaatsen waarvan het onduidelijk is of ze tot het publieke domein gerekend moeten worden (zoals in markten, het domein van de civiele samenleving of elektronische netwerken). Is internet publiek domein? Ja, maar tegelijkertijd ligt internet soms zo in het verlengde van privéaangelegenheden dat daarover moeilijk stellige uitspraken zijn te doen. Een heldere scheidslijn tussen publiek en privaat is soms maar moeilijk te trekken. Wat bijvoorbeeld te denken van ethische commissies en geestelijke gezondheidszorg in ziekenhuizen: opereren die op publiek terrein of moeten we hun functioneren eerder bezien in het verlengde van het private domein? Hoe wordt het publieke domein eigenlijk begrensd? Bovendien wordt het lastig om religie 'terug te dringen' uit domeinen die ook in andere opzichten niet (meer) neutraal zijn, ook vanwege diezelfde vervaging van grenzen.

In het licht van het bovenstaande blijkt dat er reden is de vraag te stellen of met een verwijzing naar de scheiding tussen kerk en staat wel het laatste woord over de mogelijke verhouding tussen religie en publiek domein kan worden gezegd. 4 Ook op het niveau van dergelijke beginselen en de discussies die daarover worden gevoerd manifesteren zich de gevolgen van de veranderingen die er spelen ten aanzien van religie. Dit komt bijvoorbeeld tot uitdrukking in het feit dat sommige overheden - zoals in Frankrijk en in het Verenigd Koninkrijk openlijk worstelen met de manier waarop met oude en nieuwe manifestaties van religie moet worden omgegaan (zie bijvoorbeeld in Valls 2005; Rémond 2005). Met het verminderen van omvang en betekenis van traditionele religieuze genootschappen, maar vooral ook als gevolg van de opkomst van minder of anders georganiseerde religies, wordt het voor sommige overheden moeilijker en lastiger opereren. In sommige gevallen blijkt het namelijk toch nuttig overleg te voeren tussen vertegenwoordigers van overheden en religieuze genootschappen. Dit geldt niet alleen voor ad-hocoverleg in geval van maatschappelijke conflicten (tussen bevolkingsgroepen), maar ook voor meer bestendig georganiseerd overleg over bijvoorbeeld maatschappelijke dienstverlening als geestelijke verzorging van gevangenen of militairen. 
Tal van positieve en negatieve gevolgen of externe effecten van een grotere rol van religie die in het debat te berde worden gebracht, doen zich al voor en vragen om grondigere bestudering. Het gezaghebbende tijdschrift Foreign Affairs inventariseert en problematiseert in een recent nummer de gevolgen van de grotere rol van religie in de sfeer van het buitenlands beleid. Een onder redactie van de Leidse rechtssocioloog Labuschagne uitgebrachte bundel essays stelde, mede naar aanleiding van een rede van de burgemeester van Amsterdam, Job Cohen, uitvoerig de vraag aan de orde naar de mate waarin religie als bron van sociale cohesie kan dienen (Labuschagne 2004; zie ook Hervieu-Léger 2006). Weer andere auteurs, zoals ook Wils in deze verkenning, problematiseren de rol van religie in de samenleving vanwege het aanblazen en verharden van maatschappelijke conflicten. Vooral de 'revival' van monotheïstische godsdiensten met een stellige waarheidsclaim en bijpassende moraal zouden een probleem vormen voor vreedzaam samenleven en met name voor de mogelijkheid van democratische politiek. Een dergelijke vraag stelt zich vooral ook in contexten van radicalisering en fundamentalisme, die door sommigen worden opgevat als onvermijdelijk verbonden met het fenomeen religie an sich.

De nieuwe belangstelling voor de gedaanteverwisseling van religie, maar ook de persistentie van traditionele manifestaties van religie geldt zowel de wetenschap als de wereld van beleid en bestuur. Intussen is religie weer volop onderwerp van studie en onderzoek, wat bijvoorbeeld blijkt uit de aandacht die Nederlandse instellingen als NWO en KNAW voor het fenomeen aan de dag leggen.

Ook voor de Wetenschappelijke Raad voor het Regeringsbeleid is deze hernieuwde aandacht voor religie in het wetenschappelijke en publieke debat aanleiding voor een verkenning, waarvan een eerste product hier voor $\mathrm{u}$ ligt. Het is niet nieuw voor de WRR om naar religie te kijken. Eerder adviseerde de WRR in het rapport De Europese Unie, Turkije en de islam (2004), dat het feit dat de bevolking van Turkije overwegend islamitisch is, geen bezwaar op zichzelf zou hoeven vormen voor de toetreding van Turkije tot Europa. Dit jaar is in het rapport Dynamiek in islamitisch activisme onderzocht hoe Nederland en de Europese Unie zouden kunnen bijdragen aan de ontwikkeling van de democratie in overwegend islamitische landen. Net zoals in het rapport over Waarden, normen en de last van het gedrag (2003) werd daar religie nog niet als fenomeen op zich aan de orde gesteld.

Met de onderhavige verkenning wordt beoogd om op dat lastige en omstreden terrein van de plaats van religie in het publieke domein enkele verdere stappen te zetten. Deze verkenning moet worden gezien als een meer expliciete zoektocht naar de vragen die opkomen als gevolg van de transformatie van religie binnen de transformerende grenzen van het publieke domein.

De verkenning heeft de opzet van een drieluik. De eerste twee luiken (begripsverkenning en empirische gegevensverzameling) voeden samen een derde luik, waarin een groot aantal auteurs een meer specifieke set van subthema's 
aan de orde stelt. Dat laatste luik laat zich lezen als een serie observaties, analyses en reflecties, die elk voor zich aanleiding zijn voor verdere vragen en onderzoek.

\section{Eerste luik: verkenning van definities en debatten}

In het eerste luik (de hoofdstukken 1 en 2) wordt gepoogd om door middel van een verkenning en uitwerking van in de discussies over religie en publiek domein gehanteerde (wetenschappelijke) begrippen, concepten en hypothesen, een meer algemene inleiding op de problematiek te geven. Om die reden verkennen Van de Donk en Plum in hun bijdrage (hoofdstuk 1 ) de termen van het actuele wetenschappelijke en vooral godsdienstsociologische debat, waarbij ze aandacht schenken aan de begrippen 'religie', 'levensbeschouwing', 'godsdienst', 'secularisatie', 'zingeving' en 'neutraliteit'. Ook de bijdrage van Hans Joas (hoofdstuk 2) draagt bij aan een verkenning van de actuele situatie en stand van zaken in het debat, waarbij hij met name ingaat op de in dat debat zeer dominante seculariseringsthese.

\section{Tweede luik: empirische benadering van de stand van zaken en recente ontwikkelingen}

In het tweede luik (de hoofdstukken 3 tot en met 7 ) wordt aan de hand van empirische bevindingen een beeld geschetst van de religieuze landkaart in Nederland en wordt ook een actueel inzicht gegeven in de betekenis van religie voor individuele burgers. Dit luik is van een zelfstandig leesbare inleiding voorzien door Kronjee (hoofdstuk 3), waarin ook in een bescheiden internationale vergelijking is voorzien. Voorts wordt een accent gezet dat ook in de andere bijdragen verder wordt uitgewerkt: de vraagstelling naar de betekenis van (de transformatie en afname van) religie voor sociale cohesie. De religieuze atlas van Nederland (hoofdstuk 4) geeft inzicht in cijfers over officiële deelname aan kerken, moskeeën, en andere meer traditionele religieuze instituties. Ook de bijdrage van Dekker en De Hart (hoofdstuk 5) zoomt in op de voornamelijk traditionele vormen van religiositeit. $\mathrm{Zij}$ presenteren resultaten van empirisch onderzoek naar de betekenis daarvan voor het functioneren van de 'civil society' en de maatschappelijke participatie. Daarbij laten ze zien dat de af- en toename van religiositeit niet zelfstandig maar in een bredere sociale context verstaan moeten worden. Met het kerklidmaatschap neemt immers ook het lidmaatschap van allerlei andere verenigingen en verbanden af. De WRR wil echter vooral ook inzicht verkrijgen in vormen van 'nieuwe religiositeit' en in onderzoek dat verder gaat dan het traditionele onderzoek naar godsgeloof en kerkbezoek. De bijdrage van Kronjee en Lampert (hoofdstuk 6) verkent de manieren waarop het 'religieuze' zich verbindt met of verhoudt tot een aantal leef- of burgerschapsstijlen, waarbij ook zij proberen empirisch inzicht te verwerven in een meer specifieke ontwikkeling van de betekenis van religie voor sociale samenhang en maatschappelijke participatie. Hun bevindingen bevestigen de al in het eerste luik besproken 'transformatie' van religie en laten zien hoe zich die in Nederland ontwikkelt. Wolfe bespreekt (in hoofdstuk 7) de wijze waarop die transformatie van religie ook in de Verenigde Staten van Amerika is ingebed in een bredere sociaal-cultu- 
rele ontwikkeling. Zijn bijdrage levert een bijdrage aan een vergelijking tussen landen, die in het kader van deze bundel onvermijdelijk nog het karakter van een eerste en onvolledige verkenning draagt. Een dergelijke vergelijking is nuttig om de Nederlandse situatie beter te kunnen plaatsen (zie ook Norris en Inglehart 2004). Daar waar een focus op religieuze doctrines de neiging heeft te concluderen tot divergentie tussen de verschillende religies, laat een focus op praktijken zien hoezeer die convergeren, en de transformatie van religie in de sleutel zetten van een meer algemene sociaal-culturele ontwikkeling. Zo biedt juist de veelheid aan orthodox-christelijke groeperingen van allerlei snit een keuzeaanbod dat goed past bij de op het individu gerichte Amerikaanse samenleving. Religieuze instituties (en vooral ook religieuze praktijken) voegen zich daarmee, net als in ons land, naar de moderne cultuur.

\section{Derde luik: specifieke kwesties en domeinen}

Tegen de achtergrond van de begripsverkenning en het empirische materiaal wordt in het derde luik (de hoofdstukken 8 tot en met 19) een aantal meer specifieke thema's en vraagstukken aangesneden. Ook hier is de inzet er een van een overigens zeer gevarieerde set van verkenningen. Wat ze gemeen hebben is de ambitie om te komen tot een inventarisatie en eerste analyse van ontwikkelingen en een daarop gebaseerde zoektocht naar daaruit voortvloeiende vragen. In hun diversiteit dragen ze alle bij aan het verder problematiseren van de huidige en toekomstige betekenis van de manifestatie en beleving van religie voor de sociale cohesie, voor de waardering en omgang met pluriformiteit, voor het ontstaan van en de omgang met conflicten en voor de (in)formele relaties tussen religies en staat. Er is getracht een aantal maatschappelijke gebieden te bestrijken, waar mensen religie van waarde achten of waar religie een rol speelt in botsingen tussen (groepen van) mensen. Ook is expliciet aandacht gegeven aan een aantal klassieke en nieuwe domeinen, zoals de rol van religie in geestelijke verzorging in de ziekenhuiszorg en de (nieuwe) media.

Het eerste cluster (hoofdstukken 8 tot en met 11) is vooral gericht op vragen die samenhangen met de betekenis die het beginsel van scheiding tussen kerk en staat, of laïciteit, voor democratie en publiek domein hebben. Bij de reflectie op nieuwe manifestaties van religie wordt als in een reflex vaak teruggegrepen naar het klassieke beginsel van scheiding tussen kerk en staat. Deze verkenning is echter gebaseerd op het idee dat het sec nadenken over dit beginsel a priori nog niet voldoende oplevert om adequaat te reageren op nieuwe ontwikkelingen. Het beginsel wordt daarmee geenszins aan de kant geschoven, maar als onderdeel van een veel bredere en onbevangen beschouwing van recente ontwikkelingen opgenomen. Van Bijsterveld (hoofdstuk 8) beschouwt in haar bijdrage dan ook precies de reikwijdte van het beginsel van de scheiding tussen kerk en staat, zowel in zijn historische als huidige context. Daarbij laat zij zien hoezeer dit beginsel voor allerlei doeleinden wordt gebruikt. In een bijlage besteedt zij ook aandacht aan Europese en Europeesrechtelijke ontwikkelingen die in dit verband van belang zijn (EU en EVRM). Een korte, meer historische en feitelijke schets van de wijze waarop dit beginsel zich in de loop van de Nederlandse geschiedenis heeft ont- 
wikkeld en in constitutionele teksten en wetgeving is neergeslagen, wordt gegeven door Koolen (hoofdstuk 8a). Een verdere blik over de grens geeft Jansen (hoofdstuk 9). Zij laat in haar (historische) bijdrage zien hoe 'laïciteit' zich gedurende een langere periode heeft gevormd en dat in de Franse republiek in het streven naar een strikte scheiding tussen kerk en staat, gecombineerd met de eisen aan werkelijk republikeins burgerschap, steeds nieuwe eisen werden gesteld aan joodse burgers. De assimilatie was nooit 'af' en kon steeds door de 'autochtone' bevolking opnieuw ter discussie gesteld worden. Zij laat zien hoezeer vraagstukken van religie zijn verbonden met vraagstukken van identiteit (een onderwerp waarover de WRR volgend jaar een afzonderlijk rapport zal laten verschijnen).

In zijn (in het Engels gestelde) bijdrage bespreekt Vroom (hoofdstuk 1o) op een nog andere wijze de relatie tussen religie en vraagstukken van burgerschap in een steeds meer plurale samenleving. Ook hij bespreekt uitgebreid de historische ontwikkelingen op dat punt in Frankrijk en de actuele ontwikkelingen in Canada, dat met de introductie van sharia-rechtbanken een koers is gaan varen die sterk afwijkt van die in Frankrijk. Zijn bijdrage aan deze bundel kan worden gelezen als een vergelijkende analyse van de wijzen waarop Frankrijk en Canada met vraagstukken van (religieuze) pluriformiteit zijn omgegaan. De bijdrage van Borgman (hoofdstuk 11) gaat in op de spanningen die voortvloeien uit (veranderingen in) de presentie van het religieuze in democratie en publiek domein. Hij wijst erop dat het moeten leren omgaan met de islam zelf een onderdeel is van het moderniseringsproces in Nederland, zoals dat vroeger ook gold voor de omgang met katholieken en gereformeerden. Borgman richt zich in zijn bijdrage vooral op de rol van religie in de democratie. In navolging van Habermas stelt hij dat de democratie de hele samenleving moet aanspreken, inclusief religieuze burgers. Daarom kan religie niet slechts getolereerd worden, omdat daarmee een wezenlijke inbreng in de gemeenschappelijke zoektocht zou kunnen worden genegeerd. Bovendien kan religie worden opgevat als een sleutel tot de omgang met het lijden. De vooruitgang heeft aan het lijden geen einde gemaakt en vraagt nog steeds om een antwoord. Volgens Borgman staat noch religie, noch de publieke sfeer vast: veeleer wordt hun onderlinge verhouding gekenmerkt door diffuse en ook schuivende grenzen. Daarom kunnen ook niet-religieuzen uit religieuze tradities putten en zijn ook nieuwe religies en levensbeschouwingen mogelijk van belang voor het democratische proces.

In een volgend cluster van bijdragen in dit derde luik (de hoofdstukken 12 tot en met 15) wordt de dynamiek in de verhouding tussen religie en publiek domein voor een aantal specifieke sectoren in kaart gebracht en besproken, meer in het bijzonder die van onderwijs en zorg.

Kennedy en Valenta wijzen er in hun (eveneens Engelstalige) bijdrage (hoofdstuk 12) op dat door de historisch gegroeide Nederlandse kerk-staatverhouding de Nederlandse staat, in tegenstelling tot bijvoorbeeld de Amerikaanse, een sterke invloed heeft uitgeoefend op de wijze waarop de kerk effectief en legitiem heeft 
kunnen bestaan. Nu wordt in Nederland het zoeken naar een nieuwe scheiding te veel bepaald door het idee dat modernisering leidt tot meer secularisatie. Daarbij wordt naar de mening van deze auteurs in de omgang met de islam veel te weinig gedaan met de ervaringen die zijn opgedaan met de islam door het Nederlandse bestuur in Nederlands-Indië. Dit bestuur was sterk gericht op het verspreiden van seculier nationalisme, waarbij het onderwijs werd opgevat als een tegenwicht tegen de islam. De verwaarlozing van deze ervaringen draagt bij aan de verklaring van de 'paniek' in de omgang met islamitische scholen en daarmee samenhangende, in hun ogen overhaaste, beschouwingen over de betekenis in dit domein van het beginsel van de scheiding tussen kerk en staat. Effectiever is het om religies als in een marktmechanisme te laten concurreren om gelovigen: dit leidt ertoe dat religies naar buiten moeten treden en daarmee voor maatschappelijke invloed vatbaar zijn, een kwestie die ook in de eerdergenoemde bijdrage van Borgman aan de orde kwam.

In de bijdrage van Vermeulen (hoofdstuk 13) staat de vraag ter discussie wie het kind in zijn ontwikkeling mag beïnvloeden. Daarbij gaat het niet zozeer om specifieke kennisoverdracht, maar veeleer om de specifieke sfeer die in meer of mindere mate aansluit bij de sfeer die ouders in hun eigen huis en opvoeding nastreven. Vermeulen betwijfelt de stelligheid waarmee de slechte invloed van religieus onderwijs op kinderen wordt geponeerd. Het is, zo blijkt uit zijn bijdrage, bovendien zeer de vraag of religieus onderwijs in den brede leidt tot meer of minder tolerantie jegens niet- of andersgelovigen.

Kunneman (hoofdstuk 14) en Schilderman (hoofdstuk 15) plaatsen de algemenere discussies betreffende de transformatie van religie en de daaruit voortvloeiende veranderingen in de verhouding tussen religie en publiek domein op het meer concrete veld van de geestelijke verzorging (in ziekenhuizen, gevangenissen en het leger). Uit beide bijdragen blijkt hoezeer de in het eerste luik besproken problematiek van afbakening en definiëring in dit concrete domein leidt tot tal van nieuwe vragen en problemen. Wie bepaalt nog wat religie is, als religieuze behoeften en praktijken (zoals ook Wolfe beklemtoont) zo convergeren en individualiseren? Kunneman beschrijft hoezeer empirische ontwikkelingen (de individualisering van zingevingspraktijken) en theoretische vragen (hoe is in een dergelijke context nog op een zinvolle wijze een notie als 'zendende instantie' te definiëren?) leiden tot lastige vragen voor beleidsmakers die geacht worden de voor geestelijke verzorging beschikbare middelen op een rechtvaardige wijze te verdelen. In beide bijdragen komt ook naar voren hoezeer het domein van geestelijke verzorging in de sfeer van de zorg als een buffer dient tegen een oprukkende nadruk op functionele rationaliteit, of die nu vanwege de markt of vanwege de bureaucratie wordt ingebracht. Kunneman laat echter indringend zien hoezeer de legitimiteit van de professionals in instellingen zoals ziekenhuizen en verzorgingshuizen onder druk wordt gezet door eisen van meetbaarheid en verantwoording: ook de geestelijke zorg zal zich niet kunnen onttrekken aan de zogenaamde 'diagnose-behandel-combinaties', terwijl het de vraag is of met een dergelijke benadering recht wordt gedaan aan de geestelijke gezondheidszorg. 
Schilderman schetst enkele scenario's van de wijzen waarop de geestelijke verzorging (als professie en als normatieve en kritische oriëntatie) in het genoemde domein zou kunnen reageren op de belangrijke veranderingen die in die sectoren optreden als gevolg van de meer algemene transformatie van religie.

Een laatste cluster hoofdstukken (16 tot en met 19) zet de verhouding tussen religie en publiek domein weer in een wat breder perspectief van meer omvattende ontwikkelingen in de sfeer van de sociaal-culturele conditie van de samenleving, de rol van de media en de rol van het recht, in het bijzonder de problematiek van de botsing van grondrechten.

Van den Brink (hoofdstuk 16) verbindt de 'terugkeer' van de aandacht voor religie met een meeromvattende sociaal-culturele analyse van 'de meervoudige crisis (of schaduwzijden) van de moderniteit'. In zijn bijdrage verschijnt de aandacht voor de vragen die rondom religie opkomen als een aanwijzing voor de noodzaak te komen tot een meer algemene diagnose van de samenleving. Die diagnose wijst naar zijn mening op een zekere 'gebrokenheid'. De dubbele transformatie (die van het publieke domein en die van de religie) brengt hem bij een pleidooi voor de terugkeer van idealen en burgerschap, als eigentijdse manifestaties van de normatieve oriëntaties zonder welke een samenleving niet adequaat kan functioneren. De auteur ziet het goddelijke als datgene wat verbinding brengt en verdeeldheid, althans tijdelijk, opheft. In zijn ogen hebben revoluties die de mens modernisering hebben gebracht (de wetenschappelijke, democratische, industriële en seksuele) niet geleid tot vermindering van de vraag naar het goddelijke, omdat ze onvoldoende verdeeldheid konden overbruggen. Vanuit die optiek stelt hij dat kerken in het publieke domein dan ook geen functie hebben, maar een opgave, in de zin van bijdragen aan 'heelheid'. Kerk en geloof moeten niet dienen als afweermechanisme tegen moderne ontwikkelingen, maar moeten de opgave om bij te dragen aan heelheid aanvaarden.

In zijn bijdrage (hoofdstuk 17) stelt Wils niet de 'heelheid', maar de verdeeldheid en het conflict centraal, en wordt de door Borgman en Van den Brink nog als een positieve symbiose voorgestelde relatie tussen religie en democratie/publiek domein juist geproblematiseerd. Wils stelt dat religieuze taal en metaforen de vrije politieke discussie verstoren. Religieuze standpunten dragen niet bij aan de discussie, maar werken conserverend. Ten onrechte wordt moreel (eigen) gelijk gelijkgesteld met politiek gelijk, wat botst met een basispremisse van de democratie. Compromissen sluiten is voor een religie eigenlijk onmogelijk, hoewel dat in een democratie onontbeerlijk is. Om compromissen te sluiten moeten de begrippen goed en kwaad gerelativeerd kunnen worden, wat voor een religie moeilijk zo niet onmogelijk is. In de democratie is 'goed' juist de uitkomst van een deliberatieproces, wat daarmee niet van tevoren vast kan staan. Een sterke alliantie van religie, politiek en moraal maakt burgerrechten al gauw onmogelijk. Ze mogen elkaar wel beïnvloeden, maar niet samenvallen. Absolute waarden zijn voor religies onbetwistbaar en daarom kunnen ze geen onderwerp van discursieve oordeels- en besluitvorming zijn. 
Ook in de bijdrage van Hent de Vries (hoofdstuk 18) blijkt hoezeer in onze samenleving religie is verbonden met vragen van strijd en bronnen van conflicten. Hij onderzoekt in zijn essay de nog moeilijk voorspelbare gevolgen van de uitdijende reikwijdte en transformatie van religie in de context van de moderne en nieuwe media. Ook die sferen, die van de religie en die van de nieuwe (transnationale) media, zijn nauw met elkaar verweven en beïnvloeden elkaar wederzijds. Deze zijn niet alleen een voertuig voor nieuw oplevende - traditionele religie, maar maken ook nieuwe (vormen van) religie mogelijk. Sommige nieuwe vormen van religie bestaan zelfs bij de gratie van de nieuwe communicatiemogelijkheden.

Het juridische discours en de wetenschappelijke reacties daarop laten een 'strijd' zien over de vraag wie mag definiëren wat religie en wat neutraliteit is en wat niet: achter de definitiekwestie gaat mogelijk ook een belangenstrijd schuil. Godsdienst als mening leidt tot andere rechtsbescherming dan godsdienst als een identiteitsbepalend persoonskenmerk, waarvan niet dan met grote moeite afstand gedaan kan worden. Jonkers laat in haar bijdrage (hoofdstuk 19) zien dat problemen met de definitie en identificatie van godsdienst niet alleen theologische of sociologische implicaties hebben, maar ook de rechtspraktijk beïnvloeden. De individualisering in religieuze beleving maakt het niet alleen lastiger om vast te stellen of religie in het geding is, maar ook of religie nog wel bescherming verdient.

Daarmee is ook in dit laatste hoofdstuk van dit derde luik een zowel in wetenschappelijke als bestuurlijke zin lastige vraag opgeworpen, die zich voegt in een hele serie van vragen die in deze verkenning zijn gesteld en verder ontwikkeld. Voor beantwoording van die vragen is nog immer het beginsel van scheiding tussen kerk en staat in zijn fundamentele bedoeling, dat de overheid zich niet met de kerk inlaat, en dat aan alle burgers vrijheid van godsdienst (inclusief de vrijheid niet(s) te geloven) wordt gegarandeerd, een relevant kernbeginsel van de democratische en sociale rechtsstaat. Al evenzeer beschermt het de staat tegen inmenging door de kerk. De vraag is echter gerechtvaardigd of met de transformatie en metamorfose van zowel religie als het publieke domein het klassieke beginsel van de scheiding tussen kerk en staat voldoende antwoord kan geven op de nu hier gestelde en later verder nog te ontwikkelen vragen. 


\section{NOTEN}

1 Voor zover althans van 'de' seculariseringsthese kan worden gesproken: zie voor een meer uitvoerige beschouwing van deze these de bijdragen van Van de Donk en Plum en van Joas verderop in deze bundel.

2 Zie voor een uitvoerige en belangwekkende kritische beschouwing van deze these in Stark (2006) die bovendien empirisch gefundeerde vraagtekens zet bij het met deze stelling verwante gedachtegoed dat uitgaat van een tegenstelling tussen geloof en wetenschappelijke vooruitgang.

3 Zie bijvoorbeeld de webstek www.moederoverste.nl, waarin een (van oorsprong) remonstrantse predikante, zonder kerkelijke of religieuze binding met personen die daar om vragen zelf persoonlijke, maar niet-kerkelijke rituelen wil vormgeven rond geboorte, dood, huwelijk en echtscheiding.

4 Overigens is die scheiding - hoewel ze in nagenoeg alle Europese staten is erkend - overal anders ingevuld. Een strikte invulling van de scheiding tussen kerk en staat, met de daarbij behorende noties van laïciteit en neutraliteit van de staat, is eigenlijk nergens in Europa aan te treffen, zelfs niet in Frankrijk, waar sinds 1905 een strikte scheiding tussen kerk en staat zou zijn doorgevoerd. Onlangs verscheen daar nog het overigens omstreden rapport van de commissieMachelon die pleit voor een meer pragmatische omgang met de eerder haast sacraal gekoesterde noties van laïciteit en neutraliteit. 


\section{LITERATUUR}

Doorn, J. van 'De onverwoestbaarheid van religie' in Trouw, 9 april 2005.

Commission Machelon (2006) (Commission de réflexion juridique sur les relations des cultes avec les pouvoirs public) Rapport 20 september.

Magnard, P. (2006) Pourquoi la religion? Paris: Armand Colin.

Hervieu-Léger, D. (2006) The Role of Religion in Establishing Social Cohesion, blz. 45-63 in: K. Michalsky (ed.), Religion in the New Europe, Budapest/New York: Central European University Press.

Labuschagne (red.) (2004) Religie als bron van sociale cohesie in de democratische rechtsstaat? Leiden: E.M. Meijersinstituut.

Norris, P. en R. Inglehart (2004), Sacred and Secular. Religion and Politics Worldwide, Cambridge: Cambridge University Press.

Pessers, D. (2002) Big Mother. Over de personalisering van de publieke sfeer (oratie), Den Haag: Boom Juridische Uitgevers.

Rémond, R. (2005) L'invention de la laïcité. De 1789 à demain, Paris: Bayard.

Stark, R. (2006) The Victory of Reason. How Christianity Led to Freedom, Capitalism and Western Succes, New York: Random House.

Valls, M. (2005) La Laicïté en face. Entretiens avec Virginie Malabard, Paris: Desclée de Brouwer. 


\section{LUIK 1 \\ BEGRIPPEN, THEORIEËN EN DISCIPLINAIRE BENADERINGEN}




\author{
Wim van de Donk en Rob Plum
}

In dit eerste hoofdstuk van deze verkenning, die feitelijk een serie verkenningen in zich draagt, wordt een algemeen beeld gegeven van een aantal in het oog springende wetenschappelijke inzichten en discussies, die voor het maatschappelijke debat over de (ontwikkelingen in de) verhouding tussen religie en publiek domein relevant zijn. Met name wordt ingegaan op enkele, vooral godsdienstsociologische inzichten en discussies die impliciet of expliciet worden herkend in of aanleiding zijn voor een aantal maatschappelijke debatten, die verderop, in het derde deel van deze bundel verkenningen uitgebreider aan de orde worden gesteld. Wat is er betreffende religie aan de hand, is de vraag die ons in dit eerste luik op een meer theoretische wijze bezig zal houden. Dezelfde vraag zal in het tweede luik op een meer empirische wijze aan de orde worden gesteld. In het derde deel wordt op een aantal meer specifieke kwesties en vraagstukken ingegaan, die alle verband houden met de (veranderde en veranderende) positie van religie in het publieke domein. Gezien de focus van deze verkenning op de maatschappelijke rol die religie, zo zegt men, opnieuw aan het innemen is, zullen in dit eerste hoofdstuk in het bijzonder enkele godsdienstsociologische inzichten besproken worden. Maar omdat religie ook steeds normatieve aspecten heeft, zullen soms ook theologische en filosofische inzichten gepresenteerd worden. Een belangrijk doel van deze inleiding is om enkele essentiële begrippen en concepten die in zowel wetenschappelijke als maatschappelijke discussies een belangrijke rol spelen, te duiden en te verhelderen.

\title{
1.1 SECULARISERING EN TERUGKEER VAN RELIGIE
}

Het is blijkbaar van maatschappelijk belang en betekenis dat religie in onze maatschappij is 'teruggekeerd'. Om het thema van de terugkeer van religie in onze maatschappij theoretisch te kunnen duiden, moeten we allereerst aandacht geven aan het begrip 'secularisatie'. Door de secularisatiegedachte worden we namelijk geconfronteerd met het zelfbeeld van de moderne samenleving, dat is een samenleving waarin volgens vele onderzoekers religie geen enkele, laat staan een belangrijke, plaats meer inneemt. Dat we onszelf zien als een geseculariseerde samenleving werd onlangs nog eens duidelijk toen NRC Handelsblad schreef dat het rijtje 'Verlichting, moderne samenleving, secularisatie' ons met 'de Nederlandse paplepel is ingegoten' (Smolenaars 2006).

Het gedachtegoed dat onder de naam 'secularisering', 'secularisatie' of 'seculariseringsthese' bekendstaat, vormt sinds het begin van de sociologie in de 19de eeuw - bij Auguste Comte, Émile Durkheim en Max Weber - een van de centrale leerstukken van de (godsdienst)sociologie en is sindsdien een vanzelfsprekend bestanddeel van de westerse common sense geworden (Berger 2001: 443). 
We moeten hier overigens een onderscheid maken tussen de seculariseringsgedachte in brede, impliciete zin en de seculariseringsthese en -theorie in expliciete zin. De oorsprong van de seculariseringsgedachte in bredere zin wordt meestal gesitueerd in de tijd van de achttiende-eeuwse Verlichting (Berger 1999: 2; Fox 2005: 293). Daar ziet men over het algemeen de wortels van een denken en een daarop gebouwde inrichting van de samenleving die de publieke invloed van religies wil beperken of althans wil reguleren.

De expliciete seculariseringsgedachte valt ongeveer samen met het ontstaan van de sociologie zelf. Als haar geestelijke vaders duidt men meestal de Franse socioloog Émile Durkheim en de Duitse socioloog en econoom Max Weber aan.

Max Weber (1864-1920) heeft in zijn rijke sociologische en economische oeuvre de these ontwikkeld dat het moderniseringsproces dat zich in onze samenleving voltrekt een proces van toenemende rationalisering inhoudt. Secularisering was voor Weber een gevolg van deze rationalisering (Demerath 2000: 2483). Dit proces van toenemende rationalisering zou zich, naarmate de modernisering van onze samenleving voortschrijdt, volgens Weber met een ijzeren logica voltrekken en uitmonden in een onttoverde wereld waarin voor religie geen plaats meer is. Opmerkelijk is dat men bij Weber tevens het gevoel krijgt dat hij deze constatering tot zijn spijt moest doen. Veel sociologen zien in het feit dat Weber het resultaat van deze ontwikkeling een 'onttoverde wereld' noemde, een melancholische ondertoon, hoezeer Weber zichzelf ook 'religiös unmusikalisch' noemde (Joas 2004: 67). Men noemt hem ook wel een 'agnost met religieuze nostalgie' (Berger 2001: 444). Het lijkt er kortom op dat Weber tot zijn eigen spijt heeft menen te moeten constateren dat religie aan betekenis en invloed afneemt in een moderner wordende wereld, waar de instrumentele rationaliteit dominant is (Kehrer 1997: 132).

De andere geestelijke vader van de seculariseringsthese is de Franse socioloog Émile Durkheim (1858-1917) die religie functioneel definieerde, in termen dus van haar functie in een samenleving. Durkheim was als atheïst aanzienlijk positiever over de secularisering. Hij was optimistisch over een seculiere moraal en een autonome ethiek voor de samenleving. En hoewel hij zich realiseerde dat religieus geloof vervangen zou worden door wetenschap, zou het gevoel van de samenleving als een heilig collectief blijven en religie dan ook niet verdwijnen (Demerath 2000: 2483). In de ogen van Durkheim zou religie haar sociale betekenis nooit verliezen, maar blijven bestaan omdat zij nu eenmaal een publieke functie vervulde. Een maatschappij, zo stelde hij, vereist religie om de sociale cohesie te behouden en om collectieve gevoelens en ideeën te kunnen verstevigen. Wel geloofde hij, zoals later ook Niklas Luhmann, dat bepaalde vormen van religie zouden veranderen naarmate de maatschappij veranderde. 'Il paraît de toute évidence que nous assistons à la dissolution d'une forme religieuse', schreef Durkheim al in 1907 (Durkheim 1907/1975: 169; zie ook Luhmann 2002). Ook de wetenschap zou religie niet kunnen verdrijven, hoogstens heeft ze de mogelijkheid om gedateerde religieuze dogma's uit te dagen. Maar dan toch zouden 
nieuwe religieuze vormen, die beter aansloten bij de tijd, onvermijdelijk opduiken om hun plaats in te nemen (Hamilton 2005: 294).

Meer uitgewerkt tot een theorie begint men de seculariseringsthese pas in de jaren '50 en '6o van de 20ste eeuw te ontwikkelen (Berger 1999: 2). Bryan Wilson (Religion in Secular Society (1966)), Peter Berger (The Sacred Canopy (1967)) en David Martin (The Religious and the Secular (1969)) - om hier slechts enkele van de belangrijkste auteurs te noemen - hebben allen, op zeer verschillende wijze en met verschillende accenten, een seculariseringstheorie uitgewerkt waarvan het hart gevormd werd door de bewering dat er een nauwe band (zo niet een oorzakelijk verband) bestaat tussen modernisering en de afname van religie. De wereld zou in toenemende mate seculier worden en ook waren steeds minder mensen religieus. Men schreef die toenemende secularisering toe aan de sociale krachten die verbonden zijn met de 'moderniteit' (Fox 2005: 291).

Wie de actuele toegenomen maatschappelijke belangstelling voor religie tegen deze (theoretische) achtergrond bekijkt én zich realiseert dat onze maatschappij en de actoren daarin diepgaand beïnvloed zijn door de seculariseringsgedachte, zou de ontstane verbazing over de teruggekeerde religie en de daarmee verband houdende wetenschappelijke en maatschappelijke belangstelling voor dit fenomeen gemakkelijk kunnen verklaren: secularisering en terugkeer van religie vormen eenvoudigweg een tegenstelling en die is alleen op te lossen door ofwel de seculariseringsthese te verwerpen, ofwel de verworvenheden van de secularisering nog eens in herinnering te roepen en de erop gebaseerde inrichting van onze samenleving - te denken valt vooral aan de scheiding van kerk en staat, het spreken over de neutraliteit van het publieke domein en het toeschrijven van religie aan het privédomein - opnieuw leven in te blazen en te verdedigen tegen de terugkerende en teruggekeerde religie.

Het heeft er echter alle schijn van dat wie zich de huidige samenleving en de rol van religie daarin zó voorstelt, zich schuldig maakt aan simplificatie. Die simplificatie zou maatschappelijk gezien kunnen leiden tot het creëren van onterechte en onnodige tegenstellingen. De seculariseringsthese dreigt bovendien gereduceerd te worden tot de ideologie van het secularisme en men zou de frase van de 'terugkeer van religie' kunnen uitleggen als de poging van religie om een publieke positie op te eisen die ze lang kwijt geweest is. De situatie is, zoals ook verderop nog wel zal blijken, aanmerkelijk genuanceerder en complexer dan geschetst. Dat willen we hier laten zien door de wetenschappelijke ontwikkelingen op het gebied van de seculariseringsthese en van de terugkeer van religie te schetsen. Daardoor wordt duidelijk dat er onder dit eerste niveau van de tegenstelling tussen secularisering en terugkeer van de religie een diepere laag schuilgaat.

\subsection{KRITIEK OP DE SECULARISERINGSTHESE}

Hoewel 'we' onszelf misschien nog steeds als een geseculariseerde samenleving aanduiden, staat dit begrip in de wetenschap al enige tijd onder kritiek. Er zijn 
nog maar weinigen die de these in alle volledigheid onderschrijven. Zo stelt ook Jos Becker, die jarenlang medeverantwoordelijk was voor de rapporten van het Sociaal Cultureel Planbureau over de secularisering in Nederland en die in opeenvolgende rapporten steeds weer een toename van secularisering constateerde, in een recente publicatie 'dat het begrip "secularisatie passé” is' (Smolenaars 2006). En ook de auteur van een recentelijk verschenen handboek over de godsdienstsociologie zegt dat 'vandaag de dag nog maar slechts een minderheid de visie ondersteunt dat voortgaande secularisering nog steeds plaatsvindt' (Fox 2005: 291). Het zijn slechts twee uitingen van een aanzwellende kritiek op de seculariseringsthese.

Men kan grofweg twee soorten van kritiek op de seculariseringsthese onderscheiden: de empirische en de theoretische kritiek: empirisch gezien komt de kritiek hierop neer dat onderzoek naar religie in westerse landen eenvoudigweg niet het afsterven van religie of de toenemende marginalisering ervan aan het licht brengt, maar juist een heropleving van religie of op zijn minst een constant blijven ervan (Berger 2001: 445). Wereldwijd bezien is er al helemaal geen reden om die these te steunen (zie Berger 1999 en Norris en Inglehart 2004). Wie de seculariseringsthese beperkt tot louter de bewering dat religie in een moderne samenleving geleidelijk aan steeds marginaler wordt of zelfs verdwijnt, vindt in dit empirisch bewijs een reden om de these aan de kant te schuiven en op zoek te gaan naar een nieuwe theorie. In die pogingen blijkt, maar we komen daar later nog uitvoeriger op terug, dat de seculariseringsthese veel meer zegt dan alleen dat religie zal verdwijnen (zie verder in deze tekst en in het empirische luik van deze bundel).

Naast de empirische contra-indicaties is er ook behoorlijk wat theoretische kritiek op de these, eigenlijk ook al vanaf het begin ervan in de jaren '5o en '6o. Die kritiek concentreert zich hoofdzakelijk op de vaagheid van de theorie en op het ideologische karakter ervan. Om met het laatste te beginnen: er is nogal eens beweerd dat de secularisatiethese geformuleerd zou zijn door mensen die tegen religie zijn. Bijgevolg heeft men de theorie ook wel een 'ideenpolitischer Begriff' genoemd (Hermann Lübbe) of een 'instrument in handen van mensen met contra-religieuze doeleinden' (David Martin aangehaald door: Aldridge 2001: 86; zie ook McGrath 2006). Peter Berger en Steve Bruce wijzen er daarentegen op dat voor Durkheim inderdaad gold dat hij atheïst was, maar dat van Max Weber toch op zijn minst een meer ambigu beeld geschetst moet worden, namelijk als een 'agnost met religieuze nostalgie' (Berger 2001: 444). Al met al kan men constateren dat 'de seculariseringstheorie aangehangen werd door zowel hen die de zogenoemde neergang van religie betreurden, als door hen die haar verwelkomden' (Berger 2001: 444). Een zwaarwegender kritiek komt van hen (J. Hadden) die beweren dat de theorie eerder een 'hutspot van los toegepaste ideeën is dan een systematische theorie' en dat het woord 'te veel heterogene tradities in een woord samenvat' om nog bruikbaar te kunnen zijn (Luhmann 2002: 278-9), al hebben op dit punt onderzoekers als Olivier Tschannen laten zien dat de theorie, hoewel ze verschillende varianten kent bij verschillende auteurs, wel degelijk een harde kern kent die bij alle auteurs terugkeert (Tschannen 1991). 
Dat de theorie niet duidelijk genoeg zou zijn manifesteert zich overigens ook nog in het feit dat verschillende auteurs verschillend denken over het niveau waarop de theorie betrekking heeft: volgens de een, onder wie Peter Berger, betekent secularisering dat 'religie zowel in de samenleving als in het bewustzijn van individuen in belang afneemt' (Berger 2001: 443), terwijl anderen beweren dat de seculariseringsthese alleen betrekking heeft op het macroniveau van de samenleving en/of op het mesoniveau van organisaties. Weer een ander verschil van mening over wat de seculariseringsthese nu eigenlijk beweert, gaat over de vraag of ze nu daadwerkelijk de these behelst dat het proces van neergang van religie een noodzakelijk karakter heeft.

Hoewel de seculariseringsgedachte dus in de wetenschap al langere tijd niet meer zo sterk in het zadel zit, betekent dat ook weer niet dat die brede maatschappelijke geaccepteerdheid van de seculariseringsgedachte er volledig naast zit. Want hoewel de seculariseringsthese wetenschappelijk aan toenemende kritiek blootstaat en weinigen haar geheel nog onderschrijven, zijn er anderzijds ook maar weinig wetenschappers die haar geheel verwerpen. Dus hoewel een minderheid van de sociologen nog de visie onderschrijft dat voortgaande secularisering plaatsvindt, is 'de hele kwestie van secularisering nog geenszins afgedaan' (Fox 2005: 291) en ook Peter Berger erkent dat, hoewel de wereld 'zo religieus is als ze altijd al was, en op sommige plaatsen zelfs religieuzer dan ooit, dit niet betekent dat er niet zoiets als secularisering bestaat' (Berger 2001: 445).

Dat is om te beginnen zo omdat de seculariseringsgedachte te zeer 'verweven is met alle theorieën van de moderne wereld en met het zelf-verstaan van de moderniteit' om haar, louter op grond van het feit dat er wel weer sprake is van religie, te verwerpen.

"Het zou tot een grotere conceptuele verarming leiden wanneer we het hele concept overboord zouden gooien, want in een dergelijk geval zouden we ook de herinnering verliezen aan de complexe geschiedenis die binnen dat concept geaccumuleerd is en we zouden overblijven zonder geschikte categorieën om die geschiedenis in kaart te brengen en te begrijpen.” (Casanova 1994: 18, 12)

Maar bovendien is de seculariseringsgedachte nog niet achterhaald, omdat er nog steeds delen van de wereld zijn, waaronder met name West-Europa, die geseculariseerd zijn - al zijn die delen nu 'niet meer de paradigmatische situatie van religie in de hedendaagse wereld', maar de te verklaren uitzondering (Berger 2001: 445). Desondanks is voor een beschrijving van de situatie van religie in onze samenleving de seculariseringsthese niet meer afdoende, al lijkt de waarde ervan als heuristisch begrip betrekkelijk overeind gebleven.

We bespreken in dit eerste deel vooral enkele van de belangrijkste wetenschappelijke ontwikkelingen en discussies op het terrein van de seculariseringsthese. Dat is nodig om het doorgaans nogal vlot geschetste, dualistische beeld van secularisering enerzijds en terugkeer van religie anderzijds te nuanceren en te problema- 
tiseren. In het tweede luik van deze verkenning wordt de nieuwe situatie van religie empirisch beschreven.

\section{Terugkeer van religie?}

Ook die zogenoemde 'terugkeer van religie' is minder eenduidig dan de unilaterale tegenstelling met de seculariseringsthese deed vermoeden. Wie de godsdienstsociologische literatuur hierover bekijkt, merkt dat men dit woord 'terugkeer' misleidend en zelfs onjuist vindt. Dat betekent dat hier een blikverandering zichtbaar wordt: om te beginnen gaat het om een andere visie op ons verleden. Het gebruik van het woord 'terugkeer' stelt de zaken voor als zouden we een tijd hebben gehad waarin religie gemarginaliseerd of afwezig was, en dat we ons nu in een tijd zouden bevinden waarin religie zich in een opgaande lijn beweegt. Volgens vele auteurs is dat simpelweg een weinig adequate waarneming, die soms bovendien meer over de waarnemers dan over de waarneming zelf lijkt te zeggen. Daarom kiezen sommige auteurs niet voor de term 'renaissance', 'heropleving' of 'terugkeer' van religie, maar voor de term 'vernieuwing' of voor het besef dat het verschijningsbeeld van religie sterk veranderd is (Jörns 1999: 26; Wuthnow 1992: 2).

Het bredere belang van deze wetenschappelijke ontwikkeling en van de nuancering van de term 'terugkeer van religie' is dat het een serieus vraagteken plaatst bij de visie die wij lange tijd op onszelf als moderne en geseculariseerde samenleving en op religie en haar plaats daarin hebben gehad. Het beeld wordt minder zwart-wit, want bij nader inzien blijkt dat religie nooit echt weggeweest is (Casanova 2004).

Nauw verbonden hiermee is een ander aspect waarover sinds enige tijd wordt gesproken en dat al even aan bod gekomen is: de transformatie of gedaanteverandering van religie (Sengers 2005; Borgman 2005: 34). Religie en het religieuze bewustzijn zijn intussen zelf veranderd (Walf 1983; 2000). Dat maakt eens te meer duidelijk hoe problematisch het is om te spreken over de 'terugkeer van religie', want het suggereert niet alleen dat religie lange tijd afwezig was en er nu weer is, maar bovendien dat het de ons bekende religie is die teruggekeerd is, dat die ooit als het ware ondergronds gegaan is en nu weer opduikt. Een dergelijk spreken over 'terugkeer' stelt de zaken te massief voor. Het doet voorkomen of religie een 'transcultureel en transhistorisch fenomeen' zou zijn. Dat het zou gaan om een door alle tijden heen gelijkblijvend verschijnsel (Asad 1993: 28; De Vries 1999: 1-3). Dat is niet waarschijnlijk. En ook hier speelt op de achtergrond weer de vraag wat religie nu eigenlijk is. We komen daarop later terug. Eerst gaan we nog wat nader in op die transformatie van religie.

Eén concreet voorbeeld van de beschrijving van die daadwerkelijke transformatie van religie is te vinden bij de Britse onderzoekers Paul Heelas en Linda Woodhead - die er overigens voor hebben gekozen om deze getransformeerde religie 'spiritualiteit' te noemen. Ook zij nemen een afname van traditionele religie waar, maar ze constateren ook een groei van spiritualiteit. $\mathrm{Zij}$ nemen de term 'het 
heilige' als de overkoepelende term voor 'religie' en 'spiritualiteit'. Religie en spiritualiteit zijn twee gedaanten die het heilige kan aannemen, twee vormen van het 'landschap van het heilige' (Heelas \& Woodhead 2004: 2). Religie wijst op een 'leven' volgens externe verwachtingen, terwijl spiritualiteit voor een 'leven conform mijn eigen innerlijke ervaring' staat. De wending van religie naar spiritualiteit is de wending van, om hun woorden te gebruiken, 'leven-als' naar een 'persoonlijk-leven', dat wil zeggen een leven dat geleefd wordt in diepe verbinding met de unieke ervaringen van mijzelf-in-relatie (Woodhead \& Heelas 2004: 3).

Maar ook anderen hebben deze verandering van religie geconstateerd, zoals de socioloog Karl Gabriel die van een 'verandering van het religieuze' spreekt en dan 'niet alleen van religieuze instituties, rollen en praktijken' (Gabriel 1996: 35), of de theoloog Klaus-Peter Jörns die het verkiest om van 'krachtige verandering van het "Erscheinungsbild" van religie' te spreken in plaats van over de 'wedergeboorte van religie' (Jörns 1999: 26) en de Amerikaanse socioloog Alan Wolfe die in zijn studie over de Amerikaanse religie eveneens van een 'transformation' heeft gesproken (Wolfe 2003). In dit verband kan in Nederland ook gedacht worden aan de onderzoeken van de godsdienstfilosoof Anton van Harskamp die in talrijke publicaties gewezen heeft op de 'nieuwe religiositeit' en op het nieuwe 'religieuze verlangen' (Van Harskamp \& Borgman 1998; Van Harskamp 200o) en aan de theoloog Erik Borgman die over de 'metamorfose' of gedaanteverandering van religie spreekt (Borgman 20o6). Ook de veelvuldig voorkomende terminologie 'nieuwe religiositeit' duidt op deze transformatie van religie. Religie is aan het veranderen (Zahrnt 1992: 57; Jörns 1999).

Dat dat zo is, laat ook de godsdienstsociologie zien. Lange tijd is zij kerksociologie geweest: men bracht de mate van religiositeit in kaart door te kijken naar (in zondags gedrag) zichtbare en institutionele aspecten (zoals kerklidmaatschap en kerkbezoek). Allengs werd echter steeds meer 'ontdekt' dat religie 'breder is dan kerkelijkheid' (Becker \& De Hart 2006: 7), al blijkt het nog moeilijk die andere religiositeit te beschrijven (Van Rooden 2004; SCP 2006). ${ }^{1}$ Wel is duidelijk dat de veelbesproken transformatie van religie zich ook binnen de meer traditionele religieuze uitingen voordoet, en daar de vorm aanneemt van ontkerkelijking. Daarmee zijn de veranderingen in religie onderdeel van een ook in andere domeinen van de samenleving veelvuldig herkend proces: het proces dat we doorgaans aanduiden als 'de-institutionalisering' (Gabriel 2000: 18; Luhmann 2002: 279).

Reeds in 1967 heeft de Duitse socioloog Thomas Luckmann in The Invisible Religion de seculariseringsthese verworpen: secularisatie is volgens hem een vorm van gezichtsbedrog. De reden daarvoor is dat in onze samenleving talloze vormen van het sacrale voorkomen. Het heilige in onze cultuur is volgens hem vooral geconcentreerd rond de waarden van de rationaliteit en van het soevereine individu. Luckmann heeft in dit verband als een der eersten gewezen op een 'privatisering' van religie en in beeld gebracht wat Van Harskamp later heeft omschreven als 'de in de grondstructuur van elke mens ingebakken noodzaak 
zich te transcenderen' (Van Harskamp 2000: 21). Anders dan de dominante seculariseringsthese achtte Luckmann ook deze geprivatiseerde religie 'religie', al sprak hij van de 'onzichtbare religie' (Luckmann 1967).

Andere recente theorieën die afscheid nemen van de oude seculariseringsthese, maar anderzijds nog nauw aansluiten bij de term 'religie', zijn onder meer Peter Bergers these van de 'desecularisatie' en de zogenaamde neoseculariseringsthese. Berger heeft in een publicatie uit 1999 zijn oude seculariseringsthese onjuist verklaard. Berger: 'De wereld vandaag de dag is enorm religieus, ze is allesbehalve de geseculariseerde wereld die voorspeld was door zoveel analisten van de moderniteit.' Berger gebruikt het woord 'desecularisering' om deze nieuwe ontwikkeling onder woorden te brengen. Hij tekent er tegelijk bij aan dat de uitzondering op die tegenbeweging nog steeds Europa is (Berger 1999: 9). Daar is nog steeds sprake van secularisering, maar nu is dat niet meer de norm, maar de te verklaren uitzondering. ${ }^{2}$

Daarnaast spreken sociologen als Chaves en Demerath van 'neosecularisering' om enerzijds aan te sluiten bij het oude seculariseringsparadigma, maar het daarnaast te herdefiniëren als betrekking hebbend, niet zozeer op de afname van religie als wel op de afname van religieuze autoriteit (Yamane 1997).

Verder is er ook de inmiddels tot krachtig nieuw paradigma uitgeroepen 'rationele-keuzetheorie van de religie', van Rodney Stark en zijn medewerkers, waaronder William Sims Bainbridge, Laurence Iannaccone en Roger Finke. Onderschreven Stark en Bainbridge aanvankelijk, in hun A theory of religion uit 1987, nog enkele basisaspecten van de seculariseringsthese, later heeft met name Stark de these ronduit dood verklaard, gewoonweg omdat ze in haar voorspelling dat de wereld in toenemende mate minder religieus zou zijn, faalde (Warner 1993; Stark 2006). Starks veelvuldige analyses van empirische gegevens uit de Verenigde Staten en met name van onderzoek onder hoog opgeleiden liet geen afname maar juist een toenemende vitaliteit van religie zien. Stark en de zijnen schrijven het toe aan het feit dat de overheid de markt ook in dit opzicht niet reguleert. Want alleen in een vrijgegeven markt kan, althans volgens de rationele-keuzetheoretici van de religie, de constant blijvende menselijke behoefte aan religie ook geactiveerd en gevoed worden door het aanbod op dit gebied; religie gedraagt zich immers niet anders dan andere zaken volgens economische wetmatigheden en is een zaak van de wisselwerking tussen vraag en aanbod. ${ }^{3}$

De Franse politiek filosoof Marcel Gauchet heeft met zijn in Nederland pas recent doorgedrongen boek Le désenchantement du monde nog op een andere manier bijgedragen aan het denken in termen van transformatie van religie. Hij spreekt in dat verband over 'het religieuze na de religie': 'zelfs wanneer we aannemen dat het tijdperk van de religies definitief afgesloten is, dan moeten we er niet aan twijfelen dat we (...) waarschijnlijk nooit compleet klaar zullen zijn met het religieuze' (Gauchet 1985: 200). In de lijn van Max Webers 'onttovering van de wereld' duidt ook Gauchet de geschiedenis van het Westen als een 'uittreden uit 
de religie' en in die zin als het einde van de religie. Anderzijds wijst hij op het feit dat religie in een nieuwe gedaante terugkeert, maar nu als 'gemeenschapsvormen die zich nog steeds richten op een transcendente en heteronome bron, maar zonder aanspraken op een machts- en waarheidsmonopolie' (Terpstra \& De Wit 2006: 50).

Een voorlopige conclusie moet dus zijn dat de doorgaans wat vlot geschetste beelden van een 'terugkeer' van religie en een 'geseculariseerde samenleving' het verdienen nader te worden verdiept en geproblematiseerd. Beide beelden, die in het publieke debat vaak zonder al te veel toelichting worden gehanteerd, verwijzen naar een veel meer gecompliceerde ontwikkeling, zoals ook in andere bijdragen aan deze bundel duidelijk zal worden. Veeleer is sprake van een 'transformatie van religie', die zich niet volledig laat uitdrukken in termen van secularisering en 'terugkeer'.

Al met al kan men onze situatie inzake religie misschien nog het best karakteriseren met de woorden van Hans Joas die constateert dat zowel de 'zekerheden van hen verdwenen zijn die religie voor overbodig en schadelijk hielden, maar ook die van gelovigen, die luidt dat er buiten het geloof slechts van verval sprake kan zijn' (Joas 2004: 15). Of men zou onze situatie, met de filosoof en socioloog Jürgen Habermas, 'postseculier' kunnen noemen, waarmee hij een samenleving aanduidt 'die zich instelt op het voortbestaan van religieuze gemeenschappen in een zich voortdurend seculariserende samenleving' (Joas 2004: 124).4

Een gevolg van de nuancering is dat de thema's van de terugkeer van religie en van de transformatie van religie ons sterker dan misschien verwacht met ons moderne zelf- en religiebeeld confronteren. Tegenover elkaar staan nu niet zozeer een geseculariseerd wereldbeeld, in de zin van 'vrij-van-religie' en religie - wat zo geschetst om heldere strategieën en stappen zou vragen, voor de ene kant (secularisatie) of voor de andere kant (religie) - maar een traditioneel, door de seculariseringsthese verondersteld beeld van religie en een nieuw beeld ervan. We proberen dat te laten zien aan de hand van een nadere ontvouwing van de seculariseringsthese.

Zoals gezegd staat de these aan veel kritiek bloot, empirisch en theoretisch. En toch klampen ook veel alternatieve theorieën nog sterk aan bij deze these. Dat heeft ermee te maken dat de seculariseringsthese, anders dan haar populaire interpretatie zegt, meer dan slechts de kwantitatieve bewering behelst dat religie en moderniteit zich omgekeerd evenredig tot elkaar verhouden, kortom dat er minder religie is naarmate er meer moderniteit is (Berger 2001: 443). Dat 'meer' zit hierin dat de seculariseringsthese ook ons inhoudelijk beeld van religie sterk heeft bepaald.

Om dat duidelijk te maken moet aandacht besteed worden aan het voor bijna alle seculariseringsthesen centrale aspect van 'differentiatie'. Met name Olivier Tschannen heeft in een bekend artikel uit 1991 een poging tot systematisering van 
de vele verschillende seculariseringstheorieën ondernomen. Hij is van mening dat, hoewel de seculariseringstheorie nergens in een eenduidige vorm te vinden is, 'differentiatie' een centraal begrip is in alle seculariseringstheorieën (Tschannen 1991: 404).

'Differentiatie' duidt een proces aan waardoor religie en religieuze instituties 'gedifferentieerd' worden van andere sferen. Het gaat hierbij om te beginnen om de differentiatie van het seculiere domein van het sacrale domein, oftewel de bevrijding van verschillende domeinen van de invloed van religie, maar vervolgens gaat het ook om de differentiatie van de verschillende symbolische subsystemen - economie, cultuur, onderwijs, gezondheid e.d. - ten opzichte van elkaar en om het autonoom worden van deze domeinen. Differentiatie leidt ertoe dat religie haar sociale invloed op veel aspecten van de samenleving verliest; zo domineert ze bijvoorbeeld niet langer meer het opvoedingssysteem. In plaats daarvan gaan de afzonderlijke subsystemen hun eigen interne logica volgen (Hamilton 2005: 188; Casanova 1994: 19 e.v.).

In de mate waarin de seculariseringsthese stelt dat religie in een zich moderniserende samenleving uiteindelijk zal verdwijnen, lijkt ze impliciet een begrip van religie te huldigen dat religie per definitie incompatibel maakt met differentiatie. Blijkbaar is religie van nature een alles 'totaliserend' fenomeen, of, anders gezegd, is haar core business het zich uitstrekken over de hele maatschappij. Zo dreigt de frase van de terugkeer van religie een synoniem te worden voor het aanspraak maken van religies op, opnieuw zoals vroeger, alomtegenwoordige, publieke invloed en betekenis. Denkt men zo over religie, dan is de constatering dat religies weer publiekelijk van zich doen spreken gemakkelijk uit te leggen als een terugkeer, of althans de gepoogde terugkeer, naar (ons beeld van) het verleden, toen religie nog het hele leven beheerste. De beknopt beschreven wetenschappelijke ontwikkelingen laten zien dat de huidige aanwezigheid van religie niet volgens deze eenvoudige schema's bekeken kan worden.

\subsection{RELIGIE}

In het voorafgaande is al op herhaalde plekken de vraag aan de orde geweest wat religie nu eigenlijk is. Die vraag is des te dringender geworden, nu men van transformatie van religie spreekt en nu men zich realiseert dat onze kijk op religie tot nu toe sterk gedomineerd was door één zeer bepaalde visie op religie (Gabriel 2000: 36). Nu komt de vraag op wat het criterium is om te bepalen of iets nog religie is. In de bespreking van de seculariseringsthese is ook duidelijk geworden hoe deze, zij het vaak impliciet en moeilijk tastbaar, steeds een bepaalde opvatting van religie veronderstelt. Religie lijkt dat te zijn bij de gratie van de afwezigheid waarvan onze maatschappij modern is. Tegen zo'n achtergrond is het moeilijk om de terugkeer van religie neutraal te benaderen.

Dat heeft ook veel te maken met een andere, hier nog niet genoemde, associatie die verbonden is met secularisering. In dit verband wijst men wel eens op de 
oorspronkelijk juridische betekenis van het woord 'saecularisatio' en op de negatieve connotaties die het woord 'saeculum' aanvankelijk had. Het staat als zodanig namelijk tegenover 'aeternum', dat eeuwigheid betekent, en in die oppositie had 'saeculum' de associaties van 'een door zonde en leed getekende, verlossingbehoeftige' wereld (Luhmann 2002: 279). Correctheidshalve moet hier opgemerkt worden dat het nog maar de vraag is of ons huidige woord secularisering direct terug te voeren is op dit van oorsprong juridische woord, maar een feit is wel dat de receptiegeschiedenis van het begrip secularisering ook steeds gewerkt heeft met geschiedfilosofische concepten van legitimiteit of illegitimiteit: in het kielzog van de oorspronkelijke betekenis van 'onteigening' en overdracht van oorspronkelijk kerkelijk bezit in wereldlijke handen heeft men zich namelijk ook steeds de vraag gesteld of de moderne tijd nu een legitieme erfgenaam is van de religie of niet (Blumenberg, Löwith; Zabel 1984: 8o9). Het wordt daardoor nog weer eens duidelijk hoeveel er gemoeid is met een opheldering van het fenomeen religie. Nu moet hier onmiddellijk opgemerkt worden dat noch de etymologie, noch de godsdienstwetenschappen tot eenduidige antwoorden komen op de vraag wat religie is.

Vaak tracht men de betekenis van een woord te achterhalen door naar de talige oorsprong ervan op zoek te gaan. Maar zoals bij veel woorden is die talige oorsprong ook bij 'religie' verre van eenduidig. Het is gangbaar om twee oorsprongen aan te wijzen: ofwel men voert het zelfstandige naamwoord 'religio' terug op het Latijnse werkwoord 'relegere'. Hiervoor wordt de Romeinse redenaar, politicus, advocaat en filosoof Marcus Tullius Cicero (106-43 voor Christus) aangehaald. ' 'Relegere' betekent letterlijk 'weer opnemen', 'herlezen' en 'bedenken'. Ofwel men verwijst naar de christelijke schrijver Lucius Caelius Lactantius (250-320) die voor de opvatting staat dat 'religio' in verband gebracht moet worden met het werkwoord 'religare', dat 'verbinden' betekent. ${ }^{6}$ Maar wat nu precies de oorspronkelijke betekenis is, is al vanaf het begin onderwerp van debat. Zo zet Lactantius zijn interpretatie van de oorsprong van religio expliciet af tegen die van Cicero. Volgens de Amerikaanse godsdienstwetenschapper Wilfred Cantwell Smith blijven deze twee herleidingen de bestudering van religie ook in de moderne tijd bepalen: men is ofwel van mening dat religie met objectieve werkelijkheden te maken heeft, met dat buiten de mens waarmee hij/zij is verbonden in religie, of men volgt in de lijn van Cicero de opvatting dat religie primair te maken heeft met de subjectieve houding, met de betrokkenheid waardoor men verbonden is (Smith 1962: 205). Zo nu en dan vindt men ook een derde interpretatie, volgens welke het woord 'religio' afgeleid is van 'lig', een wortel die ook in het Latijnse 'neclegere' voorkomt en die 'aandacht schenken', 'zorg besteden' betekent (Smith 1962: 205). Maar de ware etymologische oorsprong van het begrip blijft onduidelijk (zie ook Magnard 2006).?

Maar belangrijker nog dan het woord religie, met zijn onduidelijke etymologische herkomst, is het fenomeen religie dat zijn eigen specifieke historische ontwikkeling kent. Het gaat dan om wat we meestal en vaak onuitgesproken verstaan onder religie, dat wat de ons bekende, concrete grote wereldgodsdiensten (joden- 
dom, christendom, islam, hindoeïsme en boeddhisme) en de nieuwe vormen van religiositeit (waaronder new age) gemeenschappelijk hebben. Er is aan al die fenomenen blijkbaar iets gemeenschappelijk wat het rechtvaardigt en het mogelijk maakt om ze onder één noemer, 'religie', te brengen.

Wanneer we naar de oorsprong van dat religiebegrip zoeken, valt op dat we het pas in de moderne tijd vinden en dat het daarvóór minder omvattend van betekenis was dan vandaag de dag. In de 14de eeuw bijvoorbeeld functioneerden er nog meerdere begrippen om het fenomeen aan te duiden dat we vandaag de dag meestal met dit ene woord 'religie' aanduiden: men had het over 'fides' (geloof), 'leges' of 'sectae', waarbij men 'fides' vooral gebruikte om de eigen - dat wil zeggen christelijke - religie aan te duiden en 'leges' en 'sectae' om vreemde religies aan te duiden. 'Religio' stond in die tijd nog louter en alleen voor de verering van of de vrees en eerbied voor God. Pas in de moderne tijd gaat het woord religie het 'grote objectieve iets' betekenen (Smith 1962: 22) dat het vandaag de dag meestal betekent. Om precies te zijn is het in de 15de en 16de eeuw dat 'religio' de omvattendere betekenis krijgt van 'algemene relatie tot God' en 'eerbied of vrees voor God'. Het is ook in die tijd dat 'religio' iets algemeens gaat aanduiden, iets wat de mens van nature heeft en wat ook in niet-christelijke culturen te vinden is. En pas in de 17de eeuw bestaat er in Europa een werkelijke voorloper van het religiebegrip zoals het vandaag de dag door de godsdienstwetenschappen gebruikt wordt, in de betekenis namelijk van een ten opzichte van het eigen geloof neutrale term die het gemeenschappelijke van alle concrete religies probeert te benoemen en die niet meer de eigen religie als de enige ware religie tot maatstaf verheft. Al met al betekent het woord 'religie' in onze tijd, sinds het begin van de moderne tijd, beduidend meer dan daarvoor (Von Stietencron 1993).

Het begrip en fenomeen 'religie' wordt herhaaldelijk een moderne, westerse constructie genoemd. Dat betekent om te beginnen dat het fenomeen religie alleen verhelderd kan worden door ook het begrip 'moderne tijd' te verhelderen en door het te situeren in de context van de moderne tijd. Of, wat toegespitster geformuleerd, met de woorden van de Amerikaanse antropoloog Talal Asad die hier over de moderne tijd spreekt in termen van het seculiere: 'het concept van het seculiere kan niet zonder de idee van religie' (Asad 2003: 200). Ook hier blijkt de nauwe verwevenheid van de begrippen religie, moderniteit en, als een label voor de lotgevallen van religie in de moderne tijd en voor het karakter van de moderne tijd, secularisering.

Voorts betekent het van origine modern-zijn van 'religie' dat 'er in de andere dan de moderne, westerse, christelijk gevormde cultuur wellicht geen precies equivalent voor ons begrip van religie bestaat'. De betekenis van die uitspraak is niet zozeer het (simpele) feit dat andere culturen dit woord niet kennen, maar - veel fundamenteler - dat religie in onze betekenis in andere culturen ook als een voorwerp en als een fenomeen niet bestaat. Anders gezegd: in veel andere culturen is er geen afgebakend fenomeen van dat wat wij religie noemen in de werkelijkheid aan te wijzen dat met één woord te benoemen is (Von Stietencron 1993: 125). En 
zo wordt duidelijk dat het westerse begrip religie ook een westerse visie op de werkelijkheid en op religie reflecteert, namelijk de visie dat de werkelijkheid in principe op te delen is in twee domeinen: het domein van het seculiere of profane en het domein van het sacrale of heilige. Alleen een cultuur die de twee domeinen zo onderscheidt, als in principe twee van elkaar gescheiden domeinen, kan een begrip construeren voor die bereiken. ${ }^{8}$

Door religie als een bepaald domein van de werkelijkheid te zien ligt het voor de hand om vervolgens een duidelijke omschrijving te vragen. Maar die vraag stuit steeds vaker op kritiek en soms zelfs op weerstand, en de pogingen ertoe zijn dan ook mislukt gebleken. Volgens Winston King, auteur van het lemma 'religie' in de Encyclopedia of Religion van de befaamde Roemeense godsdienstwetenschapper Mircea Eliade, moeten we alleen al de 'poging om religie te definiëren, dat wil zeggen om een onderscheidend of mogelijkerwijs zelfs uniek wezenskenmerk of reeks van kwaliteiten te vinden die "het religieuze" onderscheidt van de rest van het menselijk leven' zien als een 'primair westerse aangelegenheid' (King 1987: 282). Talal Asad stelt dat er 'geen universele definitie van religie mogelijk is' (Asad 1993: 29). Toch laten we het hier niet bij die constatering. We wijzen op de verschillende definities die er in de loop van de geschiedenis zijn ontwikkeld en op de definitieproblematiek, omdat de wetenschappelijke en de maatschappelijke onzekerheid over waar de grens ligt tussen wat religie is en wat niet onduidelijk is.

Grofweg kan men de pogingen om religie te definiëren in twee kampen verdelen. De ene poging wordt 'essentialistisch' genoemd. Het is de poging om het wezen, de kern van religie te vatten. Kern en wezen worden dan vaak voorgesteld als liggend onder of achter de concrete manifestaties van religie. Nog anders gezegd: men ziet de afzonderlijke religies dan 'als takken van een boom' en 'religie' als de zichtbare stam van die boom. En als we maar goed genoeg kijken, zouden we een gemeenschappelijke structuur van betekenis kunnen ontdekken die tot een accurate, omvattende en overtuigende definitie van religie zou leiden, zo zou men de grondgedachte van een essentialistische definitie kunnen formuleren. De andere poging wordt 'functionalistisch' genoemd en bestaat erin dat men zich afzijdig houdt van een wezensaanduiding van religie en zich in plaats daarvan concentreert op de functie die religie voor de samenleving en/of het individu heeft.

Bij essentialistische definities moet men denken aan de omschrijvingen van Edward Burnett Tylor (1832-1917), die religie omschrijft als 'geloof in bovennatuurlijke wezens', of aan de omschrijving van James Frazer (1854-1941) die religie ziet als 'een geloof in machten die hoger zijn dan de mens en een poging om deze machten te behagen of gunstig te stemmen', of aan Rudolf Otto's (1869-1939) omschrijving van religie als de ervaring van het 'Heilige'.

Tot de functionalistische definities hoort om te beginnen die van Émile Durkheim (1858-1917) die religie beschreef als 'een samenhangend systeem van geloofsvoorstellingen en gebruiken die verbonden zijn met heilige zaken, dat wil 
zeggen zaken die onttrokken zijn aan het dagelijkse verkeer en als zodanig "verboden" zijn; deze geloofsvoorstellingen en gebruiken verenigen al diegenen die hierin geloven in één enkele morele gemeenschap die kerk wordt genoemd'. Ook de definitie van de antropoloog Bronislaw Malinowski (1884-1942) is een functionalistische: volgens hem houdt religie zich 'grotendeels bezig met de sacralisering van de crises van het menselijk leven, met name dan van de grootste crisis, de dood'.

Beide pogingen hebben hun eigen nadelen. Essentialistische definities worstelen met hun adequaatheid: ofwel ze zijn duidelijk in hun omschrijving, maar daardoor vallen er verschijnselen buiten de boot die algemeen wel als religieus beschouwd worden, of ze zijn te vaag in hun omschrijving, waardoor in principe alles 'religie' kan zijn. Voor de maatschappelijke praktijk betekent dit concreet dat er nieuwe vormen van religie zijn die eigenlijk, volgens een strikte opvatting van religie, buiten de definitie vallen en dus geen religie mogen heten - terwijl de betreffende fenomenen zichzelf wel als religieus beschouwen. En dus komt de vraag op wie er eigenlijk bepaalt wat religie is. Een ander probleem met essentialistische definities is dat ze vaak het probleem verleggen, omdat in de definitie woorden voorkomen die zelf weer om een definitie vragen, zoals 'transcendentie'9, 'het Heilige' of 'het bovennatuurlijke'.

Aan functionalistische definities kleeft het nadeel dat ze 'religie' meten aan een bepaalde functie ervan voor samenleving of individu. Het gevaar daarvan is dat de invulling van het religiebegrip daardoor te zeer afhangt van deze functie; in principe kan zo alles religie zijn en zo heeft het religiebegrip dus weinig contouren en slagkracht meer.

Er zijn vandaag de dag vele honderden religiedefinities (Pollack 1995: 163) die niet toevallig nog steeds niet onder één noemer gebracht zijn. Er wordt dan ook over de 'definitieproblematiek' van religie gesproken. Die problematiek wijst er om te beginnen op dat we geen sluitende definitie van religie kunnen vinden. We moeten de hoop laten varen dat we een universele definitie kunnen ontwerpen die alle religies en religieuze fenomenen in één omschrijving weet te vangen. Maar dit, op het eerste gezicht negatieve, resultaat wordt door steeds meer hedendaagse auteurs begrepen als de noodzaak om over religie na te denken in nauwe relatie met onze moderne cultuur en maatschappij. De vraag wordt verlegd van de poging om het raadsel 'religie' op te lossen - alsof het een 'groot objectief iets' is - naar een benadering die zich terdege bewust is van het feit dat het fenomeen en begrip religie een westerse constructie is, ontstaan in en door de moderne tijd en dus in nauwe samenhang met de identiteit van onze moderne tijd. ${ }^{10}$

Hoewel de woorden religie, godsdienst en geloof in de praktijk niet zelden door elkaar gebruikt worden en dit ook in deze bundel gebeurt, is het goed hier te wijzen op de verschillen - omdat zich in de afbakening van de begrippen discussies weerspiegelen die ook vandaag de dag het afbakenen van religie zo moeilijk maken. 
Anders dan het van origine Latijnse woord 'religie' is 'godsdienst' van oorsprong een Germaans woord dat van nature sterker het rituele element benadrukt en bovendien het aspect van een god of goden tot wie zich die dienst richt. In het Duits staat het woord 'Gottesdienst' nog steeds alleen daarvoor, voor de eredienst, of liturgie, terwijl het in het Nederlands vandaag de dag min of meer identiek is met religie, hoewel religie gezien kan worden als een neutraler begrip dan 'godsdienst'.

Het woord 'geloof' komt en kwam in de praktijk vaak voor in de combinatie met 'christelijk geloof'. In de christelijke theologie was het lang gebruikelijk om de eigen 'religie' niet als religie aan te duiden, maar als 'geloof', omdat in het woord 'religie' te veel het uiterlijke en culturele aspect naar voren kwam, terwijl 'geloof' eerder wees op een houding van overgave, waarbij het initiatief voorgesteld werd te liggen bij God.

In het protestantisme is het woord 'religie' met name belast geraakt door het werk van de Duitse protestantse theoloog Karl Barth (1886-1968) die zijn religiebegrip vooral ontwikkelde in scherpe kritiek op de 19de-eeuwse protestantse theoloog Friedrich Daniel Ernst Schleiermacher (1768-1834) en het religiebegrip dat hij in zijn Über die Religion. Reden an die Gebildeten unter ihren Verächtern ontwikkelde. In Barths ogen was religie 'een soort van zonde', omdat het 'de poging van de mensheid is om het goddelijke [voor Barth is dit het ongrijpbare] te begrijpen'. Religies waren in de ogen van Barth 'pogingen van de mens om zichzelf te rechtvaardigen en te sanctioneren voor een moedwillig en willekeurig geconstrueerd beeld van God' (aangehaald in: Idinopulos \& Wilson 1998: 114).

In de context van het toenemende contact en de dialoog met andere religies is ook het christendom zich als een 'religie' gaan zien, wat beschouwd moet worden als de erkenning van het feit dat ook het christendom een religie naast andere religies is die geen aanspraak kan maken op uniciteit en waarvan de waarheid niet gefundeerd kan worden door een beroep te doen op een bron die slechts voor gelovigen zelf toegankelijk is. De keuze voor het woord 'religie' reflecteert zo bezien de belangrijke opening van religies naar het publieke domein, omdat zich in de keuze voor dit woord de erkenning uitdrukt dat een deelname aan het publieke domein en aan de dialoog met andere, soortgelijke fenomenen, slechts denkbaar is door de aanspraak op een unieke openbaring, die alleen de 'eigen' gelovigen 'hebben' en begrijpen, te laten varen. Daarmee is ook een basisconditie aangegeven voor de presentie van religies in een moderne samenleving: het op een transcendente basis gegronde normatieve aspect van religies is moeilijk in te brengen in het publieke domein.

Een ander woord dat vaak gebroederlijk opduikt met 'religie' is het woord spiritualiteit. Het maakt vandaag de dag een grote opgang. Vermeld is reeds het gebruik van het woord door de Britse godsdienstwetenschappers Linda Woodhead en Paul Heelas, die 'spiritualiteit' hebben gereserveerd voor de getransformeerde religie. Ze hebben in hun boek The Spiritual Revolution. Why religion is 
giving way to spirituality op basis van empirisch onderzoek in de Britse plaats Kendal de stelling verdedigd dat religie in het Westen plaats aan het maken is voor spiritualiteit. De sterke historische band tussen westerse culturen en christendom, waarvoor kenmerkend is dat men een beroep doet op een transcendente autoriteit, is in snel tempo aan het oplossen. In de plaats daarvan is er een steeds minder gereguleerde situatie waarin het heilige ervaren wordt in nauwe relatie met het persoonlijke leven van mensen (Woodhead \& Heelas 2004: 10). Religie is voor Woodhead en Heelas nauw verbonden met 'de wijze van levenals', terwijl spiritualiteit 'nauw verbonden is met persoonlijk leven'. Bij religie wordt het persoonlijke leven ondergeschikt gemaakt aan de hogere autoriteit van transcendente betekenis, goedheid en waarheid, terwijl spiritualiteit het heilige oproept in de cultivering van het unieke persoonlijke leven, althans volgens Heelas en Woodhead (2005: 5). Maar terwijl religie en spiritualiteit in hun opvatting duidelijk tegenover elkaar staan, heeft Schneiders drie verschillende manieren van denken over die relatie onderscheiden. Ze onderscheidt om te beginnen de opvatting dat religie en spiritualiteit gescheiden ondernemingen zijn die geen noodzakelijke relatie met elkaar hebben. 'Religie en spiritualiteit zijn vreemdelingen aan het banket van transcendentie die elkaar in werkelijkheid nooit ontmoeten of met elkaar spreken.' Een tweede opvatting beschouwt religie en spiritualiteit als 'conflicterende realiteiten die omgekeerd evenredig met elkaar verbonden zijn: de meer spirituele is de minder religieuze en omgekeerd'. De derde opvatting beschouwt religie en spiritualiteit als 'twee dimensies van een enkele onderneming die, net als lichaam en geest, vaak in spanning zijn, maar wezenlijk voor elkaar zijn en samen één enkele werkelijkheid vormen' (Schneiders 2003: 164-165).

Een typisch Nederlands woord dat we vaak tegenkomen naast of in plaats van het woord 'religie' is het woord 'levensbeschouwing'. Het is een woord dat zijn synoniemen in andere talen niet kent - hoogstens kunnen het Duitse 'Weltanschauung' en het Engelse 'world view' als equivalenten gezien worden. Het woord 'levensbeschouwing' heeft in het Nederlands een zeer specifieke, institutionele geschiedenis, omdat het de eigenheid van de humanistische zuil moest funderen. Het wordt vaak gehanteerd als de neutralere term die, heel in het algemeen, 'een visie op hoe het leven goed of althans zo goed mogelijk is'. Religie wordt dan vaak behandeld als een subcategorie van levensbeschouwing, omdat er 'seculiere en religieuze levensbeschouwingen' zijn (Vroom 2002: 82).

Daarnaast is er het eveneens typisch Nederlandse woord 'zingeving', dat eveneens vaak als een zeer algemene, alles (ook religie) overkoepelende term wordt gehanteerd - terwijl anderen de verhouding tussen deze begrippen juist omdraaien en zingeving zien als een verbijzondering van religie. In de keuze voor dit woord draait het vaak om de uitleg die men geeft aan het woord 'geven'. Het woord kan staan voor het feit dat het in laatste instantie steeds de mens is die zin geeft aan de werkelijkheid, of voor het tegenovergestelde, dat ons de zin gegeven wordt. 


\subsection{RELIGIE IN HET PUBLIEKE DOMEIN}

Het thema van de terugkeer van religie doet zich vaak voor als de vraag welke rol religies in het publieke domein al dan niet mogen innemen of als de constatering dat religie zich merkwaardigerwijs weer in dit domein manifesteert. We zullen dit thema hier op twee manieren behandelen, om te beginnen door verwijzing naar het staatsrechtelijke principe van de scheiding tussen kerk en staat en vervolgens, een niveau dieper, door de aandacht te vestigen op de term 'publiek domein' en op de veranderingen daarin waarvan volgens veel sociologen sprake is vandaag de dag.

Het in menige grondwet verankerde principe van de scheiding tussen kerk en staat is het westerse middel om een publiek domein vorm te geven, dat wil zeggen een ruimte die niet eenzijdig in beslag genomen wordt door religies. In het derde deel van deze verkenning (zie met name de bijdrage van Van Bijsterveld) zal nader ingegaan worden op de betekenis en reikwijdte van dit principe vandaag de dag. Hier wordt daarom volstaan met drie opmerkingen daarover: om te beginnen moet opgemerkt worden dat dit principe in de Nederlandse grondwet niet als zodanig bestaat, althans niet in één artikel als zodanig verwoord is. Voorts heeft het principe in verschillende landen verschillende betekenissen en uiteenlopende praktische consequenties. Blijkbaar is het een verre van eenduidig principe, dat ondanks het woord 'scheiding' in de praktijk vele soorten banden tussen staat en kerk mogelijk maakt. Marcel ten Hooven en Theo de Wit hebben in hun recentelijk verschenen boek Ongewenste goden. De publieke rol van religie in Nederland eveneens gewag gemaakt van de diversiteit aan interpretaties en zelfs misverstanden die verbonden zijn met het principe van de scheiding van kerk en staat (Ten Hooven \& De Wit 2006: 28; zie ook WRR-rapport De Europese Unie, Turkije en de islam (2004). Ten derde moet opgemerkt worden dat het principe steeds meer onder druk staat, voornamelijk omdat er nieuwe vormen van religiositeit opduiken die krachtens dit principe aanspraak maken op bescherming, maar waarbij de aanduiding 'kerk' niet langer de lading dekt. Maar ook binnen de traditionele en 'kerkgebonden religies' verandert er in dit opzicht veel. Zoals gezegd is er ook van religiositeit sprake waar kerklidmaatschap of kerkbezoek gedaald zijn en nog steeds dalen. De in het woord 'kerk' veronderstelde institutionele manifestatie van religiositeit is voor veel van wat er in het religieuze landschap aan ontwikkelingen te zien is, steeds minder adequaat (in de zin van Max Weber: 'sinnhaft', adequaat).

Wanneer de betekenis van dit principe steeds vaker vragen oproept en het er sterk op lijkt dat het principe opnieuw reflectie behoeft om de volgende eeuw in te kunnen gaan, dan komt een nadere reflectie op het begrip 'publieke domein' het meest in aanmerking voor een overdenking van dit principe op een dieper gelegen niveau. Wellicht moet worden erkend dat het staatsrechtelijke principe van de scheiding van kerk en staat vooral verwees naar een historische uitwerking van een feitelijk veel fundamenteler beginsel. 
Met de term 'publieke domein' wordt, algemeen gesproken, doorgaans de openbare ruimte bedoeld, de ruimte waarin individuen met elkaar in gesprek zijn en waarin het publieke debat gevoerd wordt over zaken die de inrichting van samenleving aangaan. Vanzelfsprekend is het slechts in overdrachtelijke zin een ruimte. Wat deze 'ruimte' publiek maakt, is dat het gaat om 'zaken die het individuele en engere groepsbelang overstijgen en die van overwegend belang zijn voor de samenleving in haar geheel of delen ervan' (Kreukels \& Simonis 1988: 10). Het publieke domein is, met de woorden van een de belangrijkste theoretici op dit terrein, de filosofe Hannah Arendt, 'de wereld die wij gemeen hebben', het is een 'space of appearance' waarin de burgers kunnen en moeten handelen in het aanschijn van de anderen' (Arendt 1968: 59; Foqué \& Weyembergh 1997: 7).

Meer concreet worden onder de vraag naar de rol van religie(s) in het publieke domein kwesties begrepen als of religieuze overtuigingen als zodanig ingebracht mogen worden in het publieke debat over algemene maatschappelijke kwesties en of religieuze symbolen present mogen zijn in publieke ruimten en manifest mogen zijn in openbare functies. Het antwoord hierop lijkt vandaag de dag meer controversieel dan ooit. In dit debat wordt de publieke ruimte om die reden vaak een 'neutrale' ruimte genoemd.

Maar men verschilt aanzienlijk van mening over wat neutraliteit dan precies inhoudt. Betekent het dat ook zij die deze publieke ruimte betreden 'gedwongen zijn tot neutraliteit', of is de neutraliteit van de publieke ruimte eerder een voorwaarde scheppende eigenschap, waardoor 'deze de ontmoetingsplaats kan zijn van levensbeschouwingen, van identiteiten, van culturele diversiteit'? (Nissen 2004: 15; zie ook Belorgey 2005). In 'liberale kring koppelt men aan de neutraliteitsgedachte vaak de gedachte dat religie privaat is en dat het publieke terrein niet religieus en dus neutraal moet zijn' (Vroom 2002: 82-83). Een dergelijke opvatting wordt door weer andere auteurs geproblematiseerd: zij wijzen erop dat er achter die 'neutrale' inhoud feitelijk een zeer bepaald mens- en maatschappijbeeld schuilgaat.

"The most interesting issue sociologically is not the fact of progressive religious decline among the European population, but the fact that it is interpreted through the lenses of the secularization paradigm, and is therefore accompanied by a 'secularist' self-understanding that interprets that decline as 'normal' and 'progressive'. It is therefore seen as a quasi-normative consequence of being a 'modern' and 'enlightened' European. (...) While conservative religious persons are expected to tolerate behaviour they may consider morally abhorrent such as homosexuality, liberal secular Europeans are openly stating that European societies ought not to tolerate religious behaviour or cultural customs that are morally abhorrent, in so far as they are contrary to modern liberal secular European norms. What makes the intolerant tyranny of the secular liberal majority justifiable in principle is not just the democratic principle of majority rule, but the secularist teleological assumption, built into theories of modernization that one set of norms is reactionary, fundamentalist, and anti-modern, while the other is progressive, liberal, and modern". (Casanova 20o6: 24, 37; zie ook in Sévillia 2005 en McGrath 2006) ${ }^{11}$ 
Ook Kunneman, verderop in deze bundel, problematiseert het 'neutrale wereldbeeld' in de zin dat dat feitelijk vaak een zeer specifieke invulling krijgt. Ten aanzien van het begrip neutraliteit kan men een driedeling maken tussen exclusieve, inclusieve en compenserende neutraliteit (Van der Burg 2006). De exclusieve neutraliteit is beter bekend onder de Franse naam 'laïcité', een begrip dat ook in Nederlandse discussies over religie en publiek domein zeer regelmatig wordt ingebracht (zie voor een overzicht van geschiedenis en recente discussies in Baubérot 2004; Sevillia 2005; Machelon 2006). In dit concept van neutraliteit wordt 'levensbeschouwing geheel uitgesloten uit de publieke sfeer'. Religie hoort in de privésfeer, de publieke sfeer dient van religie vrij te zijn. Zonder in het bestek van dit betoog daarbij volledig te kunnen zijn, is er, prima facie, wel een aantal meer algemene opmerkingen te maken bij deze positie. We raken hier een belangrijke kwestie die mede onder invloed van de opkomst van de islam (mag de griffier een hoofddoek dragen?) een nieuwe actualiteit lijkt te krijgen. De laïciteit en de in Frankrijk zwaar bevochten scheiding van kerk en staat, van religie en publiek domein, worden in dat verband ook in het Nederlandse debat nadrukkelijk ingebracht als strategie om de in dat verband meestal vooral negatieve effecten van religie in het publieke domein te voorkomen of te bestrijden. Ook dit soms nogal gemakkelijk gehanteerde begrip van de laïciteit vraagt om een genuanceerde benadering: onder het algemene begrip gaan veel nuances en (impliciete) interpretaties schuil. We kunnen er in het bestek van dit hoofdstuk niet al te lang bij stilstaan, maar willen er wel op wijzen dat ook achter dit begrip een niet altijd adequaat onderscheiden set van nuances en interpretaties schuilgaat (zie onder veel meer Sévilla, 2005: 77; Belorgey 2005; Cie. Machelon 2006; zie in deze bundel de bijdrage van Jansen en ook die van Vermeulen).

In het concept van inclusieve neutraliteit daarentegen krijgen burgers juist zoveel mogelijk de gelegenheid om overeenkomstig hun eigen levensovertuiging te spreken en te handelen. Deze vorm van neutraliteit eist dat alle levensovertuigingen gelijk behandeld worden, maar niet dat ze buiten haakjes worden gezet. Inclusieve neutraliteit brengt de veelkleurigheid tot uiting, waarbij de overheid iedere groep gelijkelijk de ruimte laat en soms ondersteunt, maar geen enkele bevoordeelt.

Een derde mogelijkheid is de compenserende neutraliteit. Evenzeer als bij de inclusieve versie is er ruimte voor godsdienst in de publieke sfeer, maar de proportionaliteitsnorm voldoet niet wanneer er structurele of historische ongelijkheden bestaan die het voor minderheden moeilijker maken hun godsdienst of cultuur op voet van gelijkheid te beleven. Als men alles aan de vrije markt zou overlaten, zouden sommige groepen geen kans krijgen. Dat kan een argument zijn om hen extra te steunen. Een op deze visie gebaseerde argumentatielijn vinden we in het recent uitgebrachte rapport van de commissie-Machelon (Machelon 2006), die in een voor Franse verhoudingen opzienbarend rapport pleit voor de mogelijkheid van door (lokale) overheden georganiseerde financiële steun voor de bouw van moskeeën. 
Overigens hangen de verschillen van interpretatie van neutraliteit en van het principe van de scheiding tussen kerk en staat ook nauw samen met de manier waarop men de 18de-eeuwse Verlichting, als de geboorteplaats van de moderne neutrale staat, interpreteert. Er wordt nogal eens van uitgegaan dat de Verlichting een ronduit negatieve houding aannam ten opzichte van religie. Maar het was al de Duitse filosoof en cultuurhistoricus Ernst Cassirer die in zijn studie over de filosofie van de Verlichting (Cassirer 1932) opmerkte:

"Als we zouden moeten kijken naar een algemene karakterisering van het tijdperk van de Verlichting, dan zou het traditionele antwoord luiden dat haar fundamentele kenmerk duidelijk een kritische en sceptische houding ten opzichte van religie is. Maar wanneer we dat traditionele beeld proberen te toetsen aan concrete historische feiten, dan moeten we al snel de grootste twijfels en het grootste voorbehoud huldigen als het om het Duitse en Engelse verlichtingsdenken gaat. De Franse 18de-eeuwse filosofie lijkt het traditionele beeld daarentegen des te meer te bevestigen."

Steeds vaker laten ook hedendaagse studies naar de Verlichting zien dat de basishouding van de Verlichting ten opzichte van religie niet die van radicale verwerping is geweest, maar aanzienlijk genuanceerder was en dat ze zeker niet als een 'louter onchristelijke beweging of wijsbegeerte beschreven kan worden' (Van Rooden 1988: 1; zie ook uitvoerig hierover McGrath 2006).

Een ander element dat aandacht verdient in deze zijn de veranderingen die zich volgens sociologen voltrekken in het publieke domein zelf. Een korte historische terugblik laat zien dat het concept pas ontstaat in de moderne tijd. In de feodale samenleving bestond er nog geen onderscheid tussen de openbare en de privésfeer. Pas bij aanvang van de moderne tijd gaan de feodale machten in een langdurig proces van polarisering tot ontbinding over, en vallen als het ware uiteen in private en publieke elementen. De vraag of religies (weer) een rol mogen innemen in de publieke ruimte, wordt vaak gepareerd door te stellen dat religie een privézaak is.

Er zijn twee mogelijke reacties denkbaar op dat gegeven en twee mogelijke manieren om de vraag te beantwoorden of religie wel een rol in het publieke domein mag spelen. De ene is een empirische, de ander een meer principiële, theoretische. Op empirisch niveau staan de beweringen van hen die constateren dat de secularisering van religie tot een privatisering ervan heeft geleid tegenover met name iemand als de socioloog José Casanova (1994) die, integendeel, spreekt van een 'deprivatisering' van religie en van 'publieke religies'. Maar zelfs wanneer er een krachtig empirisch bewijs zou bestaan voor de toegenomen publieke rol die religies aan het innemen zijn, kunnen we niet voorbij gaan aan de theoretische vraag hoe 'we' over de publieke rol van religies in het publieke domein dienen te denken en oordelen, of we een verandering daarvan toelaatbaar moeten achten of niet. 
Om te beginnen lijken we te moeten constateren dat de vraag naar de rol van religie in het publieke domein zelf een publieke, maatschappelijke kwestie en vraag is geworden. Ook religie is een 'essentially contested concept', dat voordurend discussies uitlokt. Bovendien geldt ook hier, zoals met betrekking tot secularisering en de terugkeer van religie eerder in dit luik is geconstateerd, dat ook dit schema geen recht doet aan de nieuwe sociale werkelijkheid. Wie namelijk het schema hanteert van privé versus publiek kan in de constatering van een van de belangrijkste sociologen op dit punt, José Casanova, namelijk dat religies sinds de jaren '8o publiek zijn geworden, alleen maar een (mogelijk) gevaarlijke politisering van religie zien en een dreigende terugval achter moderne verworvenheden. Maar die positie gaat voorbij aan het feit dat er volgens Casanova inmiddels sprake is niet van één publiek domein, maar van drie soorten van openbaarheid: de staat, de politieke samenleving en de burgerlijke samenleving. En zo zijn publieke, openbare religies denkbaar die weliswaar de scheiding van kerk en staat respecteren, maar anderzijds toch het recht voor zich opeisen om in woord en daad in te grijpen in de openbaarheid van de burgerlijke samenleving. Casanova opent kortom een nieuwe dimensie van publiek domein: het gaat dan om 'die maatschappelijke handelings- en discoursvelden, waarin belangen georganiseerd, maatschappelijke perspectieven en handelingsmogelijkheden uitgeprobeerd, ontwerpen van een mogelijke maatschappelijke toekomst verwerkt, tegenstand tegen structurele onrechtvaardigheid en ontwaarding van mensen gemobiliseerd en zo de publieke herinnering aan het menselijke van een menselijk samenleven levendig gehouden wordt' (Werbick 2000: 102).

Een meer theoretische benadering van het publieke domein en met name van de veranderingen daarin laat zien dat de moderne publieke sfeer nog 'bij uitstek een transparante sfeer was', zoals de filosoof Gianni Vattimo zegt. Ze werd in de moderne tijd nog gedomineerd door de idee 'dat de wereld rationeel beheerst en gepland kan worden' (Vattimo aangehaald in: Weyns 1998: 260). In die moderne setting is het precies die idee van maakbaarheid en vooruitgang die de publieke sfeer behoedt voor mogelijke desintegratie - een gevaar dat theoretisch voortdurend op de loer ligt, omdat individuen kunnen overwegen zich niet al te veel aan te trekken van de publieke zaak en er zich uit terug te trekken (Weyns 1998: 262). Maar in onze tijd, die door velen gekenschetst wordt als een postmoderne tijd, zouden de sferen van het private en het publieke in toenemende mate elkaar zijn gaan doordringen. Daardoor zou zowel de publieke als de private sfeer getransformeerd zijn. Beide domeinen dringen in toenemende mate elkaar binnen. Van een duidelijk onderscheid is geen sprake meer.

Bovendien is de publieke sfeer, volgens de Italiaanse filosoof Gianni Vattimo, 'overtransparant' geworden. Hij doelt op het feit dat 'de profileratie van standpunten en meningen die allerlei groepen en individuen via de massamedia verspreiden en voor iedereen toegankelijk maken zulke vormen heeft aangenomen dat 'de werkelijkheid lijkt te zijn verdwenen onder de talloze gezichtspunten waaronder zij kan worden beschouwd'. ${ }^{12}$ Het wordt alleen maar 'moeilijker om te spreken van één realiteit'. 
Dat laatste nu lijkt in toenemende mate ook op te gaan voor religie. Daarmee wordt ook duidelijk dat de definitieproblematiek niet louter en alleen een binnen-godsdienstwetenschappelijke of theologische kwestie is. Nu religie zich op vele nieuwe wijzen voordoet en de rede, traditioneel gezien als de hoeder van het publieke domein, en het geloof, als de plek van het private, door elkaar lopen, zijn opmerkingen als dat 'het hebben van een religieuze overtuiging onverenigbaar is met elementair intellectueel fatsoen' (Philipse 2004: 164; Nissen 2004: 15) niet meer te beslechten door een neutrale rede.

De opdeling van het publieke domein in drie vormen van openbaarheid, door Casanova, wees er al op dat er een einde gekomen is aan het eenvoudige (dichotome) schema van publiek versus privaat. En daarmee zijn ook de andere binaire schema's die dit basisschema volgen, zoals die tussen neutraal en religieus en tussen rede en geloof aan het wankelen geraakt. Ten aanzien van religie staat daarmee, misschien meer dan ooit, de vraag op de maatschappelijke agenda, niet alleen wat religie is, maar wie erover gaat en hoe wij, in het moderne WestEuropa, religie zouden definiëren.

\subsection{SLOT}

In dit eerste hoofdstuk van deze bundel verkenningen gaven we, ter introductie, een overzicht van enkele belangrijke wetenschappelijke inzichten en begrippen die een belangrijke rol spelen in de recente discussies over de relatie tussen religie en publiek domein. Centraal stonden daarin twee tegenstellingen, die tussen secularisering en terugkeer van religie enerzijds en die tussen privé- en (neutraal) publiek domein anderzijds. Deze twee begrippen en tegenstellingen kenmerken in belangrijke mate het recente maatschappelijke debat over religie.

Ten aanzien van beide tegenstellingen is gebleken dat ze, om te beginnen, wetenschappelijk gezien niet meer adequaat gevonden worden. Zo is er veeleer sprake van een transformatie dan van een secularisatie en is er, alhoewel er vele aanwijzingen zijn voor een 'privatisering' van religie, geen reden om aan te nemen dat religie zich uit het publieke domein laat verdrijven. Er is een redelijk vermoeden gerezen dat deze wetenschappelijke vragen en discussies zullen doorwerken in maatschappelijke en publieke discussies. Zowel maatschappelijk als bestuurlijk klinkt de op het oog vooral wetenschappelijk interessante definitie- en afbakeningsproblematiek (wat kunnen we nog onder religie verstaan en wie definieert dat?) door in een aantal concrete kwesties, zoals in het derde luik van deze verkenning nog duidelijk blijken zal (zie bijvoorbeeld de bijdragen van Kunneman en Schilderman). Wat is de bestuurlijke betekenis van het feit dat religie steeds minder duidelijk en gezaghebbend kan worden gedefinieerd? Hoe werkt de genoemde transformatie van religie, die ook in het volgende luik nog prominent aan de orde zal zijn, door in de manier waarop religie zich met het publieke domein verbindt? 


\section{NOTEN}

Zie voor een poging daartoe het tweede luik van deze verkenning, met name het daarin opgenomen hoofdstuk van Kronjee en Lampert.

Door dergelijke ontdekkingen is ook de eurocentrische blik van de seculariseringsthese ontmaskerd en onder kritiek komen te staan als geenszins van toepassing op de Noord-Amerikaanse situatie. In dit verband wordt vaak weer verwezen naar de Franse politieke denker en historicus Alexis de Tocqueville (1805-1859) als degene die in zijn Democracy in America (1835) al wees op de grote betekenis van religie in de Verenigde Staten.

3 Religie heeft volgens Stark c.s. te maken met een specifiek soort verlangens, namelijk die verlangens waaraan door andere terreinen van het maatschappelijk leven principieel niet voldaan kan worden, omdat het gaat over het onbeheersbare.

Al vindt Joas deze formulering problematisch, omdat het woord een plotselinge toename van religiositeit na haar grootse afname suggereert (Joas 2004: 124).

Cicero: ' $Z i j$ die alles wat met de verering van de goden te maken heeft, zorgvuldig uitoefenen en als het ware steeds weer doorlezen, er gewetensvol acht op slaan, worden aangeduid als religiosi, afgeleid van "relegere” (...).' ('qui autem omnia quae ad cultum deorum pertinerent diligenter retractarent et tamquam relegerent sunt dicti religiosi ex relegendo (...)'), (in: M. T. Cicero, De Natura Deorum II., 72). Wilfred Cantwell Smith duidt Cicero's interpretatie van 'religio' als 'veeleer een kwaliteit dan een substantie, een subjectieve houding van de betroffende persoon veeleer dan op een objectieve handeling of entiteit'. Volgens Cicero is een religieus persoon iemand die 'zorgvuldig is in zijn bidden'. Lactantius verwerpt deze interpretatie met als argument dat vroomheid 'turns not on' de subjectieve vraag hoe mensen bidden, maar veeleer op de objectieve vraag wie ze aanbidden. Volgens Lactantius is het feit dat er echte verplichtingen zijn die vervuld moeten worden 'the root of the matter'. Lactantius: 'de naam religie is afgeleid van "the bond of piety", omdat God de mens aan zichzelf gebonden heeft en hem door vroomheid heeft gebonden. Want we moeten Hem als een meester dienen en Hem als vader gehoorzamen.' (Smith 1962: 204) Lactantius: 'We hebben gezegd dat het woord "religie" afgeleid is van de "keten van de vroomheid", omdat God de mens aan zich gebonden en door de vroomheid vastgebonden heeft, omdat het noodzakelijk is dat wij hem dienen als een heer en gehoorzamen als een vader.' ('diximus nomen religionis a vinculo pietatis esse deductum, quod hominem sibi deus religaverit et pietate constrinxerit, quia servire nos ei ut domino et obsequi ut parti necesse est.' aangehaald in: Smith 1962: 204).

De oorspronkelijke betekenis van de term 'religio' was al vroeg een twistpunt onder auteurs. Zo wijst Lactantius Cicero's herleiding van religio af, waartegenover hij zijn eigen herleiding van het woord religio zet.

Cfr.: W. King, 'Religion', in: Encyclopedia of Religion. Letterlijk betekent het 'transcendente' het 'overstijgende'. Het woord vormt de tegenhanger van het 'immanente', letterlijk: het in-zich-blijvende en dat wil in de praktijk zeggen: het hier en nu, het aardse. 
10 Ik spreek van 'nog steeds', omdat het zogenaamde project van de moderne tijd in onze tijd steeds meer in duigen is komen te vallen. Zo althans is de inmiddels gebruikelijke aanduiding van de 'postmoderniteit' te zien: niet als een periode na de moderniteit, maar als een kritische visie op haar pretenties.

11 Zie hierover ook de rede van Willem-Jan Otten: 'Het wonder van de losse olifanten. Een rede tot de ontwikkelden onder de verachters van de christelijke religie', Amsterdam: G.A. van Oorschot.

12 Zie over de niet slechts instrumentele functie van de huidige media voor religie: het essay van Hent de Vries. 


\section{LITERATUUR}

Aldridge, A. (2001) Religion in the Contemporary World. A Sociological Introduction, Malden MA: Blackwell Publishers.

Arendt, H. (1968) De mens. Bestaan en bestemming, Utrecht: Aula (vertaling van: Idem (1958), The Human Condition, Chicago: The University of Chicago Press).

Asad, T. (2003) Formations of the Secular. Christianity, Islam, Modernity, Stanford: Stanford University Press.

Asad, T. (1993) Genealogies of Religion. Discipline and Reasons of Power in Christianity and Islam, Baltimore/London: The Johns Hopkins University Press.

Baubérot, J. (2004) Laïcité 1905-2005, entre passion et raison, Paris: Editions du Seuil.

Becker, J., J. de Hart (2006) Godsdienstige Veranderingen in Nederland. Verschuivingen in de binding met de kerken en de christelijke traditie, Sociaal en Cultureel Planbureau, Den Haag

Belorgey, J.-M. (2005) La Laicité. zieme Conférence Erasme-Descartes: Tolerance, laïcite et integration, Amsterdam, décembre 2005.

Berger, P. (2001) 'Reflections on the Sociology of Religion Today', Sociology of Religion $62,4: 443-454$.

Berger, P. (ed.) (1999) The Desecularization of the World. Resurgent Religion and World Politics, Grand Rapids: Eerdmans.

Blumenberg, H. (1966) Die Legitimität der Neuzeit, Frankfurt am Main: Suhrkamp.

Borgman, E. (2006) Metamorfosen: over religie en moderne cultuur, Kampen: Klement.

Borgman, E., G. van den Brink \& T. Jansen (red.) (2006) Zonder geloof geen democratie (Christen Democratische Verkenningen), Amsterdam: Boom.

Burg, W. van der (2005) Over religie, moraal en politiek. Een vrijzinnig alternatief, Kampen: Ten Have.

Burg, W. van der (2006) 'Over hoofddoekjes, zwarte kousen en de seculiere samenleving. De noodzaak van een inclusieve democratie en een theologie der voorlopigheid' (rede uitgesproken bij de opening van het academisch jaar 2006/2007 aan de Theologische Universiteit Kampen op 4 september 2006).

Casanova, J. (2004) 'Der Ort der Religion im säkularen Europa', Transit 27: 86-107.

Casanova, J. (1994) Public Religions in the Modern World, Chicago: The University of Chicago Press.

Casanova, J. (2006) Religion, European Secular Identities and European Integration, blz. 23-41 in: K. Michalski (ed.), Religion in the New Europe, Budapest/New York: Central European University Press.

Cassirer, E. (1955) The Philosophy of the Enlightenment, Boston: Beacon Press.

Dekker, G. (1977) Gekerkerd geloof. Vertrossing van godsdienst en kerk, Baarn: Ambo.

Dekker, G. (1975) De mens en zijn godsdienst, Bilthoven: Ambo.

Demerath, N.J. (200o) 'Secularization', blz. 2482-2491 in: E.F. Borgatta, R. J.V. Montgomery (eds.), Encyclopedia of Sociology, Second Edition, Volume 4, New York: Macmillan.

Durkheim, E. (1975) Religion, morale, anomie (Textes, vol. 2), Paris: Les Editions de Minuit. 
Foqué, R. \& M. Weyembergh (red.) (1997), Filosofische aspecten van het privé-publiek debat, Brussel: vuв Press.

Fox, J., (2005) ‘Secularization', blz. 291-305, in: J. Hinnells (ed.), The Routledge companion to the study of religion, New York: Routledge.

Gabriel, K. (1996), 'Gesellschaft im Umbruch - Wandel des Religiösen', blz. 31-49, in: H.-J. Höhn (Hrsg.), Krise der Immanenz. Religion an der Grenze der Moderne, Frankfurt am Main: Fischer Taschenbuch Verlag.

Gabriel, K. (200o) Wie überlebt das Christentum?, Freiburg im Breisgau: Herder.

Gauchet, M. (1985) Le désenchantement du monde, Paris: Gallimard 1985.

Gauchet, M. (2006) Religie in de democratie, Amsterdam: SUN.

Habermas, J. (2001) Glauben und Wissen. Friedenspreis des Deutschen Buchhandels 2001, Frankfurt am Main: Suhrkamp.

Hamilton, M. (2005) The Sociology of Religion. Theoretical and Comparative Perspectives, New York: Routledge.

Harskamp, A. van en E. Borgman (1998) De religieuze ruis in Nederland. Thesen over de versterving en wedergeboorte van de godsdienst, Zoetermeer: Meinema.

Harskamp, A. van (200o) Het nieuw-religieuze verlangen, Kampen: Kok.

Heyde, L. e.a. (1977) Wat gebeurt er met de levensbeschouwing? Baarn: Ambo.

Hooven, M. ten, T. de Wit (red.) (2006), Ongewenste goden. De publieke rol van religie in Nederland, Amsterdam: SUN.

Idinopulos, T.A. \& B. Wilson (eds.) (1998) What is religion? Origins, Definitions, and Explanations, Leiden/Boston/Köln: Brill.

Joas, H. (2004) Braucht der Mensch Religion? Über Erfahrungen der Selbsttranszendenz, Freiburg: Herder.

Jörns, K.-P. (1999) 'Renaissance der Religion? Was Menschen heute glauben’, blz. 23-34 in: K. Hofmeister, L. Bauerochse (Hrsg.), Die Zukunft der Religion. Spurensicherung an der Schwelle zum 21. Jahrhundert, Würzburg: Echter.

Kehrer, G. (1997) 'Max Weber', blz. 121-132 in: A. Michaels (Hrsg.), Klassiker der Religionswissenschaft. Von Friedrich Schleiermacher bis Mircea Eliade, München: Beck.

King, W. (1987) ‘Religion’, blz. 283-293 in: M. Eliade, The Encyclopedia of Religion, New York: Macmillan.

Kreukels, A.M.J. \& J.B.D. Simonis (red.) (1988) Publiek domein: de veranderende balans tussen staat en samenleving, Meppel-Amsterdam: Boom.

Lübbe, H. (1971) Säkularisierung. Geschichte eines ideenpolitischen Begriffs, Freiburg im Breisgau: Alber (3de oplage).

Luckmann, Th. (1967) The Invisible Religion, London: Collier-Macmillan.

Luhmann, N. (2002) Die Religion der Gesellschaft, Frankfurt am Main: Suhrkamp.

Machelon, J.-P. (2006) Rapport du Commission de réflexion juridique sur les relations des cultes avec les pouvoirs publics, Paris: La Documentation Francaise.

McGrath, A. (2006) De ondergang van het atheïsme. Opkomst en verval van het ongeloof in de moderne wereld, Kampen: Ten Have.

Nissen, P. J.A. (2004) Tussen dogma en drama. Rede ter gelegenheid van de 81ste dies natalis van de Katholieke Universiteit Nijmegen, Nijmegen: Thieme Mediacenter.

Norris, P. en R. Inglehart (2004) Sacred and Secular. Religion and Politics Worldwide, Cambridge: Cambridge University Press. 
Pollack, D. (1995) 'Was ist Religion? Probleme der Definition', in: Zeitschrift für Religionsforschung 3, 163-190.

Schneiders, S. (2003) 'Religion vs. Spirituality: A Contemporary Conundrum', Spiritus 3: $163-185$.

Sengers, E. (ed.) (2005) The Dutch and their Gods. Secularization and Transformation of Religion in the Netherlands since 1950, Hilversum: Uitgeverij Verloren.

Sévilla, J. (2005) Quand les catholiques étaient hors la loi, Paris: Tempus.

Smith, W.C. (1962) The Meaning and End of Religion. A New Approach to the Religious Traditions of Mankind, New York: The Macmillan Company.

Smolenaars, E. (2006) 'De sociologie is van god los', NRC Handelsblad 23 mei.

Stietencron, H. von (1993) 'Der Begriff der Religion in der Religionswissenschaft', blz 111-137 in: W. Kerber (Hrsg.), Der Begriff der Religion, München: Kindt Verlag.

Stark, R. (2006) The Victory of Reason. How Christianity Led to Freedom, Capitalism, and Western Succes, New York: Random House.

Thomas, S.M. (2000) 'Taking Religious and Cultural Pluralism Seriously: The Global Resurgence of Religion and the Transformation of International Society', Millennium: Journal of International Studies 29, 3: 815-841.

Tschannen, O. (1991) 'The Secularization Paradigm: A Systematization', Journal for the Scientific Study of Religion 30, 4: 395-416.

Vries, H. De (1999) Philosophy and the Turn to Religion, Baltimore and London: The Johns Hopkins University Press.

Vroom, H., H. Woldring (red.) (2002) Religies in het publieke domein, Zoetermeer: Meinema.

Walf, K. (Hrsg.) (1983) Stille Fluchten. Zur Veränderung des religiösen Bewusstseins, München: Kösel.

Walf, K. (Hrsg.) (200o) Erosion. Zur Veränderung des religiösen Bewusstseins, Luzern: Edition Exodus.

Warner, R.S. (1993) 'Work in Progress Toward a New Paradigm for the Sociological Study of Religion in the United States', in: The American Journal of Sociology, 98, 5: 1044-1093.

Werbick (2000) 'Religion ist keine Privatsache! Theologische Einwände gegen eine politisch allzu bequeme Floskel', blz. 90-105 in: W. Thierse (Hrsg.), Religion ist keine Privatsache, Düsseldorf: Patmos.

Weyns, W. (1998) 'Grensschermutselingen. Een sociologische verkenning van de grens tussen privé en publiek domein, in: Tijdschrift voor Sociologie 19, 3: 247-270.

Woodhead, L. \& P. Heelas (with B. Seel, B. Szerszynski \& K. Tusting) (2005) The Spiritual Revolution. Why religion is giving way to spirituality, Malden: Blackwell Publishing.

Wuthnow, R. (1992) Rediscovering the Sacred: Perspectives on Religion in Contemporary Society, Grand Rapids: Eerdmans.

Zabel, H. (1984) ‘Säkularisation, Säkularisierung', blz. 789- 829 in: O. Brunner, W. Conze, R. Koselleck (Hrsg.), Geschichtliche Grundbegriffe. Historisches Lexikon zur politisch-sozialen Sprache in Deutschland, Band 5, Stuttgart: Klett-Cotta.

Zahrnt, H. (1992) Gotteswende. Christsein zwischen Atheismus und Neuer Religiosität, München: Piper. 


\title{
2 RELIGION IN THE AGE OF CONTINGENCY ${ }^{1}$
}

\author{
Hans Joas
}

In his book A Far Glory. The Quest for Faith in an Age of Credulity ${ }^{2}$ the wellknown sociologist of religion and Protestant thinker Peter Berger recounts an old American joke: "Two friends meet on the street in southern California. One looks very unhappy, and the other asks him why. 'I now have a job. A terrible job.' 'What's so terrible about it?' 'Well, let me tell you what I have to do. I work in an orange grove. All day long I sit in the shade, under a tree, and these other guys bring me oranges. I put the big ones in one basket, the little ones in a second basket, and the in-between ones in a third basket. And that's what I do all day long.' His friend says, 'I don't understand. This seems to me like a very pleasant job. What bothers you about it?' To which the first replies, 'All those decisions!'” (pp. 175f.).

This joke brings us directly into the heart of the topic of religion, contingency, and pluralism. Nobody denies that the increase in the number of options for individual action as it results from modernization processes leads to an increase in the number of decisions that have to be made, and that this increase is experienced by many people not as a realization of their freedom, but as a coercion to be free. The notion of contingency has become familiar for such paradoxical connections between individual freedom and a feeling of coercion. Likewise, nobody denies that the opportunity to decide, i.e. the existence of a certain space for selfdetermination, leads to a pluralism of cultures, subcultures, and individuals or stabilizes an already pre-given pluralism. But the ideas on how contingency and pluralism are related to each other differ widely, particularly in the area of religion. What are the consequences of contingency and pluralism for our value commitments, for faith, its vitality and tradition? The interpretations of Peter Berger to whom I owe the joke at the beginning, are particularly influential both in academic and in religious circles. In the following, I will use them as a foil against which I can clarify my own interpretations.

Peter Berger's emphasis is not so much on contingency, but on pluralism as such. Pluralism he defines - very close to ordinary usage - as "the co-existence with a measure of civic peace of different groups in one society" (p. 37). Religious pluralism is then "just one of several varieties of the phenomenon"; since the definition of the term 'co-existence' requires some amplification, he writes that "in the present context it implies more than abstaining from mutual slaughter; rather, it denotes a certain degree of social interaction". Berger puts special emphasis on this fact because co-existence without interaction, social life with insurmountable social barriers between groups, could not really - according to Berger - be called 'pluralism'. 
Berger is fully aware that modern pluralism is not a completely new thing in the world, although he tends to consider it the exception and not the rule in world history. Our modern pluralism is seen to be "uncannily similar" to that of antiquity, particularly to the life conditions of the big city-states of "late Hellenistic and Roman times". The only real specificity of modern pluralism then is nothing but its extent: the ever larger and more heterogeneous urban areas of our time, in which frequently human beings from all cultures live closely together and constantly run into each other. The culture of these urban areas and therefore of pluralism permeates the rural areas more and more if these have not been almost completely urbanized themselves.

One could now start analyzing in precise quantitative terms whether this assumption truly characterizes all cities or regions today, but much more important for Berger and also for my own project is the question of the socio-psychological dynamics of this pluralism. Berger makes very strong claims at this point. For him the peaceful co-existence of cultures and religions without major contact barriers between them necessarily leads to what he calls 'cognitive contamination', a mixture of diverse lifestyles, values and beliefs. His psychological background assumption is that people, when they encounter other values and worldviews, inevitably come to the conclusion that not everything should be taken for granted in the same way as it had been assumed by them before, and that the others might also have a point. The gap in their world-view may be tiny in the beginning, but it will have a tendency to grow and develop into a real opening. At the end of such a development we will have, according to Berger, pure relativism, the conviction that all convictions and values are of equal worth or at least equally unfounded. Applying the economic concept of 'preference' to religion, as is usual in parts of contemporary sociology of religion but also in American everyday life, is considered by Berger to be a symptom of such a creeping relativism. Berger is certainly right when he says that the phrase "religious preference (...) belongs to the language of consumer behavior, not to the language of martyrdom" (p. 34). Thus, religious faith as such and each particular faith is treated as a mere option, purely subjective and transitory. But Berger does not reject this language because for him it perfectly catches the facts: "The individual's religion (in modernity, H.J.) is not something irrevocable given, a datum that he can change no more than he can change his genetic inheritance; rather, religion becomes choice, a product of the individual's ongoing project of world- and self-construction" ( $p$. 67). Through such psychological mechanisms pluralism thus leads to secularization. For Berger pluralism is not the only cause, but an important factor in the causation of secularization. This factor reinforces the other factors (like technical and scientific progress which for Berger also have secularizing consequences) whereby a spiraling development is triggered: "Modernity can then be said to bring about an ongoing cross-fertilization of pluralism and secularity" (p.40).

One important element of Berger's diagnosis is still missing in my reconstruction. Subjectivist relativism is for him only one possible result of the "cognitive contamination" I mentioned. He distinguishes, at least with regard to Christian 
communities, four different forms of reactions: the first would be a strategy of negotiation as it is typical for liberal theology which makes many cognitive compromises with modernity in order to save the core of the faith; the second would be complete capitulation, the third is a retreat into the ghetto of believers, and the fourth a crusade with the intention of re-conquering society for the religious tradition. The third and the fourth type are important for Berger because he thinks that relativism is ultimately psychologically untenable so that at any moment a complete reversal can occur in the direction of fundamentalism both in individuals and in religious communities. I know that many people find this assumption very plausible.

I have not mentioned other elements of Berger's sociology of religion, particularly his thesis of an ongoing privatization of religion. The reason for this is simple. This thesis has been almost completely rejected in the last years, especially because of the research of José Casanova, and Berger has almost retracted it, at least insofar as privatization was identified with a decline of religion. In 1968, in the New York Times of February 25, Berger had predicted that in the year 2000 no churches and religious communities would be left, only small sects in which religious believers would huddle together to resist a worldwide secular culture. Today Berger calls this prediction the 'big mistake' of his career, but he thinks that this mistake is balanced by his crucial insight into the causal relationship between pluralism and secularization as I have sketched it here.

Well, unfortunately, this other thesis seems to be another 'big mistake'. Berger has not recognized the internal connection between the thesis he has given up and the other thesis he is still defending and for which he is making even stronger claims today. While he has changed from being a champion of radical predictions of secularization to a proponent of what he now calls a 'desecularization' theory, he does not see how deeply problematic his theory of the dynamics of pluralism is as well.

I will now explain my reasons for this harsh judgment. I see historical, sociological, and philosophical objections against Berger's construction.

1. I will start with the historical objections. Contrary to Berger I would describe European religious history as a history that has always had pluralism as an inherent feature. Europe was never completely Christian, Judaism and Islam belong to Europe as well, the pre-monotheistic religions never completely disappeared, but permeated the later forms of religion. And even the religions of antiquity had a constant subterranean influence in European cultural history. "The existence of a plurality of religious communities at the same time and in the same area has been the rule in European history" (Kippenberg). Berger's picture of modern pluralism is characterized by an exaggerated historical contrast, as if until recently it was common to be exclusively surrounded by co-religionists and to remain unaffected by religious doubts. But this is a complete distortion of European history, similar to the dichotomous contrast in Arnold 
Gehlen's book Primitive Man and Late Culture which very much influenced Berger's thinking. This theory is based on the idea that institutions are stronger if they do not allow for reflection. If institutions allow their own problematization, they are thought to lose strength. The internalization of norms and values in such institutions is allegedly more superficial and less stable.

But these are the old assumptions of an ultra-conservative theory of institutions hardly defended by anyone in the last decades. Even Helmut Schelsky, Gehlen's intellectual alter ego, admitted that a certain freedom for reflection might stabilize institutions. Berger remains skeptical in this regard and does not recognize what an enormous potential of stabilization lies in a sphere of discussion, how the periodic change between ultra-stability and collapse of institutions can be avoided if there is learning and controlled change. Similarly, he does not recognize that a flexible internalization of norms and values is not a superficial internalization, but can, on the personal level, make possible a heightened sensitivity toward others and the 'Other' within and thus lead to a dynamic (instead of static) stability - what discourses can achieve on the institutional level.

Berger's views on the destructive consequences of pluralism are influenced by this ultra-conservative concept of institution. The other major weakness is that he takes pluralism merely as an empirical fact and not also as a value! If we do not consider pluralism mostly as a danger to the stability of institutions and persons, we can also see it as an opportunity. But if pluralism contains opportunities, it can itself become a value; to overcome pluralism and to return to a pre-pluralistic state is then no longer desirable. Think of values like toleration and religious freedom as the freedom not of my own faith but of the belief of others because I support a possibility for them to develop their own authentic unforced relationship to God: Such a value is certainly not a weaker conviction than intolerant attitudes, as if toleration were only a passive acceptance of others, absent realistic better alternatives like their enforced conversion, liquidation or expulsion. Toleration can be an intensely held conviction that motivates a struggle against the enemies of toleration.

Isaiah Berlin's philosophy of value pluralism goes even further. For him values are irreducibly different so that they can never be fully synthesized into a homogeneous value system. The dream of one such system then always contains the danger of degenerating into a totalitarian project. Such value pluralism leads to a tragic view of history because it recognizes that progress always also means loss. The idea of a conflict between value systems loses much of its plausibility then because we are not confronted with hermetically closed alternatives, instead we can relate value systems to experiences, from which they emerged and which they make meaningful. And such experiences do not remain foreign to us; we can translate them into our own 'language', not without effort, it is true, but in principle. Berger's use of an allegedly pre-modern type of institutions and value systems that are said to be completely closed and indubitably taken for granted is thus inappropriate for an understanding of the specificities of the present. 
2. In the American debates about Berger's work several authors have pointed to the fact that territorial monopolies of a specific religious community have never been characteristic for America - and we just saw that even for Europe this view is an exaggeration. By assuming such an earlier monopoly the shock of adaptation for the religious communities caused by modern pluralism is exaggerated. "Only very few of the hundreds of religious organizations thriving in the U.S. today, probably only the Episcopal Church, had to adapt to the pluralistic situation. Most of them were born into it" (Steven Warner). The long tradition of religious pluralism in the U.S. has now led to a sociological school, a "new paradigm for the sociological study of religion" that practically reverses Berger's assumption. Religious pluralism, these authors claim, is not only not a cause of the weakening of religious convictions, but, on the contrary, the explanation for the enduring religious vitality of the us.

Let us now consider these sociological arguments more closely. They have been developed, as I said, mostly in the US and by using the Us as their empirical case. For them the historical fact is quite essential that this religious vitality is not, as it may look at first sight, a result of the Puritan heritage, because this vitality became stronger in the course of the 19th and early 2oth centuries. This means that we cannot speak here of secularization as a necessary corollary of modernization nor of a secularization that is only delayed compared to Europe. The real cause for religious vitality is, according to these authors, the constitutional separation of state and church in the us established in the late 18th century, therefore the organic pluralism of religious communities that compete with one another on a sort of market for religious demand. In such a situation the religious communities depend, in an economic sense, on the financial support from their 'customers' (and not from the state). This makes an entrepreneurial attitude on the side of the churches and religious communities more probable, opens opportunities for the founders of new religious enterprises, leads to internal flexibility in religious organizations and an active role in the mobilization of certain interests, for example the interests of immigrant ethnic groups. If there is an increased individualization in such a society, these American forms make it easy to adapt to them. And although these assumptions mostly aim at the Protestant communities whose theological differences have lost much of their importance (though political differences have gained importance), this Protestant sector influences all other religious communities as well. "In America even the Catholics are Protestants," remarked G.K. Chesterton almost a century ago.

Most of these arguments have been developed by rational choice sociologists. There is an intense debate about their work going on; apart from a few voices that claim that all the demonstrations of a causal connection between religious pluralism and religious vitality are based on mathematical errors in measuring these two dimensions, most authors, including non-rational choicers, accept the existence of such a connection. 
But Europe is a more difficult case. Some countries there have a high level of religious activity although they are dominated by one religious community (Poland, Ireland), while in other parts, for example in Scandinavia, the abolition of the state church may even have strengthened secularization. The causal connection cannot be quite as simple as the radical 'economists of religion' assume. If a geographically highly concentrated religious group experiences itself as a minority in a wider context, it obviously can remain vital despite its territorial monopoly. The change to other religious communities is not as arbitrary as the economic model pretends. Protestants mostly change to other religious communities in the U.S. within the Protestant sector ('church shopping'). Other 'conversions' are collective phenomena, like the conversion of poor blacks to Islam or the attraction of Pentecostalism for Catholic immigrants from Latin America. The case of East Germany leads to a further correction of the model. The collapse of the communist repression of religion there did not lead to a religious revival, probably because of a real shrinking of religious demand. Convinced atheists do not become religiously active even if there is complete religious freedom. The side of religious demand has to be seen as flexible in the same way religious supply is. The case of East Germany has to be explained from the interplay between a low attractiveness of the churches which, incidentally, dates back to the times before communism, and a shrinking demand that is new and unexpected. It is unexpected because even the most radical theoreticians of secularization had assumed that religion would disappear, but not that there would not be an equivalent for it, such as belief in the nation or in human rights (Durkheim) or democracy (Dewey).

With all these remarks I do not simply want to slightly modify and make more robust the hypothesis that there is a positive causal connection between pluralism and religious vitality; I also want to point out that it is not simply the existence of an unregulated market of religions that explains the vitality of religion in the U.S. The economists of religion are as wrong in this respect as all economists are who ascribe all sorts of positive effects to unregulated markets as such. Randall Collins has already pointed out in these debates that unregulated markets normally lead to monopolies. The decisive fact therefore is that this did not happen in the U.S. But this fact is due not simply to the existence of pluralism, but to the institutionalization of the value of pluralism. Religious pluralism in the U.S. is, as religion in general, a culturally and institutionally supported value. The economists of religion ignore this because of the fundamental limitations of their approach.

3. Although Berger and the rational choice authors are on opposite poles regarding the causal connection between religious pluralism and religious vitality, both sides assume that faith somehow is based on acts of choice. Again, I have serious doubts, philosophical and psychological doubts this time, with regard to this assumption. The assumption of utility calculation certainly is not a valid psychology of motivation. Decisions about questions such as which religious community one should join because of affinities or advantages may partly be 
based on such calculations, but the experience that is constitutive for religious faith cannot be classified as 'choice' in a phenomenologically appropriate way. Religious faith is either based on traditions internalized in the process of selfformation or on experiences of self-transcendence. For these experiences a certain passivity is characteristic, one is captivated or seized by something, one experiences self-surrender (William James). There is no question that such experiences are in need of interpretation. Only after such an experience do we know that we have experienced something; our certainty does not extend to the interpretation as if this were a mere emanation from the experience or as if it could be found completely preformed in our religious and cultural patterns of interpretation. We have to re-interpret traditions, to establish new connections, to come forward with new creative articulations, maybe even religious innovations. The sociological study of conversion is rich in examples for what I have in mind here. In every conversion or religious innovation there is, it is true, a moment of decision, a point of no return, after which the old conceptual framework is reinterpreted in terms of a new one, and I do not want to deny that at these points an act of will is necessary, a leap of faith, a willingness to follow. But this will is a willingness to surrender one's self, and therefore conceptually clearly distinguishable from a rational choice between preferences. Values are not long-term preferences or preferences of a higher order, but reflexive standards for the evaluation of our preferences, emotionally laden ideas of the desirable and not desires. They are based on feelings of evidence and certainty; these feelings guide us in our attempts at articulation and remain in their intensity when we become aware of the contingency of our biographies and experiences. As the mere knowledge of a value or acquaintance with a person does not produce a commitment, the mere knowledge of or encounter with alternatives does not shake or unsettle our existing commitments.

Berger's thesis that pluralism leads to a loss of intensity in our commitments is a result of his acceptance of the economic notion of preference. We find ourselves in an ironic situation now: Berger seems to have drawn the wrong conclusion from the empirical refutation of secularization theory. He defends the old assumption of a weakening effect of pluralism, but moves closer to the idea of religious preferences whereas he should have accepted the result of the economic studies that pluralism can increase religious vitality, but also made clear that this empirically valid statement cannot really be incorporated into the framework of an approach for which 'value' is not a central concept.

At this point, Berger becomes self-contradictory because he can very well describe experiences of transcendence as the foundation of faith. But immediately after such impressive descriptions he repeats his claim that religious convictions today are more superficial than in the past and that people with unshakable convictions are inclined toward such robust instruments of persuasion as "the sword, the torture chamber, and the stake" (p. 18o). I also find quite implausible Berger's conclusion regarding morality. He asserts, "while the pluralistic situation plunges both religion and morality into a crisis of relativization, for most of 
us the possibility of achieving some moral certainties is greater than that of achieving religious certainty" (p. 201). This seems to me to be a confusion of subjective certainty and intersubjective plausibility. It is easier for us to come to an agreement in moral questions with people of different religious convictions, but this does not mean that we are more certain in moral questions than in religious ones. The believer will also respect moral commandments whose meaning cannot be made clear outside of faith. I do not want to continue these remarks on 'contingent certainty' here, certainty that is aware of the contingent sources of itself; these remarks only served to demonstrate that Berger's understanding of faith is not fully appropriate.

Now we have assembled all the components of an alternative to Berger. Pluralism does not weaken faith, but can - under specific conditions - strengthen it. My own approach is based on a reorientation - away from the problems of pluralism and social integration, in the direction of the problems of increasing contingency. We call 'contingent' what is neither necessary nor impossible - what is, but does not have to be. 'Contingent' is the counter-notion to 'necessary', therefore its precise meaning depends on the meaning of the concept of 'necessity'. We speak of increasing contingency because the number of options for action has increased, but also the number of effects we encounter that result from human action and are not independent from it. What does that development mean for the situation of religion today? We are now familiar with Berger's pessimistic views on this. He is deeply ambivalent with regard to the processes of individualization. This ambivalence can become productive if it leads to a search for religious organizations that encourage and enable individualization. It can become sterile if it leads to a skepticism regarding the practices of ritual as the core of institutionalization. Robert Bellah, another great sociologist of religion, considers the Protestant antiinstitutionalist bias a "flaw in the Protestant code". We have to analyze the constructive potential that lies in increased contingency. 


\section{NOOT}

I Published in Joas, H. (2004) Braucht der Mensch Religion? Ueber Erfahrungen der Selbsttranszendenz. Freiburg: Herder. Forthcoming (2007) as Do we need religion? On the experience of self-transcendence, Boulder, Co: Paradigm Publishers.

2 Berger, P. (1992) A far glory: the quest for faith in an age of credulity. New York / Toronto: The Free Press / M. Macmillan. 
LUIK 2

EMPIRIE 


\title{
3 DE RELIGIEUZE TRANSFORMATIE EN DE SOCIALE COHESIE
}

\author{
Gerrit Kronjee
}

\section{$3.1 \quad$ INLEIDING}

Deze bundel kwam tot stand op het moment dat er een kentering kwam in Nederland in de gedachte dat er geen toekomst was voor de religie, dan wel dat het religieuze verschijnsel iets was wat zich beperkte tot de privésfeer. Was bij het beeld van de voortschrijdende secularisatie in Nederland niet te veel uitgegaan van een idee over de relatie tussen de religie en de samenleving dat niet meer van deze tijd was? Van een tijd waarin gezegd kon worden: geloven doe je in de kerk. Zou de religie zich nu niet anders manifesteren? Om dat vast te stellen was het zowel nuttig om informatie te verzamelen over de traditionele religieuze instituties als over de manieren waarop de bevolking ook daarbuiten zin gaf aan haar leven.

De nu volgende tekst begeleidt de vier bijdragen in deze bundel voor het empirische luik. Het empirische luik in deze bundel gaat niet uit van een aantal hypothesen. Het is wel zo dat het min of meer duidelijk was welke onderwerpen in empirisch opzicht aandacht verdienden. Het eerste stuk (hoofdstuk 4), over de religieuze atlas van Nederland, behandelt de georganiseerde religie in Nederland, volgens de traditionele benadering. Het tweede stuk (hoofdstuk 5 ) beschrijft de positie van de georganiseerde religie in de Nederlandse civil society. De volgende twee bijdragen bezien de religie vanuit een andere, culturele invalshoek en beperken zich niet tot de georganiseerde religie. Het derde stuk (hoofdstuk 6), over de leefstijlen in zingeving, beschrijft de levensbeschouwelijke profielen van de Nederlandse bevolking die voor een deel niet en voor een deel wel verbonden zijn met de georganiseerde religie. Het vierde stuk (hoofdstuk 7) gaat in op de betekenis van de Amerikaanse cultuur of leefstijl voor de religieuze praktijk in de Verenigde Staten. In de eerstvolgende paragraaf (3.2) staat een korte beschrijving van de inhoud van deze bijdragen. Daarna volgen paragrafen (3.3-3.5) die bedoeld zijn om te lezen nadat kennis genomen is van de hoofdstukken. Er wordt een internationale vergelijking gemaakt als achtergrond bij de teksten over de religieuze atlas en de kerken in de Nederlandse civil society. Vervolgens wordt nader ingegaan op een achtergrond voor de hoofdstukken over de rol van de cultuur bij de zingeving. Die achtergrond is de ontwikkeling naar een leefstijlmaatschappij waardoor de religie een andere functie krijgt en de bestaande institutionele vormgeving minder van belang is. De concluderende paragraaf gaat in op een mogelijke religieuze bewustwording, de transformatie van het religieuze en het resultaat hiervan in de ongebonden spiritualiteit en op de betekenis van een en ander voor de sociale cohesie.

Bij veel van wat hierna volgt is het mogelijk kanttekeningen te plaatsen. Er zijn tegenwerpingen mogelijk en soms kan gesteld worden dat verder onderzoek nodig is voor meer definitieve uitspraken. Niettemin is het goed voorlopig te 
markeren waartoe de empirische verkenningen in deze bundel hebben geleid. Heel kort kunnen deze markeringen als volgt worden omschreven. Het aanbod van religieuze organisaties kan een eigen dynamiek hebben, in die zin dat het los kan staan van veranderingen in de behoeften aan zingeving. Beide, zowel de zingevingsbehoeften als het institutionele aanbod, zijn onderhevig aan een meer fundamentele maatschappelijke verandering, die in dit hoofdstuk is omschreven als het ontstaan van een leefstijlmaatschappij. Die maatschappelijke achtergrond leidt tot een religieuze transformatie. Er ontstaat een religieuze beleving bij een deel van de bevolking die echter niet meer verbonden is met kerkelijke organisaties. Niet-religieuze instituties en gebruiken kunnen functioneel equivalent zijn aan kerkelijke organisaties, wat betreft het voorzien in de behoeften aan religieuze en niet-religieuze behoeften aan zingeving. De levensbeschouwelijke verschillen in leefstijlen houden risico's in voor de sociale cohesie. Dit roept weer vragen op over de consequenties voor het overheidsbeleid. De beantwoording hiervan valt echter buiten de taakstelling van dit empirische luik.

\subsection{TOELICHTING OP DE HOOFDSTUKKEN IN HET EMPIRISCHE LUIK}

\section{De religieuze atlas van Nederland}

In een empirisch luik mag een actuele statistiek van de institutionele religies niet ontbreken. In hoofdstuk 4 over de religieuze atlas van Nederland zijn cijfers opgenomen over de soorten religies die nu onderscheiden kunnen worden, hun leden, de participatiegraad van deze leden, het aantal voorgangers/beroepskrachten, het aantal vestigingsplaatsen en, uiteraard gezien de titel van het hoofdstuk, ook een globale aanduiding van de geografische spreiding. Voor zover er gegevens beschikbaar zijn, bevat dit hoofdstuk ook een schets van de ontwikkelingen in de loop van de tijd. Aan deze uitkomsten wordt hierna een internationale vergelijking toegevoegd (paragraaf 3.3).

\section{Kerken in de Nederlandse civil society}

Hoofdstuk 5 begint met een schets van de ontwikkeling in de participatie van de Nederlandse bevolking in religieuze instituties. Vervolgens wordt onderzocht hoe het gesteld is met de tolerantie en welk vertrouwen de bevolking heeft in de maatschappelijke rol van de georganiseerde religie. Verder wordt een verband gelegd met de betekenis van de religie voor de maatschappelijke participatie (vrijwilligerswerk, charitas en politieke activiteit). Kerken blijken voor hun achterban een mobilisatiemilieu te zijn voor participatie. De kerkelijke betrokkenheid vermindert, maar dat hoeft volgens de auteurs van het hoofdstuk niet te betekenen dat de rol van de religie in moreel opzicht is uitgespeeld. Maar de toekomstige ontwikkeling is onzeker in een Nederland dat als een religieuze proeftuin kan worden gezien.

\section{Leefstijlen in zingeving}

In het najaar van 2003 is door Motivaction in een enquête aan 2021 Nederlanders gevraagd welke diepere betekenis zij aan hun leven geven en hoe zij dit tot uiting 
brengen. De ondervraagden konden vrij formuleren hoe zij hierover dachten. De gegeven antwoorden waren nog niet eerder verwerkt en gepubliceerd. Het leek zinvol om dit alsnog te doen in deze bundel als een bijdrage aan het empirische luik.

De opvattingen van de Nederlander over de zin van het leven zijn door de auteurs geordend langs verschillende dimensies. Vervolgens zijn de scores op deze dimensie in verband gebracht met andere uitkomsten in hetzelfde onderzoek waarin ook andere vragen zijn gesteld over de waardering van materiële en immateriële zaken. Tevens zijn gegevens verzameld over de persoonlijke situatie, bijvoorbeeld of men wel of niet werkt. De verschillende antwoorden gezamenlijk blijken geordend te kunnen worden tot levensbeschouwelijke profielen die verwijzen naar verschillende leefstijlen.

De uitkomsten van het onderzoek passen in een religieuze transformatie, waarin een eerdere kerkgebonden zingeving verdwijnt. Er ontstaat een ongebonden spiritualiteit als leefstijl naast niet-religieuze vormen, humanistisch en niethumanistisch. Deze transformatie moet gezien en begrepen worden tegen een bredere maatschappelijke verandering in de vorm van het ontstaan van een leefstijlmaatschappij. Een volgende paragraaf (3.4) bevat een korte beschouwing over deze verandering.

\section{An introduction to American Religious Practice}

Het hoofdstuk over de religie in de Verenigde Staten brengt een onderscheid aan tussen de religieuze leer en de religieuze praktijk. Als men onderzoekt wat mensen zeggen wel of niet te geloven, lijken er onoverbrugbare tegenstellingen te bestaan. Als men echter onderzoekt hoe mensen met verschillende religieuze achtergronden met elkaar omgaan, blijken de tegenstellingen veel minder groot te zijn. De auteur legt hierbij een verband met de cultuur, met de dominantie van de Amerikaanse leefstijl, die de religie beïnvloedt en de tegenstellingen dempt. De gemeenschappelijke leefstijl wint het van de religie. Hij constateert een tendens naar convergentie voor alle Amerikaanse religies die zich steeds meer richten op het therapeutische en het persoonlijke, op het verbeteren van het individuele toekomstperspectief.

\subsection{VERGELIJKING TUSSEN LANDEN VAN DE BAND MET RELIGIE}

De ontwikkelingen in Nederland, zoals die zijn beschreven in het hoofdstuk over de religieuze atlas van Nederland, krijgen meer reliëf door een vergelijking met de buurlanden in West-Europa. Tegelijkertijd kan het zijn, zo is de eerste indruk uit de literatuur, dat de West-Europese situatie in de wereld uitzonderlijk is, wat weer de noodzaak oproept een vergelijking te maken met andere landen buiten Europa. Hierna volgen daarom enkele tabellen met gegevens over de ontwikkeling in de religieuze binding in Nederland in vergelijking met West-Europese landen en enkele andere landen die cultureel en/of wat betreft het bevolkingsaantal in de wereld een grote betekenis hebben. 
Uit tabel 3.1 volgt dat West-Europa, ten aanzien van het aantal inwoners, een afnemend aandeel heeft in de wereldbevolking. Dat kan relevant zijn bij uitspraken over de toekomstige rol van de religie in een West-Europa dat door internationale culturele contacten en migratie onder invloed zal blijven staan van religieuze ontwikkelingen in andere landen.

Tabel 3.1 Bevolkingsomvang in miljoenen in 2000 en 2050

\begin{tabular}{|lrr|} 
& 2000 & 2050 \\
Denemarken & 5 & 6 \\
Nederland & 16 & 17 \\
België & 10 & 10 \\
Duitsland & 82 & 79 \\
Groot-Brittannië & 59 & 67 \\
Frankrijk & 59 & 63 \\
Totaal West-Europa & 231 & 242 \\
Rusland & 147 & 112 \\
vs & 284 & 395 \\
Brazilië & 174 & 253 \\
Nigeria & 118 & 258 \\
Zuid-Afrika & 46 & 49 \\
India & 1021 & 1593 \\
Indonesië & 209 & 285 \\
Zuid-Korea & 47 & 45 \\
\hline
\end{tabular}

Bron: Verenigde Naties 2005

De religieuze binding kan aan de hand van verschillende indicatoren worden beschreven. Het hangt van de keuze van de indicatoren af tot welke conclusie men komt over de secularisatie. Er is wat dat betreft kritiek op het bestaande onderzoek (zie bijvoorbeeld Van Rooden 2004), waarin indicatoren worden gebruikt, zoals het lidmaatschap van een kerkgenootschap of kerkgang, die niet meer valide zouden zijn om de bestaande ontwikkeling in de religieuze bindingen te beschrijven. Op grond van een traditionele beschrijving met de kerkgang komt men tot de conclusie dat er een voortgaande secularisatie is. Tegenwoordig hoort Nederland tot de middenmoot van Europa wat betreft de secularisatie die met deze indicator wordt gemeten (Becker 2006).

Het probleem bij de beschrijving volgens traditionele indicatoren is dat deze door maatschappelijke veranderingen minder adequaat zijn. Er zal op een gegeven moment een beroep gedaan moeten worden op andere maatstaven. Bijvoorbeeld naast of in plaats van de kerkgang zullen ook andere vormen van participatie die vroeger niet voorkwamen, beschreven moeten worden. De steeds sterker vertegenwoordigde islam, intussen de tweede religie in Nederland, is anders georganiseerd dan het christendom; het moskeebezoek is daarom geen goede 
indicatie voor de mate van religiositeit dan wel secularisatie. Dit geldt overigens niet enkel voor de islam in diaspora, maar ook voor de islam in islamitische landen. De religie moet, zoals ook blijkt uit het hoofdstuk over de leefstijlen in zingeving, niet gelijkgesteld worden aan een bepaalde institutionele vorm. Als de kerkreligie verdwijnt, wil dat niet zeggen dat de religie verdwijnt (zie ook Luckmann 1967).

Ten slotte moet, bij een interpretatie van de cijfers in historisch perspectief, worden opgemerkt dat het onzeker blijft hoe de historische ontwikkeling over een langere periode is geweest; we weten in feite niet, omdat het daarvoor geschikte onderzoek ontbreekt, hoe gelovig mensen waren in vroegere tijden, de negentiende eeuw en eerder. Het is heel goed mogelijk dat religie toen vooral een ritueel karakter had en er niet een daarmee overeenstemmende omvang van persoonlijke betrokkenheid onder de bevolking was.

\section{Beschrijving van verschillende soorten bindingen}

Religieuze ontwikkelingen kunnen worden onderzocht door onderzoek onder een representatieve streekproef van de bevolking, door volkstellingen, door diepgravend onderzoek onder een specifieke groep of door een beschrijving van de rol van de religie in de media, die ook op dit gebied een steeds belangrijker rol lijken te spelen. Van de onderzoeksmethode hangt het af welke indicatoren gebruikt kunnen worden. We beperken ons nu tot de mogelijkheden die al uitgevoerde surveys bieden. De verschillende indicatoren die in dit onderzoek worden gebruikt, kunnen in de volgende hoofdgroepen worden onderverdeeld:

- persoonlijke binding of beleving;

- band met rituelen in de privésfeer;

- institutionele binding.

Het is interessant de divergenties tussen deze soorten religieuze bindingen weer te geven. Bijvoorbeeld tussen het aantal personen dat zegt lid te zijn van een kerk (institutionele binding) en het aantal dat zegt te geloven (persoonlijke binding). Dat roept de vraag op wat wij kunnen zeggen over de achtergrond van het verschil tussen persoonlijke opvattingen en praktijk. Moet hier een cultureel kenmerk worden ingevoerd, waarbij verwacht kan worden dat in een weinig pluriforme omgeving, bijvoorbeeld in een als katholiek of protestant te typeren land, dergelijke verschillen ontstaan? Is het zo dat in een pluriforme context opvattingen en praktijk meer bij elkaar passen, doordat in een concurrerende omgeving men zich meer bewust wordt van het eigen geloof? In dit verband is het nodig een maatstaf voor pluriformiteit te gebruiken, mede omdat de mate van pluriformiteit veel betekenis heeft voor de rol van de religie in het publieke domein.

Een probleem bij een onderlinge vergelijking van de enquête-uitkomsten die de basis vormen van de nu volgende vergelijking, is dat het soms lastig is een onderscheid is te maken tussen religieuze praktijken en het maatschappelijke leven. Als het een sterk met het ander is verbonden, kan er een overschatting ontstaan van 
Tabel 3.2 Persoonlijke religieuze binding

\begin{tabular}{|c|c|c|c|c|c|}
\hline & $\begin{array}{c}\text { Zelfbeeld als } \\
\text { religieus a) }^{\text {a }}\end{array}$ & $\begin{array}{c}\text { Belang } \\
\left.\text { religie }^{b}\right)\end{array}$ & $\begin{array}{c}\text { Steun } \\
\text { van religie c) }\end{array}$ & $\begin{array}{c}\text { Belang } \\
\text { van God d) }^{\text {d) }}\end{array}$ & $\begin{array}{c}\text { Bidden tot } \\
\text { God e) }\end{array}$ \\
\hline Denemarken & $69 / 73 / 77$ & $9 / 8$ & $28 / 27 / 33$ & $23 / 18 / 21$ & $25 / 17$ \\
\hline Nederland & $69 / 61 / 62$ & $19 / 17$ & $48 / 45 / 43$ & $39 / 33 / 36$ & $46 / 29$ \\
\hline België & $81 / 68 / 67$ & $15 / 18$ & $58 / 47 / 49$ & $46 / 39 / 37$ & $41 / 27$ \\
\hline Duitsland & $--/ 38 / 56$ & $16 / 9$ & $--/ 31 / 50$ & $--/ 26 / 39$ & $28 / 27$ \\
\hline Groot-Brittannië & $56 / 56 / 42$ & $16 / 13$ & $46 / 45 / 37$ & $40 / 36 / 34$ & $43 / 24$ \\
\hline Frankrijk & $53 / 51 / 47$ & $14 / 11$ & $36 / 36 / 35$ & $30 / 27 / 27$ & $34 / 15$ \\
\hline Rusland & $--/ 56 / 66$ & $12 / 12$ & $--/ 35 / 57$ & $--/ 21 / 38$ & $17 / 22$ \\
\hline vs & $83 / 84 / 83$ & $53 / 57$ & $83 / 80 / 80$ & $82 / 77 / 83$ & $78 / 71$ \\
\hline Brazilië & $--/ 88 / 85$ & $57 / 65$ & $--/ 86 / 89$ & $--/ 94 / 96$ & 87/-- \\
\hline Nigeria & $--/ 93 / 97$ & $85 / 93$ & $--/ 96 / 98$ & $--/ 98 / 97$ & 97/-- \\
\hline Zuid-Afrika & $76 / 83 / 79$ & $66 / 70$ & $--/ 89 / 89$ & $84 / 88 / 90$ & $-/ 76$ \\
\hline India & $--/ 84 / 79$ & $49 / 57$ & $--/ 81 / 85$ & $--/ 68 / 88$ & $73 / 62$ \\
\hline Indonesië & $--/-/ 84$ & $--/ 98$ & $--/-/ 100$ & $--/-/ 99$ & $--/--$ \\
\hline Zuid-Korea & $--/-/ 31$ & $26 / 23$ & $--/-/ 67$ & $--/-/ 37$ & $-/ 40$ \\
\hline
\end{tabular}

a) Percentage omstreeks resp. 1980/1990/2000 dat zichzelf als een religieus persoon ziet.

b) Percentage omstreeks resp. 1990/2000 waarvoor religie zeer belangrijk is in het leven.

c) Percentage omstreeks resp. 1980/1990/2000 dat aan religie troost en kracht ontleent.

d) Percentage omstreeks resp. 1980/1990/2000 waarvoor God in het persoonlijke leven belangrijk is.

e) Percentage omstreeks resp. 1990/2000 dat elke dag of meer dan een keer per week buiten religieuze bijeenkomsten tot God bidt.

Bron: Bewerking gegevens, o.a. uit Inglehart e.a. 2004

de betekenis van religie voor het individu, doordat het in een dergelijke samenleving niet wenselijk is hier afstand van te nemen, ook niet in de context van een enquête. Tegelijkertijd kan er in een andere maatschappelijke omgeving sprake zijn van een onderschatting, als die sociale wenselijkheid ontbreekt en de ondervraagden in een enquête niet onderkennen dat de cultuur en het dagelijkse leven sterk door de religie worden beïnvloed. Een voorbeeld van het eerste geval zou Indonesië kunnen zijn en van het tweede Zuid-Korea voor dat deel van de bevolking dat in een boeddhistische cultuur leeft.

\section{Bronnen}

Er worden verschillende bronnen voor empirische gegevens over deze landen gebruikt, maar de belangrijkste daaronder is het bronnenboek van de World Values Survey (Inglehart et al. 2004). In dit boek worden de resultaten weergegeven van enquêtes die rond 1990 en 2000 zijn gehouden in tachtig landen. Voor de weergave van de uitkomsten van een eerdere peiling, rond 1980, is een beroep gedaan op een internetbron, een beschikbare dataset bij de bibliotheek van de universiteit van Michigan. ${ }^{1}$ Uit de beschikbare gegevens zijn de vragen geselecteerd die gaan over de relatie tot het geloof of de religieuze organisatie. Verder is 
een selectie van landen gemaakt uit een totaal van meer dan tachtig landen. Een bewerking van deze gegevens, met enige aanvulling uit andere publicaties, levert de tabellen 3.2 tot en met 3.4 op.

\section{Persoonlijke binding/beleving}

Er is sprake van een persoonlijke religieuze binding bij een aanzienlijk deel van de bevolking, blijkt uit tabel 3.2. Dit is ook het geval in West-Europa, dat zich verder wel onderscheidt van de rest van de beschreven landen in het gewicht dat men hier toekent aan religie volgens de variabelen: belang van religie, steun van religie, belang van God en het bidden tot God.

Er blijkt in West-Europa een gemiddelde tendens tot een afnemende persoonlijke religieuze binding, wat onder andere blijkt uit het percentage dat tot God bidt. Het is echter opmerkelijk dat bij een verbreding van de vraagstelling, namelijk tot een vraag naar spirituele momenten (neemt $\mathrm{u}$ wel eens de tijd voor bidden, mediteren, contemplatie of iets dergelijks?) er hogere scores ontstaan. In 2000 beantwoordden de volgende percentages personen op deze vraag bevestigend: $5_{1}$ (DK), 69 (NL), 62 (B), 54 (D), 50 (GB), 41 (F). Uit meer diepgravend onderzoek in Engeland volgt dat er vooral sprake is van een groeiende aandacht voor spiritualiteit bij de oudere leeftijdscohorten en onder vrouwen (Heelas 2001). In Nederland is de samenstelling van deze spirituele categorie naar leeftijd echter anders, jonger (zie het hoofdstuk over Leefstijlen in zingeving).

Over een aantal landen zijn actuele cijfers bekend over het percentage dat religie zeer belangrijk vindt (Ipsos-Public Affairs 2005), namelijk voor Duitsland: 18\%, Verenigd Koninkrijk: 18\%, Frankrijk: 14\%, de VS: 62\% en Zuid-Korea: 22\%. Deze uitkomsten wijken nauwelijks af van de eerdere cijfers.

\section{Rituelen in de privésfeer}

Er is tevens onderzocht welk percentage van de bevolking een religieuze bijeenkomst bij de geboorte, bij het huwelijk en bij het overlijden belangrijk vindt.

Opmerkelijk is in tabel 3.3 de relatief grote betekenis van deze religieuze rituelen in West-Europa, hoewel er een gemiddeld dalende tendens te onderkennen is. Ook hier maakt het verschil hoe een religieuze binding wordt gemeten; uitkomsten over de rituele rol van de religie kunnen afwijken van de uitkomsten over de andere indicatoren voor religieuze binding.

\section{Institutionele binding}

Tabel 3.4, over de institutionele binding, laat een verrassende uitkomst zien: het grote aantal dat zich tot een religieuze denominatie rekent. Dat geldt ook voor Nederland, dat wel relatief laag scoort op dit punt. Verder kent Nederland een hoge mate van pluriformiteit.

Andere variabelen, het horen bij een religieuze/kerkelijke organisatie, het bezoeken van religieuze bijeenkomsten en het verrichten van vrijwilligerswerk in een religieuze/kerkelijke organisatie, leveren voor de beschreven Europese landen 
Tabel 3.3

Religie en rituelen in de privésfeer

\section{Religieuze dienst \\ bij de geboorte ${ }^{\text {a) }}$}

Religieuze dienst
bij het huwelijk ${ }^{\text {b) }}$

$64 / 63$

$52 / 46$

$76 / 70$

$46 / 68$

$80 / 69$

$68 / 66$

$62 / 54$

$86 /-$

82/--

95/--

93/--

79/--

--/--

$--/-$
Religieuze dienst

bij het overlijden ${ }^{c}$ )

$79 / 74$

$62 / 56$

$79 / 74$

$61 / 74$

$86 / 79$

$73 / 73$

$74 / 79$

87/--

76/--

90/--

86/--

75/--

$--/-$

$--/-$

a) Percentage dat omstreeks resp. 1990/2000 een religieuze dienst bij de geboorte belangrijk vindt.

b) Percentage dat omstreeks resp. 1990/2000 een religieuze dienst bij het huwelijk belangrijk vindt.

c) Percentage dat omstreeks resp. 1990/2000 een religieuze dienst bij het overlijden belangrijk vindt.

Bron: Bewerking gegevens uit o.a. Inglehart e.a. 2004

lage scores op. Naar verhouding zijn die scores voor Nederland echter weer relatief hoog, voor een West-Europees land.

Bij tabel 3.4, in de kolom over het behoren bij een denominatie, valt een vreemde uitkomst op bij de cijfers over Duitsland. Mogelijk klopt het gegeven over 1990 niet, of is er een effect van de samenvoeging van de West-Duitsland en OostDuitsland na de val van de Muur. Uit een recent onderzoek blijkt dat bij de keuze uit een lijst van voorgelegde denominaties van katholiek, protestant et cetera $69 \%$ in Duitsland zich rekent tot een bepaalde religie (Ipsos-Public Affairs 2005). Opmerkelijk is ook dat in hetzelfde onderzoek $71 \%$ van de Franse bevolking zich katholiek noemt. Ondanks de secularisatie in andere opzichten kan er toch nog een sterke binding zijn met een katholieke maatschappelijke cultuur.

\subsection{DE LEEFSTIJLMAATSCHAPPIJ}

In het onderzoek dat in de bijdrage over de leefstijlen in zingeving aan de orde was, zijn de verschillende manieren waarop de respondenten zin geven aan het leven opgevat als een leefstijl, als een geheel van gedragingen en persoonlijke voorkeuren dat zich op een bepaalde manier maatschappelijk onderscheidt. In het verleden kon de zingeving van het leven sterk verbonden worden met het behoren tot een bepaalde sociale klasse of organisatie. Dat is nu veel minder het geval. 
$\mathrm{Nu}$ is het nuttig de beschrijving van de verschillen in zingeving te koppelen aan de leefstijl.

De hierbij gekozen invalshoek is verwant aan de benadering van auteurs als Giddens en Beck en kan betiteld worden als post-fordistisch (Tomlinson 1998). Het is een manier van kijken naar de werkelijkheid waarvan verwacht wordt dat die beter in overeenstemming is met die werkelijkheid dan eerdere visies die gebaseerd waren op de verwachting dat het gedrag sterk bepaald werd door de sociale klassen waarin men opgroeide en de organisaties waar men deel van uitmaakte. Bij het fordisme hoort een economie en een cultuur die gekenmerkt worden door grootschaligheid en massaproductie gericht op homogene groepen onder de bevolking. Ook de manier waarop de welvaartsstaat is georganiseerd met de oriëntatie op categorieën die een bureaucratische behandeling krijgen maakt hier deel van uit. Bij een post-fordistische tijd hoort een diversiteit aan leefstijlen en een reflexief gedrag. Traditionele, aan sociale klassen gerelateerde

Tabel 3.4 Institutionele binding

\begin{tabular}{|lccccc} 
& $\begin{array}{c}\text { Hoort bij een } \\
\text { denominatie }\end{array}$ & $\begin{array}{c}\text { Religieuze } \\
\text { pluri- } \\
\text { formiteit }\end{array}$ & $\begin{array}{c}\text { Hoort bij een reli- } \\
\text { gieuze/kerkelijke } \\
\text { organisatie }\end{array}$ & $\begin{array}{c}\text { Bezoekt reli- } \\
\text { gieuze bijeen- } \\
\text { komsten }{ }^{\text {d) }}\end{array}$ & $\begin{array}{c}\text { Vrijwilligers- } \\
\text { werk }\end{array}$ \\
Denemarken & $92 / 90$ & 0,23 & $7 / 12$ & $11 / 12$ & $2 / 3$ \\
Nederland & $51 / 45$ & 0,72 & $33 / 35$ & $20 / 25$ & $10 / 11$ \\
België & $68 / 64$ & 0,21 & $12 / 12$ & $31 / 27$ & $7 / 6$ \\
Duitsland & $35 / 77$ & 0,66 & $20 / 14$ & $20 / 30$ & $9 / 6$ \\
Groot-Brittannië & $58 / 83$ & 0,69 & $16 / 5$ & $24 / 19$ & $6 / 6$ \\
Frankrijk & $62 / 58$ & 0,40 & $6 / 4$ & $17 / 12$ & $5 / 3$ \\
Rusland & $37 / 51$ & 0,44 & $1 / 2$ & $6 / 9$ & $1 / 1$ \\
vs & $77 / 79$ & 0,82 & $49 / 57$ & $58 / 60$ & $29 / 38$ \\
Brazilië & $88 / 88$ & 0,61 & $22 /--$ & $50 / 75$ & $13 /--$ \\
Nigeria & $95 / 99$ & 0,74 & $--/--$ & $88 / 95$ & $--/--$ \\
Zuid-Afrika & $--/ 86$ & 0,86 & $--/ 54$ & $--/ 68$ & $--/ 37$ \\
India & $99 / 93$ & 0,33 & $--/ 18$ & $71 / 51$ & $--/ 14$ \\
Indonesië & $--/ 100$ & 0,23 & $--/--$ & $--/ 75$ & $--/--$ \\
Zuid-Korea & $72 / 63$ & 0,66 & $39 / 42$ & $64 / 38$ & $7 / 27$ \\
\hline
\end{tabular}

a) Percentage dat omstreeks resp. 1990/2000 met ja antwoord op de vraag of men bij een religieuze denominatie behoort.

b) Pluriformiteit, gemeten aan de kans dat twee aselect gekozen personen in de bevolking tot verschillende religieuze groepen behoren.

c) Percentage dat omstreeks resp. 1990/2000 zegt te behoren bij een religieuze of kerkelijke organisatie.

d) Percentage dat omstreeks resp. 1990/2000 een keer per maand of vaker een religieuze dienst bezoekt (afgezien van doop-, huwelijks- en overlijdensdiensten e.d.).

e) Percentage dat omstreeks resp. 1990/2000 vrijwilligerswerk doet in de kerkelijke of religieuze organisatie. Bron: Bewerking gegevens o.a. uit Inglehart e.a. 2004; en Alesina e.a. 2002 
consumptiepatronen en leefwijzen verdwijnen. $\mathrm{Nu}$ is deze indeling nogal ideaaltypisch, en ze lijdt aan een gebrek aan nuance als ze gebruikt wordt om het heden in vergelijking met het verleden te beschrijven. Toch is het voor een beter begrip van de betekenis van de religieuze transformatie nuttig deze ideaaltypische schets van de maatschappelijke veranderingen te gebruiken. Hierna volgt nu een impressie van de relatie tussen de religie en de samenleving in de fordistische periode, waarin de sociale ongelijkheid en organisaties het individuele gedrag bepalen, en de post-fordistische periode waarin het individuele gedrag samenhangt met de leefstijl die tot stand komt in een meer liquide maatschappij (zie ook Bauman 200o).

\section{Sociale klassen}

Het is de vraag of indelingen in sociale klassen nu nog belangrijk zijn, of hiermee de kern wordt gevat van de zaken die verschil maken voor de zingeving. De religieuze zingeving kan verbonden worden met de sociale ongelijkheid, met de indeling naar sociale klassen. Er is een tweezijdig effect mogelijk, van de sociale ongelijkheid op de religie en van de religie op de sociale ongelijkheid. In het eerste geval valt te constateren dat er een verschil is naar klasse in de manier waarop de religie beleefd wordt en aan welke denominatie men is verbonden. Bijvoorbeeld valt dan waar te nemen dat sektarische denominaties een grotere aantrekkingskracht hebben op de lagere sociale klassen. Kerkelijk-bureaucratische organisaties met een professionele geestelijkheid hebben een grotere aantrekkingskracht op de hogere sociale klassen (Pyle en Davidson 2006). In het tweede geval kan het effect van de religie zijn dat deze een bepaalde sociale ongelijkheid versterkt, zoals dat in marxistische analyses is beschreven. Maar ook is het mogelijk dat de religie zorgt voor een emancipatie, voor een vermindering van de sociale ongelijkheid.

In Nederland heeft de religie zich uiteindelijk gekeerd tegen de sociale ongelijkheid in het Nederlandse idee van de verzuiling. De religieuze zuil kwam dwars op de horizontale lagen van de sociale klassen te staan. De emancipatie van bevolkingsgroepen kreeg hierin een plaats, bijvoorbeeld de rooms-katholieken vormden een zuil en stegen op de maatschappelijke ladder. Ook de moslims onder de immigranten leken aanvankelijk volgens dit mechanisme in de Nederlandse samenleving een plaats te zullen krijgen. De zuilen hebben echter hun betekenis verloren. Er is voor de meerderheid van de bevolking geen band meer tussen religie en sociale klasse, de rooms-katholieke emancipatie is voltooid en de bevolking maakt in de eigen beleving geen deel meer uit van een bepaalde sociale klasse. Men zou kunnen zeggen dat uit onderzoek volgt dat een aanzienlijk deel van de bevolking, in het bijzonder sommige immigranten, in sociaal-economisch opzicht toch wel onderaan de maatschappelijke ladder geplaatst kan worden. Tegelijkertijd zien zijzelf en de ontvangende samenleving juist hun leefstijl, met soms een sterke religieuze dimensie, als het belangrijkste onderscheidende kenmerk.

\section{De organisatiemaatschappij}

De meritocratische organisatiemaatschappij kwam geleidelijk in de plaats van de standensamenleving. Voor de sociale identiteit werd bepalend in welke organisa- 
tie men participeert. In het bijzonder de participatie door het verrichten van betaalde arbeid in een organisatie wordt dan gezien als iets wat veel verschil maakt. De vrouwenemancipatie en de integratie van minderheden worden op basis van die maatstaf beoordeeld. In dat licht bezien is religie dan een kwestie van het lid zijn van religieuze organisaties en deelname aan de activiteiten van die organisaties. In het perspectief van de organisatiemaatschappij wordt de secularisatie gedefinieerd als het verlaten van de kerkelijke organisaties. Minder leden van kerkgenootschappen en minder bezoek op zondag aan de kerken, dát is in een organisatiemaatschappij het gezicht van de secularisatie. In een samenleving, waarin in het algemeen organisaties het leven bepalen, is het opmerkelijk als kerkelijke organisaties hun leden verliezen. Dat is echter niet meer het geval als ook andere organisaties de band met hun leden verliezen.

Het beeld van de religieuze zingeving en de secularisatie verandert weer als de organisatie niet meer de basisstructuur is van de ordening van onze samenleving en als de participatie in organisaties niet meer datgene is wat veel verschil maakt. Berger heeft in het verleden al op het belangrijke feit gewezen dat mensen verschillende deelidentiteiten krijgen. Zij hebben binnen de moderne organisatie meestal een onduidelijke en partiële rol. Tegelijkertijd leven zij in verschillende organisatorische omgevingen (Berger, Berger en Kellner 1974). Dat relativeert de betekenis van de identiteit die men ontleent aan het lidmaatschap van de organisatie. Meer recent is er nog bij gekomen dat de sterke functionele organisatorische differentiatie is verdwenen en dat de band met organisaties losser is geworden. Merken overkoepelen verschillende organisatorische activiteiten. Het merk is belangrijker dan de organisatie. Organisaties bestaan nog steeds, maar mensen zijn ze steeds minder trouw gedurende hun hele leven. Men heeft geen baan meer voor het leven, men gaat ook niet meer elke zondag naar dezelfde kerk.

\section{De leefstijlmaatschappij}

Sociale klassen of organisaties lijken niet meer de basisstructuren van onze samenleving te zijn. Er tekenen zich nu andere patronen af. Het is nog moeilijk die te duiden. In het sociale onderzoek zien we meer een directe oriëntatie op de leefstijl als basispatroon in de samenleving (zie ook paragraaf 6.2 van het hoofdstuk 'Leefstijlen in zingeving'). Leefstijlen die te maken hebben met een binding aan marktsegmenten met merken en belevenissen. Een leefstijl is een manier van leven die tot uitdrukking komt in het sociale gedrag en in de mentaliteit. Leefstijlen blijken veel verschil te maken en dikwijls, maar niet altijd, beter gedragsverschillen te kunnen verklaren dan de positie op de sociale ladder of in de organisatiemaatschappij (zie ook Tomlinson 1998).

De leefstijl heeft niet alleen betrekking op een bepaald consumptiepatroon. De leefstijlmaatschappij bestaat uit mentaliteitsgroepen die verschillen in consumptief gedrag, in de arbeid die men verricht, in politieke oriëntatie, in ethische opvattingen en uiteraard tegelijkertijd ook in de zin die men geeft aan de werkelijkheid (zie de verschillende profielen in 'Leefstijlen in zingeving'). De verschillende mentaliteitsgroepen zijn niet gebonden aan bepaalde maatschappelijke organisaties. 
Woodhead legt ook een verband met verschillen in leefstijl, maar specifiek met die van mannen en vrouwen (Woodhead 2005; Heelas en Woodhead 2005). Volgens haar zijn de oude instituties (publiek en religieus) een mannenbolwerk. De emancipatie van de vrouw gaat dan gepaard met de ondergang van de instituties, omdat die zo door mannen bepaald waren. In die visie hebben religieuze instellingen zichzelf verzwakt door zich sterk te baseren op een in de tijd niet houdbare ongelijkheid tussen mannen en vrouwen. Dit zou een effect hebben op het publieke domein in het algemeen, en ook een andere vormgeving van religie inhouden: een ontwikkeling van grootschalige (kerkelijke) organisaties naar een religieuze beleving in het kader van meer persoonlijke contacten die meer bij de leefstijl van vrouwen behoren.

Een interessante kwestie betreft de individuele autonomie en de rol van de markt. Giddens ziet de leefstijl als het resultaat van een individuele keuze. De identiteit zou statisch noch overgedragen zijn, maar het resultaat van een reflexief proces. Dit zou bevorderd moeten worden door een leefstijlpolitiek. Mensen moeten hun leefstijl kunnen realiseren los van tradities; in een traditionele omgeving zouden mensen minder invloed hebben op hun omstandigheden (Giddens 1991). Tegelijkertijd relativeren andere auteurs toch ook de veronderstelde individuele autonomie. Mensen zouden zich nu laten sturen door hun angsten in een wereld vol gevaren (Beck 1992). Zij worden dan gevoelig voor manipulatie (Furedi 2005). De zoektocht naar individualiteit leidt tot nieuwe controle door professionals en een afhankelijkheid van adviseurs (Bauman 200o). Dit betekent dat de individuele autonomie, evenals de vrijheid van keuze van de leefstijl, uiteindelijk beperkt is.

Het ontstaan van een leefstijlmaatschappij is dan niet hetzelfde als individualisering. De beschrijving door individualisering houdt de veronderstelling in dat er sprake is van een toenemende individuele autonomie. Echter, als kerkelijke instellingen minder invloed hebben op het gedrag van mensen, houdt dat nog niet in dat er geen andere maatschappelijke invloeden op dat gedrag zijn. Het is de vraag of de moderne burger met een bepaalde leefstijl meer individuele autonomie heeft dan de Nederlander in het verleden in de toen bestaande sociale omgeving. Dat neemt niet weg dat individualisme in het vaandel kan staan van de moderne consument, van emancipatiebewegingen of van de in het artikel 'Leefstijlen in zingeving' beschreven niet gebonden religieuze categorie. Dit individualisme behelst het zich afwenden van voorheen gebruikelijke keuzen, van bestaande maatschappelijke verhoudingen of religieuze praktijken. In een leefstijlmaatschappij gaat het bij dit individualisme om een zingeving die verband houdt met het profijt voor het individu hier en nu, of in zijn directe omgeving, van de eigen gekozen belevenis. Het individuele gedrag laat zich niet meer sturen door de effecten op de langere termijn op de meer omvattende samenleving of op een transcendente werkelijkheid.

De maatschappelijke pluriformiteit houdt nu verband met de leefstijl die zich presenteert als een uitdrukking van individuele voorkeuren. Dit hoeft geen uitdrukking te zijn van een grotere individuele autonomie en is dat ook niet als 
de leefstijl onder de invloed van anderen tot stand komt. Er zijn alternatieve instituties voor de traditionele kerken die daaraan functioneel equivalent zijn, dezelfde functies kunnen vervullen voor de burger zonder dat die zich verbonden hoeft te achten aan die instituties. Niettemin kan de leefstijl daarvan afhankelijk zijn, van wat zich op de zingevingsmarkt aanbiedt. Bijvoorbeeld de media kunnen bepaalde vormen van zingeving volgen en versterken. Dat geldt ook voor de religieuze of spirituele leefstijlen die wel een transcendente dimensie hebben, maar sterker dan voorheen op het hier en nu gericht zijn. Ook als de zingeving, inclusief de religieuze zingeving, op het individu is gericht, betekent dat nog niet dat die gezien moet worden als een individueel verschijnsel. Dat kan een illusie zijn in een maatschappelijke omgeving waarin de individuele uniciteit wordt benadrukt, maar tegelijkertijd de leefstijl gedetermineerd wordt door markt en media.

\section{Leefstijl en de religieuze transformatie}

Als onderdeel van een bepaalde leefstijl krijgen de religieuze zingeving en de secularisatie weer een ander gezicht. Er is een transformatie gaande waarin de religie of de spirituele transcendentie iets is wat vooral nuttig is voor de persoon en zijn directe omgeving. Als er idealisme is, is dat een praktisch idealisme. Het is in dit verband begrijpelijk dat er nu onderzoek wordt gedaan vanuit de veronderstelling dat religie goed is voor het welbevinden en de gezondheid van de gelovige (zie o.a. Wittich et al.). Aan de andere kant is het nog steeds zo dat de ondervraagde gelovigen in 'Leefstijlen in zingeving' aangeven veel aan liefdadigheid te doen en in die zin relatief minder op het eigen heil gericht zijn. Toch zal men bij verder onderzoek kunnen vaststellen dat het christelijke geloof hebben als leefstijl nu iets heel anders is dan in het verleden het christen zijn als kerkganger en als lid van een bepaalde sociale klasse was. In de Verenigde Staten maken christelijke bewegingen nu intensief en effectief gebruik van de media. Dit is iets geheel anders dan het traditionele gedrag met de zondagse kerkgang (zie ook Wolfe 2003: 250).

Het is de vraag of religie of spiritualiteit buiten de kerk als een puur persoonlijke keuze gezien kan worden. Ook daar is sprake van institutionalisering, maar wel zonder een persoonlijke binding aan de instituties. In het algemeen is het zo dat in de samenleving een sterke functionele organisatorische differentiatie bezig is te verdwijnen en mensen minder trouw zijn aan organisaties. Gedrag wordt steeds meer gestuurd door leefstijlen die een institutionele vorm krijgen in gedrag, bijvoorbeeld in het gebruik van de media, in de wijze van wonen of de mobiliteit. De religie kan nu een dimensie zijn van het gedrag binnen institutionele kaders die niet primair een religieuze functie hebben. Niettemin kunnen die kaders, bijvoorbeeld de media, een alternatief bieden voor religieuze organisaties en daaraan dan in functioneel opzicht equivalent zijn. Dit roept vervolgens weer een vraag op over de rol van de overheid: heeft de overheid een taak ten opzichte van de media die een rol spelen bij de maatschappelijke zingeving? Het is in dit empirische luik niet de plaats om deze vraag te beantwoorden. 
De samenleving verandert en daarmee moeten we onze blik op de religieuze zingeving veranderen. Omdat de samenleving zich ontwikkelt van een klassenmaatschappij via een organisatiemaatschappij naar een samenleving met een pluriformiteit van leefstijlen, verandert ook de manier waarop we naar religie en secularisatie moeten kijken.

\subsection{DE TOEKOMST VAN RELIGIE EN SOCIALE COHESIE IN EEN LEEFSTIJLMAATSCHAPPIJ}

Op wereldschaal stijgt de religieuze aanhang en daardoor ook de betekenis van religie voor het publieke domein. De ontwikkelingen in West-Europa vertonen een afwijkend patroon, in die zin dat men zich hier afkeert van de christelijke kerken. Er zijn echter wel kansen op een grotere religieuze bewustwording en op een relatief grote betekenis van de spiritualiteit in persoonlijke relaties. Tegelijkertijd blijkt er een groep te ontstaan zonder enige levensbeschouwelijke binding. Deze ontwikkeling roept de vraag op wat het effect is op de sociale cohesie. Achtereenvolgens gaat deze paragraaf nu in op:

- de kans op een groei van de religieuze bewustwording;

- de neosecularisatie in de vorm van een transformatie van het religieuze;

- het resultaat hiervan in een ongebonden spiritualiteit;

- de sociale cohesie in een leefstijlmaatschappij waarin het religieuze een van de verschillende leefstijlen is.

Het gaat in deze concluderende paragraaf, zoals gezegd, om een poging voorlopig te markeren waartoe de empirische verkenningen in deze bundel hebben geleid. Deze markeringen kunnen aanleiding zijn voor verder onderzoek, maar zijn hopelijk ook al een nuttige bijdrage aan een bezinning op de rol van religieuze en niet-religieuze zingeving in het publieke domein.

\section{Misschien een sterkere religieuze bewustwording}

Nederland kent een grote naoorlogse geboortegolfgeneratie die een stempel zet op de samenleving. Die generatie is minder aan de kerkelijke religie verbonden dan de voorgaande generaties. Dat wil niet zeggen dat Nederland daardoor een seculiere toekomst heeft. Er kan zich een leeftijdseffect voordoen als de geboortegolfgeneratie bij het ouder worden andere (religieuze) opvattingen krijgt. Ook kunnen de allerjongste generaties weer verschillen van de geboortegolfgeneratie. Het is geen universeel verschijnsel dat ouderen religie belangrijker vinden dan jongeren (Inglehart 2004: 4). Uit onderzoek in het buitenland volgt dat de jongste generatie zich weer meer op het geloof kan oriënteren (Greeley 2003: 23). Ook uit recent Nederlands onderzoek zijn hiervoor aanwijzingen (Becker 2006: 21).

Een religieuze bewustwording kan door de migratie ontstaan. Etnische minderheden kunnen in hun nieuwe omgeving een groter gewicht gaan geven aan de religieuze overtuigingen. In dit verband wordt wel gesproken van een reactieve identiteit: in een vreemde (en zeker in een relatief vijandige) omgeving is men geneigd om terug te grijpen op de tradities in het land van herkomst, waarvan 
religie een van de voornaamste is. Daarnaast kan mogelijk ook de grotere vrijheid van godsdienst in het ontvangende land een rol spelen, waardoor men meer dan in het land van herkomst uiting durft te geven aan religieuze gevoelens. Er kan ook nog een ander mechanisme werkzaam zijn. Er zijn religieuze bewegingen die juist dankzij de globalisering zijn ontstaan en in een internationale omgeving hun invloed uitoefenen (Berger 2002: 12).

Er kan mede door de migratie meer pluriformiteit in het religieuze aanbod ontstaan, wat bevorderlijk kan zijn voor de religieuze bewustwording. In de economische literatuur is er tegenwoordig veel aandacht voor de rol van concurrentie bij religieuze bindingen. In het hoofdstuk 'Leefstijlen in zingeving' wordt in dit verband verwezen naar publicaties van Stark (Stark en Finke 2002; Finke en Stark 2005; Stark 2006). Meer religieuze pluriformiteit zou zorgen voor mobilisatie en sterkere religieuze bindingen. Dit lijkt echter nog niet op te gaan voor Nederland, dat in religieus opzicht pluriform is (zie tabel 3.4). Hier zijn ondanks de religieuze pluriformiteit de bindingen niet sterk. Misschien moet ook nog meegewogen worden welke afstand er is tussen de verschillende religieuze opvattingen. Er zijn verschillen binnen het christendom, maar grotere verschillen tussen christelijke en niet-christelijke religies. Op termijn zou deze verklaring betekenen dat in Nederland de migratie, die de binnenkomst van nieuwe niet-christelijke religies met zich meebrengt, tot een sterkere religieuze bewustwording leidt bij andere, al gevestigde bevolkingsgroepen.

In deze lijn van denken kan ook verwacht worden dat de aanhangers van seculiere visies de toenemende manifestatie van (monotheïstische) godsdienst(en) als een bedreiging zullen zien en dit ook uitspreken in het maatschappelijke debat. Dit kan het effect hebben van een verminderde aanhang van religieuze opvattingen, maar dit kan ook leiden tot een versterking van orthodoxe religieuze stromingen en hun eigen onderwijs en pers.

Stark en Bainbridge (1987) verbinden de concurrentietheorie met een cyclisch model waarbij de secularisatie, in de vorm van het verdwijnen van de aanhang van religieuze tradities, het begin is van de opkomst van nieuwe religieuze bewegingen, die meer dan de traditionele religies kunnen bieden aan het deel van de bevolking dat in een maatschappelijke situatie verkeert met weinig perspectief. Daarbij kan men ook denken aan bepaalde groepen migranten.

Ondanks de mogelijk grotere religieuze bewustwording in de toekomst zullen de vroegere vormen van institutionalisering niet snel weer algemeen worden. Als we het begrip religie reserveren voor een bepaalde geïnstitutionaliseerde vorm hiervan, voor de kerkgebonden religie, dan is in West-Europa de betekenis hiervan voorlopig en misschien wel blijvend beperkt.

\section{De neosecularisatie in de vorm van een religieuze transformatie}

Bij een internationale vergelijking blijkt dat de persoonlijke binding, de rol van de religie in de privésfeer en de institutionele binding elkaar niet volledig over- 
lappen. In het algemeen is de rituele functie van religie belangrijk, maar er is een groot verschil tussen West-Europese landen en andere landen wat betreft de maatschappelijke en persoonlijke binding. Men kan niet in alle opzichten spreken van een secularisatie, eigenlijk ook niet in alle opzichten voor West-Europa waar een groot deel van de bevolking zich als religieus beschouwt. Wel onderscheiden West-Europese landen zich van andere landen doordat hier een minderheid religie zeer belangrijk vindt.

Uitspraken over secularisatie hebben vooral betrekking op West-Europa. In de rest van de wereld is er een groeiende aanhang van islam en christendom, mede door demografische ontwikkelingen. Berger heeft een aantal jaren geleden op basis van de toen al ingezette ontwikkelingen geconstateerd dat er naast een secularisering een desecularisering kan plaatsvinden (Berger 1999). Soms heeft modernisering een seculariserend effect, maar er zijn ook tegenbewegingen ontstaan, waardoor traditionele religies groeien en er nieuwe religieuze bewegingen ontstaan. De door Berger waargenomen desecularisering lijkt niet voor West-Europa te gelden. Hier is er een afnemende aanhang in de traditionele kerkgebonden religies.

De cijfers roepen vragen op over de manier waarop secularisatie omschreven moet worden. Er kunnen in principe verschillende patronen voorkomen. Kerkelijke instellingen kunnen hun invloed houden los van individueel ongeloof. Ondanks een persoonlijk niet-geloven kon men institutioneel-maatschappelijk met religie verbonden zijn. Omgekeerd kunnen kerkelijke instellingen hun aanhang verliezen zonder dat de religieuze beleving op individueel niveau vermindert (Berger 1999: 3 e.v.). De persoonlijke spiritualiteit staat dan los van de maatschappelijke bindingen aan kerkelijke instellingen. Dat laatste blijkt in Europa voor een deel van de bevolking het geval te zijn.

Voor West-Europa lijkt een neosecularisatiethese houdbaar. Hierbij is de secularisering op maatschappelijk niveau niet onverbrekelijk verbonden met secularisering op individueel niveau. Dan zou het idee van grote veranderingen in religieus opzicht onjuist zijn. Die veranderingen zijn er misschien wel in institutioneel opzicht maar niet in de beleving. Er is kennelijk een religieuze transformatie gaande waardoor de religie maatschappelijk onzichtbaar wordt maar niet verdwijnt (zie ook Luckmann 1967). Er zijn in West-Europa veel religieuze buitenstaanders die de kerk verlaten hebben maar nog wel religieus zijn. Aan de andere kant heeft die neosecularisatie daar niet tegelijkertijd de vorm van een desecularisatie, dus van een groeiende aanhang van religieuze opvattingen.

De andere plaats van de religie in West-Europa en andere westerse landen kan men ook beschrijven als een postsecularisatie of postsecularisme. De laatste term wordt door Habermas gebruikt in een beschouwing waarin hij constateert dat religieuze inzichten belangrijk zijn in het publieke domein van een verder seculiere, liberale samenleving (Habermas 2005). 


\section{De onzichtbare religie in de ongebonden spiritualiteit}

De vraagstelling bepaalt mede hoeveel personen in een enquête zich rekenen tot een bepaalde denominatie. Bij een meer uitvoerige vraagstelling ontstaat een meer bewuste keuze en is het aandeel buitenkerkelijken hoger (zie ook Becker 2003). In 'Leefstijlen in zingeving' kunnen we op grond van een uitgebreide vraagstelling constateren dat ruim een kwart van de bevolking bij een religieuze denominatie kan worden gerekend (dat is dus aanzienlijk lager dan de $45 \%$ die in tabel 3.4 voor Nederland wordt gegeven, en die gebaseerd is op een meer beperkte directe vraag). Bij het deel dat zegt niet tot een religieuze denominatie te behoren, is er een grote verscheidenheid: een ongebonden spirituele, een humanistische en een niet-religieuze, niet-humanistische groep. Dus niet iedereen die zich niet tot een kerkgenootschap rekent, kan als seculier worden beschouwd. Een kwart van de bevolking maakt deel uit van een ongebonden spirituele groep, die men in de sfeer van de new age kan plaatsen. Met het ontstaan van deze groep is de religie gedeeltelijk onzichtbaar geworden, er is geen duidelijke binding meer aan een bepaald instituut. Het is dan moeilijk om vat te krijgen op de religie die onzichtbaar is, zeker in vergelijking met de materiële aanwezigheid van de religie in kerkgebouwen. Maar, wordt religie hierdoor een individuele zaak? En zal uiteindelijk het christendom vervangen worden door spiritualiteit en zal uiteindelijk ook de spiritualiteit verdwijnen doordat er geen overdracht plaatsvindt aan jongere generaties door een kerkelijk instituut (zie ook Heelas 2001; Heelas en Woodhead 2005)?

In verschillende in Nederland verschenen publicaties wordt deze groeiende ongebonden spiritualiteit niet als een belangrijke ontwikkeling gezien en ook niet als een substantieel alternatief voor in kerkorganisaties geïnstitutionaliseerde religie. Deze spiritualiteit zou eerder verwijzen naar een magisch wereldbeeld dan naar een sacraal, religieus wereldbeeld. New age zou geen alternatief bieden (De Graaf en Te Grotenhuis 2005: 155). Uit het hoofdstuk in deze bundel over de leefstijlen in zingeving blijkt dat, gezien de omvang van de groep, hier toch wel een belangrijk alternatief is ontstaan. De zingeving van deze categorie heeft een transcendente dimensie en inderdaad soms ook een magisch karakter. Tegelijkertijd moet ervoor worden opgepast religieuze uitingen die niet meer passen bij een bestaande institutionele vormgeving van de religie, zonder meer als een regressie naar magie te beschouwen. Het gaat in de moderne spiritualiteit niet om een magie die vergelijkbaar is met die van het prereligieuze stadium in de historische ontwikkeling. Voor zover men hierin een groeiende waardering ziet voor magie, is het een magie die sterk verbonden is met de culturele uitingen van de moderne samenleving. Het is meer adequaat om het ontstaan van een groep ongebonden spirituelen als een nieuw verschijnsel te zien. Als het dat is, is er een lange historische ontwikkelingslijn te trekken van magie via religie naar spiritualiteit als een moderne vorm van transcendentie. De ontwikkeling naar ongebonden transcendente vormen van zingeving, maar ook het ontstaan van een niet-religieuze categorie, kan geplaatst worden tegen de achtergrond van de brede maatschappelijke ontwikkeling naar een leefstijlmaatschappij. 


\section{Zingeving en sociale cohesie in de leefstijlmaatschappij}

De binding aan religieuze instituties kan een wijdere betekenis hebben voor een sociale cohesie waarin individuele vrijheid en de bescherming van rechten worden gewaarborgd. Men kan deze zaken verbinden met het tegenwicht dat ten opzichte van de staatsmacht wordt geboden door civiele instituties, waaronder religieuze organisaties. Die vrijheid en bescherming gaan vooraf aan en zijn een voorwaarde voor democratie en vrije verkiezingen (Zakaria 2004). Ook is er een verband tussen een bepaalde institutionele vormgeving en de voortbrenging van een sociaal kapitaal. Het lidmaatschap van religieuze organisaties betekent dat een sociaal kapitaal wordt gegenereerd, zoals dat is beschreven door Putnam (1995). De georganiseerde religie inspireert dan tot sociale actie en vrijwilligerswerk en kan ook een rol spelen in de opvoeding, in het bijbrengen van morele waarden. Ook blijkt, uit het hoofdstuk over de zingeving, dat de christelijke religie belangrijk kan zijn voor de liefdadigheid, ook buiten de eigen kring. Het verloren gaan van de religieuze organisatie houdt dus risico's in voor de democratie en de voortbrenging van sociaal kapitaal.

Het is de vraag wat de nieuwe vorm die het pluralisme aanneemt, die niet geordend kan worden in het patroon van de verzuiling en in het lidmaatschap van kerkelijke organisaties, in de toekomst zal betekenen voor de sociale cohesie. De uitgangspositie is in Nederland nu anders dan bijvoorbeeld in de Verenigde Staten. Het lijkt erop dat men in de Verenigde Staten een recept heeft voor de onderlinge omgang van de verschillende religies. Uit de bijdrage van Wolfe valt af te leiden dat, als er in de Verenigde Staten een conflict is tussen de religie en de cultuur, het vaak de cultuur is die wint. Amerikaanse religies convergeren daardoor. In Nederland, als Europees land, lijkt er niet een vergelijkbare in de cultuur verankerde dominante leefstijl te zijn die de verschillen dempt. Eerder lijkt er sprake te zijn van een divergentie.

Er zijn in Nederland grote verschillen in leefstijlen in zingeving. Er is een scenario denkbaar waarin de onderscheiden categorieën in de bijdrage over zingeving (religieus, spiritueel, humanistisch en niet-religieus, niet-humanistisch) niet alleen een verdeling van leefstijlen onder de bevolking weergeven, maar ook de verschillende stadia van ontwikkeling voor de gehele bevolking die uitmonden in een groeiende aanhang van de niet-religieuze, niet-humanistische categorie. Dit zou een stijgend risico inhouden voor de sociale cohesie gezien de geringe maatschappelijke betrokkenheid van de laatste categorie. Dat risico is er nu ook al door de tegenstelling tussen het profiel van deze groep en, in het bijzonder, het profiel van de overige religieuzen.

Deze groep heeft een leefstijl zonder een religieuze, spirituele of humanistische dimensie. Uit 'Leefstijlen in zingeving' blijkt dat die weerbarstige groep wel maatschappelijk participeert in betaalde arbeid, maar moeite heeft met de participatie als burger: zij zijn buitenstaanders, zijn weinig tolerant en hebben geen vertrouwen in de overheid. Het hebben van werk is dus niet voldoende om een plaats in de samenleving te vinden, iets wat in het overheidsbeleid vaak gedacht 
is. Die veronderstelling is inderdaad juist in een organisatiemaatschappij waar iedereen voor het leven verbonden is met een organisatie, maar ze is niet meer adequaat in een samenleving waarin het gedrag wordt bepaald door de leefstijl.

Veel zal afhangen van de keuzes van degenen die een burgerschapsstijl hebben waaruit blijkt dat men zich wel verantwoordelijk voelt voor publieke zaken (zie het hoofdstuk 'Leefstijlen in zingeving'). Van hen, en in het bijzonder van de nieuw ontstane categorie van de ongebonden spirituelen, mag een inbreng worden verwacht op levensbeschouwelijk gebied in de pluralistische democratie. Dit geldt bijvoorbeeld voor de media die belangrijk zijn voor de zingeving.

\section{Conclusies}

In Nederland, en in West-Europa als geheel, is de secularisatie op institutioneel niveau (het verlies van aanhang van kerkelijke instituties) niet onverbrekelijk verbonden met een secularisatie op individueel niveau. Er is een neosecularisatie in de vorm van een transformatie van de religieuze beleving naar kerkelijk ongebonden vormen. Religie, gebonden en ongebonden, is een leefstijl naast niet-religieuze leefstijlen die weer verder onderscheiden kunnen worden in humanistische en niet-humanistische. Er zijn aanwijzingen dat in de toekomst een groei in de religieuze bewustwording kan ontstaan.

Het verdwijnen van institutioneel gebonden religieuze vormen van zingeving houdt het risico in dat een negatief effect op de sociale cohesie ontstaat. Daarmee verdwijnen ook de positieve effecten op de democratie en de vorming van sociaal kapitaal. Verder is er een risico voor de sociale cohesie door het ontstaan van een bevolkingsgroep met een zingeving zonder een levensbeschouwelijke binding als leefstijl, die zich negatief verhoudt tot de omringende samenleving en de leefstijlen van religieuze groepen. 


\section{NOOT}

1 http://nds.umdl.umich.edu/cgi/s/sda/hsda?harcWEVS+wevs. 


\section{LITERATUUR}

Aleslina, A., A. Devleeschauer, W. Easterly, S. Kurlat en R. Wacziarg (2002) Fractionalization, NBER Working Paper Series, Cambridge, Massechusetts.

Bauman, Z. (200o) Liquid Modernity, Cambridge: Polity Press.

Beck, U. (1992) Risk Society: Towards a New Modernity, London: Sage.

Becker, J. (2003) De vaststelling van de kerkelijke gezindte in enquêtes, Werkdocument 92, Den Haag: SCP.

Becker, J. (2006) 'Nederland en de secularisatie. Enige trends in gegevens met betrekking tot de levensbeschouwing', Religie en samenleving 1, 1: 5-25.

Berger, P., B. Berger en H. Kellner (1974) The Homeless Mind: Modernization and Consciousness, New York: Vintage Books.

Berger, P.L. (1998) 'Protestantism and the Quest for Certainty', The Christian Century August 26-September 2, 782-796.

Berger, P.L. (1999) The Desecularization of the World, Resurgent Religion and World Politics, Michigan, Grand Rapids: William B. Eerdmans Publishing Company.

Berger, P.L. (2002) 'Introduction, the cultural dynamics of globalization', blz. 1-16 in: P.L. Berger and S.P. Huntington (eds.), Many globalizations. Cultural diversity in the contemporary world. Oxford: University Press.

Furedi, F (2005) Politics of Fear; Beyond Left and Right, Continuum International Publishing Group.

Finke, R. and R. Stark, The Churching of America, 1776-2005. Winners and Losers in Our Religious Economy, New Brunswick and London: Rutgers University Press.

Giddens, A. (1991) Modernity and Self-Identity. Self and Society in the Late Modern Age, Stanford: Stanford University Press.

De Graaf, N.D. en M. te Grotenhuis (2005) 'Afnemend geloof in God en toenemend geloof in een hogere werkelijkheid? Verklaringen van trends tussen 1979 en 2000', Mens en Maatschappij 80, 2: 143-158.

Greeley, A.M. (2003) Religion in Europe at the End of the Second Millennium, New Brunswick: Transaction Publishers.

Habermas, J. (2005) Religion in the public sphere. Lecture presented at the Holberg Prize Seminar, 29 november 2005.

Heelas (2001) geciteerd in: Alternative spirituality 'rising fast', Guardian Unlimited, 18 juni 2001.

Heelas, P. en L. Woodhead (2005) The Spiritual Revolution. Why Religion is Giving Way to Spirituality, Blackwell.

Inglehart, R., M. Basáñez., J. Díez-Medrano, L. Halman and R. Luykx (2004) Human Beliefs and Values. A cross-cultural sourcebook based on the 1999-2002 surveys, Siglo XXI Editores.

Ipsos-Public Affairs (2005) The Associated Press Poll May 13-May 26, persoonlijk verstrekte informatie.

Luckmann, T. (1967) The Invisible Religion. The problem of religion in modern society, New York/London: The Macmillan Company/Collier-Macmillan Ltd.

Putnam, R.D. (1995) 'Bowling Alone: America's Declining Social Capital', Journal of Democracy 6, 1: 65-78. 
Pyle, R.E en J.D. Davidson, 'Stratification', W.H. Swatos (ed.), Encylopedia of Religion and Society, Hartford Institute for Religion Research.

Rooden, P. van (2004) 'Oral history en het vreemde sterven van het Nederlandse christendom', BMGN 119, 4: 524-551

Stark R. and Bainbridge W.S. (1987) Theory of Religion, Rutgers University Press.

Stark, R. (2006) 'An Economics of Religion', p. 47-68 in: R.A. Segal (ed.) The Blackwell Companion to the Study of Religion, Oxford: Blackwell.

Stark, R. and R. Finke (2002) 'Beyond Church and Sect: Dynamics and Stability in Religious Economies', p. 31-62 in: T.G. Jelen (ed.), Sacred Markets and Sacred Canopies: Essays on Religious Markets and Religious Pluralism, Lanham, MD: Rowman \& Littlefield.

Tomlinson, M. (1998) Lifestyles and social classes, CRIC Discussion Paper No. 9, Manchester: Centre for Research on Innovation and Competition.

Wittich, W., M. Yampolsky, O. Overbury, G. Webb, Coping with Vision Impairment: An Interaction of Age and Spiritual Well-Being (nog niet gepubliceerd).

Wolfe, A. (2003) The transformation of American Religion. How we actually live our faith, The University of Chicago Press.

Woodhead, L. (2005) Religion in Public Life - End or New Beginning? Publiekslezing Universiteit van Tilburg, 1 september 2005.

Zakaria, F. (2004) The Future of Freedom. Illiberal Democracy at Home and Abroad, New York/London: W.W. Norton \& Company. 


\title{
4 EEN RELIGIEUZE ATLAS VAN NEDERLAND
}

\author{
Ton Bernts, Gert de Jong en Hasan Yar
}

\subsection{INLEIDING}

\subsubsection{DOEL VAN DEZE RELIGIEUZE ATLAS}

Het religieuze landschap in Nederland is zeer divers. In de eerste plaats kent ons land historisch al twee grote kerkelijke gemeenschappen: de katholieke kerk en de kerken van de reformatie. De reformatie is naderhand in vele kerken en kerkjes opgedeeld geraakt. Naast deze historische diversiteit wonen er in Nederland immigranten uit de voormalige overzeese gebiedsdelen en kennen we natuurlijk de meer recente immigratie uit met name Turkije, Marokko en Afrika. Deze allochtone Nederlanders hebben hun eigen religie meegebracht, of kennen een eigen invulling van het katholiek of protestants kerk-zijn, zoals blijkt uit de diversiteit binnen de migrantenkerken. Tot slot hebben ook secularisatie en individualisering bijgedragen aan de diversiteit van het religieuze landschap. Net als in de rest van West-Europa heeft ons land de afgelopen decennia een sterke ontkerkelijking gekend. Veel gelovigen hebben een eigen 'geloof' en geloofspraktijk ontwikkeld. Ook zijn er buiten de kerken losse en niet duidelijk aan instituties gebonden religieuze en esoterische praktijken ontwikkeld, zoals new age.

In weerwil van secularisatie en individualisering, en versterkt door de recente immigratiestromen, vormen de grote kerken en religies (nog steeds) omvangrijke instituties die het religieuze landschap in Nederland in sterke mate bepalen. Wanneer in deze voorstudie over de positie van religie in het publieke domein wordt gereflecteerd, is kennis van de belangrijkste contouren van de georganiseerde religie in Nederland dan ook van groot belang. Daarom presenteren we hier een religieuze atlas van Nederland, om aldus de lezer in staat te stellen zich in het religieus-institutionele landschap te oriënteren en gevoel te krijgen voor de omvang, organisatie en demografische gesitueerdheid van de belangrijkste kerken en religies, en stromingen daarbinnen. Daarbij gaat het om ledentallen, religieuze gebouwen, voorgangers en participatie aan religieuze praktijken.

Een religieuze atlas met deze doelstellingen impliceert meteen enkele beperkingen. In de eerste plaats worden contouren pas zichtbaar door weglating. Dat is ook hier het geval. We hebben in principe alleen kerkgenootschappen of religies meegenomen die minimaal 1o.ooo leden hebben. Hier en daar zullen in de context van een grotere kerk of stroming niettemin ook wel eens enkele kleinere kerken of religies worden vermeld.

Een tweede beperking vloeit voort uit onze focus op institutionele aspecten. In deze atlas wordt - hoe interessant ook - geen aandacht besteed aan de beleving van bijvoorbeeld kerklidmaatschap of kerkgang. Dit onderscheid tussen objectief lidmaatschap en de subjectieve beleving ervan zorgt bijvoorbeeld bij tellingen van 
het aantal katholieken en protestanten nogal eens voor verwarring. Het Centraal Bureau voor de Statistiek (CBS) hanteert in zijn publicaties een objectief criterium, namelijk 'gedoopt zijn', terwijl de cijfers van het Sociaal en Cultureel Planbureau (SCP) steeds berusten op subjectief lidmaatschap: beschouwt men zichzelf als lid? Het CBS-criterium betekent dat ook weinig of niet participerende kerkleden meetellen, hetgeen tot hogere cijfers leidt dan in de SCP-publicaties. Voor een uitvoerige vergelijking van deze beide criteria verwijzen we naar Becker (2003).

Bij de samenstelling van deze atlas zijn we uitgegaan van het objectieve criterium. Tot kerkleden of aanhangers van een religie rekenen we degenen die gedoopt zijn en/of ingeschreven bij een kerk, die een initiatierite hebben gevolgd of die conform de eigen religieuze traditie op basis van geboorte automatisch lid van de betreffende religieuze groep worden. Het mag duidelijk zijn dat de verschillende religies hierdoor qua ledental niet goed vergelijkbaar zijn. Een kind van katholieke ouders is nog niet automatisch katholiek, maar pas na het doopsel, terwijl een kind van hindoe-ouders wel meteen hindoe is.

Met inachtneming van bovengenoemde beperkingen is ons doel de lezer met deze atlas snel vertrouwd te maken in het institutionele religieuze landschap van Nederland.

\subsubsection{RELIGIES IN NEDERLAND}

In onze beschrijving van religieus Nederland hebben we op basis van de omvang van de kerken en religies een driedeling gemaakt, namelijk christendom, islam en overige religies. In tabel 1.1 staan de belangrijkste gegevens van deze religies samengevat.

Nederland telt ruim 7 miljoen christenen, circa 44 procent van de bevolking. Daarnaast zijn er circa 950.00o moslims, bijna 6 procent van de bevolking. De overige grote religies tellen samen tussen de 313 .00o en 428 .00o aanhangers of leden.

Cijfers over voorgangers, religieuze gemeenschappen en gebouwen zijn helaas niet altijd voorhanden. Wel zijn er af te toe deelcijfers bekend. Voor een nadere bespreking hiervan verwijzen we naar de betreffende paragrafen.

\subsubsection{VERANTWOORDING}

Het samenstellen van deze religieuze atlas is gebaseerd op diverse gegevens. In veel gevallen zijn ledentallen en het aantal gebouwen en voorgangers gebaseerd op eigen tellingen door de kerken of religies zelf. Soms zijn daartoe interne administraties geraadpleegd, soms hebben we ons gebaseerd op de jaarboeken die kerkgenootschappen uitgeven. De mate waarin er harde gegevens bekend zijn, varieert sterk. De Rooms-Katholieke Kerk is een zeer nauwkeurig gedocumenteerd kerkgenootschap, maar van bijvoorbeeld de hindoes in Nederland bestaan bijna alleen ruwe schattingen als het gaat om het aantal aanhangers. Waar 
Tabel 4.1 Religies in Nederland, in 2006 of meeste recente cijfers

\begin{tabular}{|c|c|c|c|c|}
\hline & leden & $\begin{array}{r}\text { voor- } \\
\text { gangers }\end{array}$ & $\begin{array}{l}\text { gemeen- } \\
\text { schappen }\end{array}$ & gebouwen \\
\hline \multicolumn{5}{|l|}{ CHRISTENDOM } \\
\hline Rooms-Katholieke Kerk & 4.406 .000 & 1.908 & 1.450 & 1.740 \\
\hline Protestantse Kerk in Nederland & 1.944 .000 & 2.173 & 1.832 & 2.840 \\
\hline Orthodox gereformeerde kerken & 238.000 & 541 & 566 & -- \\
\hline Bevindelijk gereformeerde kerken & 221.000 & 117 & 390 & -- \\
\hline Evangelische en pinksterkerken & 148.000 & -- & 890 & -- \\
\hline Vrijzinnige kerken & 19.000 & 177 & 225 & 183 \\
\hline Overige kerkgenootschappen & 156.000 & -- & -- & -- \\
\hline SUBTOTAAL & 7.132 .000 & & & \\
\hline \multicolumn{5}{|l|}{ ISLAM } \\
\hline Turkse moslims & 428.000 & 245 & -- & 245 \\
\hline Marokkaanse moslims & 296.000 & 150 & -- & 150 \\
\hline Overige moslims & 220.000 & 58 & -- & 58 \\
\hline SUBTOTAAL & 944.000 & 453 & -- & 453 \\
\hline \multicolumn{5}{|l|}{ OVERIGE RELIGIES } \\
\hline Hindoes & $100.000-215.000$ & 250 & -- & 50 \\
\hline Joden & 43.000 & 26 & 52 & -- \\
\hline Boeddhisten & 170.000 & -- & 33 & - \\
\hline SUBTOTAAL & $313.000-428.000$ & & & \\
\hline
\end{tabular}

Bron: KASKI

administratieve gegevens ontbreken, hebben we ons gebaseerd op onderzoeksgegevens van CBS of andere studies. Ook hebben we ons met name bij de minder overzichtelijk georganiseerde kerkgenootschappen of religies gebaseerd op mondelinge informatie van sleutelinformanten.

Voor het schatten van enkele trends baseren we ons veelal op het SCP. De surveygegevens van dit bureau geven betrouwbare trends aan, maar het schatten van absolute aantallen op basis van surveys blijft een heikele kwestie. Een bekend voorbeeld is het bepalen van het aantal kerkgangers. Door het KASKI wordt er jaarlijks in alle rooms-katholieke kerken op enkele weekenden in het jaar geteld. Uit deze tellingen blijkt steevast dat het aantal kerkgangers dat op basis van surveys kan worden berekend, aanzienlijk te hoog is. Respondenten zijn blijkbaar geneigd een frequentere en hogere kerkgang op te geven dan ze in werkelijkheid hebben. Wel is het zo dat de door de SCP geprognosticeerde trends in kerkgang ook worden teruggevonden in de genoemde, feitelijke tellingen.

De paragrafen 4.1 (inleiding), 4.2 (christendom) en 4.4 (overige religies) zijn door de twee eerstgenoemde auteurs, als onderzoekers van het KASKI geschreven. Para- 
graaf 4.3 over de islam is voor het grootste gedeelte samengesteld door Hasan Yar, werkzaam bij IHSAN, het Islamitisch Instituut voor Maatschappelijke Activering.

\subsection{CHRISTENDOM}

In deze paragraaf wordt een aantal kerncijfers van christelijke kerken gegeven, inclusief enige ontwikkelingen. Allereerst worden de gegevens van de RoomsKatholieke Kerk en de Protestantse Kerk in Nederland gepresenteerd, de twee grootste kerkgenootschappen in Nederland. Aansluitend volgt informatie over de orthodox gereformeerde kerken, de bevindelijk gereformeerde kerken, de evangelische en pinksterkerken en de vrijzinnige geloofsgemeenschappen. Aan het slot van de paragraaf komen de overige christelijke kerken of met het christendom verwante geloofsgemeenschappen aan bod.

\subsubsection{ROOMS-KATHOLIEKE KERK}

\section{Ledental en participatie}

De Rooms-Katholieke Kerk is het grootste kerkgenootschap in Nederland, met begin 2006 circa 4,4 miljoen kerkleden. Het kerkgenootschap bestaat uit 7 bisdommen met als naam de stad waar de bisschopszetel is gevestigd. Dit zijn Groningen, Utrecht, Haarlem, Rotterdam, Breda, 's-Hertogenbosch en Roermond. De verdeling van katholieken over ons land is als volgt.

Tabel 4.2 Spreiding katholieken over Nederland

\begin{tabular}{|lccc|} 
& $\begin{array}{c}\text { aantal } \\
\text { katholieken } \\
(\times 1.000)\end{array}$ & $\begin{array}{c}\text { percentage van } \\
\text { totaal aantal } \\
\text { katholieken }\end{array}$ & $\begin{array}{c}\text { percentage } \\
\text { van de }\end{array}$ \\
bevolking \\
Groningen & & & 4,6 \\
Friesland & 26 & 0,6 & 6,2 \\
Drenthe & 40 & 0,9 & 7,6 \\
Overijssel & 37 & 0,8 & 22,5 \\
Flevoland & 251 & 5,7 & 9,1 \\
Gelderland & 34 & 0,8 & 26,2 \\
Utrecht & 517 & 11,7 & 16,6 \\
Noord-Holland & 196 & 4,4 & 17,6 \\
Zuid-Holland & 460 & 10,4 & 15,0 \\
Zeeland & 519 & 11,8 & 19,5 \\
Noord-Brabant & 74 & 1,7 & 57,2 \\
Limburg & 1.381 & 31,3 & 76,9 \\
Nederland & 871 & 19,8 & 27,0 \\
\hline
\end{tabular}

Bron: RK Bureau Ledenadministratie en KASKI 


\section{Figuur 4.1 Aantal katholieken per provincie}

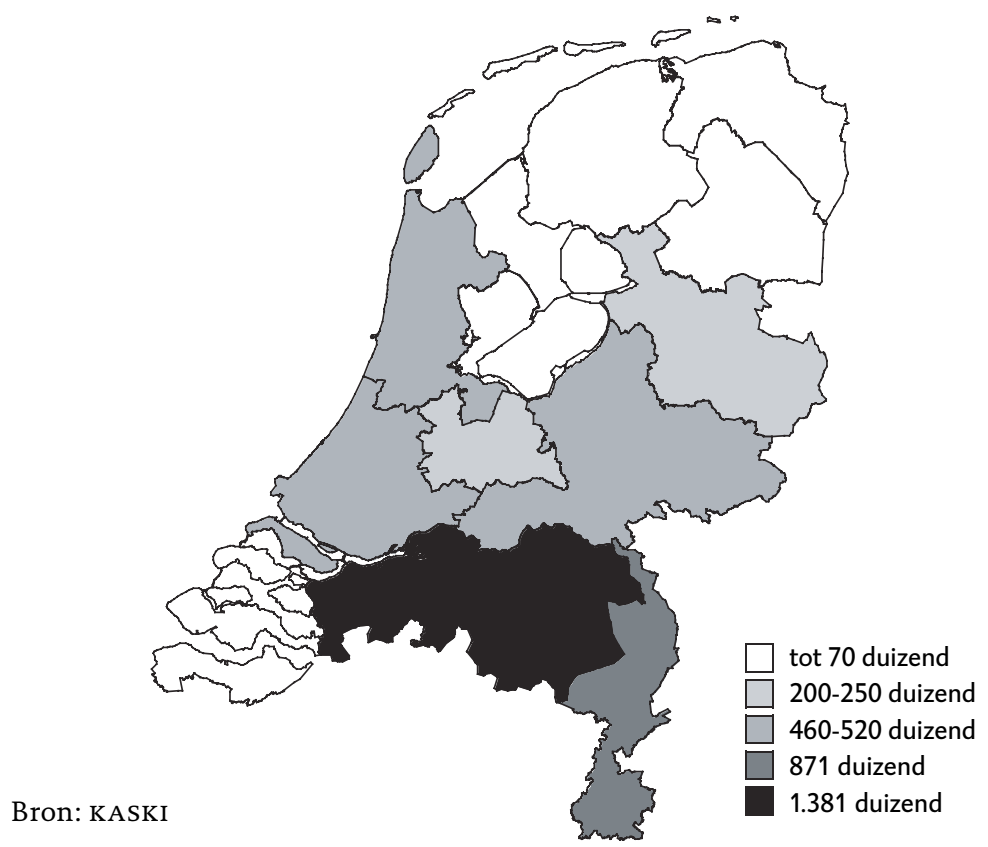

Figuur 4.2 Percentage katholieken op de bevolking

Bron: KASKI

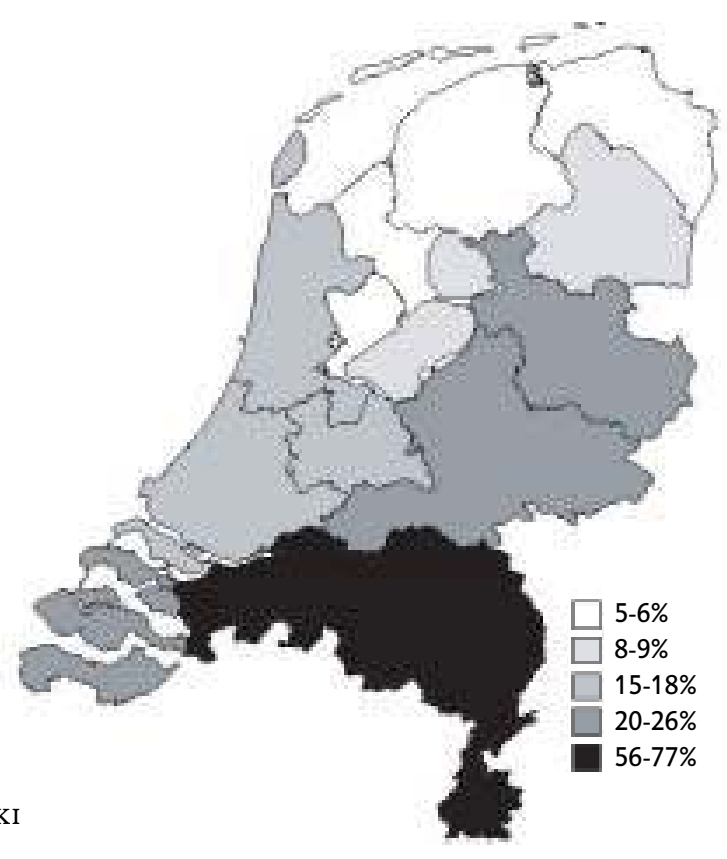


Bijna de helft van de katholieken woont in Brabant of Limburg. De overigen wonen met name in Noord-Holland, Zuid-Holland en Gelderland. Kijken we naar het aandeel op de bevolking, dan zijn naast het zuiden Zeeland, Gelderland en Overijssel te noemen als provincies met minimaal 20 procent katholieken.

Het aantal kerkgangers per weekend bedraagt volgens recente tellingen circa 350.00o. Met Kerstmis ligt het kerkbezoek het hoogst, circa 1.750.00o. Voorts zijn er 270.000 katholieken actief als vrijwilliger in hun parochie, en draagt naar schatting 45 procent van alle kerkleden financieel bij aan zijn of haar parochie.

\section{Gebouwen en professionals}

De Rooms-Katholieke Kerk telt momenteel ongeveer 1.450 parochies. In deze parochies staan 1.740 kerkgebouwen. Het aantal katholieke kerken daalt de laatste jaren met ruim 1 procent per jaar. Nieuwbouw geschiedt slechts sporadisch en nagenoeg uitsluitend ter vervanging van vaak meerdere kerkgebouwen. De afgelopen decennia zijn vooral in steden of middelgrote plaatsen veel kerken verdwenen, die juist in de jaren vijftig en zestig waren bijgebouwd.

De katholieke kerk kent gewijde voorgangers, namelijk priesters en diakens, en niet-gewijde voorgangers, namelijk pastoraal werksters en werkers. Alleen mannen kunnen tot priester of diaken worden gewijd. Per 1 januari 2006 waren er 973 priesters, 111 diakens, 428 pastoraal werkers en 352 pastoraal werksters werkzaam in de Rooms-Katholieke Kerk.

Tabel 4.3 Kerncijfers Rooms-Katholieke Kerk in Nederland, per 1 januari 2006

$\begin{array}{lr}\text { aantal leden } & 4.375 .000 \\ \text { aantal parochies } & 1.450 \\ \text { aantal kerkgebouwen } & 1.740 \\ \text { aantal pastores } & 1.864\end{array}$

Bron: RK Bureau Ledenadministratie, RK bisdommen en KASKI

Naast de kerkelijke structuur van bisdommen en parochies kent de katholieke kerk ook religieuze orden en congregaties, zoals de Franciscanen, Dominicanen, Benedictinessen of Zusters van het Heilig Hart. Hun kloosters hebben lange tijd het beeld van veel steden bepaald, maar hun aantal loopt al decennia lang sterk terug. Momenteel zijn er nog circa 10.000 religieuzen in ons land, veelal vrouwelijk en grotendeels op hoge leeftijd. Daarentegen mogen kloosterbezoek en bezinningsweekenden in kloosters zich in een grote belangstelling verheugen.

\section{Ontwikkelingen}

De Rooms-Katholieke Kerk is de afgelopen decennia sterk gekrompen, waarbij met name het kerkbezoek en het aantal priesters de grootste teruggang vertonen. De grote volkskerk gedragen door gewijde voorgangers heeft plaatsgemaakt voor 
een kleinere keuzekerk waarin vrijwilligers een groot aandeel hebben. De geschetste teruggang heeft verder geleid tot veel fusies van parochies en het sluiten van kerkgebouwen.

Voor 2020 prognosticeert het SCP (Becker en De Hart 2006) een teruggang met eenderde van het aantal leden. Deze prognose is gebaseerd op het zelf beleefde kerklidmaatschap. Kijken we puur naar het al dan niet als kerklid geregistreerd staan, dan komen we iets hoger uit en is volgens een prognose op basis van leeftijd en de huidige in- en uitstroomcijfers de verwachting dat er in 2020 circa 3,4 miljoen katholieken in Nederland zullen zijn.

\subsubsection{PROTESTANTSE KERK IN NEDERLAND}

De Protestantse Kerk in Nederland (PKN) is in mei 2004 ontstaan uit een fusie van de Nederlandse Hervormde Kerk (NHK), de Gereformeerde Kerken in Nederland (GKN) en de Evangelisch-Lutherse Kerk in het Koninkrijk der Nederlanden (ELK). Het ontstaan van de Protestantse Kerk uit de drie afzonderlijke kerken is in de volgende stamboom aangegeven. Daarin staan ook de afsplitsingen en verdere vertakkingen uit de Nederlandse Hervormde Kerk (die voor 1816 Nederduits(ch) Gereformeerde Kerk heette); deze is met de dikke zwarte lijn links aangeduid.

\section{Figuur 4.3 Stamboom van het Nederlandse protestantisme}

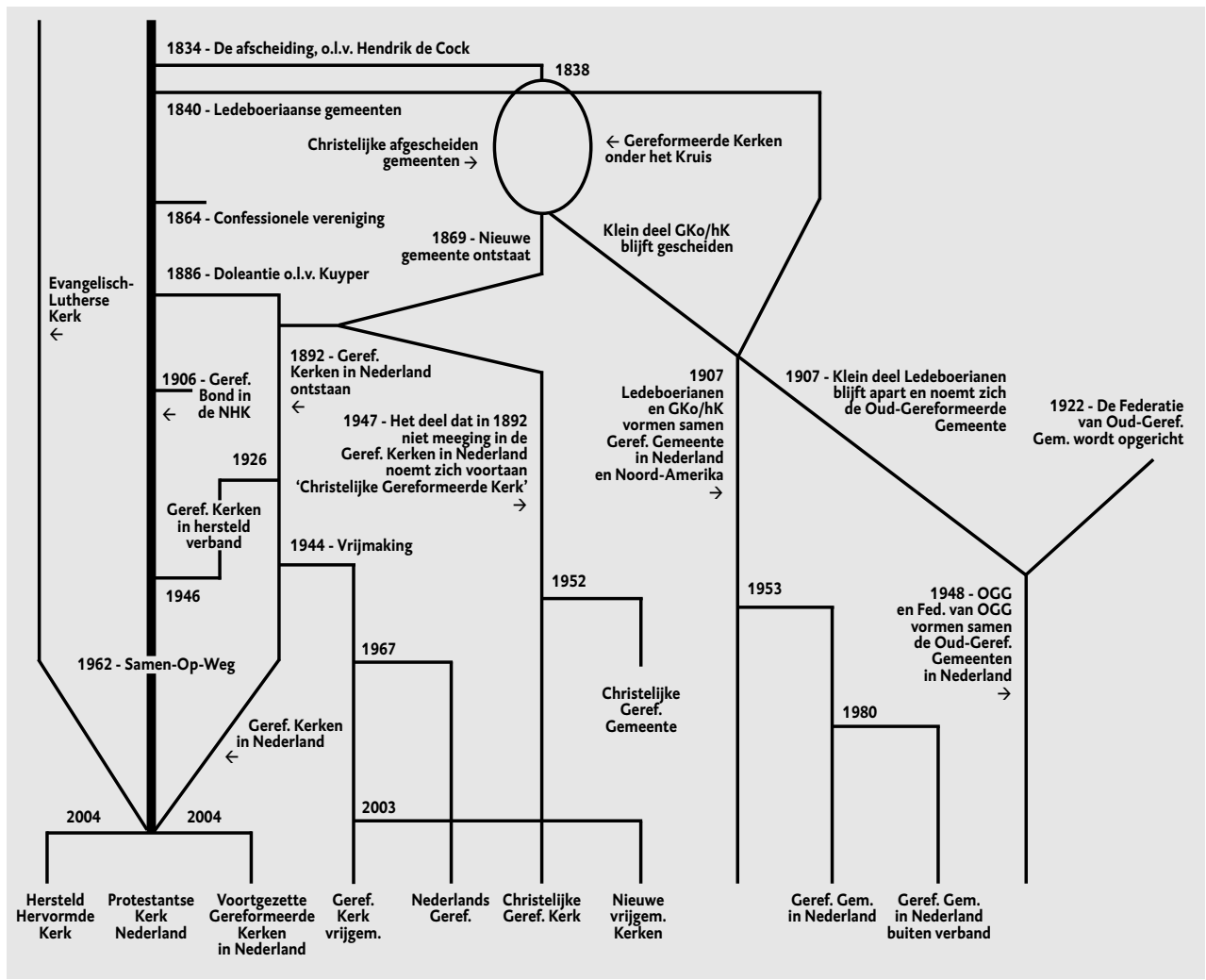

Bron: Wikipedia en Dekker en Peter (1989: 20) 
Hoewel de Nederlandse Hervormde Kerk nooit officieel staatskerk is geweest, stond dit kerkgenootschap wel te boek als 'de Vaderlandse kerk'. Dat had onder andere een zeer ruime telling van het aantal leden tot gevolg. Naast de mensen die lid waren door doop (doopleden) of door bewuste toetreding (belijdende leden) kende de Nederlandse Hervormde Kerk ook zogenaamde geboorteleden, of 'overige leden'. Deze kinderen van gedoopte ouders werden ook als lid gerekend. In deze religieuze kaart worden zij, conform de kerkorde van de PKN, niet meegeteld.

De vorming van de Protestantse Kerk had overigens twee scheuringen tot gevolg. Een groep leden en gemeentes uit de Nederlandse Hervormde Kerk wilde niet met de fusie opgaan in de PKN; zij zijn gebundeld in de Hersteld Hervormde Kerk. Een aantal leden en gemeentes uit de Gereformeerde Kerken in Nederland zijn na de fusie doorgegaan als Voortgezette Gereformeerde Kerken in Nederland (zie stamboom linksonder). Beide afsplitsingen worden in de komende paragrafen nader beschreven.

\section{Ledental en participatie}

Het aantal leden van de PKN is per 1 januari 2006 volgens de eigen administratie ongeveer 1.944.0oo. De regionale verdeling laat het volgende zien.

Tabel 4.4 Spreiding Protestanten over Nederland

\begin{tabular}{|c|c|c|c|}
\hline provincie & $\begin{array}{l}\text { aantal Protestanten } \\
\qquad(\times 1.000)\end{array}$ & $\begin{array}{l}\text { percentage van totaal } \\
\text { aantal Protestanten }\end{array}$ & $\begin{array}{c}\text { percentage van de } \\
\text { bevolking }\end{array}$ \\
\hline Groningen & 80 & 4,1 & 13,8 \\
\hline Friesland & 160 & 8,2 & 25,0 \\
\hline Drenthe & 93 & 4,8 & 19,3 \\
\hline Overijssel & 217 & 11,1 & 19,5 \\
\hline Flevoland & 31 & 1,6 & 8,4 \\
\hline Gelderland & 368 & 18,9 & 18,6 \\
\hline Utrecht & 163 & 8,4 & 13,8 \\
\hline Noord-Holland & 148 & 7,6 & 5,7 \\
\hline Zuid-Holland & 501 & 25,8 & 14,5 \\
\hline Zeeland & 76 & 3,9 & 20,1 \\
\hline Noord-Brabant & 95 & 4,9 & 3,9 \\
\hline Limburg & 12 & 0,6 & 1,0 \\
\hline TOTAAL & 1.944 & 100,0 & 11,9 \\
\hline
\end{tabular}




\section{Figuur 4.4 Aantal leden PKN per provincie}

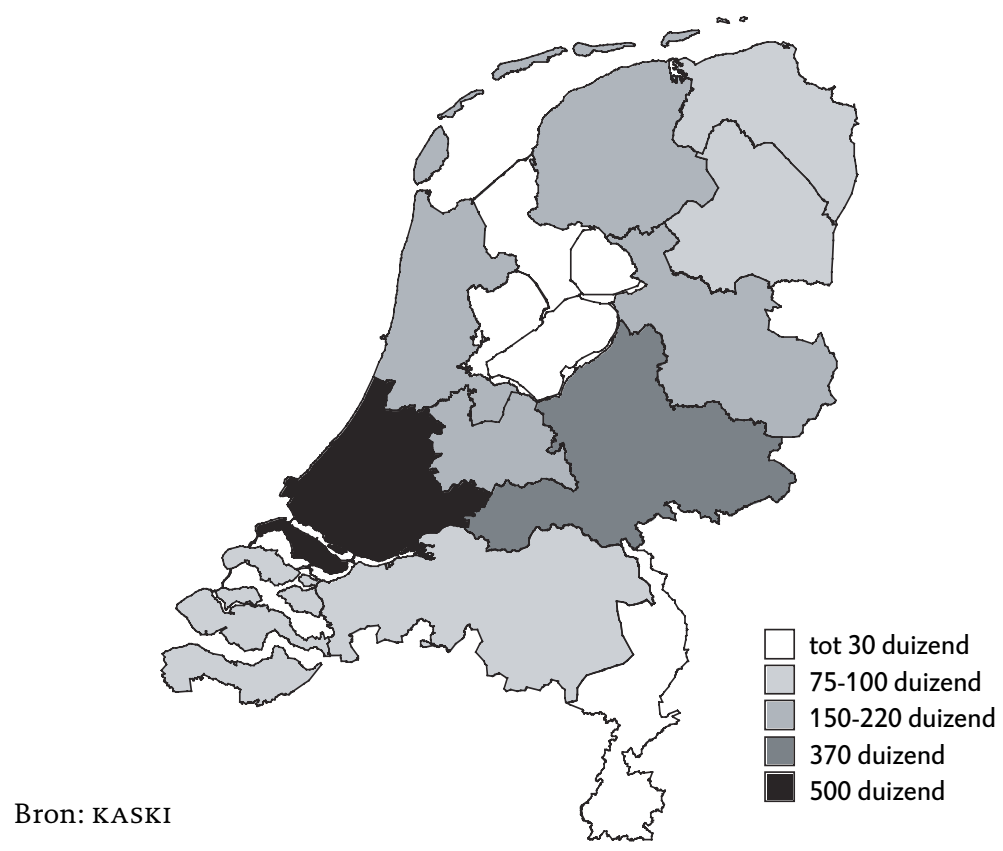

Figuur 4.5 Percentage leden PKN op de bevolking

Bron: KASKI

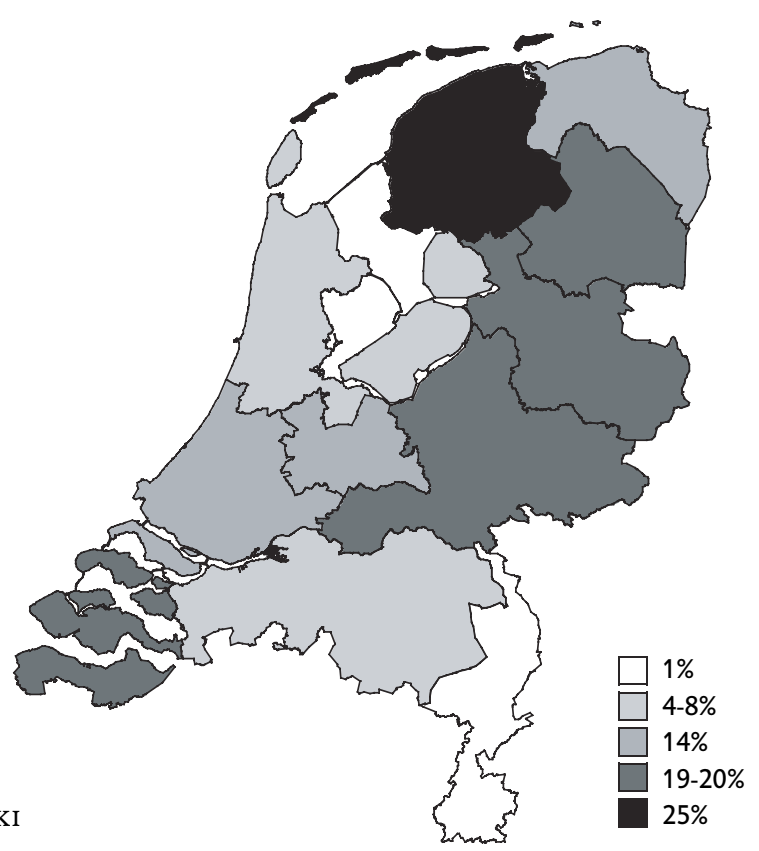


We schatten, op grond van gegevens van onder andere SCP en eerdere tellingen binnen de Protestantse Kerk, het aantal kerkgangers op 479.ooo. Dit komt overeen met ongeveer 24 procent van de doopleden en belijdende leden. Het aantal kerkgangers per zondag wordt binnen de Protestantse Kerk niet centraal bijgehouden.

In 2001 heeft het KASKI het aantal vrijwilligers binnen de Protestantse Kerk op 268.ooo berekend. De PKN schat dat het aantal vrijwilligers sinds die tijd is gedaald.

\section{Gebouwen en professionals}

Het totale aantal kerkgebouwen van de Protestantse Kerk in Nederland komt eind 2005 neer op ongeveer 2.840. Men schat dat er vanaf 2000 tussen de tien en twintig kerkgebouwen per jaar zijn gesloten. Op bescheiden schaal wordt er nieuwbouw gepleegd. Van de Protestantse Kerk in Nederland zijn slechts beperkt gegevens bekend over het aantal kerkgebouwen en de ontwikkeling hiervan in de afgelopen jaren; de getallen berusten dan ook op schattingen en aannames.

Per 1 januari 2006 telde de Protestantse Kerk 2.173 predikanten. Deze predikanten zijn niet in dienst van het landelijke kerkverband, maar verbonden aan de afzonderlijke gemeentes. Zowel mannen als vrouwen kunnen voorganger zijn.

Het volgende overzicht toont het aantal leden, het aantal kerkelijke gemeentes, kerkgebouwen en dienstdoende predikanten.

\section{Tabel 4.5 Kerncijfers Protestantse Kerk in Nederland, per 1 januari 2006}

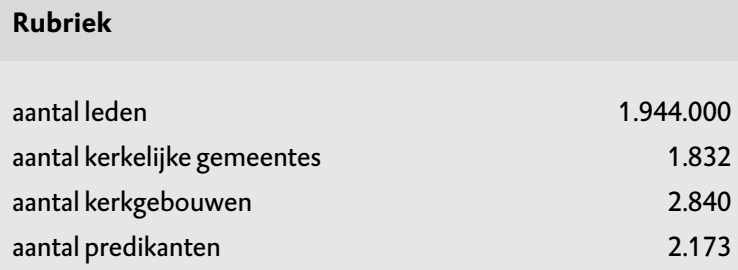

Bron: SMRA, schattingen KASKI en Protestants Landelijk Dienstencentrum

\section{Ontwikkelingen}

Het aantal leden van de Protestantse Kerk daalt de afgelopen jaren gestaag en volgens de prognoses zal die daling zich voortzetten. Op grond van de trend volgens het SCP (Becker en De Hart 2006) is in 2020 een halvering van het aantal leden $^{1}$ te verwachten.

Ook de Protestantse Kerk zelf verwacht een sterke ledendaling voor de komende tijd. De PKN vermoedt dat het aantal leden van 2005 tot 2020 zal dalen met 30 tot 35 procent. Ook houdt de PKN rekening met een flinke daling van het aantal 
predikanten, zowel naar aantal als naar werktijd (er komen steeds meer parttimepredikanten).

Het aantal gemeentes daalt op dit moment sterk. Door de fusie van NHK, GKN en ELK op landelijk niveau kunnen lokale kerkelijke gemeentes ook fuseren. In de toekomst is een daling van het aantal gemeentes door ledenverlies aannemelijk.

\subsubsection{ORTHODOX GEREFORMEERDE KERKEN}

Binnen de groep gereformeerden maken we in deze kaart een tweedeling: de orthodox gereformeerden en de in de volgende paragraaf besproken bevindelijk gereformeerden (zie o.a. Dekker en Peters 1989; Veerman 1995). De overeenkomst tussen beide is dat ze in de calvinistische traditie staan, van Nederlandse origine zijn en behoudend zijn wat de kerkelijke leer betreft.

De orthodox gereformeerden hebben een meer rationele benadering van de geloofsleer; de nadruk ligt op het onderschrijven daarvan. Daarentegen is bij de bevindelijk gereformeerden een centrale rol weggelegd voor de 'bevinding', de existentiële ervaring van een ingrijpen van God in het persoonlijke leven en de menselijke reactie daarop (Dekker en Peters 1989: 42). Cultureel gezien zijn de orthodoxen iets moderner, politiek kunnen we veel van hen plaatsen bij de ChristenUnie. De bevindelijken zijn cultureel behoudend, ze worden wel (denigrerend) aangeduid als de 'zwarte-kousenkerken'. Politiek zijn ze vooral te vinden bij de SGP.

Tot de orthodox gereformeerden rekenen we de volgende kerkgenootschappen:

- Christelijke Gereformeerde Kerken in Nederland (CGK);

- Gereformeerde Kerken in Nederland (vrijgemaakt) (GKV);

- Nederlands Gereformeerde Kerken (NGK);

- De Gereformeerde Kerken in Nederland (hersteld) (GHK);

- Voortgezette Gereformeerde Kerken in Nederland (VGKN).

Zoals uit de stamboom van kerken valt af te leiden zijn het alle vijf kerken van Nederlandse bodem die ontstaan zijn door afsplitsingen. Het hier gevoerde onderscheid met de bevindelijk gereformeerden is niet waterdicht. Zo worden de christelijke gereformeerde kerken tot de orthodox gereformeerden gerekend. Sommige leden en kerken hebben echter een meer bevindelijke inslag (Dekker en Peters 1989: 45).

Binnen de orthodox gereformeerde kerken vindt op landelijk en plaatselijk niveau (bescheiden) samenwerking plaats; hiernaar wordt soms verwezen met de term 'kleine oecumene'.

\section{Ledental en participatie}

In totaal bestaat de groep orthodox gereformeerden uit ruim 237.0oo leden. De aantallen van CGK, GKV en NGK zijn ontleend aan de jaarlijkse opgaven; aantallen 
van VGKV en VGKN berusten op schattingen, waarbij het aantal van de Voortgezette Gereformeerde Kerken in Nederland is bevestigd door de landelijke contactpersoon. Uitgesplitst naar kerkgenootschap ziet het geheel er als volgt uit.

\section{Tabel 4.6 Ledentallen orthodox gereformeerden, 2006}

$\begin{array}{lr}\text { kerkgenootschap } & \text { aantal } \\ \text { Gereformeerde Kerken in Nederland (vrijgemaakt) } & 125.970 \\ \text { Christelijke Gereformeerde Kerken in Nederland } & 74.853 \\ \text { Nederlands Gereformeerde Kerken } & 32.250 \\ \text { Voortgezette Gereformeerde Kerken in Nederland } & 3.000 \\ \text { Gereformeerde Kerken in Nederland (hersteld) } & 1.500 \\ & \\ \text { TOTAAL } & 237.573\end{array}$

Bron: KASKI

De regionale verdeling van de drie grootste orthodox gereformeerde kerkgenootschappen is in de volgende tabel weergegeven. De regionale indeling die de drie kerkgenootschappen zelf gebruiken is omgezet naar een indeling in provincie. Geringe afwijkingen zijn daarbij onvermijdelijk.

Tabel 4.7 Spreiding orthodox gereformeerden over Nederland

\begin{tabular}{|lccc|} 
provincie & $\begin{array}{c}\text { aantal orthodox } \\
\text { gereformeerden } \\
(\mathbf{x ~ 1 . 0 0 0 )}\end{array}$ & $\begin{array}{c}\text { percentage van totaal } \\
\text { aantal orthodox } \\
\text { gereformeerden }\end{array}$ & $\begin{array}{c}\text { percentage van de } \\
\text { bevolking }\end{array}$ \\
Groningen & 24 & 10,4 & 4,2 \\
Friesland & 14 & 5,8 & 2,1 \\
Drenthe & 16 & 7,1 & 3,4 \\
Overijssel & 37 & 15,9 & 3,3 \\
Flevoland & 15 & 6,6 & 4,1 \\
Gelderland & 37 & 15,9 & 1,9 \\
Utrecht & 27 & 11,5 & 2,3 \\
Noord-Holland & 14 & 6,0 & 0,5 \\
Zuid-Holland & 37 & 15,7 & 1,1 \\
Zeeland & 7 & 3,2 & 1,9 \\
Noord-Brabant & 5 & 2,0 & 0,2 \\
Limburg & 0 & 0,0 & 0,0 \\
TOTAAL & 233 & & 1,4 \\
\hline
\end{tabular}

Bron: jaarboeken en CBS 
Figuur 4.6 Aantal orthodox gereformeerden per provincie

Bron: KASKI

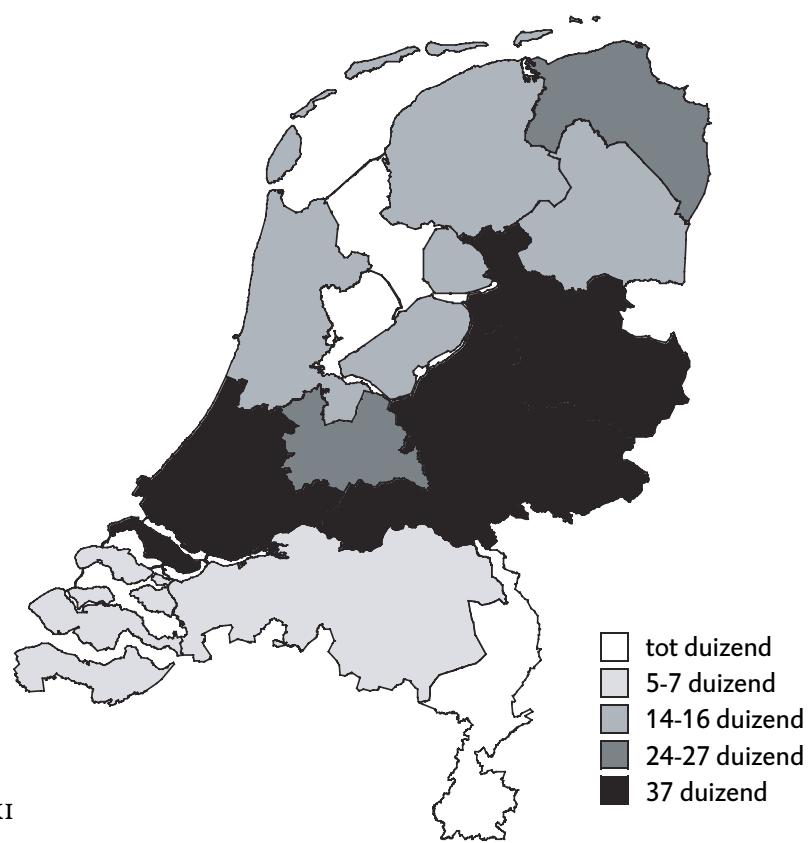

Figuur 4.7 Percentage orthodox gereformeerden op de bevolking

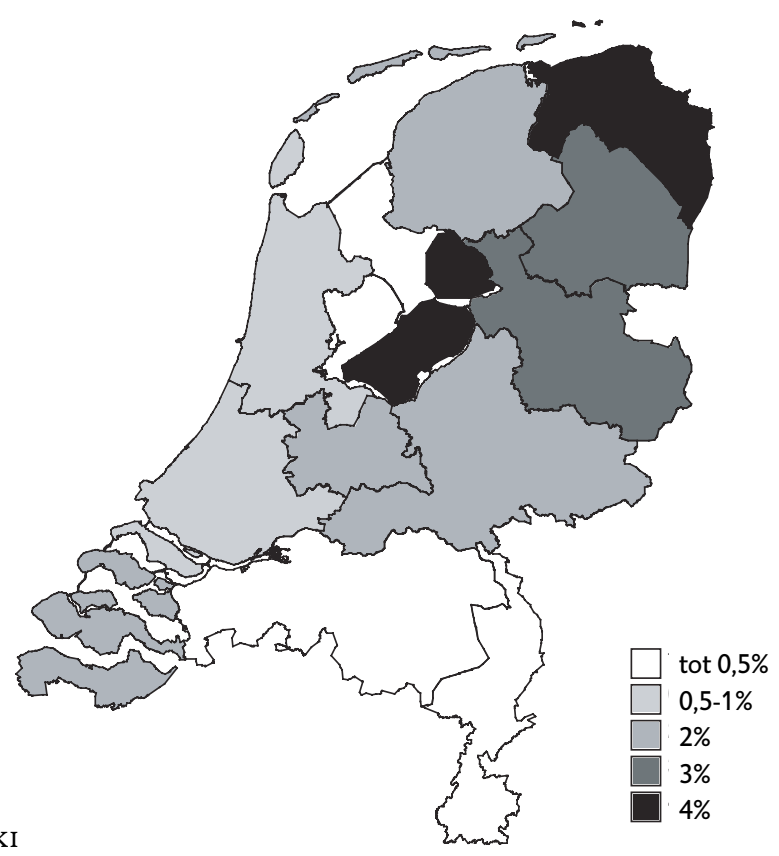


In totaal bevinden de meeste orthodoxen zich in de provincie Overijssel, gevolgd door Gelderland. Voor een deel zijn deze hoge aantallen te verklaren uit het feit dat zowel de GKV als de NGK in Kampen (Overijssel) is ontstaan.

We schatten de participatie van de orthodox gereformeerden kerkleden vrij hoog. Het is in deze kerken niet ongebruikelijk om de leden aan te spreken op hun participatie en hun bij langdurig niet participeren uitdrukkelijk te verzoeken het lidmaatschap te overwegen. Er zijn geen feitelijke cijfers voorhanden.

\section{Gebouwen en professionals}

Het volgende overzicht toont het aantal kerkelijke gemeentes, het aantal gebouwen dat bij de kerkgenootschappen hoort en het aantal dienstdoende predikanten. De orthodox gereformeerde kerken kennen alleen mannelijke predikanten.

Tabel 4.8

Kerncijfers orthodox gereformeerde kerkgenootschappen, 2006

\begin{tabular}{|lccc} 
kerkgenootschap & gemeentes & gebouwen & predikanten \\
Gereformeerde Kerken (vrijgemaakt) (GKV) & 273 & - & 294 \\
Christelijke Gereformeerde Kerken in Nederland (CGK) & 184 & - & 158 \\
Nederlands Gereformeerde Kerken (NGK) & 93 & - & 83 \\
Voortgezette Gereformeerde Kerken in Nederland (VGKN) & 9 & - & 2 \\
Gereformeerde Kerken (hersteld) & 9 & 0 & 1 \\
& & & 538
\end{tabular}

Bron: diverse jaarboeken, mondelinge informatie en internet

\section{Ontwikkelingen}

Het totale aantal orthodox gereformeerden steeg de afgelopen jaren. De GKV laat een daling zien, deels omdat er minder kinderen worden geboren en gedoopt. De groei van CGK en NGK is grotendeels toe te schrijven aan eigen aanwas en aan toetreding vanuit andere kerkgenootschappen. De twee 'voortgezette kerken' zijn te jong om uitspraken over trends te doen.

Er zijn twee tegengestelde ontwikkelingen die het lastig maken om duidelijke extrapolaties naar de toekomst te maken. Enerzijds trekken de orthodoxe kerken leden van andere kerkgenootschappen weg. Het ontstaan van de VGKN kan daarvan als voorbeeld worden gezien. De Gereformeerde Kerken in Nederland (die nu onderdeel zijn van de PKN) verloren een deel van hun leden aan de VGKN. Ook wordt de groei van de CGK verklaard doordat een kerkelijke gemeente in haar geheel is overgekomen. Het is aannemelijk dat de orthodoxe kerken nog verdere aanwas uit vooral de Protestantse Kerk zullen krijgen. Anderzijds gaat de ontkerkelijking in Nederland door en gaat die ontwikkeling niet aan de orthodox gereformeerden voorbij. De eerste tekenen van terugloop door minder gedoopten zijn reeds zichtbaar. 


\subsubsection{BEVINDELIJK GEREFORMEERDEN}

Onder de bevindelijk gereformeerde kerken verstaan we de volgende kerkgenootschappen:

- Gereformeerde Gemeenten (in Nederland en Noord-Amerika); ${ }^{2}$

- Gereformeerde Gemeenten in Nederland;

- Gereformeerde Gemeenten (buiten verband);

- Oud Gereformeerde Gemeenten in Nederland;

- Vrije Oud Gereformeerde Gemeenten in Nederland;

- Hersteld Hervormde Kerk.

Afgezien van het (relatief kleine) kerkgenootschap Vrije Oud Gereformeerde Gemeenten, staan de kerken vermeld in de stamboom (zie figuur 4.3).

\section{Ledental en participatie}

Op grond van de gegevens uit jaarboeken en telefonisch verkregen informatie schatten we het aantal bevindelijk gereformeerden op ruim 221.0oo. Uitgesplitst naar kerkgenootschap is het beeld als volgt.

Tabel 4.9 Ledentallen bevindelijk gereformeerden in 2006

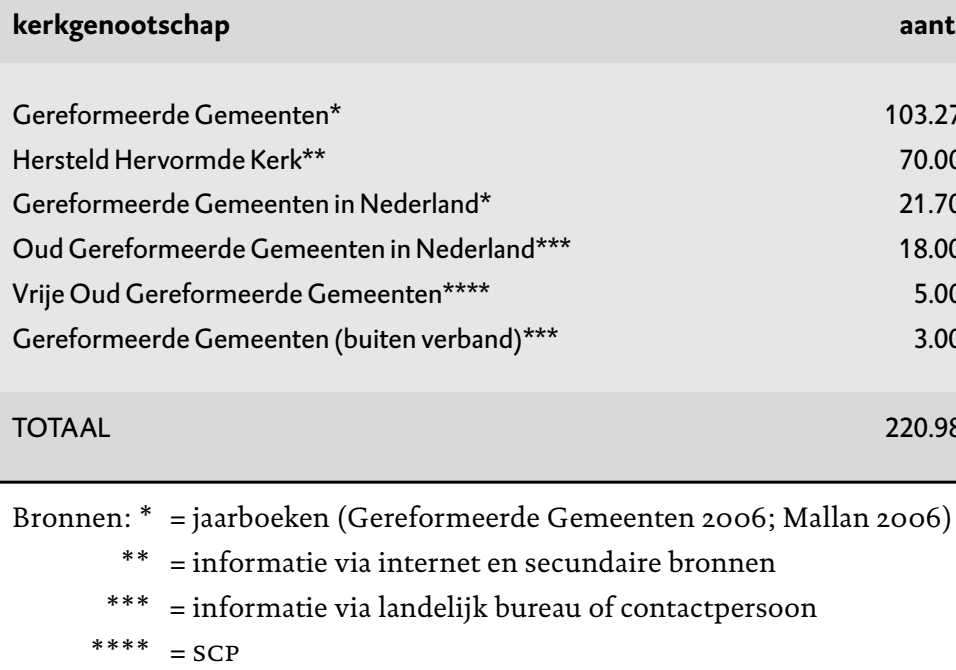

Bronnen: ${ }^{*}$ = jaarboeken (Gereformeerde Gemeenten 20o6; Mallan 2006)

$* *$ = informatie via internet en secundaire bronnen

$* * *=$ informatie via landelijk bureau of contactpersoon

$* * * *=\mathrm{SCP}$

Van vier kerkgenootschappen zijn geen exacte getallen voorhanden. Het aantal van 5.0oo leden van de Vrije Oud Gereformeerde Gemeenten berust op schattingen van het SCP uit 2004 .

Veel bevindelijk gereformeerden zijn in de zogenaamde Bijbelgordel (Bible Belt) te vinden. Die loopt van de Zeeuwse en Zuid-Hollandse eilanden, via het westen van Zuid-Holland over de Veluwe, en eindigt in Noordoost-Overijssel. Een weergave van het aantal bevindelijk gereformeerden op provincieniveau brengt dit te weinig in beeld. Daarom gebruiken we een oudere kaart (Knippenberg 
1992: 114). De verhouding van het aantal SGP stemmers in Nederland laat nog steeds dit beeld van de genoemde Bijbelgordel zien. ${ }^{3}$

Figuur 4.8 Bevindelijk gereformeerden (binnen de NHK), situatie 1920.

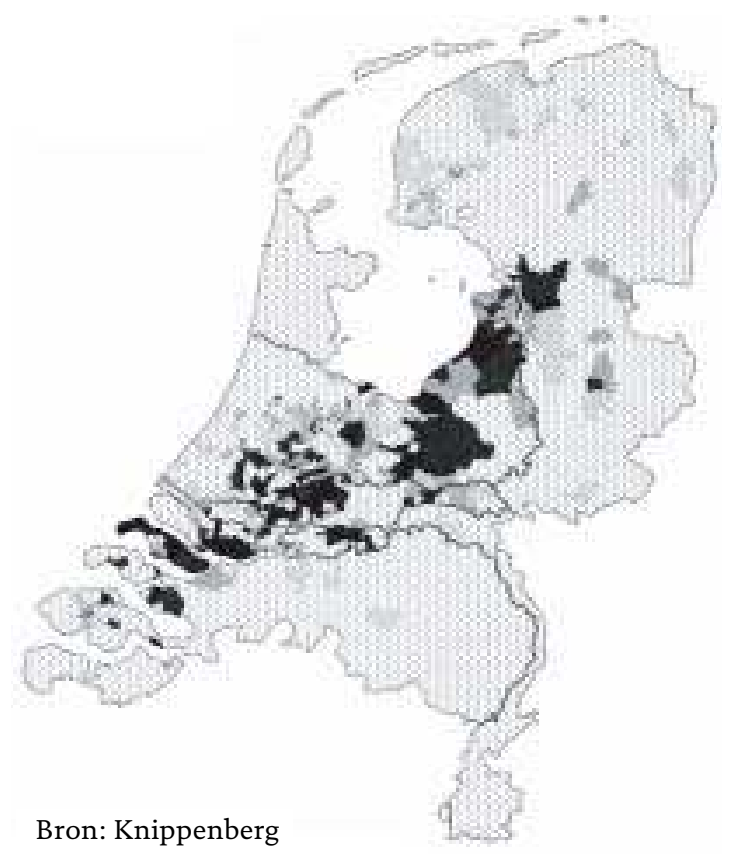

De participatie van deze groepen protestanten is zeer hoog, hoewel er geen exacte cijfers voorhanden zijn.

\section{Gebouwen en professionals}

Het volgende overzicht toont het aantal kerkelijke gemeentes, het aantal gebouwen dat bij de kerkgenootschappen hoort en het aantal dienstdoende predikanten. De bevindelijk gereformeerde kerken kennen alleen mannelijke predikanten.

Tabel 4.10 Kerncijfers bevindelijk gereformeerde kerkgenootschappen in 2006

\begin{tabular}{lccc} 
kerkgenootschap & gemeentes & gebouwen & predikanten \\
Gereformeerde Gemeenten & 153 & - & 54 \\
Hersteld Hervormde Kerk & 118 & - & 54 \\
Gereformeerde Gemeenten in Nederland & 47 & - & 5 \\
Oud Gereformeerde Gemeenten in Nederland & 65 & - & - \\
Vrije Oud Gereformeerde Gemeenten & - & 6 & 1 \\
Gereformeerde Gemeenten (buiten verband) & 7 & 6 & 117 \\
TOTAAL & 390 & & \\
\hline
\end{tabular}




\section{Ontwikkelingen}

Het aantal bevindelijk gereformeerden vertoont al jaren een constante stijging. Zo steeg het aantal leden van de Gereformeerde Gemeenten van ruim 95.00o in 1995 naar 103.000 in 2006 (+ 8 procent) en van de Gereformeerde Gemeenten in Nederland van bijna 20.000 in 1995 naar 21.700 in 2006 (+ 9 procent). De groei wordt voornamelijk veroorzaakt door een geboorteoverschot. Tegelijk is het aantal predikanten laag en lijkt dalend, terwijl ook het aantal gemeentes daalt.

\subsubsection{EVANGELISCHE EN PINKSTERKERKEN}

Pinksterchristenen vormen op de katholieken na de grootste groepering christenen op de wereld. In Nederland ligt dat anders, maar vanuit de pinkstergemeentes wordt vaak groei gemeld. Die groei wordt door sommige auteurs overigens toegeschreven aan wat wel wordt genoemd circulation of the saints (Bibby en Brinkerhoff 1973). Hiermee wordt bedoeld dat er niet zozeer sprake is van nietchristenen die zich bekeren en/of toetreden tot een (evangelische of pinkster) kerk, maar dat christenen van het ene kerkgenootschap overstappen naar het andere kerkgenootschap. In dat geval is er wel sprake van groei binnen afzonderlijke gemeentes of kerkgenootschappen, maar niet op het totale aantal christenen.

Er zijn diverse omschrijvingen van evangelisch (ook wel evangelicaal, naar het Engelse evangelical) in omloop. Eén van de omschrijvingen is van Runia (1992: 4-5) en wordt ook door de Evangelische Alliantie (een koepelorganisatie van evangelische kerken en organisaties) gebruikt:

- onvoorwaardelijke aanvaarding van de Bijbel als het gezaghebbende Woord van God;

- persoonlijke geloofsband met Jezus Christus, door het werk met de Heilige Geest; evangelischen leggen veel nadruk op het verzoenend werk van Christus en de noodzaak van wedergeboorte;

- nadruk op de missionaire taak van alle gelovigen.

De meeste evangelische en pinksterkerken zijn niet van Nederlandse origine, uitgezonderd de Bond van Vrije Evangelische Gemeenten die een afsplitsing is van de Nederlandse Hervormde Kerk (Kooten en Prins 2002). Zij zijn merendeels ontstaan tijdens de periode die in Nederland wel wordt aangeduid als het Reveil, heel globaal te plaatsen in de 18de en 19de eeuw.

Pinksterkerken beschouwen we als een specifieke groep binnen de evangelische kerken. Binnen de pinksterkerken ligt een grote nadruk op 'de gave van de Heilige Geest'. In deze kerken komen meer extatische vormen van godsdienst voor zoals het 'spreken in tongen'.

Evangelische en pinksterkerken zijn over het algemeen vrij congregationalistisch, dat wil zeggen dat zij een grote mate van zelfstandigheid van de lokale kerkelijke 
gemeente kennen. Er zijn wel landelijke kerkgenootschappen, maar deze functioneren vooral als federatie of als overkoepelend orgaan. Daarnaast zijn er tal van zelfstandige lokale gemeentes. Dit maakt het lastig om centraal ledengegevens te verzamelen. De hier gepresenteerde cijfers berusten dan ook deels op (onderbouwde) schattingen of opgaven via internet.

Tot de evangelische en pinksterkerken rekenen we de volgende kerkgenootschappen:

- Leger des Heils;

- Unie van Baptistengemeenten;

- Baptistengemeenten die niet behoren tot de Unie;

- CAMA gemeenten Nederland;

- Kerk van de Nazarener;

- Bond van Vrije Evangelische gemeenten;

- Vrije-evangelische gemeenten die niet behoren tot de Bond;

- Kerkgenootschap van de Zevende-dags Adventisten;

- Verenigde Pinkster- en Evangeliegemeenten (LP);

- Rafaël Nederland (LP);

- Bethel Pinksterkerk Nederland (LP);

- Volle Evangelie Bethel Kerk (LP);

- Bethel Pentecostal Temple Fellowship Nederland (LP);

- Victory Outreach Nederland (LP);

- Newfrontiers (LP);

- Johan Maasbach Wereld Zending

- Evangelie Gemeente 'De Deur’;

- Capitol Worship Centre;

- Evangelische Broedergemeenten.

Een zevental van de genoemde kerkgenootschappen zijn aangesloten bij de Vereniging Landelijk Platform van de Pinkster- en Volle Evangeliebeweging (LP).

Daarnaast zijn er veel niet-gebundelde lokale gemeentes. Zegwaart (2003: 162) schat hun aantal op ruim 300.

\section{Ledental en participatie}

Formeel wordt men binnen evangelische en pinkstergemeentes lid door doop. De evangelische en pinksterkerken kennen volwassendoop of 'doop op geloof', zoals dat genoemd wordt. Kinderen worden dan niet tot de leden gerekend. De getallen die beschikbaar zijn, betreffen niet alleen leden in de formele zin, maar ook kinderen.

Het aantal leden is deels verzameld door informatie te vragen bij de afzonderlijke kerkgenootschappen (inclusief informatie via internet), deels door onderbouwde schattingen te maken. Overigens berust een deel van de gegevens van de informanten van de kerkgenootschappen ook eerder op schatting dan op gegevens vanuit ledenadministratie. 
Op grond van voorhanden gegevens is de gemiddelde grootte van evangelische en pinkstergemeenten uitgerekend; dit is 160 leden per gemeente. Dit getal is gebruikt bij de schatting, wanneer geen ledentallen beschikbaar zijn.

Tabel 4.11 Ledentallen en aantal gemeentes van evangelische en pinksterkerken, 2006

\begin{tabular}{|c|c|c|}
\hline naam & aantal leden & aantal gemeentes \\
\hline vrije pinkstergemeentes* & 47.500 & 300 \\
\hline Verenigde Pinkster- en Evangeliegemeenten & 22.000 & 127 \\
\hline Evangelische Broedergemeenten & 15.000 & 7 \\
\hline Unie van Baptistengemeenten & 11.109 & 85 \\
\hline Zevende dag adventisten & 10.000 & 52 \\
\hline Leger des Heils & 6.500 & 74 \\
\hline Bond van Vrije Evangelische Gemeenten & 5.717 & 37 \\
\hline CAMA & 5.000 & 22 \\
\hline Broederschap van Baptistengemeenten & 4.200 & 22 \\
\hline Johan Maasbach Wereld Zending & 4.000 & 11 \\
\hline Rafaël Nederland & 3.500 & 42 \\
\hline Bethel Pinksterkerk Nederland* & 2.500 & 16 \\
\hline Evangelie Gemeente ‘De Deur' & 2.500 & 43 \\
\hline Victory Outreach Nederland & 2.000 & 8 \\
\hline Kerk van de Nazarener & 1.800 & 10 \\
\hline Volle Evangelie Bethel Kerk & 1.300 & 13 \\
\hline Bethel Pentecostal Temple Fellowship Nederland* & 1.300 & 8 \\
\hline Capitol Worship Centre & 900 & 8 \\
\hline Newfrontiers & 800 & 5 \\
\hline TOTAAL & 148.000 & 890 \\
\hline
\end{tabular}

Bronnen: ${ }^{*}=$ aantal door berekening bepaald

Binnen het totale aantal van 148 .0oo evangelische en pinksterchristenen schatten we 88.ooo pinksterchristenen. Hiertoe wordt ook een deel van de migrantenkerken gerekend, met name de nieuwe generatie, zoals de Evangelische Broedergemeenten, of vrije pinkstergemeentes als Volle Evangelie Gemeente Friends in Christ Fellowship, of Mount Zion Crossfire Prophetic Ministry Healing Chapel for all Nations.

Onder evangelische en pinkstergemeentes schatten we de participatie hoog. Dat geldt met name voor de relatief jongere kerken, omdat leden zich bij deze kerken uit overtuiging aansluiten. Bij de wat oudere kerkgenootschappen, zoals de Unie van Baptistengemeenten of Bond van Vrije Evangelische Gemeenten, is de kans op randkerkelijkheid groter. 


\section{Gebouwen en professionals}

Met name bij de pinksterkerken ontstaan gemeentes rond een voorganger; er bestaan in dat geval geen gemeentes zonder voorganger en daarmee is het aantal voorgangers gelijk aan het aantal gemeentes. Voorgangers zijn binnen evangelische en pinksterkerken overwegend mannen.

Lang niet alle evangelische en pinksterkerken beschikken over eigen gebouwen. Vaak wordt zaalruimte gehuurd van scholen of andere kerken, of komt men bijeen in de inmiddels spreekwoordelijke kelderboxen in de Bijlmer.

\section{Ontwikkelingen}

Zoals vermeld maken de evangelische en pinkstergemeentes gezamenlijk een flinke groei in ledental door. Dat geldt zeker niet voor alle kerkgenootschappen. De Unie van Baptistengemeenten, de Bond van Vrije Evangelische Gemeenten en het Leger des Heils laten dalingen zien. Ook is de opgave van het aantal leden van de Evangelische Broedergemeenten volgens de informant aanmerkelijk lager dan het aantal leden volgens de SCP-gegevens uit 2000 en 2004.

Andere kerkgenootschappen en vrije evangelische of pinkstergemeentes laten groei zien, maar zoals gezegd wordt die groei ook wel toegeschreven aan de eerdergenoemde circulation of the saints. Migrantenkerken hebben een grote groei doorgemaakt door de stijging van het aantal migranten in Nederland; de ontwikkeling van hun ledental zal gelijk opgaan met de ontwikkeling van het aantal migranten.

Het evangelisch christendom weet zich de laatste jaren steeds sterker te profileren. Of dit zich ook daadwerkelijk zal vertalen in een verdere stijging van de ledentallen van deze kerken is lastig te voorspellen. Binnen de Protestantse Kerk en ook binnen de orthodox gereformeerde kerken wordt gesproken over een toename van evangelische invloeden. Hoe meer die worden gehonoreerd, hoe minder behoefte evangelische christenen zullen hebben om de overstap te maken naar een ander kerkgenootschap.

\subsubsection{VRIJZINNIG}

Vrijzinnigen hechten, zoals ze zelf aangeven, meer belang aan het leven dan aan de leer. Ze nemen rond geloofszaken, en meestal ook rond ethische zaken, liberale standpunten in. Tot de vrijzinnigen worden gerekend:

- Remonstrantse Broederschap;

- Algemene Doopsgezinde Sociëteit;

- Vrijzinnige geloofsgemeenschap NPB (Nederlandse Protestanten Bond).

Tot de vrijzinnige tak van protestants Nederland worden ook gerekend de Vereniging van Vrijzinnige Protestanten (VvP: ongeveer 3.ooo leden) en de Zwinglibond (minder dan 150 leden). Beide zijn niet zozeer als kerkgenootschap te zien, maar veeleer een vereniging waarvan veel leden lid zijn van de Protestantse Kerk in Nederland. 
Alle drie de genoemde kerkgenootschappen zijn van Nederlandse origine. De Remonstrantse Broederschap is ontstaan in de 17 de eeuw. De Doopsgezinde Sociëteit ontstond ten tijde van de Reformatie; in internationaal verband worden Doopsgezinden ook wel aangeduid als Mennonieten, naar hun grondlegger Menno Simons. De Vrijzinnige geloofsgemeenschap NPB ontstond aanvankelijk als een verbond van afdelingen waarvan men lid kon worden náást het lidmaatschap van andere kerken. Tegenwoordig is de Vrijzinnige geloofsgemeenschap NPB te zien als een kerkgenootschap.

\section{Ledental en participatie}

Op grond van de gegevens van de jaarboeken (Groenveld-Kiestra en Thimm 2006; Slis 2006) en informatie van de landelijke bureaus (Vrijzinnige geloofsgemeenschap NPB en Doopsgezinde sociëteit) komen we tot ruim 19.0oo vrijzinnigen.

Het is mogelijk om naast het lidmaatschap van de NPB lid te zijn van een ander kerkgenootschap; enige dubbeltelling is dus mogelijk. De Remonstrantse Broederschap kent naast leden ook zogenaamde vrienden. Vrienden noch kinderen zijn in de telling meegenomen. Men wordt lid van een Doopsgezinde Gemeente door de doop. Alleen volwassenen worden gedoopt; het ledental is dus exclusief het aantal kinderen. Uitgesplitst naar kerkgenootschap is het beeld als volgt.

\section{Tabel 4.12 Ledentallen vrijzinnigen in 2006}

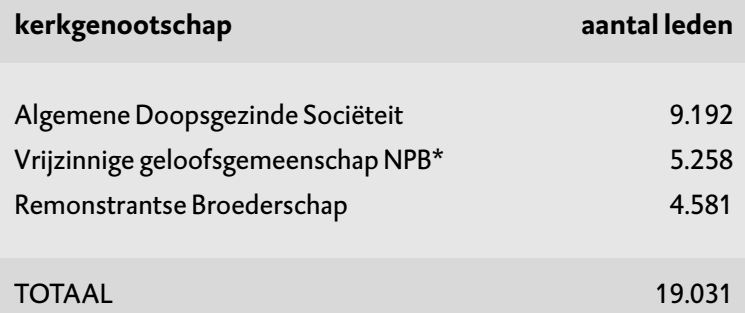

* aantal per augustus 2005

Bron: KASKI

Het volgende kaartje geeft een impressie van de verspreiding van vrijzinnige gemeenschappen in Nederland; de kaart geeft géén indicatie van het aantal vrijzinnigen. Op de kaart staan ook VVP-gemeentes aangegeven. Doopsgezinde gemeentes zijn met name in Friesland te vinden (Simons is zijn reformatie in Friesland begonnen), NPB-afdelingen liggen als een gordel in het midden van Nederland van west naar oost. 


\section{Figuur 4.9 Vrijzinnige gemeentes en afdelingen}

Bron: www.zinweb.nl

\section{Gebouwen en professionals}

Het volgende overzicht geeft het aantal gemeentes, gebouwen en voorgangers volgens de opgave van de afzonderlijke kerkgenootschappen. Op lokaal niveau wordt op veel plaatsen samengewerkt, bijvoorbeeld in DoRe-gemeentes (combinatie van Doopsgezind en Remonstrants) of in andere combinaties, al dan niet met de eerdergenoemde vVP.

Binnen de vrijzinnige kerken kunnen zowel mannen als vrouwen voorganger zijn.

\section{Tabel 4.13 Kerncijfers vrijzinnige kerkgenootschappen per 2006}

$\begin{array}{lccc}\text { kerkgenootschap } & \text { gemeentes } & \text { gebouwen } & \text { predikanten } \\ \text { Algemene Doopsgezinde Sociëteit } & 119 & 113 & 88 \\ \text { Vrijzinnige Geloofsgemeenschap NPB } & 59 & 40 & 40 \\ \text { Remonstrantse Broederschap } & 47 & 30 & 49 \\ \text { TOTAAL } & & 183 & 177\end{array}$

Bronnen: Slis 2006; Groenveld-Kiestra \& Thimm 2006; landelijk bureau NPB 


\section{Ontwikkelingen}

Het aantal vrijzinnigen is de afgelopen jaren sterk gedaald. Zo waren er in 1970 ruim 32.0oo Doopsgezinden, nu de gemelde krappe 9.ooo. Het totaal aantal leden van de drie genoemde kerkgenootschappen was in 1970 ruim $56.000, \mathrm{nu}$ ruim 19.0oo. De vrijzinnige kerkgenootschappen melden dat ze vrij vergrijsd zijn en weinig jonge aanwas hebben.

Op dit moment werken op lokaal niveau veel vrijzinnige groepen samen. Die samenwerking is er ook met de eerdergenoemde Vereniging van Vrijzinnig Protestanten (VVP). Of dit op termijn een samengaan van vrijzinnige kerken tot gevolg heeft valt te bezien. Aannemelijker is dat de Remonstrantse Broederschap (wederom) aansluiting zoekt bij de Protestantse Kerk in haar geheel. Aan doopsgezinde zijde wordt gediscussieerd over de te volgen koers; vanuit haar opvattingen rond doop en geloof is verdere samenwerking met evangelische groepen goed denkbaar. Tegelijk geldt voor de Algemene Doopsgezinde Sociëteit dat ze onderdeel uitmaakt van een wereldwijde en zeer grote kerk, namelijk de Mennonieten; steun uit het buitenland bij verdere krimp van de kerk is dan ook mogelijk.

\subsubsection{OVERIGE CHRISTELIJKE KERKEN}

Onder de categorie overige christelijke kerken beschrijven we hier een aantal kerkgenootschappen die uitdrukkelijk niet onder de eerder gebruikte categorieën kunnen worden gebracht. Onderling vertonen ze echter veel verschillen.

Binnen de Molukse Kerken zijn minstens vier kerkgenootschappen te onderscheiden; hiervan is de Geredja Indjili Maluku (GIM) de grootste. Alleen de gegevens van de GIM worden in deze atlas opgenomen.

Binnen de Oosters-Orthodoxe Kerken worden globaal drie stromingen onderscheiden: de Byzantijns-Orthodoxe traditie (o.a. Russisch- en Grieks-Orthodox), de Oriëntaals-Orthodoxe traditie (o.a. Koptisch-en Syrisch-Orthodox) en de geünieerde Chaldeeuwse kerken. Bij elkaar tellen zij ruim 30.000 leden, waaronder veel allochtonen.

De Oud-Katholieke Kerk is ontstaan vanuit de afwijzing van het centrale leiderschap van de Rooms-Katholieke Kerk. Uit de Apostolische stroming, die in de 19de eeuw ontstond, ontstonden enkele kerkgenootschappen. Binnen Nederland zijn er twee van enige omvang.

Tot slot kunnen nog tal van andere kerkgenootschappen en groepen tot het christendom worden gerekend, zoals de Mormonen (Kerk van Jezus Christus van de Heiligen der Laatste Dagen), de Quakers (Genootschap der Vrienden) en Christelijke Gemeente Nederland (Noorse Broeders). Zij blijven alle onder de grens van 10.000 leden. 


\section{Ledental en participatie}

Het aantal leden van de twee genoemde apostolische kerken is inclusief het aantal kinderen. Bij de Oud-Katholieken zijn de cijfers voor 2005. Voor Jehova's Getuigen zijn de gegevens verzameld van internet. Zij kennen alleen volwassendoop (geen kinderdoop), door de doop wordt men opgenomen in de gemeenschap. Het aantal leden dat wordt genoemd op www.watchtower.org is echter niet gelijk aan het aantal volwassen leden. Het getal is het aantal Jehova's Getuigen dat zich actief betoont in de zogenaamde predikingsdienst. Dat impliceert dat er ook Jehova's Getuigen zijn die niet actief zijn in de evangelisatie, min of meer te vergelijken met nominale leden: zij worden niet meegeteld in de statistieken (Singelenberg z.j.).

Tabel 4.14 Ledentallen overige christelijke kerken, 2006

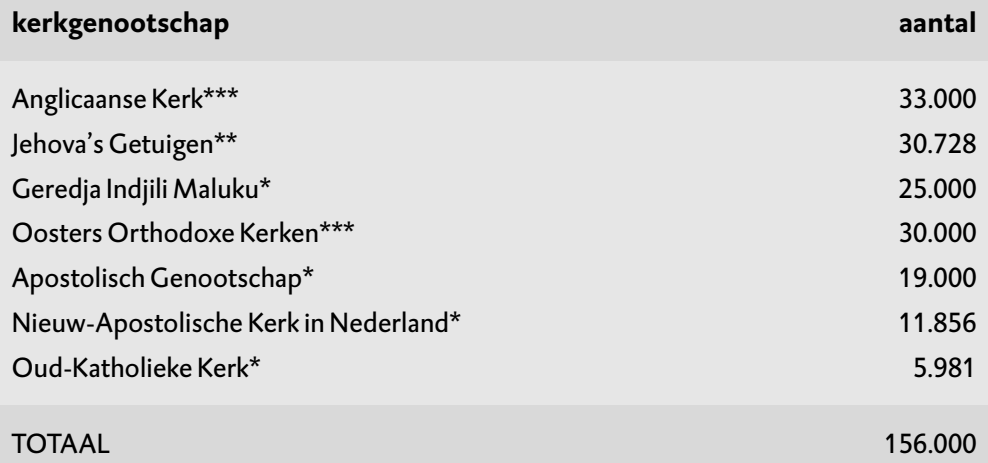

Lastiger nog dan een schatting van het aantal leden is om binnen de groep overige kerken een schatting te geven van de participatie. De Nieuw-Apostolische Kerk schat de participatie op 40 procent, de Oud-Katholieke Kerk op 43 procent meelevende leden.

\section{Gebouwen en professionals}

Zie tabel 4.15.

\section{Ontwikkelingen}

Het ledental van de hier genoemde kerken vertoont een neerwaartse lijn. De apostolische kerken laten al enige jaren een achteruitgang in ledental zien; dit geldt het sterkst voor het Apostolisch Genootschap. Ook vanuit de Molukse Kerk wordt afnemende participatie gemeld. Evenzo kampt men daar met een toenemend predikantentekort. De ledenontwikkeling van de Jehova's Getuigen kent pieken en dalen, maar de voornaamste tendens is een sterke daling van het aantal gedoopten sinds 1975 en een geleidelijke daling van het aantal leden sinds 1995. De OudKatholieke Kerk laat al jaren een daling van ledental zien. Van de Angelicaanse 
Kerk en de Oosters-Orthodoxe kerken zijn te weinig gegevens voorhanden om ontwikkelingen te schetsen.

Tabel 4.15 Kerncijfers overige christelijke kerken, 2006

kerkgenootschap
Anglicaanse Kerk
Jehova's Getuigen**
Geredja Indjili Maluku*
Oosters Orthodoxe Kerken***
Apostolisch Genootschap*
Nieuw-Apostolische Kerk in Nederland*
Oud-Katholieke Kerk*
Bronnen: ${ }^{*}=$ landelijke bureaus, voor NA K: medio 2005
$\quad * *=$ http://www.watchtower.org
$* * *=$ schatting uit secundaire bronnen

\section{$4 \cdot 3$ ISLAM}

gemeentes gebouwen voorgangers

17

419

$64 \quad 21 \quad 35$

$40 \quad-\quad 30$

$88 \quad 88 \quad 10$

$77 \quad 71$

$28 \quad 24$

In deze paragraaf wordt ingegaan op enkele demografische en sociologische aspecten van de moslims in Nederland. Allereerst wordt de ontwikkeling van het aantal moslims weergegeven, alsmede hun herkomst en geografische spreiding over Nederland. De islam in Nederland vertoont een grote diversiteit. Deze wordt niet alleen veroorzaakt door generatiewisseling, maar ook door etnische, regionale en culturele verschillen in de landen van herkomst. Daarom worden aansluitend op de cijfers over de aantallen moslims enkele hoofdrichtingen binnen de islam beschreven. Vervolgens worden de belangrijkste moslimgroepen in Nederland beschreven met het aantal leden, moskeeën en imams. Aan het eind van deze paragraaf worden enkele trends in de religieuze participatie binnen de moslimgemeenschap beschreven.

\subsubsection{AANTAL MOSLIMS}

Vóór 1950 was het aantal moslims in Nederland onbeduidend te noemen. De eerste moslimgemeenschap in Nederland manifesteerde zich in 1947. Een kleine groep moslims opende haar eerste moskee in Den Haag in 1955. In datzelfde jaar werd een andere moskee gebouwd in het Friese Balk. Het was een houten moskee voor islamitische Molukkers. Deze groep vormde de eerste omvangrijke islamitische geloofsgemeenschap in Nederland.

Vanaf de jaren zestig komen als gevolg van arbeidsmigratie en dekolonisatie meer moslims naar Nederland: vooral uit Marokko (en Tunesië), Turkije en Suriname.

Zij vormen sindsdien een onderdeel van de Nederlandse samenleving. In 1970 creëerde de vreemdelingenwet voor de buitenlandse arbeidsmigranten de moge- 
lijkheid om hun gezinsleden naar Nederland over te laten komen. Daardoor groeide het aantal moslims sterk en ontstonden er moskeeën in grote en middelgrote steden.

\section{Tabel 4.16 Ontwikkeling aantal moslims in Nederland}

\begin{tabular}{|ccccc} 
& $\begin{array}{c}\text { Aantal } \\
\mathbf{x} \mathbf{1 . 0 0 0}\end{array}$ & $\begin{array}{c}\text { percentage } \\
\text { van de bevolking }\end{array}$ & $\begin{array}{c}\text { 1ste generatie } \\
(\mathbf{x} 1.000)\end{array}$ & $\begin{array}{c}\text { 2de generatie } \\
\mathbf{( \times 1 . 0 0 0 )}\end{array}$ \\
1993 & 566 & 3,7 &. &. \\
1994 & 602 & 3,9 &. &. \\
1995 & 625 & 4,1 & 414 & 211 \\
1996 & 654 & 4,2 & 428 & 225 \\
1997 & 687 & 4,4 & 447 & 241 \\
1998 & 724 & 4,6 & 467 & 257 \\
1999 & 765 & 4,9 & 490 & 275 \\
2000 & 801 & 5,1 & 509 & 292 \\
2001 & 844 & 5,3 & 534 & 310 \\
2002 & 886 & 5,5 & 558 & 328 \\
2003 & 919 & 5,7 & 573 & 346 \\
2004 & 944 & 5,8 & 582 & 362 \\
\hline
\end{tabular}

Bron: CBS 2006

Op 1 januari 2004 woonden er 944.0oo moslims in Nederland, 25.0oo meer dan een jaar eerder en 319.000 meer dan in 1995. Dit komt overeen met 5,8 procent van de totale bevolking van Nederland, tegen 4,1 procent in 1995. Het aantal moslims groeit door immigratie, maar ook door geboorte.

Volgens de definitie van het CBs behoren in het buitenland geboren moslims met ten minste één in het buitenland geboren ouder tot de eerste generatie. Tweede-generatie-moslims zijn in Nederland geboren personen met ten minste één in het buitenland geboren ouder. Zoals uit tabel 4.16 blijkt, vormen de eerstegeneratiemoslims de meerderheid (582.00o) tegenover de tweede generatie $(362.000)$.

Moslims zijn in ons land vooral woonachtig in de grote steden. In de provincie Zuid-Holland wonen de meeste moslims; in 2003 waren dat er bijna 290.000.

De meeste in Nederland wonende moslims zijn oorspronkelijk afkomstig uit Turkije (328.0oo) en Marokko (296.0oo). Samen maken zij tweederde deel uit van het totale aantal moslims in Nederland. Verder vormen Irakezen, Afghanen, Iraniërs, Surinamers en Somaliërs belangrijke moslimgroepen. De categorie overige groepen betreft een grote variatie aan herkomstlanden. 
Tabel 4.17 Spreiding moslims over Nederland, 2003

\begin{tabular}{|lccc} 
& $\begin{array}{c}\text { aantal } \\
\text { moslims } \\
\text { (x 1.000) }\end{array}$ & $\begin{array}{c}\text { percentage } \\
\text { van totaal } \\
\text { aantal moslims }\end{array}$ & $\begin{array}{c}\text { percentage } \\
\text { van de } \\
\text { bevolking }\end{array}$ \\
Groningen & 14 & 1,5 & 2,5 \\
Friesland & 12 & 1,3 & 1,9 \\
Drenthe & 8 & 0,9 & 1,7 \\
Overijssel & 50 & 5,4 & 4,5 \\
Flevoland & 21 & 2,3 & 6,0 \\
Gelderland & 78 & 8,5 & 4,0 \\
Utrecht & 81 & 8,8 & 7,0 \\
Noord-Holland & 213 & 23,2 & 8,3 \\
Zuid-Holland & 285 & 31,0 & 8,3 \\
Zeeland & 9 & 1,0 & 2,3 \\
Noord-Brabant & 108 & 11,8 & 4,5 \\
Limburg & 40 & 4,4 & 3,5 \\
TOTAAL & & & 5,7 \\
\hline
\end{tabular}

Bron: CBS

\section{Figuur 4.10 Aantal moslims per provincie}

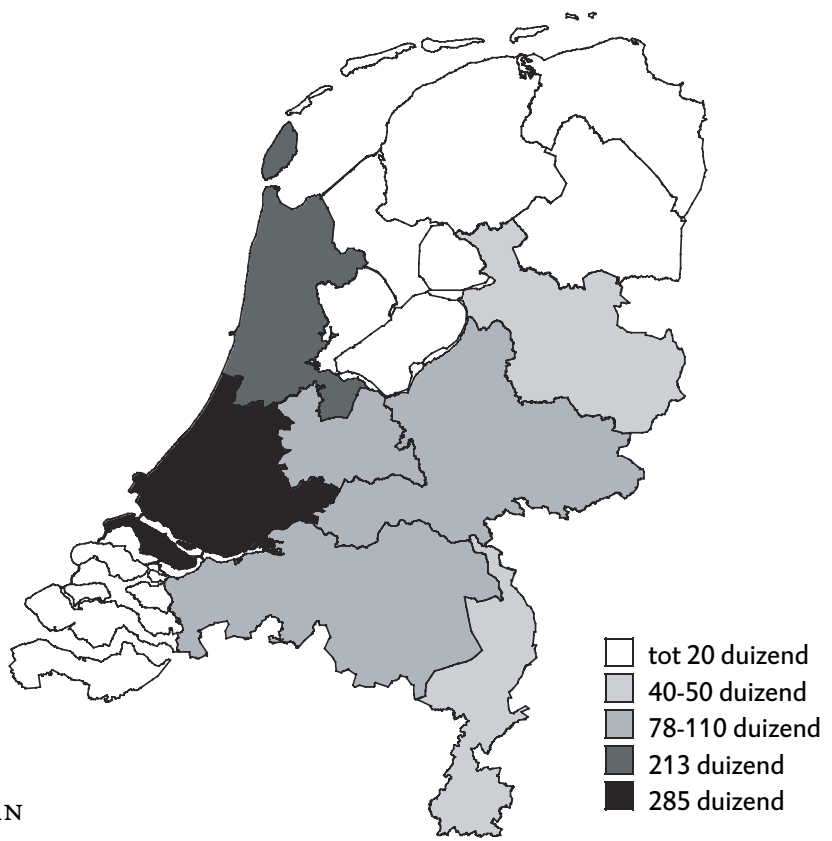

Bron: IHSAN 
Figuur 4.11 Percentage moslims op de bevolking

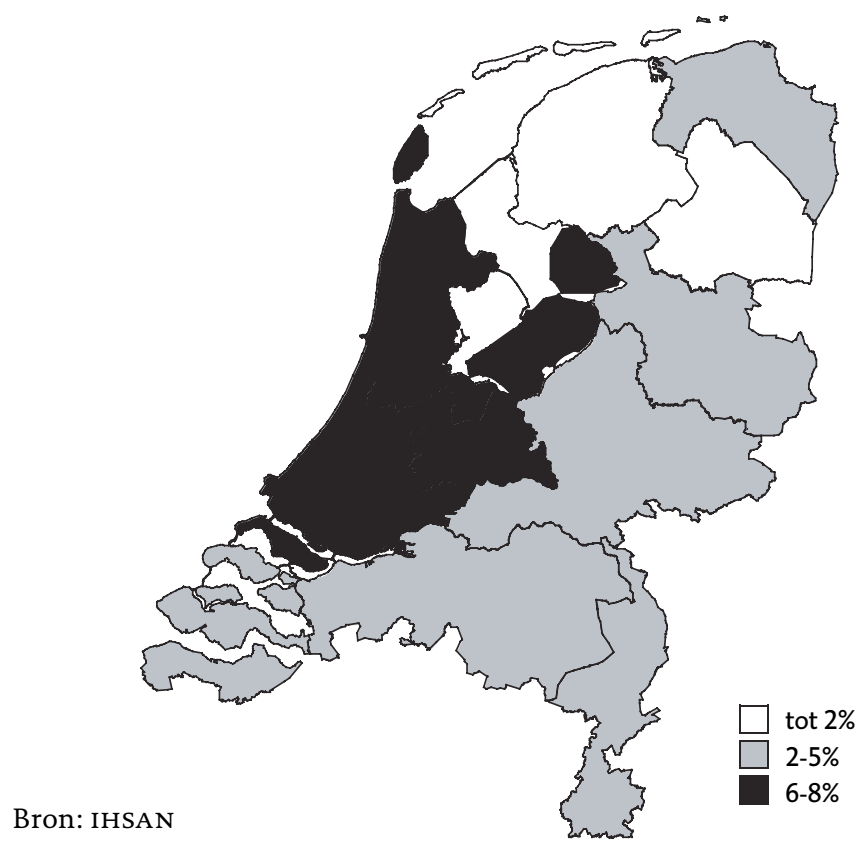

Tabel 4.18 Herkomst niet-westerse moslims in Nederland (aantal x 1.000)

\begin{tabular}{|c|c|c|c|c|c|c|c|c|}
\hline & $\begin{array}{c}\text { Afghani- } \\
\text { stan }\end{array}$ & Irak & Iran & Marokko & Somalië & $\begin{array}{l}\text { Suri- } \\
\text { name }\end{array}$ & Turkije & $\begin{array}{l}\text { Overige } \\
\text { groepen }\end{array}$ \\
\hline \multicolumn{9}{|l|}{1993} \\
\hline \multicolumn{9}{|l|}{1994} \\
\hline 1995 & 3 & 8 & 14 & 213 & 17 & 27 & 249 & 65 \\
\hline 1996 & 5 & 11 & 16 & 220 & 20 & 28 & 256 & 68 \\
\hline 1997 & 8 & 15 & 19 & 227 & 24 & 28 & 264 & 72 \\
\hline 1998 & 11 & 22 & 20 & 236 & 26 & 29 & 273 & 77 \\
\hline 1999 & 16 & 29 & 22 & 245 & 27 & 29 & 281 & 82 \\
\hline 2000 & 21 & 32 & 23 & 255 & 29 & 30 & 290 & 88 \\
\hline 2001 & 26 & 37 & 24 & 264 & 30 & 30 & 299 & 96 \\
\hline 2002 & 31 & 40 & 26 & 275 & 29 & 31 & 309 & 104 \\
\hline 2003 & 34 & 41 & 28 & 285 & 28 & 31 & 319 & 112 \\
\hline 2004 & 36 & 42 & 28 & 296 & 25 & 32 & 328 & 116 \\
\hline
\end{tabular}

Bron: CBS 2006

\subsubsection{BELANGRIJKE ISLAMITISCHE RICHTINGEN}

Hoewel vele buitenstaanders de islam en de moslims vaak als een monolithisch blok zien, kent de islam van oudsher diverse richtingen. Ook is de beleving van de islam in het ene land anders dan in het andere. De moslimwereld kent twee belang- 
rijke hoofdrichtingen, namelijk de soennieten en de sjiieten. Ongeveer 85 procent van de moslims in de hele wereld behoort tot de soennitische traditie, 10 procent tot de sjiitische traditie en 5 procent tot overige stromingen. Het overgrote deel van de Nederlandse moslims behoort tot de soennitische traditie van de islam.

\section{Soennieten}

De term 'soennieten' betekent in het Arabisch: personen die het voorbeeld van de profeet Mohammed volgen en de gemeenschap van de moslims in stand houden (Ahl al-Soenna wa'l-Jama'a). Het kenmerk van de soennitische traditie van de islam is dat deze naast de Koran ook de traditie van de profeet Mohammed als uitgangspunt neemt bij de praktisering van de islam. De Traditie (soennah) beschrijft de voorbeeldige levenswijze van de profeet Mohammed en de eerstegeneratiemoslims. Naast de Koran staat de navolging van deze levenswijze centraal bij soennieten. De soennieten vinden zowel de geest als de letter van de Koran belangrijk. De wetgeving is voornamelijk gebaseerd op deze twee bronnen. Daarnaast kent de soennitische islam nog twee bronnen van de religieuze rechtsontwikkeling, namelijk de analogie en de consensus van de schriftgeleerden (de status van de islamitische schriftgeleerde is te vergelijken met de kerkvaders in de christelijke traditie).

In tegenstelling tot de sjiitische traditie van de islam kent de soennitische traditie geen formele geestelijke hiërarchie. In principe staat het de gelovigen vrij tot wie zij zich wenden voor leiding. In de praktijk beroepen de gewone mensen zich op de imams.

\section{Sjiieten}

Het verschil tussen beide richtingen is in oorsprong politiek-theologisch van aard. De sjiieten vonden dat de profeet Mohammed alleen door een afstammeling van hem kon worden opgevolgd. Volgens de sjiieten hadden Ali (de neef en schoonzoon van de profeet Mohammed) en zijn nazaten recht op het leiderschap na het overlijden van de profeet Mohammed. De nazaten van Ali, de zogenaamde twaalf imams, zijn in de ogen van de sjiieten de 'plaatsbekleders' van Allah op aarde en de erfgenamen van de kennis van de profeet Mohammed. Ze zijn onfeilbaar en de enige autoriteit inzake religie en politiek. Sjiieten noemen zich dan ook naar Ali ('Partij van Ali').

Hoewel ook de soennieten een groot respect hebben voor Ahl al-Bayt (het gezin en de nakomelingen van de profeet Mohammed), zien ze politieke zaken niet als kwesties van geloof maar meer als wereldlijke zaken. Ze vinden dat stemmen of de consensus van vooraanstaande figuren voldoende basis vormen om de politieke leider van de geloofsgemeenschap te kiezen.

Er is ook nog een theologisch onderscheid te maken. In de sjiitische traditie van de islam spelen de schriftgeleerden een belangrijke rol bij de interpretatie van de Koran. Verder is sprake van een levendige en emotionele cultus rond de twaalf imams. Voor soennieten ligt de waarheid in de geschriften en treden de geeste- 
lijke leiders minder op de voorgrond. Ook is de godsbeleving bij sjiieten gevoelsmatiger en emotioneler.

\subsubsection{DE ORGANISATIE VAN MOSLIMGROEPEN IN NEDERLAND}

De belangrijkste moslimgroepen in Nederland hebben Turkse, Arabische (vooral Marokkaanse) of Surinaams-Hindostaanse wortels. Daarbinnen bestaat weer een grote diversiteit; met name binnen de Turkse moslimgemeenschap bestaan er bovendien belangrijke sociaal-politieke verschillen. Daarnaast zijn er kleinere moslimgemeenschappen afkomstig uit diverse landen, waaronder Indonesië, Palestina, Bosnië, Somalië en Pakistan. Behalve de Indonesiërs zijn de laatstgenoemde groepen vanaf de jaren tachtig naar Nederland gekomen, meestal als vluchteling. De beleving van de islam is bij deze groepen verschillend al naar gelang de culturele en geografische achtergrond.

De meeste moskeeën en islamitische organisaties zijn per etnische groep georganiseerd. De Turkse gemeenschap heeft relatief gezien de meeste organisaties, gevolgd door Marokkanen en Surinamers. Er zijn 356 Turkse islamitische organisaties, 171 Marokkaanse en 89 Surinaamse. Dit betekent dat alleen al de grote immigrantengroepen minstens 616 islamitische organisaties in Nederland hebben gevestigd.

Onder de islamitische organisaties bevinden zich ook moskee-organisaties. Volgens de Nederlandse moskeedatabase waren er eind 2003 in totaal 453 moskeeën in Nederland. De meerderheid is Turks (245), dan volgen de Marok-

Tabel 4.19 Aantal moskeeën naar etniciteit en organisatie, 2003

\begin{tabular}{llr} 
etniciteit & richting & aantal moskeeën \\
Turkije & Diyanet & 151 \\
& Milli Görüs & 42 \\
& Suleymanli's & 38 \\
& overig & 14 \\
\multirow{3}{*}{ Marokko } & totaal Turkse moskeeën & 245 \\
& Unie van Marokkaanse Moskee-organisaties in Nederland & 90 \\
& Unie van Marokkaanse Moskeeën in Amsterdam e.o. & 20 \\
& overig & 40 \\
Suriname & totaal Marokkaanse moskeeën & 150 \\
& World Islamic Mission & 25 \\
& Ahmadiyya & 4 \\
& overig & 4 \\
overige & totaal Surinaamse moskeeën & 33 \\
& & 25
\end{tabular}


kaanse (150) en tot slot een klein aantal Surinaamse moskeeën (33). De 25 overige moskeeën zijn grotendeels niet geclassificeerd. Daaronder vallen in ieder geval 2 Indonesische, 2 Molukse, 4 Pakistaanse, 1 Somalische en 1 Bosnische moskee.

Per etniciteit is voor de verschillende bestaande organisaties het aantal moskeeën weergegeven in tabel 4.19. Het aantal imams is min of meer gelijk aan het aantal moskeeën.

De spreiding van moskeeën over Nederland is niet gelijkmatig. De hoogste concentratie is te vinden in de grote steden Amsterdam, Rotterdam, Den Haag en Utrecht. Verder zijn hogere concentraties te vinden in Midden-Nederland, rond Eindhoven en in Twente. De laagste concentratie bevindt zich in Friesland en Zeeland.

De drie grootste etnische groepen worden hierna uitgebreid beschreven (Heelsum et al. 2004). Daarbij worden de verschillen kort behandeld en wordt tevens aangegeven hoeveel moskeeën en imams in Nederland deze moslimgroepen hebben.

\section{Turkse moslims}

De Turkse moslims in Nederland zijn grotendeels soenniet. De alevieten vormen een minderheid (naar schatting 50.00o). De Turkse moslims zijn in Nederland georganiseerd langs sociaal-politieke lijnen. Er kunnen vijf belangrijke georganiseerde groepen onderscheiden worden:

1. Islamitische Stichting Nederland (ISN) / Diyanet;

2. Milli Görüs Noord- en Zuid-Nederland (MGN);

3. Suleymanli's / Stichting Islamitisch Centrum Nederland (SICN);

4. Nurcu's;

5. HAK-DER (alevieten).

De eerste drie koepelorganisaties hebben ongeveer 231 moskeeën (meestal gaat het om gebedsruimten) in Nederland. HAK-DER en Nurcu's kennen geen moskee-organisaties als lidorganisatie. De meeste moskeeën hebben een imam (geestelijke voorganger). Maar sommige moskeeën hebben geen imam vanwege financiële en juridische belemmeringen. Ook moeten imams tegenwoordig een inburgeringstoets in het buitenland afleggen voordat men naar Nederland komt. Dat vormt een obstakel voor de aanstelling van de imams in Nederland. Met name bij de ISN/Diyanet-groep speelt dit probleem, aangezien hier de imams voor vier jaar naar Nederland worden gestuurd. Volgens een woordvoerder van ISN hebben circa 20 moskeeën geen imams vanwege deze inburgeringstoets.

De meeste Turkse imams hebben een universitaire opleiding voltooid in Turkije. De leeftijd van de imams varieert tussen 17-76 jaar. De gemiddelde leeftijd is 41 jaar. De helft van de imams (55) is jonger dan 41 jaar. Bij alle moskeeën, behalve bij die van de Turkse Diyanet, is het bestuur de werkgever van de imam. De imam wordt betaald door de geloofsgemeenschap (Canatan et al. 2005: 29-30). 
Islamitische Stichting Nederland (ISN) / Diyanet

De grootste groep soennieten in Nederland behoort tot de Turkse Diyanet. De Turkse staat heeft een seculier karakter, maar de staat organiseert wel de opleidingen van imams en het godsdienstonderwijs. De Diyanet is 'Het Presidium van godsdienstzaken' en houdt zich bezig met de geloofsleer en de eredienst van de islam. De president en de leden van de Hoge Raad voor Religieuze Zaken, het hoogste orgaan binnen de Diyanet, zijn benoemd door de regering.

Sinds het begin van de jaren tachtig stuurt de Turkse Diyanet, op verzoek van Nederlandse moslims, imams naar Nederland voor een periode van maximaal vier jaar. Diyanet betaalt ook de salarissen van de imam, maar bemoeit zich verder niet met de wijze waarop de imam zijn werk doet. Voor hij wordt uitgezonden volgt de imam in Turkije een intensieve taalcursus en een oriëntatiecursus over Nederland. Bij de benoeming speelt het lokale bestuur van de moskee een belangrijke adviserende rol.

De Diyanet is eigenaar en beheerder van 151 moskeeën in Nederland. Deze moskeeën zijn onderdeel van de koepelorganisatie Islamitische Stichting Nederland (ISN), die op zijn beurt weer nauw samenwerkt met de attaché voor godsdienstzaken van de Turkse ambassade.

De andere Turkse soennitische moskeeën wijken niet theologisch, maar vooral sociaal-maatschappelijk af van de officiële Turkse staatsislam. De groepen zijn: de Milli Görüs, Suleymanli's en Nurcu's. De moskeebesturen van deze groepen zoeken en vinden hun imam via eigen netwerken. De aanstelling vindt in principe plaats voor onbepaalde duur.

\section{Milli Görüs}

De Milli Görüs is een sociale en politieke beweging in Turkije, maar ook in Europa en Nederland. De naam Milli Görüs heeft twee betekenissen. In het Turks betekent dit letterlijk 'Nationale Visie'. De aanhangers van deze beweging geven echter de voorkeur aan de Arabische betekenis 'Religieus Perspectief'.

Milli Görüs vindt dat de islam vertaald moet worden naar de huidige tijd en moet trachten antwoorden te vinden voor de hedendaagse maatschappelijke problemen van het land waarin de leden zich bevinden. Inmiddels heeft de Milli Görüs Nederland besloten zich niet meer te bemoeien met de ingewikkelde Turkse politieke verhoudingen. Ze wil zich, vanuit de eigen islamitische inspiratie, geheel richten op de integratie van de Turkse moslims in de Nederlandse samenleving. De Milli Görüs-moskeeën zijn vaak brede sociaal-cultureel centra waarin, afgezien van de gemeenschappelijke gebedsruimte, verschillende groepen eigen activiteiten organiseren.

De Milli Görüs kent in Nederland twee landelijke koepelorganisaties: de Milli Görüs Noord-Nederland en de Milli Görüs Zuid-Nederland. Beide koepelorganisaties hebben samen ongeveer 40 moskeeën en nog eens 40 aan de moskee geli- 
eerde jongeren, vrouwen, studenten en/of sportverenigingen onder hun beheer. De plaatselijke moskeeën functioneren redelijk autonoom. Landelijk georganiseerde activiteiten zijn onder andere de zomercursussen voor kinderen, de inburgeringcursus voor imams, de bedevaart naar Mekka en de hulpacties voor arme landen tijdens de Ramadan en het offerfeest.

\title{
Suleymanli's/sıCN
}

De beweging van de Suleymanli's is vooral gericht op het organiseren van Korancursussen voor kinderen en jongeren. De naam is afgeleid van de oprichter van de beweging, Süleyman Hilmi Tunahan. Ook de beweging van de Suleymanli's heeft een landelijke koepelorganisatie, de Stichting Islamitisch Centrum Nederland (SICN). De Suleymanli's noemen zichzelf bij voorkeur de SICN-groep omdat dit neutraler is.

Op dit moment telt SICN in totaal 72 lidorganisaties waarvan 38 statutair aangesloten moskee-organisaties en 34 organisaties waarmee op verschillende terreinen en voor verschillende projecten wordt samengewerkt.

\section{Nurcu's}

De Nurcu's zijn een kleine beweging. Ze zijn alleen lokaal georganiseerd. De leden hiervan bestuderen vooral de werken (Risale-i Nur) van hun inspirator Said Nursi. In deze werken wordt een brug geslagen tussen de natuurwetenschap en de islam. De Nurcu's staan bekend als open naar andersdenkenden. Deze groep heeft geen moskeeën maar zogenaamde madrasa's en studiehuizen. Een tak van de Nurcu-beweging onder leiding van Fethullah Gulen, een Turkse imam die nu in de Verenigde Staten woont, is intensief bezig met het oprichten en beheren van (jongens- en meisjes)internaten en scholen in Turkije en vooral daarbuiten. Deze groep heeft in Nederland ruim tien internaten.

\begin{abstract}
Alevieten/HAK-DER
Verreweg de meeste alevieten in Nederland zijn van Turkse origine. Zowel in Turkije als in West-Europa is er, onder invloed van jonge intellectuelen, sprake van een opleving van het alevitisme. De traditionele cultuur wordt geherinterpreteerd in het licht van de moderne geïndustrialiseerde en verstedelijkte samenleving. De alevieten splitsten zich in de dertiende eeuw af van de sjitische traditie van de islam. Het alevitisme in Turkije is echter in de loop der tijd zo ontwikkeld dat het niet meer als zodanig te herkennen is. Alevieten benadrukken de innerlijke dimensie van de religie en propageren een vrijzinnige vorm van de islam. Met betrekking tot ethiek klinkt in de alevitische geschriften een zekere afkeer van gedetailleerde gedragsvoorschriften door en wordt de nadruk gelegd op algemeen geformuleerde grondregels. Naast Ali en zijn opvolgers, de twaalf imams, vervult nog een andere heilige een belangrijke plaats in het alevitisme: Haci Bektas Veli, een heilige die in de 13de eeuw leefde. Zijn leerstellingen en filosofie vormen een belangrijk en een geïntegreerd geheel in de alevitische denken leefwijze.
\end{abstract}


De meeste alevieten gaan niet naar de moskee, maar wel naar een 'cemevi'. De cemevi is niet een soort moskee, maar meer een plaats om rituele bijeenkomsten te organiseren, en lijkt meer op een 'tekke' (huis van een mystieke orde). Tijdens het regime van Atatürk werden niet alleen de soennitische tekke's verboden, maar ook de alevitische cemevi's. De laatste jaren worden door de alevieten de cemevi's weer geopend.

De Turkse alevieten zijn sinds 1991 landelijk georganiseerd in de Federatie van Alevitische en Bektashistische sociaal-culturele verenigingen in Nederland (HAK-DER). De federatie heeft op dit moment 14 aangesloten verenigingen in heel Nederland. In de meeste grote steden zijn zij georganiseerd. Het doel van de federatie is de belangen van de alevitische gemeenschap in Nederland - in de breedste betekenis van het woord - te behartigen.

\section{Marokkaanse moslims}

De Marokkaanse moslims zijn nagenoeg allen soennieten. In alle aspecten van het Marokkaanse sociaal-culturele leven neemt de islam een belangrijke plaats in. Volgens de grondwet van Marokko is de islam de staatsgodsdienst. De koning moet erop toezien dat de staat volgens de principes van de islam wordt bestuurd. De vorst benadrukt vooral dat hij een rechtstreekse afstammeling is van de profeet Mohammed.

Er zijn wel verschillende sociaal-politieke of culturele stromingen binnen de Marokkaanse islam, maar deze hebben geen duidelijke vorm gekregen. De Marokkaanse moskeeën in Nederland hebben ook een koepelorganisatie, de Unie van Marokkaanse Moslim-Organisaties in Nederland (UMMON). De meeste Marokkaanse moskeeën waren daarbij tot 1993 aangesloten. Na een publicatie dat de UMMON samenwerkte met de Marokkaanse autoriteiten besloot het merendeel van de Marokkaanse moskeeën zijn lidmaatschap te beëindigen. Daardoor is er in Nederland geen representatief orgaan meer waarbinnen de meeste Marokkaanse moskeeën ervaringen uitwisselen en samenwerken.

Er zijn ongeveer 150 Marokkaanse moskeeën in heel Nederland. Het is niet altijd duidelijk hoeveel van deze lokale moskeeën geestverwant zijn van de UMMON. Volgens een woordvoerder van de UMMON zijn Marokkaanse moskeeën horizontaal georganiseerd en kent de UMMON geen officieel lidmaatschap. De UMMON beschouwt circa 9o moskeeën als geestverwant. De Unie van Marokkaanse Moskeeën in Amsterdam e.o. (UMMOA) telt 20 moskeeën.

Binnen de Marokkaanse gemeenschap in Nederland is de 'politieke islam' in opkomst, vooral onder jongeren van de tweede en de derde generatie. Deze jongeren sluiten zich aan bij de Salafiyya-groep of de groepering van Moslimbroeders. De Salafiyya-groep heeft een orthodox uitgangspunt en streeft naar het herstel van de traditionele normen van de islam, zoals die golden ten tijde van de profeet Mohammed en de eerste aanhangers. De groepering van de Moslimbroeders is vooral actief op cultureel en sociaal gebied. Daarnaast is binnen de 
Marokkaanse gemeenschap de Tabligh-organisatie actief. De aanhangers van deze organisatie houden zich bezig met de traditionele betekenis van de islam, maar beperken zich daarbij tot verheldering van de grondslagen van de islam en doen dat binnen moskeeën. Ze richten zich niet op de politieke participatie van moslims in de Nederlandse samenleving. Het merendeel van de Tabligh-aanhangers behoort tot de eerste generatie Marokkanen.

In tegenstelling tot de Turkse imams hebben Marokkaanse imams vaak theologisch onderwijs gevolgd van een lagere graad. $\mathrm{Zij}$ worden door de lokale organisaties aangesteld en betaald door de gemeenschap. De maatschappelijke en juridische positie van deze imams is zeer zwak. Daarom hebben de moskeeën moeite met het vinden van hoger opgeleide imams.

\section{Surinaams-Hindostaanse moslims}

Het aantal Surinaamse moslims is ongeveer 45.00o, zij zijn vooral te vinden onder Hindostanen en Javanen. Zij werken vaak samen met Pakistaanse moslims en laten bijvoorbeeld theologen en imams uit Pakistan overkomen. Er zijn bijna 9o Surinaamse islamitische organisaties (Heelsum et al. 2005: 17).

De Surinaamse moslimgemeenschap behoort deels tot de soennitische islam en deels tot de Ahmadiyya-beweging. De meeste soennitische moskeeën zijn aangesloten bij de koepelorganisatie WIM, World Islamic Mission. Naar eigen zeggen telt de WIM 25 moskeeën. Verreweg de grootste groep die de World Islamic Mission in Nederland vertegenwoordigt, zijn de Surinaamse moslims; daarnaast ook moslims uit Pakistan en India.

De Surinaamse imams hebben geen taalprobleem zoals de Turkse en Marokkaanse imams. Zij spreken goed Nederlands en hebben meestal een hoge graad van theologische opleiding genoten. Gezien de nauwe band met Pakistan en India trekt WIM meestal gebedsvoorgangers aan uit deze landen of laat eigen imams daar scholen.

De Ahmadiyya-beweging is rond 1890 ontstaan in Brits-Indië onder leiding van de geestelijke Mirza Ghulam Ahmad. De stichter van deze beweging predikte dat de islam zich moest aanpassen aan veranderingen in de moderne maatschappij en elke vorm van dogmatisme en verstarring moest vermijden. De stichter wordt door één groep, de Qadiyani-tak, gezien als een nieuwe profeet (de reden waarom de soennitische geleerden deze groep als geloofsafvalligen zien en geëxcommuniceerd hebben) en door een andere groep, de Lahore-tak, als hervormer.

De Ahmadiyya-moskeeën of -verenigingen werken in het algemeen met vrijwillige imams, die in eigen kring worden opgeleid, deels in Nederland, deels in Lahore. De beweging telt slechts vier moskeeën in de vier grote steden.

\section{Overige moslimgroepen}

De Pakistaanse moslimgemeenschap vertoont in cultureel, religieus en organisatorisch opzicht overeenkomsten met de Surinaams-Hindostaanse moslims. 
Deels maakt zij gebruik van de religieuze voorzieningen die door de Surinamers tot stand zijn gebracht en participeren zij in hun organisaties. In Nederland wonen de Pakistanen voornamelijk in de drie grootste steden. Daar zijn ook vrijwel alle Pakistaans-islamitische organisaties te vinden. Rotterdam kent drie Pakistaanse moskeeën, Amsterdam twee en Den Haag één. Het zijn allemaal soennitische moskeeën.

In Nederland is nog steeds een relatief kleine Indonesische moslimgemeenschap gevestigd die voor het grootste deel uit Molukkers bestaat. In Rotterdam en elders zijn er enkele verenigingen waarbij een gebedsruimte aangesloten is. Deze moskee-organisaties behoren tot de koepelorganisatie PPME, Persatuan Pemuda Muslim se-Eropa (Vereniging van Islamitische Jongeren in Europa). Verder zijn er twee moskeeën van Molukkers in Waalwijk en Ridderkerk.

In de jaren negentig zijn er kleine Bosnische en Somalische moslimgemeenschappen in Nederland ontstaan ten gevolge van oorlogen in de herkomstlanden. Deze gemeenschappen zijn actief betrokken bij de ontwikkelingen in het land van herkomst en hun eigen religieuze en culturele identiteit. Beide groepen hebben maar één moskee, in Rotterdam.

\subsubsection{RELIGIEUZE PARTICIPATIE}

Over de mate van religieuze betrokkenheid van moslims hebben enkele studies plaatsgevonden. De Universiteit Utrecht heeft in 1999 een uitgebreid onderzoek gedaan naar de opvattingen van Turkse en Marokkaanse jongeren in Rotterdam en deze vergeleken met die van autochtone jongeren (Phalet et al. 2001).

Turkse en Marokkaanse jongeren ervaren een loyaliteitsconflict tussen hun vriendenkring en hun familie. Op school en in de vriendenkring tenderen de opvattingen van Turkse en Marokkaanse jongeren in de richting van die van de overige jonge Rotterdammers. Binnenshuis conformeren Turkse en Marokkaanse jongeren zich echter aan de familietradities, de normen van de islam en die van het land van herkomst. Het geloof is nog steeds erg belangrijk voor de meeste jongeren, maar hun geloofsbeleving is meer geïndividualiseerd dan die van hun ouders.

Een belangrijke conclusie van dit onderzoek was dat er een Nederlandse islam onder allochtone jongeren ontstaat, een geïndividualiseerde en plurale islam 'made in Holland'. Geïndividualiseerd, omdat de meerderheid van moslimjongeren een persoonlijke en selectieve invulling aan zijn of haar geloofsbeleving geeft. Pluraal, omdat de Nederlandse variant van de moslimidentiteit ruimte biedt voor discussie en meningsverschil, bijvoorbeeld over hoofddoekjes. Er is in het onderzoek een significant verschil gevonden tussen de eerste en de tweede generatie Turkse en Marokkaanse moslims ten opzichte van het dragen van een hoofddoek. De eerste generatie vindt gemiddeld vaker dan de tweede generatie dat hoofddoekjes 'moeten'. 
Een meer recente studie van SCP en Ercomer-ICS (Phalet en Ter Wal 2004) bevestigt het globale patroon van voortgaande secularisatie. Zo vinden we evidentie voor een terugloop in de religieuze participatie van de tweede generatie, en in mindere mate ook van de tussengeneratie, in vergelijking met de eerste generatie. Dit is het geval ondanks een even sterke subjectieve betrokkenheid bij de islam: blijkbaar is de subjectieve islambeleving bij de tweede en de tussengeneratie van jonge Turken en Marokkanen in toenemende mate losgekoppeld van hun religieuze praktijk. Dat past bij de individualisering van de islambeleving in de tweede generatie, zoals die ook uit de eerdergenoemde studie in Rotterdam naar voren komt. Interessant is daarbij de enorme invloed die uitgaat van het onderwijs: naarmate Turken en Marokkanen hogere diploma's halen, vermindert niet alleen hun religieuze participatie, maar ook het subjectieve belang van religie als persoonlijk richtsnoer.

Daarnaast zijn ook aanwijzingen gevonden voor religieuze bestendiging. Niet alle moslims blijken even vatbaar voor secularisatie; bovendien treft secularisatie vooral de religieuze participatie en veel minder de religieuze identificatie en beleving. Voor een recente religieuze heropleving is echter geen evidentie gevonden.

Verder vertoont de islambeleving van Turken en Marokkanen behoorlijk wat interne diversiteit naar sekse en (sub-)etnische herkomst. Niet alleen participeren moslimvrouwen, vooral Marokkaanse, minder dan mannen. Turken lijken over de hele lijn wat meer vatbaar voor secularisatie dan Marokkanen. Tegelijk zijn zij religieus en anderszins wel beter georganiseerd. Verder zijn Koerden (op basis van etnische zelftoewijzing) nog wat meer geseculariseerd dan hun Turkse landgenoten; Berbers daarentegen zijn zeker niet minder religieus dan hun Marokkaans-Arabische landgenoten.

Tot slot komt uit een recente studie van Van Praag (2006) onder Marokkanen een overeenkomstig beeld tevoorschijn. Zowel de eerste als de tweede generatie Marokkanen (en trouwens ook Turken) rekenen zich nagenoeg geheel of voor het overgrote deel tot de islam. Kijken we echter naar moskeebezoek, dan bezoeken jongeren veel minder vaak een moskee dan de oudere generatie. Wel nemen beide generaties deel aan de Ramadan. Verder vindt een meerderheid van de jonge Marokkanen dat ieder zijn eigen invulling aan religieuze regels moet geven.

\subsubsection{DE MAATSCHAPPELIJKE ROL VAN MOSKEEËN}

Niet alleen zien we diversiteit en verandering in religieuze betrokkenheid van individuele moslims, maar ook in de rol van de moskeeën. In de afgelopen periode hebben de gemeentes Rotterdam en Amsterdam onderzoek laten doen naar de maatschappelijke rol van moskeeën (Canatan et al. 2003). Uit die onderzoeken blijkt dat moskeeën zich steeds meer mengen in maatschappelijke vraagstukken en allerlei maatschappelijke activiteiten organiseren. 
Naast deze stedelijke onderzoeken laat een landelijk onderzoek van de stichting IHSAN zien hoe het is gesteld met de maatschappelijke rol van moskeeën.

Volgens deze studie (Canatan et al. 2005: 29-30) is tweederde van de moskeeën in meer of mindere mate maatschappelijk georiënteerd. Vooral sociaal-politieke stroming, leeftijd van bestuurders, imams, gemeenschap en ledenbestand, organisatietype (aan- of afwezigheid van gelieerde organisaties) en de aanwezigheid van contacten met de buurtorganisaties en gemeenten beïnvloeden de mate waarin moskee-organisaties maatschappelijk georiënteerd zijn.

In het algemeen kan worden gesteld dat Turkse moskeeën met een jong bestuur, een jonge imam en een relatief jonge achterban, maatschappelijk actiever zijn dan de moskee-organisaties van de andere (etnische) groepen. Dit geldt ook voor de moskee-organisaties van de kleine groepen, voor zover zij bij dit profiel passen. Hieruit kan worden geconcludeerd dat generatiewisseling de motor van verandering is voor moskee-organisaties.

Bij de maatschappelijk georiënteerde moskeeën nemen educatieve activiteiten, inclusief interreligieuze en interculturele activiteiten, een prominente plaats in binnen het geheel van maatschappelijke activiteiten. Deze activiteiten zijn - zo concluderen de onderzoekers - eerder gericht op integratie dan op isolatie.

\subsection{OVERIGE RELIGIES}

\subsubsection{HINDOEÏSME}

Het hindoeïsme is in veel opzichten een andere religie dan christendom, jodendom of islam. Er is niet een periode aan te geven waarin het is ontstaan, er is niet zozeer sprake van een heilig boek, noch van een vastomlijnde leer. Wat hindoeisme dan wel is, is niet eenduidig te beschrijven. Daarbij komt ook nog eens dat hindoes zelf bij voorkeur niet over hindoeïsme schijnen te spreken, maar over de Eeuwige Waarheid of Eeuwige Traditie (Sanatan Dharm).

Kranenborg en Antuma (1997: 7) omschrijven hindoeïsme als "een conglomeraat van riten, stromingen, opvattingen, etc. dat van oorsprong thuis is op het Indiase subcontinent en zich op de een of andere manier op de Veda's oriënteert”.

\section{Stromingen en aantallen}

De hindoes in Nederland kunnen langs verschillende lijnen nader worden onderverdeeld (Kranenborg en Antuma 1997: 49-54):

- allochtone hindoes; deze groep is verreweg het grootste, en daarbinnen vormen de Surinaamse hindoes (Hindoestanen) de grootste groep; Kranenborg schat hun aantal op 100.00o. Daarnaast zijn er nog de hindoes afkomstig uit India en Sri Lanka (Tamils);

- aanhangers van diverse 'goeroebewegingen'; hiertoe kan de Hare Krishna beweging worden gerekend, evenals Transcendente Meditatie (тм) van Maharishi Mahes Yogi en de beweging rond Bhagwan/Osho; 
- aanhangers van het gedachtegoed van bepaalde westerse stromingen; tot deze groep kunnen onder andere new age en theosofische of esoterische stromingen worden gerekend.

De informant van de Hindoeraad, dhr. Bissessur, maakt een theologisch onderscheid, waarbij twee stromingen het belangrijkst zijn, namelijk Sanatan Dharm en Arya Samaj. In Nederland wordt $7 \mathrm{O}^{4}$ tot 80 procent ${ }^{5}$ van de hindoes tot de Sanatan Dharm gerekend en 20 procent tot de Arya Samaj. Binnen de stroming Sanatan Dharm kunnen in Nederland twee substromingen worden onderscheiden, te weten de Brahmanistische (Djanamvadische) stroming en de niet-Brahmanistische (Karamvadische) stroming; de eerste is de grootste. Het geheel is schematisch weergegeven in figuur 4.12.

Figuur 4.12

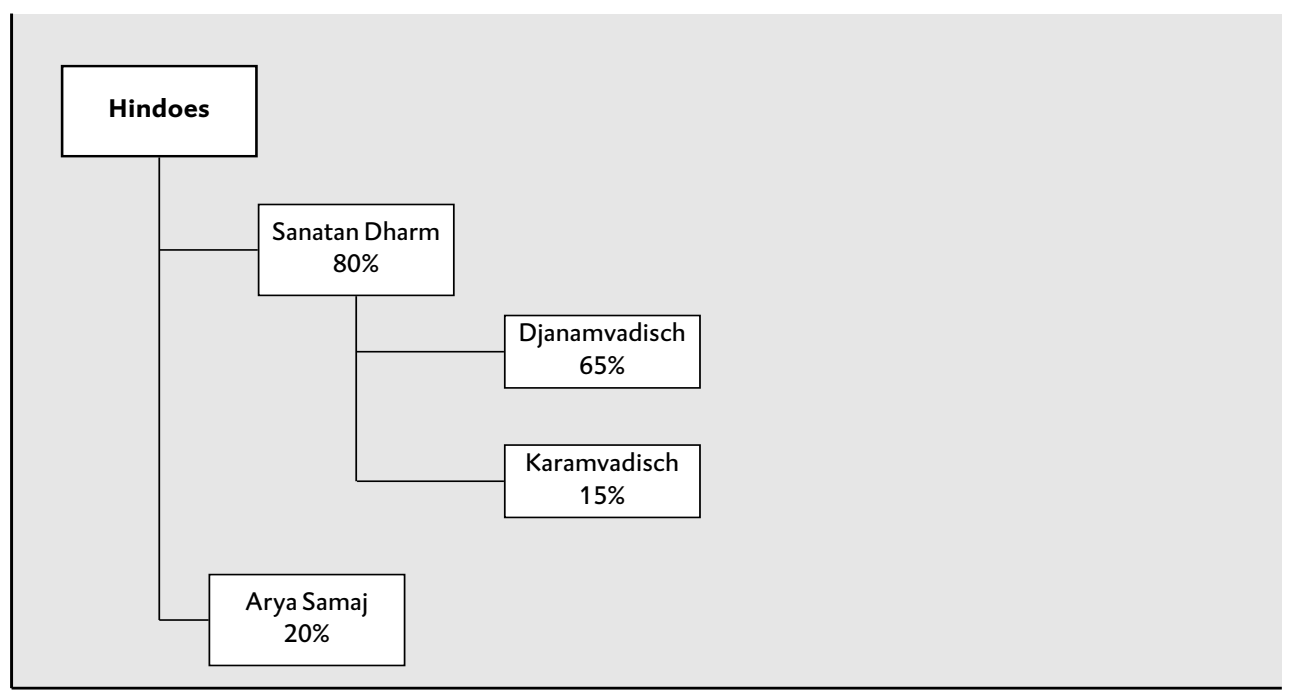

Bron: Hindoeraad

Het aantal hindoes varieert per bron. Het CBS meldt bijna 100.000 hindoes in Nederland, als volgt onderverdeeld naar etnische achtergrond.

Tabel 4.20 Overzicht van aantal hindoes in Nederland, volgens CBS, 2006

\begin{tabular}{|llr} 
groepering & land van herkomst & aantal \\
niet-westers & India & 11.000 \\
& Suriname & 83.000 \\
& overig & 5.000 \\
westers & & 1.000 \\
TOTAAL & & 100.000 \\
\hline
\end{tabular}

Bron: CBS Statline 
De website en de informant van de Hindoeraad Nederland spreken over circa 215.0oo hindoes. Dit aantal is als volgt opgebouwd.

Tabel 4.21 Overzicht van aantal hindoes in Nederland, 2006

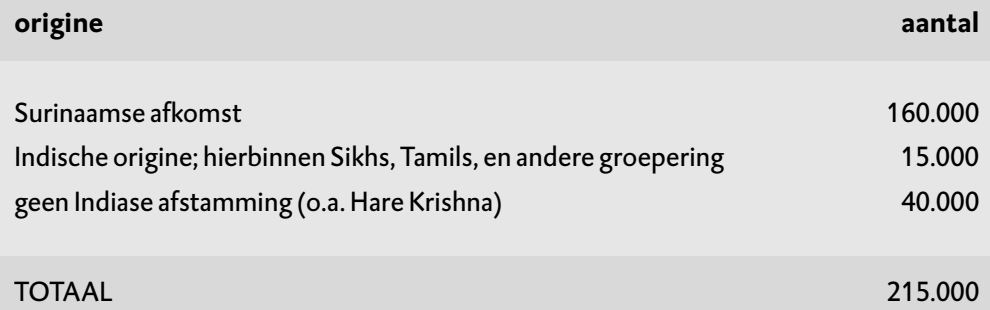

Bron: Hindoeraad

Op grond van de publicatie van Choenni en Adhin (2003) zijn weer andere getallen af te leiden. Zij spreken over 160.000 Hindoestanen ${ }^{6}$ in Nederland, waarvan 80 procent hindoe is, 18 procent moslim en 2 procent christen. Dat betekent 128.00o Surinaamse hindoes.

Voor de kaart van de regionale spreiding van hindoes nemen we de gegevens die in dit opzicht voorhanden zijn, en wel van de grootste groep onder hen, de Surinaamse hindoes (Choenni en Adhin 2003: 63).

Tabel 4.22 Spreiding Surinaamse hindoes, 2002.

\begin{tabular}{|lrcc|} 
provincie & $\begin{array}{c}\text { aantal } \\
\text { hindoes }\end{array}$ & $\begin{array}{c}\text { percentage } \\
\text { van totaal } \\
\text { aantal hindoes }\end{array}$ & $\begin{array}{c}\text { percentage } \\
\text { van de } \\
\text { bevolking }\end{array}$ \\
Groningen & 2.400 & 3,8 & 0,42 \\
Friesland & 1.600 & 1,3 & 0,25 \\
Drenthe & 800 & 0,6 & 0,17 \\
Overijssel & 2.400 & 1,9 & 0,22 \\
Flevoland & 7.200 & 5,6 & 2,11 \\
Gelderland & 4.800 & 3,8 & 0,25 \\
Utrecht & 8.000 & 6,3 & 0,70 \\
Noord-Holland & 31.200 & 24,4 & 1,22 \\
Zuid-Holland & 60.000 & 46,9 & 1,75 \\
Zeeland & 800 & 0,6 & 0,21 \\
Noord-Brabant & 8.000 & 6,3 & 0,33 \\
Limburg & 800 & 0,6 & 0,07 \\
TOTAAL & & & 0,79 \\
\hline
\end{tabular}

Bron: Choenni en Adhin 2003: 63 


\section{Figuur 4.13 Aantal hindoes per provincie}

Bron: KASKI

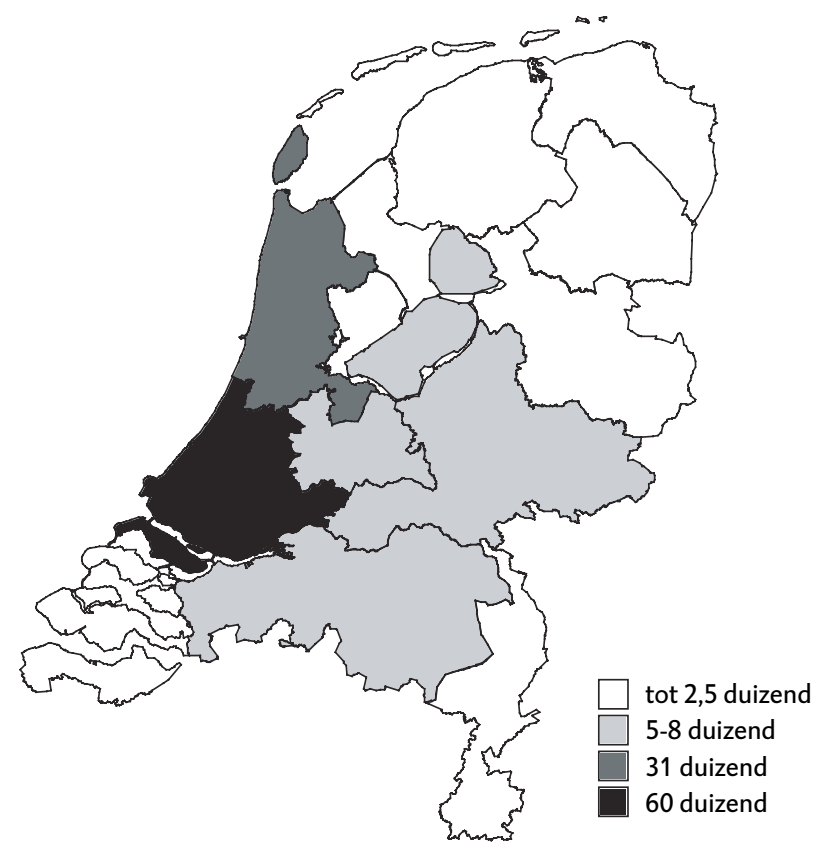

Figuur 4.14 Percentage hindoes op de bevolking

Bron: KASKI

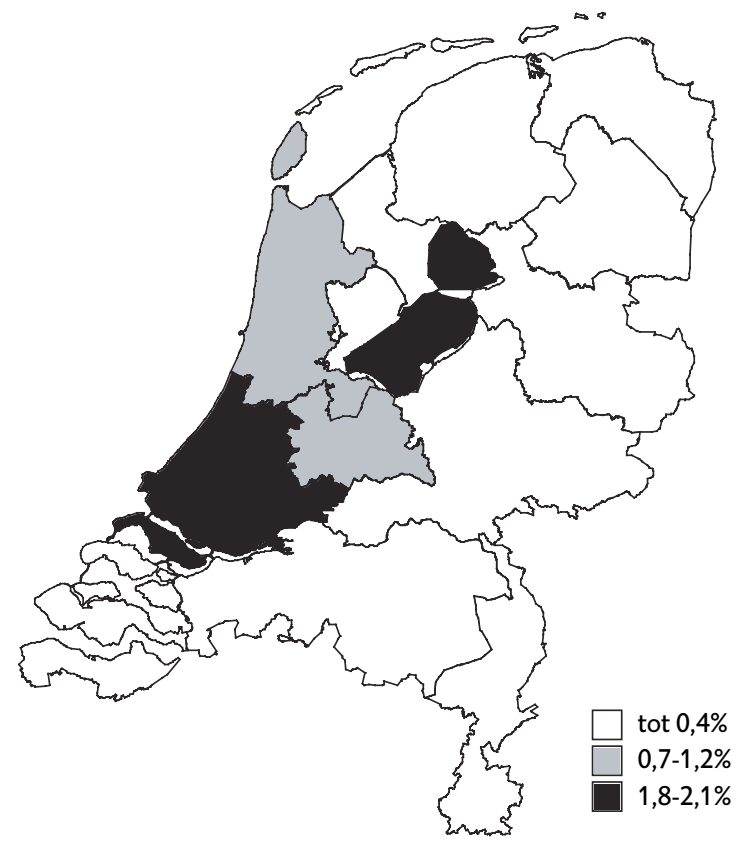


Het hoge aantal Surinaamse hindoes in Zuid-Holland komt grotendeels op het conto van Den Haag en omstreken. Daarnaast valt het hoge aantal Surinaamse hindoes in Flevoland op, vermoedelijk woonachtig in Almere.

De deelname van hindoes aan georganiseerde religieuze bijeenkomsten in tempels schat de informant op ongeveer 50 procent. Op hoogtijdagen en religieuze feestdagen is dat hoger. Naar zijn inschatting loopt de participatie terug en zijn het vooral ouderen en vrouwen die de tempels bezoeken. Naast de religieuze activiteiten in de tempels zijn er ook huisdiensten die door pandits bij families thuis worden verricht. Dit gebeurt bij ongeveer 8 o procent van de hindoes.

\section{Gebouwen en professionals}

Volgens Choenni en Adhin (2003: 110) zijn in vrijwel alle steden met hindoepopulaties van enige omvang tempels te vinden. In veel gevallen kan het gaan om locaties die thans als tempel zijn ingericht. In een aantal gevallen zijn er nieuwbouwtempels, zoals in Amsterdam of Wijchen. De informant van de Hindoeraad schat het totale aantal tempels op ongeveer 50 , waartoe hij al die ruimten rekent waar religieuze activiteiten plaatsvinden. Ook hier blijft het onderscheid tussen Sanatan Dharm en Arya Samaj 8o procent respectievelijk 20 procent.

Volgens zijn schatting telt Nederland zo'n 250 pandits (hindoevoorgangers), waarvan ongeveer de helft als (fulltime) betaalde kracht werkzaam is. De andere pandits hebben naast hun priesterschap een andere betrekking. De Sanatan Dharm pandits zijn bijna altijd mannen; bij Arya Samaj treden ook vrouwen op als pandita.

\section{Ontwikkelingen}

Men is doorgaans hindoe door geboorte: kinderen van hindoe-ouders zijn hindoe. Er is wel een aantal inwijdingsrituelen, maar die zijn niet bepalend voor de vraag of men hindoe is.

Er is nog steeds een kleine immigratie vanuit Suriname naar Nederland en daarmee een instroom van Surinaamse hindoes. Tegelijk kan er aanwas van hindoes zijn door immigratie uit andere landen (Sri Lanka, India) en door aanwas van hindoeïstische stromingen als Transcendente Meditatie (TM) of new age. Het is niet duidelijk in hoeverre de genoemde hindoeïstische stromingen als TM groeien, of in hoeverre het aantal actief betrokken bij new age groeit. Eerder lijkt het omgekeerde het geval.

Of dit tot een nettogroei of -afname van het aantal hindoes leidt is niet met cijfers te onderbouwen. Wel schetsen Choenni en Adhin (2003: 112-113) twee tegengestelde ontwikkelingen onder Surinaamse hindoes. Enerzijds stellen zij dat voor de Surinamers in Nederland de religieuze bijeenkomsten een belangrijke rol spelen bij de groepsvorming. Ook zien ze nog een grote mate van endogamie, wat de betrokkenheid bij het hindoeïsme op peil houdt. Anderzijds is er ook sprake van afnemende sociale controle in familie en gezinsverbanden, daling van 
geboortecijfer en stijgend opleidingsniveau, naast individualisering en secularisering. Dat wijst op een tegengestelde tendens. Zij constateren dan ook dat het grootste deel van de Surinaamse hindoejongeren zich over het algemeen niet of nauwelijks met het hindoeïsme bezighoudt.

\subsubsection{JODENDOM}

Met joden wordt zowel een volk als een religie aangeduid. In ieder geval in Nederland vallen deze twee niet samen. De groep die zich tot het jodendom als volk rekent is aanmerkelijk groter dan het aantal 'religieuze joden'. In deze atlas richten we ons vooral op de religieuze joden die lid zijn van een joodse gemeente. Daarbij zij nog aangetekend dat veel joden aangeven lid te zijn van een joodse gemeente, niet omdat ze gelovig zijn (dat geldt voor 17 procent), maar "omdat ik het als een plicht voel om een georganiseerde joodse gemeenschap in stand te houden" (62 procent) (Solinge en De Vries 2001: 131). Deze auteurs concluderen dan ook dat het verband tussen godsgeloof en lidmaatschap van een kerkgenootschap bij joden veel zwakker is dan bij andere religies.

\section{Stromingen en aantallen}

Er zijn verschillende getallen in omloop over het aantal joden in Nederland betreft. Dat heeft te maken met de omschrijving van het jood-zijn. Volgens de zogenaamde halachische opvatting is men jood wanneer de moeder jood is of wanneer men is toegetreden tot een joodse gemeente. Joden met een joodse vader en een niet-joodse moeder worden wel aangeduid als 'vader-joden' en worden in de ruimere tellingen wel meegeteld.

Binnen het religieuze jodendom in Nederland wordt een onderscheid gemaakt tussen liberale of progressieve joden en orthodoxe of traditionele joden, met beide hun eigen kerkgenootschap. Zo is er het Nederlands Verbond voor Progressief Jodendom 7 (voorheen Verbond van Liberaal Religieuze Joden in Nederland (LJG)) als liberaal kerkgenootschap, en het Nederlands-Israëlitisch Kerkgenootschap (NIK) als orthodox kerkgenootschap. Daarnaast bestaat er het Portugees-Israëlitisch Kerkgenootschap (PIK) dat ook tot de orthodoxie mag worden gerekend.

Sinds januari 2005 bestaat er een nieuw joods kerkgenootschap, de Masorti. Op dit moment heeft het kerkgenootschap één gemeente en zijn er drie in oprichting (vermoedelijk zullen die in 2007 als gemeente kunnen worden aangemerkt). Bij de Masorti zijn ongeveer 100 leden, grotendeels overgekomen vanuit de NIK, een enkeling ook uit de liberale gemeentes. De gegevens over Masorti berusten op informatie van dhr. Cohen, voorzitter van Masorti Almere/Weesp. Tot slot is er het kerkgenootschap Beth Hachidush dat één gemeente in Amsterdam telt met ongeveer 80 à 90 leden. Dit kerkgenootschap kan tot de progressieve tak van het jodendom worden gerekend.

Het volgende overzicht toont het aantal joden in Nederland en het aantal leden van de verschillende kerkgenootschappen, inclusief de peildatum. 
Tabel 4.23

Aantal joden in Nederland en aantal leden van joodse gemeentes

$\begin{array}{lrr}\text { categorie } & \text { peildatum } & \text { aantal } \\ & & 30.072 \\ \text { aantal joden volgens halachisch criterium } & 2000 & 43.305 \\ \text { halachische joden plus vader-joden } & 2000 & \\ & & 5.139 \\ \text { NIK } & 1-1-1999 & 3.200 \\ \text { LJG } & \text { eind 2000 } & 500 \\ \text { PIK } & \text { begin 2001 } & 100 \\ \text { Masorti } & \text { augustus 2005 } & 80-90 \\ \text { Beth Hagidush } & 2006 & 9.000 \\ \text { totaal aantal leden kerkgenootschap } & & \end{array}$

Bron: Solinge en De Vries (2001: 31 en 244); dhr. Cohen (Masorti) en dhr. Aronson (LJG) Aantallen zijn inclusief het aantal in Nederland wonende Israëlieten

Het grootste aantal joden in Nederland woont in Amsterdam. De volgende tabel toont het aantal joden in de drie grote steden en de vier regio's in Nederland. De percentages zijn van Solinge en De Vries (p. 34), de aantallen zijn omrekeningen op grond van het totaal aantal religieuze joden.

Tabel 4.24 Spreiding van religieuze joden over Nederland

\begin{tabular}{|lrr} 
regio & percentage & aantal religieuze joden \\
Amsterdam & 44 & 3.940 \\
Rotterdam & 4 & 340 \\
Den Haag & 6 & 520 \\
rest Holland/Utrecht & 25 & 2.210 \\
Noord & 4 & 370 \\
Oost & 11 & 1.010 \\
Zuid & 7 & 630 \\
TOTAAL & & 9.000 \\
\hline
\end{tabular}

Bron: Solinge en De Vries (2001)

De religieuze participatie is hoog volgens zowel de informanten als Solinge en De Vries; het gaat daarbij ook om incidentele participatie. Sommige synagogen kennen dagelijks diensten, andere sporadisch. In dat laatste geval is alleen incidentele participatie mogelijk. Solinge en De Vries schatten de participatie van leden op 92 procent: "De overgrote meerderheid van de gemeenteleden (92 procent) komt wel eens in de sjoel, maar de frequentie wisselt sterk. Onge- 
veer de helft komt er alleen op uitnodiging (bijv. voor een huwelijk) en ongeveer een kwart gaat er tijdens de feest- en hoogtijdagen heen” (p. 129).

\section{Gebouwen en professionals}

Het aantal gemeentes van de NIK wordt door een informant (dhr. Vis) geschat op 16 in Amsterdam en 25 buiten Amsterdam ${ }^{8}$, dat is inclusief de PIK-gemeente. Solinge en De Vries (2001: 130) komen op 34 gemeentes. Er zijn 20 rabbijnen werkzaam binnen het orthodoxe jodendom. Er zijn 9 liberale gemeentes, 7 gebouwen (per 2007) en 6 rabbijnen, volgens de informant vanuit het liberale jodendom, de heer Aronson. Beit Hachidush heeft één rabbijn, zij is de enige vrouwelijke rabbijn in Nederland, en één gebouw. Masorti heeft geen rabbijn en geen eigen kerkgebouwen.

\section{Ontwikkelingen}

Het aantal joden in Nederland is vanaf 1966 min of meer stabiel, wel treedt er een sterke vergrijzing op. In 1966 was 26 procent van de joden 19 jaar of jonger en 16 procent 65 jaar of ouder, in 2000 zijn deze cijfers respectievelijk 16 procent en 21 procent. Deze vergrijzing zal op termijn gevolgen hebben voor het aantal leden van de gemeentes. Kinderen worden automatisch lid van een gemeente als hun ouders lid zijn. Gebruikelijk is dat ze rond hun 18de jaar worden gevraagd of ze hun lidmaatschap willen continueren. In de praktijk heeft dit een daling van het aantal leden tot gevolg. Door exogamie zal het aantal homogene joodse gezinnen dalen en daarmee het aantal jongere leden.

Het aantal leden van de LJG is de afgelopen jaren gestegen; vanaf de jaren zestig van de vorige eeuw maakt men een grote bloei door. De PIK laat een lichte stijging zien, die vooral op conto komt van immigranten uit onder andere Irak en Iran (Solinge en De Vries 2001: 133). De NIK heeft de afgelopen tientallen jaren een ledenverlies laten zien, maar die afname is inmiddels gestopt. Er zijn op dit moment te weinig gegevens voorhanden om verdere prognoses te doen.

\subsubsection{BOEDDHISME}

Evenals het hindoeïsme is het boeddhisme een lastig te omschrijven religie. Bovendien is het boeddhisme ook te zien als een filosofie of levenswijsheid, waardoor mensen zich aangesproken voelen of waarmee ze affiniteit hebben. Vermoedelijk zijn veel in Nederland autochtone boeddhisten op deze wijze boeddhist; zij kunnen daarbij affiniteit hebben met het boeddhisme én zich tot een bepaald kerkgenootschap rekenen. Daarnaast zijn er in Nederland tal van allochtone boeddhisten. $\mathrm{Zij}$ zijn veel meer op te vatten als aanhangers van een bepaalde religie in de betekenis zoals we hier over christenen en moslims spreken.

Binnen het boeddhisme worden de volgende stromingen onderscheiden:

- Theravada;

- Mahayana (hiertoe kan ook zen worden gerekend);

- Vajrayana (waarvan het Tibetaanse boeddhisme de bekendste is). 
Over het aantal boeddhisten in Nederland is weinig bekend en bestaat weinig eenduidigheid; we komen aantallen tegen tussen de 70.00o en de 450.000.9 Volgens een informant van de Boeddhistische Unie zouden er in Nederland op dit moment 250.000 boeddhisten zijn, waarvan 100.000 van allochtone afkomst, met name Chinezen en Thai, en 150.000 van autochtone afkomst.

Op de websites van de Boeddhistische Omroep en van de Boeddhistische Unie Nederland is het getal van 170.000 te vinden met twee onderverdelingen, één naar stroming en één naar etniciteit.

Tabel 4.25 Indeling boeddhisten in Nederland naar stroming en naar etniciteit

\begin{tabular}{|lrr|} 
Indeling & aantal & percentage \\
naar stroming & & 20 \\
Theravada & 34.000 & 40 \\
Mahayana, Ch'an en Zen & 68.000 & 40 \\
Tibetaans & 68.000 & 100 \\
TOTAAL & 170.000 & 59 \\
naar etniciteit & & 24 \\
autochtonen & 100.000 & 6 \\
Chinezen & 40.000 & 4 \\
Vietnamezen & 10.000 & 7 \\
Thai & 7.500 & 100 \\
overige etniciteiten & 12.500 & \\
TOTAAL & 170.000 & \\
\hline
\end{tabular}

Er zijn in Nederland 7o boeddhistische organisaties, waarvan 33 'sangha's' (boeddhistische gemeenschappen). Het volgende overzicht geeft aan waar de gemeenschappen zich bevinden. Het zegt niets over het aantal aangesloten boeddhisten bij de sangha's. 
Tabel 4.26 Overzicht van boeddhistische organisaties in Nederland

$\begin{array}{lr}\text { Noord-Brabant } & 11 \\ \text { Noord-Holland } & 10 \\ \text { Zuid-Holland } & 8 \\ \text { Gelderland } & 7 \\ \text { Friesland } & 6 \\ \text { Drenthe } & 5 \\ \text { Overijssel } & 4 \\ \text { Groningen } & 3 \\ \text { Zeeland } & 2 \\ \text { Flevoland } & 1\end{array}$

Bron: http://www.boeddhisme.nl/home.html 


\section{NOTEN}

1 De door het SCP genoemde 4 procent van de Nederlandse bevolking heeft betrekking op het subjectief ervaren kerklidmaatschap; de mensen die zichzelf als kerklid beschouwen. Het feitelijke aantal leden volgens de ledenadministratie ligt hoger.

2 De toevoeging 'in Nederland en Noord-Amerika' is niet meer gangbaar.

3 De kaart toont alleen het aantal bevindelijken binnen de toenmalige Nederlandse Hervormde Kerk; projectie van de andere bevindelijke kerkgenootschappen levert eenzelfde beeld op.

4 Bron: http://www.indiawijzer.nl/religion_and_spirituality/hindu/saint_ sages_swamis/sanatan_dharmi.htm.

5 Bron: informant Bissessur.

6 Hindostanen zijn afstammelingen van Brits-Indië (in het Hindi heet dit Hindostan). Alle Brits-Indische emigranten in Suriname werden vanaf $1947 \mathrm{zo}$ genoemd; de groep bevat zowel hindoes (die ook wel hindoestanen worden genoemd) als moslims en christenen.

Dit is de officiële naam per oktober 2006.

$7 \quad$ Dit is de

8 Andere bronnen achten dit een royale telling.

9 Verslag Algemene Ledenvergadering Boeddhistische Unie 8 april 2006. 


\section{LITERATUUR}

Anonymus (2005) Statistics: 2005 Report of Jehovah's Witnesses Worldwide (on line), http://www.watchtower.org/statistics/worldwide_report.htm.

Becker, J. (2003) De vaststelling van de kerkelijke gezindte in enquêtes: 40 of $60 \%$ buitenkerkelijken? SCP-Werkdocument 92, Den Haag: SCP.

Becker, J. en J. de Hart, (2006) Godsdienstige veranderingen in Nederland: verschuivingen in de binding met de kerken en de christelijke traditie, SCP-Werkdocument 128 , Den Haag: SCP.

Bibby, R. W. en M.B. Brinkerhoff (1973) 'The Circulation of the Saints: A Study of People Who Join Conservative Churches', Journal for the Scientific Study of Religion, 12, 3: $273-283$.

Canatan, K., M. Popovic en R. Edinga, (2005) Maatschappelijk actiefin moskeeverband, 's-Hertogenbosch/Utrecht: Islamitisch Instituut voor Maatschappelijke Activering (IHSAN).

Canatan, K., C.H. Oudijk en A. Ljamai (2003) De maatschappelijke rol van de Rotterdamse moskeeën, Rotterdam: COS /Islamitisch Instituut voor Maatschappelijke Activering (IHSAN).

Canatan, K. (2001) Turkse Islam, perspectieven op organisatievorming en leiderschap in Nederland (proefschrift), Rotterdam: Erasmus Universiteit Rotterdam.

Cherribi, O. (2000) Imams d'Amsterdam: à travers l'exemple des imams de la diaspora marocaine (proefschrift), Amsterdam: Aksant.

Choenni, C. E. S. en K.S. Adhin (2003) Hindostanen: van Brits-Indische emigranten via Suriname tot burgers van Nederland, Den Haag: Communicatiebureau Sampreshan.

Dekker, G. en J. Peters (1989) Gereformeerden in meervoud: een onderzoek naar levensbeschouwing en waarden van de verschillende gereformeerde stromingen, Kampen: Kok.

Den Exter, J., Diyanet (1990) Een reis door de keuken van de officiële Turkse islam, Beverwijk: Centrum Buitenlanders Peregrinus.

Doomernik, J. (1991) Turkse moskeeën en maatschappelijke participatie, Nederlandse Geografische Studies 126, Amsterdam.

European Monitoring Centre on Racism and Xenophobia (2001) Anti-Islamic reactions within the European Union after the acts of terror against the USA, Synthesis Report \& Country Reports, European Monitoring Centre on Racism and Xenophobia (EUMC).

Gemeente Amsterdam (2004) Laat het van twee kanten komen, Eindrapportage van een verkenning (quick scan) van de maatschappelijke rol van moskeeën in Amsterdam.

Gereformeerde Gemeenten (2006) Kerkelijkjaarboek, Woerden: Bureau voor Kerkelijke Administratie van de Gereformeerde Gemeenten.

Groenveld-Kiestra, J. D. en A.A. Thimm (eds.) (2006) Doopsgezind jaarboekje, Amsterdam: Algemene Doopsgezinde Sociëteit.

Heelsum, A. van, M. Fennema en J. Tillie (2004) Moslims in Nederland, Islamitische organisaties in Nederland, SCP-werkdocument 106e, Den Haag/Amsterdam: SCP/IMES. 
Heelsum, A. van en E. Voorthuysen (2002) Surinaamse organisaties in Nederland, Amsterdam: Aksant.

Heelsum, A. van en J. Tillie (1999) Turkse organisaties in Nederland, Amsterdam: Het Spinhuis.

Heelsum, A. van (2001) Marokkaanse organisaties in Nederland, Amsterdam: Het Spinhuis.

Hoekstra, E.G. en M.H. Ipenburg (1995) Wegwijs in religieus en levensbeschouwelijk Nederland. Handboek religies, kerken, stromingen enorganisaties, Kampen: Kok.

Knippenberg, H. (1992) De religieuze kaart van Nederland: omvang en geografische spreiding van de godsdienstige gezindten vanaf de Reformatie tot heden, Assen: Van Gorcum.

Kooten, L. van en T.J. Prins (eds.) (2002) Bond van Vrije Evangelische Gemeenten, Kampen: Kok.

Kranenborg, R. en I.I. Antuma (1997) Hindoeïsme, Kampen: Kok.

Landman, N. (1992) Van mat tot minaret. De institutionalisering van de islam in Nederland, Amsterdam: vu Uitgeverij.

Mallan, F. (red.) (2006) Kerkelijk jaarboek. Gerformeerde Gemeenten in Nederland en reformed congregations in North America en gemeente Pretoria (Zuid-Afrika) (Vol. 59), Veenendaal: De Wachter Sions.

Praag, C. van (2006) 'Marokkanen in Nederland', Demos. Bulletin over Bevolking en Samenleving 22, 7: 61-64.

Phalet, K., C. van Lotringen en H. Entzinger (2001) Islam in de multiculturele samenleving, Opvattingen van jongeren in Rotterdam, Utrecht: Universiteit Utrecht, Ercomer.

Phalet, K. en J. ter Wal, (eds.) (2004) Moslims in Nederland, Diversiteit en verandering in religieuze betrokkenheid: Turken en Marokkanen in Nederland 1998-2002, SCP-werkdocument 106b, Den Haag/Utrecht: SCP.

Rath, J., R. Penninx, K. Groenendijk en A. Meyer (1996) Nederland en zijn islam. Een ontzuilende samenleving reageert op het ontstaan van een geloofsgemeenschap, Amsterdam: Het Spinhuis.

Runia, K. (1992) Evangelisch en gereformeerd: verkenning en herkenning, Driebergen: Evangelische Alliantie.

Shadid, W.A.R. en P.S. van Koningsveld (1997) Moslims in Nederland. Minderheden en religie in de multiculturele samenleving, Houten: Bohn Stafleu Van Loghum.

Singelenberg, R. (z.j.) Jehovah's Getuigen: overzichtsartikel, http://www.home.zonnet.nl/rsingelenberg/jehovah-rbn.htm.

Slis, P.L. (2006) De Remonstrantse Broederschap: biografischenaamlijst, 1905-2005: gemeenten, landelijke organen, predikanten en proponenten, publicaties, Delft: Eburon.

Solinge, H. van en M. de Vries (2001) De joden in Nederland anno 20oo: demografisch profiel en binding aan het jodendom, Amsterdam: Aksant.

Sunier, T. (1996) Islam in beweging. Turkse Jongeren en Islamitische organisaties, Amsterdam: Het Spinhuis.

Veerman, M. P. (1995) Mondig-bondig-zondig: drie stromingen binnen de gereformeerde wereld in Nederland, Gorinchem: Narratio.

Waardenburg, J.D.J. (2001) Institutionele vormgevingen van de islam in Nederland gezien in Europese perspectief, WRR-Werkdocument W118, Den Haag.

Yar, H. (2001) 'De islamitische sociale ethiek', Markant 1.

Zegwaart, H. (2003) Pinksterkerken, Kampen: Uitgeverij Kok. 


\title{
5 KERKEN IN DE NEDERLANDSE CIVIL SOCIETY: INSTITUTIONELE GRONDSLAG EN INDIVIDUELE INSPIRATIEBRON
}

\author{
Joep de Hart en Paul Dekker
}

\subsection{INLEIDING}

Dit hoofdstuk is gericht op de rol van de kerken als publieke instituties, als institutionele pijlers van de civil society en als sociale en normatieve milieus waarin mensen aangezet worden tot maatschappelijke deelname. De bespreking is steeds zoveel mogelijk gebaseerd op bevolkingsonderzoeken waarin deze aspecten zijn nagegaan. Aldus proberen we enig empirisch materiaal aan te dragen voor andere, meer theoretisch getinte beschouwingen in deze verkenning. Uitgangspunt zijn landelijke en internationale enquêtes en daarbinnen zullen we ons concentreren op gegevens die betrekking hebben op de positie en de invloed van de traditionele kerken. ${ }^{1}$

In de volgende paragraaf geven we eerst een kernachtige typering van de kerken als historisch belangrijke instanties binnen de Nederlandse civil society. Die typering loopt uit op de vraag of de kerken na decennia van ontkerkelijking nog steeds een grote rol spelen op het maatschappelijk middenveld. Langs drie wegen wordt vervolgens naar een antwoord gezocht, waarbij we onze bevindingen steeds in ook een internationaal perspectief zullen plaatsen. Na een introductie van de civil society en de historische ontwikkeling van de kerken daarin in paragraaf 5.2, wordt in paragraaf 5.3 enig cijfermatig inzicht geboden in de mate waarin het grote publiek religie accepteert als onderdeel van de civil society. In paragraaf 5.4 wordt daarop doorgegaan aan de hand van de vraag of de Nederlanders nog vertrouwen stellen in de kerken, vergeleken met hoe zij tegen andere instanties en instituties aankijken. De betekenis van religie vanuit het perspectief van de civil society blijft niet beperkt tot de publieke rol van kerken en geestelijk leiders. Religie is ook een inspiratiebron en achtergrond van individueel handelen. Religieuze overtuigingen, in geloofsleren verankerde normatieve voorstellingen en kerkelijke praktijken beïnvloeden wat Weber de praktische Lebensführung noemde en de houding van mensen tegenover anderen en de samenleving. Dat blijkt als we in paragraaf 5.5 vervolgens de aandacht verleggen naar religie en kerkelijkheid als achtergrond voor variërende vormen van maatschappelijke participatie en wegwijzer voor politiek handelen. Hoewel de traditionele kerken centraal staan in dit hoofdstuk, wordt - opnieuw vanuit participatieoverwegingen - apart in paragraaf 5.6 ingegaan op alternatieven voor de traditionele kerken. Daarbij komen de migrantenkerken ter sprake, evenals de islam en het brede scala aan interesses en praktijken dat wel wordt aangeduid met de term nieuwe spiritualiteit of new age. Voor een deel zal in dit stuk van het verhaal worden voortgeschreden langs de weg van de geïnformeerde redenering. In de slotparagraaf 5.7 wordt afgesloten met een resumé en kort gereflecteerd op de bevindingen. 


\subsection{DE CIVIL SOCIETY EN DE KERKEN}

Het begrip 'civil society' heeft van oudsher zowel een normatieve als een empirische betekenis. Normatief fungeert het als de conceptualisering van een beschaafde samenleving, onder andere gekenmerkt door een scheiding van machten en levenssferen, door beschaafde omgangsvormen en collectieve betrokkenheid van burgers. Meer gangbaar is tegenwoordig de empirische betekenis van civil society als aanduiding van het deel van de maatschappij waarin burgers buiten de privésfeer vrijwillige verbanden met elkaar aangaan en zich om gemeenschappelijke aangelegenheden bekommeren. In de maatschappelijke sfeer van de civil society domineren vrijwillige associaties, zowel in de vorm van verenigingen (voluntary associations) als in lossere verbanden, binnen andere organisaties en los van organisaties. De samenhang tussen beide conceptualiseringen is de veronderstelling dat een krachtige civil society als deel van de maatschappij een belangrijke bijdrage levert aan, wellicht een voorwaarde is voor het bestaan van een civil society als beschaafde maatschappij (Dekker 2002).

In verschillende opzichten nemen de kerken een bijzondere positie in te midden van de vrijwillige verbanden die typerend zijn voor de vaderlandse civil society of het maatschappelijke middenveld. ${ }^{2}$ De kerkelijke hoofdrichtingen hebben een vergeleken met andere maatschappelijke organisaties - lange geschiedenis, nog altijd aanzienlijke omvang en overwegend gemêleerd ledenbestand. De kerken zijn tevens van belang voor de maatschappelijke participatie vanwege de breedte van de onderwerpen waarop zij hun visie formuleren, de invloed die zij veelal blijken te hebben op de beslissingen van hun kernleden en de rol van moreel geweten die hun nog altijd door velen wordt toebedeeld (Dekker et al. 1997).

De meeste kerken zijn ingebed in uitgebreide sociale netwerken. Niet alleen bestaan er van oudsher tal van banden tussen de grote kerken en bestuurlijke instanties en circuits van politieke besluitvorming, maar ook plegen kerken sterk geworteld te zijn in lokale gemeenschappen en informele interactiepatronen. Meer dan vier op de tien Nederlanders staan nog steeds ingeschreven bij een van de twee grootste kerkgenootschappen (de RKK en de PKN), die beschikken over ruim vierduizend kerkgebouwen, verspreid over heel het land. Die bieden op plaatselijk niveau het middelpunt en de infrastructuur van 3.300 parochiegemeenschappen en -gemeentes. De twee kerkgenootschappen mobiliseren elk weekend ruim 800.000 kerkgangers en steunen op een legertje van 3.500 priesters, predikanten en diakens, 8 oo pastorale werkers en 545.000 vrijwilligers.

In protestante kringen is het altijd gebruikelijk geweest dat leken allerlei kerkelijke functies vervullen, maar het is ook voor de katholieken veel sterker gaan gelden. Dat de katholieke kerk de afgelopen decennia in snel tempo is omgevormd tot een geloofsgemeenschap die in hoge mate wordt gedragen door vrijwilligers en niet-gewijde krachten is een belangrijke ontwikkeling vanuit het oogpunt van civil society. Terwijl het aantal priesters de afgelopen vijfentwintig jaar afnam met 54 procent, steeg het aantal vrijwilligers met 19 procent en het 
aantal pastorale werkers met maar liefst 164 procent. In de meeste kerken vinden door de week heel wat meer activiteiten plaats dan op zondag en de twee soorten activiteiten overlappen elkaar maar ten dele.

Kerken fungeren niet alleen als instituties die spirituele en praktische bijstand geven aan hun leden, maar genereren ook vaak breder sociaal engagement. $\mathrm{Ze}$ dragen in hoge mate bij aan allerlei onbetaalde vormen van sociale dienstverlening (Van der Sar en Schoemaker 2003; Van der Sar 2004; Van der Sar en Visser 2006). In de kerkelijke gemeenschappen worden tal van activiteiten georganiseerd die mensen kunnen scholen in maatschappelijke vaardigheden en socialiseren in prosociale normen, die het maatschappelijk bewustzijn kunnen verruimen en de weg openen naar rekrutering voor ook niet-kerkelijke vormen van activisme. Verba et al. (1995) hebben laten zien dat veel mensen die vanwege hun opleidingsniveau en beroep anders veroordeeld zouden zijn tot politieke passiviteit, via hun kerkelijke activiteiten vaardigheden kunnen ontwikkelen die de weg openen voor een succesvolle participatie op andere sociale terreinen. Dat lijkt zeker op te gaan voor de migrantenkerken die zich in een breed scala aan de marge van grootschalige ontwikkelingen als de vorming van de PKN en veranderingen in de Rooms-Katholieke Kerk in Nederland manifesteren.

De Nederlandse geschiedenis biedt tal van voorbeelden van sociale bewegingen waarbij de kerken aan de basis stonden, als inspiratiebron of promotor optraden, dan wel als financiers fungeerden: van emancipatiebewegingen tot de vredesbeweging, van moral issue-organisaties tot organisaties gericht op internationale hulp en mensenrechten. Soms spelen kerken een manifeste politieke rol. Zelfs in landen met een formele scheiding tussen kerk en staat betraden kerkelijke en met de kerken geassocieerde instellingen telkens weer de politieke arena en hebben zij politieke bewegingen beïnvloed. Kerkleiders en geestelijken vertolken politieke standpunten in hun preken, herderlijke boodschappen en missiven, kerkelijke vertegenwoordigers vellen publiekelijk oordelen over sociale en morele onderwerpen, kerken leveren faciliteiten voor politieke mobilisatie en maatschappelijk protest, kerkbesturen geven ruimte aan solidariteitsbijeenkomsten of politieke discussies.

Tot ver in de jaren vijftig vormde ons land een soort religieuze archipel, elk eiland met zijn eigen levensbeschouwelijke biotoop. De katholieken leefden binnen hun zuil en namen van daaruit op geheel eigen wijze de omringende samenleving waar, hetzelfde gold voor de gereformeerden en de socialisten. Het Engelse good fences make good neighbours was gedurende honderd jaar lang het parool van omvangrijke bevolkingsgroepen. Dat Nederland bestaat niet meer. Er stak een nieuwe wind op en de turbulentie bracht de zuilen in beweging. Vanaf de jaren zestig werden de hekken in hoog tempo neergehaald, waarna de schapen zich in alle windrichtingen over het land verspreidden. Er hebben zich sindsdien sterke veranderingen voorgedaan in de religieuze beleving van de Nederlanders, waarvan de afbrokkeling van de kerkelijke deelname een van de meest zichtbare is. Niet alleen een reeks van bevolkingsenquêtes (waaronder de God in Nederland- 
onderzoeken vanaf 1966), ook institutionele tellingen brengen het verval in beeld. Volgens de registers van de kerken zelf liep het aantal aangeslotenen sinds 1970 terug van 9,7 naar 7,4 miljoen nu (dat wil zeggen van 75 procent naar 45 procent van de bevolking). Het aantal kerkgangers slonk eveneens drastisch en wel sterker dan het aantal mensen dat zich tot een kerkgenootschap (of andere religieuze gemeenschap) rekent. Dat nam volgens dezelfde enquêtes af van 75 procent naar 36 procent, ruim een halvering. De dalende kerkgang is dus zowel een gevolg van een afname van het aantal kerkelijken als van een afnemende activiteit van de kerkelijken wat betreft kerkgang (Becker en De Hart 20o6).

De teruggang in de kerkelijkheid en de kerkelijke deelname werpt de vraag op wat de betekenis van de ontkerkelijking is voor het imago van de kerken en hun bijdrage aan de vormgeving van het maatschappelijk middenveld. Een veronderstelling zou kunnen zijn dat in een ontkerkelijkt Nederland godsdienst bij gewone mensen niet langer verbonden is met specifieke opvattingen en gedragingen in het publieke domein. Vanuit de privatiseringsthese is wel gesteld dat de impact van godsdienstige achtergrond beperkt blijft tot de sfeer van gezin, opvoeding, persoonlijke ethiek en seksualiteit, en dat zij weinig invloed heeft op de keuzes van mensen in de publieke sfeer van maatschappelijke deelname, politiek of economie (Luckmann 1967; Tamney en Johnson 1985; Berger 1969; Davidson en Caddell 1994; Davis en Robinson 1996; Halman et al. 1996). Anderen nemen daarentegen vanaf de jaren tachtig juist een sterke tendens tot 'deprivatisering' waar en menen zelfs dat die zich voordoet in religieuze tradities over heel de wereld (Juergensmeyer 1993; Casanova 1994; Kurtz 1995; Wuthnow 1996). Zij zien religieuze organisaties en groepen de status-quo en bestaande machtsstructuren met hernieuwd elan ter discussie stellen, vragen opwerpen over publieke moraliteit en de handen ineenslaan met tal van initiatieven die worden ontwikkeld binnen lokale civil societies.

$\mathrm{Na}$ deze inleidende en probleemstellende overwegingen gaan we in de volgende paragrafen allereerst in op collectieve elementen: het vertrouwen dat wordt gesteld in de kerken, religie als organisatiegrondslag van het maatschappelijke leven en kerken en kerkleiders als actoren in de publieke ruimte (worden ze geaccepteerd als publieke stem?). Het vizier is daarbij gericht op het grote publiek. Daarna komen de relaties van elementen van religiositeit met individuele maatschappelijke en politieke participatie aan de orde. In hoeverre en waarom verschillen kerkelijken en niet-kerkelijken; in hoeverre is religie nog een leidraad voor maatschappelijke participatie en politiek handelen? Hier kijken we naar (veranderingen in) verschillen tussen religieus onderscheiden groepen.

\subsection{OPVATTINGEN OVER DE PLAATS VAN RELIGIE IN DE CIVIL SOCIETY}

We gaan in deze paragraaf op drie zaken in: de tolerantie voor gelovigen en voor de uitspraken en invloed van geestelijke leiders en de steun voor religie als grondslag voor maatschappelijke organisaties. We beginnen internationaal. Tabel 5.1 biedt 
een overzicht van hoe het publiek in vijftien Europese landen aankijkt tegen politieke invloed van religieuze leiders. Zoals verwacht kon worden, vertoont de houding ten aanzien van een beïnvloeding door deze leiders van het stemgedrag een positieve samenhang met hoe er wordt gedacht over de beïnvloeding van het overheidsbeleid. Nederland springt er samen met Zweden uit; in beide landen is de tolerantie naar verhouding groot voor politieke invloed van religieuze leiders. Dit in duidelijk contrast met landen als Frankrijk, Spanje, Portugal en Denemarken.

Tabel 5.1 Opvattingen over de wenselijke invloed van religieuze leiders in de hele bevolking en naar religieus lidmaatschap ${ }^{a}$ en religieuze deelname ${ }^{b}$ in procenten van de bevolking van 18 jaar en ouder

\begin{tabular}{|c|c|c|c|c|c|c|c|c|}
\hline & & & & & gemidd & accep & ie van & oed $^{c}$ \\
\hline & $\begin{array}{c}\text { geen } \\
\text { op stem }\end{array}$ & $\begin{array}{l}\text { n invloed } \\
\text { igedrag }^{\text {a }}\end{array}$ & $\begin{array}{l}\text { geen in } \\
\text { overheid }\end{array}$ & $\begin{array}{l}\text { vloed op } \\
\text { sbeleid }\end{array}$ & lidma & hap $^{d}$ & & $\mathrm{me}^{e}$ \\
\hline & eens & oneens & eens & oneens & niet & wel & niet & wel \\
\hline Finland & 68 & 17 & 58 & 21 & 13 & 20 & 17 & 32 \\
\hline Zweden & 68 & 22 & 52 & 28 & 22 & 25 & 24 & 36 \\
\hline Denemarken & 85 & 11 & 85 & 9 & 19 & 9 & 9 & 16 \\
\hline Duitsland & 75 & 10 & 71 & 13 & 6 & 14 & 8 & 21 \\
\hline Nederland & 66 & 22 & 60 & 26 & 20 & 30 & 22 & 31 \\
\hline Groot-Brittannië & 70 & 15 & 65 & 16 & 15 & 15 & 11 & 32 \\
\hline lerland & 79 & 14 & 73 & 16 & - & 15 & 11 & 17 \\
\hline België & 79 & 12 & 73 & 16 & 10 & 16 & 11 & 22 \\
\hline Luxemburg & 82 & 10 & 77 & 12 & 8 & 12 & 9 & 15 \\
\hline Frankrijk & 86 & 8 & 82 & 9 & 8 & 10 & 8 & 12 \\
\hline Spanje & 71 & 10 & 73 & 8 & 7 & 9 & 7 & 12 \\
\hline Portugal & 80 & 9 & 79 & 7 & 3 & 9 & 7 & 9 \\
\hline Oostenrijk & 85 & 7 & 79 & 11 & 5 & 10 & 7 & 12 \\
\hline Italië & 79 & 8 & 68 & 13 & 6 & 12 & 8 & 14 \\
\hline Griekenland & 78 & 7 & 59 & 15 & - & 11 & 9 & 14 \\
\hline
\end{tabular}

a 'Religieuze leiders zouden geen invloed mogen uitoefenen op het stemgedrag van mensen': '(zeer) eens' en '(zeer) oneens' (met 'eens noch oneens' optellend tot 100\%)

b 'Religieuze leiders zouden geen invloed mogen uitoefenen op overheidsbeslissingen' : '(zeer) eens' en '(zeer) oneens' (met 'eens noch oneens' optellend tot 100\%)

c Gemiddelde percentage '(zeer) oneens' voor beide uitspraken

d Beschouwt zich niet of wel als lid van een bepaald geloof of een kerkgenootschap

e Gaat niet of wel minstens eens per maand naar een religieuze dienst

Bron: European Values Study 1999-2000; gewogen resultaten. - $=\mathrm{n}<1$ oo respondenten

Elders zijn we op basis van gegevens van het International Social Survey Project 1998 uitvoeriger ingegaan op de houding tegenover een publieke rol voor godsdienstige leiders (De Hart en Dekker 2005). Zoals verwacht kon worden, bleek daar dat buitenkerkelijken het minst ophebben met pogingen van godsdienstige 
leiders om de politieke keuzes van mensen of overheidsbesluitvorming te beïnvloeden en dat ze ook het minst uit zijn op meer macht voor kerken en religieuze organisaties in ons land. Protestanten bleken op alle drie de punten het meest geporteerd van zich politiek sterk manifesterende kerken en kerkleiders, terwijl katholieken steeds een tussenpositie innemen. Internationaal weken de Nederlandse katholieken weinig af van hun geloofsgenoten in andere westerse landen, maar vielen de Nederlandse protestanten opnieuw op door hun sterke voorkeur voor politieke actieve kerken en kerkleiders.

Tabel 5.2 biedt met behulp van het longitudinale onderzoek Culturele veranderingen in Nederland inzicht in de mate waarin de bevolking vindt dat de aanhangers van drie geloofsrichtingen in ons land vrij moeten worden gelaten. De cijfers voor katholieken en protestanten zijn vrijwel identiek. De tolerantie voor moslims blijft daarbij in de hele periode achter. Vanaf de jaren negentig gaat deze het eerst en het sterkst dalen. In 2000 is ook de tolerantie voor katholieken en protestanten afgenomen en in 2002 wordt voor alle drie godsdienstige groepen een dieptepunt bereikt.

Tabel 5.2 Ontwikkelingen in religieuze tolerantie ${ }^{a}, 1980-2004$, in procenten van de bevolking van 16 jaar en ouder

\begin{tabular}{|llrrrrrrrr} 
& & 1980 & 1985 & 1991 & 1997 & 2000 & 2002 & 2004 \\
\multirow{3}{*}{ katholieken } & volledig vrijlaten & 87 & 87 & 84 & 84 & 76 & 62 & 77 \\
& tamelijk vrijlaten & 10 & 9 & 11 & 12 & 18 & 30 & 17 \\
protestanten & volledig vrijlaten & 87 & 87 & 85 & 84 & 76 & 63 & 77 \\
& tamelijk vrijlaten & 10 & 9 & 11 & 11 & 18 & 30 & 17 \\
& volledig vrijlaten & 75 & 79 & 71 & 64 & 53 & 31 & 50 \\
& tamelijk vrijlaten & 13 & 11 & 14 & 16 & 23 & 32 & 21 \\
\hline
\end{tabular}

a 'Er zijn diverse geloofsrichtingen in onze maatschappij. Voor elk van deze geloofsrichtingen zou ik graag van u willen weten in hoeverre u vindt dat zij vrijgelaten moeten worden in hun doen en laten.'

Bron: Culturele veranderingen in Nederland 1980-2004

In tabel 5.3 kijken we voor het jaar 2002 hoe het is gesteld met de tolerantie in verschillende levensbeschouwelijke groepen. Zoals bleek in tabel 5.2 was in dit jaar de tolerantie op een bijzonder laag peil. Voor de verschillen tussen bevolkingsgroepen maakt dat echter niet uit en dit jaar biedt wel het voordeel dat ook een vraag werd gesteld over de tolerantie tegenover geestelijke leiders, namelijk of men vindt dat imams vrijuit hun mening moeten kunnen geven over de Nederlandse samenleving met een beroep op hun geloof. Kerkleden of kerkgangers betonen zich ten opzichte van moslims niet toleranter dan buitenkerkelijken. Nog veel minder steun is er voor de stelling dat imams mogen zeggen van ons land wat ze willen en ook daarover bestaat tussen de christelijke denominaties weinig verschil van mening. 
Tabel 5.3 Religieuze tolerantie naar kerkelijke betrokkenheida , 2002, in procenten van de bevolking van 16 jaar en ouder

$\begin{array}{|lrrrr|} & \begin{array}{r}\text { katholieken } \\ \text { vrijlaten }^{\text {b }}\end{array} & \begin{array}{r}\text { protestanten } \\ \text { vrijlaten }^{\text {b }}\end{array} & \begin{array}{r}\text { islamieten } \\ \text { vrijlaten }^{\text {b }}\end{array} & \begin{array}{r}\text { imams mogen zeg- } \\ \text { zeggen wat ze willen }^{\text {c }}\end{array} \\ \text { allen } & 62 & 63 & 31 & 19 \\ \text { buitenkerkelijk } & 62 & 62 & 32 & 19 \\ \text { nominaal katholiek } & 60 & 60 & 28 & 16 \\ \text { kerks katholiek } & 60 & 61 & 36 & 18 \\ \text { nominaal PKN } & 66 & 65 & 29 & 13 \\ \text { kerks PKN } & 67 & 69 & 27 & 21 \\ \text { overig } & 69 & 71 & 34 & 30\end{array}$

a Kerkleden zijn kerks (gaan minstens eens per maand naar de kerk) of nominaal (gaan minder of niet); de 'overigen' bestaan uit regelmatige kerkgangers die geen lid zijn (1\%) en leden van andere groeperingen dan de Rooms-Katholieke kerk en de PKN (Protestantse Kerk in Nederland)

b 'Er zijn diverse geloofsrichtingen in onze maatschappij. Voor elk van deze geloofsrichtingen zou ik graag van u willen weten in hoeverre u vindt dat zij vrijgelaten moeten worden in hun doen en laten.' 'Volledig vrijlaten' i.p.v. 'tamelijk', 'een klein beetje' en 'helemaal niet'

c 'Hebben islamitische imams (geestelijk leiders) volgens u het recht om met een beroep op hun geloof van de Nederlandse samenleving te zeggen wat zij willen?' 'Ja' i.p.v. 'nee' en 'weet niet'

Bron: Culturele veranderingen in Nederland 2002

In tabel 5.4 staan de uitkomsten naar aanleiding van vragen naar een levensbeschouwelijk fundament en de relatie met godsdienst van maatschappelijke organisaties. ${ }^{3}$ Vanuit het oogpunt van vergelijkbaarheid valt het te betreuren dat de vraagstelling in 2002 is bijgesteld, waardoor de verschillen met eerdere jaren niet goed interpreteerbaar zijn. ${ }^{4}$ Voor de volledigheid zijn ze toch opgenomen in de tabel.

Tot halverwege de jaren negentig liep de steun voor het confessionele karakter van maatschappelijke organisaties (uitgezonderd het onderwijs) terug. In confessionele kring valt de afname vrijwel volledig op het conto van het katholieke volksdeel te schrijven waar de gemiddelde bijval voor een godsdienstige grondslag in vijfentwintig jaar daalde van 64 procent naar 44 procent. Regelmatige kerkgangers gaven in die periode geen krimp. Onder hen was en is de gehechtheid aan een levensbeschouwelijke dimensie wijdverbreid.

De vraag of men het geloof een goede wegwijzer voor de politiek vindt, gaat een stapje verder dan de steun voor een godsdienstige grondslag van politieke partijen. In tabel 5.5 is de relatie religie-politiek tegelijkertijd wat algemener en specifieker geformuleerd. Nu gaat het erom of geloof richtinggevend moet zijn voor politiek handelen. Tabel 5.5 laat als laatste van de tabellen zien dat de bevolking als geheel wat uitgesprokener is geworden in haar oordeel. Het percentage tegenstanders is gestegen, maar tegelijkertijd is het percentage dat de politieke 
Tabel 5.4 Steun voor het bestaan van confessionele politieke en maatschappelijke organisaties ${ }^{\mathrm{a}}$

\begin{tabular}{|c|c|c|c|c|c|}
\hline & 1971 & 1977 & 1986 & 1994 & $2002^{b}$ \\
\hline \multicolumn{6}{|l|}{ politieke partijen } \\
\hline - los van godsdienst & 38 & 53 & 57 & 61 & 42 \\
\hline - weet niet & 8 & 2 & 5 & 6 & 4 \\
\hline $\begin{array}{l}\text { - (ook) confessioneel } \\
\text { vakbonden }\end{array}$ & 55 & 45 & 38 & 33 & 54 \\
\hline - los van godsdienst & 42 & 57 & 65 & 67 & 58 \\
\hline - weet niet & 9 & 7 & 6 & 6 & 3 \\
\hline \multicolumn{5}{|l|}{ scholen } & 39 \\
\hline - los van godsdienst & 37 & 39 & 42 & 45 & 34 \\
\hline - weet niet & 6 & 5 & 4 & 4 & 2 \\
\hline \multicolumn{5}{|l|}{ omroepen } & 63 \\
\hline - los van godsdienst & . & 45 & 48 & 56 & 28 \\
\hline - weet niet & . & 6 & 6 & 6 & 2 \\
\hline - (ook) confessioneel & . & 49 & 46 & 37 & 70 \\
\hline gemiddelde instemming ${ }^{c}$ : allen & 47 & 46 & 40 & 37 & 52 \\
\hline • onkerkelijken & 39 & 26 & 19 & 16 & 43 \\
\hline - rooms-katholieken & 64 & 47 & 46 & 44 & 49 \\
\hline - protestanten & 67 & 68 & 67 & 68 & 74 \\
\hline frequente kerkgangers (wekelijks) & 72 & 73 & 69 & 79 & 81 \\
\hline
\end{tabular}

a In 1971-1994 is de vraag als volgt: 'Sommigen vinden dat politieke partijen geheel los moeten staan van godsdienst. Anderen vinden dat politieke partijen juist op godsdienst gebaseerd moeten zijn. Daarbij denkt men aan algemeen christelijke partijen of aan afzonderlijke rooms-katholieke en protestants-christelijke partijen. Dezelfde opvattingen zijn ook mogelijk voor de vakbonden, scholen en omroepen. Wat is uw opvatting voor wat betreft de politieke partijen?' Antwoordmogelijkheden: 1. geheel los van godsdienst; 2. algemeen christelijk; 3. afzonderlijk rooms-katholiek en protestants-christelijk; 4. niet van toepassing, andere godsdienst; 5 . weet niet. In 2002 wijkt de vraagstelling af: zie noot b!

b In 2002 luidt de vraag: 'Vindt u dat politieke partijen geheel los moeten staan van godsdienst, of bent u van mening dat er ook confessionele partijen moeten zijn, d.w.z. politieke partijen die gebaseerd zijn op godsdienst?' Antwoordmogelijkheden: 1. politieke partijen moeten geheel losstaan van godsdienst; 2. er moeten ook confessionele politieke partijen zijn; 3. weet niet. ... Vervolgens wordt de vraag herhaalt voor vakbonden, scholen en omroepen.

c Gemiddelde steun voor (ook) confessionele partijen, vakbonden en scholen.

Bron: Nationale Kiezersonderzoeken 1971-2002; gewogen resultaten

gidsfunctie van geloof onderschrijft de afgelopen drie decennia opmerkelijk constant gebleven. Onder protestanten en vooral kerkgangers is de bijval sinds de jaren zeventig toegenomen. 
Tabel 5.5 Opvattingen over 'Het geloof is voor de politiek een goede wegwijzer' in de kiesgerechtigde bevolking 1971-2003

\begin{tabular}{|c|c|c|c|c|c|c|}
\hline & 1971 & 1977 & 1986 & 1994 & 2002 & 2003 \\
\hline - helemaal mee eens & 11 & 12 & 11 & 7 & 7 & 7 \\
\hline - mee eens & 24 & 23 & 26 & 26 & 29 & 25 \\
\hline - weet niet & 13 & 13 & 6 & 4 & 4 & 2 \\
\hline - mee oneens & 37 & 33 & 33 & 43 & 39 & 42 \\
\hline - helemaal mee oneens & 15 & 20 & 24 & 20 & 20 & 24 \\
\hline (helemaal) mee eens in enkele groepen: & 35 & 34 & 37 & 33 & 36 & 32 \\
\hline - onkerkelijken & 15 & 11 & 8 & 6 & 16 & 14 \\
\hline - rooms-katholieken & 38 & 38 & 46 & 46 & 49 & 44 \\
\hline - protestanten & 53 & 58 & 67 & 67 & 70 & 66 \\
\hline frequente kerkgangers (wekelijks) & 58 & 73 & 77 & 84 & 82 & 91 \\
\hline
\end{tabular}

Bron: Nationale Kiezersonderzoeken 1971-2003; gewogen resultaten

\subsection{VERTROUWEN IN DE KERKEN}

We richten ons nu eerst op de houding van het publiek tegenover de kerken als actoren in de publieke en politieke sfeer. In de Eurobarometerenquêtes is de afgelopen jaren herhaaldelijk een vraag gesteld naar "(...) het vertrouwen dat $\mathrm{u}$ heeft in bepaalde instellingen. Zegt u mij voor elk van de volgende instellingen of $\mathrm{u}$ er eerder wel vertrouwen of eerder geen vertrouwen in heeft." Vervolgens worden vijftien instellingen genoemd: de geschreven pers; de radio; de televisie; justitie, het Nederlandse rechtssysteem; de politie; het leger; de kerk; de vakbonden; politieke partijen; grote ondernemingen; de Nederlandse regering; het Nederlands Parlement, de Tweede Kamer; de Europese Unie; de Verenigde Naties; liefdadigheidsinstellingen en vrijwilligersorganisaties. Deze Nederlandse lijst spoort goed met de Engelstalige moederlijst met uitzondering van nou net 'de kerk'. Op de moederlijst is sprake van 'religious institutions' en in alle voor ons controleerbare talen keert die term vrij letterlijk vertaald terug. 5 In tabel 5.6 is eerst het gemiddelde vertrouwen in de vijftien instituties weergegeven. In de kolommen daarna staan de afwijkingen daarvan voor wat betreft het vertrouwen in de religieuze instellingen en - ter vergelijking - in drie andere instellingen. Tot slot vindt men in de laatste kolom met welke drie instituties de religieuze instituties het sterkst correleren.

Het vertrouwen in de kerk blijft in ons land achter bij dat in andere maatschappelijke instituties en wel sterker dan in Europa gemiddeld het geval is. In dat opzicht bevinden wij ons in het gezelschap van onder anderen de Zweden, Ieren en Belgen. ${ }^{6}$ Vrijwel overal is op individueel niveau het vertrouwen in de religieuze instellingen positief gecorreleerd met het vertrouwen in andere institu- 
ties, maar in hoeverre verschilt de clustering? Onze verwachting was dat vooral in Noord- en Zuid-Europa de kerk zou worden gezien als een gezaghebbende instantie naast wereldse gezagsdragers (justitie, politie, regering), terwijl de kerken in een land als het onze meer worden beleefd als een deel van de civil society, naast vrijwilligersorganisaties, vakbonden en partijen. Die veronderstelling wordt niet bevestigd in tabel 5.6. In ons land blijkt (in de beleving van het grote publiek) het vertrouwen in de kerk vooral ingebed in het vertrouwen dat men stelt in regering, leger en parlement.

Tabel 5.6 Institutioneel vertrouwen: gemiddeld vertrouwen in 15 instituties en afwijkingen daarvan van kerken, radio, parlement en charitatieve/ vrijwilligersinstellingen ${ }^{a}$

\begin{tabular}{|c|c|c|c|c|c|c|}
\hline \multicolumn{2}{|c|}{ gemiddeld } & kerk & pers & $\begin{array}{l}\text { recht- } \\
\text { spraak }\end{array}$ & $\begin{array}{c}\text { parle- } \\
\text { ment }\end{array}$ & $\begin{array}{l}\text { vertrouwen in de kerk correleert } \\
\text { het sterkst met vertrouwen in: }\end{array}$ \\
\hline Finland & 64 & 7 & -7 & 12 & 1 & leger, politie, justitie \\
\hline Zweden & 49 & -21 & -17 & 2 & 2 & partijen, charitatief, leger \\
\hline Denemarken & 65 & 11 & -18 & 16 & 10 & leger, politie, regering \\
\hline Duitsland & 50 & 1 & 2 & 10 & -13 & leger, charitatief, partijen \\
\hline Nederland & 58 & -12 & 7 & 3 & -7 & regering, leger, parlement \\
\hline Verenigd Koninkrijk & 46 & -2 & -27 & 4 & -9 & partijen, vakbonden, parlement \\
\hline lerland & 52 & -16 & -15 & -2 & -9 & politie, charitatief, parlement \\
\hline België & 54 & -10 & 3 & -14 & -5 & politie, leger, charitatief \\
\hline Luxemburg & 59 & -17 & 1 & 2 & 11 & leger, partijen, politie \\
\hline Frankrijk & 44 & -7 & 10 & -3 & -14 & leger, regering, tv \\
\hline Spanje & 49 & -9 & 2 & 0 & -5 & leger, partijen, tv \\
\hline Portugal & 53 & 4 & 8 & -14 & -9 & leger, politie, vakbonden \\
\hline Oostenrijk & 57 & -4 & 1 & 17 & -5 & charitatief, partijen, politie \\
\hline Italië & 49 & 9 & -6 & 0 & -11 & charitatief, politie, leger \\
\hline Griekenland & 49 & 9 & -6 & 10 & 7 & politie, charitatief, leger \\
\hline landengemiddelde & 53 & -4 & -4 & 3 & -4 & \\
\hline
\end{tabular}

a Vermeld worden de percentages 'eerder wel vertrouwen' in plaats van 'eerder geen vertrouwen' en 'weet niet' van respondenten die hoogstens driemaal 'weet niet' antwoorden op het verzoek om van vijftien instituties aan te geven ze er 'eerder wel vertrouwen of eerder geen vertrouwen' in hebben.

Bron: Eurobarometer 64.2 (najaar 2005)

$\mathrm{Na}$ een algemene schets van het vertrouwen in de kerken en andere instituties in een aantal Europese landen, keren we terug naar ons land en naar eventuele verschillen die er tussen de kerkelijkheidtypen bestaan. De kerkelijke achtergrond van de ondervraagden brengt duidelijke tekening in het algemene beeld van tabel 5.6. Buitenkerkelijken hebben het minst op met kerken en religieuze organisaties, al spreekt bijna de helft toch nog wel enig vertrouwen in deze uit. Opvallend is verder het negatieve oordeel van niet minder dan 30 procent van de katholieken die niet regelmatig ter kerke gaan (vermoedelijk twee kanten van dezelfde medaille), die zich ondanks de diskwalificatie wel rekenen tot de kerk 
van Rome. Een andere markante uitkomst is het massale vertrouwen onder de kerkse leden van de Protestantse Kerk in Nederland, waarbij overigens onduidelijk is of het oordeel op kerken in het algemeen dan wel voornamelijk op de eigen geloofsgemeenschap betrekking heeft (bijvoorbeeld de Gereformeerde Bond binnen de $\mathrm{PKN}$ ).

Tabel 5.7 Vertrouwen in instituties ${ }^{\mathrm{a}}$ naar kerkelijke betrokkenheid, ${ }^{\mathrm{b}}$ 2004, in procenten van de bevolking van 16 jaar en ouder

\begin{tabular}{|c|c|c|c|c|c|c|c|}
\hline & \multirow[b]{2}{*}{$(\%)$} & \multicolumn{3}{|c|}{ kerken en religieuze organisaties } & \multicolumn{3}{|c|}{ veel of onbeperkt vertrouwen in } \\
\hline & & $\begin{array}{r}\text { geen of } \\
\text { zeer } \\
\text { weinig }\end{array}$ & $\begin{array}{l}\text { enig ver- } \\
\text { trouwen }\end{array}$ & $\begin{array}{r}\text { veel of on- } \\
\text { beperkt }\end{array}$ & kranten & $\begin{array}{r}\text { de } \\
\text { recht- } \\
\text { spraak }\end{array}$ & $\begin{array}{r}\text { de } \\
\text { Tweede } \\
\text { Kamer }\end{array}$ \\
\hline allen & $(100)$ & 37 & 43 & 19 & 19 & 34 & 14 \\
\hline buitenkerkelijk & $(60)$ & 54 & 38 & 8 & 21 & 34 & 14 \\
\hline nominaal katholiek & (10) & 30 & 57 & 13 & 17 & 22 & 14 \\
\hline kerks katholiek & (8) & 8 & 55 & 37 & 14 & 38 & 16 \\
\hline nominaal PKN & (5) & 15 & 56 & 29 & 22 & 34 & 16 \\
\hline kerks PKN & $(8)$ & 1 & 45 & 54 & 15 & 41 & 17 \\
\hline overig & (9) & 14 & 39 & 47 & 15 & 40 & 15 \\
\hline
\end{tabular}

a 'Hoeveel vertrouwen heeft u in ...' Antwoordmogelijkheden: 1 onbeperkt vertrouwen; 2 veel vertrouwen; 3 enig vertrouwen; 4 zeer weinig vertrouwen; 5 helemaal geen vertrouwen.

b Zie toelichting tabel 5.3 .

Bron: Culturele veranderingen in Nederland 2004 (incl. schriftelijke lijst); gewogen resultaten

Aan de gepresenteerde cijfers over het vertrouwen dat wordt gesteld in de kerken, kan worden toegevoegd dat deze voor veel Nederlanders nog steeds gelden als belangrijke bewakers van de publieke moraal. Gegevens die werden verzameld in het kader van de God in Nederland-onderzoeken (in 1996 en in 2006) wijzen uit dat ongeveer een kwart tot eenderde van de bevolking meent dat geloof en kerk een dam vormen tegen het oprukkende egoïsme en de verloedering van de samenleving. De steun voor de kerken als hoeders van de moraal en sociale cohesie treffen we vooral aan onder de oudere leeftijdsgroepen, gelovigen en actieve kerkleden, maar niet alleen daar. Ook van de jeugd van 17-24 jaar is bijvoorbeeld eenderde van mening dat de kerken een betrouwbare tot zeer betrouwbare bron van informatie zijn met betrekking tot belangrijke maatschappelijke vraagstukken en ook onder de niet-gelovige buitenkerkelijken is de meerderheid van oordeel dat de kerken zich moeten uitspreken over het probleem van de armoede in onze samenleving (Dekker et al. 1997; Dekker et al. 2007 - te verschijnen). 


\section{5 .5 KERKELIJKE ACHTERGRONDEN VAN INDIVIDUEEL ENGAGEMENT ${ }^{7}$}

In de voorgaande paragrafen is een impressie gegeven van de houding van de bevolking en bevolkingsgroepen tegenover wisselende aspecten van het functioneren van religie binnen de publieke ruimte. In deze paragraaf wordt vervolgens gekeken naar een andere wijze waarop religie zich op het maatschappelijk schouwtoneel kan manifesteren. Dat is in haar rol als leidraad en stimulator bij de deelname van individuen binnen de civil society. Actieve varianten van die deelname zijn het doen van vrijwilligerswerk, het ontplooien van politieke activiteiten en het participeren in collectieve acties. Maar ook het effect van het doneren

Tabel 5.8 Vrijwilligerswerk en politieke activiteiten naar religieus lidmaatschap ${ }^{a}$ en religieuze deelname ${ }^{b}$ in procenten van de bevolking van 15 jaar en ouder

vrijwilligerswerk $^{\mathrm{c}}$

\begin{tabular}{|c|c|}
\hline lidmaatschap & deelname \\
\hline niet & niet \\
\hline
\end{tabular}

Finland

Zweden

Noorwegen

Denemarken

Duitsland

Nederland

Verenigd Koninkrijk

lerland

België

Luxemburg

Frankrijk

Spanje

Portugal

Oostenrijk

Zwitserland

Italië

Griekenland

$13-12 \quad 11$

$\begin{array}{llll}13 & 12 & 11 & 24 \\ 32 & 41 & 32 & 56\end{array}$

$31 \quad 42 \quad 34 \quad 60$

$\begin{array}{llll}27 & 28 & 26 & 42\end{array}$

$18 \quad 31$

23

25

19

12

22

14

17

7

5

11

11

9

7

9

4

$$
\text { - }
$$$$
\begin{aligned}
& 5 \\
& 6
\end{aligned}
$$

6

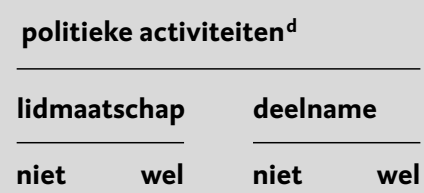

24

69

73

71

76

73

68

64

52

62

56

62

66

$$
62
$$

44

76

a Beschouwt zich niet of wel als lid van een bepaald geloof of een kerkgenootschap.

b Gaat niet of wel minstens eens per maand naar een religieuze dienst.

c Heeft in het afgelopen jaar vrijwilligerswerk gedaan voor een organisatie met vrijwillig lidmaatschap.

d Heeft in het afgelopen jaar deelgenomen aan één of meer politieke activiteiten (handtekeningenacties, contact opnemen met een politicus, een product boycotten e.a.).

Bron: European Social Survey 2002/o3; gewogen resultaten. - = niet beschikbaar / $\mathrm{n}<100$ respondenten 
van geld aan goede doelen en organisaties op het maatschappelijke middenveld moet niet onderschat worden.

Tabel 5.8 biedt eerst een beeld van de relatie tussen kerkelijke achtergrond en participatie in het vrijwilligerswerk en politieke activiteiten voor zeventien Europese landen. Vergeleken met landen als België of Ierland zijn in ons land kerkelijkheid en vooral kerkelijke deelname verbonden met duidelijke verschillen in het doen van vrijwilligerswerk. Daarin stemt Nederland overeen met bijvoorbeeld de Scandinavische landen, Duitsland, het Verenigd Koninkrijk of Frankrijk. Met betrekking tot de politieke participatie blijken kerkelijk lidmaatschap en kerkgang met veel minder verschillen gepaard te gaan. Dat is eveneens een internationaal verschijnsel.

De grotere betrokkenheid van kerkelijk actieven bij het vrijwilligerswerk dateert niet van vandaag of gisteren. Dat blijkt uit figuur 5.1, die voor ons land gedurende een langere periode de deelname aan vrijwilligerswerk toont voor de vaste drie groepen met een verschillende positie tegenover de kerk: buitenkerkelijken, nominale leden en kerkse leden. Vermeld zijn de percentages mensen die minstens één uur vrijwilligerswerk deden volgens een dagboekje in de najaarsweek waarin het onderzoek altijd gehouden wordt. Het verschil tussen de nominale kerkleden en buitenkerkelijken is steeds niet zo groot, hetgeen suggereert dat het de deelname aan het kerkelijke leven is die stimuleert tot maatschappelijk activisme en niet zozeer het zich rekenen tot een kerk of opgegroeid zijn binnen een kerkgenootschap. ${ }^{8}$

Figuur 5.1 Deelname van kerkgangers, nominale kerkleden en buitenkerkelijken aan vrijwilligerswerk (minstens een uur per week volgens een dagboekje), 1975-2005, bevolking van 18 jaar en ouder

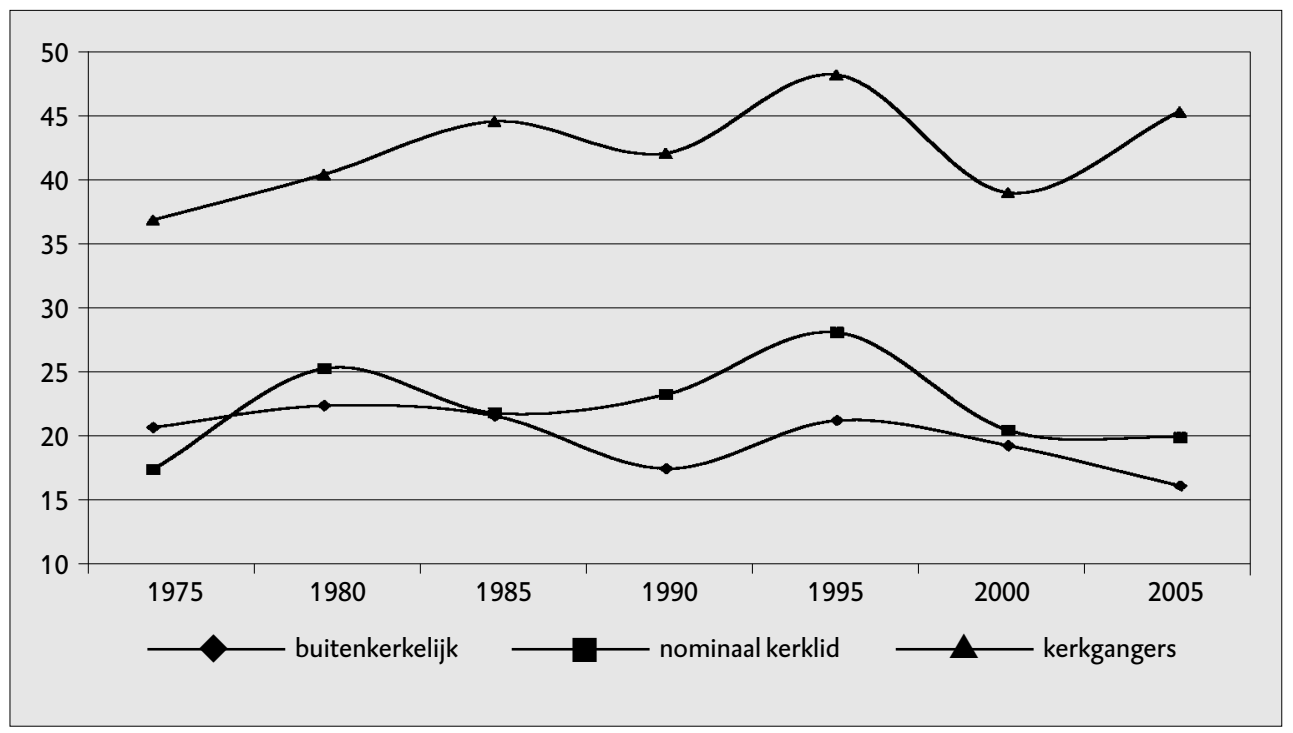

Bron: Tijdsbestedingsonderzoek SCP 
Vrijwilligerswerk is een van de meest intensieve vormen van participatie, maar er zijn meer soorten van maatschappelijke inzet, zoals het doneren van geld, het lidmaatschap van organisaties of de deelname aan collectieve acties. Tabel 5.9 biedt een overzicht van de minst georganiseerde en veelal anonieme vorm van participatie, het geven van geld aan goede doelen. De cijfers hebben betrekking op 2005 en zijn ontleend aan het onderzoek Geven in Nederland, waarover begin 2007 wordt gepubliceerd. In huishoudens van kerkgangers wordt iets massaler en gemiddeld aanzienlijk guller gegeven dan in huishoudens van mensen die zelden of nooit op zondagmorgen een kerk van binnen zien. ${ }^{9}$ En die vrijgevigheid blijft niet beperkt tot kerkelijke doelen; regelmatige kerkgangers schenken ook beduidend meer aan niet-kerkelijke doelen.

Tabel 5.9 Geld geven aan goede doelen naar kerkelijke deelname, 2005 (percentages en euro's)

\begin{tabular}{|c|c|c|c|c|}
\hline & \multirow[b]{2}{*}{$\begin{array}{r}\text { donateurs } \\
\text { (in \%) }\end{array}$} & \multicolumn{3}{|c|}{ donaties (in $€$ ) gemiddeld over allen } \\
\hline & & totaal & $\begin{array}{r}\text { kerkelijke } \\
\text { doelen }\end{array}$ & $\begin{array}{r}\text { niet-kerkelijk } \\
\text { doelen }\end{array}$ \\
\hline $\begin{array}{l}\text { allen } \\
\text { frequentie kerkgang: }\end{array}$ & 84 & 243 & 105 & 139 \\
\hline - (vrijwel) nooit & 82 & 188 & 65 & 122 \\
\hline - één of enkele malen per jaar & 88 & 162 & 54 & 108 \\
\hline - ongeveer een keer per maand & 88 & 395 & 148 & 246 \\
\hline - ongeveer een keer per week of vaker & 89 & 823 & 534 & 290 \\
\hline
\end{tabular}

a De gegevens betreffen het geefgedrag van het huishouden van de respondent, niet noodzakelijk de respondent zelf. Niet-kerkelijke doelen zijn o.a. gezondheid, internationale hulp, natuur en milieu, onderwijs en onderzoek, cultuur, sport en recreatie.

Bron: Geven in Nederland 'o7 (vu); voorlopige cijfers; gewogen resultaten

In tabel 5.10 worden op basis van het onderzoek Culturele veranderingen in Nederland 2004 de verschillen in een aantal soorten van sociale en politieke participatie op een rijtje gezet. Evenals in tabel 5.3 kunnen we binnen de katholieke en protestantse gemeenschap onderscheid maken tussen kerkse en nietkerkse leden. Ook deze gegevens laten zien dat regelmatige kerkgangers sterk oververtegenwoordigd zijn onder de vrijwilligers, hetgeen vooral voor de protestantse kerkgangers blijkt te gelden. ${ }^{10}$

De oververtegenwoordiging treedt ook nog op als vrijwilligerswerk voor 'godsdienstige en levensbeschouwelijke organisaties' wordt uitgesloten. Daarvoor verricht 11 procent van de ondervraagden (wel eens) vrijwilligerswerk. Wordt dat werk buiten beschouwing gelaten, dan vermindert het percentage vrijwilligers onder de buitenkerkelijken niet, maar daalt dat sterk onder de kerkse protestanten (van 78 procent naar 61 procent) en vooral de overigen (van 48 procent naar 
Tabel 5.10 Sociale en politieke activiteiten naar kerkelijke betrokkenheid, ${ }^{a}$ 2004, in procenten van de bevolking van 16 jaar en ouder

\begin{tabular}{|c|c|c|c|c|c|c|}
\hline & & $\begin{array}{r}\text { regelmatig } \\
\text { vrijwilligers } \\
\text { werk }^{\mathbf{b}}\end{array}$ & $\begin{array}{l}\text { enig vrijwil- } \\
\text { ligerswerk }^{c}\end{array}$ & $\begin{array}{l}\text { eculier } \\
\text { ligers- } \\
\text { werk }^{d}\end{array}$ & $\begin{array}{r}\text { collectieve } \\
\text { actie }^{\mathrm{e}}\end{array}$ & $\begin{array}{r}\text { bereid tot } \\
\text { protest }^{f}\end{array}$ \\
\hline allen & $(100)$ & 24 & 45 & 42 & 25 & 52 \\
\hline - buitenkerkelijk & $(60)$ & 20 & 39 & 39 & 24 & 54 \\
\hline - nominaal katholiek & (10) & 22 & 43 & 43 & 19 & 43 \\
\hline - kerks katholiek & (8) & 37 & 57 & 54 & 20 & 43 \\
\hline - nominaal PKN & (5) & 20 & 47 & 44 & 25 & 49 \\
\hline - kerks PKN & (8) & 46 & 78 & 61 & 42 & 57 \\
\hline - overig & (9) & 22 & 48 & 32 & 27 & 47 \\
\hline
\end{tabular}

a Zie toelichting tabel 5.3 .

b Verricht gemiddeld minstens een uur per week 'onbetaald werk' ten behoeve van of georganiseerd door een instelling of vereniging.

c Doet 'onbetaald vrijwilligerswerk' voor een of meer van elf soorten verenigingen en organisaties.

d Idem, maar zonder vrijwilligerswerk voor godsdienstige of levensbeschouwelijke organisaties.

e Heeft zich in de afgelopen twee jaar wel eens samen met anderen ingespannen voor een lokale, nationale of internationale kwestie.

f Zou zeer of enigszins waarschijnlijk iets proberen te doen als men zou menen dat de Tweede Kamer bezig was een onrechtvaardige wet aan te nemen.

Bron: Culturele veranderingen in Nederland 2004; gewogen resultaten

32 procent). Ook na deze 'correctie' blijft het aandeel vrijwilligers onder de kerkse protestanten het hoogst. ${ }^{11} \mathrm{Bij}$ de deelname aan collectieve acties springen de protestantse kerkgangers er pas echt uit; ook bij de protestbereidheid scoren ze het hoogste, maar worden ze direct gevolgd door de buitenkerkelijken.

De tot nu toe getoonde verschillen suggereren dat kerkgang belangrijker is dan de denominatie. In elders gerapporteerde analyses hebben we laten zien dat dit inderdaad het geval is en dat het positieve effect van kerkgang ook niet te herleiden is tot op sociaal-demografische kenmerken van de kerkgangers. ${ }^{12}$

Om het belang van kerkelijke achtergronden in samenhang met andere kenmerken te achterhalen, hebben we tot slot van ons onderzoek van enquêtegegevens kerkgang (al of niet minstens eens per maand) en kerklidmaatschap (geen, katholiek, protestant en anders) samen met vijf dichotome sociaal-demografische variabelen (sekse, 16-45/46+, twee opleidingsniveaus van ongeveer gelijke omvang, twee ongeveer gelijke klassen van stedelijkheid van de woonomgeving, en het al of niet verrichten van betaald werk) in een zogeheten CHAID-analyse gestopt. In zo'n analyse vindt een voortschrijdende opdeling plaats in contrastgroepen op een bepaald kenmerk, in dit geval het al of niet verrichten van regelmatig vrijwil- 
ligerswerk (zie tabel 5.10). In principe wordt automatisch op basis van een statistisch criterium steeds het belangrijkste onderscheidende kenmerk geselecteerd. Zouden we dat hebben gedaan, dan zou kerkgang als eerste onderscheidende kenmerk zijn geselecteerd. We hebben er echter voor gekozen de kerkelijke achtergronden pas te gebruiken als op de vijf sociaal-demografische kenmerken geen significant onderscheid meer kon worden gemaakt. Het resultaat wordt getoond in figuur 5.2. In alle sociaal-demografische subgroepen blijkt de kerkelijke achtergrond van belang. Daarbij is kerkgang voortdurend belangrijker dan kerklidmaatschap en maakt kerklidmaatschap geen verschil meer nadat groepen zijn onderscheiden op kerkgang. De verschillen in figuur 5.2 zijn aanzienlijk. In de sociaal-demografische segmenten doen de kerkgangers gemiddeld dubbel zo vaak vrijwilligerswerk als de niet-kerkgangers. De verschillen lopen uiteen van 13 procent regelmatige vrijwilligers onder de lager opgeleide niet-kerkgaande stedelijke jongeren tot 6 o procent onder de hoger opgeleide oudere kerkgangers zonder betaald werk.

Leesvoorbeeld van links naar rechts: In de hele bevolking van 16 en ouder doet 28 procent vrijwilligerswerk en het sterkste sociaal-demografische verschil is dat naar leeftijd: onder de ouderen doet 32 procent vrijwilligerswerk en onder de jongeren 24 procent. Zowel bij de ouderen als de jongeren is het meest onderscheidende kenmerk het opleidingsniveau: van de hoger opgeleide ouderen doet 41 procent vrijwilligerswerk, van de lager opgeleide ouderen 27 procent, etc.

\subsection{ALTERNATIEVEN VOOR DE TRADITIONELE CHRISTELIJKE KERKEN}

Tot besluit bezinnen we ons op de consequenties van enkele belangrijke ontwikkelingen in de afgelopen decennia op levensbeschouwelijk terrein voor de gesignaleerde relaties tussen religie en participatie. In de eerste plaats is er natuurlijk de ontkerkelijking. Vanuit de in het voorgaande gepresenteerde gegevens lijkt het aannemelijk dat door de ontbinding van kerkelijke gemeenschappen en het wegvallen van kerkelijke netwerken een belangrijke bron van sociaal engagement en maatschappelijke deelname op zal drogen. Naast de krimpers zijn er onder de kerken ook groeiers. Die hebben een aantal gemeenschappelijke kenmerken, zoals een duidelijke identiteit, een sterke oriëntatie op plaatselijke gemeenschappen of subculturen, veel ruimte voor spontane emoties en direct contact met het heilige. Het is echter de vraag of succesvolle stromingen als de evangelische beweging, de Pinksterbeweging of de Evangelische Broedergemeenten de leegloop en vergrijzing bij de Rooms-Katholieke en Protestantse Kerk in Nederland kunnen compenseren. Hun rekruteringskracht ontlenen zij voornamelijk aan hergroeperingen in (orthodox) protestantse kring (niet aan een toestroom van buiten de kerken) en ze zijn geassocieerd met vooral veel samenbindend sociaal kapitaal, activisme ten behoeve van de eigen religieuze gemeenschap en 'kiezen voor de eigen vertrouwde kudde’ (Becker et al. 1997; vgl. o.a. Stoffels 1990, 1995; Vellenga 1991). 
Figuur 5.2 Het belang van kerkgang voor vrijwilligerswerk: verschillen binnen sociaal-demografische segmenten (resultaat van een CHAID-analyse (zie tekst) op de gecombineerde gegevens van Culturele verandering in Nederland 2002 en 2004 (4.300 respondenten)

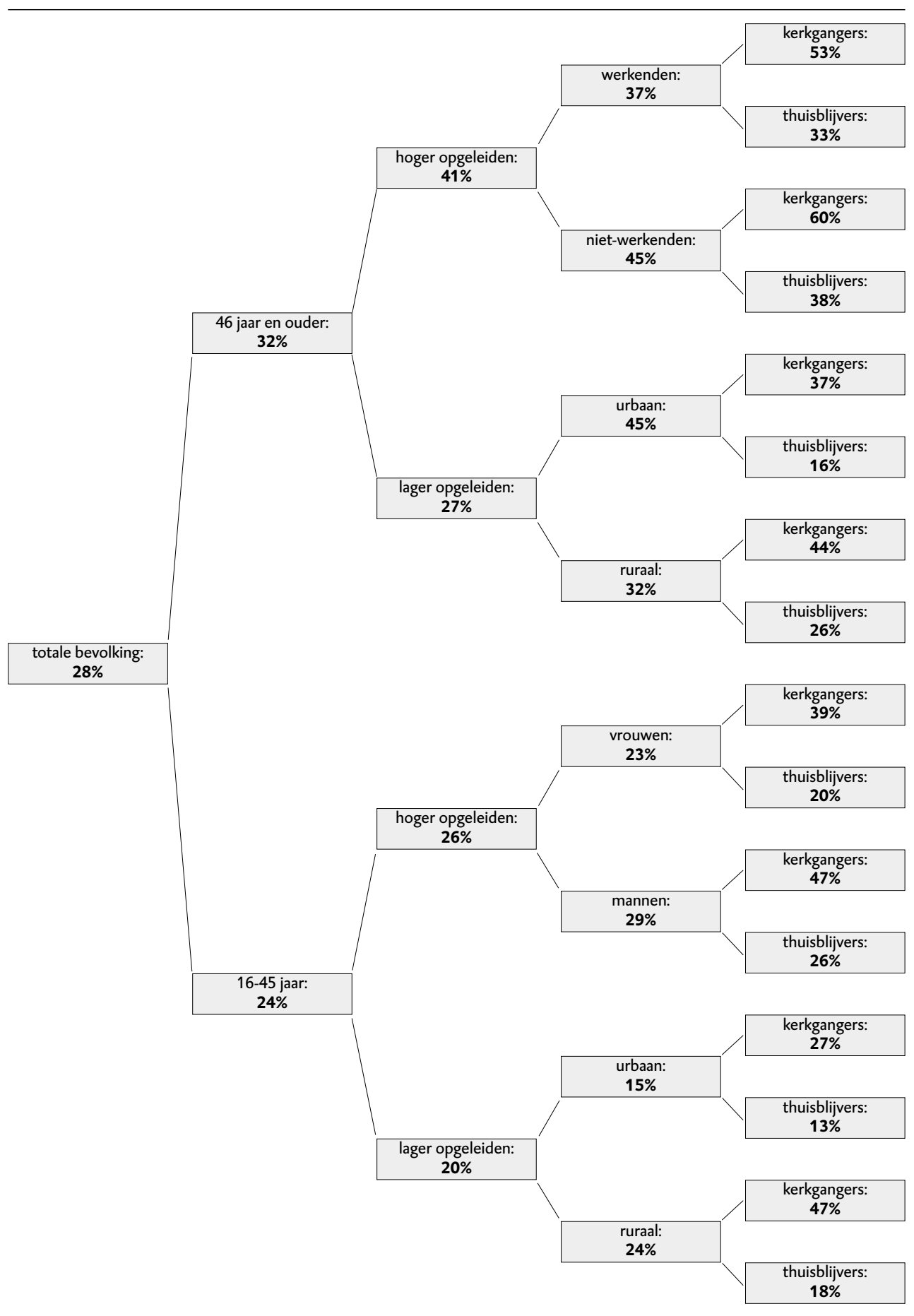


Een andere interessante ontwikkeling heeft betrekking op de zogenaamde migrantenkerken. Ons land telt momenteel naar schatting tussen de 60o.ooo en 800.000 migrantenchristenen. ${ }^{13} \mathrm{Zij}$ wonen overwegend in de Randstad en het merendeel is katholiek. Soms blijven zij deel uitmaken van de religieuze gemeenschap in het land van herkomst, soms sluiten zij zich aan bij de in ons land gevestigde kerken. Een deel sticht eigen onafhankelijke christelijke gemeenschappen en is aangesloten bij migrantenkerken. ${ }^{14}$ Die hebben vaak een informeel of laagkerkelijk karakter (huisgemeenten, bijbelkringen, gebedskringen) en de grootte varieert van enkele tientallen tot enkele honderden leden. ${ }^{15}$ Waar wel sprake is van institutionalisering gaat het overwegend om lokale gemeentevorming, gericht op een specifieke bevolkingsgroep (bijv. Ghanezen in de Amsterdamse Bijlmermeer). De participatiegraad is vaak hoog ${ }^{16}$ en de verscheidenheid (in leer, praktisering, leefstijl en cultuur) groot, evenals de dynamiek - voortdurend komen er nieuwe gemeentes bij. De sterkste groei lijkt te bestaan bij de gemeenschappen rond een charismatische voorganger, meestal van het pentecostale type.

Tot op heden is nog maar een beperkt aantal onderzoeken beschikbaar, maar die suggereren dat migrantengemeenten en migrantenkerken een aanzienlijke rol spelen bij de opvang en integratie van nieuwkomers in de Nederlandse samenleving. $\mathrm{Zij}$ bieden een ontmoetingsplaats met geestverwanten in een land dat vaak nog onvertrouwd is en zij verlenen geestelijke hulp of begeleiding bij ingrijpende gebeurtenissen (geboorte, huwelijk, rouwverwerking, ontslag, relatieproblemen). Daarnaast geven zij praktische bijstand door de migranten op allerlei terreinen wegwijs te maken in de nieuwe maatschappij (bij het aanvragen en gebruik van voorzieningen, bij medische zorg en onderwijs, bij sollicitaties en ontslag). Bijna allemaal zijn ze erop gespitst via netwerken van steun en hulp de participatie van hun leden in de Nederlandse samenleving te bevorderen. ${ }^{17} \mathrm{Zij}$ dragen bij aan een goede sociale infrastructuur voor migranten en fungeren als communicatiekanalen - als spreekbuis voor migranten, maar ook als intermediair en aanspreekpunt van de overheid waar zij migranten wil bereiken. Bij het slechten van taal- en cultuurbarrières blijken de voorgangers van de kerken niet zelden een cruciale schakel te vormen (Euser et al. 2006; Van der Sar 2004; Van der Sar en Schoemaker 2003; Van der Sar en Visser 2006; vgl. Ferrier 2002).

Tussen hemel en aarde bevindt zich, dat is bekend, meer dan men misschien in zijn wijsheid zou vermoeden. Naast de massale kerkverlating bij de grote kerken en allerlei vormen van nieuwe religieuze groepsvorming zijn er ontwikkelingen die veelal zijn geduid als secularisatie, maar beter kunnen worden samengevat onder de noemer van levensbeschouwelijke individualisering. Al enige tijd ontwikkelt de religiositeit van de Nederlanders zich van vaststaande antwoorden naar open vragen. Anders geformuleerd: van pauselijke encyclieken of de Heidelbergse Catechismus naar zoekgedrag en een ontvankelijkheid voor het waardevolle in allerlei uiteenlopende godsdienstige tradities. Voor veel hedendaagse mensen lijkt geloof - met de woorden van Octavio Paz - 'iets dat meer is dan een mening en minder dan een zekerheid' (Paz 1990: 117) en de 'zwevende kiezer' 
manifesteert zich inmiddels ook op religieus gebied. Daarbij is de toetssteen in sterke mate de ervaringsdimensie, het zelf geraakt worden. Minder belangrijk werden: sociale druk, de sleur van gewoontes, het opvolgen van voorschriften, de finesses van de officiële leer. De nadruk op beleven en ervaren (en de psychologische kant van religie) kan overal aangetroffen worden. Bij de sterke groei van de 'hallelujakerken' (zoals de al genoemde Pinkstergemeenten), maar ook bij de verkoopcijfers van populaire zelfhulp- en therapieboeken, het cursusaanbod in bezinningscentra, het aanbod van televisieprogramma's en de rubrieken van kranten en weekbladen.

In religieuze aangelegenheden kleuren hedendaagse Nederlanders graag buiten de lijntjes. Niet zelden gebeurt dit in het kader van een soort religieus pretpakket, een knuffelreligie waarbij alleen de optimistische kanten van de geloofsleer omarmd worden. Vaak echter is er eerder sprake van zoekreligiositeit (de befaamde 'quest religion' van de Amerikaanse sociaal-psycholoog C. Daniel Batson; o.a. Batson 1976). De zoektocht krijgt veelal de vorm van een levensbeschouwelijk knutselen. Vanuit wat speelt in de eigen biografie en geleid door de persoonlijke beleving, selectief en min of meer provisorisch combineert men elementen uit soms de meest uiteenlopende tradities en (sub)culturen tot een aansprekend ensemble. De brede baaierd aan denkbeelden, interesses, instituties en praktijken die tot voor kort werd aangeduid als new age drijft bij uitstek op religieuze 'zoekers', levensbeschouwelijke 'knutselaars' en 'soloreligieuzen'. ${ }^{18}$ Net als veel moderne elektronica is new age onder andere zo populair vanwege dat wat hij niet heeft: een vast stopcontact en een snoer dat de beweging aan banden legt. Moderne spiritualiteit moet bij voorkeur portable zijn. De affiniteit blijkt het grootst bij mensen die zich als religieus beschouwen en geloven in een buitenzintuiglijke werkelijkheid of hogere macht, maar tevens gekenmerkt worden door distantie ten aanzien van de kerken (Becker et al. 1997; Becker en De Hart 2006). Hier is relevant dat het gaat om vormen van spiritualiteit die verbonden lijken met weinig sociaal kapitaal en een nogal sterk accent op 'believing without belonging' (Davie 1990, 1994). De sociale basis is vrij diffuus en de omloopsnelheid groot - er wordt druk geswitcht van onderdeel naar onderdeel.

Aan het eind van zijn historische exposé over de rationele onttovering van de wereld hield Max Weber nadrukkelijk de mogelijkheid open van hetzij een opkomst van 'nieuwe profetieën of een machtige wedergeboorte van oude gedachten en idealen', hetzij 'een soort van krampachtig zichzelf serieus nemen' (Weber 1963: 204). Volgens veel critici is het op het laatste uitgedraaid. Dikwijls is betoogd dat de nieuwe spirituele interesse narcistische trekken vertoont en gepaard gaat met weinig sociaal engagement. Dat is waarschijnlijk wat overhaast geconcludeerd en doorgaans alleen gebaseerd op een analyse van het officiële ideeëngoed of de visie van de professionals (auteurs, therapeuten, cursusleiders) uit het milieu. Gelet op de individuele leden of belangstellenden ontstaat een ander beeld. Nederlanders die bijvoorbeeld tot de intensieve consumenten van new-ageproducten behoren, lijken in uiteenlopende opzichten niet minder sociaal bewogen of scrupuleus, betrokken bij vrijwilligerswerk en politiek actief dan 
de gemiddelde Nederlander of het gemiddelde kerklid (Becker et al. 1997). ${ }^{19}$ Zeker waar het gaat om bezorgdheid om het milieu, milieuactivisme en donaties aan milieuvriendelijke organisaties behoren zij juist tot de meest geëngageerden. Op individueel niveau moet levensbeschouwelijk individualisme dus niet verward worden met egoïsme. Toch lijken de sociale incoherentie, de ideologische vrijblijvendheid en het eclecticisme van dergelijke religieuze manifestaties van de Erlebnisgesellschaft geen gunstige voorwaarden te scheppen voor de opbouw van sociaal kapitaal. Zoals gebleken komen belangrijke participatievormen immers vooral tot stand via sociale netwerken, die verbonden zijn met sociale normen en sociale controle, en waarin de drempel laag is om een appèl op elkaar te doen.

Ten slotte is vooral de afgelopen jaren de aandacht gegroeid voor wat misschien het best omschreven kan worden als een hang naar nieuwe bindingen en collectieve ritualisering (o.a. Post et al. 2002; Margry 2003, 2006; De Hart 2005a). Vaak is die tamelijk vluchtig (zoals bij de oranjeroes ten tijde van voetbaltoernooien, de elfstedentocht of de rouw bij de dood van een geliefde volkszanger), maar niet altijd. Rondom catastrofes bijvoorbeeld (zoals de vuurwerkramp te Enschede, de tsunami van Kerstmis 2004 of gevallen van zinloos geweld) manifesteert zich periodiek een nationale saamhorigheid, interculturele verbroedering en ook daadwerkelijke informele hulpverlening. Die ebt na verloop van tijd weer weg, maar duidt wel op een vitale behoefte aan een publiekelijk delen en markeren van de identiteit en daarnaast een soort stand-by-solidariteit die bij sterke tegenwind gemobiliseerd kan worden.

\subsection{CONCLUSIES}

'Attentiereductie op het kruisend verkeer': politietaal voor wat wordt aangeduid als polderblindheid. Het gaat om verminderd concentratievermogen ten gevolge van een eentonige en voorspelbare weg en van een gebrek aan onverwachte omgevingsprikkels. De inschatting van afstanden wordt erdoor bemoeilijkt en bewegende objecten lijken stil te staan. In overdrachtelijke zin leden de grote kerken tot in de jaren zestig van de vorige eeuw aan een dergelijke aandachtsverslapping, die ervoor zorgde dat ze in de decennia erna hard geraakt werden door vanuit onverwachte hoeken kruisend verkeer. Veel theoretici van de moderne samenleving (sociologen, filosofen, theologen) lijken een tijdlang ten prooi te zijn gevallen aan dezelfde optische illusie. Nadat het hemels baldakijn scheuren was gaan vertonen en de zuilen aan het wankelen raakten, is er - vooral in de jaren zestig en zeventig - flink gespeculeerd over de emigratie van de religie uit de moderne samenleving. Vandaag de dag is er veel minder steun voor de 'harde varianten' van de secularisatiethese (zoals verwoord door auteurs als Steve Bruce en Bryan Wilson). Ook in ons land lijkt een keur van publicisten en opinieleiders er oog voor te hebben gekregen dat de polders niet verlaten zijn maar vol beweging. Het aantal moslims nam vanaf de jaren zeventig sterk toe, christelijke immigranten verzamelden zich massaal in een groot aantal eigen kerken, binnen de protestantse en in mindere mate katholieke wereld vonden hergroeperingen plaats die resulteerden in de evangelische beweging en charismatische gemeen- 
schappen, onder het niet-kerkse deel van de bevolking bleek slechts een minderheid zichzelf als overtuigd niet-religieus te beschouwen en waren velen actief betrokken bij uiteenlopende spirituele onderwerpen en initiatieven.

Wat betekent dit voor de publieke plaats en functies van de kerken en voor hun rol vanuit het perspectief van de civil society? Dat is de vraag die hier centraal stond en waarop we niet pretenderen een definitief antwoord te hebben gegeven. De ambitie was meer bescheiden, namelijk het aandragen van onderzoeksuitkomsten die enig licht werpen op enkele aspecten. In de eerste plaats ging het om de plaats van religie in de civil society. Onder buitenkerkelijken en katholieken nam de steun voor een levensbeschouwelijke organisatiegrondslag onmiskenbaar af tussen 1971 en 1994, niet onder protestanten en het kerkse deel van de bevolking. Van pogingen door religieuze leiders tot beïnvloeding van het stemgedrag en overheidsbesluitvorming is een ruime meerderheid van de Nederlanders binnen en buiten de kerken niet gediend. De tolerantie tegenover religieuze attitudes is in ruime mate aanwezig waar het gaat om christelijke groeperingen, maar veel minder ten aanzien van moslims en nog minder als het gaat om de religieus geïnspireerde opinies van imams over de Nederlandse samenleving.

In de tweede plaats werd aandacht geschonken aan het vertrouwen dat men stelt in de kerken als maatschappelijke instituties. Dat vertrouwen ligt in ons land onder het Europese gemiddelde en is beduidend minder groot dan bijvoorbeeld in een land als Denemarken. Het blijkt overal ingebed in een breder vertrouwen ten aanzien van maatschappelijke instituties en hier te lande vooral aanwezig onder kerkgangers. Ongeveer eenderde van de Nederlanders steunt een gidsfunctie voor religie bij het politieke handelen, een percentage dat weinig is veranderd in de afgelopen decennia en dat ongeveer overeenkomt met het deel van de bevolking dat in de kerken een hoeder van de publieke moraal ziet. Protestanten en vooral regelmatige kerkgangers zijn sinds het begin van de jaren zeventig het geloof meer als richtinggevend voor de politiek gaan beschouwen.

Vervolgens hebben we de blik verlegd naar kerkelijke betrokkenheid als inspirator van individueel engagement. Kerkelijke deelname blijkt in ons land (net als in veel andere landen) duidelijk verbonden met allerlei soorten van maatschappelijke participatie. Regelmatige kerkgangers zijn in beduidend grotere getale actief als vrijwilliger (ook in niet-kerkelijk gericht vrijwilligerswerk) en schenken ruimhartiger aan goede doelen (ook aan niet-kerkelijke goede doelen). Minder uitgesproken zijn de verschillen bij politieke activiteiten en de deelname aan collectieve acties.

Ten slotte is ingegaan op alternatieven voor de traditionele inheemse kerken, in de vorm van migrantenkerken en de welhaast hellenistisch brede baaierd aan meer individueel gekleurde vormen van spiritualiteit en levensbeschouwelijke belangstelling. Vergelijkbare gegevens als voor de gevestigde christelijke kerken zijn op dit moment nog nauwelijks beschikbaar. In zoverre migranten niet zijn aangesloten bij de katholieke kerk hebben hun geloofsgemeenschappen veelal een 
lage organisatiegraad en worden zij gekenmerkt door een grote dynamiek en verscheidenheid. Recente onderzoeken leren dat zij in allerlei opzichten een belangrijke rol spelen bij de integratie in de Nederlandse samenleving.

Over de betekenis van de rijkgeschakeerde wereld van new age, nieuwe spiritualiteit en paraculturele levensbeschouwelijke interesses lopen de meningen uiteen. Sommige commentatoren interpreteren die als een teken van (niet-kerkelijk gebonden) religieuze hervitalisering, voor andere gaat het juist om een verdere stap binnen het secularisatieproces. In elk geval kan new age beschouwd worden als de manifestatie van religieuze individualisering en als een milieu waarin veel religieuze zoekers actief zijn. Wat de betekenis is voor de civil society is niet helemaal duidelijk. Aangenomen mag worden dat die betekenis verschilt voor de uiteenlopende geledingen van de paracultuur (professionals, gewone participanten en meer gedistantieerde belangstellenden) en het soort interesse waardoor men gedreven wordt (volgers van therapieën, maatschappijcritici, geïnteresseerden in esoterische onderwerpen etc.). Onderzoek in binnen- en buitenland suggereert dat de betrokkenen door de bank genomen niet minder affiniteit hebben met maatschappelijke vraagstukken. Wel lijkt de diffuse organisatiegraad en het voor het milieu karakteristieke zapgedrag geen gunstige voorwaarden op te leveren voor de opbouw en consolidatie van stabiel sociaal kapitaal dat, zo blijkt uit zeer veel onderzoek, een cruciale brugfunctie heeft naar collectieve maatschappelijke participatievormen.

Waar het gaat om kerkelijke deelname kan vanuit het oogpunt van de Nederlandse civil society een stelligere conclusie worden getrokken. De kerken blijken voor hun actieve achterban in hoge mate als mobilisatiemilieu te fungeren voor maatschappelijke participatie. Kerken zijn niet alleen maatschappelijke instituties of organisaties met een hiërarchie van bestuurders en ambtsdragers. Aan de basis van het kerkelijk leven liggen lokale gemeenschappen, sociale netwerken en de regelmatige interacties van gelovigen. Het is vooral vanuit dat gegeven dat de kerken (en zoals mag worden aangenomen: moskeeën, tempels en synagogen) functioneren als voorraadkamers van sociaal kapitaal en katalysatoren van maatschappelijke inzet. Het is duidelijk, concludeert ook Putnam in zijn analyse van de bronnen van sociaal kapitaal, dat religieuze mensen buitengewoon actieve sociale kapitalisten zijn en dat komt vooral door de sociale banden die tussen de gelovigen bestaan: "Connectedness, not merely faith, is responsible for the beneficence of church people” (Putnam 2000: 67).

Overigens is de band tussen kerkelijk en seculier activisme naar alle waarschijnlijkheid mede afhankelijk van het type kerkgenootschap. We hebben vastgesteld dat hij sterk is onder de leden van de grote kerken (Rooms-Katholiek, Protestantse Kerk in Nederland), die vanuit kerkelijk vrijwilligerswerk vaak gestimuleerd worden tot actieve participatie, ook in niet-kerkelijke milieus. Het is de vraag of dat ook van toepassing is op kleinere, behoudende stromingen, zoals de Gereformeerde Gemeenten, de Hersteld Hervormde Kerk of de diverse pinkstergemeenten. Daar wordt bepaald niet minder of minder gemotiveerd kerkelijk 
vrijwilligerswerk verricht, maar wel met een kleinere actieradius. Het zich inzetten zal meer gedreven worden door de hang naar een sterke interne sociale cohesie, gevoelens van exclusiviteit en de wil tot behoud van een nauw omschreven eigen groepsidentiteit.

\subsection{SLOTOVERWEGINGEN}

In ons land heeft zich vanaf de jaren zestig een duidelijke ontzuiling voorgedaan. Sindsdien lijkt godsdienst geen overheersende drijfveer meer om zich maatschappelijk te organiseren, is het mobilisatievermogen van kerken ontegenzeglijk afgenomen en het gezag van kerkleiders als spreekbuis van omvangrijke delen van de bevolking getaand. Tegen die achtergrond kunnen de levensbeschouwelijke ontwikkelingen van de afgelopen halve eeuw aanleiding geven tot pessimisme. De kerken zijn leeggestroomd en veel van de alternatieven die op de hedendaagse religieuze markt aan de weg timmeren vertegenwoordigen minder of dan toch tenminste anders samengestelde vormen van sociaal kapitaal. Daar passen wel een paar kanttekeningen bij. Bij een diagnose moet in de eerste plaats de Nederlandse situatie niet verabsoluteerd worden, is het verder verstandig oog te houden voor de bredere samenleving en lijkt het bovendien onrealistisch eenzijdig een ondergangsscenario te hanteren.

Wat betreft het eerste: in de klassieke secularisatiethese wordt ervan uitgegaan dat Europa de startmotor van secularisatieprocessen levert, die in de volheid der tijden ook de rest van de wereld in hun greep zullen hebben. Maar met zulke generalisaties is het oppassen geblazen. In ons land is het hard gegaan met de ontkerkelijking, maar in andere Europese landen (Ierland, Polen) gaat nog steeds een ruime meerderheid van de bevolking regelmatig ter kerke. Mondiaal is het percentage niet-gelovigen en atheïsten (net als in ons land) gering (ongeveer 13 procent) en vertoont het geen stijgende tendens. ${ }^{20}$ De rest van de aardbewoners is verenigd in naar schatting zo'n 8.400 religies, waarvan het christendom sinds jaar en dag de grootste is. De afgelopen honderd jaar rekende zich steeds ongeveer eenderde van de wereldbevolking tot het christendom (tegen 20 procent moslims, 13 procent hindoes, 6 procent boeddhisten) en dat zal binnen afzienbare tijd niet veranderen. Dat komt vooral omdat de verliezen in met name Noordwest-Europa in ruime mate worden gecompenseerd door de enorme aanwas bij de pinkstergemeenten en charismatische opwekkingsbewegingen (die momenteel bijna 28 procent van het georganiseerde mondiale christendom vormen) in de derde wereld. Ook in Nederland zijn er, onlangs de afkalving van de grote kerken, godsdienstige groepen die de afgelopen decennia konden bogen op forse groeicijfers (een voorbeeld zijn de al genoemde pinkstergemeenten). Zoals aangegeven zijn de repercussies voor de opbouw en instandhouding van sociaal kapitaal waarschijnlijk ambigu. Worden de grote, meer vrijzinnige kerken gekenmerkt door veel overbruggend sociaal kapitaal, de snelle groeiers op de levensbeschouwelijke markt creëren vooral veel samenbindend sociaal kapitaal. Zoals aangegeven lijken de sterk geïndividualiseerde typen van religieuze beleving (in de vorm van het nieuwetijdsdenken, hedendaags mysticisme, 'soloreligiositeit' 
en andere soorten van nieuwe spiritualiteit) geen milieu te vormen waarin de stabiele netwerken die zo'n cruciale rol lijken te spelen met betrekking tot het motiveren van mensen tot sociaal en politiek activisme een belangrijke plaats innemen. Die conclusie is echter tentatief, want er is nog nauwelijks empirisch onderzoek beschikbaar naar de maatschappelijke repercussies van de levensbeschouwelijke individualisering.

Een tweede punt is dat verklaringen van religieuze veranderingen niet te rigoureus gebaseerd moeten worden op puur godsdienstige factoren. Religieuze veranderingen staan niet op zichzelf, maar zijn ingebed in bredere maatschappelijke veranderingen en religie is een onderdeel van de tegenwoordige Nederlandse civil society. Veel ontwikkelingen in de religie doen zich op bredere schaal binnen de samenleving voor: in de arbeidswereld, de vrijetijdsbesteding en in de sfeer van de persoonlijke relatievorming, in het onderwijs en de opvoeding, op politiek terrein en in de wereld van de media (Dekker 2002; De Hart 2005a/b). De concurrentie tussen organisaties is verscherpt, wat leidt tot meer aandacht voor ledenwerving en ledenbehoud, voor imago en publiciteit, voor signalen vanuit de basis. Overal op het middenveld is emancipatie als bron van het zich aaneensluiten aan het opdrogen en lijkt een toenemend aantal mensen voor steeds minder bij steeds meer organisaties aan te kloppen. Tal van verenigingen hebben te kampen met minder actieve leden. Dat hoeft niet gepaard te gaan met het verflauwen van de belangstelling voor de thematische doelstellingen van organisaties. Wel zijn bindingen tijdelijker, partiëler, functioneler en anoniemer geworden. Op uiteenlopende terreinen is de achterban een soort latrelatie met zijn organisaties gaan onderhouden en geneigd zijn engagement uit te besteden aan professionals die dan geacht worden dit op een doeltreffende en verantwoorde wijze te behartigen. Op allerlei levensgebieden fungeren organisaties steeds minder als ontmoetingsplaats tussen mensen en krijgen ze steeds meer een facilitaire rol, waarbij ze worden geacht als knooppunten van informatie en als een soort servers in de netwerksamenleving te functioneren.

Veel dingen zijn veranderd sinds de hoogtijdagen van de verzuiling. Meer dan de helft van de bevolking rekent zich inmiddels niet langer tot een kerk en onder hen die de kerk trouw bleven deed zich een sterke teruggang voor in de kerkgang en de steun voor traditionele geloofswaarheden. In het hedendaagse Nederland heeft het geïnstitutionaliseerde christendom in elk geval niet langer een monopolie op zingeving en sociale oriëntaties (als het dit al ooit had) en is het in een flinke concurrentie verwikkeld met alternatieve ideologieën en levensvisies. Veel Nederlanders zijn dan wel niet meer zo geïnteresseerd in zuilen, vaak lijken ze wel op zoek naar fundamenten. De mogelijkheden van individuen om naar hun persoonlijke smaak te winkelen in de divine supermarket zijn de afgelopen halve eeuw enorm toegenomen. En omgekeerd: individualisme als de vrijheid het leven naar eigen inzicht en behoeften in te richten lijkt een welhaast religieuze waarde gekregen te hebben in het moderne Nederland. Het is aan de basis komen te liggen van veel van onze gewoonten en hoe wij onze instituties inrichten en allemaal voorzien door Émile Durkheim. Terwijl de traditionele religie zich 
steeds meer terugtrekt uit de samenleving, krijgt volgens hem het individu en zijn ontplooiingsmogelijkheden in de moderne samenleving meer en meer een sacrale status. ${ }^{21}$ Meer dan honderd jaar geleden, in zijn reactie op het Dreyfusdebat, zag hij de locus van het heilige verplaatst worden naar individuele vrijheid en waardigheid. "Het is een religie," schreef hij, "waarin de mens tegelijkertijd gelovige en God is" (Durkheim 1898). ${ }^{22}$ Uit de inkrimping van de kerkelijke betrokkenheid en christelijke vroomheid tot steeds kleinere minderheden onder de bevolking kan niet zonder meer worden besloten dat de rol van godsdienst in moreel opzicht is uitgespeeld of dat onze samenleving bevangen is door de 'morele kilte' (froid moral) die volgens Durkheim de Derde Republiek kenmerkte.

Zoveel is zeker: aan een hemels baldakijn waaronder op sombere dagen gezamenlijk wordt weggescholen, lijkt steeds minder behoefte te bestaan. De mensen steken zo nodig hun eigen paraplu op, al doen ze dat dan ook niet zelden met velen tegelijk. Men kan een dergelijke ontwikkeling betreuren, maar het is de vraag of het anders kan. In de moderne religiositeit klinkt de echo van een samenleving die op tal van terreinen wordt gekenmerkt door diep insnijdende individualiseringsprocessen. Het is niet aannemelijk dat deze binnen afzienbare tijd een eindpunt zullen bereiken. ${ }^{23}$ In een dergelijke samenleving zullen velen hun eigen representaties van het heilige moeten maken (De Hart 1995).

De angst dat de transformatie van de religiositeit de ontbinding van de moraal inluidt kent zijn eigen perioden van hoogconjunctuur en is van alle tijden. ${ }^{24}$ Daarbij worden veelal oude conservatieve sentimenten geactiveerd, die de ontwikkeling als een indicatie beschouwen voor het egocentrisme, de anomie en de vervreemding waaraan de huidige mensheid ten prooi zou zijn gevallen: 'Wo keine Götter sind, walten Gespenster' (Novalis 1960: 520). Vandaag de dag is het een vrees die niet alleen bij een keurkorps van maatschappijcritici valt aan te treffen, maar die, zo leren de eerder geciteerde God in Nederland-enquêtes, door een niet onaanzienlijk deel van de Nederlandse bevolking wordt gedeeld. Toch moet worden opgemerkt dat er niet alleen dingen verdwijnen. Naast de teruggang van de grote kerken staan succesvolle evangelische bewegingen en sommige onderdelen van de christelijke traditie beklijven meer dan andere. ${ }^{25}$ Verder ontwikkelen zich ook nieuwe vormen van spiritualiteit. De toekomst is meer dan een voortzetting of verdwijnen van het verleden; ons land is uitgegroeid tot een religieuze proeftuin. Zoals we hebben betoogd valt nog maar te bezien of dit een positieve ontwikkeling is vanuit het oogpunt van maatschappelijke participatie. 


\section{NOTEN}

I Daarenboven komen bij de vergelijking van opvattingen en activiteiten van bevolkingsgroepen alleen de leden van de grote christelijke kerken en onkerkelijken apart in beeld. Vanwege de beperkte omvang van de gebruikte bevolkingsenquêtes en ook de ondervertegenwoordiging van immigranten is het met name niet mogelijk om apart aandacht aan moslims te besteden. Zie voor hun deelname aan verenigingen en vrijwilligerswerk en het belang van moskeebezoek Dekker en Keuzenkamp (2006) en voor beschouwingen over de rol in de civil society van religie in het algemeen en de islam in het bijzonder o.a. Herbert (2003).

De relatie met de civil society verschilt per land en wordt bovendien door kerken verschillend gepercipieerd. Zoals de vorige paus ooit lord Ralf Dahrendorf corrigeerde, toen die het had over de rol van de katholieke kerk in de Poolse civil society in de jaren tachtig: "The church does not belong to civil society but to sacred society" (Dahrendorf, mondelinge mededeling). In de literatuur wordt dit ook wel opgevat als steun voor verzuiling, maar van een verzuilingsmentaliteit hoeft geen sprake te zijn. In 2002 is meer gevraagd naar acceptatie (er moeten 'ook' confessionele partijen zijn) en in de jaren daarvoor meer naar de eigen voorkeur. Aangenomen mag worden dat 'confessioneel' vrijwel altijd als synoniem van 'christelijk' is opgevat. Met uitzondering van de Denen ('Kirken') en de Luxemburgse Luxemburgers ('D'Kiirchen'). 'De kerk' als bekend instituut en in enkelvoud zal andere associaties oproepen dan de abstractere en meervoudige 'religieuze instellingen' doen, maar de richtingen weten we niet.

Deze relatieve positie is vrij stabiel. In tien metingen van de Eurobarometer tussen eind 1997 en eind 2005 varieerde het gemiddelde institutionele vertrouwen in Nederland tussen 50 en 64 en zat 'de kerk' daar -11 tot-19 procentpunten onder. Deze paragraaf is voor een deel een bewerking van Dekker en De Hart (2006). Hetzelfde patroon komt naar voren als afgegaan wordt op wie volgens de vragenlijst van dit onderzoek 'wel eens' vrijwilligerswerk doet (Dekker en de Hart 2006). Het verschil tussen kerkgangers en de twee andere typen komt eveneens naar voren in tijdbestedingonderzoek naar informele hulp en mantelzorg. Met dank aan René Bekkers / de werkgroep Filantropie van de Vrije Universiteit. Een uitsplitsing van gegevens over 2001 laat zien dat gereformeerden zich het meest vrijgevig betonen. Van hun donaties komt 70 procent ten bate van kerkelijke doelen; bij de hervormden is dit zelfs 8 o procent en bij de katholieken slechts 40 procent. Bij de protestanten hebben vooral de orthodoxe stromingen een sterke voorkeur voor kerkelijke doelen; zie verder Bekkers 2003. Zoals elders vermeld (Dekker en De Hart 2006) gaan de verschillen bij mantelzorgers / informele helpers in dezelfde richting, maar zijn ze wel veel kleiner dan bij vrijwilligers. In het algemeen geldt dat bij vrijwilligerswerk grotere verschillen worden gevonden tussen bevolkingsgroepen dan bij informele hulp of mantelzorg. Dat zal ermee te maken hebben dat vrijwilligerswerk vaker een keuze is en informele hulp eerder iets wat gebeurt onder de druk der omstandigheden. 
Volgens ander onderzoek concentreren de gereformeerden zich het meest op kerkelijk vrijwilligerswerk, Nederlands hervormden doen dat minder en katholieken nog minder. De meest hechte en behoudende stromingen (zoals de Gereformeerde bond in de voormalige hervormde kerk en de vrijgemaakten onder de gereformeerden) beperken hun aandacht het sterkst tot de eigen kerkelijke kring (Bekkers 2003; De Hart en Dekker 2005). Een internationale vergelijking van twaalf westerse landen leert dat protestanten in ons land en de Verenigde Staten een hoger percentage vrijwilligers leveren dan katholieken. In andere landen met een gemengde godsdienstige cultuur (zoals Duitsland of Groot-Brittannië) is er geen verschil (De Hart en Dekker 2005: 178).

Zie De Hart en Dekker (2005), Dekker en De Hart (2006) en ook Bekkers (2004) en De Ruiter en De Graaf (2006). Waarschijnlijk spelen gemeenschappelijke activiteiten van kerkgangers in kleiner verband een grote rol. Deelname aan kerkelijk vrijwilligerswerk blijkt in statistische analyses een belangrijke voorspeller te zijn van het verrichten van seculier vrijwilligerswerk.

3 Schattingen lopen sterk uiteen. Zo komt Ferrier (2002) uit op 800.0oo westerse en niet-westerse migrantenchristenen; Wijsen (2003) op 640.0oo en het KASKI in een niet gepubliceerd rapport voor 2004 op minstens 573.000 en maximaal 750.00o niet-westerse christenen.

4 Over de exacte aantallen kerkelijk aangeslotenen bestaat veel onduidelijkheid; wel duidelijk is dat er voornamelijk sprake is van tamelijk kleine groepen en maar weinig grotere. Vermoedelijk ligt het totale aantal leden tussen de honderd- en tweehonderdduizend. Veel van de kerken zelf gebruiken liever niet de aanduiding 'migrantenkerk' en spreken van bijvoorbeeld 'internationale kerk'.

5 Euser et al. (2006:36) komen, voortredenerend op de inventarisaties van Van den Broek, op minimaal 930 religieuze migrantengemeenschappen in het huidige Nederland.

6 Euser et al. (2006:40) schatten dat bijvoorbeeld de Amsterdamse migrantenkerken 24.0oo regelmatige bezoekers tellen, tegen ca. 2.50o kerkgangers bij de PKN in dezelfde stad.

Voor voorbeelden zie Van der Sar en Visser 2006.

8 Zie de artikelen van Jan Oegema over wat hij betitelt als zijn Minimaal Christendom, in Trouw 8 november 2005 (De Verdieping), 24 december 2005 (Letter en Geest) en 7 januari 2006 (Letter en Geest). Vgl. de discussies in bijv. Dingemans 2005 en Biezeveld et al. 2006.

9 Maar ook binnen het alternatieve milieu is het niet altijd koekoek één zang. Er zijn aanwijzingen dat er sprake is van verschillende groepen (of tradities) binnen het new-agemilieu (zoals esoterici, therapeutisch geïnteresseerden, alternatieve leefgemeenschappen, maatschappijhervormers) met uiteenlopende maatschappelijke en politieke affiniteiten.

West- en Noord-Europa vormen mondiaal bezien een geval apart. Het geografische zwaartepunt van het christendom is in de loop van de afgelopen decennia drastisch verschoven, van het Kaukasische, op Europa gecentreerde, geïnstitutionaliseerde christendom naar niet-westerse cultuurgebieden en andere etnische groepen. De groei vindt vandaag de dag vooral plaats in de zuidelijke hemisfeer, voorop Afrika. Ter illustratie: er is becijferd dat honderd jaar geleden het chris- 
tendom voor 81 procent uit blanken bestond, een percentage dat inmiddels is gedaald tot 43 procent, nadat vanaf ongeveer 1980 blanken een minderheid gingen vormen. Zo'n 7.600 westerlingen (voornamelijk Europeanen) mogen dan op een doorsneedag de kerkdeur achter zich dichttrekken, daar staan 23.000 nieuwe christenen per dag in Afrika tegenover. In landen als Zuid Afrika, Swaziland en Zimbabwe groeien inheemse christelijke kerken als kool; hetzelfde geldt voor de pinksterbewegingen (die ook in bijvoorbeeld Brazilië en Chili kunnen bogen op forse groeicijfers) (cijfers in Barrett et al. 2001). Secularisatie naar Europese snit is geen succesvol exportartikel gebleken. Door steeds meer auteurs wordt betoogd dat Europa de uitzondering is die de regel van een steeds religieuzer wereld bevestigt.

"A mesure que toutes les autres croyances et toutes les autres pratiques prennent un caractère de moins et moins religieux, l'individu devient l'objet d'une sorte de religion" (Durkheim 1893 : 147; vgl. Durkheim 1950: 91-99).

Niet alleen leidt het individualisme volgens hem geenszins tot anarchie, maar is het zelfs voortaan de enige levensbeschouwing die de morele eenheid van het land kan garanderen. "Non seulement l'individualisme n'est pas l'anarchie, mais c'est désormais le seul système de croyances qui puisse assurer l'unité morale du pays. (...) Dès qu'une fin est poursuivie par tout un peuple, elle acquiert, par suite de cette adhésion unanime, une sorte de suprématie morale qui l'élève bien au-dessus des fins privées et lui donne ainsi un caractère religieux" (Durkheim 1898).

23 Waar mensen de wereld gingen zien als een door onpersoonlijke regels bepaalde kosmos, resteerde volgens Weber nog slechts een ongrijpbaar metafysisch achterland van individueel heilsbezit. "Der Einzelne kann sein Heil, wo diese Konsequenz restlos gezogen ist, nur als Einzelner suchen” (Weber 1963: 254).

24 In de joods-christelijke traditie gaat ze op zijn minst terug tot de profeten, maar ook een auteur als de Romeinse historicus Tacitus gaf er in zijn Annalen (eind eerste eeuw na Christus) al lucht aan.

25 Wat betreft de geloofsleer is er nog steeds veel steun voor de optimistische kanten van de christelijke traditie (zoals de zinvolheid van bidden of het bestaan van een hemel), maar weinig voor de schaduwkanten en accentuering van het menselijke onvermogen. De afgelopen vijftien jaar liep bijvoorbeeld het geloof in een hiernamaals of in religieuze wonderen onder de bevolking niet terug; veel minder aanhang heeft daarentegen het geloof in de hel en de duivel. 


\section{LITERATUUR}

Barrett, D.B., G.T. Kurian en T.M. Johnson (red.) (2001) World Christian Encyclopedia.

A Comparative Survey of Churches and Religions in The Modern World, Oxford:

Oxford University Press.

Batson, C.D. (1976) ‘Religion as prosocial: agent or double agent?’ Journal for the Scientific Study of Religion 15: 29-45.

Becker, J., J. de Hart en J. Mens (1997) Secularisatie en alternatieve zingeving in Nederland, Rijswijk/Den Haag: Sociaal en Cultureel Planbureau/vUGA.

Becker, J. en J. de Hart (2006) Godsdienstige veranderingen in Nederland. Verschuivingen in de binding met de kerken en de christelijke traditie, Den Haag: SCP.

Bekkers, R. (2003) 'De bijdragen der kerckelijken', blz. 141-172 in: Th.N.M. Schuyt (red.), Geven in Nederland 2003, Houten: Bohn Stafleu Van Loghum.

Bekkers, R. (2004) Giving and volunteering in the Netherlands, Utrecht: Universiteit Utrecht (proefschrift).

Berger, P. (1969) The sacred canopy, Garden City, N.Y.: Doubleday.

Biezeveld, K., T. de Boer, M. de Vos, G. Dingemans et al. (2006) In iets geloven. Ietsisme en het christelijk geloof, Kampen: Kok.

Casanova, J. (1994) Public religions in the modern world, Chicago: University of Chicago Press.

Davidson, J.C. en D.P. Caddell (1994) 'Religion and the meaning of work', Journal for the Scientific Study of Religion 33, 2: 135-147.

Davie, G. (1990) 'Believing without belonging', Social Compass 37, 4: 455-69.

Davie, G. (1994) Religion in Britain since 1945. Believing without belonging, Oxford: Blackwell Publishers.

Davis, N.J. en R.V. Robinson (1996) ‘Are the rumors of war exaggerated?’, American Journal of Sociology 102, 3: 756-787.

Dekker, P. (2002) De oplossing van de civil society. Over vrijwillige associaties in tijden van vervagende grenzen, Den Haag: SCP.

Dekker, P. en J. de Hart (2006) Kerkgangers. In: Sociaal en cultureel rapport 2006, Den Haag: SCP.

Dekker, G., J. de Hart en J. Peters (1997) God in Nederland 1966-1996, Amsterdam: Anthos.

Dekker, G. J. de Hart en T. Bernts (2007) God in Nederland 1966-2006, (voorlopige titel; te verschijnen in 2007).

Dekker, P. en S. Keuzenkamp (2006) 'Maatschappelijke participatie', blz. 211-233 in: S. Keuzenkamp en A. Merens (red.) Sociale atlas van vrouwen uit etnische minderheden, Den Haag: SCP.

Dingemans, G. (2005) Ietsisme. Een basis voor christelijke spiritualiteit?, Kampen: Kok.

Durkheim, É. (1898) 'L’individualisme et les intellectuels', Revue Bleue 4e série, 10: 7-13.

Durkheim, É. (1893) Leçons de sociologie: physique des mours et du droit, Parijs: PUF.

Durkheim, É. (1919) ‘La conception sociale de la religion', blz. 97-143 in: P. Jeanrenaud and F. Abauzit (red.), Le sentiment religieux à l'heure actuelle, Paris: Librairie Philosophique J. Vrin.

Durkheim, É. (1950 [1893]) De la division du travail social, Parijs: PUF. 
Euser, H. K. Goossen, M. de Vries en S. Wartena (2006) Migranten in Mokum; de betekenis van migrantenkerken voor de stad Amsterdam, Amsterdam: Vrije Universiteit (NUR 7OO).

Ferrier, K. (2002) Migrantenkerken, Kampen: Kok.

Halman, L., T. Petterson en J. Verweij (1996) The religious factor in contemporary society, Tilburg: Katholieke Universiteit Brabant (worC paper).

Hart, J. de (1995) 'Religie als menselijk project' blz. 39-62 in: H.M. Kuitert (red.), In stukken en brokken. Godsdienst en levensbeschouwing in een postmoderne tijd, Baarn: Ten Have.

Hart, J. de (2005a) Voorbeelden en nabeelden. Historische vergelijkingen naar aanleiding van de dood van Fortuyn en Hazes, Den Haag: SCP.

Hart, J. de (2005b) Landelijk verenigd. Grote ledenorganisaties over ontwikkelingen op het maatschappelijk middenveld, Den Haag: SCP.

Hart, J. de en P. Dekker (2005) 'Churches as voluntary associations', blz. 168-196 in:

S. Roßteutscher (red.), Democracy and the Role of Associations, Londen en New York: Routledge.

Herbert, D. (2003) Religion and civil society, Aldershot: Ashgate.

Juergensmeyer, M. (1993) The new cold war: religious nationalism confronts the secular state, Berkeley: University of California Press.

Kurtz, L. (1995) Gods in the global village, Thousand Oaks, California: Pine Forge Press.

Luckmann, Th. (1967) The invisible religion, New York: Macmillan.

Margry, P. J. (2003) 'The Murder of Pim Fortuyn and collective emotions', Etnofoor. Antropologisch tijdschrift 16: 102-127.

Margry, P.J. (2006) 'Stille omgang als civil religion', blz. 41-94 in: C. Caspers en P.J. Margry, Identiteit en spiritualiteit van de Amsterdamse Stille Omgang, Hilversum: Verloren.

Novalis (1960) Schriften (uitg. door P. Kluckhohn \& R. Samuel), Stuttgart: Reclam.

Paz, O. (1990) De wenteling der tekens, Zonnesteen. Amsterdam: Meulenhoff.

Post, P., A. Nugteren en H. Zondag (2002) Rituelen na rampen. Verkenning van een opkomend repertoire, Kampen: Gooi en Sticht.

Putnam, R.D. (2000) Bowling alone, New York: Simon and Schuster.

Ruiter, S. en N.D. de Graaf (2006) 'National context, religiosity, and volunteering', American Sociological Review, 71(2): 191-210.

Sar, J. van der en T. Schoemaker (2003) De Hofstad. Een cadeautje aan de samenleving, Utrecht/Apeldoorn: Oikos/СмB.

Sar, J. van der (2004) Van harte! Onderzoek naar het maatschappelijk rendement van de Protestantse Gemeente in Utrecht, Utrecht: de Pelmolen.

Sar, J. van der en R. Visser (2006) Gratis en waardevol. Rol, positie en maatschappelijk rendement van migrantenkerken in Den Haag, Rotterdam/Den Haag: Drukjoenit/Digicopy.

Stoffels, H. (1990) Wandelen in het licht. Waarden, geloofsovertuigingen en sociale posities van de Nederlandse evangelischen, Kampen: Kok.

Stoffels, H. (1995) Als een briesende leeuw. Orthodox-protestanten in de slag met de tijdgeest, Kampen: Kok.

Vellenga, S.J. (1991) Een ondernemende beweging: de groei van de evangelische beweging in Nederland, Amsterdam: vu Uitgeverij. 
Tamney, J.B. en S.D. Johnson (1985) ‘Consequential religiosity in modern society’, Review of Religious Research 26, 4: 36o-378.

Verba, S., K. Lehman Schlozman en H.E. Brady (1995) Voice and equality, Cambridge (MA): Harvard University Press.

Weber, M. (1963 [1920]) Gesammelte Aufsätze zur Religionssoziologie, Band 1. Tübingen: Mohr.

Wijsen, F. (2003) 'Op zondag willen wij onszelf zijn...', blz. 92-111 in: C. Hermans (red.), Is er nog godsdienst in 2050? Budel: Damon.

Wuthnow, R. (1996) Christianity and civil society, Valley Forge: Trinity Press. 


\title{
6 LEEFSTIJLEN EN ZINGEVING
}

\author{
Gerrit Kronjee en Martijn Lampert
}

\section{$6.1 \quad$ INLEIDING}

Waarin geloven mensen die zeggen niet te geloven? En waarin geloven mensen niet die zeggen te geloven? Wat is nu nog de betekenis van religie voor de sociale cohesie? Deze bijdrage gaat in op deze interessante vragen over de zingeving door een analyse van onderzoeksgegevens over de beleving van religie en spiritualiteit in Nederland.

De zin die men in deze tijd in Nederland aan het leven geeft kan getypeerd worden met de antwoorden op vragen in een onderzoek onder 2.021 Nederlanders van Motivaction in oktober en november 2003, over de diepere betekenis die men aan het leven geeft en over de keuzen die men in dit verband maakt. Daarnaast zijn er ook andere gegevens verzameld over de persoonlijke religieuze opvattingen. Een en ander wordt hierna in verband gebracht met het burgerschap, met de sociale bindingen die men heeft. Verwacht wordt dat levensbeschouwelijke inzichten van belang zijn voor de sociale cohesie.

In het onderzoek zijn vragen gesteld over de zingeving waarbij de antwoorden niet van tevoren waren vastgelegd in bepaalde categorieën waaruit men zou kunnen kiezen. De ondervraagden konden dus zelf geheel vrij formuleren wat voor hen de zin van het leven was. Deze antwoorden zijn na de enquête langs verschillende dimensies ingedeeld en gedifferentieerd naar de religieuze en levensbeschouwelijke achtergrond. De zingeving wordt hier gezien als een meer omvattend kenmerk dan het kenmerk van de religie. Religie is dus een van de vormen van zingeving, naast bijvoorbeeld de humanistische. Binnen de religieuze of transcendente vormen van zingeving is er weer een verschil tussen gebonden religieuze en ongebonden spirituele vormen.

Elke levensbeschouwelijke categorie is geanalyseerd naar deze zingevingsdimensies, alsook naar burgerschapsstijl, sociaal-culturele onderstromen, scores op zogenaamde Schwartzwaarden, esoterische items in de vragenlijst, mediagebruik, liefdadigheid en sociaal-demografische achtergronden. Hierna worden de meest kenmerkende bevindingen per categorie gepresenteerd en samengevat in een profiel. Een cijfermatig gegeven is een typerend kenmerk voor een profiel als er sprake is van een significante afwijking ten opzichte van het totaalgemiddelde. Hierdoor ontstaat een nadere indruk van de verschillende religieuze en levensbeschouwelijke categorieën en van de relatie met hun bredere maatschappelijke opvattingen en positie. Dit kan het verband tussen religie en burgerschap of het publieke domein verhelderen. Aan dit hoofdstuk is een bijlage met enkele opvallende gegevens toegevoegd. De profielen zijn gebaseerd op veel verschillende cijfers die niet alle in dit hoofdstuk zijn opgenomen, omdat het dan te omvang- 
rijk zou worden. De profielen, die in de paragrafen $6.4 \mathrm{t} / \mathrm{m} 6.6$ worden beschreven, bevatten de volgende dimensies:

- zingeving (de antwoorden op de vragen over zingeving, zie paragraaf 6.3);

- burgerschapsstijl (zie paragraaf 6.7 en in de bijlage figuur B-1 en tabel B-1);

- onderstromen (zie de figuren B-2 en B-3 in de bijlage);

- Schwartzwaarden (zie paragraaf 6.3 en figuur B-4 in de bijlage);

- esoterisch (zie figuren B-5 en B-6 in de bijlage);

- sociaaldemografisch (zie tabel B-2 en figuur B-7 en B-8 in de bijlage);

- media (hierover is in dit hoofdstuk geen aanvullende informatie opgenomen);

- charitatief (zie figuur B-9 in de bijlage);

- diversen (zie figuur B-1o en B-11 in de bijlage).

Dit onderzoek betreft een eenmalige peiling en kan als zodanig geen veranderingen in de loop van de tijd constateren. Toch is het belangrijk deze uitkomsten te zien als een momentopname in een veranderende werkelijkheid en ze te plaatsen in het perspectief van deze veranderingen. Het begrip leefstijl is belangrijk om die veranderingen te beschrijven. Er zijn nog meer begrippen die een beeld kunnen geven van de veranderingen in de maatschappelijke betekenis van religie. Voorafgaand aan de weergave van de onderzoeksuitkomsten gaan we hier nu nader op in.

\subsection{ACHTERGROND: VERANDERINGEN IN DE MAATSCHAPPELIJKE BETEKENIS VAN RELIGIE}

Hierna volgt een toelichting op de begrippen die, naast het begrip leefstijl, gebruikt zullen worden om de analyse te plaatsen in de religieus-maatschappelijke dynamiek: transformatie (in plaats van secularisatie), religieuze behoeften en het religieuze aanbod, functionele equivalenten.

\section{Leefstijlen}

Het onderzoek dat in dit hoofdstuk aan de orde is, vond plaats tegen de achtergrond van een toenemend belang van leefstijlen in het verklaren van gedragingen en voorkeuren van Nederlanders (Lampert 1997). Onder invloed van de stijging van het gemiddelde opleidingsniveau en de toegenomen welvaart in de afgelopen decennia zijn de Nederlandse burgers meer kritisch, zelfbewust en consumptief geworden. Zij positioneren zich individueel in een ruimte van bevolkingscategorieën met verschillende leefstijlen. Ook houdt men zich sterker dan voorheen bezig met het uitdragen van de identiteit via consumptie. In de hedendaagse cultuur identificeren en onderscheiden mensen zich minder via klasse, familie of afkomst. Er heeft, mede onder invloed van technologische ontwikkeling en van mondialisering van economie en cultuur, een 'onttraditionalisering' van de leefwereld plaatsgevonden (Beck, Giddens \& Lash 1994; Lash \& Urry 1987). Met traditionele waarden wordt door grote groepen meer reflexief en kritisch omgegaan in een veranderende wereld, waarin nieuwe oriëntaties opkomen. Lash spreekt in dit verband, in navolging van Schulze (1992), van de opkomst van een Erlebnisgesellschaft. Hierin geven mensen op esthetische, zelfreflexieve en 
expressieve wijze uiting aan hun identiteit en creëren deze op een betekenisvolle wijze. Giddens spreekt in verband met de opkomst van een postmoderne cultuur van narrations of the self en Featherstone (1991) spreekt van de stylization of life, waarin de mens als een artiest zijn leven vormgeeft en uitdraagt. Consumptieartikelen en leefpatronen worden hier als symbolen en tekens ingezet. Ook de mediatisering van de cultuur en de opkomst van een mondiale media- en communicatie-industrie hebben ertoe bijgedragen dat mensen meer stijlbewust zijn geworden en zich in toenemende mate strategisch zijn gaan onderscheiden. Deze esthetisering van het alledaagse leven voltrekt zich niet zozeer langs hiërarchische lijnen van sociale klassen, maar is sterk verbonden met leefstijlen. De postmoderne consumptiecultuur is een cultuur waarin beeld (esthetiek) en beleving (hedonisme) centraal staan (Maffesoli 1996 en 1997). De beeldcultuur verdringt de cultuur van het geschreven woord, we leven volgens Maffesoli in een time of the tribes.

De ontwikkeling naar een leefstijlmaatschappij heeft niet alleen haar weerslag op het domein van consumptie en media, maar ook op het publieke domein, het terrein van arbeid, het terrein van zingeving en het gebied van burgerschap en politieke en maatschappelijke betrokkenheid. Daarom is in dit onderzoek naar de zingeving een instrument toegepast dat wordt gebruikt om de belevingswereld, leefstijlen en basiswaarden van Nederlanders in kaart te brengen. In de beschrijving van de ontwikkeling naar een leefstijlmaatschappij zou overigens de misvatting kunnen ontstaan dat er sprake zou zijn van een steeds verder toenemende individuele autonomie. Dit is zeker niet het geval. Leefstijlen kennen een duidelijk collectief karakter, waarbinnen individuen zich positioneren; hier blijkt sprake te zijn van een duidelijke wisselwerking tussen de individuele actoren en de structuur van de leefstijl.

\section{Transformatie in plaats van secularisatie}

Uit een recent overzicht van onderzoeksuitkomsten van Becker (2006) blijkt het volgende. In Nederland neemt het aantal leden van kerkgenootschappen af; 70 procent is geen lid meer van een kerk. Dit cijfer lijkt zich voorlopig te zullen stabiliseren. In de jongste generatie neemt de gevoeligheid voor religieuze ideeën echter wel toe. Eenderde van de bevolking bidt dagelijks. Tweevijfde beschouwt zichzelf als religieus. Meer dan de helft gelooft in God. Een stijgend aandeel gelooft in een leven na de dood, van 53 procent in 1991 naar 6o procent in 1998.

In een meting van het zogenaamde Mentality-onderzoek van Motivaction van 2004 onder ruim 2.00o Nederlanders is de stelling voorgelegd 'Ik geloof in het bestaan van engelen'; 42 procent van de respondenten antwoordde bevestigend op deze stelling. Op de stelling dat de dood een doorgaande levensweg is, antwoordde 6 o procent bevestigend. In een onderzoek naar het geloof in een leven na de dood dat Motivaction in opdracht van de IKON ter gelegenheid van Pasen uitvoerde onder 15- tot 40-jarigen, bleek dat 54 procent van de autochtone $\mathrm{Ne}$ derlanders gelooft in het bestaan van een leven na de dood (Motivaction 2005); 25 procent zegt het niet te weten en 21 procent gelooft er expliciet niet in. Van 
degenen die hierin geloven of erover twijfelen, gelooft 42 procent dat de ziel voortleeft en 40 procent dat de geest voortleeft; 38 procent gelooft in het weerzien van overleden familieleden en vrienden, 27 procent gelooft in een reïncarnatie als mens en 20 procent gelooft in een leven dat men voortzet in hemel, hel of vagevuur. Aan het onderzoek hebben ook 341 personen uit migrantengroepen meegedaan. Van hen gelooft 66 procent in het bestaan van leven na de dood, 18 procent twijfelt en 17 procent gelooft er expliciet niet in. Het geloof in een andere, hogere wereld en in een hiernamaals is in Nederland dus wijdverbreid. In combinatie met de geconstateerde buitenkerkelijkheid verwijst dit ook naar het voorkomen van een categorie met spirituele opvattingen die niet meer is verbonden met enig maatschappelijk instituut.

Tot voor kort had het Nederlandse sociaal-wetenschappelijke onderzoek naar de religie dat een rol speelde in het overheidsbeleid en het publieke debat, een beperking. Er was sprake van een betrekkelijk eenzijdige beschrijving van de maatschappelijke betekenis van de religie vanuit een veronderstelde voortgaande secularisatie, waarbij de kerkgang en de aanhang van christelijke leerstellingen als een belangrijk gegeven worden gezien. Uit een verkenning van internationaal vergelijkend onderzoek op het terrein van de waarden (value surveys), waarin ook aandacht is voor Nederland, volgt echter dat met de vaststelling van een toenemende secularisatie op deze manier in een moderne samenleving er geen recht wordt gedaan aan de blijvende maatschappelijke betekenis van de religie als zingeving (zie ook het hoofdstuk in deze bundel met de titel 'De religieuze transformatie en de sociale cohesie'). Het Nederlandse onderzoek dat een oriëntatie bood voor het beleid, heeft de verschijnselen niet onderkend (en beschreven) van nieuwe vormen van zingeving bij op de media georiënteerde bewegingen en van nieuwe evangelische groeperingen en rituelen.

Als men het geloof gelijkstelt aan het christelijke geloof en de daarbij behorende traditionele leerstellingen, is er sprake van een neergang. Als men het godsbegrip ruimer stelt ligt het anders. Het begrip secularisatie is dan achterhaald, het gaat sterk uit van christelijke opvattingen die in een kerk worden beleden, terwijl mensen tegenwoordig ook religieus of spiritueel kunnen zijn zonder een band te hebben met een bepaalde kerk of religieuze leerstellingen. Beter is het te spreken van een transformatie van de religie die te typeren is als een uiting van een bredere maatschappelijke verandering. Men heeft bijvoorbeeld geen baan meer voor het leven, maar is nog wel sterk op het werken georiënteerd. Naar analogie heeft men dan geen binding meer met een bepaalde kerk of categorie, maar nog wel een binding met een transcendente spiritualiteit.

\section{Wat verandert er, religieuze behoeften of het religieuze aanbod?}

Stark meent dat het behoeftepatroon in religieus opzicht in de loop van de tijd niet verandert, althans dat veranderingen daarin niet nodig zijn om de maatschappelijke betekenis van de religie te begrijpen (Stark en Finke 2002; Finke en Stark 2005; Stark 2006). Het is de manier waarop in die behoeften wordt voorzien die in de loop van de tijd verandert. Aan de aanbodkant van de religieuze 
markt vindt een transformatie plaats. West-Europeanen zijn gelovige buitenstaanders. De religieuze participatie in West-Europa is laag, maar het geloof houdt veel aanhang. Stark denkt dat dit het gevolg is van het eerdere bestaan van een door de overheid gereguleerde en gesubsidieerde religieuze markt. Er is veel discussie over de visie van Stark. Het gaat ons om zijn inzicht dat er een religieuze transformatie in institutioneel opzicht kan plaatsvinden los van een verandering van de behoeften aan zingeving. De zingevingsbehoeften die we nu vaststellen, hoeven niet te verschillen van de behoeften van de inwoners van Nederland in het verleden (afgezien dan van het overduidelijke gegeven dat er nu in Nederland meer mensen wonen dan vroeger met een andere religie). De context waarbinnen deze behoeften zich voordoen en de manieren waarop deze behoeften worden bevredigd, zijn echter wel sterk veranderd. Het is mogelijk dat de grootste veranderingen hebben plaatsgevonden in de manier waarop in de religieuze behoeften wordt voorzien en niet in de behoeften zelf. Bijvoorbeeld, er is geconstateerd dat het aanbod van de kerken in de loop van de tijd is geïntellectualiseerd en zich daardoor verwijderd zou hebben van de zingevingsbehoeften van een deel van de bevolking (zie Jörns 1999: 25). Religie in een bredere spirituele betekenis, als grensverkeer met het oneindige en een ervaring van het mythische, zou zich handhaven (Hofmeister en Bauerochse 1999).

\section{Functionele equivalenten}

De scheiding van de veranderingen in religieuze behoeften en de veranderingen in het religieuze aanbod, dus het niet meer zonder meer veronderstellen dat het een in het verlengde van het andere ligt, biedt interessante perspectieven voor het (anders) denken over de relatie met het publieke domein en de rol van de overheid daarbij. Bijvoorbeeld het principe van de scheiding tussen kerk en staat komt in een ander licht te staan als in dezelfde transcendente behoeften niet wordt voorzien door kerken maar door andere instituties. Popconcerten, sportgebeurtenissen, toerisme en de televisie zouden religieuze functies van kerken hebben overgenomen (Hofmeister en Bauerochse 1999). De markt speelt hierin een belangrijke rol. Gelden dan ook voor deze functionele equivalenten met een voor sommigen grote betekenis voor hun zingeving, beperkingen in de rol van de staat, is dan de vraag. Niet alleen de vrijheid van meningsuiting maar ook de godsdienstvrijheid zou dan een rol kunnen spelen.

Het tegenwoordig aangetroffen patroon kan gezien worden als het gevolg van de transformatie van de religieuze beleving in deze tijd. Een belangrijke vraag is of er in het geconstateerde patroon van sociale bindingen kan worden vastgesteld of niet alleen de religieuze functies maar ook de samenbindende functies van religieuze gemeenschappen door andere instituties worden overgenomen. De religieuze beleving zou nu ook zonder een binding met een religieuze groep tot stand kunnen komen. Daarmee zou een belangrijke factor voor de sociale cohesie, die in het verleden overigens niet altijd voor de samenleving als geheel een positieve uitwerking had (zie de strijd na de Reformatie), kunnen verdwijnen. Wat dat betreft zal hierna een bijzondere aandacht uitgaan naar twee categorieën die zijn ontstaan na de ontkerkelijking: een niet-humanistische, niet-religieuze categorie 
en een niet-gebonden spirituele categorie. Deze twee categorieën zouden een afwijkende maatschappelijke binding kunnen vertonen.

\subsection{GELOOF, ONGELOOF EN DE ZINGEVING}

Naast christenen wonen er ook, voornamelijk door immigratie, aanhangers van andere religies in Nederland. Verder ontstaat er een ongebonden vorm van religie, de ongebonden spirituelen. Ook biedt het levensbeschouwelijke palet niet-religieuze aanhangers van humanistische waarden en een categorie die noch religieus noch humanistisch is. In het onderzoek is een zestal categorieën onderscheiden op basis van hun antwoorden op diverse vragen (zie figuur 6.1).

\section{Figuur 6.1 Indeling van de ondervraagden naar levensbeschouwing}

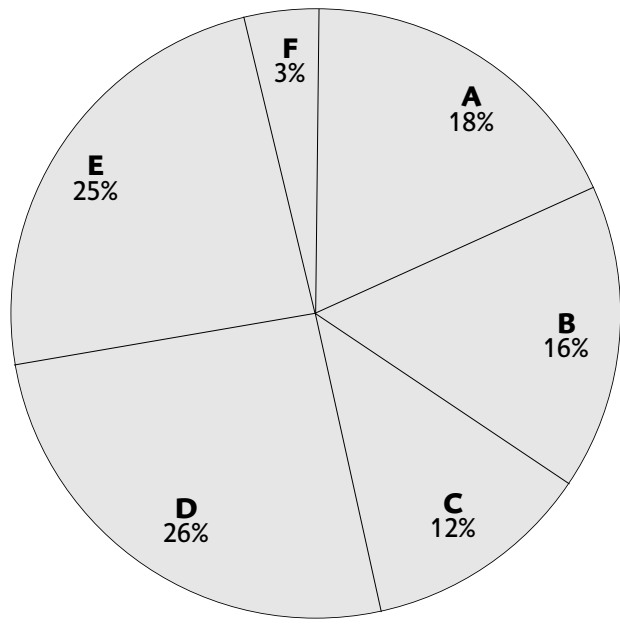

A niet-religieus, niet-humanistisch (18\%, NR\&NH)

B niet-religieus, gematigd humanistisch $(16 \%, \mathrm{NR} \& \mathrm{GH})$

C niet-religieus, humanistisch $(12 \%, \mathrm{NR} \& \mathrm{H})$

D ongebonden spiritueel (26\%, ONG-s)

E christenen $(25 \%, \mathrm{CHR})$

F overige gebonden religieuzen (3\%, OVR)

Bron: Motivaction

De zes categorieën zijn als volgt samengesteld. Als eerste is de vraag gesteld of men spiritueel/religieus is ingesteld. Vervolgens is gevraagd of men zich tot een levensbeschouwelijke/religieuze/spirituele groepering rekent. De mensen die aangaven wel (incl. enigszins) spiritueel/religieus te zijn ingesteld, maar zich niet tot een levensbeschouwelijke/religieuze/spirituele groepering rekenen zijn ingedeeld in de categorie ongebonden spirituelen. Aan de respondenten die zich (incl. enigszins) tot een levensbeschouwelijke/spirituele/religieuze groepering rekenen, is de open vraag gesteld welke groepering dit betreft. Hun antwoorden zijn geordend tot een indeling in christenen en overige gebonden religieuzen (veelal moslims van 15-35 jaar) of, wanneer men niet kon worden ondergebracht bij een van de grote religieuze stromingen, bij de categorie ongebonden spirituelen. De respondenten die niet spiritueel of religieus zijn ingesteld, en zich ook niet rekenen tot een spirituele of religieuze groepering, zijn toebedeeld aan de groep niet-religieuzen. De groep niet-religieuzen is vervolgens ingedeeld in subcategorieën aan de hand van hun score op een schaal met waarden die aansluiten bij het humanisme. In een onderzoek voor de Humanistische Omroep is deze schaal (met een Cronbach's Alpha van o,876) eerder door Motivaction geconstrueerd op basis van de centrale humanistische waarden uit de publicatie 'Leven is een kunst' van het Humanistisch Verbond. Deze schaal maakt deel uit van de scores op de Schwartzwaarden die voor alle ondervraagden zijn vastgesteld (zie figuur B-4 in de bijlage). De humanistische schaal is gebaseerd op 16 Schwartz-waarden, waaronder onafhankelijkheid (vertrouwen op jezelf), kiezen van eigen doelen (bepaling eigen levensvervulling), waarachtigheid (echtheid, puurheid), zelfrespect (geloof in eigen waarde), gelijkwaardigheid (gelijke kansen voor allen), verantwoordelijkheid (betrouwbaar, iemand op wie je kunt rekenen), ruimdenkendheid (verdraagzaamheid t.a.v. andere ideeën en geloof), wijsheid (een volwassen begrip van het leven). Door hun score op deze humanistische schaal zijn binnen de niet-religieuzen 
3 categorieën onderscheiden: de niet-humanisten, de gematigd humanisten en de humanisten. Deze indeling is door de onderzoekers gemaakt om een onderscheid te kunnen maken naar mensen die in meerdere of mindere mate humanistische waarden aanhangen. Het is niet zo dat de respondenten zichzelf expliciet als humanist hoeven te benoemen om in dit onderzoek als humanistisch te worden bestempeld. De humanistische schaal, op basis van de genoemde 16 Schwartzwaarden is toegepast op de niet-religieuze categorie, om ook binnen deze grote categorie een relevant en betekenisvol onderscheid te kunnen maken naar levensbeschouwelijke oriëntatie. Uiteraard zijn ook de religieuze categorieën te scoren op de humanistische schaal, binnen religieuze groeperingen bestaan ook meer liberale, humanistische stromingen. De categorie ongebonden spirituelen scoort op de humanistische schaal hoger dan gemiddeld, de categorieën christenen en overige religieuzen scoren hier niet afwijkend van de rest van de bevolking. De humanistische schaal is voor het bestek van dit artikel echter alleen gebruikt om een relevant levensbeschouwelijk onderscheid te kunnen maken binnen de omvangrijke niet-religieuze categorie. Er is voor gekozen om binnen de religieuze categorieën geen substromingen te onderscheiden.

De zes levensbeschouwelijke categorieën vormen niet alle zes een groep in die zin dat degenen die bij een bepaalde categorie zijn ingedeeld zich bewust zullen zijn dat zij daarbij behoren. Het onderscheid dat gemaakt is op basis van de aanhang van humanistische waarden is het resultaat van scores op een schaal, van samengevoegde houdingen, en zal niet weerspiegeld worden in de dagelijkse beleving van de eigen sociale identiteit. Maar, dit geldt niet voor elke categorie. De gebonden religieuze groepen zullen zich wel meer dan anderen bewust zijn van hun anders zijn.

Het scala aan behoeften aan zingeving wordt in dit hoofdstuk weergegeven door de antwoorden op twee vragen over zingeving, respectievelijk over wat zin aan het leven geeft en hoe men dit in keuzes die men maakte tot uitdrukking brengt. De antwoorden op deze open vragen zijn geïnventariseerd en geordend naar verschillende dimensies. De indeling is door de auteurs van dit hoofdstuk zelf gemaakt. Deze indeling blijkt valide in die zin dat, zoals uit het vervolg zal blijken, de uitkomsten van de gemaakte indeling passen bij andere kenmerken van de ondervraagden met een bepaalde levensbeschouwelijke achtergrond.

Binnen de onderscheiden dimensies, met de door de auteurs van dit hoofdstuk gegeven omschrijvingen (sociaal/moreel, transcendentie, etc.), passen de verschillende antwoordcategorieën. De belangrijkste zijn in de tabel 6.1 genoemd met de percentages van de ondervraagden die een antwoord hebben gegeven dat in deze categoriseringen paste.

Opvallend is dat de nabije ander (familie, gezin, vrienden) en God (religie, geloof in God, Allah) worden genoemd als de belangrijkste bronnen van zingeving. De sociaal/morele dimensie scoort het hoogst, gevolgd door transcendentie. Blijkbaar is datgene wat het zelf overstijgt (God of de ander) een beduidend belangrijkere bron van zingeving dan hedonisme. Een kleine minderheid geeft aan nergens in te geloven.

In de uiting van de zingeving, het antwoord op de vraag naar de manier waarop men de zin die men aan het leven geeft tot uitdrukking brengt, blijkt een zorgzame omgang met de ander overduidelijk het belangrijkst te zijn. Hier zijn de antwoorden minder exclusief dan bij de voorgaande vraag gericht op de nabije ander (gezin, familie, vrienden), maar gaat het ook om een zorgzame attitude jegens minder nabije anderen en de maatschappij. Het leven naar geloofsregels wordt door een minderheid aangegeven van belang te zijn. Dat geldt ook voor het plezier maken. Opvallend is ook dat bij de vraag naar de uiting van zingeving de dimensie transcendentie lager scoort dan hedonisme. In de handeling (de uiting) 
Tabel 6.1 Dimensies bron zingeving en uiting zingeving

\begin{tabular}{|c|c|c|c|}
\hline \multicolumn{4}{|l|}{ Dimensies zingeving } \\
\hline \multirow[t]{5}{*}{ Sociaal/moreel } & $49 \%$ & familie/gezin/vrienden & $32 \%$ \\
\hline & & respect/tolerantie/aandacht voor anderen & $10 \%$ \\
\hline & & liefde/warmte/aardig zijn voor anderen & $9 \%$ \\
\hline & & anderen/mensen (algemeen) & $5 \%$ \\
\hline & & normen en waarden proberen te behouden & $4 \%$ \\
\hline \multirow[t]{2}{*}{ Transcendentie } & $38 \%$ & religie/geloof in God/Allah & $28 \%$ \\
\hline & & spiritualiteit/'meer tussen hemel en aarde'/geloven op eigen manier & $10 \%$ \\
\hline \multirow[t]{3}{*}{ Hedonisme/egocentrisch } & $17 \%$ & met plezier/geluk/gezelligheid/lol in het leven & $10 \%$ \\
\hline & & bewust leven/gezondheid & $8 \%$ \\
\hline & & met de dag leven/je leeft maar één keer/pluk de dag & $3 \%$ \\
\hline \multirow[t]{2}{*}{ Nihilisme } & $12 \%$ & geloof nergens in/niet in God/Allah & $9 \%$ \\
\hline & & niets/geen diepere betekenis & $4 \%$ \\
\hline \multirow[t]{3}{*}{ Overige } & $24 \%$ & vertrouwen hebben(in toekomst/in mezelf) & $15 \%$ \\
\hline & & overige antwoorden & $9 \%$ \\
\hline & & weet niet/geen antwoord & $8 \%$ \\
\hline \multicolumn{4}{|l|}{ Dimensies uiting zingeving } \\
\hline \multirow[t]{5}{*}{ Sociaal/moreel } & $50 \%$ & liefde geven/aardig zijn voor anderen/behulpzaam zijn & $19 \%$ \\
\hline & & goed zijn voor familie/gezin/vrienden & $14 \%$ \\
\hline & & anderen respecteren/rekening houden met anderen/niet veroordelen & $11 \%$ \\
\hline & & anderen aandacht geven/contact houden met anderen/praten & $10 \%$ \\
\hline & & inzetten voor de maatschappij/voor de omgeving/hard werken & $8 \%$ \\
\hline \multirow[t]{4}{*}{ Hedonisme/egocentrisch } & $22 \%$ & positief blijven denken/plezier maken/gezelligheid creëren & $12 \%$ \\
\hline & & op intuïtie/gevoel afgaan/handelen & $5 \%$ \\
\hline & & gezond leven/goed eten/sporten/voor je lichaam zorgen & $3 \%$ \\
\hline & & gewoon leven/niets bijzonders & $2 \%$ \\
\hline \multirow[t]{2}{*}{ Transcendentie } & $19 \%$ & leven naar geloofsregels/de Bijbel/Koran/kerk bezoeken & $16 \%$ \\
\hline & & bidden/mediteren & $4 \%$ \\
\hline Nihilisme & $5 \%$ & doe ik niet/blijkt nergens uit & $5 \%$ \\
\hline \multirow[t]{3}{*}{ Overige } & $25 \%$ & overige antwoorden & $17 \%$ \\
\hline & & weet niet/geen antwoord & $12 \%$ \\
\hline & & weloverwogen keuzes maken/goed nadenken voor ik handel & $8 \%$ \\
\hline
\end{tabular}

Bron: Motivaction

blijkt de transcendentie dus een minder belangrijke rol te spelen dan als bron van zingeving en blijkt naast moraliteit het hedonisme ook een aandeel te hebben.

\section{Dimensies van zingeving per levensbeschouwelijke categorie}

De sociaal/morele dimensie blijkt voor alle categorieën ondervraagden belangrijk (zie figuur 6.2). Dit betreft vooral het belang van de nabije ander (gezin, familie, vrienden) als bron van zingeving. Verschillen zijn er vooral in oriëntatie op transcendentie, op nihilisme en hedonisme. De transcendentale dimensie is voor de 
Figuur 6.2

Dimensies zingeving (\%)christenen en de overige

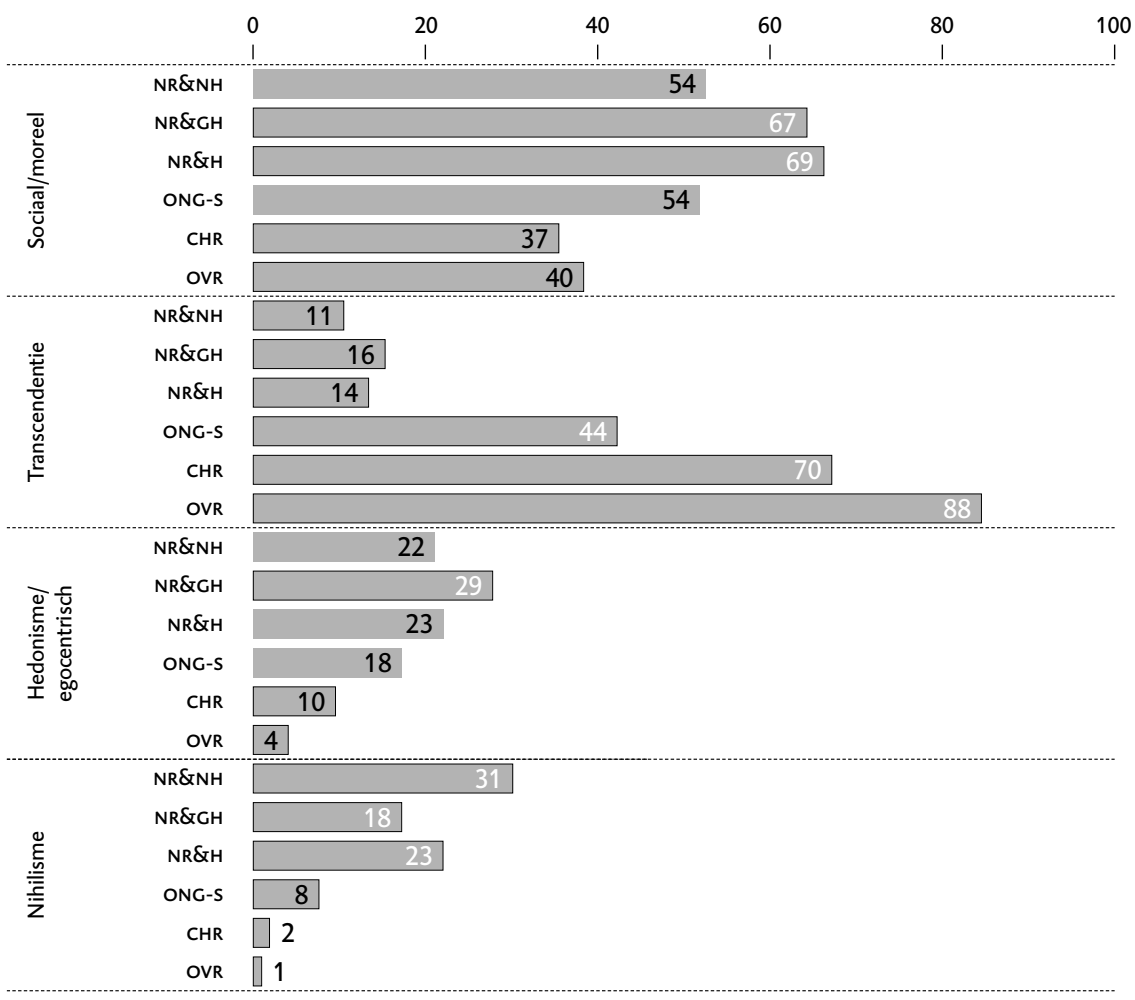

Noot: De balken met een zwarte rand geven een significant verschil aan. Binnen deze zwart omlijnde balken duiden witte waarden op een significant hoger percentage/gemiddelde en zwarte waarden op een significant lagere score ten opzichte van het totaal percentage/gemiddelde.

Bron: Motivaction

gebonden gelovigen de belangrijkste. Als we de volgorde NR\&NH, NR\&GH, NR\&H, ONG-S, CHR, OVR aanhouden, kunnen we constateren dat de nadruk op transcendentie stijgt, de sociaal/morele dimensie eerst stijgt en dan daalt, dat hetzelfde geldt voor het hedonisme, en dat het nihilisme daalt.

Ook voor de uiting van de zingeving (zie figuur 6.3) blijkt de sociaal/morele dimensie verreweg het belangrijkst te zijn voor de meeste categorieën. Voor de overige gebonden gelovigen blijft de transcendentie het belangrijkste. Bij de uiting van zingeving speelt hedonisme een meer prominente rol dan bij de vraag naar de bron van zingeving. De niet-religieuzen (NR\&NH, NR\&GH) combineren hun moraliteit met een hoge score op hedonisme. Kenmerkend is dat bij de categorie christenen transcendentie en moraliteit samen lijken te gaan en dat de categorie overige gebonden religieuzen (veelal moslims van 15-35 jaar) de laagste score heeft op de dimensie sociaal/moreel, de laagste score heeft op de dimensie hedonisme en de hoogste gerichtheid laat zien op het transcendente. De ongebonden spirituele categorie combineert de moraliteit met een hogere score op hedonisme dan op de transcendentie. 
Figuur 6.3 Dimensies uiting zingeving (\%)

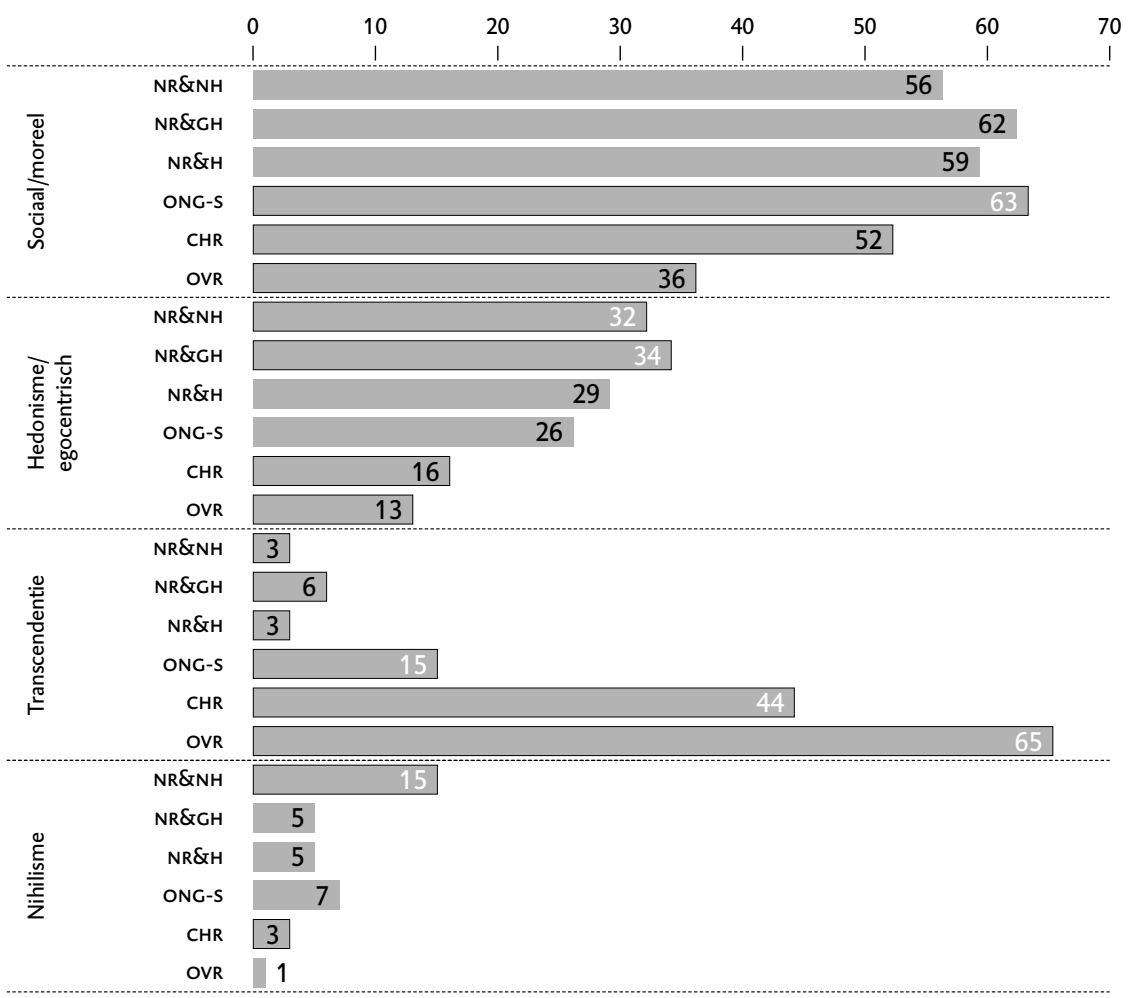

Noot: De balken met een zwarte rand geven een significant verschil aan. Binnen deze zwart omlijnde balken duiden witte waarden op een significant hoger percentage/gemiddelde en zwarte waarden op een significant lagere score ten opzichte van het totaal percentage/gemiddelde.

Bron: Motivaction

\subsection{DE NIET-RELIGIEUZE CATEGorieEN}

Zoals uit de voorgaande indeling blijkt, omvat de niet-religieuze categorie in het onderzoek een 'niet-religieuze, niet-humanistische categorie', een 'niet-religieuze, gematigd humanistische categorie' en een 'niet-religieuze, humanistische categorie'. Deze categorieën zijn onderscheiden door de antwoorden op een schaal van humanistische waarden.

\section{De niet-religieuze, niet-humanistische categorie}

De levensbeschouwing van deze categorie kenmerkt zich door een nihilistische kijk op het leven. Kenmerkend is dat deze categorie zelfbeschikking koestert, weinig tolerant is, beduidend minder op heeft met hogere 'waarden' en eerder wantrouwend in het leven staat.

In eerder onderzoek van Motivaction zijn sociaal-culturele ontwikkelingen in de Nederlandse samenleving geconstateerd die hebben geleid tot het ontstaan van een 
Tabel 6.2 Profiel van de niet-religieuze, niet-humanistische categorie

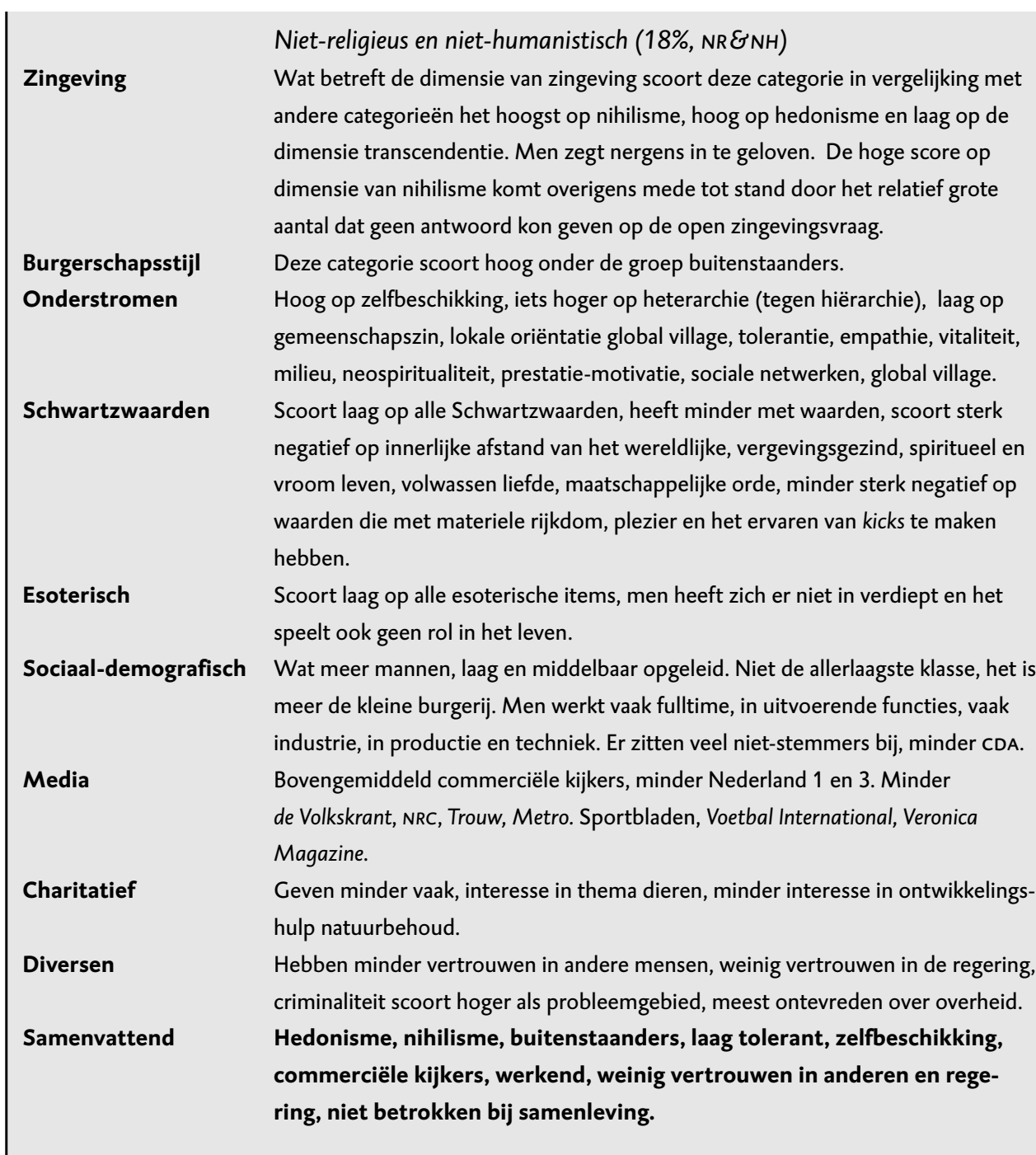

Bron: Motivaction

sociale categorie die omschreven kan worden als anomische Nederlanders, in die zin dat zij een zeker risico lopen in een anomische situatie te geraken. Deze categorie wordt getypeerd door een sterke vertegenwoordiging van buitenstaanders, mensen met een afzijdige burgerschapsstijl (Lampert et al. 2001; Spangenberg et al. 2003; WRR 2002 en 2005). Binnen deze categorie en in de interactie tussen mensen uit deze categorie en anderen, kunnen situaties ontstaan waarin gedrag niet (meer) geregeld wordt of word geregeld door niet-aanvaarde maatschappelijke normen. Deze Nederlanders staan negatief ten opzichte van transcendente waarden, zij zijn niet gelovig, maar vinden evenmin aantrekkingskracht in humanistische waarden. Zij zijn laag tolerant, voor hen speelt zelfbeschikking een belangrijke rol. Men kan vermoeden dat deze categorie gemakkelijk beïnvloedbaar is 
en dan gevoelig zal zijn voor extreme visies. Het is wel zo dat er bij deze categorie nu een sterke binding is met het werk. Risico's kunnen ontstaan als door conjuncturele omstandigheden die binding wegvalt. De vraag komt dan naar voren hoe deze categorie zo beïnvloed kan worden dat deze risico's vermeden worden. Deze vraag dringt zich mede op vanuit een historisch perspectief, dat leert dat als een aanzienlijk deel van de bevolking zich in een dergelijke situatie bevindt, dit ook op politiek gebied een weerslag heeft (zie de Duitse middenklasse in de jaren dertig).

\section{De niet-religieuze, gematigd humanistische categorie}

De levensbeschouwing van deze categorie kenmerkt zich door een hedonistische oriëntatie. De nabije ander (gezin, familie, vrienden) geeft zin aan het leven. Men is minder tolerant en minder empathisch ingesteld, is gericht op het ervaren van kicks en niet op transcendentie.

\section{Tabel 6.3 Profiel van de niet-religieuze, gematigd humanistische categorie}

\begin{tabular}{|ll} 
Zingeving & Niet-religieus en gematigd humanistisch (16\%, NR EGH) \\
& Wat betreft de dimensie van zingeving scoort deze categorie in vergelijking met \\
andere categorieën het hoogst op hedonisme en laag op de dimensie transcen- & dentie. Ook scoort deze categorie hoog op sociaal/moreel en nihilisme. Deze \\
& categorie geeft vaker aan dat familie/gezin/vrienden een diepere betekenis geven \\
& aan het leven, evenals plezier/gezelligheid en lol. \\
Burgerschapsstijl & Deze categorie is verdeeld over de burgerschapsstijlen en komt relatief minder \\
& vaak voor bij de plichtsgetrouwen. \\
Onderstromen & Hoog op zelfbeschikking, laag op neospiritualiteit, tolerantie, global village. \\
Schwartzwaarden & Scoort laag op een spiritueel leven, innerlijke afstand van het wereldlijke, laag op \\
& een vroom leven en hoog op ambitieus leven, kicks, uit je dak gaan, rijkdom, ple- \\
zier. & Scoort laag op vrijwel alle esoterische items, men heeft zich er niet in verdiept en \\
het speelt ook geen rol in het leven. \\
Esoterisch
\end{tabular}

Bron: Motivaction

\section{De niet-religieuze, humanistische categorie}

De levensbeschouwing van deze categorie kenmerkt zich door een morele oriëntatie. De nabije ander is voor deze categorie zeer belangrijk en men is tolerant, open minded ingesteld en combineert dit met een hedonistische instelling. 


\begin{tabular}{|c|c|}
\hline & Niet-religieus en humanistisch (12\%, NREH) \\
\hline Zingeving & $\begin{array}{l}\text { Deze categorie scoort het hoogst op de dimensie sociaal/moreel. Ook scoort men } \\
\text { hoger op de dimensie nihilisme en lager op transcendentie. Deze categorie geeft } \\
\text { vaker aan dat familie/gezin/vrienden een diepere betekenis geven aan het leven, } \\
\text { evenals plezier/geluk/ gezelligheid en lol. Ook geeft deze categorie in vergelijking } \\
\text { met de andere categorieën aan dat vertrouwen hebben, respect en tolerantie en } \\
\text { liefde/warmte/aandacht voor anderen een diepere betekenis geeft aan het leven. }\end{array}$ \\
\hline Burgerschapsstijl & $\begin{array}{l}\text { Deze categorie komt vaker voor onder de burgerschapsstijl pragmatici en minder } \\
\text { vaak bij de buitenstaanders en de plichtsgetrouwen. }\end{array}$ \\
\hline Onderstromen & $\begin{array}{l}\text { Hoog op zelfbeschikking, multirollen, prestatie-motivatie, strategisch navigeren, } \\
\text { technoprogressie, milieu, flexlevensvormen, sociale netwerken, tolerantie, puur } \\
\text { hedonisme, ruw hedonisme, escapisme en making magic. Lager op neospiritua- } \\
\text { liteit en law and order. }\end{array}$ \\
\hline Schwartzwaarden & $\begin{array}{l}\text { Men scoort hoog of nagenoeg hoog op alle waarden, waardeert gevarieerd leven, } \\
\text { is omnivoor in levensbeschouwelijk opzicht. Men scoort beduidend hoger op } \\
\text { genieten, lichamelijk genot, vriendschap, leren, bekwaam, intelligent, milieu, suc- } \\
\text { ces, durven, spannend leven. }\end{array}$ \\
\hline Esoterisch & Men heeft zich er wel eens in verdiept, maar het speelt geen rol in het leven. \\
\hline Sociaal-demografisch & $\begin{array}{l}\text { Meer hoger opgeleid, vaker alleenstaand/gescheiden, meer stedelijk, kleinere } \\
\text { huishoudens, vaak fulltime werkend. Minder CDA, meer GroenLinks. }\end{array}$ \\
\hline Media & $\begin{array}{l}\text { Breed, meer internationale nieuwszenders, Radio 3, meer cabaret. De Volkskrant, } \\
\text { NRC, AD, Metro, Spits, Parool, opiniebladen, Playboy, Autoweek, Voetbal Inter- } \\
\text { national, Nieuwe Revu. }\end{array}$ \\
\hline Charitatief & Minder dan gemiddeld, gevarieerd. \\
\hline Diversen & Voelt zich vaker door de samenleving in de steek gelaten. \\
\hline Samenvattend & $\begin{array}{l}\text { Sociaal/moreel, gericht op de nabije ander, pragmatici, tolerant, open } \\
\text { minded, zelfbeschikking, niet plichtsgetrouw, gevarieerd leven, omni- } \\
\text { voor. }\end{array}$ \\
\hline
\end{tabular}

Bron: Motivaction

\section{Totaalbeeld van de niet-religieuze categorie}

De niet-religieuzen onderscheiden zich van de religieuze categorieën (zie hierna) door een sterkere oriëntatie op het wereldlijke, zelfbeschikking, hedonisme en nihilisme. Deze categorie verschilt intern echter ook op vele punten (betrokkenheid, vertrouwen, tolerantie). Binnen de niet-religieuzen is een duidelijke diversiteit zichtbaar, van niet tot wel betrokken bij de maatschappij. De niet-humanistische categorie heeft weinig vertrouwen in anderen, is intolerant en heeft een sterk nihilistische oriëntatie. De gematigd humanistische categorie is gericht op de nabije ander, plezier, sterk ambitieus ingesteld en weinig tolerant. De humanistische categorie is juist tolerant, open minded ingesteld, gelooft in technologie en houdt van variëteit. Deze categorie heeft zich wel eens verdiept in esoterische zaken, maar deze spelen geen rol in het leven. 


\subsection{DE ONGEBONDEN SPIRITUELE CATEGORIE}

De levensbeschouwing van de ongebonden spirituelen kenmerkt zich door een transcendente, spirituele oriëntatie, die zich niet conformeert aan doctrines.

Deze geëmancipeerde categorie is empathisch ingesteld, gericht op harmonie met de wereld en vertrouwt op de eigen intuïtie.

De ongebonden spirituelen verschillen sterk van de overige gebonden religieuzen (moslims) en de categorie christenen. Deze nieuwe categorie is minder op religie en het leven naar geloofsregels gericht en divers samengesteld. Wat deze categorie gemeen heeft, is een sterke gerichtheid op spiritualiteit, harmonie en een hogere wereld. Ook scoren degenen die hiertoe behoren hoger dan christenen en overige gebonden religieuzen (moslims) op zelfbeschikking en emancipatie. Bij hen blijkt de spiritualiteit tot uiting te komen in een transcendente, intrinsieke motivatie die

\section{Tabel 6.5 Profiel van de ongebonden spirituele categorie}

\section{Ongebonden spiritueel (26\%, Ong. S)}

Zingeving

Burgerschapsstijl

Onderstromen

Schwartzwaarden

Esoterisch

Sociaal-demografisch

Media

Charitatief

Diversen

Samenvattend
In vergelijking met de andere categorieën scoort deze categorie hoger op de dimensie transcendentie. Ook scoort deze categorie hoog op de dimensie sociaal/moreel. Deze categorie scoort beduidend lager op de dimensie nihilisme. Religie speelt een minder belangrijke rol, spiritualiteit is belangrijker.

Deze categorie komt vaker voor binnen de burgerschapsstijl pragmatici en de burgerschapsstijl verantwoordelijken, en minder vaak onder de buitenstaanders en de plichtsgetrouwen.

Hoog op neospiritualiteit, empathie, flexibiliteit der sekserollen, zelfbeschikking, exhibitionisme, making magic, flexlevensvormen, strategisch navigeren, global village.

Hoger op een spiritueel leven, dromen, intuïtief leven, groeien, origineel zijn, loslaten, eenheid natuur, ontroering, volwassen liefde, innerlijke harmonie.

Deze categorie scoort hoger op nagenoeg alle esoterische items. Een overgrote meerderheid heeft zich erin verdiept, het speelt ook vaker een rol in het leven. Vooral hoger scoort het geloof in een hogere wereld (paranormale gaven, geesten en spirituele wezens, buitenzintuiglijke waarneming, het geloof in reïncarnatie).

Wat meer vrouwen, 35-49 jaar, stedelijker, minder vaak laag opgeleid, ietwat hogere klasse, wat vaker parttime, minder CDA.

Vaker Discovery, National Geographic, BBC, de Volkskrant, NRC.

Breed, vaker WNF, Greenpeace, Dierenbescherming, Warchild, Stop Aids Now.

Bezorgd om racisme, nationalisme, jongeren, politiek, natuur, vinden minder vaak dat politici betrouwbaar en oprecht zijn.

Transcendentie, sociaal/moreel, spiritueel, pragmatici en verantwoordelijken, zelfbeschikking, niet plichtsgetrouw, empathisch, intuïtief, hogere wereld, reïncarnatie, harmonie. 
losstaat van doctrine en een grote rol toekent aan de eigen intuïtie. In tegenstelling tot de overige gebonden religieuzen (moslims) en christenen scoren zij niet negatief op de dimensie hedonisme. Interessant is dat, waar religie soms gepaard gaat met plichtsgetrouwheid en dogma's en een grote reserve ten aanzien van licha-melijkheid en hedonisme, dat bij hen zeker niet het geval is. In het onderzoek zijn tevens een aantal esoterische items (zoals astrologie, reïncarnatie, yogaleer, werken met kristallen, etc.) meegenomen en is de vraag gesteld of men zich er wel eens in heeft verdiept en of deze zaken een rol spelen in het leven. Voor ruim de helft (53 procent) van de ongebonden spirituelen blijken een of meer van deze zaken een rol te spelen in het leven, 85 procent van hen geeft aan zich in een of meer van deze zaken te hebben verdiept.

De niet-gebonden spirituelen behoren niet tot een oudere maar eerder tot een wat jongere leeftijdscategorie. Dit is in tegenspraak met de theorie dat de alternatieve spiritualiteit een tijdelijk verschijnsel zou zijn, iets wat vooral verbonden zou zijn met de generatie die in de jaren zestig is opgegroeid (zie Heelas 2001). Volgens die theorie zou het christendom langzamerhand overschaduwd worden door alternatieve en ongebonden vormen van spiritualiteit. Met het ouder worden en langzamerhand verdwijnen van de groep die deze vorm van zingeving aanhangt, zou geleidelijk de religieuze vlam uitdoven. Voor de geldigheid van deze theorie, met name het gebonden zijn aan de oudere generatie van de spiritualiteit, is in de cijfers van het onderzoek geen aanwijzing te vinden. Er lijkt eerder sprake te zijn van een opgekomen categorie spiritueel bewusten, die breder en ook meer van deze tijd is dan de met connotaties rondom flowerpower beladen term new age doet vermoeden. Het zijn mensen met een bepaalde leefstijl die zich niet gebonden achten aan een bepaalde groep, organisatie of geestelijk leider, zoals dat dikwijls wel het geval was bij het begin van de new-agebeweging in de jaren zeventig van de vorige eeuw.

Verder willen wij bij dit profiel nog de volgende opmerkingen maken. De combinatie van het idee van een toegenomen zelfbeschikking en emancipatie met een behoefte aan transcendentie en de opmars van een alternatieve, gepersonaliseerde beleving van het transcendente, is bij deze buitenkerkelijke groepering zichtbaar. Transcendentie gaat bij hen gepaard met een geëmancipeerde instelling en een intrinsieke motivatie. Transcendentie is praktisch bruikbaar, het is bijvoorbeeld goed voor de gezondheid en voor het harmonieuze maatschappelijke functioneren van de persoon.

Bij de ongebonden spirituelen is er sprake van een divers zingevings- en uitingsaanbod. Voor hen zijn de functionele equivalenten zeer divers, onder meer de centra voor yoga en intuïtieve ontwikkeling, de sterk gegroeide spirituele boekenmarkt, mental coaches, regressietherapeuten, mediums, praatgroepen, et cetera. Deze gaan wel degelijk samen met nieuwe bindingen, maar zijn niet geïnstitutionaliseerd. Het succes van de Da Vinci code, de KRO-serie 'Wie was ik?' en mediums als Char en Jomanda passen in dit patroon, alsook de feelgood-televisieprogramma's Dr. Phil en Oprah, waarbij niet zozeer sprake is van transcendentie, 
maar wel van het geloof dat ieder mens een hoger doel heeft om zijn of haar talenten tot wasdom te laten komen. Ook moet in dit verband gewezen worden op de relatie van een spirituele oriëntatie met de aandacht voor de individuele gezondheid, met massages, healings, acupunctuur en acupressuur, wellness, etherische oliën, geneeskrachtige kristallen, relax-cd's, et cetera. Dit is een aanzienlijk segment in de religieuze markt, waarvoor in Nederland vooralsnog toch nog relatief weinig aandacht is (in tegenstelling tot de Verenigde Staten en Duitsland).

Als geheel lijkt deze categorie karakteristiek voor de door Inglehart beschreven postmaterialisten. Inglehart ziet het postmaterialisme als een leefstijl die het resultaat is van de economische ontwikkeling. Volgens Inglehart is het kenmerkend voor postmaterialisten dat zij zich minder zorgen maken om materiële zaken. Dat hoeven zij ook niet doordat hun bestaanszekerheid groter is. Dit heeft weer tot gevolg dat zij de religie, die verbonden zou zijn met bestaansonzekerheid, niet meer nodig hebben (Norris en Inglehart 2004; Inglehart et al. 2004: 7 e.v.). Economische en fysieke zekerheid worden minder belangrijk, men kiest in grotere vrijheid.

Uit het voorgaande blijkt ook dat enkele aanvullingen nodig zijn op de beschrijving van Inglehart. Men heeft in postmaterialistische kringen inderdaad kennelijk geen behoefte meer aan een geïnstitutionaliseerde, gebonden religie, maar staat open voor alternatieve, meer op het individu gerichte vormen van spiritualiteit. Het is opmerkelijk dat het transcendente onder deze postmaterialistische categorie niet is verdwenen, maar nog sterk aanwezig is. Een ander opmerkelijk feit is dat parallel aan de opkomst van de postmaterialisten ook een belangrijke categorie is ontstaan van buitenstanders, waarvan de leefstijl bepaald niet als postmaterialistisch omschreven kan worden: de hiervoor beschreven niet-religieuze, niet-humanistische categorie. Het ontstaan van deze categorie was niet te verwachten als enkel uitgegaan wordt van de theorie van Inglehart.

\subsection{DE RELIGIEUZE CATEGORIEËN}

Binnen de religieuze categorie kan een onderscheid worden aangebracht tussen christenen en overige gebonden religieuzen. Onder de christelijke groepering vallen de respondenten die te categoriseren zijn onder de groepen: rooms-katholiek (9 procent), protestant, gereformeerd, hervormd (1o procent) en de overige christelijke groepen (algemeen, baptist, evangelisch, apostolisch, 6 procent). De categorie christenen kenmerkt zich door een levensbeschouwing die gericht is op transcendentie, naastenliefde, solidariteit en gemeenschapszin en het leven naar geloofsregels.

Bij dit profiel kan nog het volgende worden opgemerkt. Christenen zijn nog steeds een relatief grote categorie in de samenleving, maar er gaan wel steeds minder christenen wekelijks naar de kerk en de kerkbezoekers vergrijzen. Rondom rituelen zoals geboorte, dood en trouwen wordt nog steeds een beroep gedaan op de kerk. Functionele equivalenten van het kerkbezoek in de huidige gemediatiseerde tijd zijn televisie-uitzendingen van bijvoorbeeld The Hour of 


\begin{tabular}{|c|c|}
\hline & Christenen (25\%, Chr.) \\
\hline Zingeving & $\begin{array}{l}\text { Hoog op transcendentie, lager op sociaal/moreel, hedonisme, nihilisme. Religie/ } \\
\text { geloof in God speelt een grote rol. Liefde geven, aardig zijn, klaar staan voor een } \\
\text { ander speelt een belangrijke rol, als ook het leven naar geloofsregels en de kerk } \\
\text { bezoeken. }\end{array}$ \\
\hline Burgerschapsstijl & $\begin{array}{l}\text { Deze categorie komt vaak voor binnen de burgerschapsstijl plichtsgetrouwen en } \\
\text { minder vaak onder de pragmatici en buitenstaanders. }\end{array}$ \\
\hline Onderstromen & $\begin{array}{l}\text { Hoog op gemeenschapszin, collectief ervaren, law and order, individualiserings- } \\
\text { angst, lokale oriëntatie, milieuweten, neospiritualiteit. Laag op zelfbeschikking, } \\
\text { heterarchie, geweldsfascinatie, puur en ruw hedonisme, making magic, esca- } \\
\text { pisme, polysensualiteit, flexlevensvormen, flexsekserollen, multirollen. }\end{array}$ \\
\hline Schwartzwaarden & $\begin{array}{l}\text { Hoger op vroom leven, innerlijke afstand van het wereldlijke, bescheidenheid, } \\
\text { nederig, gematigdheid, gehoorzaam. Lager op genieten, gevarieerd leven, licha- } \\
\text { melijk genot, intuïtief leven, spannend leven, rijkdom, dromen, kicks ervaren, uit } \\
\text { je dak gaan. }\end{array}$ \\
\hline Esoterisch & $\begin{array}{l}\text { Hoger op meditatie, gebedsgenezing, bedevaart. Lager op buitenaardse } \\
\text { wezens/ufo's, tarot, magie. }\end{array}$ \\
\hline Sociaal-demografisch & $\begin{array}{l}\text { Vaker vrouw, vaker ouder dan 50, gehuwd/samenwonend, minder stedelijk, } \\
\text { gepensioneerd, CDA, ChristenUnie/sGP. }\end{array}$ \\
\hline Media & $\begin{array}{l}\text { Vaker Nederland } 1 \text { en 2, lokale/regionale televisie, Radio } 1 \text { en 2, Classic FM, } \\
\text { regionaal dagblad, Trouw, Libelle, Margriet. }\end{array}$ \\
\hline Charitatief & $\begin{array}{l}\text { Geven bijna overal bovengemiddeld. Hoger op noodhulp, voorkomen ziektes, } \\
\text { ontwikkelingshulp, vluchtelingenhulp. Lager op bescherming van dieren. }\end{array}$ \\
\hline Diversen & $\begin{array}{l}\text { Hoger op politici zijn betrouwbaar en oprecht, meer toegewijde leiders waar het } \\
\text { volk vertrouwen in kan hebben, meer vertrouwen in overheid. Meer bezorgd om } \\
\text { zorg, normen en waarden, minder om nationalisme, economie, politiek. }\end{array}$ \\
\hline Samenvattend & $\begin{array}{l}\text { Transcendentie, naastenliefde, gemeenschapszin, plichtsgetrouw, vroom, } \\
\text { bescheidenheid, gematigdheid, vertrouwen in overheid, niet-hedonis- } \\
\text { tisch, laag op zelfbeschikking. }\end{array}$ \\
\hline
\end{tabular}

Bron: Motivaction

Power uit de Crystal Cathedral in Californië (in 16o landen) en de drukbezochte EO-jongerendagen. Vooral in de grote stad is er bij migrantengroepen sprake van het ontstaan van evangelische stromingen, waarin een vreugdevolle gedeelde beleving van de godsdienst een belangrijke rol speelt.

\section{Overige gebonden religieuzen}

Tot de categorie overige gebonden religieuzen behoren voor het overgrote deel respondenten die moslim zijn ( 2,7 procent, $n=55)$ en enkele respondenten $(n=7)$ die behoren tot de stromingen jodendom, boeddhisme en het hindoeïsme. In het oog dient gehouden te worden dat het aantal ondervraagden in deze categorie klein is en dat het vooral de jongere generatie betreft, die heeft meegedaan aan het Nederlandstalige onderzoek. De resultaten voor deze categorie dienen 
derhalve te worden beschouwd als indicatief. De levensbeschouwing van deze categorie kenmerkt zich door een nadruk op transcendentie, een groot belang van familie en het leven naar de geloofsregels van (vooral) de Koran.

\section{Tabel 6.7 Profiel van de overige gebonden religieuze categorieën}

\begin{tabular}{|c|c|}
\hline & Overige gebonden religieuzen (3\%, Ovrg R) \\
\hline Zingeving & $\begin{array}{l}\text { Hoog op transcendentie, lager op sociaal/moreel, hedonisme, nihilisme. Religie/ } \\
\text { geloof Allah speelt een grote rol. Leven naar geloofsregels / Koran. Hoger op wel- } \\
\text { overwogen keuzes maken en bidden/mediteren. }\end{array}$ \\
\hline Burgerschapsstijl & Gespreid over burgerschapsstijlen. \\
\hline Onderstromen & $\begin{array}{l}\text { Hoger op tolerantie, geweldsfascinatie, bonte wereld, global village, sociale net- } \\
\text { werken, neospiritualiteit, strategisch navigeren. Lager op zelfbeschikking, flex- } \\
\text { sekserollen, flexlevensvormen, heterarchie, milieu, onthaasten, huisvrede. }\end{array}$ \\
\hline Schwartzwaarden & $\begin{array}{l}\text { Hoger op eren ouders, schoon, zelfdiscipline, respect voor traditie, succesvol, } \\
\text { fijnzinnigheid, behoud publieke imago, familiereputatie, innerlijke afstand van het } \\
\text { wereldlijke, schaamte, spiritueel leven, vroom leven, kicks ervaren, invloedrijk } \\
\text { zijn. Lager op vakmanschap, genieten van het leven. }\end{array}$ \\
\hline Esoterisch & $\begin{array}{l}\text { Deze categorie heeft zich er vaker in verdiept, speelt ook vaker een rol in het } \\
\text { leven. Hoger op bedevaart, geesten en spirituele wezens, magie, gebedsgenezing, } \\
\text { meditatie. }\end{array}$ \\
\hline Sociaal-demografisch & $\begin{array}{l}\text { Beduidend vaker } 15-34 \text { jaar, van Turkse/Marokkaanse afkomst, inwonend bij } \\
\text { ouders, grotere huishoudens, lagere sociale klasse, vaker westen van het land } \\
\text { (zonder } 3 \text { grote steden), student, PvdA en niet-stemmers. }\end{array}$ \\
\hline Media & $\begin{array}{l}\text { Vaker Yorin, Veronica 8, TMF, MTV, Spits, Metro, Algemeen Dagblad, Autoweek, } \\
\text { Voetbal International, Yes, Sportweek, Cosmopolitan, Celebrity, Quote. }\end{array}$ \\
\hline Charitatief & $\begin{array}{l}\text { Geeft beduidend minder vaak, aansprekende thema's zijn ontwikkelingshulp, } \\
\text { beschermen rechten minderheden en vluchtelingenhulp. Lager op bescherming } \\
\text { van dieren en natuurbehoud. }\end{array}$ \\
\hline Diversen & $\begin{array}{l}\text { Lager op politici zijn betrouwbaar en oprecht. Meer bezorgd om economie, nati- } \\
\text { onalisme/racisme, minder om zorg, immigratie en criminaliteit. }\end{array}$ \\
\hline Samenvattend & $\begin{array}{l}\text { Transcendentie, leven naar Koran, familiereputatie, schaamte, vroom, } \\
\text { tolerant, minder open voor andere samenlevingsvormen en sekserollen, } \\
\text { laag op zelfbeschikking. }\end{array}$ \\
\hline
\end{tabular}

Bron: Motivaction

In het beschreven profiel is de invloed van islamitische opvattingen merkbaar in het belang van eer, schaamte en reputatie, het leven naar geloofsregels en een lagere nadruk op culturele vrijheden. Mogelijk vallen de in Nederland gebruikelijke vormen van caritas niet onder de steun die men in deze kring aan anderen geeft. Er kan bij dit profiel sprake zijn van een spanning met hedonistische, vrije en ook nihilistische opvattingen die door anderen worden aangehangen. Tegelijkertijd moet ook de relatief jonge leeftijd van deze categorie ondervraagden worden benadrukt, wat zeker een effect heeft op de scores op de verschillende dimensies van het profiel. Bijvoorbeeld, de hogere score op geweldsfascinatie 
wijkt niet af van de score in andere categorieën als rekening wordt gehouden met de verschillen in leeftijd.

In het algemeen moet ervoor gewaakt worden zonder meer een causale relatie te veronderstellen tussen de levensbeschouwing en de scores op de dimensies van de verschillende profielen. Die scores kunnen zowel het resultaat zijn van de levensbeschouwing als van de maatschappelijke achtergronden en sociaal-demografische kenmerken die verschillend zijn voor de leden van de verschillende levensbeschouwelijke categorieën. Dat neemt niet weg dat de combinatie van de verschillende andere kenmerken en achtergronden met de levensbeschouwing de identiteit vormt van de levensbeschouwelijke categorie en bepalend is voor de maatschappelijke pluriformiteit en de sociale cohesie.

\section{Totaalbeeld van de religieuze categorieën}

De religieuze categorieën (inclusief de ongebonden spirituelen) verbinden zich door een transcendente oriëntatie en een zekere afstand van het wereldlijke. Verder verschillen zij onderling op vele punten (zelfbeschikking, emancipatie, hedonisme, eer); zij zijn zeker niet als homogeen te beschouwen.

Wat de zingeving betreft scoren de twee gebonden religieuze categorieën ongeveer gelijk op de verschillende dimensies van de zingevingsvragen. Wel wordt duidelijk dat de overige gebonden religieuzen (moslims) in nog sterkere mate gericht zijn op het transcendente dan de christenen en dat de overigen bij de uiting van zingeving lager scoren op de dimensie moreel/sociaal. Zij onderscheiden zich ook bij de onderstromen, de Schwartzwaarden en de esoterische waarden. Hierin komt vooral het verschil tussen de islam en het christendom tot uitdrukking. Bij de christenen is er een sterke gerichtheid op naastenliefde en bij de overige gebonden religieuzen (moslims) een sterkere gerichtheid op de familiereputatie en het leven naar de geloofsregels. Kenmerkend is dat zowel de categorie christenen als de categorie overigen (moslims) een lage score heeft op zelfbeschikking.

\subsection{RELIGIE EN BURGERSCHAP}

Er zijn vragen gesteld over maatschappelijke bindingen: arbeidsparticipatie, media, charitatieve bijdragen en burgerschap. De weerslag hiervan was al zichtbaar in de verschillende profielen. Wij geven nu nog aanvullende informatie over dit onderwerp (zie ook tabel B-1 en figuur B-1 in de bijlage).

\section{Burgerschapsstijlen}

In eerder onderzoek, ten behoeve van de Commissie Toekomst Overheidscommunicatie, heeft Motivaction op basis van haar Mentality-onderzoek een kerntypologie van burgerschapsstijlen ontwikkeld (Motivaction 2001). Deze eerste typologie is op basis van diverse onderzoeken (waaronder WRR 2006) aangescherpt tot een viertal kerntypen, namelijk plichtsgetrouwen, verantwoordelijken, pragmatici en buitenstaanders. Deze stijlen worden in de WRR-rapporten 
De toekomst van de nationale rechtsstaat (2002) en Vertrouwen in de buurt (2006) ook wel aangeduid als afhankelijken, actieven, afwachtenden en afzijdigen.

Burgers met een plichtsgetrouwe burgerschapsstijl zijn sterk maatschappelijk betrokken, vooral bij de directe leefomgeving en de lokale overheid. Zij worden gedreven door een volgzame instelling en zijn in principe bereid zich te schikken naar het overheidsbeleid. Ze zien in de overheid een autoriteit die zij respecteren en die weet wat goed is voor de burger. Wel zijn ze behoudend ingesteld en hebben zij moeite met de complexiteit en het individualisme in de huidige maatschappij. Overheidsbeleid dat deze zaken stimuleert kan dus op weerstand stuiten van deze categorie. Vanwege hun volgzame instelling leidt dit veelal niet tot openlijke protesten maar tot onuitgesproken politieke onvrede. De categorie christenen is in de burgerschapsstijl plichtsgetrouwen beduidend oververtegenwoordigd en de grootste categorie binnen de plichtsgetrouwen. De ongebonden spirituelen, alsook de categorie niet-religieus en (gematigd) humanistisch komen binnen de plichtsgetrouwen gemiddeld minder vaak voor.

De verantwoordelijken worden gedreven door een maatschappelijke betrokkenheid en door de publieke zaak. Zij voelen zichzelf hiervoor in hoge mate verantwoordelijk. Zij zien de overheid als een belangrijk instrument om die publieke zaak te dienen en nemen een coöperatieve maar kritische houding aan ten aanzien van de overheid. Vaak werken verantwoordelijken zelf ook bij de overheid, of bijvoorbeeld in charitatieve instellingen en de journalistiek. Men is doorgaans ook goedgeïnformeerd over overheidsbeleid. De ongebonden spirituelen zijn bovengemiddeld vertegenwoordigd binnen de verantwoordelijken en vormen de grootste categorie binnen dit segment. Ook christenen zijn sterk vertegenwoordigd en zijn een grote categorie. De niet-religieuze en niet-humanistische categorie is sterk ondervertegenwoordigd binnen de verantwoordelijken. Interessant is dat, op basis van hun oriëntaties, er aanwijzingen zijn dat binnen de groepering van verantwoordelijken de ongebonden spirituelen een andere perceptie hebben van leiderschap dan de christenen. Christenen vinden gehoorzaamheid en normstellend optreden meer vanzelfsprekend en zullen zich als bewindspersoon van nature meer leidend en normstellend opstellen, terwijl de ongebonden spirituelen juist van nature niet plichtsgetrouw zijn en meer vrijblijvend zijn ingesteld; iedereen moet namelijk zijn eigen waarheid vinden en over anderen oordelen is not done. Naar verwachting zal deze categorie als leider of bewindspersoon anderen minder directief aanspreken op hun gedrag en zich minder normstellend en juist meer empathisch opstellen. Wanneer dit wordt verbonden met het effect van leiderschapsstijlen op mensen met een andere burgerschapsstijl, zoals bijvoorbeeld de buitenstaanders, die verwachten dat leiders en bewindspersonen daadkrachtig optreden, worden interessante patronen zichtbaar, bijvoorbeeld in het licht van de kloof die zichtbaar werd tussen de groep buitenstaanders en verantwoordelijken ten tijde van de opkomst van Fortuyn in 2001.

De pragmatici zijn utilitaire individualisten met een sterke materialistische gedrevenheid. Niet de publieke zaak maar het eigenbelang staat voorop en dit uit 
zich in selectieve interesse voor overheidsbeleid. Men filtert informatie van de overheid op relevantie voor de eigen positie. Als het niet relevant is, wordt er verder geen aandacht aan besteed. Men is dus op onderdelen betrokken bij de overheid en geïnformeerd over overheidsbeleid. Over het algemeen is deze categorie minder negatief over de overheid dan de buitenstaanders, ook al is men zeker niet volgzaam (zoals de plichtsgetrouwen) en is men het zeker niet altijd eens met de overheid. De ongebonden spirituelen zijn oververtegenwoordigd en vormen binnen de pragmatici de grootste categorie. Ook de niet-religieuze, humanistische categorie is oververtegenwoordigd. Christenen en de niet-religieuze, niet-humanistische categorie zijn ondervertegenwoordigd.

Buitenstaanders zijn maatschappelijk weinig betrokken, maar worden wel veelal gedreven door een behoefte aan maatschappelijke erkenning. Men voelt zich echter meestal niet erkend door de overheid, men voelt zich buitengesloten. Hiermee hangt samen dat men over het algemeen weinig vertrouwen heeft in de overheid, weinig interesse heeft voor het overheidsbeleid en negatief staat tegenover maatschappelijke verplichtingen. Deze categorie voelt zich niet (meer) verbonden met enig maatschappelijk instituut. Dit wil overigens niet zeggen dat dit segment zich nooit uitspreekt over overheidsbeleid: het ervaren isolement van deze categorie kan een voedingsbodem vormen voor plotselinge verhoogde politieke betrokkenheid en protestacties. Verschillende vormen van directe democratie vinden ook veel aanhang in deze categorie. Bovendien kenmerken buitenstaanders zich door de roep om leiderschap en een negatieve houding ten aanzien van uitbreiding van wet- en regelgeving. Binnen de buitenstaanders is de niet-religieuze, niet-humanistische categorie oververtegenwoordigd enhet grootste segment. De ongebonden spirituelen, christenen en de humanistische categorie zijn beduidend minder vertegenwoordigd binnen de buitenstaanders.

\section{Participatie in werk en liefdadigheid}

Opvallend is dat de niet-religieuze categorie vaker een volledige baan heeft dan de religieuze categorieën. De ongebonden spirituelen werken vaker in deeltijd en de christenen zijn (mede door hun hogere leeftijd) vaker met pensioen of werken als huisvrouw. Werk blijkt op het alledaagse activiteitenpatroon van de niet-religieuzen een groter beslag te leggen en is voor de categorie niet-religieuzen naar verwachting een belangrijker kader voor de dagelijkse activiteiten dan voor de ongebonden spirituelen en de christenen. Het verwerven van een inkomen is uiteraard ook van belang om te voorzien in de materialistische en hedonistische behoeften die zo kenmerkend zijn voor deze categorie.

Ook is kenmerkend dat de niet-religieuzen qua politieke oriëntatie verschillen van de religieuzen. Niet-religieuzen stemmen vaker VVD en LPF en ook de niet-stemmers zijn onder hen sterker vertegenwoordigd. Zelfbeschikking, individualisme, hedonisme en materialisme spelen bij de niet-religieuze categorieën een belangrijkere rol dan bij de religieuze categorieën. Christenen stemmen (uiteraard) vaker CDA en de overige gebonden religieuzen (vooral jonge moslims) stemmen vaker PVDA of stemmen niet. 
Wat de liefdadigheid betreft, deze krijgt vooral aandacht van de christenen; naastenliefde en bekommernis om de zwakkeren spelen hierin een belangrijke rol. Als deze categorie in de kerkelijke organisatie minder actief wordt, zal daarmee tegelijkertijd de structurele steun voor charitatieve instellingen veranderen en misschien op termijn ook verminderen. In plaats van een persoonlijke actieve inzet in de omgeving van de kerk, kan men de bijdrage beperken tot financiële steun (het giro-activisme als compensatie voor het ontbreken voor een persoonlijke inzet). Als vervolgens het aantal christenen afneemt, neemt ook het financiële draagvlak af.

\section{Totaalbeeld van religie en burgerschap}

Het blijkt dat een humanistische of transcendente oriëntatie beduidend vaker samengaat met actief en verantwoordelijk burgerschap. Wanneer deze oriëntatie ontbreekt, blijkt men in de levensbeschouwing meer gericht op hedonisme, individualisme en materialisme. De meest bij de maatschappij betrokken burgers zijn de humanistische categorie, de ongebonden spirituelen en de christenen. Het minst bij de maatschappij betrokken is de niet-religieuze, niet-humanistische categorie.

\subsection{TOT SLOT}

Het totale beeld van de analyse past in de dynamiek van de religieuze transformatie. De behoefte aan transcendentie is bij een groot deel van de bevolking zichtbaar, maar is niet meer exclusief verbonden met geïnstitutionaliseerde religies. Naast de christenen en anderen met een gebonden religie, is er een categorie ongebonden spirituelen opgekomen, die meer de transcendentie zoekt vanuit een intrinsieke motivatie en niet vanuit de geloofsregels van een religieuze organisatie. De ongebonden spirituelen hebben kennelijk alternatieven buiten de wereldreligies gevonden om in de zingevingsbehoeften te voorzien.

Het is niet zo dat het niet-religieuze deel van de bevolking in sterke mate op drift is op zingevingsgebied. Er lijkt zich een patroon uit te kristalliseren van een tweedeling tussen humanisten en niet-humanisten. Het wordt wel eens verondersteld dat Nederland een seculiere samenleving is waarin humanistische waarden algemeen verbreid zijn. Er is echter onder de niet-gelovigen naast de humanisten een categorie die laag scoort op humanistische waarden en transcendentie en die geen interesse heeft voor esoterische zaken. In deze groepering is er sprake van nihilisme en een risico op anomie.

Over functionele equivalenten voor het religieuze aanbod valt op grond van de analyse nog het volgende te melden. Er is een grote (niet-religieuze) categorie die individualistisch, hedonistisch en materialistisch is ingesteld en waarvoor de markt een divers aanbod en zingevingskader poogt te bieden (commerciële zenders gericht op vermaak, merken (brands), belevingen, festivals, reclamecampagnes). De markt verleidt tot het hier en nu consumeren, cultiveert onvrede en verlangens en biedt door haar versnippering en continue verandering geen verbindend, fundamenteel of transcendenteel (hoger) zingevingskader zoals reli- 
gie dat wel doet. Men kan dit verschijnsel ook typeren als het ontstaan van een belevenissenmaatschappij (Erlebnisgesellschaft: Schulze 1992). Het beeld, het merk, de consumptie van het product en de lichamelijke ervaring staan centraal. Het gaat om de belevenissen die men daarmee kan verbinden. Goed is dat wat effect geeft en een belevenis veroorzaakt. Dat effect is niet op de maatschappij of een hogere werkelijkheid maar op het individu zelf betrokken. Het zelf, de individuele prikkels en de nabije ander zijn voor de niet-religieuzen de belangrijkste bron van zingeving.

\section{Sociale cohesie}

Wat de sociale cohesie betreft is de nabije ander in de huidige, seculiere tijd kennelijk belangrijker als zingevingskader dan transcendentie. Voor de meeste mensen zijn persoonlijke betrekkingen het belangrijkste, daarmee wordt het eventueel aanwezige geloof verbonden (Jörns 1999: 28). De kring waarvoor men zorgzaam is, is beperkt tot de nabije ander. Het soort naastenliefde dat in sterke mate behoort bij het christendom, waarmee een deel van de ondervraagden zich verbonden voelt, gaat wel gepaard met een grote steun voor liefdadigheid op grotere afstand, ook over de grenzen heen.

Met de transformatie van de religie is de plichtsgetrouwheid afgenomen en blijkt het individualisme van de niet-religieuze categorieën prominent aanwezig in de samenleving. Binnen de niet-religieuze categorieën is er vaker sprake van een risico op anomie, zeker bij de categorie die ook geen humanistische waarden aanhangt. Dat men leeft in een sociale orde die men niet accepteert, kan gezien worden als een kenmerk van anomie. In de terminologie van Durkheim (1893) is dit een vorm van anomie die verbonden is met een gedwongen maatschappelijke arbeidsverdeling, die negatief uitwerkt op de solidariteit met anderen in de samenleving. In de categorie waar het hier om gaat blijkt men negatief over politiek en overheid te denken en heeft men geen binding met humanistische of religieuze waarden. Deze categorie is nihilistisch en is waarschijnlijk gevoelig voor populisme. Met de opkomst van de niet-religieuze, in het bijzonder de niet(of gematigd) humanistische categorieën, waarin zelfbeschikking een leidende rol speelt, staat de samenleving als totaal minder afwijzend ten opzichte van eigenrichting. Bij hen is het lontje nu eenmaal korter. Men kan echter nog niet zeggen dat voor deze categorieën elke sociale binding ontbreekt waardoor onmiddellijk risico's ontstaan. Dat is niet het geval zolang er nog een maatschappelijke binding is via het werk.

De georganiseerde religie geeft geen duidelijke maatschappelijke identiteit meer aan het grootste deel van de bevolking. Er is een grote pluriformiteit in de verschijningsvormen van religie, er zijn ook niet-religieuze varianten die in zingevingsbehoeften voorzien. Er is sprake van een zekere privatisering van de zingeving, die los komt te staan van vroegere vormen van maatschappelijke binding en participatie. Elk gezichtspunt is onderdeel van een leefstijl en wordt gezien als iets persoonlijks en daardoor relatief. Als alles waar is, is niets waar voor iedereen. Men verlangt er niet naar de ander te overtuigen van de waarde 
van de eigen visie en men wil zich niet meer daarvoor inzetten. Dit kan als consequentie hebben dat het levensbeschouwelijk pluralisme geen rol meer speelt in de maatschappelijk-politieke werkelijkheid en dat de democratie die oorspronkelijk gebaseerd is op dat pluralisme, verarmt (zie ook: Wuthnow 2006). De democratie kan verder risico's lopen door een toegenomen neiging tot eigenrichting en door de opgekomen categorie buitenstaanders

In de huidige situatie met de nu voorkomende verdeling van de bevolking naar levensbeschouwing, is een scenario denkbaar waarin de sociale cohesie onder druk komt te staan door tegenstellingen zoals die tot uitdrukking komen in de profielen, in het bijzonder de profielen van de categorie niet-religieus en niet-humanistisch en van de categorie overige religieuzen. Dit risico kan verminderen als degenen die daartoe in staat zijn leiding willen en durven te geven. Er is een grote groepering, 28 procent, met een burgerschapsstijl die als verantwoordelijk kan worden omschreven. Zeker van die groepering mag een inbreng in de democratie op levensbeschouwelijk gebied verwacht worden. Dat is een probleem maar het is ook nodig in een cultuur waarin de levensbeschouwing word t gerelativeerd en enkel opgevat als nuttig voor het persoonlijke heil en niet als het begin van een betere wereld.

\subsection{CONCLUSIES}

1. Er is sprake van een religieuze transformatie, waarbij de behoefte aan transcendentie niet meer exclusief is verbonden met geïnstitutionaliseerde religies: een ongebonden spirituele categorie is opgekomen.

2. Binnen de niet-religieuze categorie zijn er categorieën met en zonder een humanistische levensoriëntatie. De categorie zonder humanistische oriëntatie neigt tot anomie, eigenrichting en nihilisme en stelt zich rigide en individualistisch op. Er is een toenemend maatschappelijk risico van spanningen, vanwege de opkomst van deze categorie en haar verhouding tot de religieuze categorieën.

3. De niet-religieuze categorieën zijn beduidend meer materialistisch, hedonistisch en individualistisch ingesteld dan de religieuze categorieën. De markt en de beleveniseconomie biedt hun een belangrijk zingevingskader.

4. De nabije ander is in de hedendaagse tijd het belangrijkste zingevingskader, daarna volgen de transcendentie en het hedonisme.

5. Religie geeft geen duidelijke maatschappelijke identiteit meer aan het individu zoals voorheen, er is sprake van een privatisering van de zingeving en een koppeling aan een bepaalde leefstijl.

6. Een humanistische of transcendente oriëntatie gaat vaak samen met een actief en verantwoordelijk burgerschap. Wanneer deze oriëntatie ontbreekt, is men doorgaans weinig betrokken bij de samenleving. Voor het burgerschap zijn de genoemde oriëntaties bevorderlijk.

7. Van de categorie met een actieve, verantwoordelijke burgerschapsstijl mag leiderschap worden verwacht, ook op levensbeschouwelijk terrein, in de vormgeving van een betere wereld. Deze groep zou zich meer leidend en kaderstellend moeten opstellen. Meer aandacht voor zingeving komt (de ontwikkeling van) burgerschap ten goede. 


\section{BIJLAGE}

\section{ENKELE KERNGEGEVENS VAN DE LEVENSBESCHOUWELIJKE PROFIELEN}

In de figuren B-4 t/m B-11 geven de balken met een zwarte rand een significant verschil aan. Binnen deze zwart omlijnde balken duiden witte waarden op een significant hoger percentage/gemiddelde en zwarte waarden op een significant lagere score ten opzichte van het totaal percentage/gemiddelde.

Burgerschapsstijl

Figuur B-1 Burgerschapsstijlen

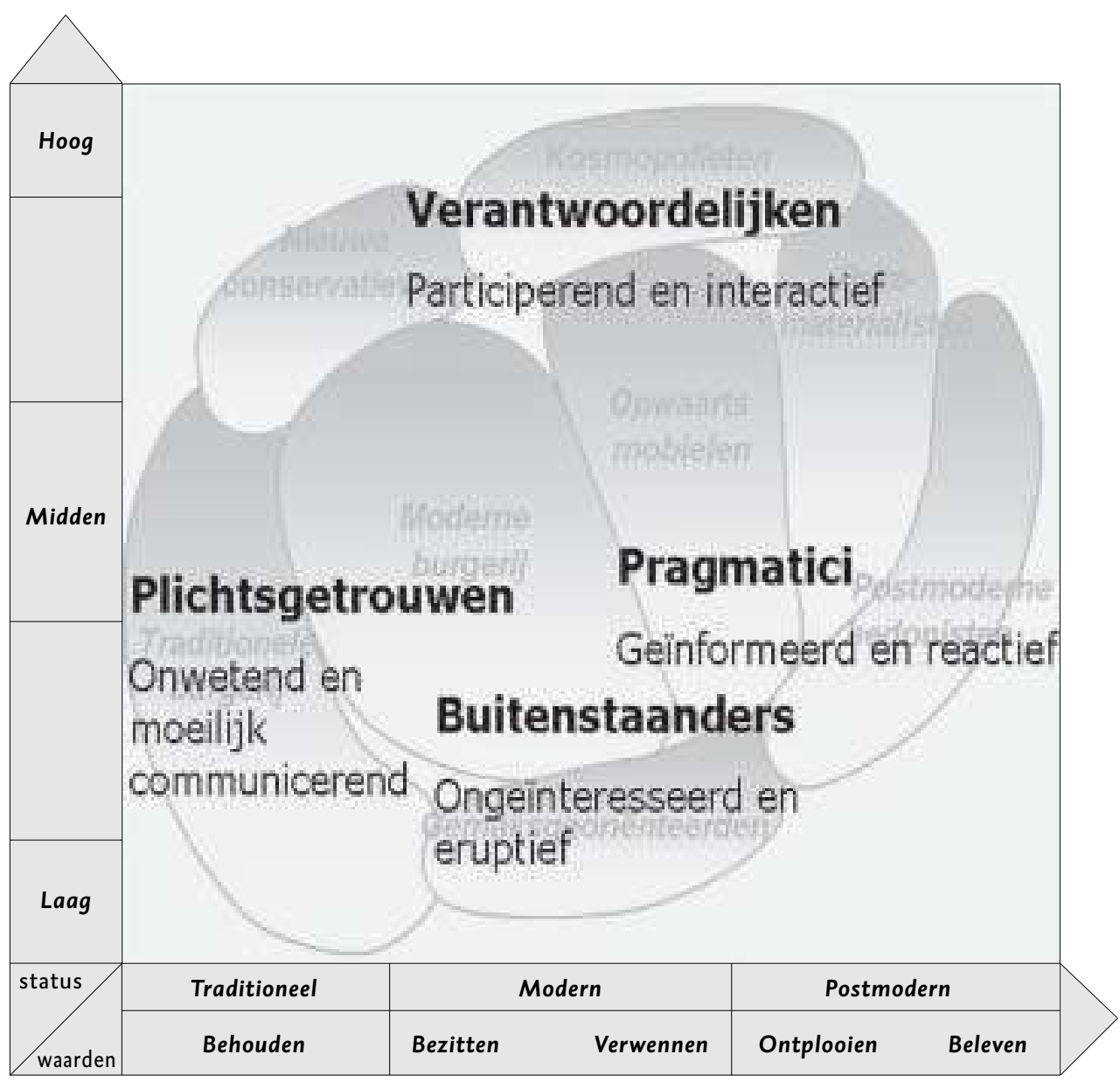

Het begrip 'status' heeft betrekking op sociaal-economische status

Bron: Motivaction 2001 - WRR 2006 
Tabel B-1 Omvang levensbeschouwelijke categorieën binnen de 4 burgerschapsstijlen

\begin{tabular}{|c|c|c|c|c|c|}
\hline & $\begin{array}{l}\text { plichts- } \\
\text { getrouwen }\end{array}$ & $\begin{array}{l}\text { prag- } \\
\text { matici }\end{array}$ & $\begin{array}{c}\text { buiten- } \\
\text { staanders }\end{array}$ & $\begin{array}{r}\text { verant- } \\
\text { woor- } \\
\text { delijken }\end{array}$ & Totaal \\
\hline Ongebonden spiritueel & 18 & 30 & 22 & 31 & 26 \\
\hline Christenen & 42 & 16 & 18 & 27 & 25 \\
\hline Niet-religieus \& niet-humanistisch & 16 & 14 & 30 & 10 & 18 \\
\hline Niet-religieus \& gemiddeld humanistisch & 13 & 18 & 17 & 16 & 16 \\
\hline Niet-religieus \& humanistisch & 8 & 17 & 10 & 14 & 12 \\
\hline Overige gebonden religieuzen & 3 & 4 & 3 & 3 & 3 \\
\hline Totaal & 100 & 100 & 100 & 100 & 100 \\
\hline
\end{tabular}

Noot: de verdeling van de ondervraagden naar hun burgerschapsstijl is als volgt: plichtgetrouwen: $18 \%$, pragmatici: $23 \%$, buitenstaanders $31 \%$ en verantwoordelijken $28 \%$. In deze tabel zijn de significante verschillen tussen de verschillende categorieën met een bepaalde burgerschapsstijl vet gedrukt.

Bron: Motivaction

\section{Onderstromen}

De in de figuren B-2 en B-3 weergegeven onderstroomscores betreffen Z-scores ( gemiddelde $=0$, standaarddeviatie $=1$ ). Deze Z-scores zijn het resultaat van een standaardisering ten behoeve van de vergelijkbaarheid van de uitkomsten op verschillende schalen. Die schalen bestaan uit reeksen stellingen waarbij de ondervraagden kunnen aangeven in welke mate zij het daarmee eens zijn. De balken in de figuren geven een positief of negatief verschil aan ten opzichte van het gemiddelde (o). Of een verschil significant is, is mede afhankelijk van de grootte van de categorie. Bij overige religieuzen, een relatief kleine categorie, is het verschil significant vanaf een waarde van o,2 of -o,2. Bij de andere categorieën is er sprake van een significant verschil vanaf een waarde van 0,1 of -0,1.

De verschillende dimensies kunnen als volgt worden omschreven.

Global village: zich verbonden voelen en contacten onderhouden met mensen in andere werelddelen.

Technoprogressie: geloof in vooruitgang door technologische ontwikkeling.

Gemeenschapszin: een betrokken en verantwoordelijke houding jegens de samenleving.

Neospiritualiteit: openstaan voor het onverklaarbare en alternatieve vormen van zingeving.

Intraceptie: zich graag inleven in de gevoelens en denkbeelden van anderen.

Zelfbeschikking: zelf willen bepalen hoe men leeft, los van richtlijnen en conventies.

Prestatiemotivatie: zichzelf uitdagende doelen stellen en willen presteren. 
Figuur B-2 Onderstroomprofiel levensbeschouwing (z-scores)

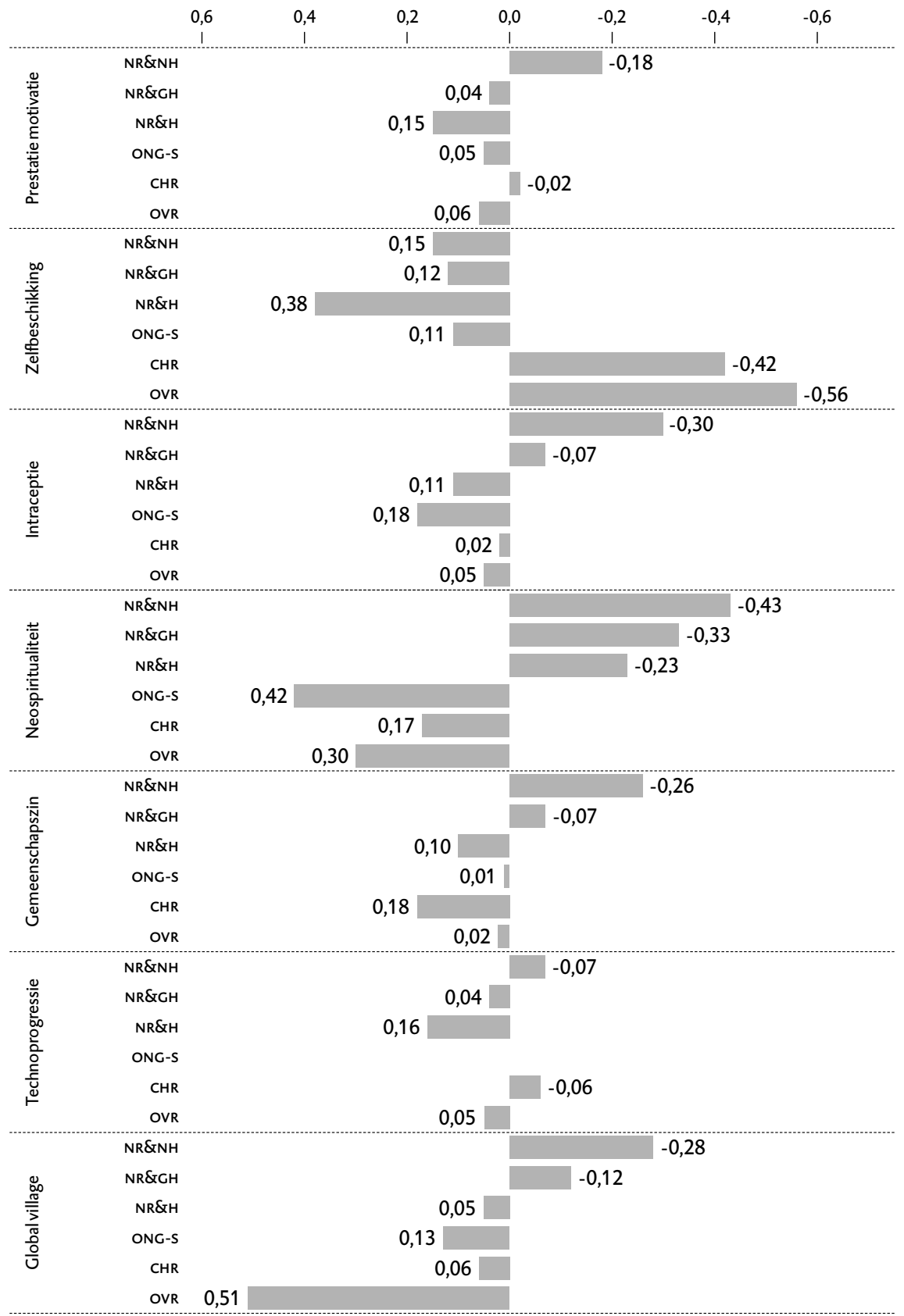

Bron: Motivaction 
Figuur B-3 Onderstroomprofiel levensbeschouwing (z-scores)

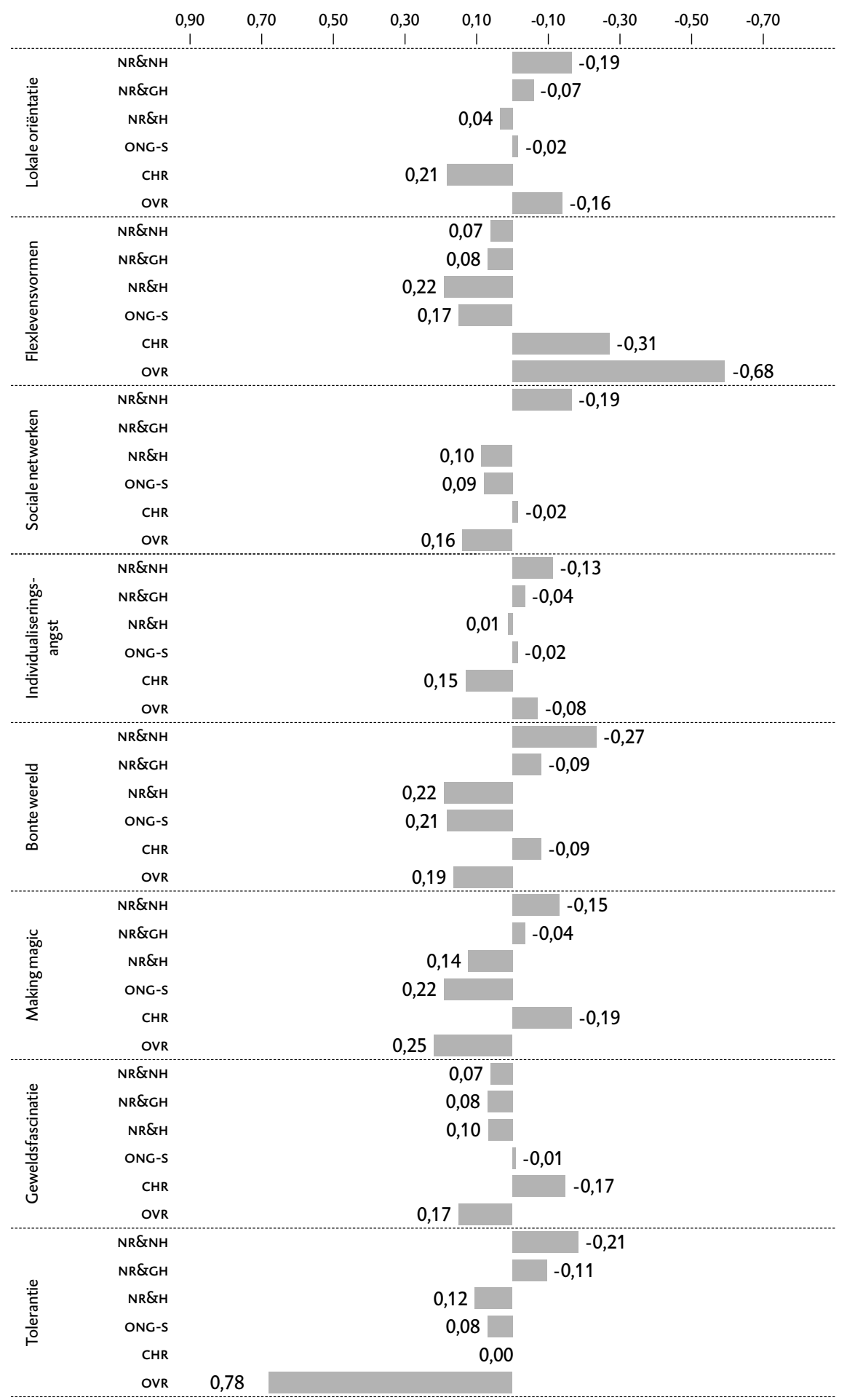

Bron: Motivaction 
Sch wartzwa arde n

\section{Figuur B-4 Schwartzwaarden (Schaal -1 tot 7)}

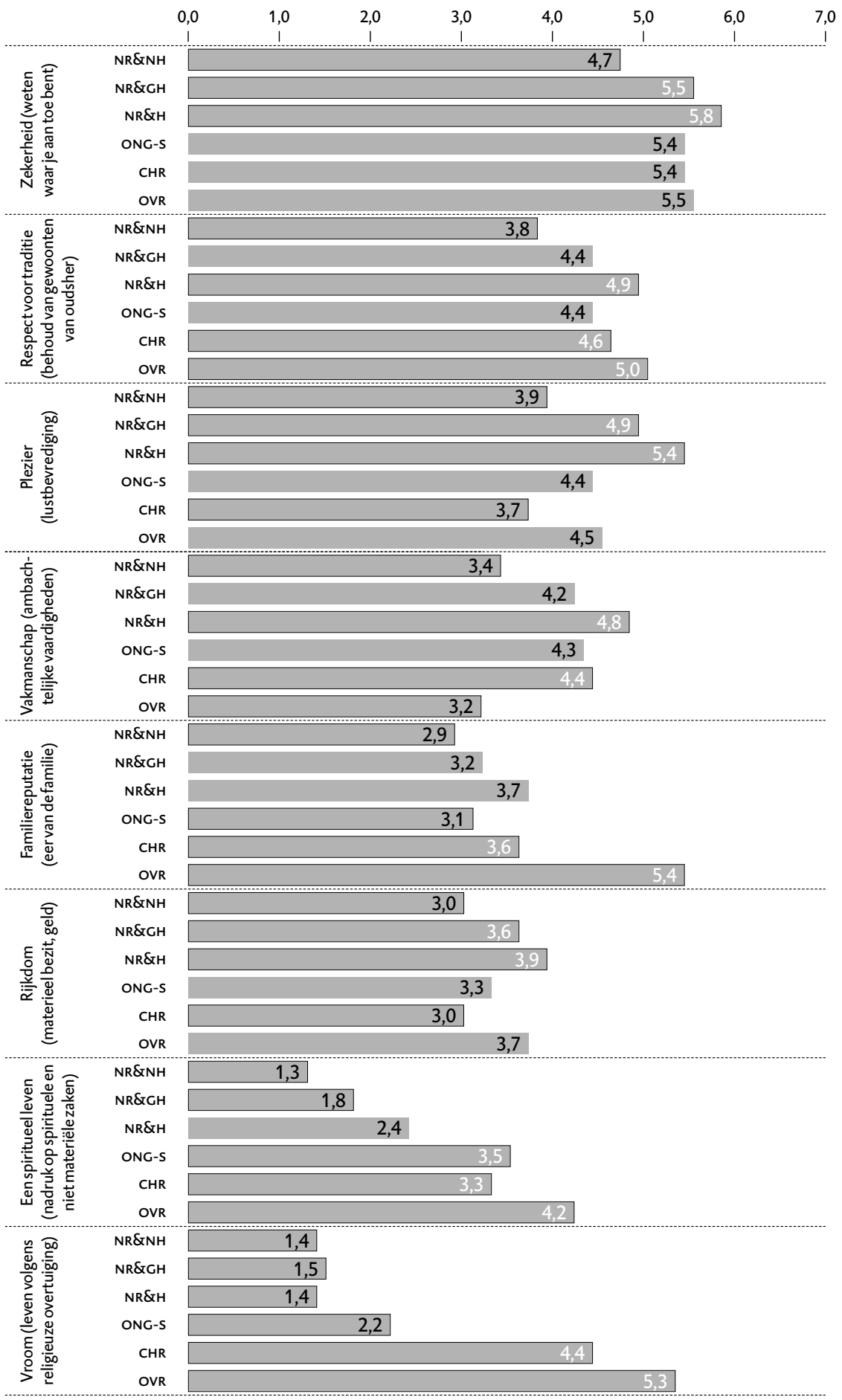

Bron: Motivaction 
Es ot erisch

Figuur B-5 Esoterische items totaal (\%)

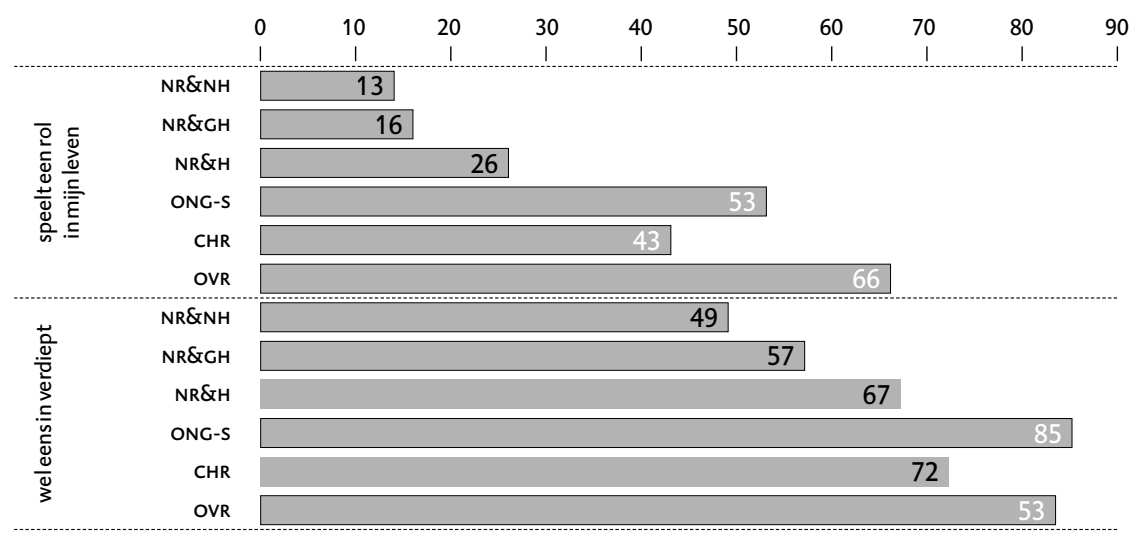

Bron: Motivaction

[Vervolg van de tekst op pagina 196]

Tolerantie: een open, gastvrije houding jegens allochtonen groepen en asielzoekers.

Geweldsfascinatie: zich aangetrokken voelen tot (uitingen van) actie en geweld.

Making magic: zich graag openstellen voor en gedreven worden door dromen en fantasieën.

Bonte wereld: interesse hebben voor gebruiken en gewoonten uit andere culturen.

Individualiseringsangst: zich zorgen maken over egocentrisme en individualisme in de samenleving.

Sociale netwerken: het gemakkelijk aangaan en onderhouden van contacten met mensen uit diverse netwerken.

Flexlevensvormen: openstaan voor alternatieve vormen van samenleven.

Lokale oriëntatie: zich verbonden voelen met en zich inzetten voor buurtgenoten en leefomgeving. 
Figuur B-6 Esoterische items: speelt een rol in mijn leven (\%)

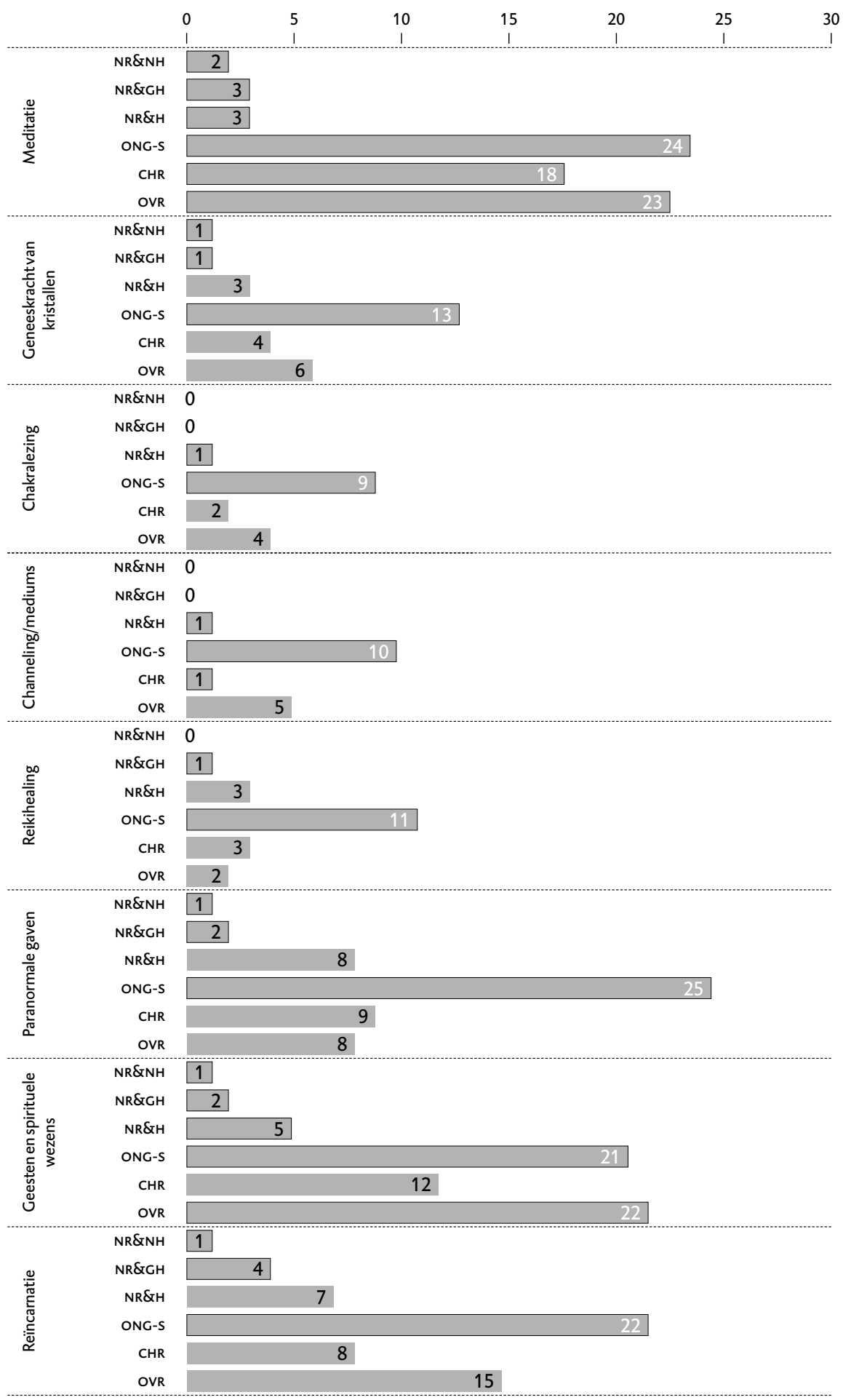

Bron: Motivaction 
Socia a l-demografisch

Figuur B-7 Sociodemografie (\%)

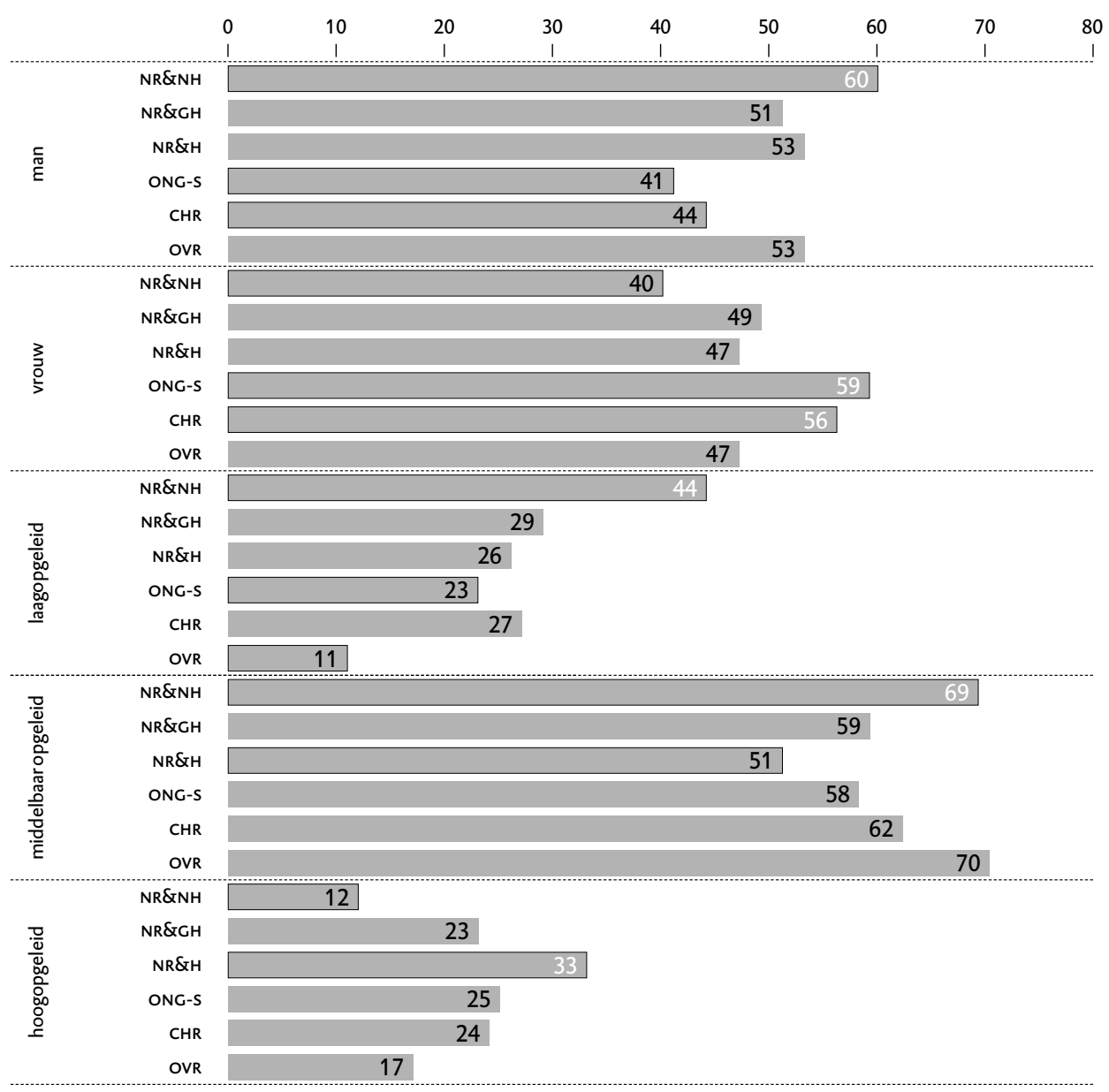

Bron: Motivaction 
Tabel B-2 Leeftijdsverdeling levensbeschouwelijke categorieën

\begin{tabular}{|lrrrrrrr} 
Leeftijdscategorie & NR\&NH & NR\&GH & NR\&H & ONG-S & CHR & OVR & Totaal \\
Leeftijd 15-24 jaar & 16 & 17 & 17 & 15 & $\mathbf{7}$ & $\mathbf{4 6}$ & $\mathbf{1 5}$ \\
Leeftijd 25-34 jaar & 19 & 21 & 22 & 23 & $\mathbf{1 6}$ & $\mathbf{3 0}$ & $\mathbf{2 0}$ \\
Leeftijd 35-44 jaar & 20 & 24 & 23 & 22 & $\mathbf{1 7}$ & $\mathbf{8}$ & $\mathbf{2 0}$ \\
Leeftijd 45-54 jaar & 21 & 16 & 16 & 20 & 19 & 10 & $\mathbf{1 8}$ \\
Leeftijd 55-64 jaar & 15 & 13 & 14 & $\mathbf{1 2}$ & $\mathbf{2 0}$ & $\mathbf{5}$ & $\mathbf{1 4}$ \\
Leeftijd 65-80 jaar & 10 & 10 & 8 & $\mathbf{8}$ & $\mathbf{2 1}$ & $\mathbf{0}$ & $\mathbf{1 2}$ \\
Totaal & 100 & 100 & 100 & 100 & 100 & 100 & $\mathbf{1 0 0}$ \\
\hline
\end{tabular}

Noot: Significante verschillen zijn vet gedrukt.

Bron: Motivaction

Figuur B-8 Beroepsstatus (\%)

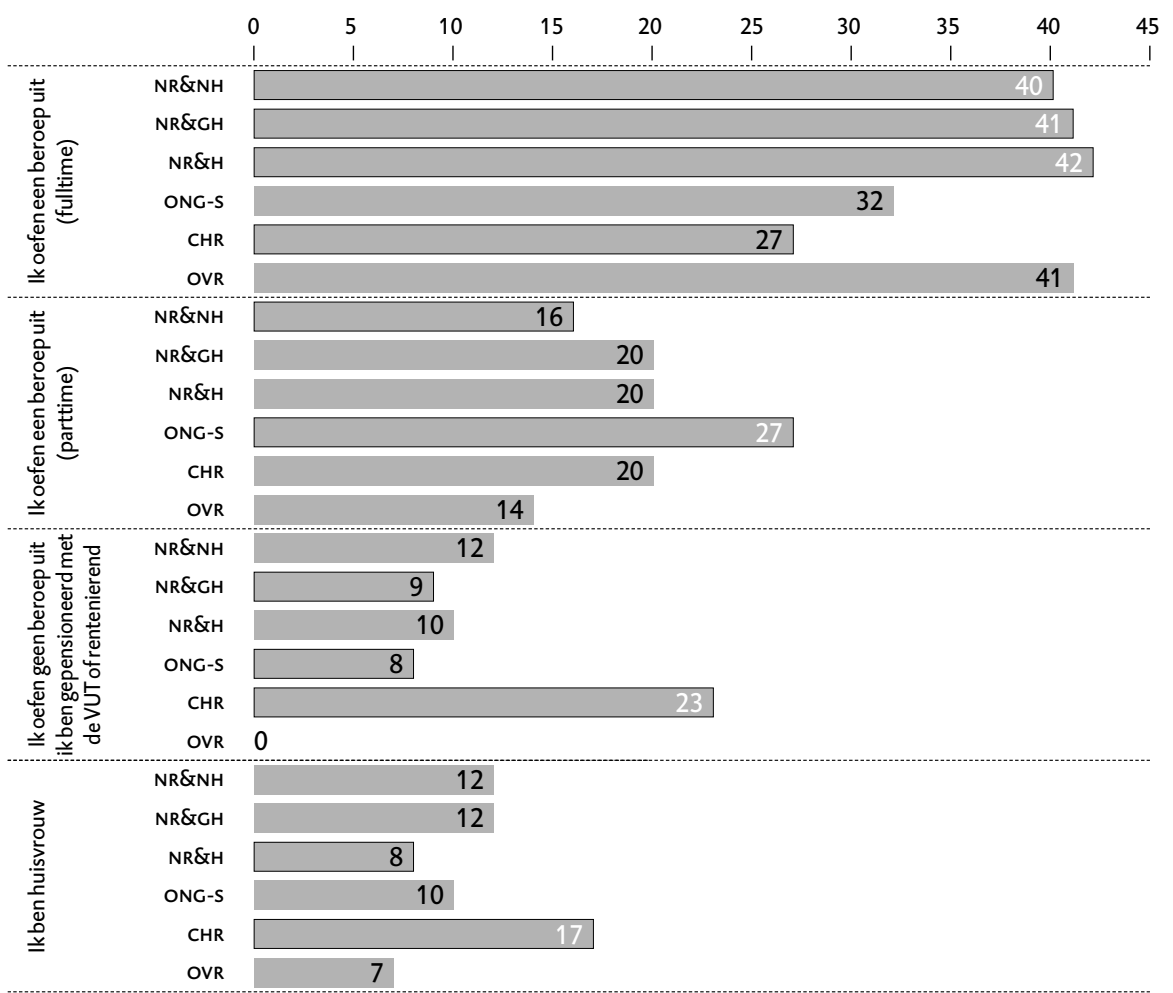

Bron: Motivaction 


\section{Charitatief}

Figuur B-9 Goede doelen (\%)

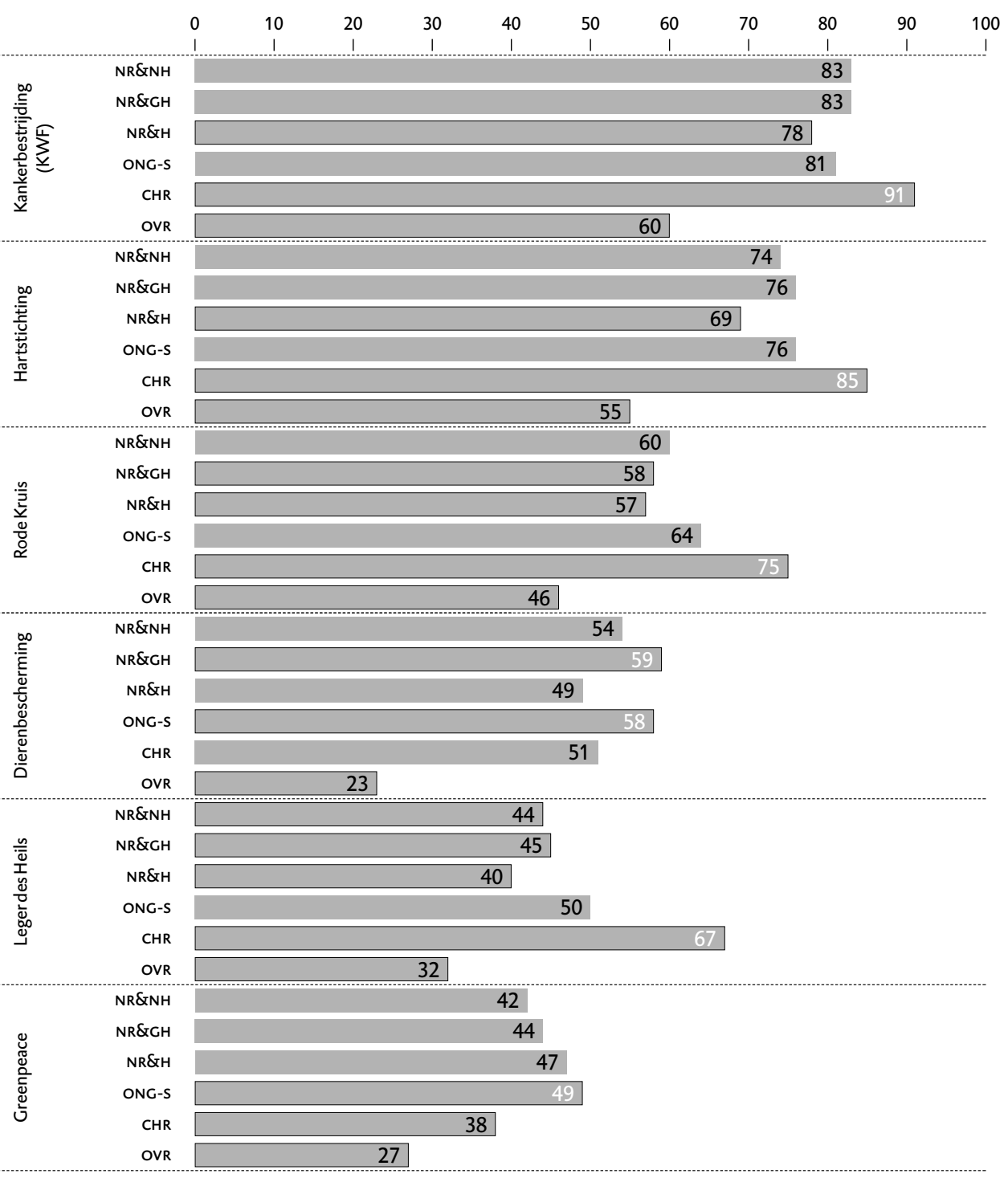

Bron: Motivaction 
Diversen

Figuur B-10 Stellingen (\% mee eens)

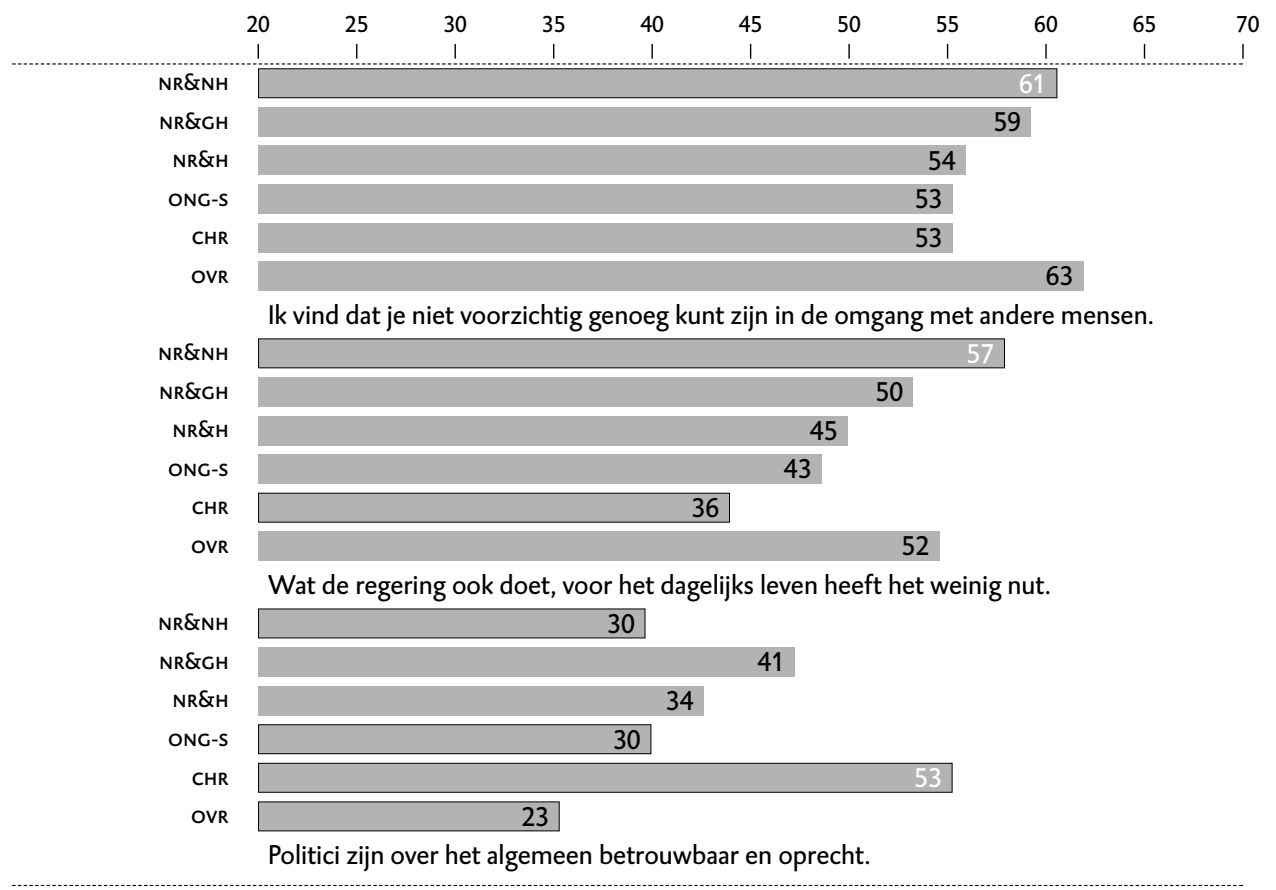

Bron: Motivaction 
Figuur B-11 Belangrijkste problemen in ons land (\%)

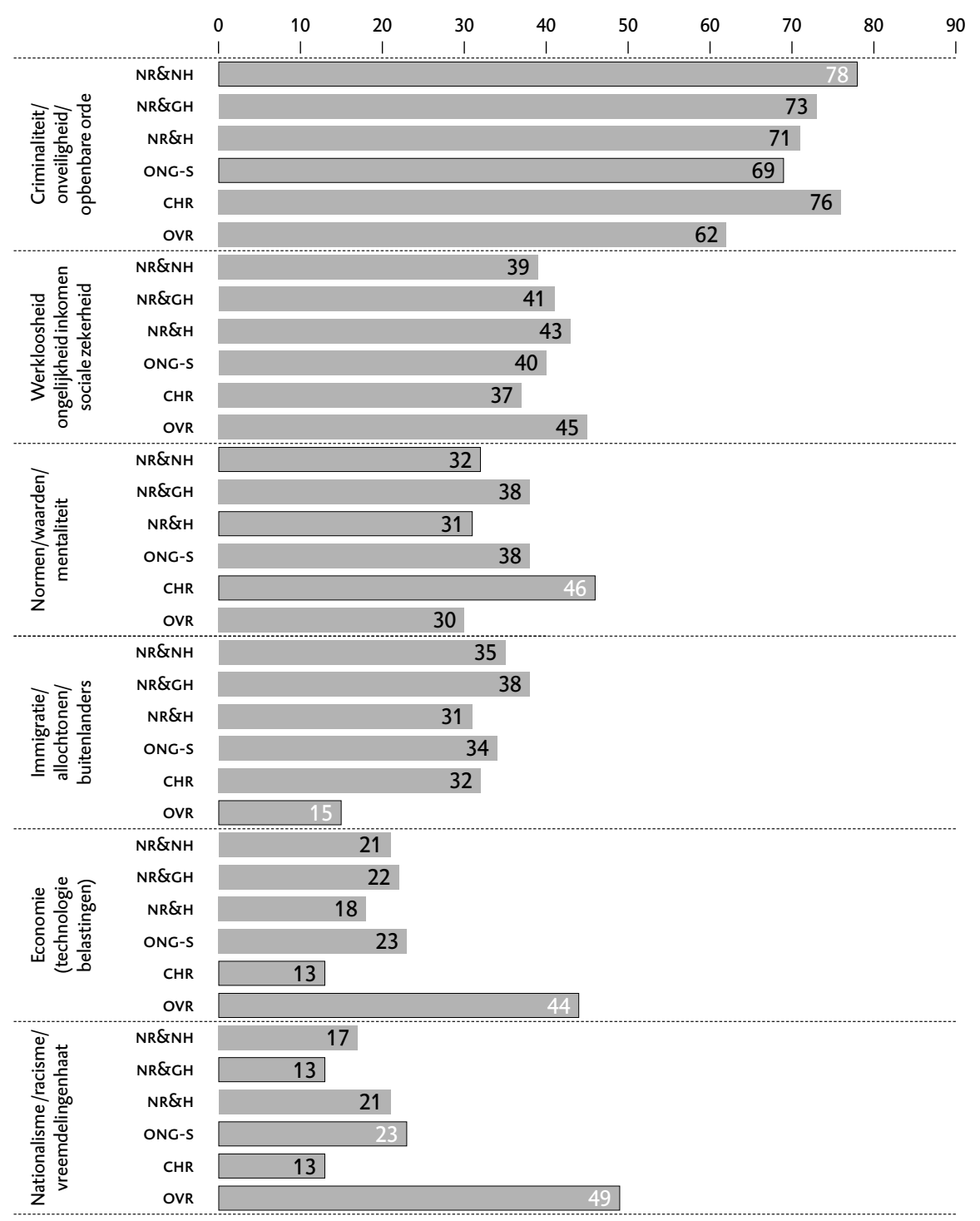

Bron: Motivaction 


\section{LITERATUUR}

Beck, U., A. Giddens, S. Lash (1994) Reflexive modernization. Politics, tradition and aesthetics in the modern social order, Cambridge: Polity Press.

Becker, J. (2006) 'Nederland en de secularisatie. Enige trends met betrekking tot levensbeschouwing', Religie $\mathbb{8}$ Samenleving, 1:1: 5-25.

Durkheim, É. (1893) De la division du travail social, Parijs: Les Presses Universitaire de France (uitgave 1967).

Featherstone, M. (1991) Consumer Culture $\&$ Postmodernism, London: Sage Publications. Finke, R. en R. Stark (2005) The Churching of America, 1776-2005. Winners and Losers in Our Religious Economy, New Brunswick en London: Rutgers University Press.

Heelas, P. (2001) geciteerd in 'Alternative spirituality rising fast', Guardian Unlimited, 18 juni 2001.

Hofmeister, K. en L. Bauerochse (1999) Die Zukunft der Religion. Spurensicherung an der Schwelle zum 21. Jahrhundert, Echter.

Inglehart, R., M. Basáñez., J. Díez-Medrano, L. Halman en R. Luykx (2004) Human Beliefs and Values. A cross-cultural sourcebook based on the 1999-2002 surveys, Siglo XXI Editores.

Jörns, K-P. (1999) 'Renaissance der Religion. Was Menschen heute glauben', blz. 23-40 in:

K. Hofmeister en L. Bauerochse, Die Zukunft der Religion. Spurensicherung an der Schwelle zum 21. Jahrhundert, Echter.

Lampert, M., F. Spangenberg, B. van der Lelij en M. Moerland (2001) Burgerschapsstijlen en overheidscommunicatie, Motivaction.

Lampert, M.A. (1997) De Dans van Dionysos Een semiometrisch onderzoek naar de onderscheidende werking van de Dionysische stijl anno 1997, Scriptie Vrijetijdwetenschappen, Katholieke Universiteit Brabant.

Lash, S. en J. Urry (1987) The End of Organized Capitalism, Cambridge: Polity Press.

Maffesoli, M. (1997) 'The Return of Dionysus', blz. 21-37 in: Sulkunen, Holmwood, Radner en Schulze, Constructing the New Consumer Society, Houndmills, Basingstoke, Hampshire \& London: Macmillan Press Ltd.

Maffesoli, M. (1996) The Time of the Tribes: The decline of individualism in mass society, London: Thousand Oaks, New Delhi: Sage Publications.

Motivaction (2005) De kijk op het leven na de dood, onderzoek in opdracht van televisieprogramma IKON Live.

Norris, P. en R. Inglehart (2004) Sacred and Secular. Religion and Politics Worldwide, Cambridge University Press.

Schulze, G. (1992) Die Erlebnisgesellschaft. Kultursociologie der Gegenwart, Campus.

Spangenberg F., M. Lampert, B. van der Lelij en R. van Ewijk (2003) Politieke onvrede en de alledaagse belevingswereld van burgers, Motivaction.

Stark, R. (2006) 'An Economics of Religion', blz. 47-68 in: R.A. Segal (ed.), The Blackwell Companion to the Study of Religion, Oxford: Blackwell.

Stark, R. en R. Finke (2002) 'Beyond Church and Sect: Dynamics and Stability in Religious Economies', blz. 31-62 in: T.G. Jelen (ed.), Sacred Markets and Sacred Canopies: Essays on Religious Markets and Religious Pluralism, Lanham, MD: Rowman \& Littlefield. 
Wetenschappelijke Raad voor het Regeringsbeleid (2006) Vertrouwen in de buurt, Rapporten aan de regering nr. 72, Amsterdam: Amsterdam University Press.

Wetenschappelijke Raad voor het Regeringsbeleid (2002) De toekomst van de nationale rechtsstaat, Rapporten aan de regering nr. 63, Den Haag: Sdu Uitgevers.

Wuthnow, R. (2006) In America All Religions are True. Implications of the New Pluralism for Democracy, Lecture March 23 at Vanderbilt University. 


\title{
7 AN INTRODUCTION TO AMERICAN RELIGIOUS PRACTICE
}

\author{
Alan Wolfe
}

\subsection{BELIEF AND PRACTICE}

There are two roads to take when trying to understand any particular religion. One involves studying the beliefs associated with that faith: its holy texts, its creedal statements, its insistence on certain truths, and the ideas that differentiate it from other religious traditions. The other includes paying attention to the practices that define a religion, such as the laws to be followed, the rituals and liturgies associated with worship, the treatment of behavior deemed to be sinful, or the ways of spreading its message to others. Correct religious belief, relying on a term stemming from the Greek, is called orthodoxy. Correct religious practice is called orthopraxis.

All religions address matters of both belief and practice, but some emphasize one more than the other. Jews, for example, place a strong emphasis on obedience to tradition, which is an aspect of religious practice. In the Middle Ages, rabbis pondered the question of who would be the better Jew: someone who followed all the laws but did not believe in God or someone who believed in God but dishonored the laws? The answer was clear: the former. Evangelical Protestants, by contrast, tend to emphasize belief in the divinity of Jesus Christ as central; if your behavior is sinful but you continue to believe, salvation is available to you. Belief, in other words, is held to transform behavior, not the other way around.

Belief is mostly of concern to theologians, while practice typically preoccupies social scientists. It is, however, important to study both in order to gain understanding of a religious tradition. Here the focus will be on practice. To fully understand American religion, we need to know more about the everyday lives of religious people. How do they worship in their churches, synagogues, and mosques? What attracts them to their religion and why? Why do some people convert from one religion to another? How do they share their enthusiasm for their faith? Fortunately, there has developed an extensive literature focusing on the ways Americans practice their faith. Summarizing what these scholars have discovered is the main focus of what follows.

\subsection{WORSHIP}

Honoring God is central to all religions, yet religions differ in how they do so. One major difference involves the role of liturgy. Liturgy refers to forms of worship which emphasize ritual, a time-tested, relatively unchanging, and constantly repeated form of prayer. The best example of a liturgical practice is the 
Catholic Mass. Developed over many centuries, it follows the same format whereever practiced and ought to be as familiar to someone living in the twenty-first century as to someone living in the fourteenth. This does not mean that the Mass never changes; the Second Vatican Council, which took place in the 196os, introduced many changes into the Mass, such as relying on vernacular languages rather than Latin and having the priest face the congregation rather than turning his back to it. Still, Catholics know what is coming at each stage in the Mass and take pride in the symbolism and dramatic expression frequently associated with ritual forms of worship.

Protestant denominations vary greatly with respect to the importance of liturgy. Some, such as the Episcopal Church (originally the Church of England) are quite close to Catholicism in their liturgical practices. Others, however, maintain a historical suspicion toward liturgical expression; the most authentic prayer, they believe, has to come from within the individual, and liturgical forms of worship, to this kind of Protestant sensibility, seems too scripted to be genuine. Pentecostal forms of Protestantism, which place priority on spiritfilled expressions of faith, including, in the extreme case, speaking in tongues and dancing in the aisles, are the most anti-liturgical of all. You cannot be sure when the spirit of God will enter you, but when it does, you share your joy in his presence. Anyone who attends worship services at a Pentecostal church, especially one attracting a largely African-American congregation, will be struck by the spontaneous enthusiasm, especially in contrast to a typically far more sedate Catholic Mass.

Despite the fact that religions vary widely on the role that liturgy ought to play in worship, there is a tendency for all American religions to converge. Even though in theory religions are timeless and transcendental, in practice religions frequently adapt themselves to the culture in which they live. And American culture has some distinct features that influence all of American religions. Many of those features stand in tension with formal liturgical practices. Liturgy involves behavior that rarely if ever changes, but American culture is innovative and ever-changing. In liturgical worship, the individual finds a place in a web of meanings defined by tradition and ritual, but American culture is highly individualistic, emphasizing that people themselves ought to choose what is best for them, whether that involves the commodities they purchase or the politicians they elect. A liturgy such as the Catholic Mass is led by a priest, but American culture is a democratic one which frequently insists that people themselves should decide what is best for them.

It is, therefore, difficult for liturgically-oriented religions to maintain their pure form in the United States. As a result, a worship practice such as the Catholic Mass, which has already been formally changed by Vatican II, is informally changed in particular Catholic churches throughout the United States. One important example of how this process works involves Latino Catholics in America. On the one hand, Latinos, typically recent immigrants to the United States, 
are more "old-fashioned" in their Catholicism than the grandchildren of previous immigrants from Ireland and Italy; they are, for example, more likely to use a rosary or to identify publicly with Jesus' sufferings on the cross. On the other hand, however, a significant number of Latino Catholics - perhaps as many as 25 percent - find themselves attracted to evangelical Protestant forms of worship, especially including Pentecostal ones. To meet the threat of withdrawal from the Catholic Church, priests in Latino neighborhoods are likely to modify the more liturgical aspects of the Mass to make it seem more welcoming, more emotional, and more personal to their parishioners. Catholicism remains a universal faith, but in the United States, now as in the past, it also possesses an identifiable ethnic dimension as one moves from one parish to another.

It is not just among Latinos, moreover, that the liturgical aspects of Catholicism are weakening. Catholic churches in wealthy neighborhoods also face a form of competition for membership, not from evangelical Protestant denominations, but from mainline Protestant ones. In suburban America, Catholic worship services are quieter and more discrete than they are among inner-city parishes, but the same is true of Protestant worship. In other words, such non-religious factors as wealth and location influence religious practice as much as the history and traditions of particular denominations. Suburban churches, whether Catholic or Methodist, will share much in common. The same is true of urban churches whether Catholic or Pentecostal. Audience matters.

Of all the features of American culture, then, one should be singled out for playing an especially important role in shaping how American religion is practiced. This is the fact that religion in America is overwhelmingly a voluntary activity. Because of the First Amendment to the us Constitution, which separates church and state, neither denominational headquarters nor local congregations are supported by public funds. Without subsidies, the only way they can remain in existence is by attracting members who will offer contributions from their own pocketbooks. Drawing members in and retaining their loyalty therefore becomes a practical necessity; if they do not succeed in these tasks, churches will simply go out of business. Understanding this, clergy and lay leadership can never wander too far from the task of satisfying the needs of potential members.

It therefore makes a certain amount of sense to understand American religion as being driven by the requirements of the market, perhaps fitting because the same eighteenth century atmosphere that produced Adam Smith's The Wealth of Nations also produced the First Amendment to the American Constitution. Based on this insight, a number of social scientists use the tools developed by economists - in particular the idea that all people are ruled by self-interest - to formulate and test hypotheses about religious behavior. While there clearly are some examples of religious behavior that are inspired by beliefs which have little basis in economic rationality, these approaches do explain a good deal about American religion. Religious behavior in the United States does have very practical dimensions because of its voluntary character. 
And this, in turn, helps explain why religions have difficulty maintaining a strong liturgical sense of practice in American culture. If religious worship appears too distant - insufficiently focused on the individual and his or her immediate needs - it is likely to lose adherents in favor of other religions that offer help with the practical difficulties of daily life. This is something that growth-oriented religions, especially evangelical ones, know full well. In the mega-churches springing up outside many American cities, there are worship services on Sundays, but these are complemented by small group meetings the rest of the time. In these groups, people seek help for such problems as troubled marriages, difficult children, and uncertain economic circumstances. While the Bible may be used to start a discussion, it is not long before Bible study crosses the line into therapy. People may confess to their weaknesses and seek support from others in the group. Others may become weepy as they discuss the challenges life has thrown in their path. Invariably a group meeting will end on an upbeat and positive note as members promise to do better, both in the world and in their faith. It is common to dismiss the therapeutic dimension of American religion as thin and lacking in substance, but there is no doubt of its attraction to people who are searching for answers.

If there is a lesson in all this it is that religions in America face a difficult choice: personalize or die. In theory, religion can inspire awe, induce dread, and impress with the commanding authority of a distant god. In practice, religion tends toward the intimate and sympathetic, worshiping a god who is a friend and companion. None of this is meant as a judgment on whether these trends are healthy or problematic. They are offered instead as examples of how religion in practice can differ from religion in theory.

\section{$7 \cdot 3$ TRADITION}

Religious believers, we are frequently told, are tradition-oriented people; indeed the word 'tradition' is frequently used as a synonym for the word 'religious.' In the United States, moreover, 'traditional' is also used as a synonym for the word 'conservative.' It therefore seems to follow that religious believers will be more likely to engage in conservative forms of behavior than the non-religious, rejecting such modern practices as two-income families, divorce, and the use of birth control. Non-believers, by contrast, are generally pictured as more willing to adapt themselves to the innovative and the new, even if such cutting-edge practices stand in sharp contrast to the traditional beliefs associated with religion.

Yet the actual practice of religious believers, especially those who belong to conservative Protestant faiths, belies this picture. If one were searching for a word that conveyed the exact opposite meaning of traditional, one just might choose the word conservative evangelicals use to describe themselves: born-again. A traditional person is one who inherits from his parents certain values and feels obligated to pass them on unchanged to his children. But this is not what bornagain Christians do. For them, authenticity of belief is central, and if one's 
parents' beliefs were not authentic - or if the beliefs the individual himself held before his conversion to Jesus were not authentic - then one is obligated to change them. To be an evangelical is to experience a disruption in your life, a moment in which all that you had thought to be true is revealed false and a new sense of the power of Jesus comes into your life.

Although evangelical Protestants in the United States, with the significant exception of African-Americans, are politically conservative - they tend to vote for the Republican Party - their religious practices are not conservative at all. Consider the question of music, an aspect of religious practice in which American Christians often have very strong feelings. 'Traditional' church music featured classical hymns, often written by famous composers such as Bach and Mendelssohn, and played on an organ prominently displayed behind the pulpit. But Protestant megachurches in the United States, which routinely attract huge numbers of new members, generally do not have organs anywhere in the building. Instead they feature electronic music, usually modeled on rock and roll and, in some cases, explicitly written to mimic the music played on popular radio stations. Rock and roll was once denounced by conservative Protestant clergy; now they welcome it to attract younger parishioners.

If the religious behavior of many conservative Protestants is non-traditional, the same applies to their personal behavior. To cite just one prominent example, states which feature large numbers of evangelicals - such as Oklahoma or Arkansas - are states with very high rates of divorce. (By contrast, Connecticut and Massachusetts, liberal states, have very low rates.) Why are marriages among evangelicals more likely to produce divorce, even though so many evangelicals consider divorce sinful? Part of the answer deals with economics: evangelicals tend to be disproportionately poor and divorce rates are higher among the poor. But part of the answer also involves an evangelical lifestyle. People who are conservative in their religious beliefs usually marry younger, have highly unrealistic expectations of what marriage ought to be like, and shun professional help in favor of prayer when their marriages run into trouble - all of which can lead to higher rates of divorce. Interestingly enough, moreover, this same pattern holds with respect to other aspects of individual personal behavior; evangelicals typically have higher rates of out-of-wedlock births than do non-evangelicals. There is, in short, generally not much of a relationship between conservative religion and conservative personal behavior, but among Mormons one does find a strong relationship between the two.

Throughout much of the twentieth century, social scientists adhered to what is called the 'secularization thesis', which held that modern society, based on science, rationality, and the division of labor, would ultimately cause religion to disappear. It is now clear that religion has not disappeared but has undergone a major revival. Yet there remains a partial truth to the secularization thesis, because this revival does not constitute an alternative to modernization but indicates the extent to which religion has adapted to modernity in order to survive. 


\subsection{FELLOWSHIP}

Not all religions are public in the sense that they seek to influence government and its policies, but outside of some highly contemplative religions associated with countries such as India, nearly all American religions are public in the sense that people come together with others in public places to worship. This desire for fellowship has long been recognized as one of the most significant aspects of American religious practice. When he came to the United States to attend the St. Louis World's Fair in 1904, the great sociologist of religion Max Weber emphasized the degree to which religion for Americans involved seeing others and being seen by them; Weber, for example, pointed how religious membership could stand in as a sign of credit worthiness in newly emerging American cities and towns.

Religion, in short, is a social institution and needs to be analyzed as such. There are major differences in the way these institutions are organized. The Catholic Church is organized hierachically (although this does not mean that all decisions come from the top.) The same is true of some Protestant denominations, but most Protestant churches are more congregational in nature; that is to say, decisions about how to organize themselves do not flow from a national headquarters down but from a local congregation up. Jews in America have by and large borrowed the denominational model from Protestants; the three main Jewish denominations are called Orthodox, Conservative, and Reform, even though some of them, like the Orthodox, are in turn divided into Ultra-Orthodox and Modern Orthodox. So important are denominations that observers have spoken of the United States as a 'denominational society.'

Yet just as American culture shapes how people worship and influences their personal behavior, it also influences the ways in which people come together to share religious experience. American culture, for one thing, is populistic in spirit; the wisdom of ordinary people is constantly being praised, while elites are often dismissed as out of touch with what the people want and need. This populistic sensibility poses a problem for any religion which is strongly organized from the top down. For this reason, it is not quite correct to view the United States as a denominational society. To be sure, religions, especially Protestant ones, are organized into denominations, and each denomination has a headquarters, a staff, and a budget. But it is as difficult for clergy in positions of national leadership to impose their will on congregations as it is for presidents to control Congress. All politics, a famous American politician once said, are local. The same could be said about religion. It is the congregation, the specific church located in a particular place that tends to retain authority. This became clear in the Southern Baptist Convention, which represents the largest Protestant denomination in the United States. At its national convention, the SBC routinely passes resolutions calling for women to submit to their husbands. But the SBC cannot enforce its pronouncements on specific Baptist churches. 
Because of America's democratic and populistic culture, there is a tendency for all religions to become congregational religions. Originally, congregationalism was the name of a specific Protestant denomination, the one descended from the Puritans. (Two other names of Protestant denominations also derive from governance structures; Episcopalian refers to government by bishops, while Presbyterian means government by elders.) But so ubiquitous is the tendency to organize religions through congregations that even religions that have historically governed themselves in other ways find themselves influenced by it. This was especially true of American Catholicism. In theory, the archbishop of a city is free to close a church or to transfer a priest at his discretion. In reality, Church leaders will be quite cognizant of the role of key lay people in particular parishes and will consult widely before taking action, especially actions that might prove controversial and thus adversely affect the ability of the Church to raise money.

Some of the most fascinating of these examples of congregationalism involve non-Christian religions in the United States. Jews in America, for example, developed their synagogues into what were called 'community centers,' complete with athletic facilities and rooms for social functions. Buddhists created temples that, like churches, performed marriages or became sites for funerals. And then there is Islam in the United States. Historically there is, with the possible exception of the Shia, no functional equivalent in Islam to the Protestant clergy. Mosques, moreover, are usually not like American churches: places with relatively fixed membership which one regularly attends. But as Muslims settle in the United States, their religious practices increasingly resemble those of the Protestant majority. Mosques will develop schools and day care facilities for children, appoint leaders to speak to the media, and create boards of directors to raise money from the faithful. It is in this sense that one can speak of the "congregationalism' of Islam in the United States.

There are restraints on congregationalism; some of them, however, come not from above, but from below. Congregations, after all, are constituted by their membership; they bring together disparate individuals for common purpose. But just as there is a strong populistic side to American culture, there is also a powerful individualistic side. Americans, we are told, resist the demands of membership in institutions; they are given, as a famous book said, to 'bowling alone.' If this is true of the voluntary sector in general, it includes religious congregations in particular. Another famous work of American social science found people in the United States so individualistic that they create religions designed only for themselves. 'Sheilaism' is the term used to characterize this phenomenon, based on a person given the name of Sheila Larson who told the sociologists who interviewed her that she just wanted something that would let her speak in "my own little voice."

The persistent individualism of American culture takes its extreme form among those who are engaged in 'home churching.' Like home schooling, a movement in which parents remove their children from public schools to educate them at 
home, home churches believe that, since Jesus had no church, they are not required to have one either; distrustful of organizations, they prefer to take faith into their own hands. Not many Americans engage in this practice. But many Americans do engage in other religious practices that illustrate American individualism. The most prominent is 'switching.' Scholars used to speak of religion as an 'ascribed status,' something a person inherited from their family background. But more and more of American religion is now 'achieved,' chosen by the individual in the course of his life. Part of the competition for souls that characterizes a marketplace in religion, Americans have relatively little loyalty to denominations and will exit them for others they find more hospitable. There is, as a result, considerable turmoil in the American religious landscape. To understand it, you have to be in possession of a map, and the map changes from year to year.

\subsection{DOCTRINE}

Doctrines refer to the belief-systems of religious traditions and in that sense are not generally part of what we mean when we talk about practice. At the same time, however, religious traditions do ask their members to act upon their beliefs. Nearly all religious traditions emphasize the importance of works as well as faith. Whether we are talking about showing compassion to others or honoring the Sabbath, we are discussing how the theological understandings of a religion are to be acted out in the course of daily life.

The idea that people who belong to a religious tradition are expected to follow the teachings of that tradition suggests that they know what those traditions are. But that very suggestion immediately raises the same kinds of questions about the influence of American culture on religion that are brought about by practices such as worship and fellowship. There exists substantial evidence that, whatever their political views, Americans know relatively little about politics, including the names of those who represent them in Congress or the dates of important events in their history. Might the same be true of religion? It has also been suggested that a strong strain of anti-intellectualism exists in American culture. Does the same apply to religion? The rise of the mass media certainly suggests that appeals to emotion resonate with Americans, who are moved by stories of personal recovery from trauma more than they are persuaded by facts and logic. If these characterizations of American culture are correct, we would expect religions to downplay the doctrines that define them in theory in favor of an emphasis on emotion and feeling borrowed from popular culture.

And this is indeed what many scholars of lived religion in America have found. American Christians talk about the importance of the Bible in their lives, and evangelical Christians insist that the Bible is the literal word of God containing authoritative commands about how we ought to lead our lives. At one level this insistence on the inerrancy of the Bible testifies to the low importance attached to doctrine, for evangelicals, in upholding the truth of the Bible, downplay the 
importance of formal theology, most of which is devoted to interpreting what the Bible actually means. Evangelicals tend to look on theology with a certain suspicion; each individual can read and discover the meaning of Biblical passages, they believe, and for that, no special category of experts - priests, theologians - is necessary. It is not therefore surprising that historians have long accused evangelicalism of being anti-intellectual, a charge that some contemporary evangelical scholars find all too truthful. Evangelicalism has not produced its share of great universities, famous works of art, or outstanding works of music. Yet the Bible is a book, a great book, and if evangelicals are familiar with it, at least one can conclude that they are guided by written texts. It therefore comes as a surprise that the knowledge that Americans, including American religious believers, have of the Bible is not that much different in degree from that they have of politics. (To cite one frequently mentioned example, Americans by overwhelming numbers believe that the expression "God helps them who help themselves" comes from the Bible, when it was actually written by Benjamin Franklin.) Even though conservative Christians can point to passages in the Bible condemning homosexuality, moreover, they are less likely to know that the Bible also calls for the death of people who eat pork. Portions of the Bible are frequently quoted and many books are written explaining what the Bible means or ought to mean, but the Bible itself is rarely understood in depth and even more rarely understood in the context of the considerable scholarship that has grown up surrounding it. And among Pentecostals, a fast-growing form of evangelicalism, the emphasis tends to be on the spirit as manifested through the body, not on ideas as brought to fruition by the mind. Conservative Protestants are strict in their faith, but it does us little good to characterize them as doctrinaire. Specific religious doctrines are not that central to the way they practice their faith.

The Bible is not the only source of doctrine for religious believers. Over the centuries, both Catholics and Protestants have produced creedal statements meant to article their basic theological beliefs, such as the Nicene Creed (381), which established the Christian trinity, or the Westminster Confession (1648), which outlined the principles of the Reformed version of Protestantism. One of those principles is predestination, or the idea that salvation comes only from God and not from the acts an individual performs during his lifetime. The Westminster Confession is a key creedal statement for Presbyterians, one of the most important of America's Protestant denominations, and it follows that people who belong to Presbyterian churches ought to at least be familiar with, if not subscribe to, the doctrine of predestination. Yet the idea that we have little control over whether salvation will be granted to us flies in the face of everyday American beliefs which emphasize both the freedom of the individual and the responsibility of the individual for the consequences of his own behavior. It should not come as a surprise, therefore, that members of Presbyterian churches are frequently surprised to learn about predestination and its original meaning. There are many reasons they may have joined a Presbyterian church, from an appreciation of its pastor or a sense of the community it inspires, but the actual doctrinal teachings of the church are usually not among them. 
Other religions have ambivalent relations with some doctrine as well. The Catholic Church, for example, expresses its teachings through the Magisterium, the word of God as interpreted over the ages by the Pope and those bishops who work with him in this regard. Frequently Papal teachings will involve matters of theology, but the Pope also issues encyclicals dealing with matters of everyday life, including, for example, questions of abortion and birth control. Catholics are generally familiar with these teachings. But this does not mean that they agree with them. By huge margins, American Catholics routinely tell survey researchers that they do not agree with the Church on an issue such as birth control. Formally, this puts them at odds with the Church and its teachings. But not only does the Church refrain from excommunicating them, most such individuals would insist that they remain Catholics in good standing. From their point of view, the Church's pronouncements are only suggestions, not commandments. The fact that Catholic teachings on these issues have roots in theological arguments that have preoccupied the Church for centuries is ignored by them.

There is one great advantage that the relative lack of interest in doctrine offers to American religion. Throughout much of Western history, doctrinal disputes have led to sectarian conflict, often of a violent sort. There is relatively little of such conflict in American religion; arguments are more likely to take place between non-believers and believers than among believers subscribing to different faiths. This gives American religion a certain peaceful quality and goes a long way in explaining why significant levels of religious toleration in the United States exist. On the other hand, this peace does come with costs. Lacking strong attachments to doctrine, Americans are likely to conclude that it is more important to believe in something irrespective of what you believe in. Yet it is difficult to maintain belief in belief. Without doctrine, religion tends to lose its content, raising the question of why it makes sense to believe in the first place.

\section{$7.6 \operatorname{SIN}$}

For most religions, sin represents a breaking of a covenant an individual has with God. We do something wrong, moreover we engage in behavior we know to be wrong. We also know that God, who is all powerful, is aware of what we have done and awaits some sign that we wish to make amends. In some religions, confession represents such a sign; we acknowledge to a member of the clergy our wrong-doing and, if we do so with genuine contrition, can expect absolution. In other religions, special days - what Jews, for example, call a day of atonement are set aside to reflect on our actions and to change them accordingly. In others, we bring Jesus into our lives and, welcoming his guidance, take steps toward our personal salvation. The means may differ and the behaviors deemed sinful may not be the same - although frequently there is remarkable similarity across religions concerning improper acts - but underlying nearly all religions is an emphasis on the transformative power of religion, its ability, provided we are willing, to change, and to change radically, how we act in this world. 
To accept the ubiquity of $\sin$ in the world is to recognize how imperfect human beings are; they would like to do the right thing, but something in their nature in Christianity, their inheritance of Adam's original sin against God - prevents them from doing so. In its extreme form, sin-focused religions insist on human depravity; we who are human are so driven by our base instincts that only through a commanding and authoritative God can we hold out any hope of redemption. Such ways of thinking about human beings have played an important role in American religious history, from the Puritans and their descendents to twentieth-century versions of fundamentalist Protestantism. But it is by no means clear that sin-focused religion can maintain such a disposition in a culture which insists that human beings are basically good and reformable. American culture has, according to many critics and scholars, become influenced by a therapeutic sensibility, one that holds out hope for even the most problematic person that, with the right methods, a new way of life is possible. Increasingly in the United States, the therapeutic and the sinful collide, and, when they do, the therapeutic frequently triumphs.

Under such circumstances, we witness what can be called 'salvation inflation.' Teachers are familiar with grade inflation, a process through which students are assigned less and less work and, in return, are given higher and higher grades. (This phenomenon is not limited to education; military officers increasingly receive greater number of metals, even in peacetime, and private companies find themselves with exceptionally large numbers of vice-presidents.) In the sphere of religion, we witness similar developments; less is expected of believers as opportunities for salvation multiply. An interesting example is offered by Pentecostals. When this movement began in the early years of the twentieth century, the list of behaviors it considered sinful was large - the list ranged from watching baseball to visiting the zoo - and prime among such examples of sinful behavior were matters attending to the body; women, for example, were not expected to dress in fancy clothes or apply make-up to themselves. But in more recent times, Pentecostals not only find nothing sinful in the idea of women wearing make-up, they want women to beautify themselves as a way of demonstrating their love for Jesus. Clearly what is sinful in one era is not in another, and the general tendency over time is for religions to lose some of their strictness in these matters. (This is not true of all religions; some, such as Mormonism, have maintained strict standards of sin and others, such as various versions of Islam attractive to AfricanAmericans, have increased their emphasis on sinfulness, particularly among women.)

The reason for the more widespread movement away from strict conceptions of sin, like so many other features of American religious practice, is due to the emphasis American religion plays on growth. It was once popular in the study of American religion to insist that strict religions, because they offer an alternative to the laxness of secular culture, are more likely to grow, but when we look at the actual practices of American religions, we find that such 'strict' religions are, in reality, not that strict at all; what makes them grow, if anything, is that they hold 
out the therapeutic message of individual salvation. American megachurches do not feature fire-breathing sermons bewailing the failings of the thousands of people sitting in the pews; the sermons themselves are typically upbeat and positive and the real work of the church takes place in small groups that rely on religion to help people deal with personal problems in their lives.

It is therefore not clear that American religion works as the 'collective conscience' of the society, to use the term popularized by Émile Durkheim. An individual's conscience is that part of us which says 'no' when our cravings want to hear 'yes.' Durkheim argued persuasively that society must also have some institutions capable of saying no to the collective preferences of groups of individuals. Based on that insight, politicians frequently look to religion to perform such

Durkheimian tasks; Americans have been told, for example, that religion can help reduce the rate of abortion by upholding ideas of chastity or that religious-based organizations can be better providers of welfare than government because they carry messages of personal responsibility and transformation.

But if so much of American religion is positive and supportive of self-esteem, it is not clear that greater religious involvement in such areas of public policy will have the expected effect. Indeed, it could turn out to be the case that religion's greater role in public life could reinforce secular trends toward therapeutic selfindulgence rather than act as a counter to them.

\subsection{WITNESS}

Some religions emphasize much more than others the importance of converting other people to their worldview. The most prominent among them are evangelical Christians. The term 'evangelical' comes from the Greek for good news, and evangelicals consider it an important aspect of their religious practice to spread the good news of the Gospel. Salvation is only possible through Jesus Christ, they believe. So important is salvation - without its prospect, life is barely worth living - that evangelicals must do everything in their power to help others achieve it. One must witness one's faith, being constantly alive to the possibility of sharing it with others.

Non-Christians are not likely to be so kindly disposed toward evangelical outreach. What seems perfectly natural to evangelicals is often looked upon by others as an intrusive invasion of their privacy. If you want to believe that Jesus saves, many non-evangelicals would conclude, that is your business. But if you insist that only Jesus can save me, then you are violating my rights to believe as I choose.

Of all forms of religious practice, evangelicalization - some would call it proselytism - is among the most controversial. This is especially the case when government is used as an instrument of evangelicalization because, according to the U.S. Constitution, there should be separation of church and state. If students are led in Christian prayer through a loudspeaker before a high school football 
game, is this a violation of the rights of all those in the audience who are not Christian? The U.S. Supreme Court has ruled that it is. The rights of religious minorities, and the rights of the non-religious, are in danger when the rights of the majority religion to spread its message are given formal endorsement.

However the legal issues around evangelization are resolved, there is an important sociological issue that is frequently overlooked: even when people feel an obligation to spread the word, how do they actually do so? It turns out that American culture also influences the way people witness their faith, and often in ways that are surprising.

Whatever one thinks about efforts to evangelize, they do involve extensive socializing: knocking on people's doors, engaging them in conversation at airports, speaking with them in shopping malls. Yet we are frequently told by social critics that the United States has become an increasingly atomistic society in which people are less likely to engage in social activities with others. Consider just knocking on people's doors, which is one way in which evangelization is expected to work. The believer willing to go out and spread the word in this fashion must have a strong sense of self-confidence, an ability to accept rejection, and a willingness to enter neighborhoods that are strange and unfamiliar - all qualities increasingly difficult to find in a society that encourages people to shop from their computers or eat take-out food at home. On the other hand, people have to be willing to open their doors to strangers, and this too is difficult when there is a general fear of crime or when people are told they need to protect their home against intruders or worry about whether they will be sued if accidents happen to people while visiting them. Neither those doing the evangelizing nor those being evangelized exist outside the cultural norms that make a society work, and today's cultural norms are not that receptive to encounters between people who do not know each other, especially when those encounters involve something as important as one's faith.

This does not mean that evangelization does not happen. But it does mean that it happens in unexpected ways. Consider what can be called 'lifestyle evangelization.' There is an alternative for those unwilling to confront strangers directly. They can instead try to act in ways that convey how important Jesus has become to them; they can, for example, show their concern to people when they have problems or meet difficult conditions with a smile and a positive attitude. When asked what makes them so happy or strong, they can respond by taking the question as an invitation to start talking about God. Some churches in America strongly encourage their members to engage in such lifestyle evangelization. And for believers themselves, it offers the option of withdrawing from an encounter if it seems unlikely to succeed while going forward if it promises to bring about results.

Much the same is true of another kind of witnessing, which we can call distant evangelizing. The idea here is to use relatively impersonal means of communica- 
tion to spread personal messages about Jesus. Television is one such medium. Despite a series of scandals involving 'televangelists' in the past, preaching on television is undergoing a resurgence in the United States; the most popular such preacher, as it happens, is tall and good-looking and comes across with great sincerity on the television screen. The internet now offers ways of spreading the message indirectly; evangelical Protestants have always been at the forefront of technology from the days when radio was invented, and they show great imagination in creating online chat groups and other ways of reaching people through virtual communities. It is in the nature of such technologies to evolve rapidly and in unusual ways, so we do not know what the next stage will be, but we can be sure that evangelicals will be part of it.

It should be emphasized that considerable differences remain among American religions concerning the obligation to witness one's faith. Jews remain relatively uninterested in active recruiting of non-Jews to their tradition; if anything, Jews have historically insisted that converts undergo rigorous education in order to become Jews. (Some of this is changing as the number of Jews in the United States decreases, leading at some Jewish clergy to be more welcoming to nonJewish spouses.) Although many African-Americans have converted from Christianity to Islam, American Muslims in general do not judge the value of their faith by how many recruits it gains. And American Catholics, the largest Christian denomination in the United States, no longer believe that non-Catholics are lost souls who need to be saved. Evangelical Protestants have not joined with all these other religions and continues to place a premium upon spreading the world; in this sense, it has been somewhat resistant to the culture. But it has modified the way it witnesses to a considerable degree to accommodate to American culture, one more example of the considerable reach the culture has.

\subsection{CONCLUSION}

Studying religious practices rather than religious beliefs can lead to very different conclusions about the role of religion in American public life. Beliefs tend to encourage a focus on the differences between religions: if one set of beliefs is true, others must be false. Study theology, and one comes away with a sense of the degree to which religion can be a force for discord.

Practices, by contrast, are sociological in nature; they grow out of what human beings do in the course of their lives. Practices can also emphasize disagreement; anthropologists point out how remarkably different the customs in Africa are from those in Asia or in Western Europe. Yet all human beings' behavior is common in some ways: how they eat, how they have children, how they die. By and large, religious practices point more to the commonality than to the differences. To be sure, there will always be different forms of worship, different conceptions of sin, and different styles of spreading the word of God. But the clear message that emerges out of the study of lived religion is the degree to which practices are shaped by the culture in which they are performed. There 
exists a huge and powerful force that gives meaning to people's lives and shapes their behavior called religion. And there is another such force doing much the same called culture. When the two conflict, culture often wins.

For some, this emphasis on religious practice would be considered bad news. Religion should, they believe, stand for firm principles. If the culture is believed to be corrupt, it ought to be resisted, not engaged. Religion speaks to timeless and transcendental matters. If it has been softened by adjusting itself to the culture, it can no longer act as a prophetic force, holding out an alternative, shaped by God, to which people ought to aspire.

At the same time, however, many societies are composed of people of quite different faiths; Europe and the United States, for example, which were once both overwhelmingly Christian, now contain significant numbers of non-Christians, primarily Muslims. In addition, even countries dominated by one particular religion cannot, in an age of electronic communications, cut themselves off from the rest of the world. We no longer live at a time when religions can find themselves in a situation of splendid isolation, cut off from others with different beliefs or even no beliefs at all.

Under these conditions, the lessons taught by an emphasis on religious practice are more positive. We have no choice but to find areas of agreement between religions even if we are reluctant to do so; peace and global security depend upon our ability to do so. It therefore behooves us to find those places in which people can use their common religious practices to modify their theological differences. Jews and Muslims, for example, disagree with each greatly, especially in the Middle East. But both are minority religions in the West and as such share some religious practices in common, including dietary laws and pressures toward gender equality. From their common experiences, hopefully, bridges of trust can be built between them.

The same is true of other religious groups. In the United States, there exists considerable talk of a 'culture war' in which conservative believers conflict with liberal ones over such issues as abortion or gay marriage. These differences are real, but in a democracy, people are accepted to disagree over important issues. What is needed is a common framework that permits disagreement to occur without spilling over into civil war. The problem of finding ways to engage in religious practice links faiths that otherwise would have little in common. It also reduces the differences between the religious and the secular, since both share in a common culture that influences how they think and act. From time to time societies need reminders of the degree to which their members, all of whom are human beings, share some common characteristics. It is instructive that religion, which for so long has been a source of disagreement, could become an area for reminding human beings of how similar they are to each other. 


\section{LITERATURE}

Wolfe, A. (2003) The transformation of American Religion. How we actually live our faith, Chicago: The University of Chicago Press. 
LUIK 3

TOPOI 


\section{SCHEIDING VAN KERK EN STAAT: EEN KLASSIEKE NORM IN EEN MODERNE TIJD}

"Over de vraag, in hoever men ten onzent scheiding van kerk en staat kent, heerscht onder de staatslieden en geleerden groote verdeeldheid en niet alleen onderling weerspreken zij elkander, ook zelf zijn zij soms van meening gewisseld" (Diepenhorst, 1946).

Sophie van Bijsterveld

\subsection{INLEIDING}

Het vraagstuk van de verhouding tussen kerk en staat is teruggekeerd als een van de belangrijke thema's in Nederland. In een toenemend aantal dossiers speelt de vraag naar de verhouding tussen kerk en staat - of, breder, godsdienst en overheid - een rol. Soms is deze verhouding impliciet aan de orde, zoals in het debat over waarden en normen of in het complex van overwegingen over de toetreding van Turkije tot de EU. De laatste jaren komt de verhouding tussen overheid en godsdienst echter steeds nadrukkelijker expliciet aan de orde in Kamerstukken en parlementaire debatten. Ook rechterlijke en quasi-rechterlijke instanties worden met spraakmakende zaken geconfronteerd waarin de verhouding tussen overheid en godsdienst opnieuw ter discussie wordt gesteld.

Hoewel de vragen die zich op dit terrein aan regering, parlement en (quasi-)rechterlijke instanties voordoen zich doorgaans manifesteren ten aanzien van heel concrete kwesties, zoals kledingvoorschriften voor ambtenaren, criteria voor financiële ondersteuning van sociaal-maatschappelijke activiteiten, toelating tot Nederland van geestelijke bedienaren, toezicht op godsdienstonderwijs, de strafbaarstelling van smalende godslastering of zelfs - in het kader van het Nederlands buitenlandse beleid - de vrijheid van godsdienst in China, gaat het daarbij niet alleen of zelfs niet in eerste instantie om technisch-juridische kwesties. Boven de concrete kwesties uitstijgende spanningsvelden worden in die vragen zichtbaar gemaakt, zoals dat van eisen van pluralisme tegenover noodzaak van sociale cohesie, of dat tussen de beleving van de eigen identiteit tegenover het belang van integratie, of tussen uitingsvrijheid en respect voor anderen. Die vragen raken daarmee de grondslagen van de Nederlandse samenleving. In constitutionele termen gaat het om fundamentele thema's als de betekenis van grondwettelijke vrijheidsrechten, publieke moraal, de betekenis van burgerschap en de aard van het gebod van gelijke behandeling, en nog verdergaand, de rol van de overheid en zelfs het functioneren van de democratie.

De hernieuwde discussie over de plaats van godsdienst in de samenleving heeft dus een fundamenteel en principieel karakter. Het is daarom niet verwonderlijk dat deze thema's ook een sterke politieke, maatschappelijke en emotionele lading hebben. Binnen het domein van de overheid wordt het thema godsdienst en overheid met ongewone heftigheid bediscussieerd, evenals daarbuiten. De hier- 
boven genoemde spanningsvelden zijn daarbij doorgaans goed te herkennen. De verlegenheid om over godsdienst en overheid te discussiëren is sinds kort verleden tijd; de gebruikelijke oriëntatiepunten lijken echter aan de discussie weinig richting te kunnen bieden.

Traditioneel wordt de verhouding tussen overheid en godsdienst in Nederland uitgedrukt in een aantal beginselen. Deze rechtsbeginselen zijn die van godsdienstvrijheid, neutraliteit van de overheid en scheiding van kerk en staat. Zelfs oppervlakkige analyse van wetenschappelijke, maatschappelijke en politieke discussies laat zien dat achter deze schijnbaar vanzelfsprekende begrippen een diepgaand verschil van mening schuilgaat over inhoud en interpretatie daarvan. Zoals het citaat over de betekenis van scheiding van kerk en staat aan het begin van deze bijdrage aanduidt, is het gegeven van het meningsverschil niet nieuw. Ook in het verleden was daarvan sprake. Voor een deel was dit debet aan het door elkaar gebruiken van deze begrippen in normatieve of juist descriptieve zin. Daarbij speelde een verschil in persoonlijke appreciatie van godsdienst als zodanig of de plaats van godsdienst in de (infrastructuur van de) samenleving.

De afgelopen jaren komen meningsverschillen opnieuw naar voren en ten aanzien van nieuwe discussies. Met een beroep op dezelfde rechtsbeginselen worden sterk uiteenlopende opvattingen verdedigd, ook binnen regering en parlement. ${ }^{1}$ Hoewel zelden wordt stilgestaan bij een nadere interpretatie van die beginselen - het gaat meestal om eenvoudige verwijzingen -, zijn de twee hierboven genoemde factoren zeker ook nu nog relevant in het duiden van de verschillen in interpretatie. Maar er is meer aan de hand.

De maatschappelijke omstandigheden waaronder de tot voor kort gangbare interpretaties werden verdedigd, zijn ingrijpend gewijzigd. Kort gezegd gaat het om veranderingen zowel in de sfeer van de godsdienst en de samenleving als van de overheid. Het zijn natuurlijk juist deze veranderde omstandigheden die mede aanleiding van de hernieuwde discussies vormen. Omdat de inkleuring van de beginselen die gelden in de verhouding tussen overheid en godsdienst sterk verknocht is geraakt met de tot voor kort vertrouwde omstandigheden, kunnen wij voor het beantwoorden van de nu actuele vragen daarover niet zonder meer teruggrijpen op de herinnering aan bekende interpretaties, die immers sterk gekleurd waren door die andere omstandigheden. Toch gebeurt dit vaak wel.

Wij moeten voor een duiding van de klassieke beginselen die wij in de loop van de tijd als bepalend voor de verhouding tussen overheid en godsdienst zijn gaan zien deze beginselen dus plaatsen in een breder perspectief. Daarvoor moeten wij een startpunt kiezen dat buiten de eigenlijke discussie over de verhouding tussen kerk en staat zelf ligt.

Dit essay handelt over één van deze beginselen, het ongeschreven rechtsbeginsel van scheiding van kerk en staat. ${ }^{2}$ Dit beginsel komt veelvuldig naar voren in debatten over godsdienst en overheid. Deze bijdrage laat zien op welke uiteenlopende wijzen 
in politiek-bestuurlijke debatten naar dit beginsel wordt verwezen en ontwikkelt en lijn om de realistische betekenis van dit beginsel te bepalen en daarmee de betekenis en het belang van dit beginsel aan te geven voor de huidige vraagstukken.

Een realistisch zicht op de betekenis van dit beginsel is niet alleen essentieel voor discussies over actuele Nederlandse vraagstukken; het is ook van belang voor een inschatting van ontwikkelingen elders in Europa en het vormen van een oordeel daarover, denk aan de ontwikkelingen in Frankrijk of de discussie over de toetreding van Turkije tot de EU. Dit is ook het geval voor een waardering van de situatie elders, wat aan de orde kan komen in het kader van het buitenlands (mensenrechten)beleid.

De opzet van dit essay is als volgt. In de volgende twee paragrafen (8.2 en 8.3) wordt achtereenvolgens aangegeven welke vooronderstellingen de laatste decennia een rol zijn gaan spelen bij de interpretatie van het beginsel van scheiding van kerk en staat en hoe dit nu tot verwarring leidt in politiek-bestuurlijke discussies over de verhouding tussen kerk en staat. In de volgende drie paragrafen $(8.4,8.5$ en 8.6) wordt de basis gelegd voor een moderne visie op het beginsel van scheiding van kerk en staat. Dat gebeurt door het beginsel van scheiding van kerk en staat te plaatsen in de sleutel van de evolutie die de Nederlandse staat zelf doormaakt. Een korte blik op de verhoudingen tussen kerk en staat in enkele buurlanden (paragraaf 8.7) plaatst de interpretatie van het beginsel van scheiding van kerk en staat in een bredere context. Vanuit deze twee lijnen (de nationale en de vergelijkende) wordt vervolgens de betekenis van het beginsel van scheiding van kerk en staat onder woorden gebracht voor de huidige tijd (par. 8.8). Tot slot volgt een conclusie (par. 8.9).

De strekking van deze bijdrage is dat het beginsel van scheiding van kerk en staat binnen de Nederlandse verhoudingen onverminderd een belangrijk beginsel is, maar dat het een beperkte betekenis heeft en dat het niet adequaat is als etiket om de relatie tussen overheid en godsdienst in al zijn facetten aan te duiden. Met andere woorden: het beginsel van scheiding van kerk en staat moet niet overvraagd worden.

\subsection{VOORONDERSTELLINGEN}

Om te begrijpen op welke wijze het beginsel van scheiding van kerk en staat gaandeweg in de loop van de laatste decennia is gepercipieerd, is het nodig stil te staan bij enkele onuitgesproken vooronderstellingen waarop de verhouding tussen kerk en staat in Nederland is gaan berusten. Die vooronderstellingen maken als zodanig geen deel uit van het beginsel van scheiding van kerk en staat, maar zijn in belangrijke mate bepalend geworden voor de manier waarop wij dat beginsel zijn gaan zien.

Een tweetal vooronderstellingen verdient bijzondere aandacht. De eerste is die van godsdienst als een privé-aangelegenheid. Godsdienst wordt exclusief als een 
hoogst persoonlijke aangelegenheid gezien, zonder verdere maatschappelijke consequenties. De tweede is die van een samenleving die zich ontwikkelt in de richting van steeds meer vrijheid. De ontwikkeling van grondrechten wordt als het ware gezien in termen van een lineair perspectief, waarin steeds meer en steeds verder reikende vrijheden worden gegarandeerd. Dit geldt ook voor godsdienstvrijheid.

Doordat nu deze vooronderstellingen de laatste jaren onder druk zijn gekomen, lijkt als vanzelf het beginsel van scheiding van kerk en staat zélf in problematisch vaarwater terecht te zijn gekomen. Dit is natuurlijk niet noodzakelijkerwijs het geval. Daarom is het nodig te onderscheiden tussen die vooronderstellingen aan de ene kant en het beginsel van scheiding van kerk en staat aan de andere kant. Dat maakt het mogelijk het functioneren van het beginsel in het licht van deze veranderingen te zien. Belangrijker nog, het opent de mogelijkheid om op een onbevangen manier de (consequenties van de) ontwikkelingen te zien voor de bredere verhouding tussen overheid en godsdienst.

Laten wij bij de eerste vooronderstelling beginnen. De verhouding tussen burger en overheid is gebaseerd op een onderscheid tussen privaat domein en publiek domein. Dit onderscheid tussen privaat en publiek is wezenlijk en fundamenteel. Het komt onder meer tot uitdrukking in het onderscheid tussen publiekrecht en privaatrecht. Het ligt ook ten grondslag aan het klassieke idee van vrijheidsrechten. Het overheidsoptreden is aan grenzen gebonden. De burger heeft een privésfeer waarbinnen de overheid niet treedt. In deze dichotomie wordt godsdienst gedefinieerd in het private domein. De garantie van de vrijheid van godsdienst als fundamenteel recht onderstreept dit nog. Ook collectieve manifestaties van godsdienst werden zo in wezen gedefinieerd in het private domein als activiteiten 'binnen de muren van het kerkgebouw' of eventueel de 'zuil'. In het verlengde daarvan kon de gedachte postvatten van een 'neutraal' publiek domein tegenover een 'bijzonder' confessioneel domein dat van een andere orde was.

Het is van belang om te beseffen dat het hier gaat om een constitutionele en politiek-filosofische constructie - niet om een werkelijkheid. Zij geeft aan dat godsdienst als zodanig geen zaak van de overheid is. Zulke constructies komen wij vaker tegen. Vergelijk bijvoorbeeld de bepaling in het Burgerlijk Wetboek dat de wet het huwelijk alleen in zijn burgerlijke betrekkingen beschouwt. Dat de wet het huwelijk als zodanig beschouwt, betekent niet dat de wet daarmee een werkelijkheid uitdrukt.

Waar het om definiëring van godsdienst tot het privédomein gaat, heeft een aantal factoren er in de afgelopen decennia toe bijgedragen dat wij de constructie ook inderdaad als een werkelijkheid zijn gaan ervaren. Als gevolg van secularisering en individualisering - hier maar even in losse zin gebruikt - zijn wij ontwend geraakt godsdienst als maatschappelijke factor te zien. Daar komt bij dat voor een groot deel de algemene maatschappelijke opvattingen en de geloofsopvattingen met elkaar spoorden; voor bekende, duidelijke en op kleine schaal 
voorkomende afwijkende opvattingen konden in veel gevallen voorzieningen worden getroffen, zoals in geval van bezwaren tegen het afsluiten van verzekeringen. Waar er sprake was van concrete conflictsituaties waarin de wet niet voorzag, zijn wij dat vooral in termen van hoogstpersoonlijke gewetensopvattingen gaan zien. En evenzeer belang: als incidentele gevallen, niet als structureel vraagstuk. Nu godsdienst zich duidelijk weer als een maatschappelijke factor manifesteert die uitstijgt boven de toevallige opvattingen van een individu, is die vooronderstelling niet meer houdbaar. Het besef is herleefd dat godsdienst consequenties heeft voor mensbeelden en maatschappijopvattingen, voor de kijk op de wereld (Van Bijsterveld 2003). Zij heeft implicaties op gevoelige terreinen van man-vrouwverhoudingen en allerlei 'lifestyle'-kwesties. Voor de islam is dit overduidelijk. Maar ook voor jodendom en christendom, meer traditioneel in Nederland gevestigde godsdiensten, is dit duidelijker geworden in tijden waarin algemene maatschappelijke opvattingen sterk in beweging zijn. ${ }^{3}$

Omdat de visie op scheiding van kerk en staat zo verknocht is geraakt met die vooronderstelling van godsdienst als een privé-aangelegenheid, roept de nieuwe verschijning van godsdienst als maatschappelijke factor meteen vragen op in het licht van de scheiding van kerk en staat. Het onderstaande citaat laat dit goed zien:

“Het meest zorgelijk vind ik dat 29 tot 36 procent van de moslims van mening is, dat religie een rol moet spelen in de publieke sfeer. Daar wil ik absoluut een reactie van de minister op. Ik vind dit nogal wat, als wij hier als uitgangspunt de scheiding tussen kerk en staat hanteren. Het lijkt mij dat hier een grote taak is weggelegd voor deze minister.” (Kamerlid Nawijn, LPF)

De inkleuring van de scheiding van kerk en staat is voor een deel door die vooronderstelling van godsdienst als uitsluitend privé-aangelegenheid bepaald. Door de vereenzelviging van de vooronderstelling met het beginsel van scheiding van kerk en staat, lijkt het beginsel zelf onder druk te staan, hetgeen niet (noodzakelijkerwijs) het geval is. De conclusie moet daarom zijn dat het plaatsen van deze discussie in de context van het beginsel van scheiding van kerk en staat die discussie onnodig belemmert. De discussie van de opgeroepen vragen is niet gediend met een onnodige verwijzing naar dit rechtsbeginsel.

Het liberale denkmodel waarin godsdienst als louter privézaak wordt gezien zonder maatschappelijke dimensie blijkt overigens ook waar het om de werkelijkheid zelf gaat bij de aanhangers van deze opvatting als niet-houdbaar gezien te worden. Een voorbeeld daarvan vormt de geschiedenis rond de terugtreding van de voorgedragen Italiaanse eurocommissaris Buttligione, die vanwege zijn godsdienstige opvattingen door het Europees Parlement niet geschikt werd geacht voor zijn functie; dit terwijl de kandidaat zelf aangaf zijn godsdienstige opvattingen niet in zijn werk te laten meespelen. ${ }^{4}$ Dit is paradoxaal als godsdienst juist als strikte privézaak wordt gezien.

De tweede vooronderstelling betreft de ontwikkeling van fundamentele vrijheidsrechten in Nederland. Op een heel andere manier grijpt deze vooronderstel- 
ling - en vooral de niet-houdbaarheid ervan - in op de perceptie van de scheiding van kerk en staat. Zoals gezegd, lijkt de afgelopen decennia impliciet de gedachte te hebben postgevat van een lineaire ontwikkeling van vrijheidsrechten: méér vrijheden en verdergaande vrijheden. Dit betreft ook het recht van godsdienstvrijheid.

De geschiedenis van de vrijheidsrechten in Nederland sinds de 19de eeuw, en vooral sinds de Grondwetsherziening van 1848 , wordt in termen van een voortschrijdende ontwikkeling van vrijheidsgaranties beschreven. Deze geschiedenis heeft een sleutelrol in de ontwikkeling van Nederland als volwaardige democratische rechtsstaat. De Grondwetsherziening van 1983 en de uitvoeringswetgeving die deze op het terrein van de grondrechtenbescherming met zich bracht, versterkte dit gevoel. Algemeen is aanvaard dat de herziening juist op het terrein van de grondrechten betekenis heeft gehad. Dit betreft niet alleen de codificatie van sociale rechten, maar zeer zeker ook de formulering van klassieke vrijheden.

Ook op het terrein van de godsdienstvrijheid was dit het geval. Hier geldt wederom dat het eenvoudig was te denken en te spreken in termen van een vrijere samenleving wanneer in de praktijk godsdienstige opvattingen spoorden met die van de samenleving in het geheel. In de meer gespecialiseerde discussie over de vrijheid van godsdienst was de geschilderde tendens ook duidelijk te herkennen. Die betrof ook uitdrukkelijk de islam. De eerste discussies over vrijheid van godsdienst voor moslims stonden in het teken van het garanderen van meer vrijheid en het uit de weg ruimen van obstakels van infrastructurele juridische aard voor de beleving ervan. In de jaren tachtig van de vorige eeuw was er ook veel aandacht voor specifiek op de islam gerichte voorzieningen. De discussie concentreerde zich daarbij vooral op rituele dimensies: het ging om de oprichting en financiering van gebedshuizen, het respecteren van religieuze feestdagen en zaken als ritueel slachten van vee.

De vooronderstelling dat de ontwikkeling van vrijheidsrechten in het teken van een lineaire voortgang van de garantie van méér vrijheid gezien moet worden, is onhoudbaar gebleken. Dat hoeft weinig betoog. Of het nu gaat om meningsuiting of privacyrechten, de discussie wordt nu onder invloed van gewijzigde maatschappelijke omstandigheden vooral gevoerd in termen van de begrenzingen daarvan. Ook ten aanzien van godsdienstvrijheid is de discussie verschoven van een die in het teken staat van betere en verder reikende garanties naar een die vooral in het teken staat van beperkingen van de vrijheid. Dit is een duidelijke cultuuromslag. Een neveneffect is daarbij dat vooral problematische kanten van meningsuiting, persoonlijke levenssfeer en godsdienst aandacht krijgen.

Onbetwist is dat vrijheidsrechten niet onbegrensd zijn en dat er in concreto ook grenzen gesteld (dienen te) worden. Waar die grenzen liggen is uiteraard voortdurend onderwerp van discussie. Waar het hier om gaat, is vast te stellen dat de inzet van de discussie een andere is geworden. Dit lijkt ook het beginsel van scheiding van kerk en staat onder druk te stellen. Immers, naar gelang er meer 
individuele vrijheden worden gegarandeerd, zullen zich uit het oogpunt van scheiding van kerk en staat weinig problemen voordoen. Waar beperkingen aan de orde zijn en waar de overheid ingrijpt in (verworven) vrijheden, lijkt eerder het beginsel van scheiding van kerk en staat in het geding. Dat kán het geval zijn, maar ook hier hoeft dat niet noodzakelijkerwijs zo te zijn.

"Bij het persoonsgerichte verstoren van radicaliseringshaarden is er een zekere spanning, omdat er grenzen zijn aan wat een land kan doen bij het aanpakken van radicale uitingen of uitingsvormen, gegeven de fundamentele vrijheidsrechten van burgers en de scheiding van kerk en staat. Dit ingewikkeld thema kan bijna niet worden besproken zonder operationele informatie." (Kamerlid Wolfsen, PvdA)

Deze tweede vooronderstelling werd gevoed door dezelfde of vergelijkbare factoren als bij de eerste vooronderstelling. Ook hier geldt dat de koppeling met het beginsel van scheiding van kerk en staat niet vanzelfsprekend is.

\subsection{GROEIENDE ONZEKERHEID}

De twee vooronderstellingen hebben dus de interpretatie van het beginsel van scheiding van kerk en staat gekleurd. Nu die vooronderstellingen geen opgeld meer kunnen doen, rijzen meteen fundamentele vragen. Hoe moeten wij omgaan met godsdienst als maatschappelijke factor? Hoe ver reikt de vrijheid van godsdienst? Welke plaats heeft godsdienst in het publieke domein? In de parlementaire discussies en ook daarbuiten worden deze vragen in (bijna) al deze gevallen in het perspectief geplaatst van de scheiding van kerk en staat. Dit beginsel lijkt het meest voor de hand liggende oriëntatiepunt. Alleen blijkt dat het deze oriëntatie maar moeilijk bieden kan. Een willekeurig gekozen aantal uiteenlopende voorbeelden uit het politieke en bestuurlijke leven maakt dit duidelijk.

Het beginsel van scheiding van kerk en staat wordt met enige regelmaat naar voren gebracht waar het gaat om de wettelijke garantie van toegang tot of beschikbaarheid van door de overheid gereguleerde voorzieningen voor kerkelijke of confessionele deelname. Het onderwijsstelsel waarvan het bijzonder onderwijs deel uitmaakt, is een voorbeeld van een dergelijke voorziening. Dit geldt ook voor het stelsel van de publieke omroep. Het relateren van het beginsel van scheiding van kerk en staat aan deze voorzieningen is niet nieuw. ${ }^{5}$ Een beroep op dit beginsel heeft doorgaans de strekking kerkelijke of confessionele deelname op gelijke voet met anderen ter discussie te stellen. Dit is ook het geval met betrekking tot de positie van kerkelijke zendgemachtigden:

\footnotetext{
"De VVD wil dat de zendtijd voor levensbeschouwelijke omroepen zonder leden wordt afgeschaft. De liberalen vinden, redenerend vanuit het beginsel van de scheiding tussen kerk en staat, dat kerken en andere levensbeschouwelijke instellingen niet mogen worden gefinancierd met belastinggeld." (VvD)
} 
De scheiding van kerk en staat wordt ook aangehaald waar het gaat om een onderlinge afbakening van institutionele verhoudingen tussen overheid en kerk. Dit is vooral het geval waar het gaat om de interne organisatorische verhoudingen binnen kerkgenootschappen of andere genootschappen op geestelijke grondslag. Hier werpt het beginsel een barrière op tegen overheidsingrijpen:

“De heer Lazrak heeft een motie ingediend over de taken en verantwoordelijkheden van de imams binnen de moskee. Deze motie gaat duidelijk veel te ver. Door de uitvoering van die motie zou onmiskenbaar een schending plaatsvinden van het beginsel van scheiding van kerk en Staat. De overheid mag zich niet bemoeien met de intern kerkelijke verhoudingen.”6 (minister De Vries)

Het beginsel van scheiding van kerk en staat wordt ook op een geheel andere manier in het debat naar voren gebracht. Zo wordt het aanroeren door bewindslieden van onderwerpen met een levensbeschouwelijke dimensie geproblematiseerd onder verwijzing naar het beginsel van scheiding van kerk en staat:

"Dat is precies wat de minister nu ook doet. Zij zet de scheiding tussen kerk, staat en wetenschap onder druk. Daarom heb ik een aantal vragen. Vindt de minister niet dat zij de grens tussen privéopvattingen en ministerschap overschrijdt als zij het debat over 'intelligent design' en de evolutietheorie niet daar laat waar het hoort, namelijk onder wetenschappers? Wat vindt zij ervan dat er in Nederland scholen zijn die de evolutietheorie überhaupt niet willen onderwijzen? Wat gaat zij daaraan doen? (...)"7 (Kamerlid Azough, GroenLinks)

Een vergelijking dringt zich op met de commotie rond de uitspraken van beoogd Europese-Commissielid Buttiglione, waar, als gezegd, de verzekering van zijn kant dat het om (louter) persoonlijke godsdienstige overtuigingen niet adequaat bleek om het vertrouwen te winnen van het Europees Parlement.

Ook het spreken van de kerk over politiek-maatschappelijke kwesties wordt in parlementaire kring met de scheiding van kerk en staat in verband gebracht. Met name is dit het geval wanneer stellingnamen inhoudelijk afwijken van gangbaar geworden maatschappelijke opvattingen:

"Indien regeringen de opvattingen van De Heilige Stoel op het gebied van seksuele en reproductieve rechten overnemen, betreuren wij dat, omdat het indruist tegen het Nederlandse beleid. Ook in dergelijke gevallen behoeft er echter geen sprake te zijn van ondermijning van de scheiding van kerk en staat, mits de besluitvorming op democratische wijze tot stand komt en de betrokken regering de opvattingen van de eigen bevolking, zoals tot uitdrukking komend in de visie van het nationale parlement, uitdraagt." (minister Bot, minister Van Ardenne-Van der Hoeven)

Met het bovenstaande citaat komen wij in de sfeer van 'waarden en normen'discussies. Waar het in het bovenstaande citaat kerkelijke stellingnamen betreft die een politiek-maatschappelijke lading hebben, wordt de scheiding van kerk en 
staat ook aangevoerd waar het om de houding van de overheid ten aanzien van geloofsinhoud gaat, of tenminste thema's die op de grens tussen geloofsinhoud en 'waarden en normen'-discussies liggen:

“(...) Naar mijn mening is het overigens wel van belang dat men bij het lezen van de teksten uit de Koran deze niet alleen in religieus, maar ook in historisch perspectief beziet. (...) Mijn doel is dat over een aantal jaren vooral in het Nederlands wordt gepredikt. Door imams die goed thuis zijn in de Nederlandse samenleving en een godsdienst uitdragen die mensen verbindt, gebaseerd op de islamitische normen en waarden én op die van de Nederlandse samenleving, zoals de scheiding tussen kerk en staat en de gelijkheid van man en vrouw. En op de vaste overtuiging dat geweld, te allen tijden, ontoelaatbaar is. (...)"9 (minister Verdonk)

De grens tussen geloofsinhoud en 'waarden en normen'-opvattingen is niet altijd eenvoudig te trekken:

"Met het oog op de scheiding tussen kerk en staat wil de regering niet inhoudelijk oordelen over de islam, maar zij lijkt toch een soort van moderne islam toe te juichen. Het lijkt de heer Van der Staaij dat er niet zoiets mag ontstaan als een islaminterpretatie die is goedgekeurd door de Nederlandse staat." ${ }^{10}$ (Kamerlid Van der Staaij, SGP)

Treffend in dit verband zijn de vragen die zijn opgerezen over de mogelijke toetreding van Turkije tot de EU, gelet op het feit dat de bevolking overwegend uit moslims bestaat. Hier gaat het niet over de geloofsinhoud als zodanig; de nadruk ligt op de implicaties daarvan voor de (Europese) samenleving en overheid. Zowel de WRR als de regering concludeert dat er geen bezwaren zijn. Voor ons doel is alleen al relevant dat de vraag als zodanig gesteld wordt.

\section{"Centrale vraag}

Vormt het feit dat de meerderheid van zijn bevolking moslim is een belemmering voor de toetreding van Turkije tot de Europese Unie (EU)?

\section{Aanleiding}

(...) Vooral echter sinds de terroristische aanslagen op 11 september 2001 zijn de zorgen over de islam en moslims in de lidstaten toegenomen. Dit heeft geleid tot een groeiende aarzeling over de vraag of het islamitische karakter van Turkije zich verdraagt met de politieke verworvenheden van de EU en haar lidstaten. Bezwaren van cultureel-religieuze aard worden inmiddels ook in politieke kringen naar voren gebracht." ${ }_{11}$

Nog een stap verder gaat het in verband brengen of ter discussie stellen van de aanwezigheid van uiterlijke tekenen van geloof in het publieke domein. ${ }^{12}$ Zoals uit het volgende tekstfragment blijkt, worden ook deze uiterlijke tekenen met het beginsel van scheiding van kerk en staat in verband gebracht: 
"Het antwoord dat het moderne denken hierop heeft gevonden, is om godsdienst tot privé-zaak te verklaren en daarom uit het publiek domein te bannen met een beroep op de scheiding van kerk en staat. Het leidt onder meer tot fundamentalistische bezwaren tegen iedere godsdienstige uiting in het openbare leven: de formule 'bij de gratie Gods', de bede in troonrede, het bijzonder onderwijs. Dat is struisvogelgedrag (...)."13 (minister Donner)

\begin{abstract}
Van geheel andere orde is de toenadering die plaatsvindt tussen overheid en kerkelijke organisaties. Daarbij komen nieuwe vormen van samenwerking tussen overheid en kerken in het vizier. Het gaat hier om een samenwerking ten dienste van samenleving en burgers. De kerken spelen een rol als maatschappelijke kracht. Deze dimensie van kerken wordt nu door de overheid weer herontdekt. Het gaat hier om het mede gestalte geven van maatschappelijke en sociale doelen door kerkelijke organisaties in het kader van speciaal daartoe in het leven geroepen wetgeving. Het onderstaande citaat van de staatssecretaris betreft de invoering van de Wet maatschappelijke ondersteuning:
\end{abstract}

"Ik zal mij met de VNG ervoor inspannen dat ook in het implementatietraject de laatste puntjes op de i worden gezet. Vooral de cliëntparticipatie zal daarin voor mij een aandachtspunt zijn. Ook als de wet in werking is getreden, zijn regering, vNG en alle organisaties die de afgelopen twee jaar bij de ontwikkeling van het wetsvoorstel zijn betrokken - van manifestpartijen tot kerkelijke organisaties - ervoor verantwoordelijk dat de wet goed landt in de samenleving. Nog een keer dan: the proof of the pudding is in the eating. Een goed recept is daarbij een voorwaarde." ${ }^{14}$ (staatssecretaris Ross-Van Dorp)

Hiervan is niet alleen sprake in eigen land, maar ook buitenslands, in het kader van ontwikkelingssamenwerking:

"Waar de staat om welke reden dan ook faalt, knappen deze [religieuze] organisaties het vuile werk op. Het is duidelijk, dat religieuze organisaties, meer dan de overheid, in staat zijn om de maatschappij op een positieve manier te mobiliseren. (...) Het is duidelijk, dat we onze religieuze wortels moeten opgraven als we echt contact willen leggen met de minderheden hier en de meerderheid daar."15 (minister Ardenne-van der Hoeven)

Niet alleen vindt afstemming of samenwerking van concrete maatschappelijke activiteiten plaats ten behoeve van samenleving en burgers. Met de ontdekking van godsdienst als maatschappelijke factor krijgt ook het overleg tussen overheid en godsdienstige of kerkelijke maatschappelijke organisaties een nieuwe betekenis:

\footnotetext{
"Maar wat moet een minister dan met een contactorgaan van moslims in Nederland? Kort gezegd: zaken doen (...) Samenwerken met het CMO. Dat is iets anders dan zich bemoeien met de interne gang van zaken. Dat laat de scheiding van kerk en staat niet toe. De oprichting van het CMO, hoe en met wie men samenwerkt, dat is overgelaten aan de moslimorganisaties zelf. Dit proces kent een
} 
eigen dynamiek. Maar dat wil niet zeggen dat de overheid zich in deze geheel lijdzaam opstelt. De overheid zal, voordat ze een contactorgaan erkent, aangeven dat ze een gesprekspartner wenst die de diversiteit van de achterban weerspiegelt, die zoveel mogelijk stromingen vertegenwoordigt en die ook specifieke groepen als vrouwen en jongeren aan bod laat komen. Daarom zal ik op korte termijn de representativiteit van het CMO tegen het licht houden om te zien of onze samenwerking van start kan gaan." ${ }^{\prime 6}$ (minister Verdonk)

Het ongemak met (uiterlijke) verschijningsvormen van godsdienst in het openbare leven is daarmee niet verdwenen. Met een beroep op het beginsel van scheiding van kerk en staat wordt een dergelijke zichtbaarheid van godsdienst wel bekritiseerd. Daarnaar verwijst het volgende citaat:

"Geloof en religie uit het publieke leven willen bannen is daarom gevaarlijk en weinig zinvol. Zonder geloof is duurzaam samenleven niet mogelijk, en zonder religie gaat het niet goed. Overheid en samenleving hebben juist belang bij het betrokken zijn van geloof en religie op de publieke zaak. Het waarborgt de voortdurende ontwikkeling van de waarden en normen waarmee nieuwe vraagstukken in de samenleving tegemoet getreden kunnen worden." ${ }^{17}$ (minister Donner)

Met bovenstaande citaten nog in gedachten is de onderstaande passage wel erg opmerkelijk:

\footnotetext{
“Dat roept de vraag op wat de relatie is tussen overheid en religie. Het antwoord is simpel: die is er niet. De overheid laat gelovige onderdanen vrij in de uitoefening van hun geloof, mengt zich niet in godsdienstige zaken en behandelt religieuze en levensbeschouwelijke stromingen in Nederland op gelijke wijze. In Nederland zijn kerk en staat gescheiden."18 (minister Verdonk)
}

Zoals impliciet al blijkt, gaan achter deze citaten recente, (deels) nieuwe ontwikkelingen schuil. Zij geven aanleiding tot evenzoveel verschillende stellingnamen en verschillen van opvatting. De worsteling met de betekenis van het beginsel van scheiding van kerk en staat is voortdurend merkbaar.

Nog belangrijker is het om op te merken dat de materie waarop deze citaten betrekking heeft sterk uiteenloopt. Zoals hierna wordt betoogd, wordt het beginsel van scheiding van kerk overvraagd door al de dimensies van de verhouding tussen overheid en godsdienst waarop die citaten betrekking hebben onder de noemer van scheiding van kerk en staat te brengen. Daarbij komt dat het beginsel van 'scheiding' van kerk en staat a priori al wijst in de richting van een antwoord. Zonder nadere analyse lijkt dit beginsel immers de richting aan te geven van het losmaken van banden tussen beide. In elk geval problematiseert zij de betrekkingen. Dit verklaart ook een deel van de worsteling met dit beginsel in de citaten. Het is tegelijkertijd ook duidelijk dat overheid en godsdienst niet volkomen los van elkaar gezien kunnen worden. 
Om het beginsel van scheiding van kerk en staat te kunnen plaatsen in deze discussies en de relevantie daarvoor te beoordelen, is het als gezegd nodig een ankerpunt te vinden dat buiten die discussie over die onderwerpen zelf is gelegen. In de volgende drie paragrafen wordt de verhouding tussen kerk en staat bezien vanuit een voornamelijk staatkundig ontwikkelingsperspectief en wordt dit vervolgens in verband gebracht met het beginsel van scheiding van kerk en staat. Achtereenvolgens staat de meer klassieke regelingsfunctie van de staat centraal, de veranderende plaats en rol van de overheid ten opzichte van de (pluralistische en complexe) samenleving en daarna de belangstelling van de staat voor het thema religie zelf. Elk van die perspectieven zorgt voor een eigen dynamiek in de verhouding tussen kerk en staat. Elk van die perspectieven heeft ook implicaties voor uiteenlopende dimensies in de verhouding tussen kerk en staat.

\subsection{ONTVLECHTING EN ACCOMMODATIE}

Vanuit het perspectief van de klassieke overheid kan er een tweetal accenten worden aangegeven in de verhouding tot kerk en godsdienst zoals die zich de laatste twee eeuwen heeft ontwikkeld. Dat zijn die van ontvlechting en accommodatie. Bij de accommodatie kan een nader onderscheid worden gemaakt tussen de stelselmatige ordening en een verdere fijnafstemming in de verhouding tussen kerk en staat. Het zwaartepunt ligt voor elk van deze accenten in een andere tijdperiode.

Ontvlechting van de verhouding tussen kerk en staat stond centraal in de 19de eeuw. De tijd van accommodatie valt samen met de aanloop en verdere ontwikkeling van de sociale verzorgingsstaat. De fijnafstemming in de verhouding tussen kerk en staat moeten wij vooral plaatsen in de laatste helft van de vorige eeuw en zien tegen de achtergrond van de enorme groei van bestuursregelgeving.

Deze korte aanduiding doet al vermoeden dat de aard van de vragen die spelen in de verhouding tussen kerk en staat van karakter veranderde mét de ontwikkeling die de activiteiten van de overheid zelf doormaakten. Voor de beoordeling van de betekenis van de scheiding van kerk en staat op elk van deze onderdelen heeft dit consequenties. Wanneer hiertussen geen onderscheid wordt gemaakt, is de verleiding groot het 'ontvlechtingsperspectief' zonder onderscheid te hanteren voor de gehele verdere ontwikkeling die volgt, ook al zijn daarin wezenlijk andere vragen aan de orde. Dit vraagt een korte toelichting.

De tijd van de ontvlechting staat in het teken van de 'scheiding van kerk en staat'. Scheiding van kerk en staat was het model op basis waarvan de institutionele verhoudingen vorm werden gegeven. Dit was een reactie op de verwevenheid die er voordien - met name in de tijd van de Republiek - bestond tussen kerk en staat. Dit proces van ontvlechting heeft tot laat in de 19de eeuw voortgeduurd. Dit ontvlechtingsperspectief is een belangrijke rol blijven spelen in de verdere ontwikkeling van de verhouding tussen kerk en staat in Nederland, ook nadat de belangrijke vragen inmiddels van karakter veranderd waren. Belangrijk is nog te 
vermelden dat het vooral om de losmaking van de kerk van de staat ging, dus om 'meer vrijheid' van de kerk ten opzichte van de overheid.

De afkoop van oude traktementsverplichtingen en de beëindiging van enkele andere specifieke financiële regelingen werden nog wel in het licht van 'scheiding' gezien en wel in de zin van 'meer vrijheid' van de overheid ten opzichte van de kerk. Zo werd hier en daar wel gesproken van privileges van kerken die werden afgeschaft, terwijl het in deze gevallen vaak ging om schadevergoedingen wegens naasting van eigendommen door de staat. Daarmee waren zij dus eigenlijk van een andere orde.

In tegenstelling tot de ontvlechtingsfase was de accommodatiefase vanuit het gezichtspunt van de overheid niet als zodanig gericht op de kerken zelf. Het ging vooral om de accommodatie van wederzijdse activiteiten die nodig werd door de expansie van de overheid en daarmee ook de regulering van terreinen waarop ook de kerk of hieraan gelieerde confessionele organisaties actief waren. Daarbij moest de staat rekening houden met het bestaan van die organisaties. Dat is gedaan door deze als het ware in te voegen in de regelgeving van de verzorgingsstaat. Dat betrof ook de regeling van bijvoorbeeld financiering en kwaliteit. Onderwijs en gezondheidszorg zijn hiervan voorbeelden bij uitstek. Ook waar nieuwe voorzieningen ontstonden, zoals op het terrein van de media, werd dit patroon als vanzelfsprekend overgenomen. De geschiedenis hiervan is genoegzaam bekend.

Het beginsel van 'scheiding van kerk en staat' wordt wel eens aangehaald bij pleidooien die strekken tot beëindiging van de positie van identiteitsgebonden instellingen in het maatschappelijk leven (denk aan onderwijs of media). Daarbij wordt vooral gewezen op de financiering die op dezelfde wijze geregeld is als die van de gelijksoortige instellingen die niet identiteitsgebonden zijn.

Voor de beoordeling van de betekenis van het beginsel van scheiding van kerk en staat op dit punt kan niet zonder meer naar financiering op zich gekeken worden. In de Nederlandse verzorgingsstaat maakt die deel uit van een meer omvattend stelsel waarin de overheid een centrale rol speelt bij de herverdeling van middelen via belastingheffing en vervolgens vormgeving en financiering van voorzieningen. Het uitsluiten van identiteitsgebonden initiatieven is daarom problematisch. ${ }^{19}$ Die voorzieningen zijn elders, denk bijvoorbeeld aan de Verenigde Staten, ingebed in een geheel andere context. De overheid speelt daar een veel meer bescheiden rol in de herverdeling van middelen en in de daadwerkelijke verwezenlijking van voorzieningen. De beoordeling van overheidsbetrokkenheid bij identiteitsgebonden initiatieven zal dáárdoor ook een andere (moeten) zijn, niet vanwege een dwingende betekenis van het beginsel van scheiding van kerk en staat op zich.

De scheiding van kerk en staat speelt wel een rol bij de vormgeving van de aard van de betrekkingen. Juist waar de overheid activiteiten ging ontplooien, moest 
met de eigen organisatiestructuur van kerken zelf rekening worden gehouden, zoals bij het vaststellen van regelingen omtrent democratisering, privacy en gelijke behandeling.

Accommodatie in de zin van fijnafstemming van de onderlinge verhoudingen wordt nodig gemaakt door de groei van bestuursregelgeving en is van meer recente datum. De verhouding tussen kerk en staat is daar niet rechtstreeks aan de orde, maar het functioneren van de kerk wordt wel door het overheidsoptreden geraakt. Het gaat hier om veelal fijnmazige wetgeving in de sfeer van bijvoorbeeld ruimtelijke en fiscale regelgeving. De interventie van de staat stuit op een complexe maatschappelijke werkelijkheid. Om aan die werkelijkheid recht te doen, zijn meestal veel uitzonderingen, differentiëring en nuances nodig. Zo worden in het kader van de regulerende energieheffing bijvoorbeeld bedrijven en huishoudens niet over één kam geschoren. Dat voor kerkgebouwen met weer een heel ander gebouw en soort gebruik ook specifieke aandacht nodig is, is in dat licht evident. Het gaat hier om wijs bestuur. De scheiding van kerk en staat - zeker in een ontvlechtingsperspectief - heeft hier geen zinnige betekenis. Ter illustratie volgt hieronder een citaat over de Wet waardering onroerende zaken (wOz).

\footnotetext{
"Voor de inwerkingtreding van de Wet wOZ werd de waarde van een kerkgebouw voor de waterschapsomslag gebouwd, bepaald op de gecorrigeerde vervangingswaarde. Bij de invoering van de Wet wOZ is bij amendement geregeld dat voor een kerk die tevens rijksmonument is, de waarde wordt bepaald op de waarde in het economische verkeer. Dit betekent in de praktijk dat de waarde van zo'n kerk veelal op één euro wordt vastgesteld. Tevens is, mede naar aanleiding van een toezegging aan het parlement, geregeld dat een kerkgebouw dat geen rijksmonument is, wordt gewaardeerd naar de (lagere) benuttingswaarde. Met deze maatregelen wordt voorkomen dat de waarde van kerkgebouwen in het kader van de Wet woz onverantwoord hoog zou worden."2o
}

Samenvattend zien wij dus dat de aard van de vragen in de verhouding tussen kerk en staat met de tijd verandert met de verschuivingen in de sfeer van de overheid(sactiviteiten). De ontwikkelingen kunnen daarom niet exclusief in het teken van scheiding van kerk en staat geduid worden. Anders gezegd: het beginsel kan niet leidend zijn voor de beantwoording van alle nieuwe vragen die zich voordoen. Het beginsel van scheiding van kerk en staat is daarmee niet onbelangrijk geworden. Het heeft alleen een beperkte reikwijdte.

\subsection{ANDERE OVERHEID ${ }^{21}$}

Het beginsel van scheiding van kerk en staat - en daarmee ook onze voorstelling van de verhouding tussen kerk en staat - is verknocht met een bepaald beeld van de staat. Dat is de klassieke democratische rechtsstaat die de formele kaders definieert voor de publieke besluitvorming. Het gaat dan ook om een staat die het brandpunt vormt van de vorming van recht en beleid. Dit beeld beantwoordt nauwelijks meer aan de werkelijkheid. Dit gegeven heeft ook implicaties voor de 
verhouding tussen kerk en staat. Daarmee is het ook relevant voor de waardering van de betekenis van het beginsel van scheiding van kerk en staat.

Door een aantal elkaar wederzijds versterkende centrifugale krachten is de centrale rol van de staat onder druk komen te staan (Van Bijsterveld 2002). Kort gezegd gaat het om ontwikkelingen van internationalisering en privatisering. Tegelijkertijd is de werkelijkheid waarmee de overheid te maken heeft complexer en dynamischer geworden en is de samenleving in hoge mate pluralistisch. Deze factoren hebben niet alleen invloed op de sturingsambitie en -pretentie van de overheid. Zij hebben ook consequenties voor het karakter van het overheidsoptreden zelf. De overheid is dan ook gewikkeld in een proces van herpositionering ten opzichte van de samenleving. Dit plaatst de klassieke kerk-en-staat-verhoudingen in een ander licht. Op drie niveaus heeft dit consequenties voor de verhouding tussen kerk en staat. Het eerste ligt op het vlak van de ontwikkeling en de uitvoering van beleid. Het tweede betreft het functioneren van maatschappelijke instituties en de ontwikkeling van maatschappelijke 'waarden en normen'-patronen. Het derde ligt op het niveau van de individuele burgers.

Wij beginnen met het eerste niveau. De veronderstelling dat recht en beleid worden gemaakt en zelfs geïnitieerd door de organen van de staat is steeds meer een anomalie. Vaak is het beleid een resultante van lange en complexe processen waaraan vele actoren deel hebben genomen. Een groot aantal zelf aangewezen belangenpartijen participeert in het (informele) besluitvormingsproces. Deze partijen kunnen een (eigen)belang hebben bij het voorgestelde beleid en uit dien hoofde menen iets te zeggen te hebben. $\mathrm{Zij}$ kunnen ook experts zijn op een betreffend gebied en overheidsorganen informatie en inzichten verschaffen die zij zelf niet kunnen genereren. Zij kunnen ook bepaalde idealen vertolken of zich inzetten voor (bepaalde dimensies van) het algemeen belang. Ondanks afwezigheid van een formeel-juridische status in het besluitvormingsproces bestaat er bij overheidsorganen een toenemende interesse om deze groeperingen en hun inzichten te betrekken in het proces van beleidsvorming. Vaak worden ook reacties van de 'civil society', het maatschappelijk middenveld, expliciet uitgelokt. Voorts zijn er allerlei informele of semi-formele 'dialogen' die plaatsvinden in de aanvangsstadia van de beleidsvoorbereiding. In dit proces participeren ook kerken en kerkelijke organisaties. Zoals dat voor andere organisaties ook geldt, is dit in wederzijds belang van de participanten, de organisaties en overheid. Voor de overheid gaat het om het verwerven van kennis, inzicht en het sonderen van draagvlak.

Expertise, draagvlak, betrokkenheid en handelingscapaciteit zijn evenzeer van belang voor de uitvoering van beleid. Voor zover de overheid überhaupt nog een taak heeft, is samenwerking met maatschappelijke instellingen vaak onmisbaar. Kerken zijn hierbij niet exclusief betrokken, maar zij zijn daarbij óók betrokken.

De ontwikkeling in de richting van dialoog en samenwerking met kerkelijke organisaties bij de ontwikkeling en uitvoering van beleid moet dan ook in het licht van deze bredere ontwikkelingen worden gezien. Uit een oogpunt van de 
scheiding van kerk en staat is dit op zichzelf allerminst problematisch. De betekenis van het beginsel van scheiding van kerk en staat ligt dan vooral bij de beoordeling van de eventuele voorwaarden waaronder die samenwerking plaatsvindt.

Het tweede en derde niveau betreffen maatschappelijke en individuele waardeontwikkeling. Het is inmiddels bekend dat de overheid in haar rol als wetgever worstelt met het reguleren van allerlei morele kwesties. Aan de ene kant kan de overheid voor het beantwoorden van nieuwe kwesties niet zonder meer terugvallen op bekende (waarden)patronen: die zijn eenvoudigweg niet voorhanden. En als ze al voorhanden zijn, dan is klassieke regulering niet altijd het meest aangewezen middel: het tempo van technische ontwikkelingen is moeilijk bij te houden en de diversiteit aan casusposities is niet altijd bij voorbaat te voorzien. Aan de andere kant maakt het pluralisme in samenleving en parlement consensus over moreel geladen kwesties moeilijk.

Het beeld van een overheid die met gezag bindende inhoudelijke normen vaststelt, is daarmee aan erosie onderhevig. Veel normen komen in een complexe ontmoeting tussen staat en samenleving tot stand. Zij zijn vaak de resultante van top-down- en bottom-up-ontwikkelingen die op een bepaald moment samenkomen. Meer dan bekend zijn de veelvoorkomende verschijnselen van delegatie van wettelijke normen naar steeds verdere niveaus binnen de overheid en ten slotte naar de praktijk. Daarnaast is het werken met open normen in de wetgeving een bekend verschijnsel. In al die gevallen betekent dit dat, nadat de regering en Staten-Generaal gesproken hebben, de eigenlijke invulling van die normen nog plaats moet vinden door overheidsinstanties en/of in de praktijk. Het kan daarbij gaan om uiterst technische aangelegenheden, maar ook vraagstukken waar wij niet kunnen terugvallen op beproefde praktijken of waarover geen morele consensus bestaat. Kerken hebben hier geen exclusieve rol; zij hebben wel een belangrijke rol in het aanreiken van morele oriëntaties. Voor de individuele burger die in het eigen persoonlijke leven meer met morele dilemma's wordt geconfronteerd is een toerusting vanuit coherente mens- en maatschappijbeelden ook van groot belang om verantwoorde persoonlijke keuzen te maken.

De actuele 'waarden en normen'-discussies wijzen ons op het inzicht dat verwoord is in de uitdrukking die in Duitsland veel wordt geciteerd, namelijk dat de staat leeft van vooronderstellingen die hij zelf niet verwezenlijken kan. Anders gezegd, voor het goed functioneren leunt een democratische rechtsstaat op maatschappelijke en culturele waarden-en-normenpatronen. Zolang die zich in rustig vaarwater bevinden, blijft deze waarheid doorgaans onzichtbaar. Wanneer er verwaarlozing optreedt of zich onvermoede verschuivingen voordoen, wordt de waarheid van die uitdrukking weer aan den lijve ondervonden. ${ }^{22}$ Het is dus van belang dat de staat blijvend de voorwaarden garandeert waaronder persoonlijke en maatschappelijke vorming ook vanuit coherente religieuze en levensbeschouwelijke waarden verzekerd is. 
Ter illustratie van de actualiteit van deze materie volgt hieronder een citaat uit de parlementaire discussie over burgerschapsvorming en onderwijs.

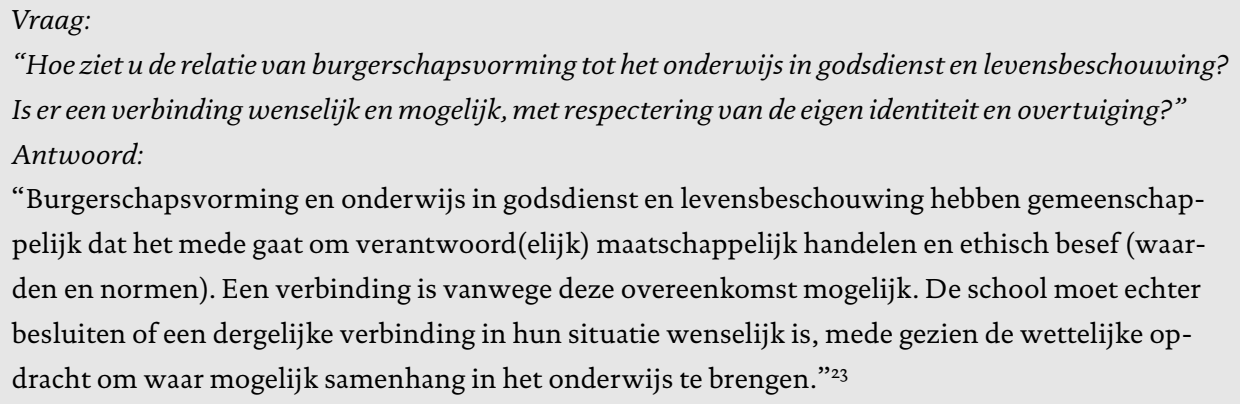

Het is duidelijk dat het beginsel van scheiding van kerk en staat voor zover dat betrekking heeft op het beeld van de klassieke democratische rechtsstaat, aan deze processen grotendeels voorbijgaat. Ook hier geldt dat het beginsel van scheiding van kerk en staat zijn betekenis niet verliest, maar niet zelf het leidende beginsel kan vormen om deze processen als zodanig te waarderen.

\subsection{ANDERE GODSDIENST}

Met het thema waarden en normen belanden wij bij de godsdienst zelf. De huidige interesse van de staat zelf in kerk en godsdienst beïnvloedt de verhouding tussen kerk en staat en roept de vraag op naar de betekenis van het beginsel van scheiding van kerk en staat. Zoals de staat niet meer de staat is, is ook de kerk niet meer de kerk. Ten aanzien van ons beeld van godsdienst staan eveneens vanzelfsprekendheden ter discussie. Voor de staat zelf is dit ook van belang.

In ieder geval de periode van de laatste anderhalve eeuw riepen ook voor de staat de begrippen 'kerk' en 'godsdienst' een vertrouwd beeld op. De kerken waren letterlijk 'bekend' bij de staat. De staat wist wat hij zich bij kerk en godsdienst moest voorstellen. De staat wist daarmee met wie hij te doen had. Voor het bepalen van de houding tot kerk en godsdienst was dit wel zo eenvoudig. De immer dynamische godsdienstige wereld leverde voor de overheid in die periode doorgaans ook geen extra problemen op, niet waar het ging om afsplitsingen van in Nederland bestaande geloofsgemeenschappen en niet waar het ging om de intrede van geloofsgemeenschappen van elders. ${ }^{24}$ De lijst met kerkgenootschappen die door het ministerie van Justitie op grond van de Wet op de kerkgenootschappen van 1853 werd beheerd, was al lang in onbruik geraakt voordat de wet uiteindelijk in 1988 werd afgeschaft.

De overheid kon toen ook gemakkelijk waarmaken dat zij niet in godsdienst als zodanig geïnteresseerd was. Geloofsopvattingen vielen samen met het min of meer gangbare waardepatroon in de Nederlandse samenleving. Met die waarden kwamen vooral problemen, niet omdat de kerkelijke opvattingen veranderden, 
maar omdat de algemeen maatschappelijke opvattingen veranderden en de kerkelijke opvattingen niet mee veranderden. Afwijkende opvattingen waren vrij duidelijk te lokaliseren, vaak dus al 'vooraf'. Zij waren in getalsmatige omvang veelal bescheiden en daarmee uit het oogpunt van de staat niet bijzonder problematisch.

Van dat laatste is nu geen sprake meer. Daarmee wordt de positie van de overheid ten opzichte van het fenomeen godsdienst en ten opzichte van van de meerderheid afwijkende opvattingen meteen anders. De acceptatie ervan wordt door die factoren duidelijk moeilijker. De volgende passage uit het SGP-vonnis van de rechtbank 's-Gravenhage laat dit treffend zien:

“3.6 Het betoog van de Staat (...) verwerpt de rechtbank. Het gaat (...) in deze immers (...) om het belang van een ieder, in het bijzonder van vrouwen, om in een democratische maatschappij te leven waarin discriminatie op grond van geslacht - met als gevolg uitsluiting van het passieve kiesrecht niet getolereerd wordt en waarin door de Staat handhavend opgetreden wordt. Dit belang krijgt een zwaardere lading als men bedenkt dat het niet denkbeeldig is dat in de (nabije) toekomst ook andere partijen opstaan die vrouwen - op godsdienstige motieven - een andere politieke en/of maatschappelijke rol toebedelen dan mannen, waardoor het gevaar van discriminatie wederom op de loer ligt. De Staat kan hierin een sturende rol spelen." ${ }^{25}$

Uiteraard worden met de 'andere partijen' die kunnen opstaan partijen bedoeld die zich baseren op de 'onbekende' islam.

Daarmee wordt de interesse van de overheid in godsdienst in wezen gedefinieerd als een kwestie van openbare orde. Het gaat dan om openbare orde in enge zin (denk aan de 'gewone' openbare orde, maar ook aan vrees voor radicalisering en terrorisme), van integratie en sociale cohesie, en het handhaven van een bepaald maatschappelijk waarden-en-normenpatroon. De interesse van de overheid in observatie (het verwerven van kennis over de godsdienst en in het op gang brengen van een kennismakingsproces) is daarmee gegeven. Een neiging tot sturing en beperking komt dan mogelijk ook in beeld. Vrijheid van godsdienst wordt daarmee een complexe aangelegenheid, die aan het beeld van het eenvoudig vrijlaten van individuele religieuze overtuigingen en het bieden van ruimte voor het uitvoeren van rituelen voorbijgaat. Desinteresse van de overheid in godsdienst maakt zo plaats voor een zeer specifieke interesse. De overheid wil weten wat er in belangrijke sectoren van de samenleving 'omgaat' en daarbij hoort zeker ook de sector godsdienst.

In de eerder gegeven citaten vinden wij deze dimensies ook allemaal terug. Het vraagstuk van het waarden-en-normenpatroon staat centraal in de vraagstelling van het WRR-rapport De Europese Unie, Turkije en de islam: sporen de waarden en normen van moslims met die van de democratische rechtsstaat?(2004) De uiterst heftige reacties uit de sfeer van parlementariërs op het recente WRR-rapport Dynamiek in islamitisch activisme. Aanknopingspunten voor democratisering en mensenrechten (2006) kunnen ook alleen maar in het licht van bovengenoemde verschijnselen worden gezien. 
Het ongemak van de overheid ten aanzien van de niet-gekende godsdienst betreft niet alleen de islam. In de jaren tachtig van de vorige eeuw ontsproot in Nederland een enigszins vergelijkbaar ongemak met de zogenaamde nieuwe religieuze bewegingen (Witteveen 1984), een fenomeen van getalsmatig zeer beperkte omvang en waarvan redelijkerwijs niet te verwachten viel dat het in de nabije toekomst grote proporties zou aannemen. Zeer recent kwam dit thema op in andere West-Europese landen. Kortom: vanuit de staat bestaat belangstelling om zicht te houden en greep te hebben op maatschappelijke processen, zeker als die consequenties hebben voor waarde- en gedragspatronen van burgers. Waar het gaat om maatschappelijke veranderingsprocessen met een religieuze of levensbeschouwelijke dimensie is dit niet anders.

Terugkerend naar de islam: het vraagstuk van de totstandkoming van een meer of minder representatieve vertegenwoordiging van 'de islam' in relatie tot de overheid is daarmee niet alleen een formele kwestie. Zoals uit het bovenstaande blijkt, vertegenwoordigt de 'antenne'-functie voor de overheid een eigen belang. Tegelijkertijd is het contact met de overheid ook voor godsdienstige organisaties zelf waardevol. Het gaat hier dus om een wederzijds belang.

Bij het ontwikkelen van contacten tussen overheid en religieuze organisaties speelt vanuit het perspectief van de overheid zeer duidelijk de wil mee om zicht en vat te krijgen op een maatschappelijk verschijnsel van betekenis. Waar tot voor kort nauwelijks onbekendheid bestond bij de overheid met het verschijnsel godsdienst en de implicaties daarvan, is daarvan nu wel sprake.

Dat hier ook meer of minder subtiele sturingsprocessen van de zijde van de overheid een rol gaan spelen is niet verwonderlijk. Van de contacten op zich kan al een zekere sturing uitgaan. Bij de voorwaarden waaronder de overheid op centraal niveau spreekt met bijvoorbeeld het CMO is dit meer expliciet het geval, zoals uit een van de eerdere citaten bleek.

Samenvattend: vanuit het gezichtspunt van de staat geven de ontwikkelingen in het domein van de godsdienst aanleiding tot een hernieuwde belangstelling voor godsdienst en de organisaties die deze dragen. Dat leidt tot veranderingen in de houding van de overheid ten opzichte van godsdienst en de betreffende organisaties. Contact en samenwerking zijn uit een oogpunt van scheiding van kerk en staat op zichzelf genomen - wederom - niet problematisch. Wel is het beginsel van belang bij de vormgeving van de onderlinge relaties. Het zal niet verbazen dat juist hier de grens tussen maatschappelijke overheidssturing en sturing op godsdienst en kerkelijke organisaties zelf dun is.

\subsection{EEN BLIK OVER DE GRENS}

In de vorige drie paragrafen is het beginsel van scheiding van kerk en staat geplaatst in de sleutel van de evolutie die de Nederlandse staat heeft doorgemaakt en nu doormaakt. Wij verlaten nu deze lijn om een blik over de grens te werpen. 
Zoals gezegd, scheiding van kerk en staat is als beginsel in Nederland onomstreden. Een blik over de grens, zelfs alleen naar onze mede EU-lidstaten, laat zien dat er ook andere modellen mogelijk zijn. Zo vinden wij het model van een staatskerk in Denemarken, Engeland en Griekenland. Systemen van samenwerking van kerk en staat komen wij tegen in Duitsland en Oostenrijk, maar ook bijvoorbeeld in Spanje en Italië. Die andere modellen wijken dus af van het Nederlandse, maar het zijn op zich legitieme modellen. Systemen die als scheiding van kerk en staat worden gekarakteriseerd zien wij in Portugal, Ierland en Frankrijk. Om een beter zicht te krijgen op het Nederlandse beginsel van scheiding van kerk en staat is het zinvol nader naar deze andere systemen te kijken. In dit bestek kan het alleen om een paar korte karakteristieken gaan op stelselniveau.

De termen die de uiteenlopende stelsels karakteriseren geven daarvan zeker een belangrijk kenmerk weer. Zoals wij al eerder betoogden ten aanzien van het Nederlandse beginsel van scheiding van kerk en staat, zijn die termen niet adequaat om de meer omvattende stand van zaken in de verhouding tussen kerk en staat weer te geven. Een blik over de grens bevestigt dit beeld alleen maar. Concrete overeenkomsten en verschillen in de meer juridische vormgeving van de verhouding tussen kerk en staat lopen deels dwars door het onderscheid tussen die typen heen. Ten aanzien van de ontwikkeling van de financiële verhoudingen tussen kerk en staat in West-Europese stelsels is wel gesproken van een 'erosie van extremen'. Die tendens is ook toepasselijk met betrekking tot de bredere ontwikkelingen in klassieke juridische vragen in de verhouding tussen kerk en staat.

Ook om andere redenen zijn die termen niet adequaat om de meer omvattende stand van zaken in de verhouding tussen kerk en staat weer te geven. Zij abstraheren van de mate waarin cruciale maatschappelijke functies worden vervuld door kerken of aan de kerk gelieerde instituten. Ook de moderne vragen en ontwikkelingen in de verhouding tussen kerk en staat onttrekken zich enigszins aan deze terminologie. Dat laatste blijkt onder meer in het onderlinge verschil in de wijze van benadering van actuele vragen van de omgang met maatschappelijke verschijningsvormen van godsdienst tussen Frankrijk en andere stelsels waarin kerk en staat gescheiden zijn (Van Bijsterveld 1998). Daarbij moeten wij bovendien beseffen dat de situatie in Frankrijk veel complexer is dan op het eerste gezicht lijkt. ${ }^{26}$

Om een ander voorbeeld te geven: in het Duitse stelsel van coöperatie ligt tegelijkertijd een 'scheiding van kerk en staat' besloten. De Duitse grondwet bepaalt dat er geen sprake is van een staatskerk en garandeert de geloofsgemeenschappen als zodanig institutionele autonomie. Er is een open systeem van rechtspersoonlijkheid voor kerken. Kerken kunnen opteren voor de status van Körperschaften des öffentlichen Rechts, mits zij aan een aantal voorwaarden voldoen in de sfeer van duurzaamheid en omvang. Stelsels met een scheiding van kerk en staat kennen een dergelijke rechtsfiguur niet. Wij moeten ons in de vergelijking echter niet exclusief richten op de rechtsvorm als zodanig. In een stelsel als het Nederlandse, waarin wij die rechtsvorm niet kennen, zijn voor het stichten van scholen of het 
hebben van toegang tot de media wel vergelijkbare criteria nodig om een zekere duurzaamheid en minimumomvang van de achterban te waarborgen. Die criteria vinden wij dus niet in het rechtspersonenrecht voor bepaalde rechtsvormen voor kerken, maar in de wetgeving die de betreffende voorziening regelt.

De relativering van deze begrippen kunnen wij nog verder uitstrekken tot de andere stelsels. Engeland en Griekenland kunnen daarbij als illustratie dienen. Het is niet moeilijk te verdedigen dat het Engelse stelsel minder verschilt van sommige stelsels van bijvoorbeeld scheiding dan van het Griekse stelsel. Engeland kent inderdaad een staatskerk, maar afgezien van de positie van de Church of England is het overigens niet fundamenteel verschillend van andere West-Europese stelsels. ${ }^{27}$ Het essentiële uitgangspunt voor de vergelijking vormt dan niet zozeer de (historische) positie van de Church of England, maar de juridische positie van de niet-gevestigde kerken en het functioneren van deze nietgevestigde kerken in de maatschappelijke en bestuurlijke realiteit. Hetzelfde geldt mutatis mutandis voor Denemarken, waar de juridische en maatschappelijke positie van de niet-staatskerken adequaat is. Juist aan dat laatste schort het wel in Griekenland. Dat is de eigenlijke aarzeling bij het Griekse stelsel, niet zozeer een traditionele, juridisch sterker verankerde positie van één kerk. De reden waarom wij een staatskerk problematisch vinden is dan in eerste instantie gelegen in de positie van de niet-gevestigde kerken en de mate van algemene openheid of geslotenheid van het stelsel.

Om terug te komen bij de reden van dit uitstapje naar andere stelsels: ook de blik over de grens bevestigt dat het klassieke beginsel 'scheiding van kerk en staat' niet als omvattende oriëntatie kan dienen voor verhouding tussen kerk en staat in bredere zin. Dat blijkt bij een vergelijking met stelsels die hetzelfde beginsel huldigen; het blijkt evenzeer bij een vergelijking met andere stelsels.

De typering in termen van de drie bovengenoemde modellen van staatskerk, coöperatie of scheiding tussen kerk en staat is zeker ook nu van belang als startpunt voor het nadenken over de verhouding tussen beide machten. Net als het beginsel van scheiding van kerk en staat richten ook de andere typeringen zich echter heel sterk op één specifiek element in de verhouding tussen kerk en staat. Dat is het element dat dominant was zo'n twee eeuwen geleden, een 'tijd van instituties'. Die karakteriseringen concentreren zich op vooral het element dat toen het meest van belang was: de institutionele dimensie in engere zin.

\subsection{WAAR GAAT HET UITEINDELIJK OM?}

$\mathrm{Nu}$ godsdienst weer duidelijker terugkomt als maatschappelijk verschijnsel en de discussie over vrijheid van godsdienst vooral in het teken staat van mogelijke beperkingen, manifesteert zich een groeiende onzekerheid over de betekenis van het beginsel van scheiding van kerk en staat ten aanzien van allerlei concrete vragen. Hoe verhoudt zich dit ter discussie stellen van de positie van de kerkelijke zendgemachtigden tot het toebedelen van een rol aan kerken in het kader van de 
Wet maatschappelijke ondersteuning? Hoe verhoudt zich de interesse van de overheid om samen te werken met moslimorganisaties tot het problematiseren van bijzonder onderwijs?

De strekking van het voorgaande is vooral geweest het aangeven dat de scheiding van kerk en staat niet het geheel van de verhouding tussen kerk en staat kan bestrijken. Het beginsel van scheiding van kerk en staat is dus niet geschikt om alle vragen over de plaats van godsdienst in het publieke domein of de houding van de overheid ten opzichte van godsdienst te beantwoorden. Maar waar gaat het dan uiteindelijk wel om bij de scheiding van kerk en staat?

Het rechtsbeginsel van scheiding van kerk en staat is niet expliciet in de Nederlandse grondwet vastgelegd. Dit is ook nimmer het geval geweest. Mede vanwege het feit dat het een ongeschreven rechtsbeginsel is, is er in de staatsrechtelijke literatuur weinig aandacht aan besteed. ${ }^{28}$ Zelfs bij de grondwetsherziening van 1983, waar wel de nodige aandacht is besteed aan de bescherming van grondrechten, het systeem van beperkingen van grondrechten en grondrechten als zodanig, kwam de betekenis van dit beginsel niet echt aan bod. Het recht op godsdienstvrijheid komt daar veel beter uit de verf. Bovendien is er ook geen sterke traditie van constitutionele theorievorming in Nederland. Daar komt bij dat (tot voor kort) het beginsel van scheiding van kerk en staat als bekend verondersteld werd en min of meer als vanzelfsprekend aanvaard. ${ }^{29}$ Vanzelfsprekendheden nodigen zelden uit tot fundamentele analyses.

Desalniettemin kunnen wij een aanduiding geven van wat het beginsel van scheiding van kerk en staat wél inhoudt. Kort gezegd houdt het beginsel in dat er in de verhouding tussen kerk en staat geen institutionele zeggenschap over en weer mag zijn, evenmin als rechtstreekse inhoudelijke zeggenschap. Om in termen van de vrijheid van onderwijs te spreken: het beginsel van scheiding van kerk en staat komt in essentie neer op een wederzijdse vrijheid van inrichting en vrijheid van richting. Er is geen formele positie van kerken in publieke besluitvormingsprocedures en er worden geen louter godsdienstige maatstaven aangelegd voor het overheidshandelen. Anderzijds: de kerken zijn vrij van overheidsinvloed in hun geloofsleer en zijn vrij in het vormgeven van de kerkelijke organisatie en in de aanstelling van hun functionarissen.

Wij hebben hiervoor steeds gesproken over het beginsel van scheiding van kerk en staat. 'Geldt' het nu ook daadwerkelijk als positief recht? Het antwoord daarop is dat het beginsel als positief recht geldt in zover het in de grondwet en verdragen uitdrukking heeft gekregen, en dat is vooral via het samenstel van bepalingen van met name artikelen 1, 6 en 23 van de grondwet en de verdragsrechtelijke equivalenten. De interpretatie die wij zojuist kort samenvatten als 'wederzijdse vrijheid van inrichting en richting' is daaronder in elk geval begrepen.

De afwezigheid van een expliciete grondwetsbepaling in combinatie met het constitutionele toetsingsverbod leidt ertoe dat ook in de rechtspraak niet veel 
aandacht is voor het beginsel van scheiding van kerk en staat. In rechtszaken waarvoor dit relevant is, speelt vooral de interpretatie van concrete (grond)wetsen verdragsbepalingen een rol. Slechts in enkele gevallen is er in een rechterlijke uitspraak een verwijzing naar het beginsel van scheiding van kerk en staat te vinden of is er in een geval van vernietiging van besluiten van gemeentebesturen door de Kroon (regering) een overweging aan het beginsel gewijd. Daarbij gaat het zelden om beschouwingen over de politiek-filosofische of juridisch-bestuurlijke betekenis ervan of over een definitie of omschrijving. Meestal is het slechts een verwijzing of vermelding ten overvloede in evidente gevallen. Een voorbeeld van dat laatste is de vernietiging door de Kroon van een bepaling uit de subsidieverordening van de gemeente Hasselt die onder meer bepaalde dat geen subsidie verstrekt werd voor activiteiten "die zijn gericht tegen Gods wet". Aangegeven werd dat de artikelen 1 en 6 , eerste lid, van de grondwet niet een toetsing toestaan aan een geloofs- of levensovertuiging. Het beginsel van scheiding van kerk en staat brengt mee "dat de overheid geen (zuiver) godsdienstige of levensbeschouwelijke normen als de onderhavige stelt". $3^{\circ}$ Godsdienstige normen bepalen niet het overheidsoptreden; de overheid bepaalt niet de inhoud van het geloof of godsdienstige stellingnamen. Dit alles neemt overigens niet weg dat overtreding van de (straf)wet niet toegestaan is.

Vrijheid van kerkelijke organisatie heeft uitwerking in allerlei specifieke wetgeving. Waarborgen zijn onder meer te vinden in de regeling van het kerkgenootschap als rechtspersoon (вw). De niet-van-toepassingverklaring van de Algemene wet gelijke behandeling op - kort gezegd - kerkgenootschappen en het geestelijk ambt is een ander voorbeeld. Uiteraard zijn inherent aan die waarborgen ook grenzen: kerken zullen niet naar willekeur kunnen handelen.

Kerk en staat zijn gescheiden, maar zij bewegen zich niet in gescheiden werelden. Indirecte beïnvloeding via het waarden-en-normenpatroon van de burgers is er uiteraard wel. ${ }^{31} \mathrm{Om}$ te beginnen stelt de (straf)wet grenzen aan de handelingsvrijheid van burgers, ook waar het gaat om de vrijheid van godsdienst en levensovertuiging. Deze grenzen zijn niet onveranderlijk; discussie daarover zal altijd (kunnen) plaatsvinden. Van rechtstreekse overheidsinvloed op geloofsinhoud zal niet snel sprake zijn. Dit wil niet zeggen dat beïnvloeding niet plaatsvindt. De beïnvloeding zal veeleer subtieler zijn. Denk bijvoorbeeld aan zaken als door de overheid gestelde voorwaarden voor overleg met godsdienstige organisaties (zie de discussie rond de representatie van vrouwen en jongeren in het CMO).

Scheiding van kerk en staat belet institutionele zeggenschap over en weer. Overleg tussen overheid en kerken en participatie van kerken of kerkelijke organisaties in de voorbereiding of uitvoering van overheidsbeleid wordt hierdoor niet uitgesloten. Zoals wij hiervoor al zagen, is zulk overleg of zulke participatie niet alleen onvermijdelijk, maar kan die zelfs geboden zijn.

Overzien wij de politieke discussies over allerlei concrete thema's die de relatie tussen overheid en godsdienst betreffen, dan komt een bonte mengeling van 
opvattingen naar voren waar het om de betekenis van scheiding van kerk en staat gaat. Verschillen van inzicht over de verhouding tussen kerk en staat en daarmee verband houdende vragen zijn, zoals het citaat van Diepenhorst aan het begin van deze bijdrage aangeeft, op zich niet nieuw. De huidige verwarring over het beginsel van scheiding van kerk en staat wordt vooral ingegeven door verwijzingen ernaar in allerlei gevallen die de reikwijdte van dat beginsel te boven gaan.

Wanneer het gaat om een abstracte omschrijving is er overigens veel meer overeenstemming over de hoofdlijnen van de betekenis van het beginsel van scheiding van kerk en staat. In bovengenoemde zin drukt ook de Nota grondrechten in een pluriforme samenleving zich uit. ${ }^{32}$

Hoewel het beginsel van scheiding van kerk en staat niet het omvattende label kan vormen voor de verhouding tussen kerk en staat, geeft het wel een belangrijke dimensie daarvan weer. Ook in de gevallen waar het niet het dominante en leidende beginsel kan vormen, blijft het wel een belangrijke randvoorwaarde bij het concreet vormgeven van die verhouding. Wanneer wij de nieuwe ontwikkelingen en vragen die hierboven geschetst zijn overzien, dan liggen met name voor de toekomst gevoelige punten bij ontwikkelingen die zich voordoen rond de nieuwe interesse van de overheid in godsdienst.

Het zal niet verbazen dat juist hier de grens tussen maatschappelijke overheidssturing en sturing op godsdienst en kerkelijke organisaties zelf delicaat is.

Wanneer godsdienst een instrument wordt in handen van de overheid of de overheid een sturende rol in de interne verhoudingen van de godsdienstige organisaties gaat uitoefenen, wordt de grens van dat beginsel overschreden; een optreden waarom de Nederlandse overheid juist andere overheden bekritiseert.

Ook is het zaak godsdienst niet als (een te makkelijk) aangrijpingspunt te kiezen om problemen op te lossen waarvoor godsdienst niet eens het geschikte aangrijpingspunt is. Nog afgezien van het instrumentele gebruik van godsdienst dat zo dreigt, is het veelal niet effectief genoeg om de doelen te bereiken die de overheid daarmee beoogt te bereiken en kan het door de algemeenheid ongewenste neveneffecten hebben op de lange termijn. Dit geldt voor thema's als integratie evenzeer als dat van terrorismebestrijding.

\subsection{SLOT}

Scheiding van kerk en staat is in Nederland een belangrijk en algemeen aanvaard beginsel. Het beginsel behoort tot de fundamentele constitutionele ordeningsprincipes, ook al is het niet expliciet in de grondwet of enig andere wet neergelegd. Van een zeker verschil van interpretatie van dit beginsel is altijd al sprake geweest. Dit hing en hangt vooral samen met de wijze waarop tegen godsdienst en de plaats ervan in de samenleving wordt aangekeken. In ieder geval heeft het feit dat het beginsel niet expliciet in de grondwet is neergelegd, gecombineerd met het ontbreken van een rechterlijk toetsingsrecht aan de grondwet, ertoe 
bijgedragen dat het beginsel in de geldende rechtsdogmatiek niet sterk ontwikkeld is. Ook de afwezigheid van een sterke traditie van constitutioneel denken of staatsleer heeft daartoe bijgedragen. Als geldend recht kan het beginsel gezien worden in de mate waarin het uitdrukking vindt in het samenstel van grondwettelijke grondrechten. Daarbij zijn vooral de artikelen 6, 1, en 23 van de grondwet van belang. Ook is het nodig dit beginsel te zien in relatie tot andere fundamentele principes zoals de vrijheid van godsdienst en het principe van neutraliteit van de overheid.

De perceptie en beoordeling van de verhouding tussen kerk en staat en de inkleuring van het beginsel van scheiding van kerk en staat de laatste decennia moeten gezien worden tegen de achtergrond van twee vooronderstellingen. Dit zijn die van godsdienst als behorend tot het privédomein en een lineaire opvatting van vrijheidsrechten. Nu deze vooronderstellingen aan het schuiven zijn, ontstaat er nieuwe verwarring rond de interpretatie van het beginsel van scheiding van kerk en staat. Ten aanzien van allerlei uiteenlopende concrete kwesties wordt naar het beginsel verwezen. Door de nieuwe vragen van vormgeving van de verhouding tussen kerk en staat weet men met de interpretatie ervan niet echt raad.

De tijd waarin het beginsel van scheiding van kerk en staat tot ontwikkeling kwam is een andere dan de huidige tijd. In die tijd vormde dat beginsel een belangrijk antwoord op vragen van die tijd over de verhouding tussen kerk en staat, namelijk de vragen van de institutionele, organisatorische plaatsbepaling tussen de instituties van kerk en staat. Ook nu zijn die vragen relevant. Er zijn nu echter ook andere, nieuwe vragen. Het beginsel van scheiding van kerk en staat is niet toereikend om alle dimensies van de verhouding tussen kerk en staat te omvatten. Daarmee wordt het overvraagd. Het beginsel blijft wel onverminderd van belang als randvoorwaarde bij de preciezere vormgeving van de verhoudingen; een verhouding, die zoals uit het voorgaande bleek, niet gebaseerd kan zijn op het buitensluiten van kerk en godsdienst.

Waarom is het nodig hier zuiver te zijn? Het is van belang dat wij fundamentele discussies over de verhouding tussen overheid en godsdienst niet vertroebelen met oneigenlijke argumenten. Het is minstens evenzeer van belang dat wij geen antwoorden zoeken op vragen bij rechtsbeginselen die daarop het antwoord niet kunnen bieden. 


\section{BIJLAGE}

\section{EUROPA: DE EU EN HET EVRM}

De verhouding tussen kerk en staat is traditioneel een exclusief nationale aangelegenheid. Deze verhouding kan echter niet alleen meer in een nationale context gezien worden. De laatste jaren is steeds duidelijker geworden dat ook hieraan een internationale dimensie verbonden is (Van Bijsterveld 200o). In strikte zien hebben deze ontwikkelingen geen betekenis voor de interpretatie van het Nederlandse beginsel van scheiding van kerk en staat. Dat neemt niet weg dat het de moeite waard is kort stil te staan bij die ontwikkelingen in het kader van deze bijdrage.

Voor ons doel zijn dan niet zozeer de internationale ontwikkelingen op zich interessant, maar gaat het vooral om de betekenis die deze ontwikkelingen - en dan met name de Europese - hebben voor het nationale niveau. Wij moeten daarbij een onderscheid maken tussen de EU en de Raad van Europa. Bij de Raad van Europa gaat het vooral om het in het kader van die organisatie gesloten Europees Verdrag voor de Rechten van de Mens (EVRM) en de rechtspraak van het Europees Hof (EHRM).

Wij beginnen met de EU. De verhouding tussen kerk en staat speelt in de EU op twee niveaus. Het ene is het niveau van de EU zelf: hoe verhoudt de EU zich tot godsdienst en kerken? Het andere niveau betreft de betekenis van EU-optreden voor de verhouding tussen kerk en staat in de lidstaten van de EU.

Waar het gaat om het tweede niveau, de invloed van de EU op nationale kerk-enstaat-verhoudingen, moeten wij het volgende beseffen. De EU is alleen tot handelen bevoegd op basis van uitdrukkelijke bevoegdheidstoekenningen in de verdragen. Het domein van de godsdienst hoort niet tot die bevoegdheden. Dat betekent om te beginnen dat niet ingegrepen mag worden in nationale kerk-enstaat-verhoudingen 'via de band' van de EU.

Kerk-en-staat-verhoudingen op nationaal niveau krijgen echter niet alleen door de algemene principes gestalte, maar ook door de uitwerking van die principes in concrete wetgeving. Nu heeft de EU door de uitbreiding van de bevoegdheden in de loop van de tijd allerlei bevoegdheden gekregen die indirect een zekere invloed kunnen uitoefenen op de desbetreffende wetgeving in de lidstaten. Afhankelijk van het nationale stelsel zal de impact van die uitwerking uiteraard anders zijn. Wij kunnen hierbij denken aan uiteenlopende zaken als belastingregelingen, media- of privacywetgeving.

Met het oog op deze indirecte invloed is bij de Slotakte van het Verdrag van Amsterdam in 1997 een Gemeenschappelijke Verklaring (nr.11) aangenomen die bepaalt: "De Europese Unie eerbiedigt en doet geen afbreuk aan de status die kerken en religieuze verenigingen en gemeenschappen volgens het nationale 
recht in de lidstaten hebben.” Net als op andere terreinen kan ook hier niet sprake zijn van een waterdichte afschotting tussen de EU en de lidstaten. Niettemin wordt hiermee een belangrijk beginsel tot uitdrukking gebracht dat ook een rol heeft gespeeld bij de totstandkoming van Europese regelgeving. Het Verdrag tot vaststelling van een grondwet voor Europa heeft deze bepaling (in een net iets andere formulering) overgenomen in artikel I-52, eerste en tweede lid. Dit betekent dus dat nationale modellen gerespecteerd worden, zonder dat die daarmee overigens gefixeerd worden.

Daarnaast is de EU zelf gehouden om grondrechten in acht te nemen. Daaronder is ook begrepen het recht van vrijheid van godsdienst. Groepen en organisaties kunnen zich in principe ook op dit recht beroepen. ${ }^{33}$ Daarmee ontstaat dus in zekere zin een kerk-en-staat-verhouding op het niveau van de EU, al is die moeilijk te onderscheiden van de dimensie die wij zojuist aanroerden. Meer in het bijzonder komt de verhouding tussen kerken en de EU zelf naar voren in de bepaling van de grondwet van Europa dat de Unie "een open, transparante en regelmatige dialoog met die kerken en organisaties [voert], onder erkenning van hun identiteit en hun specifieke bijdrage" (art. I-52, derde lid). Deze bepaling vormt een pendant van een gelijksoortige bepaling over de dialoog met "representatieve organisaties en het maatschappelijk middenveld" (art. I-47, tweede lid). Hoewel deze bepaling de EU zelf betreft en niet de relatie tot de lidstaten, is zij voor ons uiterst relevant, met name in het licht van wat wij hierboven over nationale contacten en overleg tussen overheid en kerken hebben vermeld. De opname van deze bepaling in het hoofdstuk over 'Het democratisch leven van de Unie' geeft daarbij tegelijkertijd aan dat de relatie tussen overheid en kerken niet meer exclusief in het teken van klassieke kerk-en-staat-verhoudingen gezien moet worden, maar vooral ook in het licht van de veranderende rol van overheden zelf.

De betekenis van het EVRM en de interpretatie die het Europees Hof in Straatsburg daaraan geeft, is van direct belang voor de godsdienstvrijheid op de nationale niveaus van de staten die bij het verdrag partij zijn. Bewust spreken wij hier van 'godsdienstvrijheid': artikel 9 van het EVRM garandeert het recht van gedachten, geweten en godsdienst. Het Hof toetst immers (onder andere) of de nationale staat zich schuldig heeft gemaakt aan een schending van het EVRM. Nationale kerk-en-staat-verhoudingen, die bij de lidstaten een grote verscheidenheid te zien geven, worden in principe daardoor niet bestreken. Via de interpretatie van het recht van godsdienstvrijheid kan de rechtspraak uiteraard nationale verhouding tussen staat en kerk wel beïnvloeden of tot bijstelling ervan noodzaken. ${ }^{34}$ De vrijheid van godsdienst als gegarandeerd in het EVRM vormt voor de nationale verhouding tussen kerk en staat dus een randvoorwaarde. Maar nog afgezien van de constitutionele positie van het Hof als zodanig en het feit dat ('enkel') godsdienstvrijheid de toetsingsmaatstaf vormt, leidt zeker de verscheidenheid aan stelsels bij de lidstaten tot een terughoudendheid waar het gaat om systeemkenmerken als zodanig. Zoals het Hof het zelf uitdrukt, laat het een beoordelingsmarge "particularly with regard to establishment of the delicate relations between the Churches and the State" (EHRM 2000). 
Dit neemt niet weg dat het Hof ook nadruk legt op het belang van het vrij kunnen functioneren van kerken en het niet-inmengen of partij kiezen door de staat in interne kerkelijke conflicten. ${ }^{35}$ Kerkelijke en religieuze organisaties kunnen zelf als organisatie ook een beroep doen op het recht van godsdienstvrijheid; het Hof volgt hierbij de constructie dat zij dit doen namens de gelovigen. 


\section{NOTEN}

Zie hierover nader paragraaf 8.3.

Het beginsel van scheiding van kerk en staat is niet expliciet in de Nederlandse (grond)wet of enig internationaal verdrag neergelegd. Zie nader paragraaf 8.9. Het beginsel wordt geacht besloten te liggen in het samenstel van een aantal grondwetsartikelen, met name artikel 6 (vrijheid van godsdienst of levensovertuiging), artikel I (gebod van gelijke behandeling en non-discriminatie). Andere artikelen zijn echter ook relevant.

Zie de voorbeelden van de volgende paragraaf.

4 Ook waren hier ongetwijfeld andere factoren in het spel. Dit neemt niet weg dat de kwestie van de geloofsopvattingen van de kandidaat-eurocommissaris een rol speelden.

Zie hiervoor verder paragraaf 8.4 .

Handelingen II, 2001-2002, 90-5374.

Handelingen II, 2004-2005, 83-4970.

Aanhangsel Handelingen II, 2005-2006, nr. 975, p. 2067 (Antwoord van minister Bot (Buitenlandse Zaken) en minister Van Ardenne-van der Hoeven (Ontwikkelingssamenwerking)).

Toespraak minister Verdonk voor Vreemdelingenzaken en Integratie bij de in ontvangstneming van de Koranvertaling voor Ahmadiyya-stroming, Haags Congrescentrum, 10 maart 2005. Uit: http://www.justitie.nl/pers/speeches/ archief/archief_2005/50311Koran.asp.

Kamerstukken II, 2004-2005, 29 800 VI, nr. 150, p. 5. WRR (2004), De Europese Unie, Turkije en de islam, Amsterdam: AUP. Zie daarvoor ook August Hans den Boef, Nederland seculier! Tegen religieuze privileges in wetten, regels, praktijken, gewoonten en attitudes, Amsterdam: Van Gennep 2003.

3 Lezing van minister Donner van Justitie 'Religie en samenleving', tijdens CDA-bijeenkomst 'Religie in de stad, bindende kracht of scheidende macht' op 17 december 2005 in de Hofkerk te Amsterdam. Uit: http://www.justitie.nl/ pers/speeches/archief/archief_2005/51220Religie_en_samenleving.asp.

14 Kamerstukken II, 2005-2006, 30 131, nr. 98, p. 78.

15 “Niet om zieltjes te winnen, maar om levens te redden”, Artikel van minister Ardenne-van der Hoeven, in NRC Handelsblad, 1o september 2005. http://www.europaportaal.nl.econom-i.com/default.asp?CMS_ITEM=5Do9A3

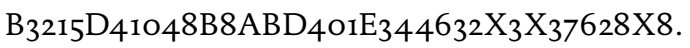

6 Toespraak minister Verdonk bij de presentatie Contactorgaan Moslims en Overheid op zaterdag 7 februari 2004. Uit: http://www.justitie.nl/pers/speeches/ archief/archief_2004/070204_presentatie_cmo.asp.

7 Toespraak van minister Donner bij de start van de nieuwbouw van de moskee Milligörus (de Westermoskee) te Amsterdam op 28 februari 2006. http://www.justitie.nl/pers/speeches/archief/archief_2006/60302Westermoskee.asp.

8 Toespraak minister Verdonk bij de presentatie Contactorgaan Moslims en Over- 
heid op zaterdag 7 februari 2004. http://www.justitie.nl/pers/speeches/ archief/archief_2004/070204_presentatie_cmo.asp. Vgl. (1946) ARRvS 18 december 1986, AB 1987, 260 (Jeugdcentrale Hellevoetsluis). Kamerstukken II, 2003-2004, 29 612, nr. 3, p. 7. Vgl. het gelijknamige actieprogramma van het kabinet-Balkenende II. Kamerstukken II, 2003-2004, 29 362, nr. 1. Zie voor gevoeligheden van de staat bij verschuivingen van dat patroon, ook de volgende paragraaf. Kamerstukken II, 2003-2004, 29 536, nr. 2, p. 34. Dit lag overigens anders in de eerste helft van de 19 de eeuw. Rechtbank's-Gravenhage, uitspraak 7 september 2005. Hoewel er sterke nadruk is op de laïcité, kent Frankrijk bijvoorbeeld een drietal departementen waarin nog het napoleontische concordaatsregime geldt. Bovendien zijn ook de laatste decennia allerlei betrekkingen ontwikkeld tussen overheid en (institutionele dragers van) religie. En een aantal andere karakteristieken eigen aan een common law rechtssysteem. Zie over het beginsel van scheiding van kerk en staat, voorts B.P. Vermeulen, 'Artikel 6' in A.K. Koekkoek (ed.) De Grondwet. Een systematisch en artikelsgewijs commentaar, Deventer Tjeenk Willink 2000, p. 93-108; M.M. den Boer 'Artikel 6' Grondwet: vrijheid van godsdienst en levensovertuiging in: NJCMBulletin 1987, p. 110-127; Overheid, godsdienst en levensovertuiging, Eindrapport van de Commissie van advies inzake de criteria voor steunverlening door de overheid aan kerkgenootschappen en andere genootschappen op geestelijke grondslag (Commissie-Hirsch Ballin), 's-Gravenhage 1988; E.M.H. Hirsch Ballin, 'Geloof en politiek: living apart together', in: Ars Aequi, juli/augustus 2003, p. 549-551. Als eerder gezegd, heeft altijd wel verschil van inzicht bestaan; in relatief rustige tijden leidt dat niet tot veel praktische consequenties.

$30 \mathrm{~KB}, 4$ december 1984, Stb.685.

31 Zie hierover nader onder meer S.C. van Bijsterveld, 'Church Autonomy in the Netherlands. The Distinctiveness of the Church. The Interplay between Legal, Popular, and Ecclesiastical Perspectives. Church Autonomy as a "Test Case", in: Hildegard Warnink (ed.), Legal Position of Churches and Church Autonomy, Leuven 2001, p. 147-163.

32 Zie met name, Kamerstukken II, 2003-2004, 29 614, nr. 2 (Nota grondrechten in een pluriforme samenleving), p.7 e.v..

Het voert hier te ver om in te gaan op het interessante vraagstuk van de grondrechtenbescherming in de EU zelf. Van belang is het wel om te constateren dat het recht van vrijheid van godsdienst is opgenomen in het EVRM, waaraan ook de EU zich gecommitteerd heeft. Verder kent ook het - op dit moment niet bindende Handvest voor de grondrechten van de EU het recht van godsdienstvrijheid alsmede andere rechten die in dit verband van belang zijn. In het Verdrag tot vaststelling van een grondwet voor Europa is dit opgenomen in artikel II-70.

34 Ook hier geldt dat het in dit bestek slechts om een summiere behandeling van dit onderwerp kan gaan. 
35 Zie bijvoorbeeld EHRM, 16 december 2004, Supreme Holy council of the Muslim Community; EHRM, 13 december 2001, Metropolitan Church of Bessarabia and Others; EHRM, 26 Oktober 200o, Hasan and Chaush. 


\section{LITERATUUR}

Bijsterveld, S.C. van (1998) Godsdienstvrijheid in Europees perspectief, Deventer: W.E.J. Tjeenk Willink.

Bijsterveld, Sophie van (200oa) 'The legal status of Islam in the Kingdom of the Netherlands', blz. 125-145 in: Silvio Ferrari, Anthony Bradley (eds.), Islam and European Legal Systems, Aldershot: Ashgate.

Bijsterveld, Sophie van (200ob) 'Religion, International Law and Policy in the Wider European Arena: New Dimensions and Developments', blz. 163-180 in: Rex J. Ahdar (ed.), Law and Religion, Aldershot: Ashgate.

Bijsterveld, S.C. van (2001) 'Church Autonomy in the Netherlands. The Distinctiveness of the Church. The Interplay between Legal, Popular, and Ecclesiastical Perspectives. Church Autonomy as a "Test Case", blz. 147-163 in: Hildegard Warnink (ed.), Legal Position of Churches and Church Autonomy, Leuven 2001.

Bijsterveld, Sophie van (2002) The Empty Throne: Democracy and the Rule of Law in Transition, Utrecht: Lemma.

Bijsterveld, S.C. van (2003) 'De controversiële godsdienst- en meningsuiting', blz. 533540 in: Ars Aequi, juli/augustus.

Burgerlijk Wetboek, artikel 1: 3o, tweede lid.

Burgerlijk Wetboek, artikel 2:2 en daarmee samenhangende artikelen.

Boef, August Hans den (2003) Nederland seculier! Tegen religieuze privileges in wetten, regels, praktijken, gewoonten en attitudes, Amsterdam: Van Gennep.

Boer, M.M. den (1987) 'Artikel 6 Grondwet: vrijheid van godsdienst en levensovertuiging', blz. 110-127 in: NJCM-Bulletin.

Commissie-Hirsch Ballin (1988) Overheid, godsdienst en levensovertuiging, Eindrapport van de Commissie van advies inzake de criteria voor steunverlening door de overheid aan kerkgenootschappen en andere genootschappen op geestelijke grondslag, Den Haag.

Diepenhorst, I.A. (1946) De verhouding tusschen kerk en staat in Nederland, Kemink en Zoon: Utrecht z.j.

EHRM (2000) Cha'are Shalom Ve Tsedek, 27 juni 200o, 84.

Hirsch Ballin, E.M.H. (2003) 'Geloof en politiek: living apart together', blz. 549-551 in: Ars Aequi juli/augustus.

Labuschagne, B.C. (red.) (2004) Religie als bron van sociale cohesie in de democratische rechtsstaat?, Ars Aequi Libri: Nijmegen.

Shadid, W.A.R., P.S. van Koningsveld (1990) Moslims in Nederland. Minderheden en religie in een multiculturele samenleving, Alphen aan den Rijn: Samsom Staflieu.

Tweede Kamerstukken, Aanhangsel Handelingen II, 2004-2005, nr. 832, p. 1747.

Tweede Kamerstukken I, 200o-2001, Aanhangsel Handelingen, nr. 2, p. 3-4.

Tweede Kamerstukken II, 2004-2005, 29 80o VI, nr. 101, p. 26.

Tweede Kamerstukken II, 2005-2006, 29754 , nr. 64, p. 3.

Vermeulen, B.P. (200o) 'Artikel 6', blz. 93-108 in: A.K. Koekkoek (ed.) De Grondwet. Een systematisch en artikelsgewijs commentaar, Deventer.

VVD, VVD wil subsidie kerkomroepen afschaffen, http://www.vvd.nl/index.aspx? FilterId $=974 \&$ ChapterId $=1147 \&$ Content Id $=4175$. 
Witteveen, T.A.M. (1984) Overheid en nieuwe religieuze bewegingen, 's-Gravenhage.

Wetenschappelijke Raad voor het Regeringsbeleid (2004) De Europese Unie, Turkije en de islam, Amsterdam: Amsterdam University Press.

Wetenschappelijke Raad voor het Regeringsbeleid (2006) Dynamiek in islamitisch activisme. Aanknopingspunten voor democratisering en mensenrechten, Amsterdam: Amsterdam University Press. 


\section{A INTERMEZZO: STAPPEN IN DE TIJD \\ HET BEGINSEL VAN DE SCHEIDING VAN KERK EN STAAT \\ EN DE VRIJHEID VAN GODSDIENST EN LEVENSOVERTUIGING}

Ben Koolen

De in onderstaand overzicht cursief gestelde teksten zijn citaten.

\author{
1. \\ Jaar \\ 1576 \\ Pacificatie van Gent \\ 1579 \\ Unie van Utrecht
}

1618/1619

Synode van Dordt

1796,1798

Bataafse Staatsregeling
2.

Het beginsel van de SCHEIDING VAN

KERK EN STAAT (de verhouding tussen staat en institutie betreffend).
3.

Het beginsel van de VRIJHEID

VAN GODSDIENST EN LEVENS-

OVERTUIGING (de verhouding tussen staat en burger betreffend).

1579: ... dat een yder particulier in sijn religie vrij sal moegen blijven ende dat nyemant ter cause van de Religie sal moegen achterhaelen ofte ondersoucken, volgende die voorsz. Pacificatie tot Geldt
Nationale synode met toestemming van de Staten-Generaal. De gereformeerde godsdienst als enige erkend.

De Staten-Generaal wijzen nadien stelselmatig elk verzoek om een volgende nationale synode af.

1798 Art. 19 De Maatschappij verleent, ten deze opzigte [= vrijheid van godsdienst], aan allen gelijke zekerheid en bescherming; mids de openbaare orde, door de Wet gevestigd, door hunnen uiterlijken eerdienst nimmer gestoord worde.

Art. 21 Elk kerkgenootschap zorgt voor het onderhoud van zynen eerdienst, deszelfs bedienaaren en gestigten.

Art. 22 De gemeenschaplyke godsdienstoefening word verrigt binnen de daartoe bestemde gebouwen en wel met ontslooten deuren.
Dank zij de provinciale en stedelijke autonomie krijgen de remonstranten vanaf 1623 weer ruimte voor hun belijdenis; in de 18de eeuw wordt deze vaak stilzwijgend ook de lutheranen en rooms-katholieken gegeven.

1798 Art. 8 De eerbiedige erkentenis van een albestuurend opperwezen versterkt de banden der maatchappy en blyft iederen burger ten duursten aanbevolen.

Art. 9 Elke Burger heeft de vryheid, om god te dienen naar de overtuiging van ziyn hart [zie vervolg in kolom 2]. Art. 2o Geene burgerlyke voordeelen of nadeelen zyn aan de belydenis van enig kerklyk leerstelsel gehegt. 
1803

Besluit 11 augustus 1803 van het Uitvoerend Bewind

1808

1814

Grondwet [vóór de vereniging met de Zuidelijke Nederlanden]
Art. 23 Niemand zal met enig ordeskleed of teeken van een kerklyk genootschap buiten zyn kerkgebouw verschynen.

Zondagsrust wordt weer regeringszaak, De godsdienst moet worden beschouwd regentenbanken in de kerken werden als voor de burgerlijke maatschappij van herplaatst. De beroeping van predikanten wordt weer aan de goedkeuring van de vroedschap onderworpen, de provin- den onttrokken. ciale synoden worden door commissarissen-politiek bijgewoond, de opgeheven theologische faculteiten hersteld.

Conform eerder (Frans) besluit worden alle kerkelijke eigendommen genationaliseerd.

Art. 86 Dezelve Staten [der Provinciën en Landschappen] worden belast met de uitvoering der wetten en bevelen omtrent de bevordering van godsdienst, openbaar onderwijs en armbestuur, de aanmoediging van den landbouw, den koophandel, de fabrieken en trafieken, en voorts omtrent alle andere zaken tot de algemeene belangen betrekkelijk, welke aan hen, te dien einde, door den Souvereinen Vorst worden toegezonden.

Art. 133 De christelijke hervormde Godsdienst is die van den Souvereinen Vorst.

Art. 135 Alle openbare uitoefening van Godsdienst wordt toegelaten, voor zoo verre dezelve niet kan gerekend worden eenige stoornis aan de publieke orde en rust te zullen toebrengen.

Art. 136 Aan de christelijke hervormde kerkwordt bijvoortduring verzekerd de voldoening uit's Lands kasse van alle zoodanige tractementen, pensioenen, weduwen-, kinderschool- en academiegelden, als voormaals aan derzelver leeraren, het zij directelijk uit's Lands kas
Art. 134 Aan alle bestaande Godsdiensten wordt gelijke bescherming verleend; de belijders van dezelve genieten dezelfde burgerlijke voorregten en hebben gelijke aanspraak op het bekleeden, van waardigheden, ambten en bedieningen.

Art. 140 Ter bevordering van Godsdienst, als een vaste steun van den Staat en ter uitbreiding van kennis is het openbaar onderwijs op de hooge, middelbare en lage scholen een aanhoudend voorwerp van de zorge der Regering. De Souvereine Vorst doet van den staat dier scholen jaarlijks aan de Staten Generaal een uitvoerig verslag geven.

Art. ${ }_{141}$ Als eene zaak van hoog belang wordt ook het armbestuur en de opvoeding der armkinderen der aanhoudende zorg der Regering aanbevolen. De Souvereine Vorst doet insgelijks van de inrigtingen dienaangaande jaarlijks een uitvoerig verslag aan de Staten Generaal geven. 
of uit de daartoe bestemde inkomsten van geestelijke en kerkelijke goederen of eenige plaatselijke inkomsten, zijn betaald geworden.

Art. 137 Van alle toelagen, welke laatstelijk aan de andere gezindheden uit 's Lands kas zijn toegestaan geweest, wordt almede het genot, bij voortduring, aan gemelde gezindheden toegekend.

Art. 138 In de behoeften van die gezindheden, welke tot hiertoe geene of min toereikende toelage van's Lands wege genoten hebben, zal, op aanvrage daartoe te doen, in billijkheid door den Souvereinen Vorst, met overleg van de Staten Generaal, kunnen voorzien worden.

Art. 139 Onverminderd het regt en de gehoudenis van den Souvereinen Vorst, om zoodanig toezigt over alle de godsdienstige gezindheden uitteoefenen, als voor de belangen van den Staat dienstig zal bevonden worden, heeft Dezelve bovendien in het bijzonder het regt van inzage en beschikking omtrent de inrigtingen van die gezindheden, welke, volgens een der voorgaande artikelen, eenige betaling of toelage uit's Lands kas genieten.

1815

Grondwet [na de vereniging met de Zuidelijke Nederlanden]
Art. 145 De Staten [Provinciaal] worden belast met de uitvoering der wetten opzigtelijk de bescherming der verschillende godsdienstige gezindheden en derzelver uitwendige eeredienst, het openbaar onderwijs en armbestuur, de aanmoediging van den landbouw, den koophandel, defabrijken en trafijken, en voorts omtrent alle andere zaken tot de algemeene belangen betrekkelijk, welke aan hen te dien einde door den Koning worden toegezonden.
De eedformule Zowaar helpe mij God almagtig! wordt in de Grondwet vastgelegd.

Art. 192 De belijders der onderscheiden godsdiensten genieten allen dezelfde burgerlijke en politieke voorregten, en hebben gelijke aanspraak op het bekleeden van waardigheden, ambten en bedieningen. 
Art. 190 Devolkomen vrijheidvan godsdienstige begrippen wordt aan elk gewaarborgd.

Art. 191 Aan alle godsdienstige gezindheden in het Koningrijk bestaande, wordt gelijke bescherming verleend.

Art. 193 Geene openbare oefening van Godsdienst kan worden belemmerd, dan in gevalle dezelve de openbare orde of veiligheid zoude kunnen storen.

Art. 194 De traktementen, pensioenen en andere inkomsten, van welken aard ook, thans door de onderscheidene godsdienstige gezindheden of derzelver leeraars genoten wordende, blijven aan dezelve gezindheden verzekerd. Aan de leeraars, welke tot nog toe uit's Lands kas geen, of een niet toereikend traktement genieten, kan een traktement toegelegd, of het bestaande vermeerderd worden.

Art. 195 De Koning zorgt dat de toegestane penningen die voor de openbare Godsdienst uit's Lands kas worden betaald, tot geene andere einden besteed worden, dan waartoe dezelven bestemd zijn.

Art. 196 De Koning zorgt dat geene Godsdienst gestoord worde in de vrijheid van uitoefening, die de Grondwet waarborgt. Hij zorgt tevens dat alle godsdienstige gezindheden zich houden binnen de palen van gehoorzaamheid aan de wetten van den staat.

1848

Grondwet
Art. 165 Aan alle kerkgenootschappen in het Rijkwordt gelijke bescherming verleend.

Art. 167 Alle openbare godsdienstoefening binnen gebouwen en besloten plaatsen wordt toegelaten, behoudens
Art. 51 e.v. Naast de bestaande eedformule wordt de formulering Dat beloofik opengesteld.

Art. 164 Ieder belijdt zijne godsdienstige meeningen met volkomen vrijheid, behoudens de bescherming der maat- 
de noodige maatregelen ter verzekering der openbare orde en rust. Onder dezelfde bepaling blijft de openbare godsdienstoefening buiten de gebouwen en besloten plaatsen geoorloofd, waar zij thans naar de wetten en reglementen is toegelaten [processieverbod].

Art. 168 De traktementen, pensioenen en andere inkomsten, van welken aard ook, thans door de onderscheidene godsdienstige gezindheden of derzelver leeraars genoten wordende, blijven aan dezelve gezindheden verzekerd. Aan de leeraars, welke tot nog toe uit's Lands kas geen, of een niet toereikend traktement genieten, kan een traktement toegelegd, of het bestaande vermeerderd worden.

Art. ${ }_{169}$ De Koning waakt, dat alle kerkgenootschappen zich houden binnen de palen van gehoorzaamheid aan de wetten van den Staat.

Art. 170 De tusschenkomst der Regeering word t niet vereischt bij de briefwisseling met de hoofden der onderscheidene kerkgenootschappen, noch, behoudens verantwoordelijkheid volgens de wet, bij de afkondiging van kerkelijke voorschriften.

1853

Art. 1 Aan alle kerkgenootschappen is en

Wet op de kerkgenootschappen blijft de volkomen vrijheid verzekerd, alles wat hunne godsdienst en de uitoefening daarvan in hunnen eigen boezem betreft, te regelen. De bepalingen betreffende de inrigting en het bestuur worden, voor zooveel zij niet reeds aan Ons bekend zijn gemaakt, binnen eene maand na de afkondiging dezer wet, door de bestuurders of hoofden der kerkgenootschappen aan Ons medegedeeld. Nieuw te maken bepalingen worden mede vóór of bij het in werking brengen daarvan,op gelijke wijze te Onzer kennis gebracht. Voor zooveel er zich onder de bepalingen, schappij en harer leden tegen de overtreding der strafwet.

Art. 166 De belijders der onderscheidene godsdiensten genieten allen dezelfde burgerlijke en burgerschapsrechten, en hebben gelijke aanspraak op het bekleeden van waardigheden, ambten en bedieningen. 
bij dit artikel bedoeld, eenige bevindt, welke de medewerking van het Staatsgezag vereischt, wordt die medewerking niet verleend, tenzij de bepaling door Ons is goedgekeurd.

Art. 2 Vreemdelingen aanvaarden geene kerkelijke bediening, dan na daartoe Onze toestemming te hebben verkregen. Alleen in het belang der openbare orde en rust kan die toestemming geweigerd worden.

Art. 6 De bedienaren der openbare godsdienst dragen het gewaad voor kerkelijke plegtigheden of bij de uitoefening van de openbare godsdienst in hun kerkgenootschap gebruikelijk, niet dan binnen gebouwen en besloten plaatsen, of daar, waar de openbare godsdienstoefening naar het ze lid van art. 107 der Grondwet, is toegelaten.

Art. 7 Elke oprigting of inrigting van een gebouw tot uitoefening van de openbare godsdienst, binnen den afstand van tweehonderd ellen van een bestaande kerk, vereischt in het belang der openbare orde een onderzoek omtrent de plaats van vestiging. Voor dat de oprigting of inrigting wordt toegelaten, wordt daaromtrent door het gemeentebestuur beslist. Deze beslissing is vatbaar voor een beroep op Gedeputeerde Staten, en bij bezwaar ook tegen de beslissing van deze, wordt hunne uitspraak aan Onze eindbeslissing onderworpen. Het besluit, door Ons te nemen, na den Raadvan State te hebben gehoord, word t met redenen omkleed en openbaar gemaakt.

Wanneer de oprigting of inrigting zonder verlofheeft plaats gehad, wordt het gebouw gesloten. 
Art. 192 Het onderwijs is een voorwerp van de aanhoudende zorg der Regeering. Het geven van onderwijs is vrij, behoudens het toezicht der Overheid, en bovendien, voor zoover het algemeen vormend zoowel lager als middelbaar onderwijs betreft, behoudens het onderzoek naar de bekwaamheid en de zedelijkheid van den onderwijzer, een en ander bij de wet te regelen. Het openbaar onderwijs wordt, met eerbiediging van ieders godsdienstige begrippen, bij de wet geregeld. In elke gemeente wordt van Overheidswege voldoend openbaar algemeen vormend lager onderwijs gegeven in een genoegzaam aantal scholen. Volgens bij de wet te stellen regels kan afwijking van deze bepaling worden toegelaten, mits tot het ontvangen van zoodanig onderwijs gelegenheid wordt gegeven. De eischen van deugdelijkheid, aan het geheel of ten deele uit de openbare kas te bekostigen onderwijs te stellen, worden bij de wet geregeld, met inachtneming, voor zoover het bijzonder onderwijs betreft, van de vrijheid van richting. Deze eischen worden voor het algemeen vormend lager onderwijs zoodanig geregeld, dat de deugdelijkheid van het geheel uit de openbare kas bekostigd bijzonder onderwijs en van het openbaar onderwijs even afdoende wordt gewaarborgd. Bij die regeling word t met name de vrijheid van het bijzonder onderwijs betreffende de keuze der leermiddelen en de aanstelling der onderwijzers geerbiedigd. Het bijzonder algemeen vormend lager onderwijs, dat aan de bij de wet te stellen voorwaarden voldoet, wordt naar denzelfden maatstaf als het openbaar onderwijs uit de openbare kas bekostigd. De wet stelt de voorwaarden vast, waarop voor het bijzonder algemeen vormend middelbaar en voorbereidend hooger onderwijs bijdragen uit de openbare kas worden verleend. De Koning doet jaarlijks van den staat 
1948

Universele

Verklaring van de

rechten van de

Mens

1950

Europees verdrag tot bescherming

van de rechten

van de mens en van

de fundamentele

vrijheden van het onderwijs aan de Staten-Generaal verslag geven.

Art. 18 Een ieder heeft recht op vrijheid van gedachte, geweten en godsdienst; dit recht omvat tevens de vrijheid om van godsdienst of overtuiging te veranderen alsmede de vrijheid hetzij alleen, hetzij met anderen zowel in het openbaar als in zijn particuliere leven zijn godsdienst of overtuiging te belijden door het onderwijzen ervan, door de praktische toepassing door eredienst en het onderhouden van de geboden en voorschriften.

In art. 9 lid 1 Een ieder heeft recht op vrijheid van gedachte, geweten en godsdienst; dit recht omvat tevens de vrijheid om van godsdienst of overtuiging te veranderen, alsmede de vrijheid hetzij alleen, hetzij met anderen, zowel in het openbaar als privé zijn godsdienst te belijden of overtuiging tot uitdrukking te brengen in erediensten, in onderricht en in het onderhouden van geboden en voorschriften.

Lid 2 Devrijheid de godsdienst te belijden of overtuiging tot uitdrukking te brengen kan aan geen andere beperkingen worden onderworpen dan aan die bij de wetzijn voorzien en in een democratische samenleving noodzakelijk zijn in het belang van de openbare veiligheid, voor de bescherming van de openbare orde, gezondheid of goede zeden ofvoor de bescherming van de rechten en vrijheden van anderen.

Art. 26 Allen zijn gelijk voor de wet en hebben zonder discrimintie aanspraak op gelijke bescherming door de wet. In dit verband verbiedt de wet discriminatie van welke aard ook, zoals ras, huidskleur, geslacht, taal, godsdienst, politieke of andere overtuigingen, nationale of maatschappelijke afkomst, eigendom, geboorte of andere status. 
1972

Grondwet

1975-1986

Subsidieregeling moskeeën

1983

Grondwet
In vergelijking met het vorenstaande ongewijzigd, behoudens de bepaling ad art. 185 (= Grondwet 1848, art.168) die vervallen wordt verklaard.

Additioneel artikel X Totdat ter zake bij wettelijke regeling een voorziening zal zijn getroffen, blijft de volgende bepaling van kracht: De traktementen, pensioenen en andere inkomsten, van welke aard ook, thans door de onderscheidene godsdienstige gezindheden of derzelver leraars genoten wordende, blijven aan dezelfde gezindheden verzekerd. Aan de leraars, welke tot nog toe uit's Lands kas geen, of niet een toereikend traktement genieten, kan een traktement toegelegd, of het bestaande vermeerderd worden.

Het kabinet (CRM) stelt een subsidieregeling in werking voor de oprichting/ inrichting van moskeeën voor moslims van Turkse en Marokkaanse afkomst, tot ten hoogste f. 32.0oo. Naar aanleiding van moties [Dales/Wiebenga 1983, 1985] die stopzetting van deze regeling vroegen als strijdig met de scheiding van kerk en staat, werd de regeling in 1986 beëindigd.

Art. 6 lid 2 De wet kan ter zake van de uitoefening van dit recht buiten gebouwen en besloten plaatsen regels stellen ter bescherming van de gezondheid, in het belang van het verkeer en ter bestrijding ofvoorkoming van wanordelijkheden
Art. 27 In Staten waar zich etnische, godsdienstige of linguïstische minderheden bevinden, mag aan personen die tot die minderheden behoren niet het recht worden ontzegd, in gemeenschap met andere leden van hun groep, hun eigen cultuur te beleven, hun eigen godsdienst te belijden en in praktijk toe te passen, of zich van hun eigen taal te bedienen.

Als Grondwet 1917, art. 172.
Art. 1 Discriminatie wegens godsdienst, levensovertuiging, politieke gezindheid, ras, geslacht of op welke grond ook, is niet toegestaan.

Art. 6 lid 1 Ieder heeft het recht zijn gods- 
dienst oflevensovertuiging, individueel of in gemeenschap met anderen, vrijte belijden, behoudens ieders verantwoordelijkheid volgens de wet.

Art. 23 lid 1 Het onderwijs is een voorwerp van de aanhoudende zorg der regering.

Lid 2 Het geven van onderwijs is vrij, behoudens het toezicht van de overheid en, voor wat bij de wet aangewezen vormen van onderwijs betreft, het onderzoek naar de bekwaamheid en de zedelijkheid van hen die onderwijs geven, een en ander bij de wet te regelen.

Lid 3 Het openbaar onderwijs wordt, met eerbiediging van ieders godsdienst of levensovertuiging, bij de wet geregeld. Lid 4 In elke gemeente wordt van overheidswege voldoend openbaar algemeen vormend lager onderwijs gegeven in een genoegzaam aantal scholen. Volgens bij de wet te stellen regels kan afwijking van deze bepaling worden toegelaten, mits tot het ontvangen van zodanig onderwijs gelegenheid wordt gegeven.

Lid 5 De eisen van deugdelijkheid, aan het geheel of ten dele uit de openbare kas te bekostigen onderwijs te stellen, worden bij de wet geregeld, met inachtneming, voor zover het bijzonder onderwijs betreft, van de vrijheid van richting.

Lid 6 Deze eisen worden voor het algemeen vormend lager onderwijs zodanig geregeld, dat de deugdelijkheid van het geheel uit de openbare kas bekostigd bijzonder onderwijs en van het openbaar onderwijs even afdoende wordt gewaarborgd. Bij die regeling wordt met name de vrijheid van het bijzonder onderwijs betreffende de keuze der leermiddelen en de aanstelling der onderwijzers geëerbiedigd.

Lid 7 Het bijzonder algemeen vormend lager onderwijs, dat aan de bij de wet te stellen voorwaarden voldoet, wordt naar 
1983

Wet beëindiging

financiële

verhouding tussen

Staat en Kerk

1988

Wet openbare manifestaties
Art. 2 De aanspraken ingevolge additioneel artikel IVvan de Grondwet naar de tekst van 1983 (additioneel artikel X van de Grondwet naar de tekst van 1972) van godsdienstige gezindheden en hun leraren vervallen.

Art. 2 De bij of krachtens de bepalingen [...] aan overheidsorganen gegeven bevoegdheden tot beperking van het recht tot het belijden van godsdienst of levensovertuiging en het recht tot vergadering en betoging, kunnen slechts worden aangewend ter bescherming van de gezondheid, in het belang van het verkeer en ter bestrijding of voorkoming van wanordelijkheden.

Art. 3 lid 1 De gemeenteraad stelt bij verordening vast met betrekking tot de gevallen waarin voor samenkomsten tot het belijden van godsdienst of levensovertuiging op openbare plaatsen een voorafgaande kennisgeving vereist is. Lid 4 Over de inhoud van hetgeen wordt beleden worden geen gegevens verlangd. Art. 5 lid 1 De burgemeester kan naar aanleiding van een kennisgeving voorschriften en beperkingen stellen of een verbod geven.

Lid 3 Een voorschrift, beperking of verbod kan geen betrekking hebben op de inhoud van hetgeen wordt beleden, onderscheidenlijk van de te openbaren gedachten of gevoelens.

Art. 6 De burgemeester kan tijdens een dezelfde maatstafals het openbaar onderwijs uit de openbare kas bekostigd. De wet stelt de voorwaarden vast, waarop voor het bijzonder algemeen vormend middelbaar en voorbereidend hoger onderwijs bijdragen uit de openbare kas worden verleend.

lid 8 De regering doet jaarlijks van de staat van het onderwijs verslag aan de Staten-Generaal. 
samenkomst tot het belijden van gods-

dienst of levensovertuiging, vergadering of betoging aanwijzingen geven, die degenen die deze houden of daaraan deelnemen in acht moeten nemen.

Art. 7 De burgemeester kan aan degenen die een samenkomst van godsdienst of levensovertuiging, vergadering of betoging houden of daaraan deelnemen opdracht geven deze terstond te beëindigen en uiteen te gaan indien (a) de vereiste kennisgeving niet is voldaan, of een verbod is gegeven, (b) in strijd wordt gehandeld met een voorschrift, beperking of aanwijzing, (c) een van de in artikel 2 genoemde belangen dit vordert.

Art. 10 Klokgelui ter gelegenheid van godsdienstige en levensbeschouwelijke plechtigheden en lijkplechtigheden, alsmede oproepen tot het belijden van godsdienst of levensovertuiging, zijn toegestaan. De gemeenteraad is bevoegd ter zake regels te stellen met betrekking tot duur en geluidsniveau.

In zijn reactie-1989 [min. Van Dijk] viel het kabinet het commissievoorstel bij om ten behoeve van de geestelijke ver-

1989, 1991

Reactie kabinet op rapport Overheid, godsdienst en levensovertuiging [1988]

TK 1989-90, 20868 , nr. 2

TK 1990-1, 20868 , nr. 3 zorging in de krijgsmacht en in penitentiaire inrichtingen telkens twee formatieplaatsen beschikbaar te stellen voor de geestelijke verzorging op hindoe- en evenveel plaatsen op islamitische grondslag. Het oordeel over het voorstel, de subsidieregeling voor gebedsruimtes voor moslims van Turkse en Marokkaanse afkomst wederom in te voeren, liet het kabinet aan de Tweede Kamer over.

In zijn reactie-1991 [min. Dales] wees het kabinet het voorstel tot subsidieverstrekking aan moskeeën af. Voor de invulling van de geestelijke verzorging 
1993

Burgerlijk

Wetboek, boek 2, titel 1

1994

Algemene wet gelijke behandeling van moslims en hindoes acht het kabinet de totstandkoming van 'zendende instanties' binnen de moslim- en hindoegemeenschappen noodzakelijk.

Art. 2 lid 1 Kerkgenootschappen, alsmede hun zelfstandige onderdelen en lichamen waarin zij zijn verenigd, bezitten rechtspersoonlijkheid.

Lid 2 Ze worden geregeerd door hun eigen statuut, voor zover dit niet in strijd is met de wet. Met uitzondering van artikel 5 gelden de volgende artikelen van deze titel niet voor hen; overeenkomstige toepassing is geoorloofd, voor zover deze is te verenigen met hun statuut en met de aard der onderlinge verhoudingen.

Art. 3 Deze wet is niet van toepassing op: a. rechtsverhoudingen binnen kerkgenootschappen alsmede hun zelfstandige onderdelen en lichamen waarin zij zijn verenigd, alsmede binnen andere genootschappen op geestelijke grondslag;

b. het geestelijk ambt.

1997, 1998 Imam-opleiding De staatssecretaris van OC en $\mathrm{W}$ en de minister van Binnenlandse Zaken onderstrepen aan de hand van een rapport-Landman de noodzaak van een Nederlandse opleiding tot het ambt van imam, maar het initiatief dient uit te gaan van de moslimgemeenschap.

\section{9}

Het welslagen van het integratiebeleid Integratiebeleid en godsdienst \& levensovertuiging TK 1999-2000, 26333 , nr. 13 deze waardering wordt veelal bepaald is in hoge mate afhankelijk van de waardering van nieuwe landgenoten en autochtonen ten opzichte van elkaar; door ieders grondwaarden. De overheid past terughoudendheid bij aangelegenheden van levensbeschouwelijke aard. 
Het beginsel van de scheiding van kerk en staat houdt in dat de staat:

(a) de zelfstandigheid van richtingen respecteert en zich dient te onthouden van elke bemoeienis met de belijdenis of inhoud van de godsdienst of levensovertuiging;

(b) geen bemoeienis heeft met de interne organisatie van de richting; daartoe behoort ook de opleiding en aanstelling van geestelijke bedienaren;

(c) op grond van art. 1 van de Grondwet alle kerkgenootschappen en genootschappen op geestelijke grondslag op gelijke voet dient te behandelen,

(d) geen partij mag kiezen voor één bepaalde richting. 


\title{
9 LAÏCITÉ IN HET LICHT VAN DE GESCHIEDENIS VAN DE FRANSE ASSIMILATIEPOLITIEK ${ }^{1}$
}

\author{
Yolande Jansen
}

\begin{abstract}
"En u denkt dat de bijzondere scholen hun leerlingen aanleren om vrijmetselaren en joden te verachten (...). En het is waar dat, sinds enkele jaren, onder hen die deze scholen hebben bezocht, men geen joden meer ontvangt, wat ons op zich onverschillig laat, maar wat een teken is van die gevaarlijke geestesgesteldheid waarin de Affaire heeft kunnen ontstaan, etc. Maar ik zal u vertellen dat in Illiers, de kleine gemeente waar mijn vader eergisteren de 'uitreiking van de prijzen' voorzat, men sinds de wetten van Ferry de pastoor niet meer uitnodigt. Men went de leerlingen eraan om degenen die hem bezoeken te beschouwen als mensen met wie je niet omgaat, en van die zijde wordt dus, evenzeer als van de andere zijde, gewerkt aan het creëren van twee Frankrijken"2 (Proust, 1903).
\end{abstract}

In de moderne filosofie en sociologie is vaak gesuggereerd dat de scheiding van kerk en staat impliceert dat religie een privéaangelegenheid moet worden: dat is wat men meestal met 'secularisme' bedoelt. Aanpassing aan het secularisme zou een voorwaarde zijn voor de verenigbaarheid van religie met moderniteit. Deze visie is de laatste jaren veel bekritiseerd, bijvoorbeeld door José Casanova (1994) en Marcel Gauchet (1998). Zij betogen dat publieke religie verenigbaar is met moderniteit, mits deze religie niet het ondermijnen van de democratische rechtsstaat voorstaat. Het is echter de vraag wat dit voor het secularisme betekent en waar de grenzen voor een publieke religie dan zouden moeten liggen.

De visie dat een vorm van secularisme een essentiële voorwaarde is voor democratie, heeft weer aan kracht gewonnen met de wereldwijde opkomst van politieke conflicten waarin religie een belangrijke rol speelt. In de Europese context betreft het vaak conflicten over de plaats van de islam in de publieke sfeer. Een sprekend voorbeeld zijn de zogenaamde 'hoofddoekenaffaires' in Frankrijk, naar aanleiding waarvan vele discussies over het begrip laïcité (secularisme) zijn gevoerd. Deze affaires betroffen vooral de vraag of leerlingen van openbare middelbare scholen op school een hoofddoek mogen dragen. Ook in Nederland en andere Europese landen zijn veel debatten gehouden over de plaats van de islam in de publieke sfeer aan de hand van discussies over hoofddoeken. Het ging dan bijvoorbeeld om de vraag of het dragen van een hoofddoek toegestaan moet zijn voor werknemers van instellingen zoals openbare scholen en de rechterlijke macht, of bijvoorbeeld voor presentatoren van televisieprogramma's op publieke zenders, zoals recentelijk in Denemarken aan de orde was.

In dergelijke debatten over de plaats van de islam in de publieke sfeer is de laatste jaren een bijna geruisloze overgang tot stand gekomen van spreken in termen van 'cultuur' en 'cultureel verschil' naar spreken in termen van 'religie in de publieke sfeer'. Ik zal in dit essay betogen dat juist het verband tussen cultuur en religie in 
de context van het secularisme aan de orde gesteld moet worden. Hierbij zal ik in herinnering brengen hoe secularisme een rol speelde in de theorie en praktijk van de 'assimilatie' van de Franse joden in de vroege Derde Republiek (1870-1905), omdat hier het kruisverband tussen cultuur en religie scherp aan het licht treedt.

Dit essay bestaat uit vier delen. Ten eerste presenteert het een korte analyse van het hedendaagse Franse discours over de laïcité. Dit maakt het mogelijk enkele centrale begrippen met betrekking tot het private of publieke karakter van religie kritisch te belichten. Vervolgens plaatst het deze debatten in de context van de geschiedenis van het begrip laïcité in de Derde Republiek. Ten derde onderzoekt het de mogelijke verbanden tussen laïcité en de assimilatiepolitiek in de Derde Republiek. Ten slotte probeer ik aan te geven op welke manier het in de bredere en actuele Europese context relevant kan zijn om de historische verwevenheid van secularisme en assimilatiepolitiek in Frankrijk in herinnering te brengen.

\subsection{LAÏCITÉ, EEN JURIDISCH BEGRIP MET EEN CULTURELE LADING}

In november 1989 plaatsten vijf neorepublikeinse intellectuelen een advertentie in Le Nouvel Observateur over het dreigende 'München van de Republiek' als het dragen van hoofddoeken op openbare scholen zou worden toegestaan. ${ }^{3}$ Dit was het begin van een lange reeks debatten die niet alleen de hoofddoeken zelf betrof, maar meer in het algemeen de plaats van religie, en met name de islam, in de publieke ruimte. De secularisten meenden dat elke publieke manifestatie van religieuze affiliaties het kader van de laïcité overschrijdt, en verdedigden daarmee een versie van de laïcité die meestal als de klassieke versie wordt gezien. Daarin wordt een strikte scheiding tussen private religie en publieke neutraliteit bepleit.

Deze klassieke versie is met betrekking tot leerlingen op middelbare scholen echter nauwelijks op een institutioneel niveau verdedigd. Het feit dat er door het dragen van een hoofddoek een religieuze affiliatie publiek wordt, werd door belangrijke Franse instanties niet als reden voor een verbod geaccepteerd. In 1989 deed het Conseil d'État bijvoorbeeld een uitspraak waarin werd gesteld dat het dragen van een hoofddoek op school in principe een privékeuze van de persoon in kwestie is. Het dragen van een hoofddoek werd alleen als problematisch beschouwd wanneer dat gepaard ging met propaganda of bekeringsdrang (prosélytisme).4

De conflicten bleven echter voortduren en mede na een rel in de zomer van 2003, toen de dochters van een joodse mensenrechtenadvocaat gesluierd naar hun school in Aubervilliers (een buitenwijk van Parijs) wensten te gaan, stelde president Chirac in september 2003 de zogenaamde commissie-Stasi in. Deze commissie kreeg de opdracht een rapport te schrijven waarin het begrip laïcité werd herijkt en waarin een definitief standpunt over de hoofddoekenkwesties naar voren werd gebracht. ${ }^{5}$

De commissie was er niet op uit om de klassieke versie van laïcité te doen herleven, na decennia van relatieve rust en toenadering tussen Republiek en religie. In 
plaats daarvan beoogde men een actuele herformulering van de laïcité, die zich beter tot pluralisme en diversiteit zou verhouden dan de oude 'strijdbare laïcité' (laïcité de combat), die min of meer als de erfgenaam van het revolutionaire jakobinisme werd gezien. Daarom wordt in het rapport het belang benadrukt van openbaar pluralisme, en nadrukkelijk afstand genomen van de laïcité de combat (Stasi 2003: 2.3). ${ }^{6}$ Heel symbolisch eindigt het rapport met de woorden 'het pluralisme, de diversiteit' (Conclusion).

In eerste instantie lijkt het rapport van de commissie-Stasi inderdaad een van de meest pluralistische documenten die in officiële Franse kringen zijn geproduceerd. Bijvoorbeeld met betrekking tot het onderwijs stelt de commissie verschillende pluraliserende maatregelen voor. Ze bepleit dat er meer aandacht komt voor de geschiedenis van migranten, voor koloniale geschiedenis en voor religie in het algemeen. Ook wordt gepleit voor betere voorzieningen voor islamitische gevangenen en de erkenning van niet-christelijke feestdagen.

Niettemin is het rapport van de commissie-Stasi vooral bekend geworden vanwege het advies om het dragen van 'opvallende religieuze tekens' voor leerlingen op openbare middelbare scholen te verbieden. De commissie verdedigt het verbod op religieuze attributen zoals hoofddoeken, keppels en 'grote kruizen' niet met het argument dat het hier 'religieuze tekens' betreft, maar 'opvallende religieuze tekens', die eerder politiek-religieuze of 'communitaristische' uitwassen dan een vrij gekozen religieuze beleving tot uitdrukking brengen. Mijns inziens is dit verbod echter toch het effect van de doorwerking van de klassieke versie van laïcité als een diepgeworteld cultureel schema. Dit kan duidelijker worden wanneer we de redenering van de commissie-Stasi nader analyseren.

Het advies voor een wetsvoorstel om het dragen van 'opvallende religieuze tekens' te verbieden wordt zoals gezegd niet op de klassieke manier gerechtvaardigd. Niet de zichtbaarheid van de religieuze verbondenheid in de publieke ruimte wordt als reden voor het verbod genoemd, maar het vermoeden dat met het dragen van dergelijke tekens het aanhangen van een religie tot uitdrukking wordt gebracht die niet met de moderne principes van gelijkheid en vrijheid verenigbaar is. Zo wordt bijvoorbeeld gesteld dat niet het "horen bij een religieuze groepering" (appartenance) of een openlijke religieuze motivatie voor bepaalde opvattingen problematisch is, maar wel een "plicht om erbij te horen" (devoir d'appartenance) die door bepaalde gemeenschappen aan individuen wordt opgelegd (4.1.2.2). Ook de bekeringsdrang die in de uitspraak van het Conseil d'État uit 1989 werd genoemd is nog steeds aanwezig, in de zin dat de commissie wijst op het feit dat een prosélytisme agressif niet verenigbaar is met laïcité (1.2.3). Verder wordt ook "la différence" niet geproblematiseerd, echter wel een "fanatisme de la différence" (1.2.4).

Tekenend voor de 'nieuwe' grens die de commissie-Stasi wil stellen is ook de uitleg van een van de leden van de commissie, de bekende socioloog Alain Touraine, voor zijn instemming met het advies om een verbod in te stellen. Hij 
was jarenlang een van de gematigde secularisten geweest die het dragen van de hoofddoek had verdedigd als een vorm van knutselwerk (bricolage) met identiteiten, dat goed verenigbaar was met het principe van de laïcité in zijn liberale vorm. Touraine interpreteerde de hoofddoek toen als een teken van hybriditeit waarbij de eigen inbreng van de migranten werd gerespecteerd. Tijdens de interviews met de meisjes die hoofddoeken droegen bleek echter dat zij een 'onwenselijk communautarisme' bepleitten. Zijn rechtvaardiging voor zijn instemming met het advies voor het wetsvoorstel was dan ook dat hij zo was geschrokken van wat hij had gehoord tijdens de interviews dat hij tot de conclusie was gekomen dat niet hij van mening was veranderd, maar Frankrijk, dat een 'communitaristisch' land was geworden (Touraine 2003). ${ }^{7}$

De grond voor deze interpretatie van de wens een religieus teken te dragen blijft echter wankel. De betekenis van religieuze attributen en de diversiteit van de redenen om ze te dragen is hierdoor officieel door de Franse staat beperkt en vastgelegd in een mate die nauwelijks kan worden gerechtvaardigd. Er kan bijvoorbeeld onmogelijk beweerd worden dat alle meisjes die hoofddoeken dragen dit doen op basis van groepsdwang of separatistische motieven, maar toch wordt dit door de commissie gesuggereerd.

Bovendien is het sterk de vraag, zoals Pierre Tevanian (2004), Gérard Noiriel en Stéphane Béaud (2004) en vele anderen hebben betoogd, of de meisjes uit de banlieues die onder dwang een hoofddoek dragen, geholpen zijn met een verbod. Zij wijzen erop dat wetten die bepaalde vrouwen uitsluiten hoogstwaarschijnlijk niet de gelijkheid van man en vrouw zullen bevorderen. De fixatie op de hoofddoeken zou voortkomen uit een blindheid voor de werkelijke problemen: sociaaleconomische uitsluiting, de structuur van de banlieues, de armoedigheid van het onderwijs. Bruno Latour (2004) voegde daaraan toe dat degenen die hoopten dat een verbod "een einde zou maken aan de oneindige discussies" over de hoofddoeken er een mooie opvatting over de Republiek als leerschool voor de democratie op na hielden. ${ }^{8}$

De redenering van de commissie is systematisch gezien vooral problematisch, omdat de overgang tussen de legitieme en illegitieme vormen van gemeenschapsvorming, tussen différence en fanatisme de la différence buitengewoon vaag wordt gehouden en er nauwelijks voorbeelden worden gegeven. Deze vaagheid, waarbij men genoegen neemt met bedenkingen tegen communautarisme in het algemeen, herinnert aan de klassieke versie van de laïcité. Ze komt voort uit het oude republikeinse wantrouwen tegen alle publieke associaties die zich tussen individu en staat bevinden. ${ }^{9}$ De Franse politiek filosofe Cécile Laborde heeft deze lading van laïcité mooi geformuleerd door te stellen dat juist de Franse republikeinse traditie vaak uitgaat van de noodzaak van "publieke eenheid", waarbij gepoogd wordt "democratische burgerlijke loyaliteit in de plaats te stellen van religieuze en traditionele bindingen” (Laborde 2002: 170-171, mijn cursivering). De openlijke tekens dat deze bindingen nog zouden bestaan, zoals het gebruik van regionale talen (Bretons) en bepaalde klederdrachten, zijn in deze 
republikeinse traditie vaak geproblematiseerd. We kunnen meer duidelijkheid over deze traditie in de interpretatie van het laïcité-begrip krijgen door de context van de invoering van de laïcité in de vroege Derde Republiek, van 1870 tot 1905, te belichten.

\subsection{LAÏCITÉ IN DE DERDE REPUBLIEK}

De laïcité is een erfenis van de strijd die de Franse Republiek vanaf de Revolutie heeft gevoerd om politieke onafhankelijkheid te winnen van de Katholieke Kerk en de monarchie. Deze strijd werd pas in 1905 definitief beslist met de invoering van de zogenaamde 'Separatiewet' die kerk en staat principieel scheidde. Frankrijk is nu een van de weinige landen in Europa waarvan de seculiere status grondwettelijk is vastgelegd. De wet van 1905 was door republikeinen vanaf het begin van de Derde Republiek voorbereid. In 1870, ten tijde van de Frans-Duitse oorlog, moest de zojuist ingestelde Derde Republiek een verwoest land gaan regeren, dat bovendien extreem verdeeld was vanwege de strijd tussen de deux France. Het ene Frankrijk was de prerevolutionaire 'oudste dochter' van de Katholieke Kerk, het Frankrijk van de middeleeuwse wereldorde dat sterk met Rome verbonden was. Na de Revolutie was dat Frankrijk geclaimd (en geconstrueerd) door traditionalisten en contrarevolutionairen als het ware Frankrijk. Het andere Frankrijk was de postrevolutionaire État-nation. Als het negatief van het eerste Frankrijk construeerde de natiestaat zichzelf als een autonome, zichzelf constituerende politieke natie, zonder goddelijke maar ook zonder internationale invloeden.

De conflicten tussen klerikalen en secularisten in de Derde Republiek gingen in belangrijke mate om de hearts and minds van het Franse volk, nadat in de loop van de 19de eeuw het algemeen kiesrecht was ingevoerd. Via het openbaar onderwijs, dat aan de controle van de jezuïeten onttrokken moest worden, zou het mogelijk zijn te verhinderen dat het volk zich door autoritaire krachten zou laten verleiden (Baubérot 2003). ${ }^{10}$ De beroemde pedagoog Ferdinand Buisson stelde in 1899 het belang van openbaar onderwijs voor het republikeinse project eenduidig vast:

“Er zijn twee voorwaarden om een Republiek tot stand te brengen. De ene is gemakkelijk te vervullen: een Republiek moet een Republikeinse Constitutie hebben. De andere voorwaarde impliceert een veel moeilijker opdracht: een Republiek moet door Republikeinen bevolkt worden.”

De laïcité die in 1905 juridisch werd vastgelegd, is echter geen strikt antireligieus begrip. Het richt zich niet tegen religie in het algemeen, maar garandeert daarentegen de vrijheid van elk individu om een religie aan te hangen of niet, om van religie te veranderen, of om een andere religie dan wie dan ook aan te hangen. De twee centrale eerste artikelen van de wet luiden als volgt: 
“Artikel 1: De Republiek garandeert de vrijheid van geweten. Ze garandeert de vrije uitoefening van de godsdiensten (cultes), en wordt slechts beperkt door [enkele] restricties (...) in het belang van de openbare orde (...). Artikel 2: De Republiek erkent, salarieert of subsidieert geen enkele godsdienst." ${ }_{11}$

In deze formulering ondersteunt de staat religie dus op geen enkele manier, noch inhoudelijk noch financieel, maar tegelijk wordt de vrijheid van godsdienst en de uitoefening daarvan nadrukkelijk gegarandeerd. In dit opzicht verschilt laïcité sterk van het Jacobijnse republicanisme, dat hoopte sociale en religieuze verbanden te vervangen door universeel burgerschap. Laïcité als juridisch principe verzet zich dus alleen tegen religie voor zover die als bron van de wet wordt gepresenteerd, en niet voor zover ze een bron van moraliteit, geloof of betekenisvolle ervaring is: in die zin is het een liberaal begrip. ${ }^{12}$

De onderliggende, meer culturele dan geïnstitutionaliseerde betekenis van laïcité die ik zojuist al noemde, is echter veel sterker aan de jakobijnse kant van de Verlichting verwant. Ze komt bijvoorbeeld naar voren in de rijke verzameling spotprenten en posters die rond 1905 over de laïcité zijn gemaakt. Ik bespreek hier een didactische poster van Charles Fournigault.

Op deze poster vinden we een duidelijke scheiding tussen 'vroeger' (autrefois) en 'tegenwoordig' (aujourd'hui). 'Vroeger' wordt verbeeld door rurale en sterk hiërarchische verhoudingen. Een kasteel, een bevelende edelman en de Bastille torenen hoog boven de onderdanen uit. In het centrum van het dorp staat de kerk, de bewaker van deze orde. Interessant is dat hier het woord commune (gemeenschap) gebruikt wordt. Dit begrip vormt de basis van het communautarisme dat in Frankrijk de gangbare aanduiding voor multiculturalisme is. Het is in de iconologie van de moderniteit nauw met premoderne, ongelijke verhoudingen en met religieus conservatisme geassocieerd. Tegenover 'vroeger' staat 'tegenwoordig', dat wordt gekenmerkt door stedelijke ruimtes waarin de macht van de natuur door de moderne mens aan banden is gelegd en in evenwicht gebracht. De gelijke verdeling van de ruiten in beide ruimtes symboliseert deze moderne orde. De leraar staat hoger dan de leerlingen, maar in het stemlokaal bevindt ieder zich op gelijke hoogte.

Wat in het kader van deze illustratie vooral van belang is, is dat er een duidelijke of-of-relatie wordt gesuggereerd tussen vroeger en nu. De contrasten zouden niet groter kunnen zijn, en het is duidelijk dat men óf in hiërarchische, premoderne verhoudingen kan leven óf in moderne, democratische. Kortom, men kan in religieuze communes georganiseerd zijn of als moderne burgers in de staat, maar veel bemiddeling tussen beide vormen van menselijke organisatie is er niet.

De conflicten over de laïcité in de Derde Republiek speelden zich voornamelijk af tussen republikeinen en klerikaal denkende katholieken, maar dat betekende niet dat minderheden er niet in betrokken waren. Dit gold op een specifieke manier 


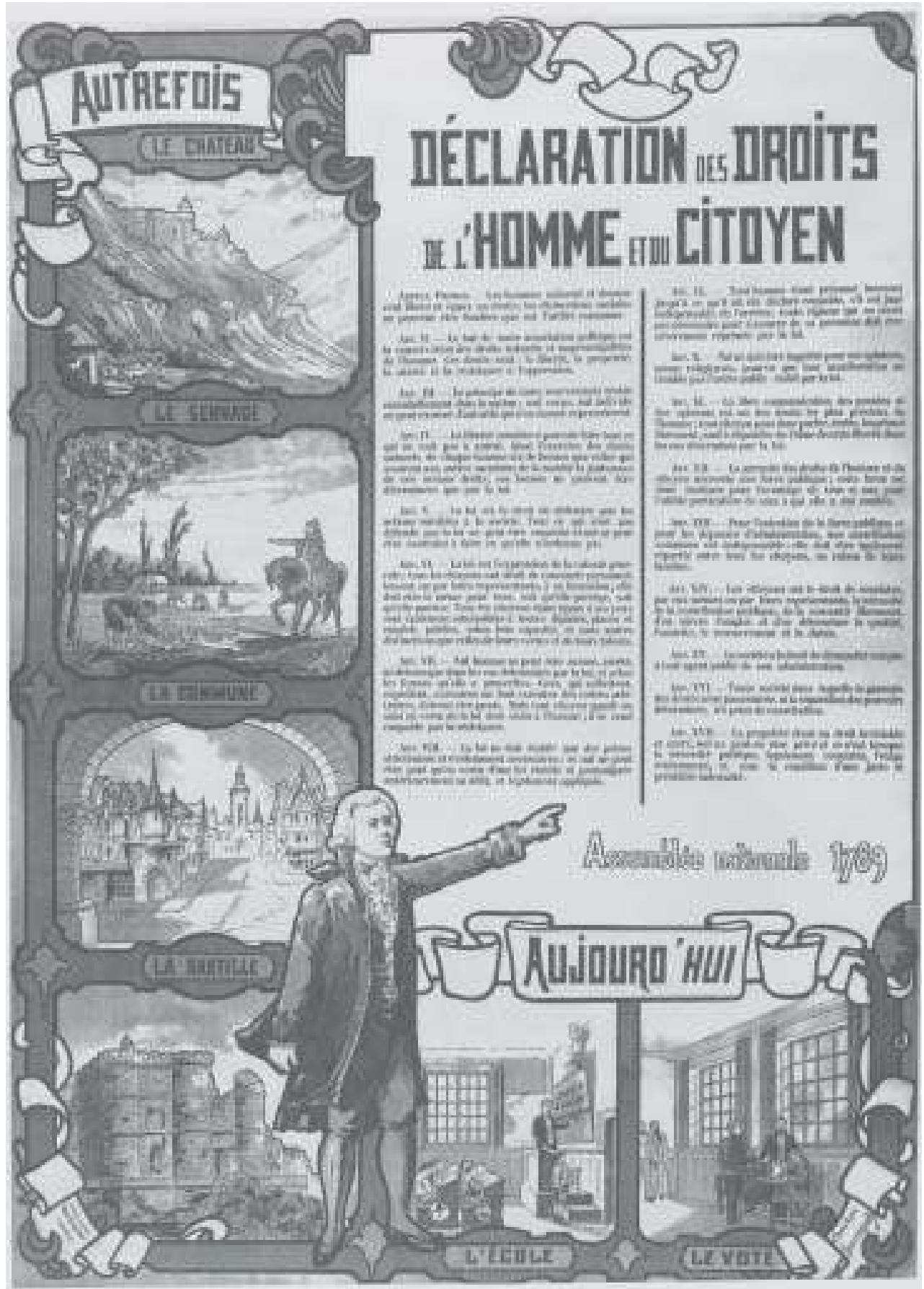

Charles Fournigault: la déclaration des droits de l'homme et du citoyen, 1905 
voor de joden. Zij hadden in 1791 burgerrechten verworven, maar daarna moesten zij nog regelmatig 'bewijzen' dat zij loyaal aan de Republiek waren. Eén van de middelen om die loyaliteit expliciet te maken was het verwijderen van de 'tekens' van hun collectieve (religieuze) leven uit de publieke sfeer. Dit had echter niet noodzakelijk geleid tot het vertrouwen dat ze dat collectieve leven ook werkelijk achter zich gelaten hadden. Het is mijns inziens van belang om juist déze problematiek in de context van de plaats van de islam in het huidige Europa in herinnering te roepen. De herinnering aan het franco-judaïsme wordt overigens ook door de commissie-Stasi aangehaald, maar dan in positieve zin. De commissie stelt de aanpassingen van het Franse jodendom in het kader van de laïcité expliciet als voorbeeld aan de hedendaagse islam. De commissie vergeet daarbij echter een aantal centrale problemen van het franco-judaïsme te benoemen die een veel kritischer houding ten aanzien van dit 'model' zouden rechtvaardigen.

\subsection{LAÏCITÉ EN ASSIMILATIEPOLITIEK}

De republikeinse visie dat solidariteit van de burgers met de Republiek zou ontstaan als zij van hun traditionele banden werden losgeweekt, leidde er zoals gezegd toe dat alle vormen van publieke organisatie tussen staat en individu ter discussie kwamen te staan. De centraliserende staat probeerde deze in meerdere of mindere mate te controleren of zelfs te vernietigen (zie bijv. Birnbaum 1998).

Dit gold ook sterk voor de organisaties van de joden, wier relatieve autonomie (vooral in de Elzas) al ten tijde van de Revolutie grote belangstelling had gewekt in revolutionaire kringen. In zekere zin werden zij tot model gemaakt van de nieuwe burger die traditionele banden had doorbroken en die in ruil daarvoor burgerrechten in de moderne staat ontving (Birnbaum 1998). Hun publieke collectieve identificaties als joden moesten daartoe plaatsmaken voor een geprivatiseerde religie waar elke referentie werd vermeden aan "een collectieve cultuur en identiteit die het kader van religieuze riten en geloof overschrijden" (Benbassa 2003: 66). Dit blijkt bijvoorbeeld uit een beroemde uitspraak van de graaf van Clermont-Tonnerre tijdens de debatten in de Assemblée in 1789 over de verwerving van burgerrechten door de joden. Clermont-Tonnerre was een voorstander van deze rechten, maar gaf aan wat volgens hem de voorwaarden hiervoor moesten zijn:

“(...) we moeten de joden als volk (nation) alles weigeren en hen alles toestaan als individuen (...) ze moeten binnen de Staat niet meer een apart politiek lichaam noch een orde vormen; ze moeten individueel burger zijn (...) het staat ons tegen dat er binnen de staat een maatschappij van nietburgers zou bestaan, of een natie binnen de natie. (...) Als ze het weigeren, dan moeten ze het zeggen, opdat we ze kunnen verbannen" (Noriel 1992: 278).

De privatisering van religie heeft dus niet alleen tot doel religie uit de staat te verdrijven. Ze staat ook in dienst van de centralisering van de natiestaat, die concurrerende maatschappelijke verbanden zoveel mogelijk probeert te verzwakken. ${ }^{14} \mathrm{Al}$ tijdens de Revolutie kwam daarbij aan de orde dat het afleggen van de 
tekens van het horen bij een andere groep zou kunnen gelden als een soort 'bewijs' dat de joden werkelijk bij Frankrijk hoorden en ook wilden horen. ${ }^{15}$ Dit wordt echter nog duidelijker in een beroemd citaat uit 1884 van de historicus Théodore Reinach, een van de eerste historici van het jodendom in Europa. Hieruit blijkt tevens dat tijdens de Derde Republiek het schema van de Revolutie nog steeds centraal stond in de wijze waarop de positie van de joden in Europa begrepen werd. Reinach zag een nauwe samenhang tussen laïcisering en wat hij verstond onder assimilatie:

\begin{abstract}
"De Franse Revolutie betekende een nieuw tijdperk in de geschiedenis van het jodendom, evenals in de geschiedenis van West-Europa. Ze heeft de antieke notie van de Staat van goddelijk en historisch recht (l'État de droit divin et historique), die was gefundeerd op onderscheiden naar kaste en ras, vervangen door die van de puur menselijke en seculiere staat, waarin men de mensen niet aanziet naar het bloed dat in hun aderen stroomt, noch naar hun intieme geloof, noch naar hun manier om God te eren, maar waar alle burgers dezelfde rechten hebben, op voorwaarde dat zij dezelfde plichten vervullen. De consequentie van dit principe is enerzijds dat de joden, net zoals katholieken, protestanten, moslims en vrijdenkers, in de geciviliseerde staat zonder één enkele restrictie van alle burgerlijke en politieke rechten gebruik moeten kunnen maken; anderzijds dat zij, zodra zij niet meer als paria's behandeld worden, zich moeten identificeren, in hun hart en door hun handelingen, met de naties die hen hebben geaccepteerd, en afzien van de praktijken, aspiraties, bijzonderheden in kleding en taal die ertoe zouden kunnen leiden dat ze van hun medeburgers geïsoleerd raakten, in één woord, op te houden een verstrooide natie te zijn, en zich alleen nog als religieuze confessie opvatten. De Emancipatie en assimilatie van de Israëlieten (...)” (Reinach 1901 [1884]: 305-06).
\end{abstract}

Hierbij moet worden opgemerkt dat assimilatie voor Reinach dus niet het totale verlies van culturele identiteit betekent, zoals het begrip 'assimilatie' tegenwoordig vaak in contrast met multiculturalisme wordt gebruikt. In plaats daarvan gebruikt hij het begrip veel nauwkeuriger, op een manier die een nauw verband met secularisering impliceert: assimilatie betekent de transformatie van een vorm van collectiviteit die is gebaseerd op gecombineerde etnische en religieuze praktijken - zoals een gedeelde taal, een gedeelde wijze van kleden, religieuze rituelen, theorieën en wetgeving - in een geprivatiseerde religie die het domein van de strikt religieuze rituelen en de moraliteit niet meer overschrijdt. Volgens Reinach was deze vrijwillige 'secularisatie' van het jodendom de waarborg om niet meer als ander of als lid van een andere nation gezien te worden, maar op gelijke voet met alle medeburgers te staan.

De problematisering van deze belofte van het franco-judaïsme door critici van de assimilatiepolitiek zoals Hannah Arendt en Zygmunt Bauman verloopt niet, zoals tegenwoordig meestal het geval is, via een beroep op het recht op culturele diversiteit of 'behoud van eigen identiteit'. In plaats daarvan leggen Arendt en Bauman een paradoxaal mechanisme in de assimilatiepolitiek bloot, dat ervoor zorgde dat de verwachtingspatronen met betrekking tot de assimilatie juist tot de uitsluiting van de joden leidden. Juist deze paradox kan er een reden voor zijn om een secularistisch, in wezen assimilationistisch verwachtingpatroon dat wenst 
dat de leden van etnisch-religieuze minderheden geen 'tekens' van (opvallende) andersheid meer zullen vertonen, kritisch te belichten.

\section{Hannah Arendt, Zygmunt Bauman en de paradox van de assimilatie}

Hannah Arendt wees er als een van de eersten op dat het negentiende-eeuwse Franse antisemitisme niet zozeer de nog niet uitgewoede erfenis was van het oude christelijke antisemitisme, maar dat de moderniteit haar eigen bronnen had voor nieuwe vormen van antisemitisme. $\mathrm{Zij}$ formuleerde in The Origins of Totalitarianism (1948) een mechanisme dat later door Zygmunt Bauman werd benoemd als de 'paradox van de assimilatie' (1988). Deze paradox betreft het negatieve effect van assimilatiepolitiek op de mogelijkheid om als volwaardig burger in de moderne staat te kunnen functioneren.

Volgens Arendt vond in de loop van de negentiende eeuw de gewenste assimilatie van de joden in Frankrijk plaats in die zin dat het 'judaïsme' als collectiviteit in de vorm van een gedeelde religie, taal en wet, steeds meer verloren ging. Religie werd beperkt tot de privésfeer, en 'joods-zijn' werd vaak zelfs een kwestie van pure subjectiviteit of beleving. Volgens Arendt leidde deze assimilatie echter niet tot een geleidelijke 'dejudaïsering' zoals men had verwacht. In plaats daarvan werd juist het privéleven tot het centrum van joods-zijn. Deze subjectivering leidde vervolgens zelfs tot een naturalisatie in termen van ras en aangeboren eigenschappen. Arendt vat dit op als de transformatie van Judaïsm in Jewishness.

$\mathrm{Nu}$ zijn er allerlei punten van kritiek mogelijk op de visie van Arendt, onder meer omdat zij het resultaat van de assimilatiepolitiek in negentiende-eeuws Frankrijk wel erg definitief schetst. ${ }^{17}$ Haar vermoeden dat assimilatiepolitiek niet noodzakelijk hoeft te leiden tot het irrelevant worden van etnisch-religieuze achtergronden is echter nauwelijks betwist (zie bijv. Bauman 1988; 1989; Jansen 2006).

Arendt kwam tot haar inzicht in de paradox van de assimilatie aan de hand van een interpretatie van Marcel Prousts roman Op zoek naar de verloren tijd. Zij meende dat Proust er getuige van was hoe vanwege de Dreyfus-affaire een fascinatie ontstond voor de zogenaamde 'andersheid' van joden. Aan de hand van Prousts roman kunnen we echter laten zien dat de waarneming van de joden als 'anders' meer structurele oorzaken had. Zij was terug te voeren op de verwachting dat er een duidelijke scheiding kan bestaan tussen het 'publiek' functioneren als burger en een eventueel 'privé' horen bij een specifieke groep, dat irrelevant is voor het functioneren als burger.

Prousts roman maakt het mogelijk te analyseren dat door dit verwachtingspatroon een mechanisme ontstond waarbij juist diegenen die hun religieuze achtergrond als publiek irrelevant beschouwden, door leden van de meerderheid werden aangezien voor personen die onder hun neutrale optreden als burger wel degelijk nog een solidariteit met specifieke groepen verborgen hielden. Het ideaal van het republikeinse burgerschap dat religieus 'verschil' in principe tot de privésfeer had beperkt, zorgde er daarnaast voor dat deze vorm van identificatie moei- 
lijk bespreekbaar werd. In Op zoek naar de verloren tijd ontwikkelt een antiDreyfusard op een gegeven moment bijvoorbeeld de theorie dat "je maar een klein beetje hoeft te krabben" en je vindt onder elke Dreyfusard "het getto, vreemd bloed, homoseksuele neigingen of een buitensporige liefde voor Wagner” (1988, III: 1390).

Dit hoofdstuk biedt niet de ruimte om meer dan dit korte citaat te bespreken, maar elders heb ik geprobeerd te laten zien dat Prousts roman op allerlei manieren duidelijk maakt dat verwachtingen met betrekking tot assimilatie juist tot verharde identiteiten kunnen leiden in de interactie tussen meerderheden en minderheden (Jansen 2006). Dit mechanisme trof met name de joden, die door Shmuel Trigano treffend de "gijzelaars van het universele" zijn genoemd (geciteerd in Schechter 2003: 4). Terwijl zij zichzelf met universeel republikeins burgerschap en eventueel hun geprivatiseerde religie identificeerden, werden ze juist door de leden van de meerderheid gezien als 'anders', op een manier die wel degelijk publieke effecten had.

Zygmunt Bauman (1988) heeft nog een laag aan de problematisering van assimilatiepolitiek toegevoegd. Volgens hem ontstaat de paradox van de assimilatie doordat een verborgen principe van segregatie actief blijft in de moderne wereld, terwijl zij officieel gelijkheid in de publieke sfeer belooft. Het feit dat joden bijvoorbeeld op allerlei plekken in de maatschappij werkzaam werden, leidde niet tot het irrelevant worden van de oude verschillen, maar juist tot theorieën dat er een 'verjoodsing' ontstond van bepaalde sectoren. Er ontstond een 'semineutrale' maatschappij met een onderliggend principe van segregatie.

Dit betekende dat de belofte die door de moderne staat was gedaan, niet werd waargemaakt. In plaats daarvan werden de regels van het spel tijdens het spelen door de meerderheid veranderd. Volgens Bauman moet dit leiden tot de conclusie dat de leden van minderheden onmogelijk op gelijke voet met de meerderheid kunnen komen te staan, wanneer zij geen medezeggenschap hebben over de regels van het spel. Ten tijde van het vertrouwen in de assimilatiepolitiek werd de mislukking echter niet aan een 'fout' in de belofte zelf toegeschreven, maar vooral aan het feit dat sommige joden, bijvoorbeeld arme migranten uit Oost-Europa, nog niet genoeg geassimileerd zouden zijn en herinneringen opriepen aan het premoderne jodendom. In Baumans uitleg van het mechanisme dat hierdoor ontstond keert de metafoor van het 'krabben' weer terug:

“De meerderheid die als gastheer optreedt is buitengewoon moeilijk tevreden te stellen. Steeds zal ze erop gebrand zijn om aan te duiden dat de op het oog geassimileerde burger (ostensibly assimilated citizen) met een joodse achtergrond een masker draagt dat te dun is om betrouwbaar te zijn; dat, wanneer eraan gekrabd zou worden, het masker gemakkelijk de duidelijke overeenkomst met het ongeciviliseerde wezen zou blootgeven waarvan de assimilandi hadden aangegeven dat ze het achter zich hadden gelaten. De beste strategie om de verdenkingen van de gastheer af te leiden was als men zijn afkeuren liet blijken van het eigen in diskrediet geraakte verleden." (Bauman 1988: 57, mijn cursivering). 
Zou het toevallig zijn dat in dit citaat een soort tegenwicht van de 'opvallende religieuze tekens' uit het rapport van de commissie-Stasi opduikt? De uitsluiting betreft hier degenen die zich geassimileerde burgers betonen (ostensibly assimilated citizens), maar over wie de meerderheid vermoedt dat er onder hun 'nieuwe identiteit' nog iets verborgen ligt.

De analyse van de 'paradox van de assimilatie' leidt tot het inzicht dat een fixatie op de vraag of onze medeburgers 'tekens' vertonen van toebehoren aan de natiestaat of ook nog aan een andere community, kan leiden tot een onoplosbare vervreemding, zelfs van diegenen die 'schijnbaar' elke andere identiteit achter zich gelaten hebben. Wanneer wij van etnisch-religieuze minderheden vragen om hun 'tekens' van andersheid te verwijderen, opdat zij tonen als burger in de publieke ruimte te willen functioneren, moeten wij ons afvragen of we niet op hetzelfde moment een mechanisme herinvoeren waarin er altijd wel een teken van andersheid gevonden kan worden, als wij besluiten dat dit er is.

\subsection{ASSIMILATIE ALS HERINNERING VOOR EEN HEDENDAAGS SECULARISME}

Het is de vraag of het paradoxale mechanisme van de assimilatie specifiek gebonden is geweest aan de positie van de joden in de Derde Republiek. Bauman en Arendt suggereren beiden dat we met een algemeen mechanisme van de moderniteit te maken hebben, dat echter bijzonder duidelijk aan het licht trad ten tijde van de hoogtijdagen van de Franse assimilatiepolitiek. Dit was met name het geval omdat de nadruk op het private karakter van moderne religie toen zo sterk verbonden was met het idee dat alle 'tekens' die zouden kunnen wijzen op het behoren bij een groep naast het burgerschap vermeden moesten worden.

Er zijn vele factoren die maken dat de hedendaagse situatie sterk verschilt van de situatie in de Derde Republiek. Zygmunt Bauman meende in 1988 dat in het postmoderne tijdperk assimilatie als individuele strategie niet meer aan de orde was, omdat de postmoderniteit de vermenging van allerlei identiteiten mogelijk maakte. Vele anderen hebben gewezen op de pluralisering van de postmoderne maatschappijen en de toegenomen culturele diversiteit. Daarnaast zijn er natuurlijk grote verschillen tussen de positie van joden toen en die van moslims nu. Bovendien heeft de verwerking van de geschiedenis van de joden in Europa tot vele waarborgen voor minderheden geleid.

Toch is het niet voor niets dat Pierre Birnbaum (1998), Esther Benbassa (2003), Talal Asad (2004) en anderen hebben gewezen op de vergelijkbaarheid van bepaalde assimilationistische mechanismen in negentiende-eeuws Frankrijk en de houding tegenover moslims nu. In Frankrijk leeft de assimilationistische traditie voort in de fixatie op de 'tekens' van etnisch-religieus verschil. Sinds 11 september 2001 is de fixatie op hoofddoeken en moskeeën als 'indringers' in 'onze' vermeend neutrale publieke ruimte ook in andere Europese landen toegenomen. ${ }^{19}$ Ook de stoere taal tegenover migranten, de nieuwe moeilijkheden om 
een dubbele nationaliteit te verwerven en te behouden en misschien vooral de fascinatie voor de eigen 'nationale identiteit', tekenen de precaire situatie waarin serieuze vormen van postmoderne identiteitsvorming terecht zijn gekomen, en suggereren een toegenomen druk om te assimileren.

Ik zou willen bepleiten dat wij de conflicten over de hoofddoeken en andere religieuze tekens interpreteren in het licht van de assimilationistische aspecten van het secularisme. Een belangrijke reden om de specifieke geschiedenis van de 'assimilatie' van de Franse joden in herinnering te brengen is dat ze ons bewust kan maken van een problematiek die ons lijkt te ontgaan wanneer we de kwesties met betrekking tot 'publieke islam' alleen in termen van de positie van religie in de publieke sfeer aan de orde stellen. Het lijkt dan vaak te gaan om de belangen van conservatieve religieuze groepen die expliciet of impliciet meer ruimte voor zichzelf willen opeisen en die zelfs willen proberen bepaalde ideeën over moraal aan anderen op te leggen.

Het in herinnering brengen van de paradoxen rond de assimilatie van de Franse joden kan ons echter leren dat we in verband met het publiek verschijnen van etnisch-religieuze bindingen met een dubbelzinnige en veellagige problematiek te maken hebben. Het gaat daarbij niet alleen om de belangen van conservatieve religieuze groepen, maar ook om de noodzaak een sluipende identificatie tegen te gaan van de leden van etnisch-religieuze groepen - of van degenen die daarmee geassocieerd worden - als 'anderen' die er op een of andere manier toch nooit helemaal bij zullen horen.

Op beleidsniveau zou dat mijns inziens als consequentie moeten hebben dat we niet langer suggereren dat de 'tekens' die mensen dragen hen ongeschikt zouden kunnen maken voor het representeren van de staat. Het uitsluiten van mensen van publieke functies nodigt uit tot een glijdende schaal waarin ook uitsluiting plaatsvindt in het bedrijfsleven, etc. Bovendien zou deze uitsluiting niet alleen vrouwen met hoofddoeken kunnen treffen, maar ook degenen die met hen geassocieerd worden. Met betrekking tot leerlingen van middelbare scholen is er (gelukkig) in de meeste Europese landen weinig discussie, maar ook een leraar of rechter moet een hoofddoek mogen dragen. Dat wijst niet op grotere of onoverkomelijkere partijdigheid dan de onzichtbare partijdigheid van het 'wij' dat zichzelf misschien wat al te gemakkelijk als representant van de neutrale staat durft te benoemen. 


\section{NOTEN}

1 Dit hoofdstuk is tot stand gekomen op basis van mijn proefschrift getiteld Stuck in a Revolving Door: Secularism, Assimilation and Democratic Pluralism (2006, UvA).

Dit citaat van Proust behoeft een korte verklarende woordenlijst: 'bijzondere scholen' impliceerde in Frankrijk in 1903 over het algemeen katholieke scholen, die onder controle van de klerikalen (jezuïeten) stonden. Met 'de Affaire' doelt hij op de Dreyfus affaire (1894-1906) waarin een joodse kapitein in het Franse leger op valse (en gedeeltelijk antisemitische) gronden van landverraad aan de Duitsers werd beschuldigd. 'Illiers' is de naam van het dorpje dat model stond voor Combray in Prousts roman Op zoek naar de verloren tijd. Met 'de wetten van Ferry' doelt Proust op de laïcistische onderwijswetten die in de eerste decennia van de Derde Republiek (vanaf 1870) door minister Jules Ferry waren ingevoerd, die de invloed van de clerus op het onderwijs aan banden hadden gelegd.

De ondertekenaars van deze brief waren Elizabeth Badinter, Régis Debray, Alain Finkielkraut, Élizabeth de Fontenay en Cathérine Kintzler.

In 2004 heeft het Conseil d'État zijn jaarrapport overigens gewijd aan een uitgebreide en genuanceerde reflectie op 100 jaar laïcité. Daarin wordt ook de uitspraak uit 1989 in het licht van latere ontwikkelingen belicht.

De commissie heette officieel de 'Commissie voor de reflectie op de toepassing van het principe van de laïcité in de Republiek', maar dit werd al snel afgekort tot 'commissie-Stasi'. De voorzitter van de commissie was de christen-democratische politicus Bernard Stasi. Bekende leden van de commissie waren onder meer de socioloog Alain Touraine, de historicus Jean Baubérot, de migratiedeskundige Patrick Weil, de filosofen Henri Pena-Ruiz en Régis Debray, de juriste Jacqueline Costa-Lascoux en de islamoloog Gilles Kepel. Omdat er zoveel verschillende uitgaven van het rapport in omloop zijn, refereer ik niet aan paginanummers maar aan paragraafnummers.

Dit had hem ertoe geleid voor het advies voor een verbod te stemmen. De historicus Jean Baubérot was daarmee de enige in de commissie die tegen het advies stemde.

8 Vele andere Franse intellectuelen hebben op problematische aspecten van de redeneringen van de commissie-Stasi gewezen, en de grote consensus in de commissie en in het parlement bij aanname van de wet vertekent de heftige discussies die in Franse kranten hebben plaatsgevonden. Een grote groep intellectuelen ondertekende de petitie 'Oui à la laïcité, non aux lois d'exception' (Wel laïcité, geen wetten die uitsluiten). Om enkele andere bekende critici te noemen: de filosofen Etienne Balibar, Paul Ricoeur en Monique Canto-Sperber, Jean-Luc Nancy, de socioloog Émile Poulat en de historicus Gérard Noiriel. Dit wordt nog duidelijker wanneer wij de overdreven beeldvorming bekijken rond de gevaren van communautarisme, dat in het Franse discours ook vaak met dramatiserende termen als 'ottomanisering', 'balkanisering', 'libanisering' en 'tribalisering' wordt aangeduid. Het begrip 'tribalisering' heeft overigens recentelijk een ironische omweg via Nederland gemaakt. Hier is het begrip onder meer 
door Herman Philipse gebruikt, die expliciet door het Franse neorepublikanisme is beïnvloed. Toen de commissie-Stasi in de herfst van 2003 naar Nederland kwam, was Herman Philipse één van degenen met wie zij spraken. Hij wordt (als enige niet-Fransman) in het rapport geciteerd als een 'chercheur néerlandais' die de 'tribalisering' van Nederland heeft geconstateerd. De commissie vermeldt er niet bij dat het wetenschappelijke werk van Philipse zich voornamelijk op het gebied van de klassieke en analytische filosofie bevindt, en dat er chercheurs néerlandais met meer empirische kennis zijn die deze 'tribalisering' niet direct zouden bevestigen. wilden laten verwijderen tegenover meer gematigde figuren zoals de bovengenoemde Buisson, die er in 1888 al op wees dat het ongunstig zou zijn de laïcisering van het onderwijs te laten uitlopen op een 'beeldenstormende kruistocht' ('croisade iconoclaste').

11 Geciteerd uit Pena-Ruiz 2003: 276

12 In de praktijk werkt de scheiding van kerk en staat overigens minder principieel dan in theorie. Niet alleen heeft Frankrijk net als andere Europese landen een systeem waarin ook bijzonder onderwijs, mits het aan bepaalde voorwaarden voldoet, gedeeltelijk door de staat wordt gefinancierd. Frankrijk heeft ook een lange traditie van de 'gestion' van religies, waarbij uitgebreid contact wordt gehouden tussen religieuze vertegenwoordigers en de staat, die de religies zelfs in meer of mindere mate controleert. Dit gold met name voor de koloniën. In Algerije is de laïcité wel ingevoerd, maar al snel keerde men op zijn schreden terug en ze is nooit werkelijk in de praktijk gebracht, omdat de controle over religie belangrijker werd geacht dan het definitief verbreken van alle banden van de staat met religie (zie Maussen 2006).

13 Merk overigens op dat diverse metaforen die gebruikt worden om de vooronderstelde bronnen van onderlinge solidariteit van joden aan te duiden de bewoordingen waren die in eerste instantie voor katholieken, met name Jezuïeten waren gebruikt: de joden mogen geen 'apart politiek lichaam', geen 'orde' vormen. Termen als 'natie binnen de natie', of de 'staat binnen de staat', waren voor de Revolutie al gebruikt om zowel de positie van jezuïeten als van joden te omschrijven (zie Poliakov 1955).

14 Tijdens de debatten in de Assemblée over de burgerrechten stelde bijvoorbeeld een van de sprekers dat 'we ermee moeten beginnen om alle vernederende tekens die hen als joden onderscheiden, te vernietigen, zodat hun kleding, hun uiterlijke verschijnen, ons toont dat ze medeburgers zijn' (geciteerd uit Burns 1992: 11. Overigens is de referentie die Burns geeft onduidelijk).

15 In werkelijkheid was dit echter niet het geval, zoals bijvoorbeeld de Franse historica Esther Benbassa heeft laten zien. Er bleven allerlei collectieve aspecten van joods-zijn bewaard. Er werden bijvoorbeeld relatief weinig gemengde huwelijken gesloten. Voorts was het tekenend dat veel mensen met een joodse achtergrond zich 'Juif' bleven noemen en niet overgingen op 'Israélite', een onderscheid dat in de negentiende eeuw was ingevoerd om het verschil aan te duiden tussen de associatie van joods-zijn met het behoren bij een 'volk', of alleen actief gekozen hebben voor een bepaalde religie (Benbassa 2003). 
16 Zie voor een kritiek op de these van de neutraliteit van de staat of zelfs van de publieke sfeer bijvoorbeeld Kymlicka (2002). 


\section{LITERATUUR}

Arendt, Hannah (1979) [1948] The Origins of Totalitarianism, San Diego, New York, and London: Harcourt Brace \& Company.

Asad, Talal (2004) Reflections on laïcité and the Public Sphere, http://www.ssrc.org/publications/items/v5n3/reflections4.html [2 Juni 2005].

Badinter, Élizabeth, Régis Debray, Alain Finkielkraut, Elizabeth de Fontenay en Cathérine Kintzler (1989) 'Le Munich de l'école républicaine', Le Nouvel Observateur, november 2-8: 30

Balibar, Etienne (2003) 'Dissonances within laïcité', Constellations 11 (3): 353-67.

Baubérot, Jean (2000) Histoire de la laïcité en France, Paris: PUF.

Bauman, Zygmunt (1988) 'Entry Tickets and Exit Visas: Paradoxes of Jewish Assimilation', Telos 77: 45-77.

Bauman, Zygmunt (1989) Modernity and the Holocaust, Cambridge: Polity Press.

Bauman, Zygmunt (1998) 'Assimilation into Exile: The Jew as a Polish Writer', blz. 321-53 in: Susan Rubin Suleiman (ed.), Exile and Creativity. Signposts, Travellers, Outsiders, Backward Glances, Durham and London: Duke University Press.

Benbassa, Esther (2003) La République face à ses minorités. Les Juifs hier, les Musulmans aujourd'hui, Paris: Mille et une nuits.

Birnbaum, Pierre (1989) 'Sur l'étatisation révolutionnaire: l'abbé Grégoire et le destin de l'identité juive', Le Débat 53: 157-173.

Birnbaum, Pierre (1998) La France imaginée, Paris: Gallimard.

Buisson, Ferdinand (1888) 'Neutralité' in Ferdinand Buisson (ed.), Dictionnaire de pédagogie et d'instruction primaire, Paris: Librairie Hachette \& Cie: 2021.

Buisson, Ferdinand (1899) 'Le devoir présent de la jeunesse', in: Émile Boutroux (ed.) La morale sociale, Paris.

Burns, Michael (1991) Dreyfus: A Family Affair, from the French Revolution to the Holocaust, New York: Harper Collins.

Casanova, José (1994) Public Religions in the Modern World, Chicago and London: University of Chicago Press

Conseil d'État (2004) Rapport public 2004: jurisprudence et avis 2003. Un siècle de laïcité, http://www.ladocumentationfrancaise.fr/rapportspublics/044000121/index.shtml [25 september 2006].

Gauchet, Marcel (1998) La religion dans la démocratie: Parcours de la laïcité, Paris: Gallimard.

Jansen, Yolande (2006) Stuck in a Revolving Door; Secularism, Assimilation and Democratic Pluralism, Amsterdam: Dissertatie Universiteit van Amsterdam.

Kymlicka, Will(2002) Contemporary Political Philosophy, Oxford: Oxford University Press. Laborde, Cécile (2002) ‘On Republican Toleration', Constellations 9 (2): 167-83.

Marrus, Michael R. (1971) The Politics of Assimilation. A Study of the French Jewish Community at the Time of the Dreyfus Affair, Oxford: Clarendon Press.

Maussen, Marcel (2006) Ruimte voor islam? Stedelijk beleid, voorzieningen, organisaties, Utrecht: Forum.

Noiriel, Gérard (1992) ‘Français et étrangers’, blz. 276-319 in: Les lieux de mémoire. Pierre Nora (red.), Parijs: Gallimard. 
Noiriel, Gérard en Stéphane Béaud (2004) 'Les nouveaux parias de la République’. Le Monde, 19 februari.

Pena-Ruiz, Henri (2003) Qu'est-ce que la laïcité?, Paris: Gallimard.

Poliakov, Léon (1981) [1955] Histoire de l'antisémitisme 2:l'âge de la science, Paris:

Calmann-Lévy.

Proust, Marcel (1970-1993) Correspondance, 21 volumes, édition présentée, établie et annotée par Philip Kolb. Paris: Plon.

Proust, Marcel (1987-1989) À la recherche du temps perdu, 4 delen, Ed. Jean-Yves Tadié. Paris: Gallimard, Bibliothèque de la Pléiade.

Reinach, Théodore (1901) [1884] Histoire des Israélites; depuis la ruine de leur indépendance jusqu'à nos jours, Paris: Hachette.

Schechter, Ronald (2003) Obstinate Hebrews: Representations of Jews in France, 1715-1815, Berkeley and Los Angeles: University of California Press.

Stasi, Bernard (Commission de réflexion sur l'application du principe de laïcité dans la République) (2003) Rapport au Président de la République, http://lesrapports.ladocumentationfrancaise.fr/BRP/o34000725/oooo.pdf [1 januari 2006]

Tevanian, Pierre (2004) ‘Une loi antilaïque, antiféministe et antisociale’, Le Monde diplomatique, 8 februari.

Touraine, Alain (2003) 'Membre de la commission Stasi, Alain Touraine raconte sa conversion au principe d'une loi', Le Monde, 18 december. 


\title{
10 'CHURCH'-STATE RELATIONS IN THE PUBLIC SQUARE: FRENCH LAICISM AND CANADIAN MULTICULTURALISM ${ }^{1}$
}

\author{
Hendrik M. Vroom
}

\subsection{INTRODUCTION}

The religious plurality of the world demands that we rethink the relation between religion and the state. The relation between church and state has always been problematic, and there is no easy solution to this problem in the modern, pluralist situation. It is clear enough that, in states guaranteeing freedom of religion, religious organisations, or 'church', and the state should be independent of each other. Church and state should be separate, but we do need to acknowledge that 'worldview traditions' pass on ideas of the good life and try to build communities that help people live out their faith - under local conditions and in conversation with culture as a whole.

A faith can sometimes be combined easily with what is considered normal in a society, but it may also be very hard to live as a good Christian, Muslim, Jewish, Buddhist, Wiccan or humanist in a society with a very different background. Those religious views entail viewing certain acts as evil - what one should never do - even though such acts are, nevertheless, done in some cultures. For instance, some people keep and trade slaves - an act abhorred and condemned by others. It is important to realize that views of what counts as evil are even more conflictual than ideas about what is good. Even if people agree on ideals, the problem of the scarcity of resources and the public exposure of religious ideals will lead to conflict. Because religions tend to influence cultures, religion and culture are indeed interwoven and cannot be completely separated. Worldview traditions have helped stamp the values and organisations of societies: German law has been informed by Christianity and Saudi Arabic law has been influenced strongly by Muslim ideas.

In view of the above those who claim that in the pluralistic society of today the state should be neutral are right. Yet this raises the question: What does that neutrality imply? And does a genuine neutrality exist, i.e. a neutrality that discounts the formative traditional and religious 'powers' that have helped to form the variegated whole of values in a society and state?

On the institutional level, the separation of church and state may be easy enough to realize, but on an ideological level it is more difficult, because traces of worldviews enter the public and political domains. In this article I will focus on one question: How much space can governments grant people to be open about their religious adherence in the public square, to have public places of worship and to organize their lives according to the norms of their religious communities? I will 
describe two very different approaches to this question: that of the French Republic and that of the Canadian province of Ontario. We will see how people wrestle with the separation between church and state and the space that the state leaves for religious groups in the public arena. I will end by drawing some conclusions from the ways in which both systems - as we will see - have had to compromise.

First, I will describe the approach of the French Republic, which is based on the principle of laïcité or laicism. I will take time to explain the background of the law and deal briefly with the notorious example of the prohibition of headscarves. Second, I will deal with a recent discussion in Ontario, Canada: appealing to Canada's law on multiculturalism, an Islamic organisation has requested to be able to arbitrate in cases of marriage problems and inheritance according to shar$i$ 'ah law. Here I will focus on the attempt to allow groups to regulate their own cultural-religious affairs and the subsequent wrestling with the consequences of this attempt. Clearly, both countries take an opposite position in relation to cultural and religious differences - which is reflected in several regulations for schools, headscarves, hospitals with a religious background, etc. ${ }^{3}$

\subsection{LAÏCITÉ/LAICISM}

The French law on laicism dates from 1905 and was amended in 1908, 1914, 1966, 1998 , and 2000. The law itself refers to laws from 1880,1884 , and 1890 . Before I give a sketch of the historical background one point must be clarified: why it was not until the period between 1880 and 1905 that the separation of state and church became a matter of law - a full century after the French Revolution granted freedom of religion and, therefore, separated church and state. Soon after the Revolution Napoleon was crowned as emperor, and within a few years he united Europe once again (as the Romans and Charlemagne had done previously). In 1801 Napoleon concluded a Concordat with the pope, the other great leader in Europe, as the Vatican had done with many states. This Concordat granted a number of rights to the Catholic Church. After Napoleon's fall, the more traditional and conservative parts of the population remained very influential - the Communist Manifesto of Marx and Engels (1848) was the start of a counter-movement that would determine the political scene in Europe in the twentieth century. During the nineteenth century the church regained influence in France. The law on laicism was a return to the French Revolution and freedom of conscience.

\subsubsection{THE LAW}

Freedom of conscience and the free exercise of worship are guaranteed in France. One of the main constitutional values is equality, which implies that no one has power over the consciences of others. Therefore, the state and all public organisations must be neutral. Religious organisations are private initiatives undertaken by citizens with a common worldview; they may gather in remembrance of what 
they believe happened at Mount Sinai, at the Jordan, near the Kaaba and be sympathetic towards Rome, Geneva, Benares or Kyoto, but others display more sympathy for Spinoza, Kant, Marx, etc. Freedom of conscience puts Christianity, Islam, Hinduism and Buddhism on the same level as atheism, humanism and agnosticism. However, freedom of religion may include organisations with places of worship and one can argue that what happens there is private. But is what is thought and said in the Notre Dame in Paris merely private? The state cannot ignore religion and the influence that religion can have on believers. How did the French deal with the influence of the Holy See and the bishops? Let us now look at the law itself.

The law of December 9, 1905 formulates two principles. 4

Article 1: "The Republic confirms the freedom of conscience. It guarantees the free exercise of worship (des cultes) under only those restrictions required by the public interest mentioned below.”

Article 2 draws an immediate conclusion:

"The Republic does not recognize, pay for or subsidize any worship. By consequence, from January 1 after this Law has become Rule, all budgets of the state, the provinces and the local communities, will be undone regarding all costs related to worship."

Article 4 rules that all church buildings would be transferred into the possession of new local associations of citizens, established to organize worship (culte: associations cultuelles). This entailed that foreign institutions lost their property. This was clearly a major operation, which was more in line with Protestant churches and their local church councils than with the Catholic hierarchy and its notion of central leadership and ownership. The Catholic Church refused to establish local associations and complained that the role of the hierarchy - and church law - was not taken into account (Rapport, 280f.). 5 Therefore, in April 1908 the law was modified. Article 9 states that all church goods that have not been claimed by associations will be transferred into the possession of local authorities. Those buildings - churches, schools, monasteries and their gardens, seminaries, libraries, and theological schools - that were owned by such associations would come into the possession of the state, the provinces (departements) or cities. The property of church welfare organisations had to be transferred to neutral welfare organisations in the same region, otherwise they would become city property and the provinces or cities would have to ensure that they would be used for welfare purposes.

The Catholic Church in France thus lost its cathedrals, churches, monasteries, lands, seminaries, schools, and welfare institutions - not through a revolution but through a political process in which the state liberated itself from the grip of the church. Nevertheless, it was difficult for the state to organize Mass in the Notre Dame, the cathedrals of Reims or Chartres, and in local churches, or to train priests. Thus, what the state took with the right hand it returned with the 
left - for use only. Article 14 stipulates that the buildings of the archbishops, bishops, presbyteries and their annexes, the great seminaries and Protestant faculties of theology can be used for free by public foundations for worship (Établissements publics $d u$ culte) - for certain periods. "However, they are not responsible for major repairs." Article 19 declares that the state will take charge of repairs on buildings owned by religious associations for public worship, whether they are historical monuments or not. Protestants and currently three mosques therefore have their buildings paid for entirely or partly by the government (Conseil d'État, Rapport 2004: 413; on Muslims cf. p. 325).

\subsubsection{HISTORICAL BACKGROUND}

The law on laicism is not anti-religious, but it is anti-clerical. The background of this anti-clericalism lies in the French Revolution, which ended the hegemony of the Catholic kings and their close cooperation with the Catholic Church.

Throughout history Germany consisted of several principalities, dukedoms, and city-states until the end of the nineteenth century, but France had had a central government for a long time and was one of the most feudalistic states in Western Europe. The Revolution executed the royal family, granted equal rights to Protestants (December 1789) and to Jews (September 1791), ended the public acknowledgement of vows and religious orders (February 1790, August 1792) and established a secular state in 1792. Monks and nuns had to live a secular life or go abroad. In defence of these decisions, the Revolution referred to the rights of the people. ${ }^{6}$ In its preamble the French Declaration of the Rights of Man and of the Citizen (1789) recalls the suffering caused by the administration, corruption and the violations of human rights. From then on government would be based on simple principles evident to everybody. It would be bound by the constitution and have human welfare as its main aim. Article 1 declares that all human beings are born and remain free and have equal rights. The only justification for social distinctions is their usefulness for the public interest. Article 2 states that the following human rights are inalienable from human nature: freedom, property, security, and resistance to oppression. The source of sovereignty is the nation: legitimate authority resides in the nation (Article 3). The acknowledgement that the nation is the source of sovereignty implies the rejection of the authority of the church. The starting point here is the general well-being of the population and not the interests of groups, individuals and those in superior positions (cf. Article 6). ${ }^{7}$ This law is based on the idea of a common human nature: we all are Humans - with a capital letter. The freedom of religion was included because of the pressure of the Huguenots who had been persecuted since the St. Bartholomew's Day Massacre (1572). A more tolerant period began with the Edict of Nantes (1599), which granted them religious freedom in certain areas determined by law, but that edict was suspended in 1685. Many had died at the hands of the Inquisition and many others fled to Berlin, Holland, Manhattan, and the Cape in South Africa. Freedom of religion entailed that no one was to suffer as a result of his opinions, even if they were religious, as long as they did not endanger public order (Articles 10 and 11). ${ }^{8}$ 


\subsubsection{REALITY UNDER LAICISM}

Life, of course, is more powerful than doctrine. The Report of the French Council of State states that laicism is a dynamic principle. In the course of a century new questions arose that had to be answered. The basic assumptions of the law are important for further developments that had to be controlled by the Commission Stasi pour l'application du principe de laïcité. Basic to the law are a number of ideas: separation of church and state, the state's responsibility for everyone, freedom of conscience, freedom of worship, and, by implication, equality and freedom from coercion in conscience and religion. It would be a misunderstanding of laicism to see it as more characteristic than equality for France: freedom of conscience presupposes equality and both principles are completely intertwined. Next, as stated above, laicism is not anti-religious but anti-clerical - which so far has meant in practice that especially the power to exercise control over large areas of social life has been taken from the Catholic Church. The report by the Council of State holds that laicism is not meant to minimize religions or their manifestations in public life and make them merely private. ${ }^{9}$ The display of religious symbols is prohibited on monuments and some public buildings (Rapport, 262). The report states that the law is not inimical to religion and leaves the possibility open for a liberal interpretation (Rapport, 264). It describes the state responsibility for major repairs of cathedrals and churches (305-312), chaplains' homes, slaughterhouses, and Christian holy days.

This system is open to other religious traditions. The large mosque in Paris and those in Lyon and Evry and the synagogue of the Jewish Association of Paris have been accepted as part of the system.

A special case is the matter of headscarves, which were at first allowed in public places but were later prohibited. Muslims point out that Jews and Christian nuns wear a yarmulka or headscarf as well. In 1989 the Council of State ruled that "the freedom of the students entailed the right to express and manifest their religious faiths in the buildings of the schools" - with respect for the opinions of other students and without consequences for the classes. The boundaries of this freedom were, of course, putting pressure on others, provocation and proselytism (Rapport, 338). In 1994 a government rule was circulated that such signs should be unobtrusive-simply showing that one belongs to a religious group-and not conspicuous (signes ostentatoires), because they would otherwise be proselytistic and possibly discriminatory. The Council of State ruled that this ministerial rule did not prohibit the wearing of headscarves (Rapport, 339). A headscarf can mean various things (Rapport, 341). After a series of incidents and broad discussions in 2003 a committee appointed by the National Assembly advised that all signs of religious or political memberships in public spaces be suppressed, including public schools. The committee, on reflecting on the application of the law of laicism, advised prohibiting all clothes and signs that openly displayed religious affiliation. The General Assembly of the Council of State agreed with the draft of a law prohibiting such clothes and signs in all primary and secondary schools and colleges. If some con- 
tested that the prohibition did not apply to them, the courts would decide whether the religious signs were in conformity with the law on laicism (Rapport, 342).

\subsubsection{DISCUSSIONS}

If religion can be very influential on our attitude in life and helps to determine ideals that go somewhat beyond what is considered to be 'normal,' then the relation between the state and religious leadership will always remain problematic. The French solution is marked by the French past. Inevitably, there was some discontent. The Catholic hierarchy does not fit well into the law on laicism, even though the state does respect the church orders of the various religious organisations - within the limits of the law. The grand rabbi of France stated that "the reductionist view of religion in the law on laicism has been implanted step by step in positive law. The state has the right to decide sovereignly upon what is truly religious, and that has decreased comme peau de chagrin" (Rapport, 285f). In relation to Muslim wishes, the report argues that the state has to distinguish time and again between the truly religious matters that have to be integrated and those that do not belong to the religious domain. Some people want to interpret the law on laicism in an open and liberal way - and it is important to note that the report of the Council of State takes this line. But others want to remove all religion from the public domain. An example of the latter is Henry Pena-Ruiz, member of the Stasi Committee for the application of the principle of laicism. In his Dieu et Marianne: Philosophie de la laïcité he argues for the removal of all religious signs from the public domain (Pena-Ruis, 2005). He stresses that this principle is not hostile to religion but guarantees a neutral and equal treatment of everybody. The principles of the French state are - in line with the French Revolution - equality, freedom of conscience for everyone, state sovereignty, and the oneness of the French people. The educational system should have no place for religious education.

Compared with the report by the Council of State, Pena-Ruiz is somewhat rigid. His philosophical hero is Spinoza - expelled by the Amsterdam synagogue and sent into exile by the city council because of his heretical beliefs. But Spinoza, in Pena-Ruiz' view, was right to stress the commonality of human beings; his hermeneutical programme in the exegesis of Scripture is plausible: stick to the universal truths! Pena-Ruiz is therefore not a friend of the French post-modern philosophers but a proud heir of strict Enlightenment thought: one common human nature, one reason, equality, and the privatization of that which we cannot know with certainty. Because of these human commonalities we are united by universals; as far as the rest of our beliefs are concerned, we should take them for what they are: not established facts but (irrational!) beliefs. And we should not cling to them too strongly but rather tentatively - strong beliefs do not allow for a great deal of tolerance (Pena-Ruiz 2005: 105, 181, 215). A free, civil society requires a republic of equals, working together on the basis of reason, and the privatization of religion - which is not a matter of reason but one that belongs to another area of existence (Pena-Ruiz 2005: 103, cf. 178). Thus, Pena-Ruiz' esti- 
mation of laicism is very different from that of the report of the Council of State. He repeatedly rejects an "open laicism" that tries to give religious organisations a place in the public sphere.

So far, we have seen the main line of the law on laicism, its historical background, its dynamic interpretation in the twentieth century, and the opposition to a freer and more "liberal" interpretation. Pluralism has given new urgency to the debate. Headscarves had been allowed, but after $9 / 11$ they were prohibited in public buildings and schools. France is wrestling with religious pluralism. A Moroccan philosopher complained once (in 1995): “In France we are accepted as Moroccans but never as Muslims!" 10 I will return to the French situation after an exposition of the recent so-called shari'ah discussion in the Canadian province of Ontario.

\subsection{A SHARI'AH COURT IN TORONTO?}

The Canadian constitution grants people the right to live according to their own traditions. ${ }^{11}$ In the background here are Canada's French- and English-speaking populations and its two official languages and the immigration of many from Europe and other parts of the world..$^{12}$ The First Peoples of the Americas have been granted full rights and immigrants from Western Europe and East Asia live everywhere in the country. The name of the street south of the University of Toronto, College Street, is written in both English and Chinese. Canada welcomes differences and does not try to assimilate everyone into a French or English straightjacket.

The space for people to follow their own cultures and traditions has been made law in the Multiculturalism Act of 1985 (assented to 1988), which refers in its introduction to the constitution:

“(...) Canada is a party to the International Convention on the Elimination of All Forms of Racial Discrimination, which Convention recognizes that all human beings are equal before the law and are entitled to equal protection of the law against any discrimination and against any incitement to discrimination, and to the International Covenant on Civil and Political Rights, which Covenant provides that persons belonging to ethnic, religious or linguistic minorities shall not be denied the right to enjoy their own culture, to profess and practise their own religion or to use their own language;"

“(...) the Government of Canada recognizes the diversity of Canadians as regards race, national or ethnic origin, colour and religion as a fundamental characteristic of Canadian society and is committed to a policy of multiculturalism designed to preserve and enhance the multicultural heritage of Canadians while working to achieve the equality of all Canadians in the economic, social, cultural and political life of Canada (...).”

On this basis the Canadian government has the obligation to grant people the right to follow their own way of life and to provide opportunities for them to do 
so - culturally, ethnically and religiously. Thus, Canadian policy is not a copy of Paris's policy - to say the least. Pena-Ruiz holds that the aim in Paris should not be assimilation but integration - on the basis of a common rational humanity all kinds of differences are possible (Pena-Ruiz 2005: 211). Canada starts with one law for all that recognizes differences. Let us see how far this brings us in the case of the request for Ontario to recognize a shari'ah court as competent to arbitrate. Can Muslims follow their own rules in family law?

\subsubsection{ARBITRATION}

The Canadian Law on Arbitration (1991) grants the possibility of arbitration by arbiters whose decisions are binding. Divorce can be decided only by the courts, but the lesser decision regarding separation can be done through arbitration, if both partners agree on the arbitration and the choice of the arbiter. This (cheaper) procedure allows for a decision in conformity with local or religious custom or rules. An arbiter is more able to take personal circumstances into consideration than a court could (Boyd 2005: 36). Rules for the upbringing of children, financial responsibilities and even inheritance can be arranged by arbitration. If people agree to take the road of arbitration, the decisions are binding - unless they are contrary to other laws.

Religious communities make use of this possibility. Churches have rules for their members. Catholic dioceses have church laws concerning marriage and divorce. Protestant churches may not have inscribed these rules into a church order, but they do have moral requirements for full membership. Thus, people may choose a church member as arbiter or go to the church court. In the Jewish and Islamic communities the strict following of halachah and Islamic law is more important than following similar rules in most Christian churches because, among other reasons, of the warnings against legalism in the Sermon on the Mount and in the letters of Paul. Members of the Jewish community have to obey and will be judged by the Beis Din, which makes decisions according to the Jewish religious laws, halachah. The majority of cases brought to the Beis Din by orthodox, conservative and reform Jews concerns the get, the amount that, according to the halachah, has to be paid for the wife. ${ }^{13}$ In an average of thirty cases per year the Ontario Beis Din decides on support, custody, and property division and access and, according to the law on arbitration, those decisions are binding. A Muslim organisation requested the same status for the shari'ah as the Beis Din, a request that resulted in a great deal of discussion that lasted two years in Ontario and other places.

The Islamic Institute of Civil Justice (IICJ) in Ontario asked the provincial government to recognize a shari'ah court as a committee for arbitrage and to grant legal, binding power to its decisions on separation and hereditary settlements. Given the upheaval and protests from people who argue for laicism, feminist organisations, a Muslima Group and others in newspapers, on radio and television, in June 2004 the government in Toronto asked Marion Boyd 
- a former minister of 'Woman's Issues' - for advice on whether and how such Muslim arbitration would be possible. After consulting with almost every group in Ontario, she presented her advice publicly in December 2004. This advice was again received with sharp criticism by secular, Jewish, and feminist groups although, as Mrs Boyd convincingly pointed out, the intentions of the IICJ had not been very well understood. After lengthy discussions, the Ontario Parliament decided on February 15, 2006 to change the Family Law and Arbitration Acts.

\subsubsection{THE BACKGROUND: ISLAM IN THE WEST}

For a good understanding of the question of the IICJ we need to delve a bit into its background. Part of the misunderstanding lies in how the term shari'ah has often been understood in the West. Shari'ah is the main body of classical Islamic law (and ethics), laid down in the Koran, hadith and which has been applied and elaborated in the four important Islamic traditions in law (shari'ah). Those traditions differ a great deal in rules concerning prayers, gifts, Ramadan, hadj and the main confession but also in respect to various contextual applications of the old rules that are derived from the Koran and hadith (stories about the life and sayings of the Prophet and his early followers). Just as New Testament scholars have a genealogy of manuscripts of the New Testament books, so Muslims have a genealogy of hadith with indications of how many and which witnesses support the story told by a hadith. From these sources - the Koran and hadith - the four main Islamic law schools (traditions) derive their jurisprudence (figh) in accordance with certain (hermeneutical) principles. The study of principles (Usul alFiqh) is one of the main areas of Islamic theology.

Thus, shari'ah means the basic ethical rules of Islam. Muslims who want to follow shari'ah simply want to be directed in obedience to God by God's laws as given in the Koran and by the examples of the earliest witnesses of the faithful lives of the Prophet and his first followers, like his wives, daughters, and friends. Some Muslims follow the strictest schools in shari'ah. These schools follow the Koranic rules and earliest hadith, because they want to purify Islam by returning to the old sources. A religious renewal requires a new interpretation of its sources - as Luther and the people who gathered in Azusa Street in Los Angeles in 1906 did. In one way or another Muslims have to decide which principles are basic and which are contextual - Moroccan, Arabic, Turkish, Pro-Islamic Indonesian, etc. (see Vroom, forthcoming).

Therefore, that Muslims wish to live in accordance with shari'ah is quite understandable and does not say that much about the rules that they will actually follow in business and family life. The central lines of Islamic ethics are clear, as are the central lines of Christian ethics, but in the modern context and, for Muslims, the minority situation requires a great deal of hermeneutics. Therefore, if Muslims talk about a shari'ah court, it would be better to ask their view of figh and the principles of jurisprudence than to oppose such terms immediately. 
Muslims live in Canada and other Western countries under a law that has its roots in Roman and Christian cultures and has gone through a long history of religious wars, peace treaties and the Enlightenment. Of course they want to find a Muslim way of life in these societies. And therefore one question is how much space do Western countries with their Christian, Jewish, and humanist backgrounds grant to Muslim, Confucian or other communities. The second question is how Muslims will find their way. Muftis have the right to pass fatwas that tell people what is correct Islamic conduct. There are many muftis - local, bound to Muslim communities and on the internet - and they have many conflicting insights. Muslims share in the modern condition of people in affluent societies: we live locally and globally - although our basic human interests are financially and socially local. In the case of family problems, people depend mainly on local communities for acceptance and support. Therefore the proposal of the IICJ was quite natural. Why not institute an Islamic court like the Beis Din that can help them live their lives with a good Muslim conscience?

Against this background we can understand a few elements in the fierce discussion about the shari'ah court in Ontario: 1) the necessity for the Islamic communities to follow a Muslim way of life within the system of Canadian law; 2) the actualization of their constitutional freedom to live according to their cultural and religious customs and opinions; 3 ) the settling of problems having to do with marriage and inheritance according to shari'ah;4) the need for expertise on the settlements that Muslims can make in Ontario.

\subsubsection{THE MAIN OBJECTIONS}

Many of the objections to a shari'ah court on family arbitration presuppose that it would leave women in a backward position. The Canadian Council of Muslim Women and other organisations point out that what many forms of Muslim family law have in common is that they perpetuate a patriarchal model - in polygamy, rules for divorce and inheritance (48). However, Boyd refers to studies that show how widely the positions of women in Islamic countries differ.

Because of the variety of the law schools in Islam, the classical rules are applied in widely divergent ways (Boyd 2005: 42f.).

Some groups object to the presence of religious principles in Canadian law. The Humanist Association of Canada feels that there should be "no religious alternative to the secular laws that govern family law and inheritance matters in Canada" (47). Boyd answers that many who oppose the presence of any religious principles in Canadian law have "little memory of the extent to which religious principles have informed the laws which we tend now to regard as secular in this country” (Boyd 2005: 46): these laws "look patently 'Christian' in nature, enshrining as they do such 'Christian' values as monogamy in marriage or restrictions around divorce, not to mention official holidays and the defined work week" (46). 
Another important objection states that the composition of the Muslim community in Canada - like almost everywhere in the West - is very diverse, and not all Muslims agree on the same set of rules. Therefore, during her many consultations she heard that people thought there would "never be a single, centralized shari'ah tribunal that all Muslims will accept," just as not all Muslims would accept fatwas from Al-Azhar or the European Islamic Council (43f.). Boyd replies to this objection by pointing out that there are some Islamic Conciliation and Arbitration Boards in fourteen jurisdictions around the world; in Canada there were five, with formal rules for conciliation and arbitration, adopted in 1990. Between 1998 and 2003 these arbiters dealt with 769 cases, with a success rate of 69 per cent (58; appendices IV and V). A Toronto mosque offers guidance and arbitration and, in fact, "Muslim family law has been and is being used now to resolve disputes successfully in both Shi'a and Sunni contexts" (61).

Thus, the government of Ontario had to compromise between the constitutional right to live according to one's own tradition and the principles of equality and nondiscrimination. Native Americans underlined the value of religious arbitration: "It could be argued that Jewish law, Christianity, Shari'ah law, native healing circles and religions in general are, in essence, non-violent or violence-reducing conflict resolution systems" (65) - especially, as Muslims added, for minorities (Boyd 66). In communities with extended families, other family members are affected by conflicts and divorces - and it is not certain that a secular, modern court would take their interests into account (66f.). However, some suspicions were raised by a declaration made by a member of the Muslim leadership in a convention called by IICJ on the foundation of a "Darul Qada-Muslim Court of Arbitration" (March 2004) that Muslim law is superior: "A Muslim cannot be a Muslim without obeying Muslim law in its totality." 14 This can be interpreted in various ways indeed.

\subsubsection{REASONS AND ADVICE}

Of course, Boyd would consider such arbitration only if people were free to submit their case to Islamic arbitration or not. Canada is bound to guarantee people freedom of religion and enhance the multicultural inheritance of Canadians (Boyd 2005: 73). All arbitration falls within the power of the state, which determines the boundaries of what can be organized ( 76$)$. But the government acknowledges a private sphere in which people may make private arrangements by means of contracts $(76)$. Of course, safeguards are needed to prevent people from being forced to accept rules that they do not want.

Boyd concludes: "I do not believe the Constitution prohibits the use of arbitration, faith-based or otherwise, for resolving disputes about family law and inheritance" (77). Canada, she says, "is a delicate balancing act where protection of the religious, language and legal rights of both French and English have marked our ethos from the beginning" (79). In Britain, since 1982 "the Islamic Shari'ah Council (UK) provides (...) professional conciliation services to couples on various aspects of Islamic law and has established for this purpose standard procedures, 
forms and certificates," and many important disputes among them never come before the official courts (81).

Boyd's starting point lies in the balancing of two principles: the equal value of each individual and the rights of minorities that are acknowledged in the Canadian law on multiculturalism (89). Therefore, she rejects two opposite 'solutions' to the problem of community and multiculturalism. The first view can be called 'secular absolutism' - the model commonly associated with France. This model is based on the assumption that secular laws treat everyone equally. The primary shortcoming of this model, she says, is that it fails to acknowledge that some people live their lives in a manner more closely aligned to their faiths than others, so that secularism is experienced as a constraint. In such a system legal selfexpressions are impossible (8gf.).

The opposite view holds that each minority community has the possibility of instituting its own internal regulations; this policy can be called "non-intervention." This policy is difficult for those who feel that some minorities do not have much respect for some of their members, such as women (gof.). This is relevant in this case, because some Muslim leaders have made statements that justify the unequal treatment of women (93; cf. 97), although it is debatable whether all Islam is that patriarchal, and basic Islamic principles could be interpreted otherwise (99). Boyd stresses the interests of women and children. Because of the tension between individual rights and some group customs, individuals should not be stopped from appealing to common law. Therefore, the distinction between public and private cannot be drawn too sharply; it would exclude some important information - relevant to a group's identity - from the public conversation (91). "The line between private and public shifts, and is in constant negotiation," she says (91). Next, she rightly states that individuals are always at the intersection of various identities. Therefore, it is impossible to define cultural, ethnic, or religious groups in too harsh a way.

Boyd advises improving the structure of the arbitration and refers to advice that has been given to her: clear independent legal advice for persons who are considering arbitration (cf. Boyd 2005: 105, 120f.), regulations and requirements concerning the qualifications of arbiters (109-17), equal treatment of women during arbitration (117f.), keeping records and a survey of the reasons behind the decisions of the arbiter (118-19), and other possibilities for appeal or review of decisions (124f.). The report gives a list of proposals for the improvement of the Arbitration Act; in the case of religious arbitration, a decision should include a statement of the principles of faith-based arbitration (136f.).

\subsubsection{REVISION OF THE ONTARIO LAWS}

After a year of political discussion, the government decided to change the Family Law and Arbitration Acts. I will quote some of the new amendments of the laws, decided upon on February 15, 2006: 


\section{Family Law Act}

The law defines "family arbitration" as arbitration that

"(a) deals with matters that could be dealt with in a marriage contract, separation agreement, cohabitation agreement or paternity agreement under this Part, and

(b) is conducted exclusively in accordance with the law of Ontario or of another Canadian jurisdiction; "family arbitration agreement" and "family arbitration award" have meanings that correspond to the meaning of "family arbitration." 15

\section{Arbitration Act (see e-laws.gov.on.ca: 81)}

"58. The Lieutenant Governor in Council may make regulations,

(a) requiring that every family arbitration agreement contain specified standard provisions;

(b) requiring that every arbitrator who conducts a family arbitration be a member of a specified dispute resolution organisation or of a specified class of members of the organisation;

(c) requiring every arbitrator who conducts a family arbitration to provide specified information about the award, not including the names of the parties or any other identifying information, to a specified person;

(d) requiring any arbitrator who conducts a family arbitration to have received training, approved by the Attorney General, that includes training in screening parties for power imbalances and domestic violence;

(e) requiring that every arbitrator who conducts a family arbitration shall, (i) ensure that the parties are separately screened for power imbalances and domestic violence, by someone other than the arbitrator, and

(ii) review and consider the results of the screening before and during the family arbitration;

(f) requiring every arbitrator who conducts a family arbitration to create a record of the arbitration containing the specified matters, to keep the record for the specified period and to protect the confidentiality of the record;

(g) specifying standard provisions for the purpose of clause."

\subsubsection{CONCLUSION}

Thus, the law now grants individual persons the possibility of arbitration in their own ethnic or religious community but states additional qualifications for arbiters, the procedure of their decisions, control and clearer possibilities of appeal, and independent information from both partners concerning the process and the criteria that will be used. The individuals may choose to be helped by an arbiter from their religious community. The law does not determine the communities from which arbiters may come but grants them equal treatment and responsibilities within the framework of wider Ontario and Canadian Law. 


\subsection{COMPARISON AND OBSERVATIONS}

It is clear that France has the strictest separation between state and church and Canada is the country that most clearly grants rights to ethnic, cultural and religious minorities. These policies are very much within the atmosphere of the twentieth century and will come under a great deal of pressure in the global, pluralist culture of the twenty-first century.

French laicism has its roots in the treatment of Protestants - and at an earlier stage Waldensians and others - and the close ties between the absolute king (l'état, c'est moi) and the clerical hierarchy. Napoleon reversed the new order and the restoration of the post-revolutionary period did the rest. Since the latter part of the nineteenth century France has tried to loosen those old ties and to treat every citizen equally, granting freedom of conscience and freedom of worship. The new policy was built on an Enlightenment idea of a universal nature - supported by the Christian beliefs of the large majority of the population. Pena-Ruiz' view of an actual common human nature is exaggerated - it is simply uninformed and Eurocentric or even "West-Eurocentric" - but he is right in that such a view of a general, reasonable basis of society is basic to the idea of laicism.

We have to acknowledge that there is a deep gap between the idea of an actual moral consensus on a common set of values and the idea that all people have such values in common on a deeper level (so that everyone who neglects them acts against her own nature). Those who want to improve the world are continually making the error of neglecting this difference. Secularized liberals think that the public domain can be neutral, without a particular worldview and governed by reason alone: all differences are circumstantial, private, and have no meaning for society at large because all things common are steered by reason alone: sola ratio humana. That is the rhetoric of Pena-Ruiz' understanding of laicism as wellalthough it is not the reality.

The Canadian Multiculturalism Act dates from 1985, a period of wealth in the West, with a rather strong sensitivity to other cultures and Western failures, and shame over how the First Peoples of the Americas had been treated. ${ }^{16}$ Cultural relativism was in the air and below the awareness of difference lay an enlightened trust that on a deeper level of human nature all people are equal - and that all moral 'systems' are ultimately decent and that people can learn to understand and learn from one another. North America had a different Enlightenment from the one France had - not anti-clerical and much less atheistic. Canada has granted rights to a small minority of native people who live partly in a few areas. But Canada is now beginning to be confronted with larger groups of 'aliens' - in Ontario there are about 220, ooo Muslims and even larger numbers of East Asians in the western provinces. Muslims resist Western ideas of a liberal and rational common human nature that makes everybody an autonomous but equal individual. So Ontario had to extend the Arbitration Act and make it more 'Western' in the sense that Muslims would be bound by existing law - stemming from a 
mainly 'Christian' background, as Boyd rightly states. (Muslim) arbiters have to be educated, not because they are suspect but to make sure that they act according to the standards of the dominant culture: personal freedom, equality and rules about the care for children.

The most striking feature of both examples is that they meet with the same problems - real cultural and religious differences - and have to compromise. Laicism is not as strict as people like Pena-Ruiz claim. The Rapport du Conseil de l'État is clear on this and Boyd gives similar examples from Canada: holidays, the structure of the week - and we could add the whole structure of social and medical care, the very idea of a more general commonality that transcends families and clans. Canada has made room for ethnic and religious particularities and is now forced to preserve the common values of the old majority that are thought to be part of Canadian identity. France comes from the other side and has to find a way to make room for other differences: the slaughter of animals, permission for mosques, state support for the building of mosques - a treatment equal to the Catholic use of state cathedrals? Headscarves were permitted until after 9/11, 2001. They increasingly became signs of a Muslim identity over against secularism and thus of a protest against the acceptance of people from Morocco, Algeria, Tunisia, etc. as French citizens but not as Muslims. Canada and France struggle with the same problems of religious and cultural pluralism but approach it from opposite sides.

These problems cannot be solved if we do not accept that the idea of a common human nature is always part of a specific worldview. Through international law we acknowledge the idea of a common humanity, but the actual understandings thereof vary rather widely from culture to culture and between worldview traditions. Perhaps some of the differences will disappear in the next centuries, but some valuable elements of the contemporary understanding of common humanity will disappear as well. In the end it is clear that both the Canadian and the French solutions are historical and contextual solutions for the problem of religion, state and culture, and not purely rational findings or compromises for all time.

What is lacking too much in these discussions is the question of evil. It is quite common to discuss different ideas of the common good but belonging to such ideas are views of what is wrong to do. If others permit something that one thinks should never be done and certainly not allowed, this is a much deeper conflict than that caused by different priorities among desirable aims. Part of the collision between the liberal Western culture and Muslims concerns evil: Muslims reject Western liberalism and the idea that we are free to do what God, in their view, has forbidden. Westerners abhor the conflicts between Arabic clans, an attitude of laziness towards modern forms of slavery and the unequal treatment of women - I will leave aside the question of whether such things are present in Western societies as well. Deep conflicts arise from what people reject and cannot allow on religious grounds. In her report Boyd deals extensively with 
the treatment of women and children but much less with what Muslims do not like in Western culture. The report by the Conseil d'État on laicism lacks an analysis of the objections of Muslims to French society, and in the liberal plea in Dieu et Marianne religion and France are present, God and Marianne, but not ideas of other cultures about life and society.

We have a long way to go in learning to discuss state-religion relations and value pluralism. There are two levels here. The first level is within our own 'communities' - as they are pluralistic in themselves. We have to discuss the values of our tradition and to what extent we have made them part of the culture. The second level is the public and political discussion on life and how society should be organized. Religions should play an important role in that discussion - as we have seen, religion plays a role in society and is not 'just private'. Both in Ontario and France and everywhere else, politicians have to discover what that role can be. 


\section{NOTEN}

This contribution was first published in Studies in Interreligious Dialogue 16 (2006): 190-210.

In what follows I will use the term "church" to refer to all religious and secular worldview organisations and will use the term religion in a very broad way, including organized secular worldview traditions in it as well - for no other reason than that "religion" is a more well-known and shorter expression.

According to the 2004 Report on Public Affairs and Laicism by the French Council of State (37of.), of the fifteen original member states of the European Union, France and the Netherlands have the strictest constitutional separation of church and state. It is widely known that Franc is the strictest on this point.

For the French text of law see Conseil d'Etat, Rapport public 2004; 405-415.

In 1920 France re-established diplomatic relations with the Holy See; cf. Rapport, 281.

Déclaration des Droits de l'Homme et du citoyen de 1789: Les Représentants du Peuple Français, constitués en Assemblée Nation ale, considérant que l’ignorance, l'oubli ou le mépris des droits de l'Homme sont les seules causes des malheurs publics et de la corruption des Gouvernements, ont résolu d'exposer, dans une Déclaration solennelle, les droits naturels, inaliénables et sacrés de l'Homme, afin que cette Déclaration, constamment présente à tous les Membres du corps social, leur rappelle sans cesse leurs droits et leurs devoirs; afin que leurs actes du pouvoir législatif, et ceux du pouvoir exécutif, pouvant être à chaque instant comparés avec le but de toute institution politique, en soient plus respectés; afin que les réclamations des citoyens, fondées désormais sur des principes simples et incontestables, tournent toujours au maintien de la Constitution et au bonheur de tous.

En conséquence, l'Assemblée Nationale reconnaît et déclare, en présence et sous les auspices de l'Etre suprême, les droits suivants de l'Homme et du Citoyen. Art. 1. Les hommes naissent et demeurent libres et égaux en droits. Les distinctions sociales ne peuvent être fondées que sur l'utilité commune.

Art. 2. Le but de toute association politique est la conservation des droits naturels et imprescriptibles de l'Homme. Ces droits sont la liberté, la propriété, la sûreté, et la résistance à l'oppression.

Art. 3. Le principe de toute Souveraineté réside essentiellement dans la Nation. Nul corps, nul individu ne peut exercer d'autorité qui n'en émane expressément. In English (Laquier and Rubin 1990):

The representatives of the French people, organized in National Assembly, considering that ignorance, forgetfulness, or contempt of the right of man are the sole causes of public misfortunes and of the corruption of governments, have resolved to set forth in a solemn declaration the natural, inalienable, and sacred rights of man, in order that such declaration, continually before all members of the social body, may be a perpetual reminder of their rights and duties, in order that the acts of the legislative power and those of the executive power may constantly be more respected, in order that the demands of the citizens, founded henceforth upon simple and incontestable principles, may always be directed 
towards the maintenance of the Constitution and the welfare of all. Accordingly, the National Assembly recognizes and proclaims, in the presence and under the auspices of the Supreme Being, the following rights of man and citizen.

1. Men are born and remain free and equal in rights; social distinctions may be based only upon general usefulness.

3. The aim of every political association is the preservation of the natural and inalienable rights of man; these rights are liberty, property, security, and resistance to oppression.

4. The source of all sovereignty resides essentially in the nation; no group, no individual may exercise authority not emanating expressly there from.

Déclaration, Art. 6. La Loi est l'expression de la volonté générale. Tous les Citoyens ont droit de concourir personnellement, ou par leurs Représentants, à sa formation. Elle doit être la même pour tous, soit qu'elle protège, soit qu'elle punisse. Tous les Citoyens étant égaux à ses yeux sont également admissibles à toutes dignités, places et emplois publics, selon leur capacité, et sans autre distinction que celle de leurs vertus et de leurs talents.

English:

Law is the expression of the general will; all citizens have the right to concur personally, or through their representatives, in its formation; it must be the same for all, whether it protects or punishes. All citizens, being equal before it, are equally admissible to all public offices, positions, and employments, according to their capacity, and without other distinction than that of virtues and talents. Déclaration, Art. 10. Nul ne doit être inquiété pour ses opinions, même religieuses, pourvu que leur manifestation ne trouble pas l'ordre public établi par la Loi. Art. 11. La libre communication des pensées et des opinions est un des droits les plus précieux de l'Homme: tout Citoyen peut donc parler, écrire, imprimer librement, sauf à répondre à l'abus de cette liberté dans les cas déterminés par la Loi. English:

Art. 10. No one is to be disquieted because of his opinions, even religious, provided their manifestation does not disturb the public order established by law. Art. 11: Free communication of ideas and opinions is one of the most precious rights of man. Consequently, every citizen may speak, write, and print freely, subject to responsibility for the abuse of such liberty in the cases guaranteed by law. Rapport, 263: "Pour les pères fondateur de la loi de 1905, puis de celle de 1907 sur les cultes, la laïcité n'est pas le refoulement des religions ou de leurs manifestations de l'espace public vers la sphère privée. C'est le refus de l'accaparement (seizure) de l'Etat et de la société par les religions et, inversement, de la main mise de l'État sur celles-ci." M.A. Al-Jabri at the Conference "Le Société civile et le dialogue euro-arabe," held in Casablanca, December 14-16, 1995. Conference papers were published in 1996 under the same title by the Secréteriat Euro-Arab Dialogue at The Hague. Constitution, 3 (see the website of the Canadian Government). (1) It is hereby declared to be the policy of the Government of Canada to

I. recognize and promote the understanding that multiculturalism reflects the cultural and racial diversity of Canadian society and acknowledges the freedom of all members of Canadian society to preserve, enhance and share their 
cultural heritage; recognize and promote the understanding that multiculturalism is a fundamental characteristic of the Canadian heritage and identity and that it provides an invaluable resource in the shaping of Canada's future;

III. promote the full and equitable participation of individuals and communities of all origins in the continuing evolution and shaping of all aspects of Canadian society and assist the and assist them in the elimination of any barrier to that participation;

IV. recognize the existence of communities whose members share a common origin and their historic contribution to Canadian society, and enhance their development;

v. ensure that all individuals receive equal treatment and equal protection under the law, while respecting and valuing their diversity;

VI. encourage and assist the social, cultural, economic and political institutions of Canada to be both respectful and inclusive of Canada's multicultural character;

VII. promote the understanding and creativity that arise from the interaction between individuals and communities of different origins; foster the recognition and appreciation of the diverse cultures of Canadian society and promote the reflection and the evolving expressions of those cultures; preserve and enhance the use of languages other than English and French, while strengthening the status and use of the official languages of Canada; and advance multiculturalism throughout Canada in harmony with the national commitment to the official languages of Canada. belief that all citizens are equal. Multiculturalism ensures that all citizens can keep their identities, can take pride in their ancestry and have a sense of belonging. Acceptance gives Canadians a feeling of security and self-confidence, making them more open to, and accepting of, diverse cultures. The Canadian experience has shown that multiculturalism encourages racial and ethnic harmony and cross-cultural understanding, and discourages ghettoization, hatred, discrimination and violence."

13 For the Roman Catholic Church see Boyd 2005: 39; for the Anglican Church, 40; for Jewish and Catholic courts see 39-41. According to the information given to Boyd, Orthodox Jews are forbidden to bring a lawsuit before secular judges (55). The Report can be found on the website of the Attorney General of Ontario, as can the various laws mentioned above.

14 Boyd, 2005: 62, quotes Syed Mumtaz Ali, “Islamic Institute of Civil Justice and Muslim Court of Arbitration," News Bulletin, (Canadian Society of Muslims, August 2004), 2.6.

15 Further amendation of the law: Conditions for enforceability:

59.6 (1) A family arbitration award is enforceable only if,

(a) the family arbitration agreement under which the award is made is made in writing and complies with any regulations made under the Arbitration Act, 1991;

(c) each of the parties to the agreement receives independent legal advice before making the agreement; 
(d) the requirements of section 38 of the Arbitration Act, 1991 are met (formal requirements, writing, reasons, delivery to parties); and

(e) the arbitrator complies with any regulations made under the Arbitration Act, 1991. 2006, c. 1, s. 5 (10).

Certificate of independent legal advice

(2) When a person receives independent legal advice as described in clause (1) (b), the lawyer who provides the advice shall complete a certificate of independent legal advice, which may be in a form approved by the Attorney General.2006, c. 1, s. 5 (10).

16 The present constitution dates from 1982. 


\section{LITERATURE}

Boyd, Marion (2005) Dispute Resolution in Family Law: Protecting Choice, Promoting Inclusion, http://www.attorneygeneral.jus.gov.on.ca/english/about/pubs/ boyd/.

Conseil d’État (2004) 'Rapport Public 2004: Jurisprudence et avis de 2003. Un siècle de laïcité’, Etudes et documents, Conseil d’Etat. No. 55. Paris: La Documentation française.

Laquier, Walter and Barry Rubin (1990) The Human Rights Reader. New York: Reprint.

Pena-Ruiz, Henry. (2005) Dieu et Marianne: Philosophie de la laïcité. 3rd Rev. Ed. Paris: Presse universitaire de France.

Vroom, Hendrik M. (2006) 'Interreligious Relations: Incongruent Relations and Rationalities' Studies in Interreligious Dialogue 16: 59-71. Leuven: Uitgeverij Peeters.

Vroom, Hendrik M. (Forthcoming) 'Islam's Adaptation to the West: On the Deconstruction and Reconstruction of Religion' Scottish Journal of Theology. 
11 DE ONLOSMAKELIJKE VERBONDENHEID VAN RELIGIE EN PUBLIEK DOMEIN: PLEIDOOI VOOR EEN 'OMGEKEERDE DOORBRAAK'

\author{
Erik Borgman
}

\title{
11.1 INLEIDING
}

Het seculariseringsconcept ligt met recht onder vuur, maar niet altijd om de juiste redenen. Vaak wordt gezegd dat de secularisatiethese voorspelt dat voortgaande modernisering achteruitgang van religie betekent en dat deze voorspelling niet blijkt uit te komen (vgl. Berger 1989; zie ook Thomas 2005). Maar ten eerste is het claimen van een wereldwijde tendens tot desecularisering, waarbij Europa dan een uitzondering zou vormen, dubieus (vgl. Norris en Inglehart 2004). Ten tweede is de secularisatietheorie niet zozeer een voorspellende, maar veeleer een verklarende theorie.

De secularisatietheorie verklaart kwantitatieve en kwalitatieve achteruitgang in de aanhang van religieuze instituties en religieuze opvattingen met een verwijzing naar de ingrijpende maatschappelijke en culturele veranderingen die worden aangeduid als 'modernisering'. Die centrale verandering vatte de socioloog Max Weber samen in de term 'rationalisering'. In een moderniserende cultuur gaan mensen hun wereld steeds meer zien in termen van middelen die dienen om efficiënt - rationeel-een doel te bereiken. Dat moeten zij ook doen om zich te handhaven in de moderne samenleving die zelf steeds rationeler wordt in deze zin, dat wil zeggen: gericht is op het efficiënt realiseren van doelen. Zo neemt een gerationaliseerd wereldbeeld dat denkt in termen van doelen en middelen de plaats in van het religieuze wereldbeeld, dat denkt in termen van intrinsieke waarde en betekenis.

De paradox is dat Weber de moderne rationalisering op haar beurt verklaart met een verwijzing naar religieuze tradities die de wereld presenteren als beheersbaar en het menselijk leven als een onderneming met een te realiseren doel. In het geval van het calvinistische christendom, dat naar Webers bekende these ten grondslag ligt aan de westerse moderniteit, met name ook in haar economische gestalte, was het doel van het menselijk bestaan oorspronkelijk een goddelijke redding na het aardse leven. In de moderniteit raakt het buitenwereldse doel verbonden met concrete binnenwereldse doelen die te bereiken zijn met binnenwereldse middelen: het leiden van een ascetisch bestaan draagt bij aan het vergaren van rijkdom, die eerst gold als teken van goddelijke uitverkiezing, maar vervolgens doel in zichzelf werd. Zo wordt de religieuze rationaliteit seculier letterlijk te gelde gemaakt (Weber 1904-05/1988). ${ }^{1}$

De paradox dat secularisatie vanuit de religieuze tradities te verklaren is, suggereert de belangrijkste tekortkoming van het gebruikelijke seculariseringsconcept: de politieke metafoor waarop het is gebaseerd. Secularisering verwees oorspron- 
kelijk naar de onteigening van kerkelijk eigendom en het overdragen ervan aan wereldlijke machten. Deze onteigening wordt vervolgens analoog ook op cultureel niveau waargenomen. De religie staat haar heerschappij over steeds meer terreinen van het leven af en draagt deze over aan de moderne doelrationaliteit. Webers analyse dat secularisering in de zin van moderne rationalisering plaatsvindt binnen de ruimte van een religieuze traditie (vgl. Stark 2005), suggereert dat secularisering niet zonder meer begrepen kan worden als machtsovername. ${ }^{2}$ In het seculiere blijven sporen van het religieuze aanwezig (vgl. Nancy 1998).

De centrale these van dit essay is dat de combinatie van opleving van (belangstelling voor) religie en voortgaande secularisering, zoals deze het laatste decennium wordt waargenomen - op de vraag hoe deze waarneming te begrijpen valt, kom ik later terug - laat zien dat secularisering en presentie van religie elkaar niet uitsluiten. Ten eerste kiest moderne religiositeit altijd positie ten opzichte van de moderne rationalisering en gaat ze de strijd aan over de vraag hoe deze rationalisering in religieuze termen moet worden geïnterpreteerd. Maar belangrijker nog, in de reflectie van de moderne cultuur op zichzelf zoals deze op vele niveaus plaatsvindt - van de debatten in de politieke arena en in de media tot de sociaal- en geestenwetenschappelijke onderzoeksprojecten op de universiteiten - functioneren behalve overwegingen van doelmatigheid ook religieuze en met religieuze tradities verbonden visies op wat nastrevenswaardig is in het individuele en collectieve bestaan.

Ik zal beargumenteren dat dit erom vraagt een fundamenteel andere visie op de verhouding tussen religie en publiek domein te ontwikkelen dan die in de huidige publieke discussie in Nederland gebruikelijk is. De contouren van een dergelijke visie schets ik, en de plausibiliteit ervan verdedig ik, in nauwe aansluiting bij gedachten die de Duitse filosoof Jürgen Habermas na ' $9 / 11$ ' ontwikkelde over religie en publiek domein. Vervolgens ontwikkel ik aan de hand van een concreet voorbeeld van religieuze presentie in de seculiere samenleving enige gedachten over de wijze waarop religie van belang is voor het publieke bestuur en wat dit kan betekenen voor een toekomstige onderzoeks- en debatagenda.

\subsection{DE 'TERUGKEER' VAN RELIGIE - MAX WEBER}

Dat religie onverwacht zou zijn teruggekeerd op de maatschappelijke agenda is inmiddels een cliché. Zodra echter de vraag gesteld wordt wat deze terugkeer nu precies betekent, en zelfs of er eigenlijk wel werkelijk sprake is van een dergelijke terugkeer, blijkt grote onenigheid te bestaan. Toch laat deze discussie zelf al zien dat er iets fundamenteel veranderd is in het zelfbeeld van de hedendaagse cultuur. Om deze cultuur - wereldwijd, maar ook in West-Europa en in Nederland - te begrijpen, is inzicht in en een visie op haar verhouding tot religie onontbeerlijk. Dit betekent een omslag in het sociale bewustzijn vergeleken met een decennium geleden, toen het geenszins vanzelfsprekend was dat voor een goed begrip van de actualiteit inzicht nodig was in haar relatie met religie. Voor deze omslag is uiteraard de niet te negeren presentie van de islam op het mondiale en lokale politieke toneel een belangrijke aanleiding. 
In april 2006 publiceerde de Wetenschappelijke Raad voor het Regeringsbeleid een onderzoek getiteld Dynamiek in islamitisch activisme. Het rapporteert uitvoerig over islamitische stromingen en bewegingen die volgens de gebruikelijke moderne westerse visie het religieuze en politieke niveau met elkaar vermengen. Het wijst binnen deze stromingen en bewegingen tendensen aan waarin aanzetten te vinden zouden zijn voor het vergroten van het respect voor mensenrechten en het versterken van de democratie. Het rapport lokte ongekend felle reacties uit. Velen ervan betwistten oppervlakkig gezien concrete feiten of analyses in het rapport, maar stelden eigenlijk de vraag aan de orde welke houding onze samenleving moet innemen ten opzichte van individuen en groepen met een religieuze visie op de verhouding tussen de rechten van het individu en de gemeenschap en op de mate van zeggenschap van mensen over hun eigen leven. Moeten deze wel genuanceerd bestudeerd worden? Moeten ze niet veeleer worden afgewezen en bestreden?

Het rapport Dynamiek en islamitisch activisme bespreekt de vraag met welke houding een politiek doel waarover maatschappelijk grote eensgezindheid bestaat - het respecteren van democratie en mensenrechten - het best bevorderd kan worden. Dominante stemmen in de publieke discussie suggereerden dat het serieus overwegen van samenwerking met organisaties die zich voor, volgens hen, radicale politieke standpunten beroepen op de islam - of in sommige gevallen: samenwerking met groepen die zich voor welk politiek standpunt dan ook beroepen op een religie - in zichzelf al immoreel zou zijn. Zoals vaker sinds de opkomst van Fortuyn, komen ook hier achter de schijnbaar pragmatische discussies die in de Nederlandse politieke arena de toon zetten, fundamentele vragen tevoorschijn naar onze identiteit en naar onze verhouding tot anderen met een andere achtergrond en een ander zelfbegrip.

De vragen wie wij zijn en willen zijn, individueel en collectief, en welke verhouding tot anderen dit impliceert, zijn religieuze vragen. In ieder geval in de ogen van Max Weber, voor wie de rationele afweging van waarden en overtuigingen waarop de antwoorden op deze vragen gebaseerd zijn, onmogelijk is. In zijn ogen zijn "de verschillende waardesystemen van de wereld" uiteindelijk verwikkeld "in een onoplosbare onderlinge strijd", zoals verschillende vormen van geloof die elkaar wederzijds uitsluiten. In het spoor van John Stuart Mill (1869/1969:431) meende Weber dat uitsluitend van de ervaring uitgaan tot polytheïsme zou leiden: een veelheid van te respecteren visies en waardesystemen die naast en tegenover elkaar staan en zich niet met elkaar laten verbinden, maar wier belang zich ook niet argumentatief tegen elkaar laat afwegen (Weber 1919/1988). Rationeel valt volgens Weber alleen uit te maken of, als men een bepaalde waarde als doel nastreeft, deze waarde met de aangewende middelen inderdaad bereikt wordt.

Weber ziet heel goed in dat deze identificatie van rationaliteit met doelrationaliteit typisch modern is. De dominantie van doelrationaliteit onderscheidt volgens hem de door de kapitalistische economie gedomineerde moderne cultuur van voorafgaande culturen. Maar er is geen mogelijkheid om hier buiten te gaan 
staan, zelfs niet als het denken in termen van doelen en middelen op den duur tot een crisis leidt, hetgeen volgens Weber het geval is. Als alles uiteindelijk zal worden beleefd als middel en niet meer als doel in zichzelf en intrinsiek van waarde, ontstaat volgens Weber de ervaring te leven in een door bureaucratische mechanismen geleide, doodse maatschappij als in een "ijzeren kooi" ("stahlhartes Gehäuse") waaruit niet te ontsnappen valt. Alleen nog een vlucht in de irrationaliteit van bijvoorbeeld de sport biedt hieruit een schijnbare verlossing. Hieraan voegt Weber onmiddellijk toe dat de vraag of dit goed of slecht is, ons in "het gebied van waarde- en geloofsoordelen" brengt (Weber 1904-05/1988).

De confrontatie van dergelijke oordelen, die niet op rationele gronden tegen elkaar kunnen worden afgewogen, vindt volgens Weber plaats in de politieke arena (Weber 1904/1988: 149-151). Nu dacht Weber dat het belang van waardeen geloofsoordelen in een kapitalistische economie steeds kleiner zou worden. Hij meende dat de economische organisatie van de kapitalistische samenleving in zijn tijd al in belangrijke mate de sturingsfunctie had overgenomen die eerder toekwam aan een wereldbeeld, een cultureel zelfbeeld, een maatschappelijk ideaal of een religie. Hij verwachtte dat deze tendens zich verder zou voortzetten.

De heftige recente discussies en confrontaties over religie en identiteit, over de vraag waar de grens ligt van de tolerantie in onze samenleving voor afwijkende visies en afwijkende gedragingen en hoe wij onszelf als samenleving zien, maakt duidelijk dat wat Weber 'waarde- en geloofsoordelen' noemt, in onze laatkapitalistische en laatmoderne samenleving wel degelijk van belang is (vgl. Joas 1997). Verschijnselen zoals het hernieuwde belang van de rol van religies op het wereldtoneel, zowel in het concrete leven van mensen als in de politieke discussies, het verlangen van mensen en collectieven naar oriëntatie en perspectief dat hieruit spreekt, de geïndividualiseerde belangstelling voor spiritualiteit en religieus erfgoed in het Westen, lijken in ieder geval hierop te wijzen.

De snelle, ingrijpende en voortdurende maatschappelijke en culturele veranderingen die onze samenleving eigen zijn, roepen vragen op die in deze brede zin religieus genoemd kunnen worden. Dit maakt zichtbaar dat dergelijke religieuze vragen van essentieel belang zijn in de publieke discussie over maatschappelijke en politieke kwesties. Het maakt het bovendien hoogst urgent manieren te vinden om te doen wat volgens Weber onmogelijk was: rationeel discussiëren over waarde- en geloofsoordelen.

\subsection{DE 'TERUGKEER' VAN RELIGIE AAN HET EINDE VAN DE NEGENTIENDE EEUW}

Het inzicht dat 'waarde- en geloofsoordelen' en politieke vormgeving van de samenleving, dat op deze wijze religie en politiek onlosmakelijk met elkaar verbonden zijn, sluit beter aan bij de Nederlandse geschiedenis dan vaak gedacht wordt. De verhouding tussen religie en de Nederlandse samenleving 
wordt doorgaans vooral gezien in termen die ontleend zijn aan de situatie van verzuiling. Van deze verzuiling beleven wij sinds de jaren zeventig van de vorige eeuw, en versterkt door de opkomst van de geïndividualiseerde en gemondialiseerde samenleving vanaf de jaren negentig, de nadagen. Dit leek het einde te betekenen van religie en levensbeschouwing als bepalende factor in de Nederlandse samenleving en de Nederlandse politiek, tot de recente opkomst van de islam.

Meer echter dan de situatie van de verzuiling kan het proces dat in de tweede helft van de negentiende eeuw tot de verzuilde Nederlandse samenleving zou leiden, en waarin religieuze en andere levensbeschouwelijke stromingen en hun aanhangers toegang zochten tot de moderne samenleving, de moderne publieke discussie en de moderne politiek, de situatie verhelderen waarin wij nu verkeren. Hierbij doel ik nu niet op de parallellen en analogieën tussen de hedendaagse strijd om de maatschappelijke en culturele plaats van de islam en de negentiendeeeuwse strijd rond de plaats van katholieken (zie Magry 200o). Deze zijn inderdaad opmerkelijk en de nadere studie ervan kan bijdragen aan het heilzame inzicht dat het bij integratie mede gaat om het symbolische niveau en het recht herkenbaar present te zijn in de gemeenschappelijke publieke ruimte (vgl. Salemink 2005a; 2005b). Ik richt mij hier met name op de wijze waarop religieuze en levensbeschouwelijke overtuigingen mede de vormgeving van Nederland bepaalden, in een periode waarin net als nu sterke behoefte was aan maatschappelijke en politieke vernieuwing.

In de laatste decennia van de negentiende eeuw zag men in brede kring dat het van belang was een einde te maken aan de burgerlijke gezapigheid van de periode ervoor. Abraham Kuyper en Herman Schaepman legden in naam van respectievelijk gereformeerden en katholieken een organisatiedrift aan de dag die Nederland op een radicaal nieuwe manier vorm zou geven. De nieuwe religieuze dynamiek van die dagen was tevens een nieuwe maatschappelijke dynamiek. Dit werd ingezien door de vrijzinnig-liberale beweging 'Jong Amsterdam'. De aanhangers hiervan namen eind jaren tachtig naar eigen zeggen afstand van hun 'ouders en grootouders', die

"gewoon [waren] de baas te spelen. (...) Zij zaten de Roomschen en de orthodoxe Gereformeerden op hun kop. Nu is dat anders geworden. Die lieden zijn uit hun ogen gaan kijken, zij zijn gaan belangstellen in de openbare zaak (...).” (Hack van Outheusden 1888: 107-114)

De vertegenwoordiger van 'Jong Amsterdam' die hier onder pseudoniem aan het woord is, de latere sociaal-democratische voorman Frank van der Goes (18591939), zag in 1888 in dat het bij de nieuwe maatschappelijke en politieke organisaties van katholieken en gereformeerden niet alleen ging om een emancipatiestrijd van bepaalde bevolkingsgroepen. Het ging om een nieuwe vormgeving van Nederland. De confessionelen voelden goed aan waar de religieuze en spirituele strijd in de eigen tijd werd gevoerd: 
"Dat zooveel kerkelijke stervelingen thans in de eerste plaats staatkundige aspiraties hebben, dat zij mérken hoe zij in de gewone samenleving door de ongeloovigen worden beetgenomen, dat zij zich daartegen verzetten, is een echt modern verschijnsel. (...) De Heeren Kuyper en Schaepman weten heel wel dat zij te goed zijn voor den preekstoel. De Kamer, de couranten, de kiesverenigingen, dat zijn de kerken, of als men liever wil, de kapelletjes van onzen tijd." (Hack van Outheusden 1888: 465-466)

Maar het omgekeerde geldt evenzeer. Schaepman en Kuyper vonden niet alleen onder nieuwe omstandigheden opnieuw de religie uit op een wijze die haar midden in de tijd present stelde, maar zij vonden tegelijkertijd opnieuw de politiek uit. Wie op een adequate manier politiek wil bedrijven, moet kranten en politieke bijeenkomsten beleven als kerken en kapellen in deze zin, als plaatsen waar in relatie met de actuele wereld de mens een collectieve vorm krijgt en zich een identiteit verwerft. Wie zo politiek wil bedrijven, die kan naar de overtuiging van Van der Goes van de confessionelen leren.

Voor Van der Goes was de vrije discussie fundamenteel voor de waarachtig democratische samenleving die hij nastreefde. Hij zag in dat deze vrije discussie bevorderd werd doordat de confessionelen zich een toegang forceerden tot het publieke debat. Zij plaatsten belangrijke nieuwe zaken, zoals de 'sociale quaestie', op de maatschappelijke agenda (vgl. Kuyper 1891). Hij liet er geen misverstand over bestaan dat hij "hunne wereldbeschouwing even onrechtvaardig als verouderd" achtte, maar verkoos "de oprechtheid van hunne leer (...) boven de georganiseerde huichelarij van de liberalen" (Hack van Outheusden 1889a: 285). Op basis van een marxistische analyse van de belangentegenstellingen zag Van der Goes bovendien mogelijkheden tot een nieuwe, ten aanzien van het heersende liberalisme hervormingsgezinde volkspartij waarvan ook katholieken en kuyperianen deel zouden kunnen gaan uitmaken (Hack van Outheusden 1889b: 286299). Dit was duidelijk een ontwikkeling waarop hij ook hoopte.

Opmerkelijk in de positie van Van der Goes is vooral de scherpe wijze waarop hij de maatschappelijke en culturele dynamiek waarnam in de nieuwe politieke manifestaties van religieuze groepen. Zijn opstelling van ruim een eeuw geleden suggereert dat afkeer van concrete religieuze standpunten, of zelfs van religieuze tegenstellingen in het algemeen, niet het zicht mag belemmeren op het feit dat zij een uitdrukking zijn van de situatie in de samenleving en een vormgeving van de strijd die erin gevoerd wordt tussen verschillende posities en visies. Als groepen ruimte opeisen voor hun religie en haar uitingsvormen, dan is het van belang te zien dat zij klaarblijkelijk toegang wensen tot de samenleving waarin zij leven maar waarvan zij zich uitgesloten voelen. $\mathrm{Zij}$ zijn eropuit wel ingesloten te worden en laten dat blijken door te proberen de samenleving vanuit hun visie te hervormen. Tegenover de dominante blik die overal onoverbrugbare kloven ziet opdoemen, lijkt het van belang eens op deze wijze tegen de huidige verhoudingen met en onder moslims te kijken. 
Dan zouden de lopende debatten over bijvoorbeeld de verhouding tussen islam en moderniteit verschijnen als onderdeel van het nader vormgeven van de moderniteit en van het nader vormgeven van de islam. Moslims die naar mogelijkheden zoeken om publiek uitdrukking te geven aan hun religie, staan niet buiten de samenleving en de maatschappelijke vraag is niet of ze kunnen of moeten worden toegelaten. Ze zijn onderdeel van de huidige Nederlandse samenleving, zoals Van der Goes de liberalen ervan probeerde te overtuigen dat de katholieken die zich onder leiding van Schaepman publiek manifesteerden en de gereformeerden dat onder leiding van Kuyper deden, niet alleen bestreden of genegeerd konden worden. Zij waren, en de huidige moslims zijn de uitdrukking van de onvermijdelijke dynamiek van onderlinge positionering en het strijden om de machts- en krachtsverhoudingen die de moderne samenleving is (vgl. Borgman 2006: 113-128). Over de beste vormgeving van deze samenleving moet publiek gedebatteerd worden en dit publieke debat is de wijze waarop een democratische samenleving de maatschappelijke dynamiek nader vorm geeft (vgl. Van Gunsteren 2004, in de lijn van Habermas 1992).

Dit impliceert dat moslims in het gesprek over de toekomst van de samenleving betrokken moeten zijn en dat - in bredere zin - het publieke domein intrinsiek met religie verbonden is en zich daarvan niet kan afsluiten. Religie maakt deel uit van het leven van burgers van de samenleving en is één van de wijzen waarop burgers hun maatschappelijke aspiraties, visies en idealen uitdrukken. Omgang met dit gegeven is een maatschappelijke en politieke kwestie van het grootste belang (Gauchet 1998). Zij kan niet worden tenietgedaan door bezweringsformules over de scheiding tussen kerk en staat en de noodzaak van religieuze neutraliteit voor de publieke ruimte. Zij vraagt om fundamentele doordenking.

\subsection{RELIGIE IN HET PUBLIEK DOMEIN - JÜRGEN HABERMAS}

“Op 11 september is de spanning tussen seculiere samenleving en religie (...) geëxplodeerd", zei de Duitse filosoof en publieke intellectueel Jürgen Habermas op 14 oktober 2001. Habermas heeft altijd het seculiere karakter van het publieke domein benadrukt. In 1962 stelde hij in een nog altijd invloedrijk werk dat in de moderne samenleving een beroep op religie in de publieke discussie betekenisloos geworden is. Het gaat er volgens de in dit boek ingenomen positie in de moderniteit niet langer om aan te tonen dat men het goede leven realiseert volgens een statisch normatief model, zoals religieuze tradities dit voorhouden. In plaats hiervan gaat het om de voortdurende bereidheid verantwoording af te leggen van ingenomen standpunten, uitgedragen visies en vormgegeven praktijken, en om de bereidheid deze indien nodig op basis van nieuwe feiten of argumenten te herzien (Habermas 1962).

Op 14 oktober 2001 nam Habermas de in dat jaar aan hem toegekende vredesprijs van de Duitse boekhandel in ontvangst. De "deprimerende actualiteit van de dag" had hem naar zijn besef de keuze van het thema voor zijn lezing bij deze gelegenheid uit handen geslagen, maar hij wilde naar eigen zeggen ook niet toegeven aan 
de verleiding om met "de John Waynes onder de intellectuelen" te wedijveren om het snelste schot vanuit de heup (Habermas 2001: cit. 9). Het getuigt inderdaad van opmerkelijke bezonnenheid dat hij er iets meer dan een maand na 11 september een lans voor brak dat westerse publieke intellectuelen zich opnieuw zouden buigen over de verhouding tussen religie en publiek domein, tussen geloof en weten. De overwegingen die Habermas hierover naar voren heeft gebracht, zowel in deze rede als daarna, zijn van groot belang, maar hebben in de Nederlandse discussie tot nu toe nauwelijks invloed gehad. Dit is opmerkelijk, gezien de populariteit waarin Habermas zich in de jaren tachtig onder Nederlandse intellectuelen mocht verheugen. Juist Habermas, die zich steeds verzet heeft tegen de door Weber geformuleerde en in het hedendaagse bewustzijn sterk levende gedachte dat over 'waarde- en geloofsoordelen' niet redelijk te discussiëren valt (vgl. o.a. Habermas 1981: 205-366), kan helpen om redelijk met de nieuwe presentie van dergelijke oordelen in de publieke discussie om te gaan.

In zijn vredesprijsrede van oktober 2001 stelt Habermas onder de titel 'Geloven en weten' met - gezien het geweld waarmee het gepaard ging - opmerkelijke nuchterheid vast dat op 11 september gebleken is dat er krachtige religieuze gemeenschappen zijn te midden van de geseculariseerde en zich nog steeds verder seculariserende moderniteit. Wij moeten ons er volgens hem op instellen dat dit in ieder geval voorlopig zo zal blijven. Habermas spreekt hierbij van een 'postseculiere' samenleving en dit zou kunnen suggereren dat er na 11 september sprake is van een nieuw tijdperk. ${ }^{3}$ Met deze term lijkt hij echter vooral een nieuwe fase in de moderniteit als project af te kondigen. In deze nieuwe fase wordt in Habermas' voorstelling de specifiek moderne secularisering voortgezet, maar onder nieuwe omstandigheden en daarom met nieuwe middelen. Moderne secularisering betekent in Habermas' visie met name het ontstaan van de openbare mening als eigen, autonome sfeer waarin de samenleving over zichzelf tegenover zichzelf verantwoording aflegt. Niet meer een normatieve visie vanuit een traditie is de norm voor wat waar en goed is, maar dat wat Habermas in het spoor van John Rawls het 'verlichte gezond verstand' noemt, is de beoordelingsinstantie van alle autoriteits- en waarheidsclaims, of deze nu komen van de wetenschap, de overheid of de religie (Habermas 2001: 13-14).

Habermas' inzet is dit 'verlichte gezonde verstand' in de publieke sfeer zijn werk te laten doen in een situatie waarin religieuze tradities een hernieuwde politieke en maatschappelijke betekenis voor zichzelf opeisen. Hiertoe is het volgens hem nodig datgene wat deze tradities te zeggen hebben zo te vertalen dat het voor dit 'verlichte gezonde verstand' begrijpelijk en beoordeelbaar is. Habermas is van mening dat wij "voorbij het zwijgende geweld van zowel het terrorisme als de raketten (van de Amerikaanse bestrijding van het terrorisme, EB), een gezamenlijke taal moeten ontwikkelen” (Habermas 2001: 11; vgl. Goode 2005; Johnson 2006).

In maart 2005 hield Habermas een lezing aan de University of San Diego in Californië. In de eerst op internet gepubliceerde en later in een iets uitgebreide Duitse gedrukte tekst hiervan wordt duidelijk hoezeer Habermas' nieuwe be- 
langstelling voor religie samenhangt met zijn visie op democratie (Habermas 2005a; 2005b). Democratie is voor hem de politieke vormgeving bij uitstek van de moderniteit, van het verlichte principe dat beslissingen niet op grond van autoriteit tot stand moeten komen, maar op grond van publieke beraadslaging en gereguleerde besluitvorming.

Op basis hiervan keert Habermas zich tegen de invloedrijke idee van John Rawls dat religieuze argumenten niet in de publieke sfeer thuishoren (Rawls 1971). Deze idee schendt volgens hem het democratische gelijkheidsbeginsel. Het belast religieuze mensen zwaarder dan seculiere door hun vrijheid om hun meningen en visies in de openbare discussies in te brengen, aan voorwaarden te binden. Bij religieuze mensen zijn religieuze en politiek-maatschappelijke overtuigingen innig met elkaar verweven en niet zomaar van elkaar te scheiden, en het verbod om religieuze argumenten in de publieke discussie in te brengen verplicht ze op z'n best tot ingewikkelde vertaaloperaties en legt ze op z'n slechtst censuur op (Habermas 2005b: 133-134; vgl. ook Audi en Wolterstorff 1997: 105). Habermas onderscheidt daarom tussen de politiek in strikte zin, die naar zijn overtuiging inderdaad levensbeschouwelijk neutraal moet zijn, en de publieke sfeer in wijdere zin. In deze laatste kunnen levensbeschouwelijk c.q. religieus geladen overwegingen een rol spelen, mits ze naar voren worden gebracht in het volle bewustzijn van het pluralisme dat in de discussies heerst. Degenen die religieuze standpunten naar voren brengen, moeten in staat zijn ook vanuit een buitenperspectief naar hun eigen positie te kunnen kijken en een verbinding te leggen tussen hun visies op maatschappelijke kwesties en seculiere opvattingen (Habermas 2005b: 136).

Habermas ontwikkelt een zeer omvattende en normatieve visie op democratie. Iedereen moet zijn eigen standpunten en opvattingen ongehinderd naar voren kunnen brengen. Tegelijkertijd wordt zij of hij er door het democratische gesprek zelf toe verplicht dit zo te doen dat in de verantwoording ervan niet alleen de eigen groep maar de samenleving als geheel wordt aangesproken. Habermas' visie lijkt in eerste instantie een politiek-filosofische pendant van de uitspraak in het beginselprogramma van de Sozialdemokratische Partei Deutschlands uit 1989, waarin het expliciet wordt toegejuicht "wanneer kerken en religieuze gemeenschappen, kerkelijke groepen en individuele gelovigen invloed uitoefenen door middel van kritiek, stimulans en praktische medewerking en zich daarmee ook openstellen voor openbare kritiek" (geciteerd in Thierse 200o).

Maar Habermas' visie op de democratie voert hem aanzienlijk verder, misschien zelfs verder dan hij zelf helemaal doorziet. Volgens hem - en dat is het pièce de résistance - behoort het tot de normatieve vooronderstellingen van de democratie dat burgers elkaar dienen te bejegenen als redelijke personen die in staat zijn zichzelf voor hun visies en hun daden te verantwoorden en de verantwoordingen van anderen te beoordelen. Alleen dan kan de publieke sfeer werkelijk gezien worden als discussieveld en niet slechts als een strijdperk waarin gestreden wordt om de macht van de meerderheid. 
Dit impliceert voor Habermas dat wanneer een substantieel deel van de burgers van een samenleving religieus is, seculiere burgers religieuze overtuigingen niet a priori kunnen zien als "archaïsche relicten die vanuit voor-moderne samenlevingen tot in het heden voortbestaan"; in dat geval zien zij de vrijheid van godsdienst niet als een grondrecht, maar hanteren haar als vorm van "culturele natuurbescherming voor uitstervende soorten". Waarachtige democratische discussie vereist niet alleen dat religieuze mensen wordt toegestaan hun visie in het publiek domein naar voren te brengen, maar dat bovendien niet wordt uitgesloten dat hetgeen zij naar voren brengen waardevolle, belangwekkende en ware inzichten bevat. "Hiervan gaan religieuze burgers zonder meer uit, maar van seculiere burgers veronderstelt het een mentaliteit die allesbehalve vanzelfsprekend is", constateert Habermas met gevoel voor understatement (Habermas 2005b: 145).

Op 19 januari 2004 voerde Habermas in München een discussie met Joseph Ratzinger, toen nog kardinaal en hoofd van de Congregatie voor de Geloofsleer van de Rooms-Katholieke Kerk en inmiddels paus Benedictus XVI (Habermas 2005c). Bij deze gelegenheid verzette Habermas zich sterk tegen de stelling, veelvuldig door religieuze mensen betrokken, dat het democratische proces een inhoudelijke aanvulling nodig heeft. In zichzelf genomen zou democratie in deze visie een lege procedure zijn om discussies te voeren en te beslechten. Niet alleen de opvattingen waarover beslissingen genomen moeten worden, komen volgens deze gedachtegang van elders, maar eveneens de waarden die de afweging tussen dergelijke opvattingen mogelijk maken. Vertegenwoordigers van religieuze tradities neigen ertoe - en Ratzinger doet dat op zijn manier ook (vgl. Ratzinger 2005) - te claimen dat alleen hun tradities in deze waarden kunnen voorzien.

Hiertegenover stelt Habermas met klem dat de samenleving bij elkaar wordt gehouden door het democratische proces zelf. De maatschappelijke samenhang kan niet worden geponeerd - niet seculier, door wat in de Nederlandse discussie verlichtingsfundamentalisme is gaan heten, en niet religieus, door vertegenwoordigers van één religieuze traditie -, maar ligt in het gemeenschappelijke communicatieve en discursieve proces waarin de publieke opinie zichzelf vormgeeft (Habermas 2005c: 24).

Hier komt een paradox aan het licht die raakt aan paradoxen uit de mystiek. In de op Augustinus gebaseerde christelijke mystiek van het Westen is het zelf dat wij zoeken in de vraag wie wij zijn, niet een of andere substantiële kern die diep in het innerlijk verborgen is, maar het zelf dat zoekt. In het gegeven dat wij op deze manier voortdurend aan onszelf onttrokken zijn, zijn wij beeld van God die naar christelijke overtuiging in de werkelijkheid present is als aan deze werkelijkheid transcendent en zich steeds onttrekkend aan pogingen om hem te vatten en vast te leggen (vgl. Turner 1995 en ter achtergrond met name boek X van Augustinus' Belijdenissen). In Habermas' visie op de democratische publieke discussie ligt de gemeenschappelijke grondslag die ons als samenleving bij elkaar houdt niet in een substantieel corpus van bijvoorbeeld typisch Nederlandse, typisch westerse 
of joods-christelijke waarden en normen, maar in het gemeenschappelijk zoeken naar de grondslag die ons bindt. Deze grondslag is present, maar alleen als dat wat gezocht wordt en nooit zonder meer wordt gevat.

Zo bezien hoort niet alleen de presentie van religieuze posities in het publieke domein wezenlijk tot de democratie, maar heeft de democratie zelf een religieus aspect. Het gaat er niet zozeer om dat het publieke debat gevoed wordt door opvattingen die vanuit religieuze tradities komen, en het gaat er ook niet zozeer om dat de democratie zelf gebaseerd is op waarden die verbonden zijn met religieuze tradities. Het gaat erom dat de democratie in zichzelf toewijding impliceert aan een waarheid en een gemeenschappelijk goed dat niet zonder meer gegeven is, maar slechts toegankelijk is in het gemeenschappelijk zoeken ernaar en het onderlinge debat erover (vgl. Borgman 2006: 146-163).

\subsection{HET MAATSCHAPPELIJKE BELANG VAN 'WAARDE- EN GELOOFSOORDELEN'}

Zo ver gaat Habermas niet. Voor hemzelf is zijn omvattende opvatting van democratie de uiteindelijke grondslag voor de stelling dat religieuze standpunten thuishoren in het democratische publieke debat. Het democratische proces is in zijn visie uiteindelijk de argumentatieve confrontatie van allen met de opvattingen van allen. In dat proces van confrontatie en discussie komt de samenleving tot stand en bindt zij haar burgers. Opvattingen die de bestaande consensus onder druk zetten moeten niet alleen getolereerd worden om de aanhangers van deze opvattingen in de samenleving te integreren, maar hun inbreng is fundamenteel voor de voortgang van de democratische discussie zelf.

Voor Habermas is het van beslissend belang dat blijft gebeuren wat in het verleden de westerse cultuur beslissend heeft gevormd. In de westerse geschiedenis zijn door religieuze tradities getekende concepten - in het verleden ging het hierbij uiteraard met name om door het christendom getekende concepten - steeds opnieuw seculier vertaald. De christelijke visie op de mens als beeld van God is mede bron van de basisovertuiging van de westerse cultuur dat ieder mens onvervreemdbaar van waarde is en het christelijke gebod tot naastenliefde droeg fundamenteel bij aan de overtuiging dat samenlevingen de plicht hebben voor hun armen en zieken te zorgen. Dit proces moet volgens Habermas onder de huidige, nieuwe omstandigheden voortgaan. Religieuze concepten moeten zo worden vertaald dat zij in het seculiere maatschappelijk debat betekenis hebben en in het publieke debat worden ingebracht. Dit is fundamenteel voor de voortgang van het moderne project als voortgaande publieke zelfverantwoording van de samenleving tegenover zichzelf. Dit maakt deze vertaalarbeid in Habermas' visie niet alleen een opdracht voor religieuze, maar eveneens voor seculiere intellectuelen (Habermas 2001: 22; 2005b: 136-138).

Als Habermas concreet aangeeft wat in zijn ogen het tegoed van religie is dat zou moeten worden ingebracht in de publieke discussie, zijn zijn voorbeelden tame- 
lijk klassiek. Ook voor Habermas komt religie vooral in beeld wanneer er morele grenzen gesteld moeten worden aan menselijk handelen en wanneer er verzoening nodig is van mensen met hun lot. In de vredesprijsrede uit 2001 snijdt hij de kwestie aan van de verhouding van God als schepper en de mens als schepsel. Het belang dat Habermas aan deze verhouding hecht, hangt samen met zijn visie op gentechnologie. ${ }^{4}$ Schepping door God, zegt Habermas in een korte reflectie op een passage uit Hegels godsdienstfilosofie, is een manier van voortbrengen die het geschapene niet instrumenteel vastlegt, maar die het vrijheid schenkt. Tegelijk ordent de schepping door God deze vrijheid met behulp van een interne gerichtheid op het goede. Wanneer daartegenover niet God, maar een mens via technische manipulatie van het genetisch materiaal de constitutie van een ander mens bepaalt, wordt in Habermas' ogen deze wel degelijk vastgelegd en wordt de vrijheid vernietigd die mensen ten opzichte van elkaar toekomt (Habermas 2001: 29-31; vgl. Hegel 1829/1969: 92-96). Met al Habermas' kritiek op instrumenteel gebruik, zet hij hier het tegoed van religie tamelijk instrumenteel in ten dienste van het door hem gewenste moratorium met betrekking tot gentechnologie.

Een tweede met religie verbonden themaveld dat Habermas in de huidige fase van de ontwikkeling van de moderniteit belangrijk acht, is de omgang met schuld en tekort. De grote catastrofes van de geschiedenis - Habermas noemt hier met name de holocaust - laten zien dat geen vooruitgang het exces aan menselijk lijden goed kan maken. Als het moderne project betekent dat mensen de wereld moeten vermenselijken, impliceert dit tegelijkertijd dat wij mensen elkaar meer verschuldigd zijn dan wij feitelijk geven en kunnen geven (Habermas 2001: 2425). Hiermee komt Habermas toch dicht in de buurt van een visie op het moderne, democratische project als in zichzelf religieus. Hij suggereert niet alleen een onverwachte actualiteit voor de grote christelijke thema's van lijden en verlossing, schuld en verzoening, en van een genade die de geschiedenis door alle catastrofes heen draagt en omvat, en van verwante thema's uit andere religieuze tradities. Hij suggereert bovendien dat de vraag of het lukt de religieuze omgang met deze thema's te vertalen naar het seculiere, democratische publieke bewustzijn, cruciaal is met het oog op de voortgang van het moderne project zelf.

Deze voortgang wordt immers bedreigd door enerzijds het besef dat het mensen voor onmogelijke opgaven stelt en daarom niet werkelijk verplichtend kan zijn. Mensen kunnen naar algemeen hedendaags inzicht alleen gehouden zijn tot het mogelijke; veel politieke discussies gaan daarom niet over de vraag wat wenselijk of moreel verplichtend zou zijn, maar wat economisch en sociaal mogelijk is. Religieuze tradities presenteren hiertegenover het onmogelijke als niettemin reële en verplichtende horizon voor actueel handelen. ${ }^{5} \mathrm{Zij}$ hebben tegelijkertijd vormen gevonden zich te verzoenen met het voortdurende tekortschieten dat dit impliceert. Dit is in verband met de voortgang van de moderniteit ook van belang, want die wordt anderzijds bedreigd door het inzicht dat zij haar grootse belofte van een menselijke wereld niet inlost en daarom veeleer dient te worden aangevallen dan te worden voortgezet. De terroristische aanslagen van 11 september 2001 en daarna kunnen worden gezien als een aanklacht dat de moderniteit 
haar vergaande pretenties om vrede en geluk voor allen te realiseren, niet waarmaakt. Van hieruit wordt ze dan gezien als uitdrukking van menselijke hubris en als vorm van afgodendienst. Om het terrorisme de wind uit de zeilen te nemen, moet het publieke debat daarom de omgang met het onvermijdelijke tekort van de moderniteit expliciet tot onderdeel maken van het moderne project zelf. Alleen dan is uiteindelijk acceptatie van het verplichtend karakter ervan mogelijk.

Men kan Habermas verwijten dat hij een typisch filosofische visie op religie heeft. Religie is voor hem slechts van belang voor zover zij bijdraagt aan het project van de moderniteit. Zij komt hierbij bovendien alleen in beeld als leverancier van aan de filosofie verwante theorieën en verschijnt zo als een soort proto-filosofie of -theologie. Dat religie bijvoorbeeld ook persoonlijke en collectieve identiteit geeft en via rituelen voor haar aanhangers een plaats schept in de wereld om thuis te zijn, speelt in zijn reflecties nauwelijks een rol. Niettemin lijkt zijn signalering van de urgentie van de vraag naar de omgang met het falen en het tekort aan te sluiten bij een belangrijke ontwikkeling in het hedendaagse religieuze bewustzijn. Er lijkt een duidelijk verband tussen vormen van hedendaagse belangstelling voor religie en spiritualiteit en het gevoel van mensen overvraagd te worden als zij, zoals de huidige cultuur hun laat weten, zelf hun leven goed en gelukkig moeten maken. Zij verlangen naar veiligheid en geborgenheid, naar betrokkenheid.

Soms uit zich dit verlangen in mentale terugtrekking uit de wereld, het zoeken van veiligheid in de eigen binnenruimte en het cultiveren van een sterk 'zelf' (vgl. Van Harskamp 2000; Borgman en Van Harskamp 2003). Soms uit het zich in de projectie van messiaanse kwaliteiten op politici - men denke aan de geschiedenis met Pim Fortuyn - of andere publieke figuren. Soms uit het zich in stille tochten of massale uitingen van medeleven met slachtoffers van een misdaad of van wat in de publieke opinie gezien wordt als nalatigheid van de overheid (vgl. Borgman 2006: 97-112). De laatmoderne actualiteit levert in haar combinatie van individualisering en mondialisering voor velen existentieel vooral onveiligheid, angst en onzekerheid op (Beck 1986). Mensen lijden gevoelige verliezen met betrekking tot het overzicht en de controle over hun eigen leven, maar worden wel steeds meer verantwoordelijk gehouden voor hetgeen zij van hun leven weten te maken (Sennet 1998). In nieuwe en oude vormen van religieus gedrag manifesteert zich hun verlangen naar leefbare en zorgzame verhoudingen, ook op maatschappelijk, politiek en bestuurlijk gebied. Zij verlangen naar een samenleving waarin ze gezien worden in wat zij kunnen maar die ook compassie heeft met wat zij niet kunnen.

Overheden en bestuurders klagen dat burgers zich gedragen als onverantwoordelijke consumenten die in hun handelen slechts hun individuele belang voor ogen hebben. Zij willen meer onderlinge verbondenheid en solidariteit van burgers. Van hun kant verlangen burgers naar meer verbondenheid, geborgenheid en saamhorigheid in de samenleving, waarbij ze de overheid veelal eerder als een verstoorder dan een facilitator ervaren. Veel van dit verlangen uit zich in religieuze of quasi-religieuze vormen, in 'waarde- en geloofsoordelen' die hetzij verbaal, hetzij praktisch handelend worden uitgedrukt. Aangezien een democra- 
tische samenleving door haar burgers zelf wordt opgebouwd en bestuurd, zich al discussiërend over de visies die in haar leven een beeld vormend van wat zij is en wil zijn, is het in de lijn van Habermas zaak deze 'waarde- en geloofsoordelen' zodanig te vertalen dat zij ook in de publieke discussie een rol kunnen spelen.

Op deze manier worden enerzijds burgers die er deze 'waarde- en geloofsoordelen' op na houden met behulp van de discussie over deze oordelen gebonden aan de samenleving. Anderzijds wordt tegelijkertijd het publieke debat gevoed met hun inzichten in wat waar en goed is, en wat daarom te doen valt. Opnieuw gedacht in de lijn van Habermas ligt de verantwoordelijkheid voor deze vertaaloperatie niet alleen bij de aanhangers van deze 'waarde- en geloofsoordelen', maar evenzeer bij intellectuelen en onderzoekers met een speciale verantwoordelijkheid voor het publieke domein en de publieke discussie: van academici via journalisten en studiesecretarissen van vormingscentra en debatfora, tot beleidsambtenaren in uiteenlopende maatschappelijke sectoren. En natuurlijk van bestuurders en politici zelf.

Op deze wijze aansluiten bij Habermas, impliceert tegelijkertijd in twee opzichten een breuk met diens opvattingen. Ten eerste wordt op deze manier de grens tussen het publieke debat en de interne religieuze bezinning uitermate vloeiend, veel vloeiender dan Habermas verdisconteert. De vraag wat een religieuze traditie in de actuele context betekent en wat seculiere verhoudingen voor een religieuze traditie betekenen, zijn niet langer vragen die alleen voor aanhangers van de traditie van belang zijn. Ze zijn onderdeel van de voortdurende discussie die de moderne democratische samenleving voert over zichzelf en haar toekomst. Natuurlijk blijven enerzijds de gelovigen verantwoordelijk voor de vormgeving van hun eigen gemeenschappen en dienen deze gemeenschappen gevrijwaard te blijven van directe inmenging van de overheid. Natuurlijk dient anderzijds de publieke sfeer gevrijwaard te blijven van overheersing door één religieuze of levensbeschouwelijke traditie. Deze dubbele vrijwaarding is de oorspronkelijke betekenis van het zoveel besproken, maar vaak verkeerd begrepen principe van scheiding tussen kerk en staat.

Van belang is echter dat de gemeenschap die gelovigen vormgeven erop gericht is vanuit een specifieke positie en een verbondenheid met een specifieke traditie, bij te dragen aan de publieke discussie. De publieke sfeer die de overheid vormgeeft kan alleen functioneren als zij burgers en hun organisaties, inclusief hun religieuze organisaties, stimuleert en verlokt tot het leveren van een bijdrage aan een dergelijk debat. Hierdoor wordt de verhouding van religie tot de publieke sfeer een dynamische. Noch wat religie is en doet, noch wat de eigenheid is van de publieke sfeer staat tevoren vast. Het is zelf mede inzet van voortdurend debat en doorlopende onderhandeling.

Ten tweede verdwijnt op deze manier de plausibiliteit van Habermas' feitelijke beperking tot de inbreng van grote, eerbiedwaardige en/of door hun getalsmatige aanhang machtige religieuze tradities en hun tegoed. Juist ook nieuwe religieuze 
en quasi-religieuze vormen, juist ook nieuwe expressies van levensbeschouwelijke of morele overtuigingen bevatten een tegoed ten opzichte van wat de hedendaagse samenleving realiseert. Juist ook dit tegoed moet in de actuele publieke discussie worden ingebracht.

\subsection{DE PRESENTIE VAN RELIGIE IN DE HEDENDAAGSE SAMENLEVING - EEN VOORBEELD}

Maar zijn dit meer dan filosofische speculaties en bespiegelingen over hoe de democratie 'eigenlijk' zou moeten werken? In wat er nog van dit essay rest, presenteer ik een casus waarin iets van het bespiegelde inderdaad oplicht. Hierbij is het van belang te zien dat er nog tal van open vragen liggen, zowel vragen om over te debatteren als vragen om nader te onderzoeken. Als de grenzen tussen religie en de publieke sfeer vloeiend worden, zoals ik met behulp van Habermas heb betoogd, kunnen ook de beelden van wat religie is en wat het niet is niet onaangetast blijven. Toch zijn juist deze beelden taai en schijnbaar vanzelfsprekend. De bezinning op de situatie rond religie in de huidige samenleving wordt sterk belemmerd door de clichématige wijze waarop religie gezien wordt en waarop er over religie wordt gedacht (Borgman, Van den Brink en Jansen 2006).

Het hieronder uitgewerkte voorbeeld van publieke vormgeving van religieuze toewijding is nadrukkelijk bedoeld om de clichés te doorbreken en er zo aan bij te dragen dat de werkelijke vragen boven water komen. De rol van religie bij de integratie van allochtonen in de Nederlandse samenleving wordt doorgaans vooral gezien als een remmende en complicerende. Nog geheel afgezien van het feit dat er hierbij onterecht van wordt uitgegaan dat migranten die in de Nederlandse samenleving problemen veroorzaken per definitie moslims zijn - de Caribischkatholieke achtergrond van Antilliaanse jongeren die problemen veroorzaken wordt bijvoorbeeld zelden in de discussies over hun positie en gedrag betrokken - wordt hierbij vergeten dat de integratieproblematiek het eerst serieus genomen werd door nadrukkelijk religieus geëngageerde mensen. Zij pakten de problemen vervolgens ook concreet aan op basis van motieven die naar hun eigen overtuiging religieus waren.

Het waren met de kerken verbonden individuen en organisaties die in de tweede helft van de jaren zeventig van de vorige eeuw, en in versterkte mate in de jaren tachtig toen in de samenleving de problemen rond integratie langzamerhand zichtbaar begonnen te worden, de integratie daadwerkelijk ter hand namen. Zij zetten in buurten laagdrempelige, kleinschalige projecten op om allochtonen en autochtonen met elkaar in contact te brengen, ook op religieus gebied. Halverwege de jaren tachtig was de publieke belangstelling voor de religieuze achtergronden van moslims nog gering, maar gelovige christenen meenden dat het goed was dat zij in gesprek zouden komen met de gelovige moslims in hun midden over hun religie en de wijze waarop zij die beleefden. Dit leidde zowel tot vervreemding als tot herkenning, maar het contact bleef bestaan, ondanks de 
moeilijkheden die er ook voortdurend waren - en zijn, want een aantal van de in de jaren zeventig ontstane initiatieven zijn nog altijd levend.

Het zou goed zijn naar dergelijke initiatieven, de ontwikkelingen erbinnen en de verwikkelingen eromheen nader onderzoek te doen. Zoals het ook de moeite waard zou zijn de 'waarde- en geloofsoordelen' te onderzoeken op basis waarvan mensen zich engageren om deze en andere vormen van veeleisend en voor de samenleving cruciaal vrijwilligerswerk te doen, of voor laaggewaardeerde en matig betaalde, maar voor de samenleving cruciale beroepen in het onderwijs of de zorg te kiezen en erin werkzaam te blijven. Dan kan werkelijk zicht ontstaan op de maatschappelijke rol die religie in de brede zin van het woord speelt in de hedendaagse samenleving. Bij ontstentenis van dergelijk onderzoek baseer ik mij voor het volgende op gegevens van de in 1985 opgerichte Interkerkelijke Stichting Kerken en Buitenlanders (ISKB) in Utrecht (vgl. Krikke, Rozema en Rozema-Van der Geest 2000).

In de huidige publieke discussie wordt religie verbonden met particulariteit en eigenheid. In de geschiedenis van de Utrechts ISK B wordt zichtbaar dat religie mensen evenzeer kan stimuleren zich met anderen te identificeren en te verbinden. ${ }^{6}$ Omdat zij geloven in een samenleving waarin iedereen een plaats heeft, in wat in de christelijke traditie wordt aangeduid met de term 'Koninkrijk van God', beschouwen de werkers van de ISKB de marginale maatschappelijke positie van anderen als hun probleem. Omdat het Koninkrijk van God geen beleidsdoel is, maar datgene wat volgens de christelijke traditie 'nabij' is en van godswege aanbreekt, vertalen zij hun verbondenheid niet allereerst in programma's, maar in concrete activiteiten. Opmerkelijk is met name het zogenoemde Vrouwen OntmoetingsProject (VOP), waarin Nederlandse vrijwilligsters langdurig met allochtone vrouwen optrekken. Ze helpen deze vrouwen concreet de weg te vinden in de Nederlandse samenleving, die voor wie hier niet geboren en opgegroeid is steeds weer erg onoverzichtelijk blijkt te zijn. Ze ondersteunen bij het verwerven van vaardigheden die voor het functioneren in deze samenleving nodig zijn. Tegelijkertijd realiseren zij met hun verbondenheid en vriendschap (sporen van) de geïntegreerde, respectvolle en ruimhartige samenleving waarvoor zij zich inzetten.

Het project is niet naïef. De vrijwilligsters rusten elkaar toe in de omgang met de vreemde wereld waarmee zij geconfronteerd worden en de verwarrende ervaringen die zij daar opdoen. Zij spreken over wat deze voor hen persoonlijk betekenen, maar ook over wat hierin maatschappelijk en cultureel gezien aan het licht komt. Van deze ervaringen maakt het contact met de religie van de ander, ook hier vrijwel steeds de islam, deel uit.

In deze contacten is sprake van een verwarrende asymmetrie. De autochtone vrijwilligsters hebben vaak een nieuwe vorm van religieuze inzet en een nieuwe zin voor hun religieuze toewijding gevonden in hun vrijwilligerswerk en hun contacten met allochtonen. De religieuze praktijk van degene met wie zij optrek- 
ken, hoort allereerst bij de wereld van de ander waarvan ze kennis willen nemen en waarmee ze verbinding willen krijgen. De allochtone vrouwen voelen zich zo ook uitgenodigd hun religieuze praktijk te tonen en hun beleving ervan te verwoorden. $\mathrm{Zij}$ herkennen echter van hun kant de toewijding van de vrijwilligsters zelden als religieus en tonen weinig nieuwsgierigheid naar hun religieuze beleving. Op deze manier komt het religieuze gesprek dat allochtonen en autochtonen samen voeren zelden voorbij de uitwisseling, waarbij de nadruk ligt op wat de allochtone vrouwen willen delen. Wat zij te horen krijgen heeft bij de autochtone vrijwilligsters vaak duidelijk invloed op hun eigen religieuze beleving, maar dit wordt vrijwel nooit met de allochtone vrouwen besproken.

Deze gang van zaken wordt binnen het ISKB en het VOP inmiddels als een probleem gezien. Men probeert op de voorpost van de altijd door uiteenvallen bedreigde, maar zich ook steeds weer integrerende samenleving waar men zichzelf gepositioneerd heeft, het interreligieuze en interculturele gesprek minder vrijblijvend te maken. Inzet is de diepgaande verschillen in visies en opvattingen die mensen uit elkaar dreigen te drijven, om te zetten in grondstof voor een discussie die mensen in hun verschillen bij elkaar brengt met het oog op een gezamenlijke, zij het nooit spanningsloze of onomstreden toekomst. Dit kan waarschijnlijk ook alleen op een plaats gebeuren waar visie op de samenleving en het dagelijkse leven rechtstreeks met elkaar verweven zijn. Deze verwevenheid lijkt typisch voor religie, waarin visioenen die de geschiedenis en de kosmos omvatten en overstijgen steeds verbonden zijn met concrete praktijken te midden van het alledaagse leven van mensen.

Wat religieus gemotiveerd engagement met name lijkt bij te dragen zijn geduld en langdurige verbondenheid. Het publieke bestuur biedt doorgaans ofwel faciliteiten aan waarvan burgers vervolgens zelf gebruik moeten weten te maken, ofwel het legt eisen op waaraan burgers moeten voldoen. Organisaties als het ISKB verbinden zich met mensen die buiten de samenleving dreigen te vallen en trekken met ze op. Zo herstellen zij iets van de dreigende desintegratie om vervolgens, op basis van verbondenheid, de mogelijkheden te onderzoeken de situatie te veranderen. Waar de door het publiek bestuur georganiseerde hulpverlening doorgaans sterk bureaucratisch en geprotocoliseerd is, blijken vrijwilligers en professionals vanuit een religieuze achtergrond in staat tot een vorm van aandachtige en toegewijde presentie. Op basis van de gedachte dat de problemen van de ander niet alleen zijn of haar problemen zijn en dat inzet voor een samenleving die ook hen omvat de beste manier is een samenleving vorm te geven die voor iedereen goed is, biedt deze zogenoemde presentiebenadering meer dan concrete hulp. Door actief contact te zoeken met mensen die doorgaans vooral in beeld komen als probleemgevallen en vaak zichzelf ook zo zien, laat zij deze mensen blijken dat zij wel degelijk van belang zijn. Zo geeft zij hun opnieuw zelfvertrouwen en hoop. ${ }^{7}$ 


\subsection{PLEIDOOI VOOR EEN 'OMGEKEERDE DOORBRAAK' - CONCLUSIE}

Bij de gemeenteraadverkiezingen van 7 maart 2006 won de Partij van de Arbeid grote aantallen stemmen van allochtonen met een islamitische achtergrond. Mede tegen deze achtergrond pleitte op 9 juni de Amsterdamse burgemeester Job Cohen (2006) in een rede voor een 'omgekeerde doorbraak' binnen de Partij van de Arbeid. Cohen sloot hiermee aan bij de direct na de oorlog onder leiding van vooral Willem Banning (1888-1971) nagestreefde 'doorbraak' van belijdende christenen naar de sociaal-democratie, die toen slechts zeer partieel slaagde, maar in de loop van de jaren zestig en zeventig wel plaatsvond. Gelovigen gingen de sociaal-democratie zien als politieke stroming waarbinnen christelijk geïnspireerde politieke idealen samen met niet-christenen op productieve wijze konden worden nagestreefd.

Na het geloof in de secularisatie en het antireligieuze affect die de partij sinds de jaren zeventig langere tijd domineerden, wordt het volgens Cohen nu tijd voor een doorbraak van sociaal-democraten naar de religie. Ook als zij zelf niet gelovig zijn, moeten zij religie niet allereerst zien als achterhaald en bedreigend, maar als belangrijke en potentieel waardevolle vormen van engagement en sociaal gedrag.

Het lijkt niet overdreven te zeggen dat een dergelijke 'omgekeerde doorbraak' van de politiek en het publieke bestuur naar de religie voor de hele Nederlandse samenleving evenzeer van belang zou zijn. Niet om de publieke ruimte te deseculariseren en de samenleving te religioniseren, maar om (1) de feitelijke aanwezigheid van 'waarde- en geloofsoordelen' in de samenleving waar te nemen, als (2) van groot belang voor het maatschappelijk gedrag van mensen en hun onderlinge sociale verkeer en als (3) evenzeer van groot belang voor het vrije en allen omvattende maatschappelijk debat dat de kern is van een democratische samenleving. Dit betekent dat:

_ ten eerste de diffuse en steeds weer verschuivende grens tussen religie en publiek domein wordt geaccepteerd als eigen aan hun onderlinge verhouding;

_ ten tweede de overheid en publieke bestuur het tot hun taak rekenen bijdragen vanuit religieuze en levensbeschouwelijke achtergrond aan de publieke discussie te faciliteren en te stimuleren, met het oog op de versterking van de publieke discussie zelf en daarmee van de democratie;

_ ten derde de clichébeelden over religies en hun rol in de samenleving worden losgelaten, het onderzoek naar de rol die zij feitelijk spelen zowel in de breedte als in de diepte wordt uitgebreid en het beleid op de te verwerven kennis wordt afgestemd.

De verhouding tot religieuze tradities en hun erfenis en de omgang ermee, is voor de westerse samenlevingen altijd van identiteitsbepalende betekenis geweest. Het opnieuw bepalen van deze verhouding in het huidige tijdsgewricht waarin de religieuze situatie aan ingrijpende veranderingen onderhevig is, is een zaak van fundamenteel belang die aanzienlijk meer intellectuele aandacht, politieke steun en bestuurlijke en financiële facilitering verdient dan zij nu krijgt. 


\section{NOTEN}

Naast deze beroemde studie deed Weber uitvoerig onderzoek naar 'Die Wirtschaftsethik der Weltreligionen', zie Weber 1920/1988: 237-573 (confucianisme en taoïsme), Weber 1921/1988a: 1-378 (hindoeïsme en boeddhisme) en Weber 1921/1988b: 1-441 (jodendom). Weber 1904-05/1988 ontwikkelt welbewust een alternatief voor de ideeënhistorische visie op modernisering in termen van de wetenschappelijke kennis die de macht van het religieuze geloof zou overnemen, zie Radkau 2005: 316-350. Voor een visie op seculariteit als steeds ontstaand te midden van en onder invloed van een religieuze context en constellatie, zie Asad 2003.

Voor kritiek op Habermas' gebruik van de categorie 'postseculier', zie Joas 2004: 122-128.

4 Zoals bekend is dit een belangrijk punt voor Habermas, dat leidde tot een felle controverse met de filosoof Peter Sloterdijk naar aanleiding van diens 'Regels voor het mensenpark' (Sloterdijk 1999). Vgl. hiervoor, en voor de literatuur erover Dassen 2001. Habermas had in zijn vredesprijsrede oorspronkelijk over gentechnologie willen spreken.

de laatste decennia met zijn werk hebben beziggehouden. Zij hebben er steeds op gewezen dat het ideaal van de machtsvrije communicatie van allen met allen, dat de horizon vormt van Habermas visie, feitelijk nergens gerealiseerd is. Meer nog, de menselijke eindigheid en de gewelddadige dood maakt een dergelijke situatie onbestaanbaar, want zij leggen vele stemmen het zwijgen op voordat zij zich kunnen uitspreken. Volgens deze theologen verwijst Habermas' theorie van het communicatieve handelen dus niet naar een realiseerbare situatie, maar naar een contrafactisch ideaal zoals de christelijke traditie dat bijvoorbeeld thematiseert in het symbool van het koninkrijk van God: eens zullen de stemmen van allen worden gehoord, ook die voortijdig het zwijgen zijn opgelegd. Zie m.n. Peukert 1978. Voor een overzicht van de theologische confrontaties met Habermas, zie Adams 2006.

6 Vanwege de kerkelijke herkomst van de ISKB gaat het navolgende vooral over de rol van de christelijke traditie. Met anderen, onder wie enkele islamitische auteurs en theologen, bereid ik een boek voor over de verschillende aspecten van 'verantwoordelijkheid' in de islam. Hierin zal blijken dat een dergelijke religieus gemotiveerde gerichtheid op het welzijn van mensen die geen deel zijn van de eigen traditie, ook voor moslims mogelijk is.

De presentiebenadering bestond allereerst in de praktijk in groepen als het ISKB, maar vooral in het zogenoemde 'Oude Wijken Pastoraat', een vorm van kerkelijke presentie onder mensen die niet allen van de kerken, maar ook vaak van de samenleving vervreemd zijn. De benadering is systematiserend beschreven en handelingstheoretisch bereflecteerd in: Baart 2001. Vanuit de zorgethiek en een reflectie op de zorgpraktijk van vrouwelijke religieuzen in de 19de en zoste eeuw wordt duidelijk in welke zin een dergelijke benadering typisch religieus te noemen is; zie Van Heijst 2002; 2005. 2005. 


\section{LITERATUUR}

Adams, N. (2006) Habermas and Theology, Cambridge: Cambridge University Press.

Asad, T. (2003) Formations of the Secular. Christianity, Islam, Modernity, Stanford: Stanford University Press.

Audi, R. en N. P. Wolterstorff (1997) Religion in the Public Sphere, Lanham: Rowman and Littlefield.

Baart, A. (2001) Een theorie van de presentie, Utrecht: Lemma.

Beck, U. (1986) Risikogesellschaft. Auf den Weg zu eine andere Moderne, Frankfurt am Main: Suhrkamp.

Berger, P.L. (ed.) (1999) The Desecularisation of the World. Resurgent Religion and World Politics, Grand Rapids: Eerdmans.

Borgman, E. (2006) Metamorfose. Over religie en moderne cultuur, Kampen: Klement.

Borgman, E., G. van den Brink en Th. Jansen (2006) 'De waarheid zal u vrijmaken. Elf stellingen over geloof en democratie', blz. 18-34 in: E. Borgman, G. van den Brink en Th. Jansen (red.), Zonder geloof geen democratie, Amsterdam: Boom.

Cohen, J. (2006) 'Sociaal-democratie en religie. De omgekeerde doorbraak', Socialisme \& Democratie 63, 7/8: 49-53.

Dassen, P. (2001) 'Het hoeden van de moraal in de Bondsrepubliek', blz. 121-142 in: P. Dassen en Ton Nijhuis (ed.) Gegijzeld door het verleden. Controverses in Duitsland van de Historikerstreit tot het Sloterdijkdebat, Amsterdam: Boom.

Gauchet, M. (1998) La religion dans la démocratie. Parcours de la laïcité, Paris: Gallimard.

Goode, L. (2005) Jürgen Habermas. Democracy and the Public Sphere, London: Pluto Press.

Gunsteren, H. van (2004) Gevaarlijk veilig. Terreurbestrijding in de democratie, Amsterdam: Van Gennep.

Habermas, J. (1962) Strukturwandel der Öffentlichkeit, Frankfurt am Main: Suhrkamp.

Habermas, J. (1981) Theorie des kommunikativen Handelns. Band 1: Handlungsrationalität und gesellschaftliche Rationalisierung, Frankfurt am Main: Suhrkamp.

Habermas, J. (1992) Faktizität und Geltung. Beiträge zur Diskurstheorie des Rechts und des demokratischen Rechtsstaats, Frankfurt am Main: Suhrkamp.

Habermas, J. (2001) 'Glauben und Wissen', blz. 9-31 in: Jürgen Habermas, Glauben und Wissen: Friedespreis des Deutschen Buchhandels 2001, Frankfurt am Main: Suhrkamp.

Habermas, J. (2005a) Religion in the Public Sphere, http://www.sandiego.edu/pdf/ pdf_library/habermaslectureo31105_c939cceb2abo87bdfc6df291ecofc3fa.pdf

Habermas, J. (2005b) 'Religion in der Öffentlichkeit. Kognitive Voraussetzungen für den “öffentlichen Vernunftgebrauch” religiöser und sekularen Bürger', blz. 119-154 in: J. Habermas, Zwischen Naturalismus und Religion. Philosophische Aufsätze, Frankfurt am Main: Suhrkamp.

Habermas, J. (2005c) ‘Vorpolitische Grundlagen des demokratischen Rechtsstaates?’, blz. 15-37 in: J. Habermas en J. Ratzinger, Dialektik der Säkularisierung, Freiburg: Herder.

Hack van Outheusden, Ph. (1888) 'Jong-Amsterdam', De Nieuwe Gids 3, 1: 460-474.

Hack van Outheusden, Ph., (1889a) ‘Jong Amsterdam', De Nieuwe Gids 4, 1: 281-298. 
Hack van Outheusden, Ph. (1989b) 'Jong Amsterdam', De Nieuwe Gids 4, 2: 286-299. Harskamp, A. van (2000) Het nieuwe religieuze verlangen, Kampen: Kok.

Harskamp, A. van en E. Borgman (2003) 'Nieuwe religieuze bewegingen', blz. 21-62 in: H. Geerts (red.), Hunkering naar heelheid. Over nieuwe religiositeit in Nederland, Budel: Damon.

Hegel, G.W.F. (1829/1969) Vorlesungen über die Philosophie der Religion, II: Vorlesungen über das Beweis vom Dasein Gottes, Frankfurt am Main: Suhrkamp.

Heijst, A. van (2002) Liefdewerk. Een herwaardering van de caritas bij de Arme Zusters van het Goddelijk Kind, sinds 1852, Hilversum: Verloren.

Heijst, A. van (2005) Menslievende zorg. Een ethische kijk op professionaliteit, Kampen: Klement.

Joas, H. (997) Die Entstehung der Werte, Frankfurt am Main: Suhrkamp.

Joas, H. (2004) Braucht der Mensch Religion? Über Erfahrungen der Selbsttranzendenz, Freiburg: Herder.

Johnson, P. (2006) Habermas: Rescuing the Public Sphere, London: Routledge.

Krikke, H., W. Rozema en P. Rozema-Van der Geest (red.) (200o) Hand in eigen boezem. Vijftien jaar pionieren in de multiculturele samenleving, Heeswijk en Utrecht: Dabar-Luyten en ISKB.

Kuyper, A. (1891) Het sociale vraagstuk en de Christelijke religie. Rede bij de opening van het sociaal congres op 9 November 1891 gehouden, Amsterdam: Wormser.

Magry, P.J. (2000) Teedere Quaesties - Religieuze rituelen in confict. Confronaties tussen katholieken en protestanten rond de processiecultuur in 19e eeuws Nederland, Hilversum: Verloren.

Mill, J.S. (1869/1969) 'Three Essays On Religion. Nature, the Utility of Religion, and Theism', blz.369-489 in: J.S. Mill, Collected Works, X, Toronto/London: University of Toronto Press/Routledge \& Kenan Paul, 369-489.

Nancy, J.L. (1998) 'Le déconstruction du Christianisme', in: Les etudes philosophiques 4: 503-519.

Norris, P. en R. Inglehart (2004) Sacred and Secular. Religion and Politics Worldwide, Cambridge: Cambridge University Press.

Peukert, H. (1978) Wissenschaftstheorie - Handlungstheorie - Fundamentale Theologie. Analysen zur Status und Ansatz theologischer Theoriebildung, Frankfurt am Main: Surhkamp.

Radkau, J. (2005) Max Weber. Die Leidenschaft des Denkens, München: Hanser.

Ratzinger, J. (2005) 'Was die Welt zusammenhält. Vorpolitische moralische Grundlagen eines freiheitlichen Staates', blz. 15-37 in: J. Habermas en J. Ratzinger, Dialektik der Säkularisierung, Freiburg: Herder.

Rawls, J. (1971) A Theory of Justice, Cambridge: Harvard University Press.

Ruiter, F. en W. Smulders (1996) Literatuur en moderniteit in Nederland 1840-1990, Amsterdam: Arbeiderspers.

Salemink, Th. (2005a) 'Sluit orthodoxie democratie uit? De geschiedenis van de Nederlandse katholieken en het actuele debat over de islam', blz. 119-138 in: J. Duyndam, M. Poorthuis en Th. de Wit (red.) Humanisme en religie. Controverses, bruggen, perspectieven, Delft: Eburon.

Salemink, Th. (2005b) 'Orthodoxie und Aufklärung, Katholizismus und Islam', Schweizerische Zeitschrift für Religions- und Kulturgeschichte, 99: 465-488. 
Schaepman, H.J.A.M. (1891) "Rerum novarum". Rede over de jongste Encycliek van Z.H. Paus Leo XIII, Utrecht: Van Rossum.

Sennett, R. (1998) The Corrosion of Character. The Personal Consequences of Work in the New Capitalism, London: Norton.

Sloterdijk, P. (1999) 'Regels voor het mensenpark', blz. 18-50 in: P. Sloterdijk, Regels voor het mensenpark. Kroniek van een debat, Amsterdam: Boom.

Stark, R. (2005) The Victory of Reason. How Christianity Led to Freedom, Capitalism, and Western Success, New York: Random House.

Thierse, W. (200o) 'Religion ist keine Privatsache', blz. 7-13 in: W. Thierse (Hg.) Religion ist keine Privatsache, Düsseldorf: Patmos.

Thomas, S.M. (2005) The Global Resurgence of Religion and the Transformation of International Relations. The Struggle of the Soul of the Twenty-First Century, New York: Palgrave MacMillan.

Turner, D. (1995) The Darkness of God. Negativity in Christian Mysticism, Cambridge: Cambridge University Press.

Weber,M. (1904/1988), 'Die Objektivität sozialwissenschaftlicher und sozialpolitischer Erkenntnis’, blz. 146-214 in: M. Weber, Gesammelte Aufsätze zur Wissenschaftslehre, Tübingen: Mohr.

Weber, M. (1904-05/1988) 'Die protestantische Ethik und der Geist des Kapitalismus', blz. 17-206 in: M. Weber, Gesammelte Aufsätze zur Religionssoziologie I, Tübingen: Mohr.

Weber, M. (1919/1988) 'Wissenschaft als Beruf', blz. 582-613 in: id., Gesammelte Aufsätze zur Wissenschaftslehre, Tübingen: Mohr.

Weber, M. (1920/1988) Gesammelte Aufsätze zur Religionssoziologie I, Hg. M. Weber, Tübingen: Mohr.

Weber, M. (1921/1988a) Gesammelte Aufsätze zur Religionssoziologie II, Hg. M. Weber, Tübingen: Mohr.

Weber, M. (1921/1988b) Gesammelte Aufsätze zur Religionssoziologie III, Hg. M. Weber, Tübingen: Mohr.

Wetenschappelijke Raad voor het Regeringsbeleid (2006) Dynamiek in islamitisch activisme. Aanknopingspunten voor democratisering en mensenrechten, Amsterdam: Amsterdam University Press. 


\title{
12 RELIGIOUS PLURALISM AND THE DUTCH STATE: REFLECTIONS ON THE FUTURE OF ARTICLE 23
}

\author{
James Kennedy and Markha Valenta
}

\subsection{INTRODUCTION}

What should be the state's relation to religion and to religious institutions in a setting where the nature and function of both state and religion are changing significantly? More specifically, what is the place and the use of Article 23 in a society that is no longer officially organized along socio-religious lines and where many consider such divisions disruptive rather than productive? And more generally, how are we to understand the role of schooling in a multi-religious and multi-ethnic democratic society?

The place of religion in public life is determined by a number of factors, not least the state, which determines the 'constitutional' conditions under which religion plays a legitimate role in public life. In this respect, the state can never be neutral with respect to religion, and it is precisely the fiction of state neutrality that has exacerbated political and social conflict in countries where this naïve assumption is held to be the underpinning of public life, including France, and in a different way, the United States. In America, the principle of state neutrality in the domain of education has been interpreted in two, often contradictory ways: the state is neutral insofar as it is non-sectarian (it posits a broad civil religion that stands above 'sectarian' faith), or the state is neutral insofar as it avoids or proscribes any religious expression. This whole debate has been fueled since the 1960 os by educational issues, in particular the role, if any, for school prayer in American public schools and, more recently, the question of whether or not to teach Intelligent Design in biology classes. The American situation illustrates the impossibility of a state being 'neutral' in respect to religion (Kennedy 2006). For this reason, it is unfortunate that many Dutch have in recent years spoken more of the need for the 'separation of church and state', a Jeffersonian phrase that in American history has helped render debate over church-state relationships largely unfruitful (Hamburger 2002).

\subsection{RELIGION IN THE DUTCH PUBLIC SPHERE: THE LEGACY OF PILLARIZATION AND DEPILLARIZATION}

The Dutch state itself has never been neutral in respect to religion; indeed, extensive involvement of the state with religious expression in public life has been the traditional approach. Extensive involvement of the state with religious expression, including religious-inspired education, however, is not how many Dutch view the situation. The 'pacification' of 1917 - namely the passage of Article 23 establishing complete state funding for previously 'private' schools with a religious identity while safeguarding such schools' freedom to determine their 
educational content - was the result of long efforts on the part of orthodox Protestants and Roman Catholics to keep the state at a distance from a realm, education, that did not in the first instance belong to it, but to parents. The neoCalvinist notion of 'sphere sovereignty' and the Catholic subsidarity principle insisted, in different ways, that intermediary groups, not the state, assume the primary task of educating the young. In an important sense, then, the Dutch educational arrangements of nearly a century ago delimited the role of the state in education. To this day, in fact, the Dutch government is hesitant to intrude too directly in the religious and other 'levensbeschouwelijke' mission of 'private' ('bijzondere') schools despite the fact that they are almost wholly dependent on state financing. For example, the recent discussion, launched by the Minister of Education among others, of how to promote citizenship in the curriculum is partly defined by the issue of whether private schools should in any measure be forced to adopt a curriculum that might undermine their religious foundations. For these reasons, the Dutch system has generated support from defenders of private schools who are thankful for an educational system that gives them a great deal of latitude to sustain their own religious identities (Monsma and Soper 1996).

For precisely the same reasons, the Dutch educational system has engendered critics, particularly in recent years, who regard the system as too accommodating toward religion. This has led them to decry a situation in which the secular state has been constrained from ensuring that all Dutch pupils be able, or mandated, to free themselves from religious traditions that are presented as highly 'unfree', dated, oppressive and discriminating. In particular, widespread concern has been expressed with regard to the state-financed institutionalization of Islamic education. The intensity and breadth of concerns in Dutch society with regard to Islamic education, in turn, has both strengthened and expanded the number of critics who oppose the current system as obsolescent, because its great accommodation of religious conviction would seem to no longer jibe with the realities of a strongly secularized, democratic society. Here, in general terms, the argument is essentially the same as in the more specific critique of Islamic schools: the secular state has conceded too much to religious particularism. These critics have been most vocal on the issue of state funding of private religious schools, arguing that it should be entirely abolished. They are less clear, and less unified, with regard to the second component of Article 23, namely freedom of education: should only state funding of educational institutions with a specific religious content and identity be prohibited, or should this measure be extended to also prohibiting the existence of any private religious schools whatsoever within Dutch society (a standpoint potentially in conflict with the European Convention on Human Rights)?

But the fact that Dutch schools enjoy a measure of religious autonomy and that many people object to this autonomy, should not obscure the fact that in reality private schools have actually been operating deeply within the Dutch state's orbit of influence. This is most transparently the case with respect to financing and 
inspection; in most respects, schools are obliged to follow the guidelines issued by the state, as they are evaluated annually along universal criteria and subjected to government financing. In the United States, this has in fact been one reason (though probably not the most important) that state subsidies to religious schools have not been systematically enacted; some religious conservatives treat state subsidies with suspicion, precisely because they see such funding as the end of institutional independence for religious schools. And indeed, the resolve of many privately funded American schools to establish their own curricula and develop a countercultural identity is generally more assertive than that of many of the state-financed, private schools in the Netherlands.

By contrast, the limits that state financing might place on religious schools' maneuvering room has seldom constituted much of a concern here in the Netherlands in past decades, though a few orthodox Protestant seminaries reject state funding on these grounds. Only more recently has the issue indirectly come to the fore, and then as a result of the discovery that traditionalist Islamic schools in this country were being partially financed by Saudi sources. In other words, the concern here was not so much the issue of state influence on educational institutions per se, as that of a foreign government's influence on educational establishments within the Netherlands. Given, however, that the French, British and American governments, among others, have for years either had their own educational institutions or in other ways have contributed to educational institutions in the Netherlands, the issue here too was most specifically the question of how to respond to the new situation of Dutch students attending institutions possibly influenced not so much by a foreign government per se but by a nonWestern, Islamic one. This suggests that the deep emotional charge that has marked debates about state funding for religious education in recent years derives not only, and perhaps not even primarily, from the issue of church-state relations as such, but rather from the question of how to transmit Dutch national identity, values and ways of life in the face of what might be called an increasing 'intimacy' and direct intermingling between Western and non-Western peoples, cultures and institutions in the Netherlands. To the extent that this is not acknowledged, this makes the debate about Article 23 particularly messy, insofar as this one topic - the relation of the state to religious institutions - is simultaneously functioning as the means to another discussion - the place and role of citizens of non-Western descent in Dutch society when Dutch society no longer can be shielded from the effects of globalization (a point to which we'll return below).

First, however, it should be remarked that more important than money and regulations alone in shaping the relatively comfortable relation between Dutch private religious schools and the state, is the fact that private schools have never stood apart from the Dutch political establishment. Private schools are wellrepresented in (semi-)governmental organs and their representatives have long networked with administrators and politicians (across the political spectrum rather than only those representing the Christian political parties) in setting policy. Nor was this merely a matter of educational groups lobbying government; 
in P.E. Kraemer's 'societal state', his classic 1966 study of Dutch public life, the distinction between state and society (including its formally private schools) could scarcely be made (Kraemer 1966). In effect, the state, in subsidizing the organs of civil society - including religious schools - helped support and sustain religious practices and communities that extended beyond the institutional church.

All of this is well-known. But it is important to note - for that is now often forgotten - that these broad concessions to religious groups did not lead to an American-style arrangement as described by De Tocqueville, in which 'strong' religion stood over and against a 'weak' state (Gret Haller 2002), and where religious groups were given free rein to define civil society according to their influence and insight. Rather, these concessions by the Dutch state to various religious institutions have enabled the state to closely monitor and regulate what many religious groups are doing, and set the parameters for their continuing participation in public life. Religiously-inspired organizations with state subsidies - including religious schools - have not operated independently of the state. Rather, in lending its aid, and through the interrelationship of Dutch elites, the state has in effect helped define religious subcultures with their own organizations and elites, who have understood their collective identities in ways that would be considerably different if they did not receive support from, and were less directly supervised by, the state. In other words, the state has played a considerable role in determining the way in which religious groups - including religiously-affiliated schools - can both effectively and legitimately participate in public life. For example, for many decades it has been considered normal that religion expresses itself in the educational sphere, especially if that religion is commensurate with the dominant social values of Dutch society. In this respect, then, 'pillarization' - to put it provocatively - generated a semi-establishment of religion, in which not churches as such but affiliated religious groups - chiefly Catholic and Protestant - enjoyed special privileges while simultaneously being channeled to play a certain, carefully defined role in public life.

This is not to say, of course, that church-state relations were invariably predictable, that the churches were always in agreement with each other about the moral order (think of the conflicting position of the episcopal 'Mandement' of 1954 and its rebuttal by the Dutch Reformed Church a year later), or that members of the political establishment always agreed with each other about the importance of religion in public life - some were outrightly skeptical or hostile to an extensive public role for religion. But the 'pillarized religious regime' (Van Rooden 1996) normalized church-state relations and gave them a stabilizing and predictable character.

The point here is not that the semi-establishment of religion is a bad arrangement per se, or that this extensive involvement of the state with religious expression in public life in general, or in religious education in particular, is an illegitimate use of state power in a modern Western democracy. As we have noted before, the 
state cannot retreat to a neutral position even if everyone desired it to be neutral. The point, then, is to make visible the ways the Dutch state has defined and sustained religion in public life, in particular religiously-inspired education. With this foregrounded, it becomes clear how this extensive state influence on religion's public role, historically so strong, is now in something of a crisis precisely because its influence is weakening. In other words, the state has less of a grip on the public expression of religious life than it did in the recent past, and the effect of this loss of grip is part of the crisis in public confidence. Contrary to the general tenor of current discussions, the actual question confronting the Dutch state today is not whether or not to reduce its support of religion and religious institutions. It is about if and how the state can reassert its supervisory role over religion's public role in the face of the increasing independence and diversification of Dutch religious life.

Why do the Dutch feel compelled to revisit this issue? In recent years, the state's compelling interest in regulating religion's public role, and above all its public ability to do so, has eroded in the face of substantial social change. The weakening of traditional religious institutions and affiliations has weakened the very fabric of the Dutch 'societal state,' and in this sense the decline of traditional religion - and the rich set of networks it generated - has generated a serious problem for the political system, undermining its representative character and, according to some, the quality of its representatives. This situation in part stems from the fact that the 'secularization' of Dutch society in the 1960s, 1970s and 1980s did not bring an end to the religious settlement; rather, the institutions that had been part of the old 'religious regime' made their identities more 'inclusive,' thereby ensuring that the old networks that regulated church-state relations remained largely in place. But the relatively stable church-state relationship at the top was nevertheless undermined by the falling away of religious support at the base, rendering problematic the representative character of many (nominally) religious schools in particular and religious institutions in general. Moreover, the growth of non-denominational, non-confessional forms of belief, religious consumerism, and interest in New Age and non-Western religious traditions have transformed the Netherlands from a setting consisting of relatively few, clearly defined religious communities, each with its own distinct confessional content and way of life, into a much more fluid and undefined one (Groot 2006).

Church-state relations in the United States, by way of contrast, have seldom been as institutionally defined as in the Netherlands, in part because American religion has itself been less institutionally stable, in part because churches and religious organizations constituted less of the 'substance' of American state and local government, and in part because religion has been required to develop within a liberal market-based system rather than parallel to or protected from it. The church-state relationship may or may not be changing now with the rise of the Religious Right. But the American state and society has for a long time accommodated itself to the dynamism of religious change. It is not, by contrast, evident that Dutch society, used to the old relationship between religious communities 
and the state and still largely shaped by a teleology that expects modernity to generate increasing secularization, is able or willing to think in new ways about how the largely unexpected and diffuse religious impulses can and ought to play a role in contemporary public life.

\subsection{RELIGION IN THE DUTCH PUBLIC SPHERE: THE COLONIAL LEGACY}

These developments have been made more complex by the arrival of non-Western religious communities, particularly Islamic ones, whose forms and practices are shifting across generations from the effects of urbanization, Europeanization, and globalization. The presence of non-Western religious communities in particular has underscored the larger reality of the so-called 'return of the religious' to the public and political realm, which is part of a global pattern, particularly outside of Europe. The emergence of globally operating Islamicist movements, while perhaps gaining the most extensive media attention, in fact constitutes only the most evident variation of a pattern of increasingly transnational religiosity characteristic of all the world's major religions. Even as such globalization has helped to increase the political significance and influence of religion, it has made it more difficult to easily situate the religious within a primarily national context and within traditional and relatively predictable confessional parameters. Moreover, the rise of 'fundamentalism' in various world religions has not yet translated into a stable pattern on the basis of which political systems can effectively define a new churchstate relationship. In short, one could argue that the (Dutch) state no longer has the same capacity to regulate the religious as it had in the past, nor can it draw the same level of support from religious organizations and networks as it once could, even as once nationally-defined religious communities are exceeding the boundaries of both nation and state.

One result of all of this is that the issue of the state's relation to religion at present emerges not just from changes in traditional Dutch forms of religious belief and community but is closely caught up with the issues of immigration, economic inequality, cultural difference, and new ethno-racial divisions of Dutch society. Globalization itself is not a new phenomenon to the Dutch; in fact, the great merchant empire they began to develop in the sixteenth century was not only the first modern global empire but in general terms provided the model for others that would follow. This global role early on brought the Dutch in touch with the diversity of the world's religious beliefs and communities on all continents.

In instances of long-term Dutch settlement, business and governmental presence, such as in the Dutch East Indies, such contact transformed into the active study of other religious practices and communities and the development of detailed and carefully thought out Dutch government policies towards these. C. Snouck Hurgronje, for example, the most famous and influential advisor to the Dutch government about its colonial policies, wrote more than 1,40o papers, many of which addressed the position of Islam in the East Indies and the possibilities for Dutch 
use, control and containment of Islamic structures. Hurgronje in fact converted to Islam, though the seriousness of this conversion is questionable, and became world famous after the appearance of his two-volume study of Mecca was published (including a detailed analysis of pilgrims from the Dutch East Indies). Most centrally, in advising the Dutch government, Hurgronje argued that Islam and Muslims needed to be modernized along Western lines. This entailed, in Hurgronje's eyes, the repression of Islamic militancy (including in its anti-colonial form) and the separation of religion and politics, considered endemic to Islam. The prime institutions to carry out this task were those of education, whose purpose would be to inculcate secular Dutch culture in the Netherlands' East Indies subjects without necessitating government interference with Islamic religious practices (Peter van der Veer 2002). Hurgronje's advice was made in the interests of promoting what he envisioned as an enlightened Dutch colonialism. His careful studies of the Aceh culture and communities and his close work with General Van Heutsz, however, not only helped to turn the Aceh war in the Dutch interest but enabled one of the most repressive and bloody colonial regimes.

Crucially, this aspect of Dutch history is rarely recalled in current discussions where all too often the encounter between the Dutch state and non-Western religions is presented as a highly recent event. Not only is this a factual misreading of Dutch history, but it both prevents current discussions from building on historical experience and obscures the persistence of certain Dutch frameworks and patterns for managing this encounter between the Western and non-Western, particularly as this Dutch church-state relations.

In considering this record, one should also mention that an important, but today much less well-known colleague of Hurgronje was Sayyid 'Uthmân. 'Uthmân was an East Indies-born ulama of Arab descent and member of the Islamic religious nobility, who likewise worked for and advised the Dutch colonial administration. The author and publisher of more than 150 books, 'Uthmân was at the same time involved in the spread of nineteenth-century, Middle-East-based Islamic ideals and ideologies of modernization to Southeast Asia (having spent some years studying in Saudi Arabia), as well as being in contact with anti-colonial movements (Nico Kaptein; Azyumardi Azra). Essentially unknown in the Netherlands and until recently little studied, 'Uthmân was a prominent Muslim scholar who significantly shaped the development of Islam in the East Indies. Hurgronje and 'Uthmân's collaboration and their service for the Dutch colonial administration reveal, then, that the Netherlands already a century ago had developed a multifaceted, complex, even contradictory relation to the East Indies and, somewhat more indirectly, Middle Eastern - Islam and Muslim subjects.

More specifically, the issue of education was central to this relation, both as an institution specifically deployed to address and redress the problem of Islam among recalcitrant colonial subjects and more generally to mediate between what was understood to be a superior Western culture, on the one hand, and ethnically and religious inferior peoples, on the other. Precisely for this reason and in light 
of these assumptions, secular national(ist) Dutch education was conceptualized and deployed more easily and widely in the East Indies than it was in the Netherlands itself. It was at this very moment, after all, that at home on the European continent Dutch society was beginning actively to institutionalize socio-religious 'pillarization' as a means for addressing religious difference, inequality, and historical discrimination. That is to say, considering Dutch late nineteenthand twentieth-century history, we see a tendency to officially recognize at the domestic level, including in the field of education, both (Christian) religious difference and political difference while at the same time attempting in the colonial setting to secularize or bypass (Islamic) religious difference, to repress (indigenous) political difference and in all cases to prevent a political Islam.

The important point here is that this suggests that the history of Dutch churchstate relations, and the role of education in these, does not so much consist of a development from the religious to the secular but rather that both of these models were developed and institutionalized simultaneously but deployed differentially across the Dutch empire. In this sense, moreover, the current call for the removal of Article 23, partially in the interests of promoting the integration of Islamic minorities, constitutes not so much a new historical development but rather a return to past (colonial) strategies under new conditions.

At the same time, Dutch colonial education not only constituted a response to what was considered to be an inferior indigenous culture and religiosity - that is as a project of civilizational uplift and enlightenment - but also entered into competition with transnational Islamic religious movements offering their own educational visions. These were likewise committed to the (Islamic) modernization of their East Indies students, and their insertion into a larger community, but from a Middle-East-centered, religious perspective. Not surprisingly, Hurgronje for one suggested that pilgrimages from the East Indies to Mecca should be discouraged. That is, the colonial Dutch encounter with Muslims was from the beginning not only local but global, competing simultaneously domestically and within an international arena for pedagogical, ideological and cultural influence and allegiance. In the course of this process, the Dutch distinguished between the relatively 'weak' Islamic nature of their East Indies colonial subjects, whom they saw to be in need of education, modernization and secularization, and the 'aggressive' violent Islam of the Middle East needing to be prevented from contaminating Dutch colonial subjects.

More generally, it should also be remarked that the large Muslim population of the Dutch East Indies meant that until Indonesian independence in 1949, the Netherlands technically constituted the world's largest 'Muslim' empire (Peter van der Veer). Needless to say, this has not been the standard self-conception of the Netherlands. In fact, the general tendency, not only in the popular Dutch imagination and narration but also in much international scholarly work, has been to 'repress' the predominantly Islamic character of Indonesian society and the centrality of Islam in shaping the historic encounter between the Netherlands and its East Indian colo- 
nial subjects (Azyumardi Azra; William R. Roff). As a result, the majority of Dutch today, including many politicians and policymakers consider the recent arrival of a sizable Muslim minority in the Netherlands as the first encounter between Dutch society and Islam and, more specifically, between the Dutch state and Islamic education. This has at moments helped to sustain a widespread moral panic in the media, among politicians and society at large in the face of what is portrayed to be a deeply alien Islamic presence within the Dutch realm. That is to say, more generally, a weak and sporadic knowledge of Dutch imperial encounters with non-Western religions means that the insights such a history offers into the current encounter remain under-utilized. This strengthens the notion of Islam and, more generally, religion as entities that are essentially resistant to Dutch modernity when in fact they for more than a century have been deeply engaged and channeled by the modern Dutch state both abroad and at home.

\subsection{A NEW CHURCH-STATE RELATIONSHIP FOR THE NETHER- LANDS?}

Crucially, it is the power of this moral panic in relation to Islam and the conviction that this is a radically new situation calling for new answers that now is driving Dutch society and the state to reconsider the entire church-state relation and take steps it had previously hesitated to carry out. The judicial decision to abolish state funding of the orthodox Protestant SGP on the grounds that it discriminates against women is only one example of this. While the tension between Dutch antidiscrimination legislation and the SGP practice of gender differentiation has been obvious for many years, it only became problematic at the moment the state considered it to be necessary and in its interest to exert pressure on Islamic communities to practice greater gender equality. That is to say, it is important to recognize the extent to which current Dutch discussions about the relation between religion and the secular state are discussions about the Netherlands' relation to Islam, irrespective the actual religion being considered. This is reinforced by the widespread assumption that all religions, whatever their divergences, essentially share in common inherent tendencies towards violence, irrationality, dogmatism and authoritarianism that need to be carefully monitored and controlled if modern egalitarian social relations and democracy are not to come under threat. Within this framework, the question with regard to Article 23 then quickly comes to be framed as essentially the question of how best to contain religious excess. Does state subsidy for religiously-informed schools help ensure careful state supervision of religion's public face, or does the withholding of state subsidy (in the interest of limiting state support of religion in any form) promote a secular public space?

Crucially, there are a number of factors that make achieving the second option, a secular public space, unlikely. The first of these is that the 'return of the religious' to the public space in recent decades has been a global phenomenon to which it is unlikely that a country as small, culturally permeable, and globally integrated as the Netherlands could realistically offer any significant resistance. One important aspect of this is that through global migration, and the arrival for the first time in 
centuries of non-Western immigrants in Western Europe, global problems and conflicts whose center lie outside the West now are becoming domestic 'Western' problems as well. The most dramatic of these is clearly the Israeli-Palestinian conflict, but this is the case as well with much less widely contested issues such as the question of recognizing the Armenian genocide, the Dutch contribution to Pakistan's development of atomic weaponry in its race with India, or even something so small as France's attempts in recent years to prevent the Swiss scholar Tariq Ramadan from speaking freely in the Netherlands.

Similarly, a number of the more important Dutch public critics of Islam and/or of religion in the public sphere such as Herman Philipse, Ayaan Hirsi Ali, Leon de Winter and Bart Jan Spruyt have also been influenced by internationally movements, including conservative American think-tanks. Think-tanks which helped provide the blueprints for American relations to the Middle East and the Islamic world under Bush and that envision Europe as a prime battleground in the fight against violent Islamicist ideologies. Many of those arguing for the abolition of Article 23 share this vision, arguing against multiculturalism and state funding of schools with a religious/Islamic identity in the interests of protecting Dutch and Western cultural values and socio-political freedoms. This is merely to say that not only the new Dutch Islamicists but also the new Dutch 'conservatives' and secularists (not to mention other contenders in the public debate) have at times drawn some of their most important inspiration and ideas from abroad. The debates over religion's role in the Dutch public square a century ago were informed by international socialism and Catholicism; international influences are scarcely less important now, on either side of the issue.

At the same time, more generally, the various media, particularly the internet, continue to develop new ways in which religious practices and ideas from other countries and regions are reshaping the ways that the Dutch (and other Europeans) define their individual and collective religious outlook, whether in more diffuse forms of spirituality, more evangelical or Pentecostal forms of Christian practice, or, of course, the ways in which Islam is interpreted. In a word, under the conditions generated by globalization it becomes increasingly difficult to keep local and global spheres distinct, whether at the level of religion or politics or culture, and irrespective of the position from which one speaks: religious or secularist, Christian or Muslim, 'Western' or 'non-Western.' It should not come as a surprise, then, that some of those most vocal in the promotion of Western secularism within the West, and of the abolition of state funding for schools with a religious identity, should be immigrants of non-Western descent such as Ayaan Hirsi Ali and Afshin Ellian.

In this respect the question of religion, religious identity, and religious education's place in Dutch society is not so much a matter of a 'local' country finding ways to accommodate the challenging introduction of a foreign tradition and culture, but rather of the local elaboration of international and transnational encounters. Crucially, these local elaborations in turn shape global developments 
in a process of continual movement, deployment and revision taking place at all levels simultaneously, though not necessarily in concert with each other. In that sense to consider the state's relation to religion, the nature of its support for and constraint of religious education is also to address, if indirectly, the question of the Dutch response to (post)colonialism, globalization and migration. That is to say, these now have become domestic 'Dutch' issues; even as the large-scale, complex movement of peoples, money, goods and ideas that these entail put the continuity of 'Dutchness' and of established Dutch church-state relations and Dutch schooling under pressure.

Another important factor in considering the future of Article 23 and the place of the religious in the public sphere is that to remove state subsidy of religiouslyinformed educational institutions will likely have the effect of reducing state supervision of religious transmission. Putting an end to state subsidies for religiously-inspired institutions frees religious communities and institutions to develop much more idiosyncratically and independently than when they are subject to state requirements and supervision. At the same time, in search of alternative support, religious communities and the religious field may develop into a religious 'market' more similar to that found in the Us, in which the content and presentation of religious thought may be geared either to attracting the largest number of supporters or towards specializing in a niche-market, including at moments variously extremist ones. The result, then, is not only most likely to make the direction of religious practices, ideas and communities less predictable and more inclined towards differentiation and competition, but to stimulate a system in which the survival of religious communities depends precisely on their public visibility (Sengers 2006). In other words, to end state support of religious institutions may turn out to be one of the most effective ways of stimulating religions' public manifestation.

Finally, there is the issue of the state's own changing role in society as a result of globalization, the privatization of public services and individualization, among other factors - in general making it less able to fully address these kinds of issues. For some time, the state's response has been to present itself as a kind of mediator, seeking to ensure the widest range of choices for the voter-consumer, while reducing the direct influence it exerts on the institutions providing fundamental services and products to the voter. This has meant a real and perceived reduction in the power, effectiveness and influence of politicians, as well as encouraging a sense that there is an increasing gap between politicians and their constituents. Given politicians' decreased (sense of) control and influence over the institutions, forces and factors shaping our lives, they are decreasingly able to translate the concerns of voters into effective policy. One important response by politicians to this decreasing influence and effectiveness has been to turn to a 'politics of fear', in contrast to the ideologically sustained party politics we consider so characteristic of modernity. Today, to put it rather bluntly, rather than offering a vision of a new future, the task of the politicians becomes that of protecting us from the myriad dangers we produce in our (post)modern world (see Ulrich Beck 
on the 'risk society' and the production of catastrophic scenarios; Frank Furedi, more specifically, on the culture of fear among parents and its effects on education). This shift in strategy is allowing politicians to regain voters' attention and their influence, at moments with great drama, such as that which accompanied the rise of Pim Fortuyn. It comes to be in the politicians' interest to become highly skilled, on the one hand, at promoting and articulating a sense of imminent danger while, on the other hand, convincing the electorate they have the will and capability for addressing the threat. One effect of this has been the rise, at moments, of symbolic politics such as the Dutch Parliament's recent support for a wholesale ban on the burqa in the Netherlands while fewer than 100 women wear such Islamic covering (or, in the American case, the refusal to allow the Dubai Port Company to take over American holdings that would involve port security even as the UAE is one of the US's most important allies in the Middle East and closely involved in ensuring the security of American military there).

To what extent and in what ways might the debate around the abolition of Article 23 itself also potentially be an example of such symbolic politics? Serious consideration of this possibility is warranted particularly by the fact that Dutch voters themselves are more than willing to send their children to religiously-informed schools even when they themselves have an essentially secular worldview and lifestyle - if in part because many of these schools are not terribly religious in character. In any event, the question of abolishing Article 23 is perhaps predominantly an issue fueled by the needs of politicians and publicists rather than those of the voters themselves. The one exception to this, possibly, is the skittishness created among some Dutch by the growing presence of Islamic schools. In its most extreme form, the worry is that Islamic schools promote anti-Western, Islamicist and sexist ideologies and practices, a worry not born out by a series of school inspections, though a few of the schools were deficient in their organization and quality control. More generally, however, the worry is that such schools promote a separate and distinct 'Islamic' or ethno-Islamic identity among its students, in competition with, even disrupting their ability to identify themselves as first and foremost Dutch citizens.

More essential is the larger question this raises: what is to be the place of minorities in Dutch society? Since the 1960s, Dutch society has developed, for the first time, into a majoritarian society, displacing what before was a constellation of separate but equal religious and ideological collectivities. Dutch history has a long tradition of tolerance; but this was a structural tolerance that mediated the relations between communities of belief (and unbelief) without requiring that individual members be particularly tolerant. In fact, one could argue quite the opposite: that the separate but equal institutions of Dutch pillarized society enabled the equitable distribution of government monies and support across communities, while stimulating an intense distrust and intolerance between communities, particularly at the individual and ideological level. It is precisely this history of religiouslybased practices of intolerance within structures of tolerance that the Dutch fear will return through the support of minority communities, particularly, but not limited 
to, Islamic ones. In this sense, much of the upheaval of recent years and the processes we now see to question some of the most important inherited Dutch traditions, such as those of government support for minority education, can be explained as the Dutch today attempting to discover the new form their tolerance will take, of trying to discover how to actively practice tolerance at all levels, at a time when both national collectivity and (trans)national plurality are on the rise.

On the basis of the developments above the question, then, is: given the new forms of religion, the new forms of Dutch society, new global issues, and the reduced power of the state what is the best way to organize the relation between state and religion? As we have been at pains to argue, the fate of Article 23 cannot be answered in isolation, but requires a wider conceptualization about both the state's role in respect to religion's role in the public square and the Dutch experience with religious and secular education, within and beyond its current borders.

This essay has explored the ramifications of two positions left to the (Dutch) state at present in respect to its relationship with organized religion: state withdrawal and state involvement which, in the Dutch case, means a significant recalibration of its past involvement with organized religion. Withdrawal constitutes a break with the Dutch tradition. It means, of course, that the state does not structurally support religious communities. In increasing the distance between state and religion, however, it also loses sight of what is happening within religious communities and the possibility of directing developments. Withdrawal thus also may have the effect of freeing up religious communities to go their own way much more than when under close state supervision.

At the same time, in practice (looking, for example, at the United States), it turns out to be very difficult, almost impossible, to fully separate state and religion. So if this approach solves one set of problems (such as the knotty problem of distributing public resources and funding problematic groups), it creates a new set. In any event, it does not make the state 'neutral' but puts it in the position of promoting a particular secular vision and public space that has complex relations to the forms of religion in its midst. Such an approach will not so much 'privatize' religion as make the relationship between church and state more diffuse, less 'manageable' but perhaps also more dynamic. Dutch society - and the Dutch political leadership - will have to make decisions about whether it is willing to take on the potential risks and advantages of a freer religious market, or whether it can find fruitful ways to maintain, in a more pluralist society, the close relationship between religious and political life that was long the feature of public life within the Netherlands.

Should the Dutch state, however, choose to sustain its traditional strategy of involvement with religion in the future, this, too, will signal a break with Dutch tradition. Religious pluralism after all can no longer be effectively organized along structural, institutional lines as it used to be, as these depended on the maintenance of highly segregated socio-religious communities living apart from each other. Correspondingly, religious difference will have to be 'pacified' through 
developing new forms of interactive diversity which are not easily reconciled with the forms of segmentation with which the Dutch - still - are most familiar. The first question to be answered is whether the state is the best institution to promote such interactive diversity, or whether this is change which, in true democratic fashion, must come from below, through the aggregation of a multiplicity of changes at the grassroots, municipal and even individual level. Either way, such forms of interactive diversity depend on developing new forms of public contestation and collaboration, authority and decision-making that integrate traditional and newer Dutch and non-Dutch styles, institutions and ideals.

At the same time, precisely because of Dutch familiarity with segmentation, we are also seeing a host of initiatives whose result is, in fact, to transform the highly fragmented community of Dutch Muslims into a more coherent 'pillar' with its own umbrella organizations, elite representatives, media organs, and so forth. This effectively creates a negotiating partner, 'gesprekspartner' for the Dutch government as it seeks to respond most effectively to a quite substantial religious community. At the same time, however, given the extensive diversity of the Muslim community (along lines of belief, ethnicity, generation, etc.) and the absence of a centralized religious authority, it is the question if a coherent and effective Islamic pillar could ever be truly established. The very semblance of such a pillar simultaneously generates renewed fears that the Muslim schools and political parties inevitably stimulated by such institutionalized streamlining will actually increase conflicts and decrease the integration of Muslims. In other words, the fear is that state involvement with Muslims (among others) will serve to reinforce their difference and distance from mainstream Dutch society rather than becoming an instrument of integration as it was in the past.

In the end, the options open to the state are (not so much) those between involvement or withdrawal. It is on the one hand, between a model that 'manages' ethnic religious difference through fluidity or through more institutionalized, pillarized forms. On the other hand, it is between egalitarian and hierarchical forms of democratic pluralism, between a state that encourages grassroots participation or a form of democracy that stresses the top-down organization of public life. Ultimately, then, this is the question most fundamentally of how to conceive the future of Dutch democracy. This is not the choice between a 'problem' and a 'solution'; rather between multiple forms of state-religion and state-minority relations, each of which has its own traditions, challenges and resources for sustaining the coherence and future of the nation-state. The question is whether the democracy we have inherited from the recent past is adequate to the democracy we need today, under conditions of complex pluralism and globalization. This paper, written by two American academicians with many years of experience in the Netherlands, hopes to contribute to this discussion by conceptualizing, partly on the basis of international experience (not least the United States) the changing ways religion takes part in public life in response to the role the state endeavors to assign 'the religious.' 


\section{LITERATURE}

Azyumardi, A. (1997) 'A Hadhrami Religious Scholar in Indonesia: Sayyid 'Uthman', in U. Freitag and W.G. Clarence-Smith (eds.) Hadhrami Traders, Scholars, and Statesmen in the Indian Ocean, Leiden: E.J. Brill, 1997.

Groot G. (2006) 'Tweeslachtige neutraliteit. Godsdienst, onderwijs en het uniform van de Staat', blz. 294-301 in Marcel ten Hooven and Theo de Wit (eds.) Ongewenste goden. De publieke rol van religie in Nederland, Amsterdam: Boom.

Haller, Gret (2002) Die Grenzen der Solidarität .Europa und die USA im Umgang mit Staat, Nation und Religion, Berlin: Aufbau.

Philip Hamburger (2002) Separation of Church and State, Cambridge: Harvard University Press, 1-9.

Kaptein, Nico (1998) 'The Sayyid and the Queen: Sayyid 'Uthman on Queen Wilhelmina's Inauguration on the Throne of the Netherlands in 1898', Journal of Islamic studies 9,2: 158-177.

Kennedy, James (2006) 'Een religieus volk met een seculiere staat. De rol van religie in het Amerikaanse publieke leven' blz. 174-187 in Marcel ten Hooven and Theo de Wit (eds.) Ongewenste goden. De publieke rol van religie in Nederland, Amsterdam: Boom.

Kraemer, P.E. (1966) The Societal State, Amsterdam: Boom.

Monsma, Stephen V. and Christopher Soper (1997) The Challenge of Pluralism, Lanham: Rowman and Littlefield.

Rooden, Peter van (1996) Religieuze Regimes. Over godsdienst en maatschappij in Nederland, 1570-1999, Amsterdam: Bert Bakker.

Sengers, Erik (2006) Aantrekkelijke kerk. Nieuwe bewegingen in kerkelijk Nederland op de religieuze markt, Delft: Eburon.

Veer, P. T. van der (2002) Islam en het 'beschaafde' Westen: essays over de 'achterlijkheid' van religies, Amsterdam: Meulenhoff. 


\title{
13 EEN SCHETS EN EVALUATIE VAN DE KRITIEK OP DE OVERHEIDSFINANCIERING VAN HET BIJZONDER ONDERWIJS
}

\author{
Ben Vermeulen
}

\subsection{INLEIDING}

Religie heeft een belangrijke plaats in het Nederlandse onderwijsbestel, en vormt een belangrijk thema in de daarmee samenhangende politieke kwesties. De schoolstrijd, de in de negentiende en begin-twintigste eeuw gevoerde maatschappelijke en politieke strijd voor vrijheid en vervolgens ook overheidsfinanciering van religieus gefundeerd (bijzonder) onderwijs, is zelfs de basis geweest van de verzuiling en de politieke partijvorming.

Al lang staat de invloed van religie in het huidige onderwijsbestel echter onder kritiek. Vaak wordt gesteld dat zeker in het bekostigd bijzonder onderwijs aan religie geen enkele, of tenminste een veel beperktere rol dient toe te komen. Artikel 23 van de grondwet, waarin de vrijheid van het onderwijs inclusief de aanspraak op overheidsfinanciering van dit onderwijs vervat is, wordt door vele niet-confessionele partijen en stromingen gezien als een belangrijke belemmering van modernisering en verbetering van het onderwijsbestel. In hun optiek vormt dit artikel een instrument in handen van gevestigde, vooral confessionele, belangen dat noodzakelijke aanpassing van het bestel in de weg staat. Gesteld wordt onder meer dat overheidsfinanciering van het confessioneel onderwijs een fundamentele inbreuk maakt op het beginsel van scheiding van kerk en staat, en op het principe van de individuele autonomie van het kind. Daarnaast wordt frequent naar voren gebracht dat het onderscheid tussen openbaar en bijzonder onderwijs achterhaald is. En ten slotte wordt aangevoerd dat (financiering van) het bijzonder onderwijs de tendens naar segregatie langs etnische, religieuze en ideologische lijnen versterkt.

In deze bijdrage beperk ik mij tot een kort aanstippen van de huidige positie van religie binnen het primair en voortgezet onderwijs, en het geven van een beknopte evaluatie van de genoemde - belangrijkste - kritiekpunten ter zake.

\subsection{ONDERWIJSSTELSELS}

Wat in vergelijking met andere westerse onderwijsstelsels opvalt, is de grote omvang van wat we in Nederland bijzonder onderwijs noemen. Bijzonder onderwijs is dat onderwijs dat niet uitgaat van de overheid maar van door particulieren bestuurde rechtspersonen (verenigingen, stichtingen). In Nederland gaat ongeveer $2 / 3$ van alle leerlingen naar het bijzonder onderwijs. Het grootste deel van dit bijzonder onderwijs - zo'n go procent - gaat formeel uit van een godsdienst of levensbeschouwing (richting). Daarbinnen vormen het protestants-christelijk en 
katholiek onderwijs de hoofdstromingen. De laatste 15 jaar is sprake van een bescheiden groei van islamitische scholen, en een nog bescheidener groei van hindoe- en evangelische scholen.

Nogal eens wordt beweerd dat het Nederlandse stelsel vanwege deze positie van het bijzonder onderwijs uniek - en dus afwijkend - zou zijn. Daar valt evenwel over te twisten; of althans: die stelling moet genuanceerd worden. Alle westerse landen kennen naast een publieke sector van overheidsscholen ook een private sector van door particulieren bestuurde - veelal op een religie of levensbeschouwing gebaseerde - bijzondere scholen. Uit de in grondwetten en mensenrechtenverdragen gewaarborgde vrijheid van onderwijs vloeit het recht voort om bijzondere scholen op te richten en - mits ze voldoen aan de algemene basiskwaliteitseisen - de diploma's die deze scholen afgeven erkend te krijgen. Vermoedelijk vloeit uit de mensenrechtenverdragen evenwel geen harde juridische aanspraak op overheidsfinanciering voort. Of de overheid het bijzonder confessioneel onderwijs bekostigt is dus grotendeels afhankelijk van het nationale recht.

Mogelijk is het Nederlandse stelsel wel in zoverre uniek dat de omvang van het overheidsgefinancierd bijzonder onderwijs groter is dan elders; waarschijnlijk alleen Vlaanderen beschikt over een tak van bijzonder ('vrij') onderwijs met een vergelijkbare omvang. Een belangrijke verklaring is het gegeven van de volledige financiering van het bijzonder onderwijs en de historie van de verzuiling.

Het Nederlandse stelsel is echter niet uniek in de zin dat de overheid bijzondere, confessionele scholen financiert. Veeleer vormen stelsels waarin met een beroep op de scheiding van kerk en staat overheidsfinanciering van dergelijke scholen afgewezen wordt in West-Europa en Noord-Amerika de uitzondering. Anders dan critici van het Nederlandse bestel menen, wordt het confessionele (meestal katholieke) onderwijs bijvoorbeeld ook in Frankrijk gefinancierd (overigens slechts partieel, door lokale overheden). In sommige landen vormt wat wij bijzonder onderwijs noemen zelfs grotendeels onderdeel van het stelsel van overheidsscholen, denk aan Duitsland en het Verenigd Koninkrijk. En ook het onderwijssysteem in de Verenigde Staten, waarin met een beroep op de grondwettelijke scheiding van kerk en staat elke rechtstreekse overheidsfinanciering van confessioneel onderwijs afgewezen wordt, kent thans als gevolg van het arrestZelman (2002) ruimte voor indirecte overheidsfinanciering van zulk onderwijs, doordat aan ouders vouchers ter beschikking gesteld mogen worden die ook bij 'denominational schools' ingezet mogen worden.

\section{$13 \cdot 3$ SCHEIDING VAN KERK EN STAAT}

De stelling dat het Nederlandse duale bestel, waarin het openbare, neutrale overheidsonderwijs en het (veelal) confessioneel gekleurde bijzonder onderwijs op voet van gelijkheid door de staat gefinancierd worden, in strijd is met de scheiding van kerk en staat en de daaruit voortvloeiende neutraliteit van de overheid, is dan ook onjuist. Hooguit is dit bestel in strijd met een zeldzaam voorkomende, 
specifieke (overigens juridisch aanvaardbare) variant van de scheiding van kerk en staat.

Het is derhalve noodzakelijk voor ogen te hebben dat er niet één maar meerdere varianten van scheiding van kerk en staat zijn, die elk binnen de randvoorwaarden van de mensenrechtenverdragen toelaatbaar zijn. Er zijn daarin ten minste drie ideaaltypen te onderscheiden. Daarvan vormen twee ideaaltypen de uitersten van het spectrum, terwijl het derde ideaaltype zich ophoudt tussen beide 'polen'. Welke van deze typen is uitgekristalliseerd, en hoe daarbinnen het onderwijsbestel gestalte is gegeven, is vergaand bepaald door de specifieke historische ontwikkeling van het betreffende land. Daarbij is veelal sprake van mengvormen, waarin eigenschappen van meerdere ideaaltypen gecombineerd worden.

Aan de ene kant van het spectrum staan stelsels waarin geen sprake is van een scherpe scheiding van kerk en staat. In dergelijke stelsels heeft een bepaalde religie de status van heersende godsdienst, of hebben een of meer specifieke religies ten minste - formeel of in feite - de positie van door de staat bevoorrechte godsdiensten. In een dergelijk stelsel zullen de door de overheid bestuurde en door de overheid bekostigde scholen in het algemeen uitgaan van (de basiswaarden van) de heersende godsdienst of bevoorrechte godsdiensten, en zullen scholen die van een andere religie of levensbeschouwing uitgaan niet door de overheid bekostigd worden. Het Griekse systeem, met de dominante status van de Grieks-orthodoxe Kerk, en in zekere mate de door de orthodoxie gedomineerde stelsels in de OostEuropese landen zijn representanten van deze variant. In deze stelsels zijn de meeste scholen openbaar, in de zin dat ze direct of indirect van de overheid uitgaan; tegelijkertijd zijn ze veelal niet levensbeschouwelijk neutraal, maar gebaseerd op een specifieke orthodox-christelijke grondslag.

Aan de andere kant van het spectrum bevinden zich de stelsels die uitgaan van een strikte scheiding van kerk en staat. Deze kenmerken zich door een scherp onderscheid tussen enerzijds de door de overheid bestuurde en bekostigde scholen, die uitdrukkelijk levensbeschouwelijk neutraal zijn, en anderzijds door particuliere instellingen bestuurde en bekostigde scholen, die veelal levensbeschouwelijk gefundeerd zijn. Het standaardvoorbeeld van zo'n stelsel vormt dat van de Verenigde Staten, waar uitgegaan wordt van een 'wall of separation between Church and State' (Jefferson). Met een beroep op de grondwet werd daar tot voor kort elke vorm van financiering van scholen op religieuze grondslag, en elke vorm van invloed van religie op het onderwijs in door de overheid gefinancierde scholen afgewezen. Ook het Franse onderwijsbestel met zijn 1oo-procentoverheidsfinanciering van de publieke 'école laïque' en beperkte financiering van andere scholen, bevindt zich meer aan deze kant van het spectrum.

Min of meer in het midden tussen deze ideaaltypische polen bevinden zich onder meer het Nederlandse en Vlaamse onderwijssysteem. In dit systeem is geen sprake van een heersende, door de overheid bevoorrechte religie, en een daarmee corresponderende dominantie van die religie in het overheidsonderwijs. Het 
openbaar (door of vanwege de overheid bestuurde) onderwijs is levensbeschouwelijk neutraal. Anderzijds wordt de scheiding van kerk en staat niet zo stringent opgevat dat de overheid zich heeft te onthouden van subsidiëring van scholen op godsdienstige of levensbeschouwelijke grondslag. In Nederland worden dergelijke scholen, indien zij voldoen aan dezelfde of gelijkwaardige deugdelijkheidseisen als het openbaar onderwijs, zelfs voor 100 procent gefinancierd.

Het voorgaande sluit niet uit dat op andere gronden dan abstracte principes van overheidsneutraliteit kritiek op de dominante positie van het bijzonder-confessioneel onderwijs uitgeoefend kan worden. Deze komt in de navolgende paragrafen aan bod.

\subsection{VERVAGING VAN HET ONDERSCHEID TUSSEN OPENBAAR EN BIJZONDER ONDERWIJS}

Een tweede kritische stroming legt minder de nadruk op de scheiding van kerk en staat, en veel meer op het gegeven dat het onderscheid tussen openbaar-neutraal en bijzonder-confessioneel onderwijs al lang vervaagd is (zie bijvoorbeeld de bijdrage van Dodde in Bierens et al. 2006). Enerzijds hebben grote delen van het bijzonder onderwijs de verbinding met een bepaalde geloofsovertuiging losgelaten. De invloed van de oorspronkelijke richting op het onderwijs en het personeelsbeleid is veelal vergaand afgezwakt en soms zelfs nagenoeg verdwenen. Leerlingenselectie op basis van de richting vindt binnen de grote confessionele protestants-christelijke en katholieke stromingen al veel langer nauwelijks plaats.

Anderzijds is het openbaar onderwijs aan het 'verbijzonderen'. Al lang is dit onderwijs niet meer antireligieus en scherp secularistisch: de meeste openbare scholen zijn veeleer pluriform, proberen onpartijdig de veelheid aan overtuigingen te laten zien zonder daarin een standpunt te kiezen. Bovendien is het sinds een aantal jaren mogelijk dat het gemeentebestuur zijn openbare scholen 'op afstand zet', wat bijvoorbeeld kan gebeuren door het bestuur van deze scholen over te dragen aan een privaatrechtelijke stichting. In zo'n stichting is ouderinvloed op het bestuur gewaarborgd.

Een verdergaande ontwikkeling wordt gevormd door de introductie van organisatievormen waarbij openbaar en bijzonder onderwijs onder één bestuur gaan ressorteren, of zelfs binnen één school plaatsvinden. Sinds een aantal jaren is het zogenaamde samenwerkingsbestuur mogelijk, een bestuur dat zowel openbare als bijzondere scholen onder zich heeft. En sinds medio 2006 maakt een wijziging van het vierde lid van artikel 23 grondwet het mogelijk ook expliciet de ruimte te bieden voor de samenwerkingsschool, waar binnen het verband van één en dezelfde school zowel openbaar als bijzonder onderwijs aangeboden wordt. Overigens fungeren in de praktijk al langer enkele tientallen samenwerkingsscholen. 
Ten slotte moet geconstateerd worden dat de ouderinvloed op de schoolbesturen in het bijzonder onderwijs tanende is. Er is zowel in het voortgezet als thans ook het primair onderwijs een sterke trend naar schaalvergroting, waarbij onder één schoolbestuur vele - soms zelfs tientallen - scholen ressorteren. In het algemeen zullen deze schoolbesturen bemand worden door goedbetaalde professionals, ofwel feitelijk - beslissend krachtens een ruim mandaat namens het ouder/amateurbestuur - ofwel ook rechtens - doordat het ouder/amateurbestuur terugtreedt en de professionals ook in juridische zin het bestuur gaan uitmaken. Deze ontwikkeling wordt versterkt door het streven naar 'governance' (al dan niet voorafgegaan door termen als 'good' en 'educational'). Dit streven is erop gericht om een scheiding van bestuur en toezicht ook in het onderwijs in te voeren, waarbij de voorkeur bestaat voor een aparte raad van toezicht die het bestuur controleert. De meest voorkomende variant is die, waarbij het ouder/amateurbestuur omgevormd wordt tot raad van toezicht, en de tot dan in mandaat beslissende bovenschoolse directie promoveert tot (college van) bestuur. Een dergelijke omvorming heeft bijna vanzelf als gevolg dat de invloed van de identiteit - op welke titel en met welk oogmerk veel ouders in het bijzonder onderwijsbestuur zitten - verwatert ten gunste van de financieel-organisatorische afwegingen van managers.

Dit vervagen van de grenzen tussen openbaar en bijzonder onderwijs, dit naar elkaar toegroeien van de beide 'takken', en deze afzwakking van ouderinvloed roept natuurlijk de vraag op waarom eigenlijk nog aan het duale bestel vastgehouden zou moeten worden. Waarom zou het niet zo kunnen zijn dat alle leerlingen naar eenzelfde soort gemeenschappelijke, professioneel bestuurde school gaan, waarin de verschillende overtuigingen op voet van gelijkheid en zonder vooringenomenheid aan bod komen? Is dat niet veel beter met het oog op integratie en efficiency?

De eerste tegenvraag is dan echter hoe zo'n gemeenschappelijke school eruit zou moeten zien. Als die school de school voor allen is, moet het bestuur ervan dan niet noodzakelijkerwijs bij de overheid berusten, die daarbij heeft toe te zien op het algemeen-neutrale karakter van school en onderwijs? En betekent dat dan niet dat de invloed van anderen, zoals ouders en maatschappelijke organisaties, noodzakelijkerwijs nog verder teruggedrongen zal moeten worden?

Een tweede vraag is waarom verwatering van het onderscheid tussen openbaar en bijzonder onderwijs vanuit de critici bezien een argument zou moeten zijn om het op te heffen. Als het toch al één pot nat is, waarom dan nog over dat formele onderscheid zo moeilijk doen?

En een laatste tegenwerping luidt: wat te doen met die groep ouders - niet zo groot, maar ook niet zo verwaarloosbaar klein als de critici doen voorkomen - die voor hun kinderen nog immer onderwijs wensen met een uitgesproken religieus profiel? Wat te doen met scholen die nog immer kleur geven aan het onderscheid met het openbaar onderwijs, en waarin het amateur/ouderbestuur het nog wel in 
belangrijke mate voor het zeggen heeft? Ik vraag mij in gemoede af of het wel aangaat om de mogelijkheid van een school met een specifieke godsdienstige richting, met een klassiek ouderbestuur, uit te sluiten. Is het wel fair om daartoe als argument aan te voeren dat ze die school 'dan maar zelf moeten betalen', omdat godsdienst een privézaak is waaraan de overheid geen belastinggeld dient uit te geven, terwijl zij evengoed als alle anderen belasting betalen, en door die overheid via de leerplicht genoodzaakt worden hun kinderen naar school te sturen? Komt dus het streven naar een school voor allen niet neer op een onevenredige aantasting van vrijheden en keuzemogelijkheden?

\section{5 'WITTE' EN 'ZWARTE' SCHOLEN: ETNISCHE SEGREGATIE}

Daarnaast is er kritiek op de tweedeling in openbaar-neutrale en bijzonderconfessionele scholen, met name op de uitwerking ervan op leerlingen. Zo wordt veelal aan deze tweedeling toegeschreven dat al vanaf de jaren tachtig sprake is van een voortgaande opsplitsing van scholen langs etnische en sociaal-economische scheidslijnen, een trend die meestal aangeduid wordt met termen als 'witte en zwarte scholen', 'segregatie' en 'tweedeling'. Zo is het aantal 'zwarte scholen', door het ministerie gedefinieerd als scholen met 70 procent of meer allochtone achterstandsleerlingen (de zgn. 1,9-leerlingen), van 1998 tot 2004 gegroeid van 286 naar 343 scholen.

Alleen al uit de gebruikte terminologie valt af te leiden dat deze trend als maatschappelijk ongewenst gezien wordt. Deze perceptie ligt nogal voor de hand. Zo is de tweedeling in het scholenbestand vermoedelijk nadelig voor allochtone leerlingen met onderwijsachterstanden: een heterogene of overwegend 'witte' school vormt waarschijnlijk een gunstiger milieu om deze achterstanden te verminderen dan een 'zwarte' school. Met name is het plausibel dat het leren van de Nederlandse taal voor een allochtone leerling gemakkelijker is in een schoolsituatie waarin de meerderheid van de leerlingen van huis uit Nederlands spreekt, en waarin het Nederlands de dominante taal op het schoolplein is. Daarnaast zal het integreren van minderheden in een dominante 'witte' cultuur en het aankweken van begrip voor de eigen waarde en betekenis van allochtone culturen veelal eenvoudiger gaan wanneer leerlingen uit de verschillende groepen elkaar in het onderwijs dagelijks tegenkomen. Simpel gezegd: het ligt voor de hand dat autochtone en allochtone kinderen eerder vriendschappen sluiten en waardering voor elkaar hebben wanneer zij elkaar op school ontmoeten, dan wanneer zij naar verschillende scholen gaan.

Verklaringen voor het ontstaan van witte en zwarte scholen zijn onder meer te vinden in een studie van Karsten en anderen uit 2002. Uit deze studie - door de Onderwijsraad in de verkenning Vaste grond onder de voeten (2002) als uitgangspunt genomen - blijkt dat de vorming van 'witte' en 'zwarte' scholen primair samenhangt met de bevolkingssamenstelling in met name de grote steden. Scholen zijn veelal 'zwart' omdat ze in 'zwarte' wijken staan; ze zijn veelal 'wit' omdat ze in 'witte' wijken gelegen zijn. Daarnaast is (aldus Karsten et al. 2002) het 
schoolkeuzegedrag van de onderwijsconsumenten - ouders, leerlingen - in de vorm van een 'witte vlucht' en een zekere voorkeur van allochtone ouders voor openbare en islamitische scholen een oorzaak voor de etnische tweedeling in scholen. Voor een deel hangt deze tweedeling daarnaast samen met de opdeling van het voortgezet onderwijs in verschillende schoolsoorten. 'Zwarte' middelbare scholen zijn meestal vmbo-scholen; havo/vwo-scholen zijn meestal wit. Ten slotte vloeit deze tweedeling in beperkte mate voort uit selectie- en profileringsgedrag van bijzondere en openbare scholen. Meestal gaat het om bijzondere scholen met een orthodoxe identiteit, en om bijzondere en openbare scholen met een wat elitaire inslag. Van deze factoren is de laatstgenoemde - het beleid van scholen - de minst belangrijke, zoals ook de commissie-Blok, de parlementaire commissie die in 2004 haar bevindingen ter zake van het integratiebeleid publiceerde, heeft geconcludeerd.

In lijn hiermee constateert de regering in de brief Onderwijs, Integratie en Burgerschap, dat het bijzonder onderwijs een belangrijk deel van de achterstandsleerlingen voor zijn rekening neemt, en dat de segregatie dan ook slechts in beperkte mate aan denominatief gekleurd toelatingsbeleid te wijten is. Generaliserend: de segregatieproblematiek is in belangrijke mate onafhankelijk van de positie van het bijzonder-confessioneel onderwijs binnen een nationaal bestel. Dat blijkt ook wel uit het feit dat deze problematiek zich in dezelfde omvang of nog ernstiger mate voordoet in andere landen met een heel ander stelsel, waarbinnen de omvang van het bijzonder onderwijs veel kleiner en zwakker is.

Een en ander lijkt bevestigd te worden door de verdeling van achterstandsleerlingen in het primair onderwijs over openbaar en bijzonder onderwijs. Daaruit blijkt dat er een lichte oververtegenwoordiging is van het openbaar onderwijs waar het gaat om de allochtone achterstandsleerlingen. Als een beperkt deel van deze leerlingen van het openbaar naar het bijzonder onderwijs zou overstappen is, zou er op systeemniveau sprake zijn van evenredigheid. En wat betreft de zogenaamde 1,25-leerlingen, de autochtone achterstandsleerlingen, is overigens sprake van een perfecte 'match' (Onderwijsraad 2002).

\subsection{ISLAMITISCHE SCHOLEN}

Voor een (beperkt) deel vloeit de tweedeling in 'witte' en 'zwarte' scholen voort uit de toename van het aantal islamitische scholen, die bijna per definitie 'zwart' zijn. Zoals gezegd hebben 'zwarte' scholen een leerlingenbestand dat in meerderheid bestaat uit allochtone achterstandsleerlingen. In de politiek leeft de opvatting dat islamitische scholen ongewenst zijn, omdat (a) binnen deze scholen de integratie van leerlingen onvoldoende plaatsvindt en (b) in deze scholen mogelijk gedachtegoed verspreid wordt dat strijdig is met de beginselen van de democratische rechtsstaat.

Het is de vraag of deze aannames juist zijn. Begin 2002 bracht de Binnenlandse veiligheidsdienst een rapport uit, getiteld De democratische rechtsorde en islami- 
tisch onderwijs. In dat rapport concludeerde de BVD dat zich op een ruime meerderheid van de islamitische onderwijsinstellingen in Nederland weinig zaken voordoen die schadelijk zijn voor de democratische rechtsorde. Wel stelde de BVD dat bepaalde buitenlandse orthodox-islamitische organisaties in enkele van die instellingen invloed hadden verworven. Eind 2002 publiceerde de onderwijsinspectie een rapport, Islamitische scholen en sociale cohesie, waarin zij concludeerde dat bijna alle islamitische scholen een positieve rol vervullen bij het bevorderen van de condities waaronder sociale cohesie tot stand kan komen. Op dit rapport werd evenwel, vooral op methodologische gronden, nogal wat kritiek geuit. Naar aanleiding van een algemeen overleg van de vaste Kamercommissie van OC\&W met de minister over het rapport werd de inspectie om een nader onderzoek gevraagd. In oktober 2003 bracht de inspectie het vervolgonderzoek uit (Islamitische scholen nader onderzocht), waarin zij het volgende vaststelde:

"De belangrijkste conclusie is dat geen bevindingen zijn gedaan, die tot onrust zouden moeten leiden of tot ernstige ontevredenheid. Het onderwijs is niet in strijd met de basiswaarden van de democratische rechtsstaat, en de onderzochte scholen bevorderen in meer of mindere mate de condities die de integratie van leerlingen ten goede komen. De onderwijskansen die islamitische scholen leerlingen bieden zijn niet zoveel anders (soms wat beter) dan op vergelijkbare (zwarte) scholen."

Wel stelde de inspectie vast dat de pedagogisch-didactische kwaliteit van het godsdienstonderwijs op veel scholen nog te wensen overlaat, en wees zij op de bestuurlijke kwetsbaarheid van het islamitisch onderwijs. Niettemin was de overkoepelende conclusie van de inspectie dat met het islamitisch onderwijs niet zoveel mis is.

Overigens, ook als de inspectie onverhoopt wel had moeten concluderen dat het onderwijs aan bepaalde islamitische scholen in strijd is met de basiswaarden van de democratische rechtsstaat, en zich richt tegen integratie in de Nederlandse samenleving, dan nog zie ik niet goed hoe dat een argument zou dienen te zijn om de overheidsfinanciering van het gehele bekostigde bijzonder onderwijs te staken. Waarom zou er dan niet mee volstaan kunnen worden om de bekostiging van die specifieke scholen in te trekken, en indien daarvoor termen zijn de rechtspersonen die deze scholen in stand houden op grond van redenen van openbare orde te ontbinden? Waarom het kind met het badwater weggooien?

\subsection{IDEOLOGISCHE SEGREGATIE}

Met de voorgaande punten samenhangend, maar daarvan te onderscheiden, wordt veelal een andere argumentatie ontwikkeld. Het confessioneel-bijzonder onderwijs - aldus deze argumentatie - gaat uit van een specifieke religieuze ideologie die leerlingen door zijn eenzijdige, soms indoctrinerende opstelling kennis en aanraking met alternatieve overtuigingen en met leerlingen van andere gezindten onthoudt. Daardoor veroorzaakt dit onderwijs religieus-culturele 
apartheid, bestendigt het ook de etnische scheidslijnen en is het een oorzaak van verdere maatschappelijke desintegratie. Dat is juist nu problematisch, nu het onderwijs zo belangrijk is als noodzakelijk instrument voor integratie en burgerschapsvorming. Vaak gaat deze kritiek gepaard met de opvatting dat religie een particulier-subjectief (zelfs irrationeel) fenomeen is. Als men religieuze overtuigingen wil overdragen, dan moet men dat maar in de privésfeer doen. In ieder geval moet de overheid afzien van financiering en ondersteuning van onderwijsinstellingen die zulks tot doel hebben.

Het is lastig om de juistheid van deze argumentatie op waarde te schatten. Er is tot op heden weinig empirisch bewijs dat religieus gefundeerd onderwijs daadwerkelijk in grote omvang de hiervoor aangestipte negatieve gevolgen heeft. Onderzoek naar de invloed van het schoolklimaat op onderwijsprestaties komt vooral uit de Verenigde Staten. Coleman, Hoffer en Kilgore (1982) kwamen in het begin van de jaren tachtig voor het eerst met een onderzoekspublicatie die aantoonde dat leerlingen op katholieke scholen in Amerika systematisch betere schoolresultaten behaalden dan hun leeftijdgenoten op publieke scholen. De onderzoeken van Coleman et al. concentreerden zich op resultaten als reken- en taalvaardigheid. Latere onderzoeken tonen echter aan dat leerlingen op katholieke scholen ook hun burgerschapscompetenties beter uitbouwen. Deze leerlingen ontwikkelen een groter maatschappelijk bewustzijn en zijn eerder geneigd tot sociale participatie. Verder laten leerlingen van katholieke scholen een ruimere vaardigheid zien in burgerschapsactiviteiten (zoals het houden van voordrachten, het organiseren van bijeenkomsten en het schrijven van brieven aan onbekenden) en beschikken ze over een groter vertrouwen om deze vaardigheden in de praktijk te brengen. Tot slot laten de onderzoeken zien dat deze leerlingen een grotere kennis bezitten over politieke aangelegenheden en toleranter staan tegenover mensen met een afwijkende opvatting of ideologie. Dit verschil tussen katholieke en publieke scholen bleef ook bestaan na controle op sociale achtergrondkenmerken van leerlingen (o.a. opleidingsniveau en mate van sociale participatie van ouders) en na correctie voor het gegeven dat sommige katholieke scholen vrijwilligerswerk of een maatschappelijke stage verplicht aan hun leerlingen opleggen (Campbell 2001).

Als verklaring (die ik mede aan Fons van Wieringen ontleen) voor de betere prestaties wordt gewezen op de aanwezigheid van sociale netwerken die van katholieke scholen een bijzondere 'community' maken. Deze sociale netwerken, die bepalend zijn voor het heersende schoolklimaat, bestaan uit een mix van zowel brede als losse sociale verbanden. Aan de ene kant worden 'value communities' onderscheiden. Katholieke scholen in de Verenigde Staten dragen min of meer vanzelfsprekend waarden uit die zij ontlenen aan hun religieuze achtergrond. Maar een waardegemeenschap kan zich ook concentreren rond een bepaalde instructiemethode (bijv. Montessori) of een strikte discipline (bijv. Britse kostscholen). Aan de andere kant worden 'functional communities' onderscheiden. Hiermee wordt verwezen naar hechte sociale verbanden die een hoge frequentie van sociale interactie vertonen - binnen en buiten schooltijd. De over- 
lap van waarde- en functionele gemeenschappen is van belang voor een schoolklimaat dat een positief effect heeft op de ontwikkeling van burgerschaps- en sociale beroepscompetenties. Publieke scholen kunnen een extensie zijn van een functionele gemeenschap, maar vormen vaak geen waardegemeenschap. En seculiere private scholen vertegenwoordigen meestal waardegemeenschappen, maar hebben vaak geen functionele component. Katholieke scholen in de Verenigde Staten blijken structureel beide soorten gemeenschapskenmerken te combineren (Campbell 2001; zie nader Glenn en De Groof 2005, Vol. I: 6-16).

Het is evenwel onduidelijk in hoeverre de Coleman-these naar de Nederlandse situatie getransponeerd kan worden. Deze these heeft betrekking op katholieke scholen in de specifieke setting van de VS. Het is de vraag of de betreffende bevindingen ook opgaan voor de Nederlandse situatie, met een sterk gediversificeerd scholenbestand, waarbij het merendeel van de bijzondere confessionele scholen een sterk verwaterde identiteit heeft. In 2000 concludeerde Dijkstra dan ook dat over de effecten van de verzuiling (het Nederlandse stelsel van openbaarneutraal en bijzonder-confessioneel onderwijs) op de wijze waarop het onderwijssysteem zijn functies vervult maar weinig empirisch valide kennis bestaat, al is er enige aanwijzing voor een wat gunstiger score van het bijzonder onderwijs (Dijkstra 2000: 258).

Recenter onderzoek van Dronkers en Robert (2004) maakt niettemin aannemelijk dat voor Nederland en 18 andere OESO-landen geldt dat leerlingen van private, overheidsafhankelijke scholen (bijzondere scholen) beter presteren dan vergelijkbare publieke scholen, wederom na controle voor de sociaal-wetenschappelijke, demografische, gedrags- en houdingskenmerken van leerlingen. In de conclusie van hun onderzoek stellen Dronkers en Robert (2004: 189-190) dat de verschillen in schoolprestaties in hoofdzaak verklaard worden door het gunstiger schoolklimaat op private, overheidsafhankelijke scholen: "de leerlingen gedragen zich beter en het moreel van het docentencorps is hoger." De onderzoekers vermoeden dat door een relatief losse toegangsselectie de private, overheidsafhankelijke scholen meer moeten investeren in een effectief schoolbeleid om goede schoolprestaties te garanderen. Het betere schoolklimaat lijkt daarbij het meest succesvolle middel te zijn. Het doel van schoolbeleid is het vormen van een schoolklimaat dat aanzet tot sociaal actieve deelnemers. De basis van zo'n schoolklimaat dat uitgaat van een 'community'-gedachte, wordt gevormd door het cultiveren van een waardegemeenschap, bestaande uit gedeelde en te delen normen en waarden die voor een reëel deel samenvalt met functionele netwerken van deelnemers binnen en buiten de schoolomgeving.

De bevindingen van Dronkers en Robert (2004) hebben weliswaar ook op Nederland betrekking, maar zij zijn naderhand wat afgezwakt (Corten en Dronkers 2005); bovendien zien hun bevindingen niet zozeer op sociaal-morele houding, maar op cognitieve prestaties. Maar in ieder geval is tot op heden niet aangetoond dat leerlingen op religieus gefundeerde scholen in intellectuele zin minder presteren. En evenmin is aannemelijk gemaakt dat zij zich meer dan andere leerlingen 
tegen andersdenkenden afzetten, minder bereid zijn zich voor de gemeenschap in te zetten, et cetera (Braster en Zwanenburg 1998). Zo is tot nu toe niet gebleken dat de burgerschapscompetenties van leerlingen in het openbaar onderwijs superieur zijn aan die van leerlingen in het confessioneel onderwijs.

\subsection{AANTASTING VAN DE AUTONOMIE VAN HET KIND}

Met de voorgaande punten samenhangend, maar daarvan te onderscheiden, is ten slotte een argumentatie die het confessioneel onderwijs verwerpt, omdat dat de autonomie van het lerende kind zou aantasten (zie bijvoorbeeld de bijdragen van Bierens/Van Schie en Van den Berg in Bierens 2006). Het confessioneel bijzonder onderwijs gaat - zo wordt daarin gesteld - uit van een specifieke religieuze ideologie. Het onthoudt leerlingen door zijn eenzijdige - soms indoctrinerende opstelling relevante kennis en aanraking met alternatieve overtuigingen en andere gezindten. Aldus handelt dit onderwijs in strijd met de autonomie van het kind. Dit principe van de individuele autonomie brengt met zich mee dat het onderwijs moet volstaan met het aanreiken van alternatieve normatieve stelsels, zonder daar een eigen voorkeur voor uit te spreken. Waar het om gaat is dat het jonge individu op objectieve wijze een palet aan overtuigingen aangereikt krijgt, en aldus in staat gesteld wordt daaruit in vrijheid te kiezen. Als men al religieuze overtuigingen wil overdragen, dan moet men dat maar in de privésfeer doen. In ieder geval moet de overheid afzien van financiering en ondersteuning van de confessionele onderwijsinstellingen die zulks tot doel hebben.

Het is lastig om de juistheid van deze argumentatie op waarde te schatten. $\mathrm{Zij}$ gaat - als ik het goed zie - niet zo ver dat ouders hun kinderen ook binnen de sfeer van het gezin niet conform een godsdienst of een ander stelsel van normen en waarden zouden mogen opvoeden. Zou dat wel zo zijn, dan zou deze opvatting strijdig zijn met de in mensenrechtenverdragen neergelegde opvoedingsvrijheid, en de deur wagenwijd openzetten voor een diep in de privésfeer ingrijpende overheidsbemoeienis en staatspedagogiek. Zij gaat ook niet zo ver dat het ouders verboden wordt om binnen de eigen privaat gefinancierde instellingen - waaronder scholen - hun godsdienst aan hun kinderen te doen overdragen: ook die vrijheid is in de mensenrechtenverdragen gewaarborgd. Blijkbaar gaat het er slechts om dat de overheid daar geen positieve, financiële bijdrage aan zou mogen leveren.

De vooronderstelling in deze opvatting is dat het mogelijk en wenselijk is dat kinderen na verloop van tijd vanuit een blanco situatie in vrijheid kunnen kiezen uit verschillende leefstijlen en waardestelsels. Ik betwijfel allereerst of dat werkelijk kan. Aan de hand waarvan zou dan immers gekozen moeten worden? Waar haalt het opgroeiende kind zijn criteria vandaan op grond waarvan voor de ene dan wel de andere visie, de ene dan wel de andere levensstijl gekozen wordt? Ook als die criteria niet mede door de school aangereikt worden, dan nog zullen zij van buitenaf - het gezin, de peergroup, de media - in meerdere of mindere mate van dwingendheid overgedragen worden. De idee dat het opgroeiende kind 
vanuit het niets zijn levensplan trekt en ongehinderd door externe factoren in een cafetaria van levensvisies zijn vrije keuze maakt lijkt mij een fictie.

Tegengeworpen zou kunnen worden dat dat wel waar moge zijn, maar dat althans de (overheidsgefinancierde) school niet tot taak mag hebben het keuzeproces te beïnvloeden. Maar waarom zou dat niet mogen? Ik vermag, ten eerste, niet in te zien wat erop tegen is dat ouders opteren voor een school waarvan het ethos in het verlengde ligt van de thuis overgedragen normen en waarden. Wat is ertegen dat zij ervan uitgaan dat het ingroeien in een coherente levensvisie een goede basis vormt om tot volwaardig mens uit te groeien, zonder dat dat overigens uitsluit dat de betrokkene na verloop van tijd toch andere keuzes maakt (Thiessen 1993: 237, 246-247)?

Natuurlijk, de op school uitgedragen visie dient aan bepaalde randvoorwaarden te voldoen. Zij dient zich te bewegen binnen de grenzen getrokken door de democratische rechtsstaat, en moet voldoen aan de door de onderwijswetgeving gestelde eisen, inclusief eisen gericht op het bijbrengen van bepaalde algemene basiswaarden, burgerschapsvorming etc. Maar het is moeilijk na te volgen waarom ouders niet binnen die randvoorwaarden mogen opteren voor een school die van een eenduidige religieuze of levensbeschouwelijke visie uitgaat. Waarom zou een overheid die mogelijkheid niet mogen faciliteren door dergelijke scholen op voet van gelijkheid met neutrale scholen te financieren?

Daarbij komt dat er geen empirisch bewijs voorhanden is dat een dergelijke optie binnen de onderwijsstelsels van de westerse staten in het algemeen negatief voor de leerling of de maatschappij uitpakt. Wat er aan - ik geef toe, beperkt - onderzoek is wijst erop dat leerlingen van bijzondere scholen met een uitdrukkelijk religieus ethos in het algemeen zelfs wat beter dan leerlingen van neutrale scholen scoren op onderwijsprestaties en burgerschapscompetenties.

In dit verband kan zeker niet uitgesloten worden dat bepaalde confessionele scholen juist vanuit hun religieuze ethos beter in staat zijn de waarden zoals respect, tolerantie en mededogen bij te brengen die ook de critici zo belangrijk vinden. Het zou wel eens zo kunnen zijn dat dergelijke scholen juist, omdat zij uit kunnen gaan van een normatieve traditie en deze kunnen 'voorleven', beter tot waardenoverdracht in staat zijn dan scholen die gebonden zijn aan de taak om in de vorm van neutrale kennisoverdracht een variatie aan tradities de revue te laten passeren.

Het komt mij voor dat er in feite voor gepleit wordt dat de overheid aan (al) het bekostigd onderwijs het ideaal van individuele autonomie en persoonlijke vrijheid oplegt. Mijns inziens is dat, gezien het voorgaande, niet nodig en zelfs disproportioneel. De democratische rechtsstaat dient vergaand ruimte te laten voor pluriformiteit, waarbinnen onder randvoorwaarden ook grote ruimte is voor alternatieve idealen van meer collectieve aard. 


\subsection{AFRONDENDE BESCHOUWINGEN}

De meeste critici van overheidsfinanciering van het bijzonder onderwijs worden gedreven door oprechte zorgen en wezenlijke idealen. Toch meen ik dat hun kritiek onvoldoende hout snijdt.

Het verwateren van het onderscheid tussen openbaar en bijzonder onderwijs is moeilijk als argument op te voeren: als het onderscheid er niet meer toe doet, waarom zou je je dan nog druk maken over opheffing ervan? Overigens: ik meen dat het onderscheid nog wel betekenis heeft. Maar de verwijten die met name jegens het sterk confessionele deel van het bijzonder onderwijs geuit worden zijn onvoldoende steekhoudend. Het beroep op de scheiding van kerk en staat ziet voorbij aan de variatie van acceptabele invullingen die aan dit principe gegeven kunnen worden. Het bijzonder onderwijs is slechts in beperkte mate debet aan de etnische segregatie. Er zijn geen aanwijzingen dat het religieuze karakter van bepaalde bijzondere scholen afbreuk doet aan de onderwijsprestaties en burgerschapscompetenties van de leerlingen. En tegenover het beroep op de persoonlijke autonomie kan evengoed aangevoerd worden dat religieuze socialisatie een stevige bodem kan verschaffen op basis waarvan de leerling geleidelijk een eigen gekozen levenspad in kan slaan.

Nederland is en blijft een land van minderheden. Dat betekent mijns inziens dat de staat - ook in het onderwijsbeleid - zo min mogelijk uit moet gaan van een inhoudelijk mensbeeld. Zelfs het ideaal van de persoonlijke autonomie acht ik in dat verband te omvattend, te inhoudelijk om als het door alle scholen te realiseren doel te fungeren. Veeleer dient er voldoende ruimte te blijven voor alternatieve principes, uiteraard binnen door de wet getrokken minimumgrenzen. De democratische rechtsstaat dient een open huis te zijn, met zeer verschillende leefruimten waarin ook minderheden van religieuze en andere snit zich thuis kunnen voelen. 


\section{LITERATUUR}

Bierens, W.S.P., C.L.C. Richert en P.G.C. van Schie (red.) (2006) Grondrechten gewogen. Enkele constitutionele waarden in het actuele politieke debat, Den Haag: Teldersstichting.

Boef, A.H. den (2003) Nederland seculier!, Amsterdam: Van Gennep.

Braster, J.F.A. en M.A. Zwanenburg (1998) Geloof in levensstijl. Een empirisch onderzoek onder de Nederlandse jeugd, Erasmus Universiteit Rotterdam.

Campbell, David E. (2001) 'Making Democratic Education Work - Schools, Social Capital, and Civic Education', EducationNext, http://media.hoover.org/documents/ ednext20o1zunabridged_campbell.html.

Coleman, J.S., T.B. Hoffer and S. Kilgore (1982) High School Achievement: Public, Catholic, and Other Private Schools Compared, New York: Basic Books.

Coleman, J. (1988) 'Social capital in the creation of human capital', American Journal of Sociology, 94, Issue Supplement, S95-S120.

Corten, R. en J. Dronkers (2005) 'Schoolprestaties van leerlingen uit de lagere strata op openbare, bijzondere en privé-scholen: een cross-nationale test van de Coleman \& Hoffer-these', Pedagogische Studiën 205-222.

Dijkstra (200o) 'Opbrengsten van onderwijsvrijheid. Over de effecten van verzuild onderwijs', blz. 243-26o in: T.J. van der Ploeg et al., De vrijheid van onderwijs, de ontwikkeling van een bijzonder grondrecht, Utrecht: Lemma.

Dronkers, J. en P. Robert (2004) 'De effectiviteit van openbaar en bijzonder onderwijs: een crossnationale analyse’, Mens $\mathbb{\&}$ Maatschappij, jaargang 79, 2: 170-192.

Glenn, Ch. en J. de Groof (2005) Balancing Freedom, Autonomy and Accountability in Education (3 vols.), Nijmegen: Wolf Legal Publishers.

Hegener, M. (2005) Vrijheid van godsdienst, Amsterdam/Antwerpen: Contact.

Jong, M.J. de (1998) Waardenopvoeding en onderwijsvrijheid, Katholieke Universiteit Nijmegen.

Leest-Borst, A. van (2005) Fundamentalistische opvoeding vanuit liberaal-democratisch perspectief, Enschede.

Onderwijsraad (2002) Vaste grond onder de voeten, Den Haag 2002.

Thiessen, E.J. (1993) Teaching for Commitment: Liberal Education, Indoctrination, and Christian Nurture, Montreal: McGill-Queen's University Press.

Wolf, P.J. and S. Macedo (eds.) (2004) Educating citizens. International perspectives on civic values and school choice, Washington D.C.: Brookings Institution Press. 


\title{
14 HORIZONTALE TRANSCENDENTIE EN NORMATIEVE PROFESSIONALISERING: DE CASUS GEESTELIJKE VERZORGING
}

\author{
Harry Kunneman
}

\subsection{INLEIDING}

Geestelijk verzorgers vormen een relatief kleine beroepsgroep die nauwelijks aan de weg timmert. ${ }^{1}$ Het is desalniettemin begrijpelijk dat in deze studie twee bijdragen betrekking hebben op geestelijke verzorging: de ontwikkelingen in dit werkveld vormen een boeiende casus in het kader van de discussies rond de rol van religie en levensbeschouwing in het publieke domein. Daarbij gaat het mij met name om een problematiek die in deze discussies meestal op de achtergrond blijft, namelijk de bijzonder positie die religie, levensbeschouwing en moreel beraad innemen binnen semi-publieke organisaties zoals justitiële inrichtingen, de krijgsmacht, ziekenhuizen, verpleeg- en verzorgingshuizen, de GGZ, de jeugdzorg en het openbaar onderwijs. Omdat hier existentiële vragen en morele waarden in het geding zijn die de privé-overtuigingen van de betrokken burgers tegelijkertijd raken en overstijgen, nemen dergelijke organisaties een interessante en spanningsvolle middenpositie in tussen enerzijds de privésfeer en anderzijds het publieke domein in wijdere zin. Het gaat hier bijvoorbeeld om vragen rond moraliteit en burgerschap in het openbaar onderwijs, om goede zorgverlening aan ouderen in verpleeghuizen, om humane detentie en resocialisatie in justitiële inrichtingen of om verantwoord handelen van militairen in crisissituaties. Mogelijke antwoorden op dergelijke vragen bevinden zich op het snijvlak van professionele kennis, levensbeschouwelijke tradities en de persoonlijke overtuigingen van de betrokkenen. $\mathrm{Zij}$ hebben enerzijds een specialistisch karakter, omdat zij verweven zijn met bijzondere kenmerken en problemen van de maatschappelijke domeinen in kwestie en specifieke wetenschappelijke en professionele expertise in het geding brengen. Anderzijds hebben de vragen die hier aan de orde zijn een wijdere maatschappelijke relevantie. Zij raken aan fundamentele morele dilemma's en achterliggende zingevingsvragen, zoals bijvoorbeeld zichtbaar wordt in de discussie rond de 'pyamadagen' in verpleeghuizen of het gedrag van militairen tijdens uitzendingen, of het overlijden van een meisje als Savannah, ook al was haar moeder omstuwd door hulpverleners. De omgang met die vragen kan bovendien niet goed ondergebracht worden in het model van de burger of consument die op grond van eigen overtuigingen in vrijheid politieke keuzes maakt of goederen of diensten afneemt. Leerlingen, verpleeghuisbewoners, gevangenen, uitgezonden militairen of cliënten van de jeugdzorg hebben nauwelijks keuzevrijheid en slechts een geringe invloed op geldende regels en procedures binnen de organisaties in kwestie, ook al grijpen die soms diep in hun leven in. ${ }^{2}$

In het licht van de scheiding tussen kerk en staat is het opmerkelijk dat in bijna al deze organisaties geestelijk verzorgers te vinden zijn die uit publieke middelen 
bekostigd worden. De kern van hun werk wordt gevormd door persoonlijke gesprekken over existentiële en morele vragen, in het bijzonder vragen rond ervaringen van begrenzing, eindigheid en verlies, maar ook morele vragen rond solidariteit en zorg die doorgaans met existentiële vragen verbonden zijn. Daarnaast begeleiden geestelijk verzorgers groepsgesprekken, leiden zij rituelen, geven zij ethiekonderwijs en zijn zij betrokken bij beleidsontwikkeling op het gebied van ethische en morele vragen binnen de organisaties waar zij werkzaam zijn.

Aan de hand van de dilemma's en uitdagingen die in het verlengde hiervan voor geestelijk verzorgers opdoemen, wil ik in dit hoofdstuk een bijdrage leveren aan de zoektocht die ook in een aantal andere bijdragen in deze verkenning aan de orde is. Het gaat hier om pogingen beweging te brengen in de herhaling van zetten die een groot deel van het debat rond de rol van religie en levensbeschouwing in het publieke domein te zien geeft. De meeste bijdragen aan dit debat staan in het teken van historische constellaties die (in ieder geval in ons land) niet meer van toepassing zijn, maar nog steeds hun donkere schaduwen over het debat werpen, met als gevolg dat bijdragen aan de discussie bijna onweerstaanbaar naar een van de volgende twee polen gezogen worden. Aan de ene pool worden religie en levensbeschouwing systematisch in verband gebracht met dogmatisme en moreel imperialisme, waartegenover dan individuele (keuze)vrijheid als centrale waarde wordt geponeerd en volledige neutraliteit van de overheid wordt geëist op het gebied van religie en levensbeschouwing. Daartegenover wordt aan de andere pool met grote kracht gehamerd op het belang van bovenindividuele waarden en van omvattende zingevingskaders, in het bijzonder religieuze tradities. Die zouden niet alleen een noodzakelijke bedding bieden voor het omgaan met onontkoombare bestaansvragen, maar ook een culturele humuslaag voor morele waarden, in het bijzonder maatschappelijke solidariteit. In het verlengde daarvan zou de overheid religieuze en levensbeschouwelijke organisaties en hun aanwezigheid in het publieke domein actief moeten ondersteunen en bevorderen.

Aan de hand van de historische ontwikkeling van het geestelijk werk en de uitdagingen waar deze beroepsgroep mee geconfronteerd wordt, wil ik de contouren schetsen van een zoekrichting die voorbij de complementaire eenzijdigheid van deze twee dominante posities wijst. Twee richtingwijzers zijn voor die zoekrichting van bijzonder belang.
a. De uitwaaiering van zingevingsstijlen en de erosie van morele betrokkenheid In de eerste plaats is de associatie van religie en levensbeschouwing met dogma- tisme en moreel imperialisme sociologisch gezien volledig achterhaald, althans wat ons land betreft. Met uitzondering van een aantal marginale fundamentalisti- sche kerkgenootschappen en (in omvang nog beperktere) groepen die fundamen- talistische en extremistische versies van de islam aanhangen ${ }^{3}$, is volgens recent onderzoek de overgrote meerderheid van de Nederlandse bevolking betrokken op waarden als respect voor anderen en tolerantie. Dat komt duidelijk naar voren uit de bijdrage van Kronjee en Lampert aan deze verkenning. $\mathrm{Zij}$ betogen dat reli- gieuze uitgangspunten en perspectieven in West-Europese samenlevingen 
inmiddels één 'levensstijl' belichamen - of één zingevingsstijl zoals ik liever zeg te midden van andere. ${ }^{4}$ In ons land omvat de groep van mensen die een christelijke overtuiging aanhangen en daaraan in kerkverband inhoud geven ongeveer 25 procent. Samen met de 3 procent moslims en overige 'gebonden religieuzen' is deze 'zingevingsstijl' kenmerkend voor 28 procent van de bevolking. Daarnaast is sprake van een aanzienlijke groep van mensen met een humanistische of gematigd-humanistische overtuiging (26\%) en een bijna even grote groep van 'ongebonden spirituelen'. Ten slotte onderscheiden Kronjee en Lampert op grond van hun onderzoeksmateriaal een iets kleinere, niet-religieuze, niet-humanistische groep, die hoog scoort op nihilisme en op hedonisme en laag op 'transcendentie' (18\%). In het licht hiervan kan gesteld worden dat inmiddels in ons land sprake is van vier dominante zingevingstijlen: respectievelijk een kerkelijke, een humanistische, een spirituele en een nihilistische zingevingsstijl. Deze zienswijze werpt een verhelderend licht op de complementaire eenzijdigheid van de twee polen waar de meeste bijdragen aan het debat rond de rol van religie en levensbeschouwing in het publieke domein omheen blijven cirkelen.

Om te beginnen volgt uit de analyse van Kronjee en Lampert dat zorgen rond religie als bron van dogmatisme en afsluiting vooral op hun plaats zijn met betrekking tot de bijna 20 procent van onze bevolking die geen enkele binding heeft met religieuze, spirituele of humanistische overtuigingen:

“Deze Nederlanders staan negatief ten opzichte van transcendente waarden, zij zijn niet gelovig, maar vinden evenmin aantrekkingskracht in humanistische waarden. $\mathrm{Zij}$ zijn laag tolerant, voor hen speelt zelfbeschikking een belangrijke rol. Men kan vermoeden dat deze groep gemakkelijk beïnvloedbaar is en dan gevoelig zal zijn voor extreme visies.” (35/36)

Omgekeerd blijken evenmin goede gronden te bestaan voor het pleidooi van de kant van religieuze en levensbeschouwelijke organisaties voor overheidssteun, op grond van het veronderstelde belang van hun publieke bijdrage op het gebied van moreel besef en onderlinge solidariteit. Minder dan 30 procent van de Nederlandse bevolking geeft inhoud aan haar geloof of levensovertuiging binnen het kader van een georganiseerde religie. De humanisten en gematigd humanisten $(26 \%)$ bezitten vanwege hun betrokkenheid op autonomie en individualiteit van oudsher een lage organisatiegraad ${ }^{5}$, en de bijna even grote groep van ongebonden spirituelen wordt door geen enkele overkoepelende organisatie vertegenwoordigd.

In het licht daarvan dienen twee zaken helder onderscheiden te worden. Enerzijds de belangrijke bijdrage die christelijke, humanistische en spirituele waarden en alle daarmee verbonden overtuigingen leveren aan de 'culturele humuslaag' die de voedingsbodem vormt voor morele betrokkenheid en onderlinge solidariteit in ons land. Anderzijds het feit dat kerken en levensbeschouwelijke organisaties niet langer kunnen claimen dat zij de exclusieve institutionele hoeders zijn van deze humuslaag. Het probleem waar zij mee kampen is juist dat de tradities die zij vertegenwoordigen weliswaar op inhoudsniveau nog steeds van groot 
belang zijn voor uitgewaaierde en geïndividualiseerde zingevingsprocessen, maar dat de culturele humuslaag die de voedingsbodem vormt voor morele betrokkenheid en onderlinge solidariteit slechts voor een klein deel door hen beheerd en beheerst wordt en niet langer als hun exclusieve verantwoordelijkheid kan worden beschouwd.

Wanneer deze uitwaaiering van zingevingsstijlen als uitgangspunt wordt genomen, verschuift de kern van het probleem: de scheiding van kerk en staat is in ons land lang en breed gerealiseerd en loopt niet of nauwelijks gevaar, maar dat geldt niet voor de scheiding van staat en zingevingsstijlen. Op grond van de ontwikkelingen die de afgelopen decennia hebben plaatsgevonden in semi-publieke domeinen en de weerslag daarvan op de geestelijke verzorging, is de vraag op zijn plaats of de overheid niet een actieve bijdrage levert aan de erosie van de culturele humuslaag voor morele betrokkenheid en onderlinge solidariteit, door binnen semi-publieke organisaties de facto één specifieke, 'nihilistische' en 'hedonistische' zingevingsstijl te ondersteunen. ${ }^{6}$

\section{b. De omvorming van existentiële en morele vragen tot technisch oplosbare proble- men}

Deze vraag verwijst naar de tweede richtingwijzer die ik in deze bijdrage wil verkennen aan de hand van ontwikkelingen in de geestelijke verzorging, namelijk de toenemende verstrengeling van existentiële en morele vragen met organisatorische contexten en professionele taalspelen en de gelijktijdige omvorming daarvan tot technisch oplosbare problemen. In semi-publieke domeinen als de zorg, het onderwijs en het welzijnswerk, maar ook in organisaties als het leger en in instellingen van justitie, zijn voortdurend moreel geladen vragen aan de orde die naar achterliggende zingevingskaders verwijzen en tegelijkertijd in hoge mate verstrengeld zijn met professionele vraagstellingen en technische oplossingspatronen. Vanwege deze interne verbinding met professionele kennis kunnen die vragen niet beantwoord worden met een beroep op waarden ontleend aan één specifiek zingevingskader: het particuliere karakter daarvan staat op gespannen voet met het algemene, voor kritische toetsing toegankelijke karakter van professionele kennis en kunde. Vanwege hun waardegeladen karakter kunnen die vragen echter niet op basis van objectieve wetenschappelijke inzichten beantwoord worden. Evenmin kunnen zij als een pure privézaak worden beschouwd: het handelen van militairen op vredesmissies, de manier waarop leraren op school met vragen rond seks en geweld omgaan of de bejegening van demente bejaarden brengen morele afwegingen en zingevingsvragen in het spel die de particuliere overtuigingen van de betrokken individuen en organisaties overstijgen.

In het licht daarvan kunnen grote vraagtekens gezet worden bij de toenemende nadruk die van overheidswege wordt gelegd op doelmatigheid, transparantie en resultaatverantwoording binnen publieke en semi-publieke organisaties. In naam van neutraliteit en doelmatigheid bevordert de overheid binnen deze domeinen de dominantie van bedrijfsmatig georiënteerde managementmodellen en van technische vormen van professionaliteit. Daarmee werkt zij actief mee aan de 
massieve omvorming van de existentiële en morele vragen die zich hier steeds weer opdringen tot technisch oplosbare problemen, die op basis van specialistische kennis van hooggeschoolde professionals uit de wereld geholpen kunnen worden. Het komt mij voor dat zij daarmee de facto een keuze maakt voor één specifieke zingevingsstijl, namelijk een zingevingsstijl waaruit elke verwijzing naar transcendente waarden verbannen is. Zoals de dagelijkse praktijk van geestelijke verzorgers laat zien, vraagt het omgaan met existentiële vragen rond eindigheid en verlies en met morele vragen rond betrokkenheid en zorg (resp. onverschilligheid en verwaarlozing) ook andere hulpbronnen en organisatievormen dan empirisch getoetste kennis en technische beheersingsmacht. Het gaat hier om diepgang en inspiratie, om levenskunst en levenswijsheid en vooral ook om morele bewogenheid door het lot van anderen, ook en juist wanneer geen menswaardige technische oplossingen beschikbaar zijn voor de vragen waar zij mee kampen en het er vooral om gaat hen niet in de steek te laten en te laten ervaren dat zij hoe dan ook betekenisvol blijven (Alma 2004; Baart 2005; Van Heijst 2005).

Tegen deze achtergrond bieden de ontwikkelingen binnen de beroepsgroep van geestelijk verzorgers een interessant onderzoeksveld. Als specialisten op het gebied van waarden en zingevingsvragen worden zij dagelijks geconfronteerd met indringende existentiële en morele vragen. Daarbij stuiten zij op het tekortschieten van beide dominante modellen. De uitwaaiering van zingevingsstijlen en de levensbeschouwelijke individualisering zijn zo ver voortgeschreden dat nog maar weinig cliënten behoefte hebben aan geestelijke begeleiding op basis van één omvattend zingevingskader. Maar de complementaire strategie schiet, zoals ik zal laten zien, evenzeer tekort. Het zoveel mogelijk omvormen van existentiële en morele vragen tot technisch-professionele problemen en het reduceren van de technisch onverwerkbare rest tot privékeuzes, betekent in de praktijk een keuze voor een 'nihilistische' zingevingsstijl, waaruit met een beroep op keuzevrijheid en autonomie elke verwijzing naar transcendente waarden is verbannen. De begrippen horizontale transcendentie en normatieve professionalisering die het afgelopen decennium in discussie met de beroepsgroep ontwikkeld zijn, geven een zoekrichting aan die voorbij dit dilemma wijst.7 Voordat ik die zoekrichting nader verken, ga ik kort in op de geschiedenis van de geestelijke verzorging.

\subsection{HISTORISCHE CONTEXT}

Geestelijk verzorgers nemen van oudsher een aparte positie in binnen de instellingen en organisaties waar zij werkzaam zijn. Enerzijds hebben zij een professionele training achter de rug (doorgaans op universitair niveau), anderzijds treden zij van oudsher binnen die organisaties op als vertegenwoordigers van een religie of levensbeschouwing. Geestelijk verzorgers zijn met andere woorden 'ambtsdragers' die inhoudelijk aangestuurd worden vanuit hun eigen kerk, religieus genootschap of levensbeschouwelijke organisatie, ook al staan ze op de loonlijst bij defensie, justitie of een verpleeghuis. De inhoudelijke verantwoording over 
het werk dat zij verrichten, zowel kwalitatief als kwantitatief, wordt uitsluitend afgelegd aan het 'zendend genootschap', dat ook verantwoordelijk is voor de opleiding, de selectie, de aanstelling en eventueel het ontslag van de betrokkenen. Dat was althans tot voor kort de dominante praktijk. Die is het laatste decennium in snel tempo veranderd. De verstrekkende gevolgen van die verandering krijgen reliëf tegen de achtergrond van de argumenten waarmee in de jaren vijftig de financiering werd gelegitimeerd van geestelijke verzorging uit publieke middelen binnen het leger en binnen justitiële instellingen.

Centraal in die argumentatie staat de vrijheid van geloof en levensovertuiging, zoals vastgelegd in artikel 6 van de grondwet. Dat beginsel garandeert enerzijds autonomie van individuen, groepen en stromingen bij de inhoudelijke vormgeving en organisatorische inbedding van hun levensovertuiging, en vrijheid in het 'belijden' daarvan; anderzijds impliceert het de scheiding van kerk en staat. Die scheiding is echter niet volledig. Weliswaar dient de overheid zich te onthouden van iedere inmenging in geloofszaken, in het bijzonder van een inhoudelijk oordeel over de (relatieve) waarde en betekenis van levensovertuigingen. Maar de staat is de "hoedster van het vrij belijden van geloof en levensovertuiging", zoals Buijs stelt in zijn onderzoek naar geestelijke verzorging in de krijgsmacht. ${ }^{8}$ In het verlengde van het gelijkheidsbeginsel uit artikel 1 van de grondwet betekent dit dat de overheid ervoor dient te zorgen dat de vrijheid van geloof en levensovertuiging alle burgers gelijkelijk toevalt. In de krijgsmacht en in justitiële inrichtingen zijn burgers echter afgesneden van de mogelijkheden die hun onder normale omstandigheden ter beschikking staan om aan hun geloof of levensovertuiging inhoud te geven binnen de eigen gemeenschap en daar geestelijke steun aan te ontlenen. Omdat de overheid medeverantwoordelijk is voor het blokkeren van die mogelijkheden, komt haar in deze omstandigheden een speciale verantwoordelijkheid toe om voor de betrokkenen de vrijheid van geloof en levensovertuiging te waarborgen. Vanaf de Eerste Wereldoorlog en op grotere schaal na de Tweede Wereldoorlog, geeft de overheid inhoud aan die verantwoordelijkheid door het bekostigen van geestelijke verzorging in de krijgsmacht en in justitiële inrichtingen door vertegenwoordigers van de belangrijkste 'geestelijke stromingen' in ons land: in de jaren vijftig vooral van protestantse, rooms-katholieke en joodse huize, in de loop van de jaren zestig ook humanistisch geestelijk verzorgers, een klein aantal hindoeïstische pandits en ten slotte (eerst mondjesmaat, inmiddels op iets grotere schaal) islamitische geestelijk verzorgers.

Van begin af aan was duidelijk dat deze financiering door de overheid het risico met zich meebrengt dat de overheid en haar vertegenwoordigers zich ook met de inhoud van de geestelijke verzorging zouden bemoeien, en daarmee de vrijheid van geloof en levensovertuiging in gevaar zouden brengen. Om dat te voorkomen is de constructie van de vrijplaats in het leven geroepen. De vrijplaats vormt als het ware een miniatuurreplica van het levensbeschouwelijke milieu van de verschillende denominaties binnen semi-publieke organisaties als de krijgsmacht en instellingen van justitie: katholieken verkeren binnen de vrijplaats met een pastoor, de protestanten met een dominee en humanisten met een humanistische 
raadsman of raadsvrouw. De rechten en garanties die met deze vrijplaats verbonden zijn voor geestelijke verzorgers en hun cliënten, strekken zeer ver. De vrijplaats garandeert niet alleen de volstrekte vertrouwelijkheid van de inhoud van de gevoerde gesprekken, ook wanneer die betrekking hebben op belastende feiten; bovendien leggen geestelijk verzorgers over de inhoud en voortgang van hun werk uitsluitend verantwoording af aan hun eigen 'hoofd van dienst', die rechtstreeks aangestuurd wordt vanuit de 'eigen' kerk of het levensbeschouwelijk genootschap. Dit betekent ook dat geestelijk verzorgers niet betrokken zijn bij de registratie- en beoordelingsprocessen waaraan zowel gevangenen als dienstplichtigen onderworpen zijn. Terwijl de rapportages van psychologen bijvoorbeeld een belangrijke rol spelen bij beslissingen over vervroegde invrijheidstelling van veroordeelden, nemen geestelijk verzorgers niet deel aan de teambesprekingen en beslisprocedures in kwestie. Deze organisatorische afzondering levert een belangrijke bijdrage aan de kwaliteit van de gesprekken die zij met hun cliënten voeren, want bij geestelijk verzorgers valt in strategisch opzicht weinig tot niets te halen. ${ }^{9}$ Anderzijds betekent dit ook dat zij slechts weinig invloed uit kunnen oefenen binnen de organisatie waar zij werken en betrekkelijk machteloos staan ten opzichte van de misstanden waarmee zij - juist op basis van de intensieve en vertrouwelijke gesprekken die zij bijvoorbeeld met gevangenen en militairen voeren - regelmatig geconfronteerd worden.

De basis van de geestelijke verzorging als zelfstandig beroep ligt dus in de bijzondere verantwoordelijkheid die de overheid vanaf de jaren vijftig op zich genomen heeft voor financiering van geestelijke verzorging in de krijgsmacht en in justitiele instellingen. Van daaruit heeft het beroep zich ook een plaats verworven in de gezondheidszorg, met name in ziekenhuizen, in verpleeg- en verzorgingshuizen, in GGZ-instellingen en in de jeugdzorg. Met uitzondering van grote ziekenhuizen gaat het in de meeste gevallen om kleine tot zeer kleine aanstellingen, omdat de overheid hier niet rechtstreeks als financier optreedt, maar de instellingen zelf verantwoordelijk zijn voor betaling van geestelijk verzorgers en voor de verdeling van formatie over één of meer denominaties. Dat heeft in de zorgsector geleid tot grote regionale en lokale verschillen, waarbij de levensbeschouwelijke kleur van de betrokken organisaties en het belang dat het bestuur daarvan aan geestelijke verzorging hecht, in hoge mate bepalend zijn voor de omvang en de inhoudelijke samenstelling van de afdelingen geestelijke verzorging. In de Kwaliteitswet Zorginstellingen die in 1996 van kracht werd, wordt weliswaar bepaald dat patiënten of cliënten die langer dan 24 uur in een zorginstelling verblijven recht hebben op geestelijke verzorging die aansluit bij de eigen levensovertuiging, maar het staat de betrokken directies vrij om daarvoor een vaste formatie te reserveren of geestelijke verzorging op uurbasis extern in te huren. De verplichting om geestelijke verzorging beschikbaar te stellen geldt namelijk alleen wanneer patiënten of cliënten daar expliciet om vragen: het gaat om beschikbaarheid 'op afroep'. In de praktijk betekent dit alles dat omvang en samenstelling van de geestelijke verzorging in de zorgsector niet alleen grote lokale, regionale en sectorale verschillen te zien geeft, maar ook dat geestelijke verzorging hier in het algemeen slechts mondjesmaat beschikbaar is. In de zorg heeft het beroep 
zodoende nog grotere moeite om zich te handhaven dan in andere domeinen waar geestelijk verzorgers actief zijn. Die benarde positie hangt samen met de culturele en maatschappelijke ontwikkelingen die ik hierboven al heb aangestipt: in de eerste plaats de uitwaaiering van zingevingsstijlen en de daarmee verbonden levensbeschouwelijke individualisering; in de tweede plaats de toenemende verstrengeling van existentiële en morele vragen met organisatorische contexten en professionele taalspelen en de omvorming van die vragen tot technisch oplosbare problemen, mede onder invloed van bedrijfsmatig georiënteerde vormen van management en bestuur. Aan de hand van illustraties uit de verschillende domeinen waar geestelijk verzorgers werkzaam zijn, ga ik in de volgende paragrafen dieper op deze ontwikkelingen in. Daarbij probeer ik zichtbaar te maken dat uit de vragen en dilemma's waarmee de beroepsgroep geconfronteerd wordt, een zoekrichting gedestilleerd kan worden die voorbij de herhaling van zetten wijst in het debat over de positie van religie en levensbeschouwing in het publieke domein.

\section{$14 \cdot 3$ LEVENSBESCHOUWELIJKE INDIVIDUALISERING}

De uitwaaiering van zingevingsstijlen en de daarmee verbonden levensbeschouwelijke individualisering hebben voor geestelijke verzorging als beroep ingrijpende consequenties, omdat de oorspronkelijke legitimatie voor geestelijke verzorging gebaseerd is op de veronderstelling dat bijna alle burgers deel uitmaken van een religieus of levensbeschouwelijk genootschap en vanuit die geestelijke thuishaven steun behoeven en verwachten. Ten gevolge van de uitwaaiering van zingevingsstijlen zoals die in het onderzoek van Kronjee en Lampert gedocumenteerd wordt, heeft inmiddels bijna tweederde van de bevolking geen duidelijke 'geestelijke thuishaven' meer. Voor degenen die zichzelf nog wel tot een van de gevestigde denominaties rekenen, is bovendien sprake van voortschrijdende levensbeschouwelijke individualisering. Dit begrip verwijst niet alleen naar het sterk afgenomen belang van levensbeschouwelijke instituties en organisaties op het niveau van het dagelijks leven. Het verwijst ook naar een diepgaande verandering binnen de afbrokkelende geloofsgemeenschappen en levensbeschouwelijke groeperingen zelf. Het geloof of de levensovertuiging wordt steeds meer als een vorm van individuele zingeving beleefd, ook wanneer de betrokkenen zichzelf nog als katholiek, protestant, islamitisch of humanistisch beschouwen. Dat heeft vergaande consequenties. In een formulering van de Franse sociaal-filosoof Gauchet: religieuze en levensbeschouwelijke tradities "hebben in de eerste plaats waarde voor zover ze mijn traditie zijn: voor zover ze mij in mijn singuliere identiteit constitueren" (Gauchet 1998: 194). In plaats van het hiernamaals en het eeuwige leven (of het eeuwige tandenknarsen) is de oriënterende en zingevende functie van het geloof steeds meer verschoven naar het aardse bestaan van individuele gelovigen. Door deze 'interne individualisering' verandert ook de betekenis van de geloofsgemeenschap ingrijpend van karakter. Deel uitmaken van een geloofsgemeenschap vormt voor veel gelovigen niet langer de toegang tot een transcendente realiteit die ontzag oproept en de bron vormt van absoluut geldende waarden en leefregels. In plaats daarvan is ook geloven en het deelne- 
men aan de daarmee verbonden rituelen vooral een vorm van zingeving aan het eigen leven geworden: "De toe-eigening van de overgeleverde gemeenschapskenmerken fungeert nu als steunpunt om zich als persoon te onderscheiden", zoals Gauchet zegt (1998: 101). Deze analyse wordt door het onderzoek van Kronjee en Lampert op hoofdlijnen bevestigd. Net als Gauchet nemen zij een transformatie waar "waarin religie of de spirituele transcendentie iets is wat vooral nuttig is voor de persoon en zijn directe omgeving. Als er idealisme is, is dat een praktisch idealisme" (Kronjee en Lampert 2006).

\section{Algemene geestelijke verzorging}

Deze ontwikkeling brengt ook een diepgaande verandering met zich mee van de positie van de vertegenwoordigers van de verschillende geloofsgemeenschappen en denominaties. Aan de ontwikkeling van de geestelijke verzorging in zorginstellingen laat die verandering zich duidelijk aflezen. Met name in grote ziekenhuizen heeft zich de praktijk ontwikkeld dat geestelijke verzorging niet langer op basis van de geloofsachtergrond van patiënten wordt verleend, maar in 'algemene' vorm wordt aangeboden. Vanuit de dienst geestelijke verzorging worden in overleg de verdiepingen of vleugels verdeeld, zodat bijvoorbeeld alle patiënten op de eerste verdieping een geestelijk verzorger van katholieke huize aan hun bed krijgen, de protestantse geestelijk verzorger op de tweede verdieping actief is en de humanistisch raadsvrouw de derde etage voor haar rekening neemt. Dit betekent ook dat de betrokkenen zich niet als vertegenwoordiger van een specifieke denominatie presenteren, maar hun diensten aanbieden vanuit hun beroepsidentiteit als geestelijk verzorger die bereid en in staat is om voor alle gezindten te werken. Alleen wanneer patiënten uitdrukkelijk verzoeken om geestelijke verzorging vanuit een specifieke levensbeschouwelijke achtergrond of bij rituele vieringen komt de religieuze of levensbeschouwelijke traditie van waaruit geestelijke verzorgers werken expliciet in beeld.

Zowel de uitwaaiering van zingevingsstijlen als de levensbeschouwelijke individualisering treden hier aan het licht: enerzijds het feit dat de meerderheid van de Nederlandse bevolking niet meer actief participeert in een geloofsgemeenschap of levensbeschouwelijk genootschap maar een andere zingevingsstijl hanteert; anderzijds het feit dat de grote meerderheid van degenen die actieve banden met een van de denominaties onderhouden, daarbinnen hun eigen geloof of levensovertuiging in toenemende mate op individuele wijze beleven en vormgeven. In de persoon van geestelijk verzorgers zoeken en vinden zij dan niet zozeer een vertegenwoordiger van geloofswaarheden ontleend aan een specifieke levensbeschouwelijke traditie, als wel een betrokken, breed geïnformeerde gesprekspartner die in staat is met hen mee te denken over fundamentele zingevingsvragen vanuit eigen ervaringen en persoonlijk verantwoorde inspiratiebronnen. De herkomst daarvan uit deze of gene traditie is daarbij van secundair belang. De doorslag geeft of de geestelijke verzorger als authentiek wordt ervaren en de eigen inspiratiebronnen en overtuigingen op basis van gelijkwaardigheid in het gesprek kan laten doorschijnen. Het is de patiënt of cliënt zelf die als het centrum van het proces van zingeving verschijnt; de geestelijk verzorger assisteert en ondersteunt 
daarbij vanuit levensbeschouwelijke inspiratiebronnen die hun betekenis niet primair aan hun transcendente status ontlenen maar aan de waarde daarvan voor het eigen oriëntatie- en verwerkingsproces van cliënten. Religie, spiritualiteit en levensbeschouwing maar ook poëzie en muziek functioneren daarbij als gelijkwaardige bronnen van steun en inspiratie.

De gevolgen van de levensbeschouwelijke individualisering manifesteren zich in de zorgsector met grotere kracht dan in andere domeinen waar geestelijk verzorgers werkzaam zijn, maar verwante ontwikkelingen zijn ook elders terug te vinden, bijvoorbeeld bij de krijgsmacht. Zo is het bij de marine op pragmatische gronden ondoenlijk om op alle schepen geestelijke verzorgers van de verschillende denominaties mee te laten varen. GV'ers van de verschillende denominaties draaien dan bij toerbeurt mee en vertegenwoordigen dan 'het geestelijke domein' in het algemeen, waarbij hun eigen geestelijke traditie de facto als één mogelijke inhoudelijke inspiratiebron functioneert in plaats van als het overkoepelende kader. Hetzelfde geldt voor de geestelijk verzorgers die meegezonden worden op vredesmissies van het leger. In de kleine legerkampen in Afghanistan bijvoorbeeld wisselen de aalmoezenier, de humanistisch raadsman en de dominee elkaar af. In de praktijk komen zodoende de professionele competenties en kwaliteiten die geestelijk verzorgers van verschillende denominaties delen steeds meer op de voorgrond te staan en verliezen claims op de exclusieve geldigheid en het overkoepelende karakter van de eigen overtuiging hun geloofwaardigheid.

\section{Horizontale transcendentie}

Voortbouwend op inzichten van denkers als Theo de Boer, Gianni Vattimo, Hent de Vries en Luce Irigaray heb ik de achtergronden van deze ontwikkeling proberen te verhelderen via het onderscheid tussen verticale en horizontale vormen van transcendentie (Kunneman 2005). Waar verticale transcendentie naar een absoluut gestelde oorsprong verwijst, daar hebben horizontale articulaties van transcendentie betrekking op een horizon van transcendente waarden die alleen op kan lichten zolang hij niet bezet wordt door één specifieke articulatie van de waarden in kwestie en het onderliggende zingevingskader, of daarin nu de Rede, God of de Natuur centraal staat. Horizontale vormen van transcendentie zijn anders gezegd intern betrokken op pluraliteit en dialoog, op leerzame wrijving tussen verschillende inhoudelijke evocaties van transcendente waarden en de achterliggende zingevingskaders, als voorwaarde voor het kunnen oplichten van de inzichten en de inspiratie die daarin besloten liggen. ${ }^{10}$ De praktijk van de geestelijke verzorging zoals die zich de laatste decennia ontwikkeld heeft, biedt daar een duidelijke illustratie van. Niet alleen in de gedaante van de min of meer dialogische relaties die zich - ondanks alle spanningen rond formatieperikelen tussen de verschillende denominaties ontwikkeld hebben, maar ook in de vorm van de co-creatie van de kant van de cliënten van geestelijk verzorgers: die hebben nadrukkelijk het laatste woord bij de articulatie van mogelijke bronnen van zingeving en morele oriëntatie. ${ }^{11}$ 


\subsection{VERSTRENGELING EN OMVORMING}

Het optreden van 'leerzame wrijving' tussen verschillende inhoudelijke evocaties van transcendente waarden en de achterliggende zingevingskaders is niet alleen afhankelijk van de dialogische vermogens van de betrokkenen, maar wordt ook gevoed door een tweede ontwikkeling die het aanzien van de geestelijke verzorging de afgelopen decennia in hoge mate beïnvloed heeft, namelijk de toenemende verstrengeling van existentiële en morele vragen met professionele taalspelen en met organisatorische krachtenvelden en de gelijktijdige omvorming daarvan tot technisch oplosbare problemen.

\subsubsection{VERSTRENGELING}

Een eerste illustratie van deze verstrengeling binnen het domein van de geestelijke verzorging biedt het invloedrijke rapport van de commissie-Hirsch Ballin uit 1986 en de nieuwe legitimatie voor financiering van geestelijke verzorging uit publieke middelen die daarin wordt geboden.

De centrale inzet van dit rapport komt al naar voren uit de naam van de commissie: 'Commissie van advies inzake criteria voor steunverlening aan kerkgenootschappen en andere genootschappen op geestelijke grondslag'. Dit rapport vormt een reactie op de gevolgen van de levensbeschouwelijke individualisering die in de jaren zestig en zeventig op gang was gekomen en de daarmee verbonden afbrokkeling van de legitimatie voor financiering van geestelijke verzorging uit publieke middelen. De gevolgen daarvan drongen zich vooral in de krijgsmacht met grote kracht op, door het afschaffen van de dienstplicht en de overgang naar een beroepsleger. Wanneer burgers vrijwillig kiezen voor een professionele loopbaan bij een van de krijgsmachtonderdelen is het niet langer vanzelfsprekend dat de overheid geestelijke verzorging op basis van hun eigen geloof of levensovertuiging financiert. Dat gebeurt immers op de koopvaardij ook niet, zoals Buijs constateert. ${ }^{12}$ In een interim-rapport uit 1986 dat speciaal gewijd is aan de verdeling van geestelijke verzorgers in de krijgsmacht, presenteert de commissieHirsch Ballin dan ook een heel andere argumentatie voor overheidsfinanciering van geestelijke verzorging in de krijgsmacht:

\footnotetext{
"Een andere factor die bepalend is voor de bijzondere overheidsverantwoordelijkheid in deze is dat het verblijf in de krijgsmacht religieus-levensbeschouwelijke vragen meebrengt in verband met het gebruik van middelen van geweld waarbij men door dienstvervulling kan worden betrokken. (...) Deze vraagstukken hebben een diep moreel en levensbeschouwelijk aspect, waarmee de militairen moeten kunnen omgaan - zowel in tijd van vrede als in tijd van oorlog. Begeleiding door een geestelijk verzorger die bekend is met de krijgsmacht als organisatie en met de specifieke vragen op dit terrein is van groot belang. De diensten geestelijke verzorging hebben hun eigen plaats in het geheel van de krijgsmacht bij het bespreken van dergelijke principiële vragen. Anderen in de krijgsmacht zijn daartoe niet of onvoldoende geëquipeerd.” (Hirsch Ballin 1986)
} 
Hiermee brengt de commissie een (voor de beroepsgroep zeer welkome) nieuwe argumentatie in voor voortgezette overheidsfinanciering van geestelijke verzorging. Bovendien wijst ze hiermee impliciet op een ontwikkeling die voor het debat over de rol van religie en levensbeschouwing in het publieke domein bijzonder interessant is, namelijk de toenemende verstrengeling van existentiële en morele vragen met specifieke institutionele en organisatorische contexten en de daarbinnen dominerende professionele taalspelen. De commissie zoekt de legitimatie voor overheidsfinanciering niet meer alleen in het grondwettelijke recht van individuen op vrijheid van geloof en levensovertuiging en op waarborging van die vrijheid door de overheid. Aan dit 'klassieke' argument wordt een nieuwe argumentatielijn toegevoegd die betrekking heeft op de institutionele en organisatorische context: het zijn de specifieke ethische en morele vragen waarmee militairen in de krijgsmacht geconfronteerd worden, die deskundige ondersteuning door geestelijk verzorgers noodzakelijk maken. Het hart van hun professionele bijdrage verschuift daarmee van het vertegenwoordigen van een specifieke religieuze of levensbeschouwelijke traditie in een 'vrijplaats' binnen de organisatie, naar de specifieke morele en existentiële vragen die binnen de krijgsmacht als organisatie aan de orde zijn. De inhoudelijke verschillen tussen de 'diensten geestelijke verzorging' en de denominaties waarmee zij verbonden zijn verschuiven daarmee tendentieel naar de achtergrond en hun gemeenschappelijke professionele verantwoordelijkheid en expertise voor de specifieke 'geestelijke problematiek' die zich in de krijgsmacht voordoen, komt op de voorgrond te staan.

\section{Herstelrecht}

Binnen de krijgsmacht is deze ontwikkeling in een stroomversnelling geraakt door de overgang naar een beroepsleger. Ook in andere sectoren waar geestelijk verzorgers werkzaam zijn doen zich echter verwante ontwikkelingen voor. Een illustratief voorbeeld biedt de recente aandacht voor herstelrechtelijke benaderingen binnen de diensten geestelijke verzorging bij justitie. Onder het begrip 'herstelrecht' gaat een bonte verzameling schuil van geëngageerde burgers, wetenschappers, professionals bij politie en justitie en levensbeschouwelijke groeperingen, die verbonden worden door een kritische houding ten opzichte van punitief gerichte benaderingen binnen het strafrecht en een verschuiving bepleiten naar herstelgerichte benaderingen van vragen rond criminaliteit en bestraffing (Boutellier et al. 2002; Kunneman 2005). Centraal daarbij staan vrijwillige daderslachtofferontmoetingen, waarbij volgens een strikt geregeld patroon beide partijen, het slachtoffer voorop, de kans krijgen om hun ervaringen en emoties naar voren te brengen, gesteund door familie en bekenden. Het doel is herstel van de verbroken verhoudingen. ${ }^{13}$ Cruciaal daarvoor is de bereidheid van de dader om schuld te erkennen en, voor zover dat überhaupt mogelijk is, de schade en het leed dat hij of zij berokkend heeft te vereffenen. Vanuit de diensten geestelijke verzorging, met name de humanisten, worden experimenten ondernomen met herstelgerichte conferenties in justitiële inrichtingen en met intensieve begeleiding van ex-veroordeelden na het verlaten van de gevangenis, mede door hun netwerk daar actief bij te betrekken: het herstel betreft niet alleen de relatie slachtoffer-dader, 
voor zover herstel daarbij überhaupt mogelijk is, maar ook het herstel van de exveroordeelden in een positie van volwaardig burgerschap.

Net zoals geestelijke verzorging bij de krijgsmacht gericht is op de specifieke morele vragen die binnen deze organisatie aan de orde zijn, zo zijn ook de vragen rond schuld, bestraffing, verantwoordelijkheid en vergeving waarop de herstelrecht-beweging zich richt intern verbonden met de specifieke kenmerken van justitiële inrichtingen en de klemmende morele vragen die daarbinnen aan de orde zijn. Een verwante analyse is mogelijk met betrekking tot geestelijke verzorging in de GGZ, in de ouderenzorg of in de jeugdzorg. Steeds gaat het om morele dilemma's en onderliggende existentiële vragen die intern verbonden zijn met de specifieke vragen en problemen van de betrokken cliënten en met de institutionele en organisatorische kaders en professionele taalspelen waarbinnen die 'hanteerbaar' worden gemaakt.

\subsubsection{OMVORMING}

Naast de toenemende verstrengeling van existentiële en morele vragen met professionele taalspelen en met organisatorische krachtenvelden worden geestelijk verzorgers ook geconfronteerd met de gelijktijdige omvorming daarvan tot technisch oplosbare problemen. In combinatie met de levensbeschouwelijke individualisering leidt deze ontwikkeling tot een massieve verdringing van existentiële en morele vragen in het kader van semi-publieke organisaties. Die worden bij voorkeur getransformeerd in een technisch oplosbaar probleem, en wanneer dat niet meer lukt gereduceerd tot persoonlijke keuzes in naam van respect voor individuele vrijheid en autonomie. De geestelijke verzorging zit min of meer klem tussen deze twee ontwikkelingen. Enerzijds zien zij de traditionele legitimatie van hun werk in termen van de verzuilde samenleving steeds verder afbrokkelen en zoeken zij die legitimatie steeds meer in hun (denominatie-overstijgende, 'algemene') professionele kennis en kunde. Anderzijds zien zij zich binnen de organisaties waar zij werken gedwongen om hun professionele competenties in termen van kosten en resultaten te verantwoorden, waarmee zij het eigen karakter van de zingevingsvragen waarop zij zich richten geweld aandoen en nolens volens meewerken aan het verdringen van die vragen uit het heersende taalspel binnen die organisaties.

Een goede illustratie hiervan bieden de gevolgen die de herziening van het zorgstelsel heeft voor de positie van geestelijk verzorgers, in het bijzonder de modernisering van de AWBZ, de centrale indicatiestelling en de invoering van 'diagnose-behandel-combinaties' in ziekenhuizen en in de GGZ. Zoals hierboven al is aangestipt, wordt de (smalle) financiële grondslag voor geestelijke verzorging in zorginstellingen geboden door de Kwaliteitswet Zorginstellingen uit 1996.

Deze wet vereist dat in zorginstellingen geestelijke verzorging beschikbaar is die aansluit bij de eigen levensovertuiging indien mensen langer dan 24 uur daarbinnen verblijven. Daarbij gaat het nadrukkelijk om beschikbaarheid van geestelijke verzorging 'op afroep', zoals naar voren komt uit het antwoord van de 
betrokken staatssecretaris op Kamervragen over de positie van geestelijke verzorging in de gemoderniseerde AWBZ:

"Naar aanleiding van de vraag van de heer Van der Vlies over de plaats van de geestelijke verzorging in de gemoderniseerde AWBZ merk ik het volgende op. Een van de belangrijkste doelstellingen van de moderniseringsoperatie is het bieden van meer ruimte aan zorgaanbieders om de dynamiek en pluriformiteit in de zorg te vergroten. Daarin past ook het bieden van identiteitsgebonden zorg ervan uitgaande dat er voldoende vraag is in het licht van de keuzevrijheid van de klant. De Kwaliteitswet schrijft voor dat bij zorg met verblijf geestelijke verzorging deel uitmaakt van de zorg. Door de modernisering verandert dat niet. In het nieuwe bekostigingssysteem zal daar ook rekening mee worden gehouden, net zoals dat nu het geval is. De koppeling met verblijf is bewust gekozen, omdat er dan sprake is van verandering van woonplaats. Uitgangspunt bij extramurale zorgverlening is het zo lang mogelijk thuis of dicht bij huis leveren van zorg omdat de zorgvrager dan in de eigen vertrouwde omgeving kan blijven. Bij die vertrouwde omgeving hoort ook de geloofsgemeenschap en de dominee, pastoor of imam die van daaruit werkt. De extramuralisering kan op deze manier bijdragen aan het geven van een volwaardige plaats aan de zorg in de lokale gemeenschap. In het kader van de extramuralisering zal aan de geestelijke verzorging ook aandacht worden geschonken in het overleg met onder andere de patiëntenorganisaties." ${ }^{14}$

Geheel in overeenstemming met de levensbeschouwelijke individualisering en de omvorming van geloof tot één 'zingevingsstijl' te midden van andere, is het bieden van 'identiteitsgebonden zorg' volgens de staatssecretaris afhankelijk van de aanwezigheid van "voldoende vraag in het licht van de keuzevrijheid van de klant”. De keuzevrijheid van 'klanten' biedt met andere woorden het overkoepelende kader, waarbinnen aan individuen met een expliciete 'levensbeschouwelijke identiteit' het recht wordt toegekend om geestelijke verzorging te vragen die in overeenstemming is met die identiteit. In het licht van het onderzoek van Kronjee en Lampert is dat opmerkelijk, omdat hiermee bijna tweederde van de bevolking de facto uitgesloten wordt van geestelijke verzorging. In relatie tot de extramuralisering van de zorg plaatst de staatssecretaris geestelijke zorg in het kader van 'de geloofsgemeenschap en de dominee, pastoor of imam die van daaruit werkt'. Maar het grootste deel van onze bevolking valt daar inmiddels buiten. De groep van (christelijke en niet-christelijke) 'religieus gebondenen' omvat volgens Kronjee en Lampert 28 procent van de bevolking, terwijl onder het humanistische deel iets minder dan de helft (12\%) als expliciet humanistisch kan worden aangemerkt. De overige 6o procent - de ongebonden spirituelen, de gematigde humanisten en de 'nihilisten' - behoren nadrukkelijk niet tot een geloofsgemeenschap of georganiseerde levensbeschouwing, maar behoren eerder tot de levensbeschouwelijke 'bricoleurs', die hun eigen zingevingsstijl uit wisselende stukken en brokken in elkaar knutselen en er niet over piekeren om geestelijke steun te vragen van 'een dominee, pastoor of imam'. Hoogstens zullen zij met een geestelijk verzorger in gesprek gaan over zingevingsvragen wanneer die zich als een professional profileert die voor alle gezindten werkt. ${ }^{15}$ Financiering van geestelijke verzorging op 'algemene grondslag' is echter nadrukkelijk niet voorzien in de Kwaliteitswet Zorg: het klassieke model van identiteitsgebonden 
geestelijke zorg is hier maatgevend, terwijl tegelijkertijd de neergang daarvan versterkt wordt door het in te bedden in een marktgericht denkkader waarin individuele vraag en keuzevrijheid de boventoon voeren.

\section{Professionele legitimatie}

Doordat de klassieke financieringsgrondslag op basis van levensbeschouwelijke identiteiten gestaag afbrokkelt, terwijl tegelijkertijd de vragen waarmee geestelijk verzorgers in de zorg geconfronteerd worden steeds verder verstrengeld raken met de specifieke kenmerken van de organisaties waarbinnen zij werken, schuift de beroepsgroep steeds meer op in de richting van een professionele in plaats van een levensbeschouwelijke legitimatie van hun positie en hun specifieke bijdrage. Een duidelijke indicatie daarvan vormt de opkomst van 'ongebonden geestelijk verzorgers', die geen ambtsdrager zijn vanwege een religieus of levensbeschouwelijk genootschap, maar wel een academische opleiding als geestelijk verzorger hebben gevolgd. Hun positie is binnen de beroepsgroep omstreden, zoals naar voren komt uit de discussie die in 2006 heeft plaatsgevonden binnen de beroepsvereniging van geestelijk verzorgers in de zorg. De inzet van die discussie werd gevormd door de criteria voor opname in het nieuw te ontwikkelen Beroepsregister voor Geestelijk Verzorgers. Het voorstel van een bestuurscommissie om 'zending' of 'levensbeschouwelijke binding' niet als criterium voor opname in het beroepsregister te hanteren - en daarmee ook 'ongebonden' geestelijk verzorgers als volledig gekwalificeerde professionals te erkennen - riep binnen de beroepsvereniging veel commotie op. In een toelichting op het desbetreffende voorstel formuleert een van de commissieleden het dilemma als volgt:

“(...) de hamvraag is: laten we collega’s tot het beroepsregister toe die zonder zending werken? Want die collega's zijn er. Die zijn er veel. Ze hebben de opleiding, doen aan nascholing, hebben werk, maar de legitimatie/zending ontbreekt. Om allerlei redenen:

- Omdat kerken weigeren hen te benoemen.

- Omdat de passende organisatie voor benoeming ontbreekt, zoals bij onze islamitische en hindoecollega's.

- Omdat ze vrijgevestigd zijn en niet intramuraal werkzaam zijn.

- Ten slotte zijn er collega's die zonder levensbeschouwelijke binding willen werken. 'Buitenstander zijn' is een element van hun levensbeschouwelijke denkgoed, zeg maar. Ze kunnen zich niet vinden in de levensbeschouwelijke hoofdstromen die ons land kent, boeiend verschijnsel van onze tijd."16

Volgens de commissie dienen opleiding, werkervaring en deskundigheidsbevordering bepalend te zijn voor opname in het Beroepsregister: de aan- of afwezigheid van een levensbeschouwelijke binding zou wel in het register vermeld dienen te worden, maar geen criterium mogen zijn voor opname in het register. Hoewel de discussie in de beroepsgroep op dit punt nog niet tot uitsluitsel heeft geleid, lijken degenen die vast willen houden aan de zending en de ambtshalve binding als onderscheidend kenmerk van het beroep op lange termijn het onderspit te zullen delven. 
Dat wordt niet alleen duidelijk uit het onderzoek van Kronjee en Lampert, maar komt ook naar voren uit de (vooralsnog) mislukte pogingen om geestelijke verzorging volgens het klassieke model gefinancierd te krijgen bij de politie en voor ambulancepersoneel. Uit onderzoek onder deze professionals blijkt duidelijk dat er behoefte bestaat aan begeleiding bij het omgaan met de existentiële en morele vragen die hun werk met zich meebrengt. Maar geestelijke verzorging volgens het klassieke model valt niet goed meer in de hedendaagse bedrijfsvoering in te passen: het aanstellen van geestelijk verzorgers vanuit drie of vier verschillende denominaties met precies dezelfde professionele taakstelling bleek niet 'te verkopen'.

\section{Meetbare resultaten}

Als resultaat van deze ontwikkelingen wordt geestelijke verzorging steeds meer in de richting van een professionele invulling en legitimatie van het werk getrokken, terwijl de levensbeschouwelijke wortels van het beroep langzaam afbrokkelen. Dat betekent echter dat de beroepsgroep aan zeer sterke druk bloot komt te staan vanuit dominerende bedrijfsmatig georiënteerde bestuurs- en managementmodellen om de eigen bijdrage aan het functioneren van de organisatie in kwestie te verantwoorden in termen van meetbare, 'transparante' resultaten. Als zij nolens volens de 'vrijplaats' binnen de organisatie inruilen voor een positie die qua resultaatverantwoording min of meer analoog is aan die van psychologen, dan worden zij ook steeds verder in de richting van een methodisch-technische invulling van het beroep gedwongen, compleet met diagnoses en 'behandelplannen'. In ziekenhuizen en in de GGz is die druk het sterkst voelbaar, omdat alle professionele activiteiten hier in principe in termen van een diagnose-behandelcombinatie ('DBC') geoperationaliseerd dienen te zijn. Maar ook in de ouderenzorg manifesteert deze druk zich duidelijk, met name door de invoering van de centrale indicatiestelling en de noodzaak voor geestelijk verzorgers om hun activiteiten in één of meer van de zeven nauwkeurig omschreven en strikt afgepaalde zorgfuncties onder te brengen. Omdat de functie 'behandeling' bovendien financieel hoger ingeschaald is dan functies als 'ondersteunende begeleiding' en 'activerende begeleiding', is binnen de beroepsgroep een duidelijke 'pull' waarneembaar in de richting van een profilering van het beroep als een methodisch-technische professie te midden van andere 'behandelaars', inclusief eigen diagnostische categorieën en kwantitatieve resultaatverantwoording. ${ }^{17}$

\subsection{NORMATIEVE PROFESSIONALISERING}

Daarmee kom ik bij het sluitstuk van mijn betoog. Aan het begin van dit hoofdstuk heb ik gesteld dat uit de ontwikkelingen die in het beroepsveld van geestelijk verzorgers plaatsvinden een nieuwe zoekrichting gedestilleerd kan worden in het debat over de rol van religie en levensbeschouwing in het publieke domein, een zoekrichting die voorbij de twee polen wijst waar de meeste bijdragen aan dit debat omheen blijven cirkelen: enerzijds de associatie van religie en levensbeschouwing met dogmatisme en moreel imperialisme; anderzijds het claimen van een geprivilegieerde positie voor religieuze en levensbeschouwelijke instituties en 
organisaties als hoeder van moreel besef en sociale cohesie. De eerste pool verwijst naar een strikte scheiding van 'kerk en staat'; de tweede legitimeert ondersteuning van de publieke rol van kerken en levensbeschouwelijke organisaties, inclusief overheidsfinanciering van geestelijke verzorging op levensbeschouwelijke grondslag.

\section{De scheiding van staat en zingevingsstijlen}

Een eerste markering van de zoekrichting die voorbij deze ingesleten denkrichtingen wijst, biedt de constatering dat inmiddels bijna tweederde van onze bevolking een ongebonden zingevingsstijl aanhangt die geheel losstaat van welke kerk of levensbeschouwelijk genootschap dan ook en gekenmerkt wordt door bricolage, door dynamische verbindingen van heterogene elementen, in plaats van door eenheid en overkoepeling. Tevens dient geconstateerd te worden dat voor ongeveer tweederde van de bevolking transcendente waarden met een religieuze, spirituele of humanistische herkomst, een centrale rol spelen bij de eigen zingeving. Dit impliceert in mijn ogen dat de kern van het debat niet langer betrekking heeft op de meer of minder strikte scheiding van kerk en staat, maar een heel andere scheiding betreft, namelijk de scheiding van staat en zingevingsstijlen.

Wanneer de centrale inzet van het debat zó geformuleerd wordt, dringt zich de conclusie op dat de overheid in het kader van de semi-publieke organisaties waar geestelijk verzorgers werkzaam zijn, op grond van argumenten die uit een voorbij tijdperk stammen, de facto een voorkeur tentoonspreidt voor één specifieke zingevingsstijl, die niet als zodanig wordt herkend of benoemd. Het gaat hier om de zingevingsstijl die kenmerkend is voor de bijna 20 procent van onze bevolking die geen enkele binding heeft met religieuze, spirituele of humanistische overtuigingen: "Deze Nederlanders staan negatief ten opzichte van transcendente waarden, zij zijn niet gelovig, maar vinden evenmin aantrekkingskracht in humanistische waarden... voor hen speelt zelfbeschikking een belangrijke rol." 18 Door de consequente nadruk die met name in de zorgsector wordt gelegd op individuele keuzevrijheid en op het zo efficiënt mogelijk voldoen aan de verwachtingen en eisen van zorgconsumenten, inclusief de bijbehorende nadruk op transparantie en op meetbare resultaten van de betrokken professionals, wordt de facto elke verwijzing naar transcendente waarden en naar religieuze, spirituele of humanistische hulpbronnen om die waarden inhoud te geven tot een strikte privézaak gereduceerd en buiten het functioneren van de organisatie gebannen.

Uit deze ontwikkelingen en de daarmee verbonden dilemma's voor geestelijk verzorgers, kan echter ook een nieuwe zoekrichting gedestilleerd worden voor het debat over de rol van religie en levensbeschouwing in het publieke domein.

\section{Derde-orde-rechtvaardigingen}

Om die zoekrichting nader te specificeren, knoop ik aan bij het bekende onderscheid van John Rawls tussen eerste-orde- en tweede-orde-rechtvaardigingen (Rawls 1996). Rechtvaardigingen van de eerste orde blijven binnen het raamwerk van eigen religieuze, levensbeschouwelijke of politieke overtuigingen. Zij hebben 
met andere woorden een grote interne overtuigingskracht en vanzelfsprekendheid, maar kunnen buiten de eigen kring alleen gezag laten gelden in confrontatie met andere overtuigingen. Die confrontaties kunnen tot tweede-orde-rechtvaardigingen leiden. "Rechtvaardigingen van de tweede orde houden op een positieve manier rekening met de dissensus, die in de publieke ruimte feitelijk aanwezig is", zoals Jean-Pierre Wils elders in deze studie stelt. Wils specificeert dit 'rekening houden met' in termen van de bereidheid naar een 'overlappende consensus te zoeken' en de compromissen die daartoe noodzakelijk zijn als 'eervol' te beschouwen. Maar bij die bereidheid wringt hem natuurlijk de schoen. Binnen het filosofische kader van Rawls duikt hier dezelfde problematiek op die bij Habermas verbonden is met de 'anticipatie op de ideale gesprekssituatie': het 'verlichte gezonde verstand' dat beiden in de werkelijkheid willen bevorderen, wordt op filosofisch niveau voorondersteld, om het vervolgens in de werkelijkheid terug te kunnen vinden. Juist het maatschappelijke debat rond de rol van religie en levensbeschouwing in het publieke domein, zowel in ons eigen land als op mondiaal niveau, maakt duidelijk hoe gering het aandeel van het 'verlichte gezonde verstand' in veel gevallen is: in plaats van 'overlappende consensus' lijkt dit debat eerder tot verdergaande polarisering en wederzijds verkettering te leiden.

Naast allerlei voor de hand liggende politieke en economische macrofactoren en daarmee verbonden belangen, hangt het moeizame karakter van de overgang van 'eerste-' naar 'tweede-orde-rechtvaardigingen' in mijn ogen mede samen met het feit dat de debatten in kwestie doorgaans op abstract-algemeen niveau gevoerd worden en betrekking hebben op de grondprincipes die bepalend dienen te zijn voor de inrichting van de publieke ruimte in zijn geheel. Het principe van de scheiding van kerk en staat biedt daar een duidelijk voorbeeld van, maar ook andere belangrijke thema's in het debat zoals 'de betekenis van het verlichtingsdenken' of 'de sociale functies van religie'. Zolang het debat op dit algemene niveau gevoerd wordt, blijft de overgang van eerste- naar tweede-orde-rechtvaardigingen het karakter houden van 'water bij de wijn doen'. De deelnemers aan het debat worden dan als het ware gedwongen om hun eigen wijn te 'verdunnen', zodat die zijn karakteristieke smaak en daarmee zijn waarde grotendeels verliest.

Uit de huidige praktijk van de geestelijke verzorging rijst echter een andere zoekrichting op die - voortbouwend op het onderscheid van Rawls - aangeduid kan worden als 'derde-orde-rechtvaardigingen'. Het gaat hier om de betekenis die specifieke zingevingskaders en tradities hebben voor het omgaan met praktische vragen en problemen die in afzonderlijke institutionele domeinen en organisaties aan de orde zijn, zoals de zorg, de krijgsmacht, justitiële instellingen, het onderwijs of de sociale sector. In dergelijke semi-publieke domeinen is de betekenis van waardegeladen overtuigingen aan een vorm van praktische toetsing onderhevig, die op het niveau van het algemene publieke debat grotendeels ontbreekt. Deze praktische toetsing betreft de concrete bijdrage vanuit uiteenlopende waardegeladen overtuigingen en de tradities waaruit die putten aan de 'zaak' die 
in de verschillende domeinen aan de orde is; bijvoorbeeld goede en betrokken zorg voor ouderen in verpleeghuizen of humane detentie en resocialisatie in justitiële inrichtingen of het eerbiedigen van mensenrechten en het respectvol omgaan met culturele verschillen op buitenlandse missies van de krijgsmacht. De morele en existentiële vragen waar het hier om gaat zijn zoals betoogd in hoge mate verstrengeld met de alledaagse, praktische gang van zaken binnen de organisaties in kwestie en met de specifieke taak waarvoor zij staan. Daarmee is een praktische toets verbonden. Wat hebben verschillende overtuigingen bijvoorbeeld bij te dragen aan het verminderen van bedekte vormen van discriminatie jegens vrouwen en homo's binnen de krijgsmacht? Of aan het vergroten van moreel zelfinzicht van gedetineerden? Of aan de verwerking van rouw en verlies in de confrontatie met ziekte en dood? Of aan het versterken van de betrokkenheid en de empathische vermogens van hulpverleners?

Deze voorbeelden verwijzen naar een even belangrijk als verstrekkend verschil tussen dergelijke 'derde-orde-rechtvaardigingen' en rechtvaardigingen van de tweede orde waarop Rawls, Habermas, Benhabib en vele andere moderne verlichtingsdenkers zich richten. Voor derde-orde rechtvaardigingen is géén omzetting noodzakelijk van de narratieve vorm die kenmerkend is voor veel religieuze en levensbeschouwelijke inzichten in publiek te verdedigen argumenten. Het verhaal van de barmhartige Samaritaan, of de brieven over tolerantie van Erasmus, of de documentaires van Hedy Honigman zijn juist in hun narratieve gedaante betekenisvol en verliezen hun inspirerende vermogen wanneer zij tot materiaal voor deliberatieve argumentaties worden omgevormd. Hetzelfde geldt a fortiori voor de - klassieke en eigentijdse - rituelen, voor de muziek en voor de uiteenlopende vormen van meditatieve verstilling die niet alleen deel uitmaken van het professionele arsenaal van geestelijk verzorgers en de tradities waar zij uit putten, maar ook een belangrijke plaats innemen binnen de bricolage die de zingevingsstijl van de ongebonden spirituelen en vele humanisten kenmerkt.

\section{Horizontale transcendentie en derde-orde-rechtvaardigingen}

Aan de hand van het idee van derde-orde-rechtvaardigingen, kan ook het begrip horizontale transcendentie dat ik hierboven kort heb aangestipt, verder worden uitgewerkt. Verticale articulaties van transcendente waarden zijn intern verbonden met eerste-orde-rechtvaardigingen in de zin van Rawls. Horizontale articulaties van transcendente waarden worden echter gekenmerkt door de betrokkenheid op pluraliteit, op 'leerzame wrijving' met andere articulaties van transcendente waarden en onderliggende tradities of perspectieven. Die leerzame wrijving kan óók een argumentatieve gedaante aannemen, maar dat is niet noodzakelijk. Juist in narratieve vorm kunnen horizontale articulaties van transcendente waarden bijdragen aan het ontwikkelen en in stand houden van een 'humuslaag' van inspirerende perspectieven, metaforen en verhalen binnen specifieke maatschappelijke domeinen en organisaties, waaruit contextgebonden inzichten op kunnen rijzen ten aanzien van de existentiële vragen en morele dilemma's die daarbinnen aan de orde zijn. De mate waarin specifieke zingevingskaders erin slagen vruchtbare bijdragen aan een dergelijke humuslaag te 
genereren en daarmee inhoud te geven aan horizontale vormen van transcendentie, vormt een derde-orde-rechtvaardiging voor hun publieke betekenis. Instructieve voorbeelden daarvan bieden de presentiebenadering die door Andries Baart is ontwikkeld in het verlengde van het Utrechtse buurtpastoraat (waarnaar ook Erik Borgman in zijn bijdrage verwijst); of het concept van de levensloopbestendige woningen en de integratie van cure, care, wonen en welzijn in het teken van humane waarden, zoals ontwikkeld door Hans Becker van Humanitas Rotterdam, of het project En nu iets positiefs, voortgekomen uit samenwerking van Marokkaanse buurtvaders met een breed scala van sociale partners in Amsterdam. Kenmerkend voor alle drie deze voorbeelden is in de eerste plaats de betrokkenheid op waarden die individuele belangen overstijgen, zoals aandachtige zorg, solidariteit en onderlinge steun, waarvoor in het bijzonder geput wordt uit het gedachtegoed en het narratieve repertoire van één traditie, maar dan op zo'n manier dat deze waarden niet exclusief geclaimd worden voor één traditie, maar actief naar aansluiting (en leerzame wrijving) vanuit andere tradities en overtuigingen wordt gestreefd, met het oog op het dichterbij brengen van een gedeeld praktisch doel.

In de tweede plaats is voor alle drie deze voorbeelden kenmerkend dat de praktische doelen waar het om gaat alleen gerealiseerd kunnen worden op basis van cocreatie met de cliënten of buurtbewoners in kwestie. De 'horizontale dynamiek' die in alle drie deze voorbeelden in het spel is, strekt zich niet alleen uit tot andere overtuigingen, maar heeft met name ook betrekking op het aandachtig en respectvol zoeken van aansluiting bij de eigen overtuigingen en de eigen hulpbronnen van de betrokkenen. De professionals en vrijwilligers waar het hier om gaat handelen met andere woorden niet primair vanuit een technische expertise van waaruit de ander tot object van cognitief gefundeerde interventies wordt gemaakt. In plaats daarvan vormen de eigen zingevingsmogelijkheden en de actorpositie van de cliënten of buurtbewoners het centrale oriëntatiepunt: horizontale transcendentie en co-creatie zijn onlosmakelijk met elkaar verbonden. De mate waarin levensbeschouwelijke tradities en zingevingskaders erin slagen om daar in concrete praktijken gestalte aan te geven, vormt een derde-orde-rechtvaardiging voor hun publieke betekenis.

\section{Normatieve professionalisering}

Daarmee kom ik ten slotte bij het begrip dat hierboven al een aantal keren is genoemd als concretisering van de nieuwe zoekrichting die uit de ontwikkelingen binnen de geestelijke verzorging gedestilleerd kan worden: normatieve professionalisering. Dit begrip is ontwikkeld vanuit de praktijk van het humanistisch geestelijk werk, het buurtpastoraat en de kritische traditie binnen het sociaal werk. De centrale inzet was daarbij om zowel op conceptueel niveau als op het niveau van de praktijk tegenwicht te kunnen bieden aan de dominantie van bedrijfsmatig georiënteerde managementmodellen en de bijbehorende 'technische' invulling van professioneel handelen, waarin het doeltreffend en efficiënt oplossen van nauwkeurig te specificeren problemen op basis van objectieve kennis centraal staat. 
Met behulp van het begrip normatieve professionalisering wordt in de eerste plaats de aandacht gevestigd op de normatieve kaders waaraan alle vormen van professioneel handelen in mensgerichte beroepen binnen semi-publieke domeinen gebonden zijn. Die normen, en de achterliggende waarden waarnaar die verwijzen, hebben betrekking op drie verschillende niveaus die in het professionele handelen samenkomen. In de eerste plaats gaat hier om de algemene normen van het normale burgerlijke verkeer, zoals die in het recht zijn vastgelegd, door nieuwe wetgeving voortdurend worden bijgesteld en geconcretiseerd worden in het kader van specifieke regelingen en organisatorische kaders. Het gaat hier bijvoorbeeld om het nakomen van contractuele verplichtingen, om vragen rond integriteit, maar bijvoorbeeld ook om de normen die de toegang tot AWBZ-gefinancierde voorzieningen bepalen. In de tweede plaats wordt het professionele handelen in mensgerichte beroepen geleid door normen die verbonden zijn met de specifieke kennisbasis en deskundigheid van het beroep in kwestie. In technisch georiënteerde opvattingen van professioneel handelen, wordt deze kennisbasis cognitief opgevat: adequaat professioneel handelen dient gebaseerd te zijn op objectieve, wetenschappelijk getoetste kennis en idealiter 'evidence based' te zijn. Kenmerkend voor dergelijke vormen van technische professionaliteit is het verdringen van het derde niveau waarop de activiteiten van mensgerichte professionals onlosmakelijk verbonden zijn met normen en waarden. Op dit derde niveau kunnen verschillende dimensies onderscheiden worden van het professionele handelen in mensgerichte beroepen. In de eerste plaats gaat het hier om de specifieke morele betekenis van het beroep in kwestie, zoals mensen helpen, voor hen zorgen, de verantwoordelijkheid voor hun opvoeding nemen, of bij proberen te dragen aan het genezen van lichamelijke en geestelijke aandoeningen. In het verlengde van de waarden waar het hier om gaat zijn hier in de tweede plaats relationele waarden en normen in het spel, die betrekking hebben op de zorgvuldige, respectvolle en betrokken afstemming op de uniciteit van de personen in kwestie en op hun eigen levensverhaal en zingevingskader. Ten slotte gaat het hier om de existentiële en morele vragen die - soms expliciet, soms impliciet - mee resoneren in de vragen en problemen waarop de betrokken professionals een antwoord proberen te bieden.

Met het oog op deze drie niveaus waarop waarden en normen in mensgerichte beroepen in het spel zijn, brengt het begrip normatieve professionalisering de noodzaak tot uitdrukking van een professionele omgang met deze waarden en normen. Professionaliteit wordt daarbij verstaan als doeltreffend, publiek te verantwoorden handelen, dat gebaseerd is op een kritiseerbare kennisbasis. Door de constitutieve rol van normen en waarden voor het handelen van mensgerichte professionals centraal te stellen, vestigt het begrip normatieve professionalisering de aandacht op het gemengde karakter van de kennisbasis voor professioneel handelen in mensgerichte beroepen. De kennis en inzichten waar het hier om gaat verwijzen niet alleen naar cognitieve kennis op basis van empirisch toetsbare wetenschappelijke kennis, en naar ervaringskennis van de betrokken professionals en hun cliënten, maar altijd ook naar morele en existentiële inzichten. 
Hier ligt nu de grote betekenis van de ontwikkelingen die het geestelijk werk de afgelopen decennia heeft doorgemaakt, in het bijzonder rond de verstrengeling van existentiële en morele vragen met specifieke organisatorische contexten en de gelijktijdige verdringing daarvan onder invloed van bedrijfsmatig georiënteerde managementmodellen en bijbehorende technische opvattingen van professionaliteit. In het verlengde hiervan heeft de beroepsgroep zich ontwikkeld tot een interessante en vruchtbare proeftuin voor normatieve professionalisering, in het teken van horizontale transcendentie en leerzame wrijving tussen uiteenlopende waardegeladen perspectieven. De beroepspraktijk van geestelijk verzorgers laat zien dat de identificatie van religieuze en levensbeschouwelijke zingevingskaders met verticale, gesloten articulaties van transcendentie die de discussie rond de scheiding van kerk en staat lange tijd heeft gedomineerd, niet langer van toepassing is. Geestelijk verzorgers voeren op individueel en op groepsniveau leerzame gesprekken met cliënten die een breed scala aan zingevingsstijlen vertegenwoordigen, van religieus gebonden, tot ongebonden spiritueel en humanistisch, en brengen daarbij hun eigen existentiële en morele perspectieven en inzichten op horizontale basis in het spel, in het teken van co-creatie en leerzame wrijving.

\section{Nieuwe morele vrijplaatsen}

Daarmee bieden zij een model aan voor een reflexieve, kritiseerbare omgang met waardegeladen vragen binnen semi-publieke organisaties dat ook voor andere professionals daarbinnen van groot belang is. De massieve verdringing van dergelijke vragen uit de zorg, de GGZ, het welzijnswerk en uit andere semi-publieke domeinen, roept in toenemende mate kritiek en verzet op. Auteurs als Pauline Meurs, Evelien Tonkens, Ad Verbrugge, Guy Widdershoven en vele anderen, wijzen op de noodzaak om de 'ziel' van professioneel handelen te redden, om recht te doen aan de centrale rol van waarden en inspiratie voor de kwaliteit van professioneel handelen en om nieuwe vormen van betrokken, 'dienend' management te ontwikkelen. De vrijplaatsfunctie zoals die van oudsher door geestelijk verzorgers wordt vervuld, biedt daarvoor een vruchtbaar aanknopingspunt, zij het in een getransformeerde gedaante. Om de normatieve professionaliteit van professionals in mensgerichte beroepen te kunnen voeden en ondersteunen, zijn nieuwe morele vrijplaatsen vereist binnen semi-publieke organisaties, waarin ruimte wordt geschapen voor de eigen vorm van leren en inzicht die bij het omgaan met existentiële en morele vragen in het spel is en voor leerzame wrijving tussen de narratieve bronnen die dergelijke vormen van inzicht kunnen voeden, zowel aan de kant van professionals als aan de kant van cliënten. ${ }^{19}$ Het ontwikkelingspad dat de commissie-Hirsch Ballin in 1986 voor de geestelijke verzorging heeft uitgezet, namelijk aansluiten bij de specifieke morele vragen die bij defensie aan de orde zijn, wordt daarmee doorgetrokken naar alle professionals in semi-publieke domeinen. Tevens wordt daarmee recht gedaan aan de uitwaaiering van zingevingsstijlen die in ons land is opgetreden en aan eigentijdse mogelijkheden om leerzame wrijving daartussen te bevorderen in het licht van praktische vragen. ${ }^{20}$ 
Geestelijk verzorgers kunnen een onmisbare inspirerende en ondersteunende rol spelen bij het ontwikkelen en in stand houden van dergelijke morele vrijplaatsen, maar de verantwoordelijkheid daarvoor kan niet exclusief aan hen gedelegeerd worden. In plaats daarvan ware het wenselijk dat de overheid en haar vertegenwoordigers in semi-publieke domeinen onder ogen zouden zien dat de exclusieve aandacht voor bedrijfsmatige vormen van sturing, voor efficiency en voor resultaatverantwoording, de facto één specifieke zingevingsstijl binnen de organisaties in kwestie bevoordeelt: een zingevingsstijl waarbinnen elke verwijzing naar transcendente waarden ontbreekt en zingeving als een strikte privézaak wordt beschouwd. Door gerichte aandacht en steun te bieden aan normatieve vormen van professionalisering op basis van horizontale articulaties van transcendente waarden en het bevorderen van leerzame wrijving daartussen binnen nieuwe morele vrijplaatsen, kunnen de betrokken organisaties recht doen aan het feit dat de meerderheid van onze bevolking niet alleen een proces van levensbeschouwelijke individualisering heeft doorgemaakt, maar ook een betrokkenheid toont op transcendente waarden in het teken van menselijke waardigheid. In het licht van de grote druk vanuit economische en technologische krachtenvelden die hedonistische en nihilistische vormen van individualisering bevorderen, heeft een dergelijk tegenwicht een groot maatschappelijk belang.

Het stimuleren en inhoudelijk voeden van normatieve professionalisering door middel van nieuwe morele vrijplaatsen, zou een belangrijke, democratisch te rechtvaardigen, 'horizontale' bijdrage kunnen vormen vanuit religieuze en levensbeschouwelijke tradities aan het reilen en zeilen van semi-publieke organisaties. Daarmee doemt een praktische zoekrichting op voor een eigentijdse bijdrage vanuit religie en levensbeschouwing aan het publieke domein, die voorbij de uitgesleten groeven wijst waarin het huidige debat al te vaak blijft steken. 


\section{NOTEN}

Volgens opgave van de beroepsvereniging de VGVZ zijn in de zorgsector een kleine duizend geestelijk verzorgers werkzaam. Samen met de geestelijk verzorgers in de krijgsmacht en in Inrichtingen van Justitie brengt dat de totale beroepsgroep op ongeveer 1300 leden, waarbij bedacht moet worden dat vooral in de zorgsector de meeste aanstellingen slechts enkele dagen per week omvatten. Het overgrote deel heeft een academische opleiding, maar de laatste jaren zijn er verschillende opleidingen op hbo-niveau ontstaan.

Een simpel voorbeeld daarvan biedt het feit dat in verpleeghuizen in ons land pas sinds kort beweging begint te komen in de ijzeren wet dat de warme maaltijd (op grond van efficiency-overwegingen) rond het middaguur gebruikt dient te worden, ook al hebben veel bewoners hun ontbijt dan pas kort achter hun kiezen. Bij de krijgsmacht en in gevangenissen zijn dergelijke systeeminvloeden nog veel dwingender.

Vgl. recent onderzoek daarnaar: Frank J. Buijs, Froukje Demant \& Atef Handy, Strijders van eigen bodem. Radicale en democratische moslims in Nederland, Amsterdam University Press 2006. Interessant aan dit onderzoek is ondermeer de interne wrijving die eruit naar voren komt tussen verschillende fundamentalistische groepen, die tot een relatief isolement van de 'extremisten' leidt.

Ik geef de voorkeur aan het begrip 'zingevingsstijl' boven het begrip 'levensstijl' dat Kronjee en Lampert hanteren, omdat het begrip levensstijl in dit verband te breed is en het begrip 'zingevingsstijl' nauwkeuriger aangeeft waar het om gaat, namelijk alternatieve vormen van moreel geladen zingeving.

Het is in dit verband opvallend dat de belangrijkste humanistische organisaties die verenigd zijn in de Humanistische Alliantie (zoals Humanitas en zijn vele werkstichtingen, de organisatie voor ontwikkelingssamenwerking Hivos, het Humanistisch Vormingsonderwijs en de Universiteit voor Humanistiek) hun maatschappelijke draagvlak niet primair ontlenen aan leden en donateurs, zoals het Humanistisch Verbond, maar aan de inhoudelijke kwaliteit van de praktische bijdrage die zij op een specifiek maatschappelijk terrein leveren. Zie hiervoor ook mijn artikel 'De toekomst van de het humanisme en de rol van de Humanistische Alliantie' in het recente themanummer van het Tijdschrift voor Humanistiek, 5e jrg. nr. 25, april 2006.

Vgl. voor uiteenlopende analyses van de achtergronden en oorzaken van deze erosie ondermeer J. Habermas (1981); A. Giddens (1991); N. Luhmann (1999) en R. Sennet (1998 en 2006). Ik ga hier verder voorbij aan de economische en technologische krachtenvelden die deze erosie mede bepalen. Vgl. daarvoor Kunneman 2005 .

Het begrip normatieve professionalisering is ontwikkeld vanuit de Universiteit voor Humanistiek en de Katholieke Theologische Universiteit Utrecht, in samenwerking met onderzoekers uit de sociale sector, waaronder Geert van der Laan. Vgl. de bijdragen van Andries Baart, Marjolijn Gelauff, Douwe Van Houten, Geert van der Laan en Harry Kunneman aan het themanummer van het tijdschrift Sociale Interventie over normatieve professionaliteit, jaargang 5, nr. 3, 1996. Het begrip 
horizontale transcendentie staat centraal in een door Nwo gefinancierd onderzoek in het kader van het programma 'The future of the religious past', dat wordt uitgevoerd aan de UvH. Vgl. Kunneman 2005; Van den Ende 2005; Halsema 2006. Vgl. F. Buijs, Contouren van nieuw beleid. Een onderzoek naar de toekomst van de humanistische geestelijke verzorging in de krijgsmacht, Universiteit voor Humanistiek, Utrecht 200o, p. 54. Buijs baseert zich ondermeer op het invloedrijke rapport van de commissie-Hirsch Ballin: Commissie van advies inzake criteria voor steunverlening aan kerkgenootschappen en andere genootschappen op geestelijke grondslag, Den Haag 1986.

Vgl. Desanka Kempers, 'Het levensverhaal als materiaal voor geestelijke verzorging bij gedetineerden', Tijdschrift voor Humanistiek, nr. 11, jrg. 3, 2002. In de krijgsmacht nemen geestelijk verzorgers overigens sinds kort wel deel aan multidisciplinair overleg, met name in het kader van uitzendingen. Vgl. Voor een inspirerende formulering van hetzelfde grondidee vanuit andere bronnen: Otto Duintjer, Onuitputtelijk is de waarheid, Damon 2001. In het verlangde daarvan kan de stelling verdedigd worden dat geestelijke verzorging als beroep steeds meer de richting uit is gegaan die van het begin af aan door de humanistische geestelijke verzorging is ingeslagen. De keerzijde daarvan is natuurlijk dat daarmee de scheidslijnen tussen humanisme en niet-dogmatische vormen van religiositeit en spiritualiteit vervagen. Vgl. E. Hoogeveen, Eenvoud en strategie, De Tijdstroom, Utrecht 1996 en Duyndam, J., Porthuis, M. de Wit, T. (red.) Humanisme en religie. Controverses, bruggen perspectieven, Eburon, Delft 2005.

12 Vgl. F. Buijs, 1.c, blz. 55.

13 Vgl. voor de meest recente ontwikkelingen en discussies het nieuwe Tijdschrift voor herstelrecht, uitg. SWP, Amsterdam en www.herstelrecht.nl.

14 Vgl. brief Ministerie vws, Kenmerk AWBZ 237 2837, mei 2003.

15 Het is overigens in dit verband een interessante vraag of de humanisten met recht kunnen claimen dat zij deze groep der 'buitenkerkelijken' vertegenwoordigen. In de praktijk is het zonder twijfel waar dat de drempel voor 'buitenkerkelijken' om GV van een humanistische raadsman of vrouw te accepteren lager is dan van een geestelijk verzorger met een expliciete religieuze identiteit. Maar ook humanisten staan voor het dilemma of zij zichzelf in het kader van het klassieke model als een expliciete levensbeschouwing afficheren, maar dan ook geen speciale 'rechten' kunnen laten gelden op de bricoleurs, dan wel afstand doen van dit model en de levensbeschouwelijke individualisering en de ontwikkeling van 'gemeenschappelijke morele vrijplaatsen' als uitgangspunt voor GV accepteren, met alle consequenties van dien.

16 Vgl. op de website van de vGVZ de ingang 'register', pagina: “Toelichting Register tijdens de hearings, door Hans Bomhof”, www.vgvz.nl. Vgl. hiervoor bijvoorbeeld de discussie in het Tijdschrift voor geestelijke verzorging tussen Ton Jorna, die een spiritueel gerichte invulling van geestelijke verzorging voorstaat (TGV, 8, nr. 34, blz. 36-46) en Johan Bouwer, die de belangrijkste pleitbezorger is van levensbeschouwelijke diagnostiek binnen de beroepsgroep (TGV, 8, nr. 37, blz. 37-47). Vgl. ook de oratie van Johan Bouwer: Van de kaart naar het gebied. Het domein van de geestelijke zorgverlening, Kamper oraties, Kampen 2003. 
Kronjee en Lampert 2006, 1.c.

19 Ik spreek hier over 'nieuwe morele vrijplaatsen', omdat deze vrijplaatsen primair een verantwoordelijkheid vormen van de betrokken organisaties, in plaats van ingevuld te worden vanuit zendende genootschappen. Dit betekent dat het daarbinnen ten principale om leerzame wrijving gaat tussen meerdere inhoudelijke perspectieven in plaats van om (meer of minder afgezwakte) vormen van 'zending'. De 'oude' vrijplaatsen worden daarmee uiteraard niet overbodig: geïnspireerde en gespecialiseerde geestelijke verzorging aan individuen blijft onverminderd van belang. Maar de verantwoordelijkheid voor 'het geestelijke' en voor morele vragen binnen organisaties kan en moet gedeeld gaan worden met andere professionals, wat alleen mogelijk is wanneer het management zich daar op grond van eigen morele hulpbronnen én zakelijke afwegingen mee verbindt. Hiervoor kan ook aansluiting gevonden worden bij de theorievorming rond maatschappelijk verantwoord ondernemen, bij bewegingen als 'dienend leiderschap' en bij alle eigentijdse aandacht voor zingeving en cultuurontwikkeling in organisaties. Vgl. bijv. Senge, P. et al. Presence, Exploring profound change in people, organizations and society, Nicholas Brealey Publishin, London 2005; Korten, David, C. The Post-Corporate World, Berret-Koehler Publishers, San Francisco 1999; Tonja van den Ende, Harry Kunneman en Ireen Dubel (red.) Cosmetische humanisering? Maatschappelijk verantwoord ondernemen ter discussie, Humanistics University Press/SWP, Amsterdam 2005. Vgl. voor een praktisch voorbeeld daarvan de experimenten met 'moreel beraad' in de zorg die vanuit de Universiteit van Maastricht ontwikkeld zijn door ondermeer Guy Widdershoven en Hans van Dartel. Vgl. Widdershoven, G. Ethiek in de kliniek, Boom, Amsterdam 2000; Dartel. H. van, Van ethische commissie naar stuurgroep ethiek?: over de implementatie van moreel beraad in het kwaliteitsbeleid van instellingen voor gezondheidszorg, 2002. 


\section{LITERATUUR}

Bouwer, J. (2003) Van de kaart naar het gebied. Het domein van de geestelijke zorgverlening, Kampen: Kamper oraties.

Boutellier, H., H. Kunneman \& J. Leest (red.) (2001) De strafvoorbij. Morele praktijken rondom het strafrecht, Amsterdam: SWP.

Buijs, F. (200o) Contouren van nieuw beleid. Een onderzoek naar de toekomst van de humanistische geestelijke verzorging in de krijgsmacht, Utrecht: Universiteit voor Humanistiek.

Buijs, F., F. Demant en A. Handy (2006) Strijders van eigen bodem. Radicale en democratische moslims in Nederland, Amsterdam: Amsterdam University Press.

Dartel, H. van (2002) Van ethische commissie naar stuurgroep ethiek?: over de implementatie van moreel beraad in het kwaliteitsbeleid van instellingen voor gezondheidszorg, Landelijk Bureau Ethiek in de Zorg, Utrecht.

Duyndam, J., M. Porthuis, T. de Wit (red.) (2005) Humanisme en religie. Controverses, bruggen, perspectieven, Delft: Eburon.

Ende, T. van den (2005) 'Horizontale transcendentie als humanistisch perspectief', blz. 393-404 in: J. Duyndam, M. Porthuis, T. de Wit (red.) (2004) Humanisme en religie. Controverses, bruggen perspectieven, Delft: Eburon.

Ende, T. van den, H. Kunneman en I. Dubel (red.) (2005) Cosmetische humanisering? Maatschappelijk verantwoord ondernemen ter discussie, Amsterdam: Humanistics University Press/swP.

Giddens, A. (1991) Modernity and Self-Identity, Cambridge: Polity Press.

Habermas, J. (1981) Theorie des Kommunikativen Handelns, Frankfurt am Main: Suhrkamp.

Hirsch Ballin et al. (1986) Commissie van advies inzake criteria voor steunverlening aan kerkgenootschappen en andere genootschappen op geestelijke grondslag, Den Haag.

Kempers, D. (2002) 'Het levensverhaal als materiaal voor geestelijke verzorging bij gedetineerden. Over slijtage en inspiratie in het werk', Tijdschrift voor Humanistiek 11, 3 .

Korten, David, C. (1999) The Post-Corporate World, San Francisco: Berret-Koehler Publishers.

Kunneman, H. (2005) Voorbij het dikke-ik. Bouwstenen voor een kritisch humanisme, Amsterdam: Humanistics University Press/sw P.

Kunneman, H. (april 2006) 'De toekomst van de het humanisme en de rol van de Humanistische Alliantie', Tijdschrift voor Humanistiek 25, 5 .

Luhmann, N. (1999) Die Gesellschaft der Gesellschaft, Suhrkamp, Frankfurt am Main.

Rawls, J. (1996) Political Liberalism, Columbia University Press.

Senge, P. et al. (2005) Presence, Exploring profound change in people, organizations and society, London: Nicholas Brealey Publishing.

Sennett, R. (1998) The Corrosion of Character. The Personal Consequences of Work in the New Capitalism, New York/Londen: WW. Norton \& Company.

Sennett, R. (2006) The culture of the New Capitalism, New Haven \& London: Yale University Press.

Widdershoven, G. (200o) Ethiek in de kliniek, Amsterdam: Boom. 


\title{
15 RELIGIE EN ZORG IN HET PUBLIEKE DOMEIN
}

\author{
Hans Schilderman
}

\subsection{PROBLEEMSTELLING}

Het constitutionele beginsel dat de grondslag biedt voor de positie van religie in het publieke domein kent negatieve én positieve formuleringen. De negatieve formulering is die van scheiding van kerk en staat; de positieve die van vrijheid van godsdienst en levensovertuiging. In het eerste geval legt de overheid zich een restrictieve rol op, namelijk die van ontvlechting van banden tussen overheid en religieuze genootschappen. In het tweede geval is de rol van de overheid juist faciliterend, namelijk door zorg te dragen voor het vrijelijk kunnen belijden van overtuigingen van religieuze of niet-religieuze aard. ${ }^{1}$ Deze ambivalentie van de religieuze vrijheid wordt vooral voelbaar op die plaatsen waar overheid en kerken op elkaar een beroep doen. Dat is bijvoorbeeld het geval bij de geestelijke verzorging die immers een van de weinige functionele samenwerkingsverbanden tussen kerk en overheid vertegenwoordigt waar 'religieus kapitaal' buiten de kerkmuren in het publieke domein geïnvesteerd wordt. Terwijl het domein van de zorg tot in de recente geschiedenis ook een religieuze signatuur kende, is die door ontvlechting van de formele banden tussen kerk en staat in onze moderne instituties goeddeels verloren gegaan. De geestelijke verzorging staat daarmee voor de vraag of en hoe 'religieus kapitaal' te investeren valt in professionele bijdragen aan en in de zorg.

Deze probleemstelling werk ik in deze bijdrage als volgt uit. Eerst schets ik welke ideaaltypische functies religie in het publieke domein van de maatschappij vervult. Dan licht ik enkele risico's toe die samenhangen met het feit dat dergelijke functies in het maatschappelijke domein van de zorg steeds meer aan belang en betekenis blijken in te boeten. Ik beschrijf vervolgens op grond daarvan enkele professionele uitdagingen voor de geestelijke verzorging, die immers op te vatten is als een institutionele uitdrukking van de beschreven functies van religie in het publieke domein van de zorg. Ten slotte besluit ik deze bijdrage met een schets van enkele scenario's waarbinnen de geestelijke verzorging 'religieus kapitaal' in de toekomst professioneel kan blijven investeren in de zorg.

\subsection{MAATSCHAPPELIJKE FUNCTIES VAN RELIGIE}

Een van de gezichtspunten die in staatsrechtelijke en politieke discussies over de positie van religie in het publieke domein doorgaans slechts zijdelings ingenomen wordt betreft de feitelijke betekenis van religie voor de samenleving. Religie wordt - overigens om vrij voor de hand liggende redenen - met de gevestigde kerken geïdentificeerd, waardoor de afbakening van institutionele verantwoordelijkheden centraal komt te staan en sociaal-culturele betekenissen van religie ondergesneeuwd dreigen te raken. Een eenzijdige behartiging van het constituti- 
onele beginsel van scheiding van kerk en staat loopt zo het risico te miskennen welke maatschappelijke functies religie in het maatschappelijke domein kan hebben. Om de betekenis van dit sociaal-culturele belang van religie te blijven onderkennen kan beter van 'religieus kapitaal' gesproken worden. Het maatschappelijke fenomeen van religieuze overtuigingen wordt dan opgevat als een vorm van sociaal kapitaal waarvan het investeringspotentieel afhankelijk is van de mogelijkheden die kerk en staat daartoe bieden. Religieus kapitaal verwijst naar het geheel van bekwaamheden, ervaringen en vertrouwensbanden dat in religieuze tradities vervat ligt en dat in sociaal en maatschappelijk initiatief geïnvesteerd kan worden (Furbey 2006). Dergelijke investeringen van religieus kapitaal kunnen ideaaltypisch als functies omschreven worden die samengesteld zijn uit de saillante kenmerken van religies. ${ }^{2}$ Religies leveren conform dergelijke functies unieke bijdragen aan het maatschappelijke domein, maar vertegenwoordigen daarin ook potentiële risico's. Anders gezegd, het religieuze kapitaal, dat wil zeggen het talent voor en de verbondenheid met een specifieke religieuze cultuur, kan zowel door kerken als door de samenleving beïnvloed worden en kan vervolgens - afhankelijk van sociale kansen en omstandigheden - zowel gunstige als ongunstige consequenties hebben. ${ }^{3}$ Het is precies daar waar de vrijheid van godsdienst en levensovertuiging ook normatieve betekenis heeft in en voor het publieke domein. Alvorens in te gaan op dergelijke mogelijke bijdragen van religie in het publieke domein, zal ik eerst twee motieven aangeven die mogelijk verklaren waarom de discussie over dergelijke functies veronachtzaamd dreigt te worden.

Het eerste motief om functies van religie in het maatschappelijke domein weinig aandacht te schenken treft men aan onder degenen die menen dat religie - althans in westerse contexten als die van Nederland - verdwijnt. Welke functie men ook aan religies zou willen toekennen; het leidt tot overbodige discussies omdat kerkverlating en verlies van religieuze betrokkenheid min of meer lineaire en onomkeerbare processen vertegenwoordigen die iedere mogelijke invloed van kerk of religie op overheid a fortiori irrelevant maken. Zo althans luidt - enigszins kortweg - de bewering (Bruce 2002). Er is inderdaad overvloedig empirisch bewijs dat de rol van gevestigde (volks)kerken in West-Europa en in het bijzonder in Nederland sterk in belang afneemt. Bij dergelijke claims van secularisatiesociologen zijn echter vragen te stellen. Zo zijn er ook contra-indicaties aanwijsbaar die wijzen op bestendiging, aanpassing, revitalisering of innovatie van religieus kapitaal, zoals het beklijven van een geïndividualiseerde diffuse religiositeit ('spiritual quest'), herlevende orthodoxie, het succes van pinksterkerken en de opkomst van de islam. Door secularisatietheoretici worden dergelijke fenomenen weliswaar geregeld afgedaan als randverschijnselen, maar 'rational choice'-theoretici in de godsdienstsociologie ageren daartegen vanuit comparatieve perspectieven redelijk succesvol (Stark en Bainbridge 200o). Het secularisatieparadigma kan echter ook zelf de gedaante van een maatschappelijke overtuiging aannemen. De term secularisme drukt in dat geval de overtuiging uit dat de scheiding van kerk en staat een intrinsiek belang vertegenwoordigt. Het constitutionele beginsel van vrijheid van religie ('freedom of religion') wordt dan opgevat als een bevrijding 
van religie ('freedom from religion') die ook in sociaal-cultureel opzicht behartigd moet worden. In minimaal opzicht kan een overheid religie nog gedogen; in ruimer opzicht verdient religie bestrijding door de overheid, althans in het publieke domein. Ofschoon er weinig politici zullen zijn die een dergelijk uitgangspunt publiekelijk zullen onderschrijven, moet de betekenis en werking van impliciete overtuigingen op dit punt niet onderschat worden. Secularisme hangt immers samen met de krachtige invloed die de Verlichting heeft uitgeoefend op het staatsbestel en op de rationele levensvoering, en die regelmatig aanwijsbaar blijkt in tal van controverses die dagelijks de politieke revue passeren. ${ }^{4}$ Hoe dan ook dient een dergelijke ideologiegevoeligheid van de begrippen 'secularisatie' en 'secularisme' niet onderschat te worden; die dreigt althans de argumentatieve discussie over functies van religie van meet af aan te immuniseren. ${ }^{5}$

Het tweede motief om religieuze functies in het publieke domein weinig aandacht te schenken treft men juist aan onder religieus geïnteresseerde intellectuelen. Hier luidt het motief dat een discussie over functies van religie het gevaar oproept van functionalisme. Het verwijt luidt dan dat een systeemperspectief de definitie van religie bepaalt. Religie wordt voorgesteld als een middel om vastliggende doeleinden te bereiken, terwijl zij juist helpt om het open einde van dergelijke doeleinden persoonlijk en cultureel betekenis te geven. Het gevaar is dat religie slechts op haar effecten beoordeeld wordt waardoor haar intrinsieke betekenis verdwijnt en het belang van een religieus vocabulaire voor de eigen identiteitsbepaling miskend wordt. Inderdaad moet onderkend worden dat op de eigen belijdenis gebaseerde definities van religie de traditie en missie meer consequent in het vizier houden en dat daardoor een scherper profiel gewaarborgd wordt. Anderzijds moet ook geconstateerd worden dat dergelijke intrinsieke omschrijvingen vaker de doctrines van gevestigde religies volgen en dat de universaliteitsaanspraken ervan analyse en classificatie bemoeilijken. Daardoor dreigt niet alleen het religieus kapitaal buiten de kerken aan het oog onttrokken te worden, maar wordt het bovendien moeilijker om adequate vergelijkingen te maken tussen religies onderling. Overigens kan men vanuit een binnenperspectief een 'semantische voorrang' van een religieus vocabulaire in de zelfdefinitie van religies beamen en tegelijkertijd vanuit een buitenperspectief de vraag naar religieuze functies blijven stellen. Zo komt tenminste de mogelijkheid van religieuze disfuncties ter discussie te staan en worden de belijdenis, traditie en missie van een religie argumentatief in verband gebracht met de vraag of, wanneer, waar en hoe religie de maatschappelijke betekenis krijgt die ze kennelijk beoogt.

De motieven om de functies van religie niet te agenderen zijn dus inzichtelijk, maar bevatten ook het risico dat het debat over religie in het publieke domein slechts in staatrechtelijke of ideologische zin gevoerd wordt. Daarom is de vraag gerechtvaardigd welke maatschappelijke functies religie vervult en of religieus kapitaal - het erfgoed dat religies in sociaal initiatief vertegenwoordigen - in voorkomende gevallen goed geïnvesteerd wordt. Daarom blijft de vraag van belang welke de specialiteit van religie is in het publieke domein van de samenle- 
ving. Op grond van godsdienstsociologische literatuur kan daarbij onderscheid gemaakt worden naar een zestal generieke functies van religie (Kaufmann 1989; Pollack 2000: 55-81).

Een eerste functie is dat religie identiteit sticht. Religies verhelderen voor personen en groepen dat ze een eenheid vertegenwoordigen. Die eenheid heeft allereerst betrekking op een historische continuiteit die verder gaat dan het generatief vermogen van families. Religies bieden referentiekaders in de overdracht van cultureel erfgoed en baseren de geschiedenis zelf op symbolische en motivationele noties van archaïsche oorsprong en uiteindelijke bestemming. Die identiteit is bovenal sociaal van karakter. Religies maken ervaring van toebehoren mogelijk en bieden socialisatiekaders voor de groepsvorming die ervoor nodig is. Bovendien bieden ze overtuigingen met een vocabulaire voor de interiorisatie en expressie van die collectieve identiteit. De identiteitsstichting is dan ook een morele categorie. Religies installeren personen en groepen als morele actoren die over de tijd heen aanspreekbaar blijven op hun verantwoordelijkheid voor eigen keuzes en gedrag, en wel op grond van kernovertuigingen ten aanzien van die identiteit zelf ('geweten', 'goddelijke vonk', 'ziel'). Deze identiteitsstichting door religies is institutioneel verankerd waardoor de affecten van 'kleine zielen' normatief gebonden raken aan eeuwenoude collectieve zelfbepalingen (Gehlen 1975).

Een tweede functie van religie is eveneens van normatieve aard. Typisch voor religies is dat ze leiding bieden aan handelen in buitengewone omstandigheden. Ofschoon religies vaak afgeschilderd worden als slaafse dragers van conventies bieden ze in hun tradities vaak meer en ook wat anders dan gangbare moraliteit (Ricoeur 1992; Van der Ven 1998: 13-21). Religie biedt gelovigen de vrijheid om te handelen 'vor Gut und Böse'. In religieuze verhalen blijkt telkens dat een gevestigde moraal mensen niet ontslaat van de oproep om vrijmoedig te zijn door in keuzesituaties ook een premoreel perspectief in te nemen. De plausibiliteit en geldigheid van gangbare waarden en normen wordt namelijk in religieuze gelijkenissen geregeld op losse schroeven gezet, waardoor juist een beroep gedaan wordt op contra-intuïtief handelen in dergelijke situaties. Het morele - richtinggevende - karakter van handelen wordt dan niet in termen van vanzelfsprekendheden bevestigd maar juist ter discussie gesteld, waardoor religies althans in potentie bijdragen tot innovatie van een moraal. Daarbij komt dat religieuze tradities doorgaans doordrongen zijn van de grenzen van moreel handelen. Aan elk handelen zijn nu eenmaal actieve én passieve aspecten te onderkennen waardoor motieven en gevolgen van gedrag lang niet altijd overzichtelijk zijn, maar juist gekenmerkt worden door fragiliteit, gebrokenheid en tragiek. Religies kunnen spreken waar een moraal moet zwijgen.

Een derde functie van religie betreft de veel bediscussieerde notie van 'contingentie-erkenning'. Contingentie is toeval: alles wat aan de regievoering van het leven ontsnapt en daarmee de openheid en ongewisheid van menselijke ervaring blootlegt en de relativiteit aantoont van kennis en handelen voor de realisering van primaire levensdoelen. Religieus kapitaal vertegenwoordigt een “Kultur des Verhal- 
tens zum Unverfügbaren" en maakt het dus mogelijk dat mensen niet resigneren voor toeval of noodlot, maar dit juist in vrijheid aanvaarden als mogelijkheid tot zingeving (Lübbe 1986; Dalferth 200o). Contingentie wordt van oudsher ook in referentie aan de theodiceeproblematiek geïnterpreteerd (hoe goddelijke predicaten van almacht en goedheid te verbinden met de overmacht van menselijk leed?), en geldt ten minste vanaf Leibniz en Weber ook als probleem van de moderne tijd. De onmogelijkheid om in dat type omstandigheden van leed en gebrek oorzaak of betekenis toe te kennen tast overtuigingen weliswaar aan maar doet er ook een beroep op. Confrontatie met contingentie roept latente waarden wakker en betekenisverlening op, zij het in de vorm van een religieuze belijdenis of als een spirituele zoektocht. Deze contingentie is overigens een maatschappelijke realiteit die niet losstaat van de ontwikkeling van wetenschap en techniek. Zo wordt het gebrek aan levensregie op beslissende wijze beïnvloed door de voortgang van sociale en medische technieken en heeft zo ook gevolgen voor de maatschappelijke functie van religies en kerken.

Er is nog een vierde functie van religie, namelijk sociaal-rituele integratie die ze vervult door legitimaties te bieden die verder reiken dan de solidariteit die in die sociale functie zelf besloten ligt. Religieuze overtuigingen worden in rituele praktijken betrokken op heilige plaatsen en tijden en smeden daarin mensen tot een morele gemeenschap aaneen. Riten richten de aandacht op een gemeenschappelijke focus waardoor het handelen van deelnemers, althans in hun beleving op dat moment, getransformeerd raakt en als deelname aan een goddelijk gebeuren ervaren kan worden. Het profane karakter van de groep wordt opgeheven en als een heilige presentie opgevat, waardoor de aanvankelijke zelftoeschrijving als sociaal verband een sacrale betekenis krijgt (Durkheim 1912). Een dergelijke, vaak als 'primitief' aangeduide rituele functie van religie staat weliswaar onder de rationaliseringsdruk van functionele differentiatieprocessen in samenlevingen, maar blijft in veel specifieke of afgezwakte vormen aantoonbaar in moderne contexten.

Een vijfde functie van religie verwijst naar de basale vraag van de uiteindelijke betekenis van de samenleving. In hoeverre kan de samenleving een 'kosmos' bieden, dat wil zeggen een orde die door ieder die er deel van uitmaakt als zingevende eenheid beleefd kan worden? Religies bieden hiervoor universele modellen aan die het mogelijk maken om de samenleving als één geheel te ervaren dwars door de chaos van alledag heen. Die ervaring heeft 'eschatologische' kenmerken: de functie stelt althans in staat om een geviseerde (geloofde, gehoopte) werkelijkheid te ervaren als aanbrekend of als reeds gerealiseerd waardoor modellen voor de samenleving en modellen van de samenleving in elkaar grijpen. In die 'kosmische' betekenis van universaliteit ligt een ervaring van transcendentie besloten waarin de 'diepte' van de werkelijkheid verbonden raakt met aspiraties ten aanzien van die werkelijkheid. De samenleving verliest haar 'common sense'-karakter en raakt doordrenkt van overtuigingen die haar de geviseerde orde verschaffen (Geertz 1993; 2000).

Een zesde functie betreft ten slotte het mobiliserende en emancipatoire vermogen van religies. Lang voordat de scheiding van kerk en staat zich tot een consti- 
tutioneel feit ontwikkelde hebben religies onrechtvaardige of immorele praktijken in de samenleving aan de orde gesteld. Religies vertegenwoordigen sociale ordeningsbeginselen die in dergelijke gevallen de seculiere orde aanklagen en bekritiseren. Hun functie is die van contrapunt: harmonieus tegengeluid voor zover de seculiere orde eenzelfde muzikaliteit ten gehore brengt, maar een militante verzetshaard als andere melodieën gespeeld worden die onverenigbaar zijn met een religieuze toonzetting. Dat betekent dus zowel selectieve affiniteit indien religie en samenleving sporen, alsook tegenbeweging zodra de sporen niet langer parallelle banen volgen. Anders gezegd, religies bieden een distantiemogelijkheid ten opzichte van gangbare maatschappelijke ordeningssystemen; doorgaans niet met de pretentie om het betere politieke alternatief te vertegenwoordigen als wel om een spirituele spiegelfunctie te vervullen telkens als de politieke realiteit in haar eigen mechanismen verward raakt (Weber 1947).

Deze zes functies van identiteitsstichting, normatieve innovatie, contingentieverwerking, sociaal-rituele integratie, kosmische betekenisverlening en kritische mobilisering zijn traditionele specialiteiten van religie die nog steeds in het publieke domein van moderne samenlevingen aan te treffen zijn. Daarmee wordt de suggestie gewekt dat religies functies vervullen die andere instituties, nietreligieuze levensbeschouwingen of politieke overheden per definitie niet (kunnen) vervullen. Dit is echter in contemporaine contexten maar zeer de vraag. 'Religieus kapitaal' kan immers ook buitenkerkelijk vorm krijgen, zoals in lokale en clanverbanden ('personal devotion', 'memory sites', 'pilgrimages'), niches in de markt van welzijn en geluk ('new age', 'spiritual therapies'), quasi-rationele innovaties ('scientology', 'quest-bricolages'), revivalbewegingen ('charismatics', 'pentecostals'), etnisch-religieuze subpopulaties ('migrantenkerken', islam), tegenbewegingen ('fundamentalists'), culturele en ecologische belangengroepen. Functies van religie kunnen daarnaast ook door moderne instituties overgenomen en aangepast (en doorgaans gerationaliseerd) worden. Anderzijds kan ook niet uitgesloten worden dat juist in weerstand tegen dergelijke dominante moderniseringsprocessen de archaïsche functies van religie opnieuw in het geweer worden gebracht en bijdragen tot leefstijlen of sociale bewegingen die op gespannen voet staan met maatschappelijke belangen.

\section{$15 \cdot 3$ ONTVLECHTING VAN RELIGIE EN ZORG}

Typisch voor de Nederlandse samenleving is een lange en evidente traditie waarin religieus kapitaal juist buiten de kerk is geïnvesteerd. Ik doel op de verzuiling waarin het christendom de Nederlandse cultuur diepgaand heeft beïnvloed in tal van niet-kerkelijke instituties. Dat geldt in het bijzonder de (gezondheids)zorg. Weliswaar zijn de geschetste functies van religie gedurende de laatste decennia minder pregnant geworden door de ontvlechting van religie en zorg; maar dat laat het historische belang van het in de zorg geïnvesteerde religieuze kapitaal onverlet. 
Religie en kerk staan aan de oorsprong van de zorg voor wat De Swaan de 'fatale trias' van armoede, ziekte, en onwetendheid heeft genoemd (1988). Niet alleen werden leed en gebrek eeuwenlang steeds in een levensbeschouwelijk vocabulaire omschreven; er werd van oudsher lokaal ook kerkelijk en charitatief zorg voor gedragen. Daarbij bestond aanvankelijk nauwelijks onderscheid tussen de rol van priester en die van arts, leraar, maatschappelijk werker of therapeut. De gezondheidszorg ontwikkelde zich vanuit rurale verbanden, maar kreeg door urbanisering een steeds meer stedelijke schaal. Door ontsluiting van steden, aanleg van riolering, water- en elektriciteitsvoorziening, alsook de uitwaaiering van diensten werd een betere gezondheidszorg mogelijk die een steeds meer specialistisch karakter droeg. Een beslissende stap is de ontwikkeling geweest van het sociale-verzekeringsstelsel in de loop van de 19de en 20 ste eeuw, waarbij op grond van collectivisering van het overdrachtsvermogen sociale risico's op nationale schaal afgedekt konden worden. Professionele regimes van hulpverleners vonden in dergelijke collectieve fondsen hun bestaansrecht en zij definieerden conform hun specialisme in toenemende mate zowel leed en gebrek als de remedies daarvoor in geprofessionaliseerde dienstverlening vanuit sociaal-technisch hoogontwikkelde (d.w.z. gebureaucratiseerde) zorgvoorzieningen. Een van de gevolgen daarvan is met De Swaan te kenschetsen als 'gegeneraliseerde verafhankelijking': de ketens van menselijke interdependentie worden langer en de solidariteit die mensen in de zorg voorheen bond krijgt een meer universeel karakter. Het gegeven dat de zorg voor armoede, ziekte en onwetendheid in de loop van de 2 oste eeuw behartigd werd door voorzieningen voor gezondheidszorg, onderwijs en sociale bijstand betekende ook een explicitering van het overheidsgezag over dergelijke zorg, zij het rechtstreeks volgens onmiddellijke invloed, zij het indirect via procedures van arbeidsregulering, kwaliteitszorg of verzekeringstoezicht. Met de professionalisering van de zorg verdwijnt haar verzuilde structuur. Behoeften in plaats van overtuigingen worden maatgevend. Burgers zijn cliënten geworden.

De zorg raakte zo ontvlochten van haar religieuze vocabulaire en kerkelijke invloed die tijdens de verzuiling zo evident aanwezig was. Gedurende de periode tussen halverwege de 19de eeuw tot diep in de zoste eeuw bood de verzuiling een institutionele structuur om de multiculturele samenleving per overtuiging te bedienen in een aanbod van voorzieningen op grond van religie (rooms-katholieke en protestante zuil) en politieke levensbeschouwing (socialistische en libe$\mathrm{raal} /$ neutrale zuil). Dat het geen statische organisatie was blijkt uit het succes van de verzuiling. Het zo geïnvesteerde religieus kapitaal bood immers gedepriveerde groepen (katholieken, gereformeerden) de gelegenheid om zich te emanciperen, en overigens ten gevolge van dat succes de verzuilde structuur in de tweede helft van de 20 ste eeuw goeddeels van zich af te schudden. Het beginsel van scheiding van kerk en staat betekent vanaf dat moment dan ook dat religieuze genootschappen in de behartiging van zorg een marginale positie toegewezen kregen. Kerken vullen met hun charitatieve en diaconale activiteiten met wisselend succes hooguit de gaten van de verzorgingsstaat. De verzorgingsstaat als enig overgebleven en voor velen onzichtbare - want evidente - zuil vertoont echter gedurende het 
laatste decennium ook barsten en scheuren. De sociale voorzieningen zijn demografisch moeilijk langer op te brengen, ook al vanwege het feit dat de voortgang van sociale en medische techniek tot een steeds groter hulpaanbod leidt dat op zijn beurt weer nieuwe zorgvragen genereert. De overheid maakt in antwoord daarop twee beleidsbewegingen, namelijk enerzijds het toelaten van marktwerking in de zorg volgens het Angelsaksische liberale model en anderzijds het mobiliseren van maatschappelijk draagvlak voor steun en hulp conform het continentale en corporatistische ideaal. Dat roept de vraag op welk alternatief er bestaat voor de teloorgang van de band tussen (religieuze) overtuigingen en zorg. Kunnen markt en gemeenschap de zorg faciliteren zonder dat religieuze of seculiere overtuigingen die in sociaal en cultureel opzicht borgen? In verband met deze vraag naar zorglegitimiteit zijn verschillende risico's te onderkennen die ik kort zal schetsen, namelijk de anonimisering van solidariteit, de 'verzorgelijking' van de moraal en de kwestie van de rehabilitatie en reïntegratieproblematiek.

Een eerste risico dat verbonden is met de ontvlechting van religie en zorg is de mogelijke verzwakking van solidariteit als een herkenbare waarde in de zorg. De Swaan constateert in zijn civilisatiesociologisch betoog een voortgaande beschaving van sociaal bewustzijn op grond van collectiviseringsprocessen. Bij een dergelijk vooruitgangsidee hangt echter veel af van de vraag hoe men sociaal bewustzijn opvat en welke rol men groepen en overtuigingen daarin toekent. De tegenhypothese is die van een anonimisering van solidariteit: maatschappelijke cohesie vermindert omdat sociale groepsbanden en gedeelde ideologieën een minder krachtige functie vervullen voor de zorg. Ongetwijfeld heeft de vraag naar zorg in vroegere tijden meer kans gehad om als een morele categorie ervaren te worden dan tegenwoordig, nu de zorg een band verloren lijkt te hebben met 'face-to-face' contacten, lokale voorzieningen voor hulp en ondersteuning en min of meer gedeelde overtuigingen. Het charitatief ondernemerschap van lokale kerken is in dit opzicht een historische categorie geworden die op gespannen voet is komen te staan met de sociale consequenties van modernisering. Een transformatie van liefdadigheid naar sociaal bewustzijn is winst voor de rechtsbescherming van ieder die door welke omstandigheid dan ook zorg behoeft. Steeds duidelijker wordt echter ook dat men van de overheid niet kan vragen wat de samenleving niet meer bieden kan. Tenzij men van burgerschap en positief recht voldoende evidentie voor solidariteit verwacht, moet men het als riskant aanmerken dat de band van zorg met overtuigingen en een daarop gebaseerd sociaal netwerk verloren gaat en dat solidariteit zich tot een anonieme veronderstelling onder de zorg ontwikkelt.

Er is nog een risico te onderkennen dat samenhangt met de ontvlechting van religie en zorg, namelijk iets wat als 'verzorgelijking van de moraal' aangeduid kan worden. Het door De Swaan geïntroduceerde begrip 'proto-professionalisering' houdt in dat leed en gebrek in toenemende mate in termen van het diagnostische en hulpverleningsrepertoire van de professionele regimes uit de verzorgingsstaat worden gedefinieerd. De cliëntèle vat eigen hulpvragen en zorgbehoeften in toenemende mate op in medisch-technische termen en daaraan corresponde- 
rende verwachtingen als het gaat om genezing en zorgaanbod. In aansluiting op de geschetste ontwikkeling van anonimisering van solidariteit wordt daarmee het morele vocabulaire van gebrek en leed goeddeels verlaten. Dat is niet zonder gevolgen voor de geleefde moraal die namelijk evenmin ontkomt aan een dergelijke 'proto-professionalisering'. Maatschappelijk het meest markant komt dat tot uitdrukking in medisch-ethische discussies waarin zorgvuldigheidseisen enerzijds geformuleerd worden in strikt medische terminologie en anderzijds in referentie aan quasi-plausibele termen ('kwaliteit van leven', 'ondraaglijk en uitzichtloos lijden', 'klaar met leven') die niet zelden generieke rechten suggereren waar doorgaans individuele tragiek heerst. Tal van morele kwesties, zoals die rond seksualiteit, abortus, euthanasie of suïcide worden voorwerp van zorg waaraan enerzijds een vocabulaire van gezondheidszorg correspondeert en waarmee anderzijds een recht op zelfbeschikking wordt geïnstalleerd. Afgezien van de positie die men in het debat over dergelijke kwesties inneemt kan men constateren dat thema's die eertijds tot het domein van de ethiek behoorden in toenemende mate tot het zorgdomein gerekend kunnen worden. ${ }^{6}$ Belangrijk is dat dergelijke professionele ontwikkelingen niet alleen sociale oorzaken maar ook sociale consequenties hebben.7 Tot die sociale consequenties behoren ook die van de geleefde moraal. Zo is het beroep op het recht van zelfbeschikking in sociaal opzicht ook als een impliciete plicht op te vatten, wanneer men bijvoorbeeld op individuele besluitvorming aandringt in controversiële zaken waarvoor in morele zin geen sociaal of cultureel kader van overtuigingen meer bestaat. De moraal lijkt aldus steeds meer voorwerp van de verzorgingsstaat te worden. Dat is overigens op te vatten als een feitelijk arrangement voor het verval van overtuigingen waarbij volstaan wordt met professionele zorg bij besluiten waarvan de verantwoordelijkheid steeds meer in het privédomein gedragen wordt. Riskant daaraan is dat de morele draaglast en de mentale draagkracht niet vanzelfsprekend in evenwicht met elkaar zijn, en dat het afbrokkelende sociaal-culturele kader van overtuigingen voor een dergelijk evenwicht steeds minder steun biedt.

Ten slotte is er nog een risico ten gevolge van de ontvlechting van religie en zorg aanwijsbaar dat betrekking heeft op de rehabilitatie- en reïntegratieproblematiek. In het overheidsbeleid om bij te dragen aan vermaatschappelijking van de zorg gaat het om de vraag hoe de autonomie van cliënten bevorderd kan worden in het omgaan met beperkingen (rehabilitatie) en hoe de lokale omgeving daarin kan ondersteunen (reïntegratie). De praktische aspecten hebben betrekking op het beleid om intensieve zorgbehoeften in de thuisomgeving gestalte te geven, zowel in fysieke zin (extramuralisering) als in sociaal opzicht (mantelzorg) (Koops en Kwekkeboom 2005). Achter dergelijk beleid ligt echter de vraag in hoeverre de eerder geschetste formaliseringstendensen van de zorg gedurende de laatste vijftig jaar om te buigen zijn naar een informalisering van de zorg. Daarbij doet zich immers de paradox voor dat de feitelijke individualisering van het zorgbestel zoals die door introductie van marktwerking of door bezuinigingsmaatregelen veroorzaakt wordt, op gespannen voet staat met een beroep op de sociale infrastructuur daarvoor in termen van informele zorg. Weliswaar ontbreekt deze infrastructuur niet en is er onder de (3,7 miljoen!) mantelzorgers blijvende 
bereidheid tot hulp constateerbaar, maar deze hulp is evenzeer geïndividualiseerd en staat vanwege de heterogeniteit ervan bij specifieke groepen al onder druk nog voordat politieke besluiten als herstructurering van de AWBZ of introductie van de WMO doorgevoerd zijn en dus sociale effecten kunnen sorteren (Boer 2005). Weliswaar bieden religieuze overtuigingen en kerkelijke netwerken voor deze vermaatschappelijking een zekere infrastructuur, zowel gelet op een aantoonbare religieuze ondersteuning van maatschappelijk engagement als in de feitelijke inzet van kerkleden binnen het vrijwilligerswerk (Dekker, de Hart, Leijenaar, Niemöller en Uslaner 1999). Riskant is echter dat de vergrijzing van het kerkelijke vrijwilligerskorps en de personeelsproblematiek onder pastoraal personeel niet kan opvangen wat de overheid niet meer bieden of garanderen kan.

\subsection{PROFESSIONELE ZORG VOOR RELIGIEUZE OVERTUIGINGEN}

De geschetste functies van religie hebben door het ontzuilingproces in de zorg aan invloed en betekenis ingeboet. Ofschoon religieus kapitaal aldus minder geïnvesteerd kan worden in de zorg, blijft een formele overheidsverantwoordelijkheid voor religie aanwijsbaar die samenhangt met de vrijheid van godsdienst en levensovertuiging. Het betreft dan de garanties die de overheid biedt voor de facilitering van geestelijke verzorging namens de kerkelijke achtergrondgenootschappen in de zorg. De beroepsgroep van geestelijk verzorgers kampt weliswaar eveneens met de problematiek rond de ontvlechting van religie en zorg, maar biedt anderzijds ook een professionele bijdrage om de risico's die deze ontvlechting genereert tenminste te onderkennen en binnen het bereik van de bescheiden mogelijkheden te hanteren.

Behalve binnen de kerken krijgen maatschappelijke functies van religie ook professioneel gestalte in het aanbod van geestelijke verzorging in overheidsgerelateerde instituties. Het gaat dan om geestelijk verzorgers die - behalve binnen justitie (justitiële inrichtingen) en defensie (krijgsmacht) - werkzaam zijn in diverse settings van de gezondheidszorg (ziekenhuizen, psychiatrische klinieken, verzorging- en verpleeghuizen). De term 'geestelijke verzorging' wordt door de beroepsvereniging Vereniging van Geestelijk Verzorgers in Zorginstellingen (VGVZ) opgevat als: "de professionele en ambtshalve begeleiding van en hulpverlening aan mensen bij zingeving aan hun bestaan, vanuit en op basis van geloofsen levensovertuiging en de professionele advisering inzake ethische en/of levensbeschouwelijke aspecten in zorgverlening en beleidsvorming". ${ }^{8}$ De rol die de overheid inneemt bij de behartiging van geestelijke verzorging is complex en steeds aan veranderingen onderhevig. De banden tussen kerk en staat zijn vanaf de regelingen van de Unie van Utrecht (1579) tot aan de afschaffing van de zogenaamde zilveren koorden (1981) steeds behartigd in duidelijke bepalingen van het wederzijdse grensverkeer. In de jaren tachtig werd door vele politieke partijen het standpunt gehuldigd dat geestelijke verzorging geen overheidstaak is en dat de verantwoordelijkheid voor zorgfinanciering bij kerken en achtergrondgenootschappen gelegd dient te worden. In dat politiek bewustzijn kwam verandering door het rapport-Hirsch Ballin (1988) dat een advies bevatte over de criteria van 
overheidssteun aan kerken en andere genootschappen op geestelijke grondslag. Het rapport achtte de scheiding van kerk en staat niet strijdig met overheidsbemoeienis inzake geestelijke verzorging. Daartoe voerden de auteurs, mede op grond van een internationale vergelijking, argumenten aan rond een overheidsplicht bij grondrechten, in het bijzonder de bescherming van godsdienstvrijheid; de sociale en morele betekenis van godsdienst en levensovertuiging voor het algemeen belang; en condities en doelen van het minderhedenbeleid. Het advies stelde dat overheidssteun geïndiceerd is steeds daar waar een beroep op beschikbaarheid van die geestelijke verzorging onlosmakelijk verbonden is met overheidstaken. In het rapport wordt geestelijke verzorging als een integraal aspect van de zorg opgevat waarvoor de overheid financiële garanties dient te bieden; zij het rechtstreeks door bescherming van formatieplaatsen van geestelijk verzorgers in instellingen waarvoor de overheid onmiddellijke verantwoordelijkheid draagt; zij het indirect door waarborging van geestelijke verzorging binnen het basispakket van het individuele en collectieve verzekeringsstelsel. ${ }^{9}$ Het rapport-Hirsch Ballin leidde indertijd weliswaar tot een uitvoerig en instemmend kabinetsstandpunt, maar het behield in feite zijn adviesstatus. ${ }^{10}$ Tot een beoogde 'Wet op de geestelijke verzorging' die op dit punt een integrale regelgeving voor defensie, justitie en gezondheidszorg zou moeten bieden kwam het niet. In 1997 sneuvelde het wetsvoorstel in de Eerste Kamer, vooral op grond van het argument dat andere wetgeving al voorzag in de bedoelde regelingen.

In de zorgsector geldt geestelijke verzorging niet als individueel beroep in de gezondheidszorg, waardoor normen van geestelijke verzorging wettelijk niet in relatie tot persoonsgericht geneeskundig handelen worden omschreven, maar op instellingsniveau worden geformuleerd en behartigd, en wel in relatie tot uiteenlopende aspecten van kwaliteitsbeleid. Daardoor is slechts de Kwaliteitswet Zorginstellingen van toepassing die geestelijke verzorging bindt (en dus ook bekostigt) op grond van het verblijf in een zorginstelling, ongeacht de vraag of het hier ziekenhuizen, verpleeghuizen of andere zorginstellingen betreft zoals in de Kwaliteitswet bedoeld. In deze wet wordt geestelijke verzorging kort maar expliciet genoemd in het kader van verantwoorde zorg. ${ }^{11}$ Geestelijke verzorging is een integraal onderdeel van de zorg op grond van de norm dat zij beschikbaar en toegankelijk moet zijn voor categorieën mensen die niet of althans niet optimaal door de eigen kerk of het eigen genootschap kunnen worden bereikt. Deze norm wordt op haar beurt weer gelegitimeerd conform artikel 6 van de grondwet, waar de vrijheid van godsdienst en levensbeschouwing omschreven wordt. ${ }^{12}$ De taken van de geestelijk verzorger in de zorg variëren naar werksetting en worden als generieke functie bij voorbeeld getypeerd aan de hand van de FWG 3.o waarbijin opdracht van werkgevers en werknemersverbanden - de werkzaamheden en werkomstandigheden die zorgfuncties typeren gemeten worden aan generieke maatstaven van professionele zorg (Vincken 2004). Het functieniveau is academisch. Op basis van verschillende schattingen zijn er tussen de 900 en 1.150 geestelijk verzorgers werkzaam in de zorgsector, waarvan ongeveer 41 procent in verpleeg- en verzorgingshuizen; 38 procent in ziekenhuizen; 13 procent in de geestelijke gezondheidszorg; en de rest in gehandicaptenzorg, revalidatiehuizen, 
de jeugdhulpverlening en thuiszorg. Gelet op denominatie is 43 procent van de geestelijk verzorgers rooms-katholiek; 45 procent is protestant; 5 procent humanist. Ongeveer 75 procent werkt op basis van een zendingsopdracht door een achtergrondgenootschap. ${ }^{13}$ De beroepsgroep van geestelijk verzorgers wordt momenteel geconfronteerd met uitdagingen die typisch samenhangen met de ontvlechting van religie en zorg in het publieke domein (Schilderman 2005 en 2006). Dergelijke uitdagingen houden verband met het functioneren op het breukvlak van kerk en staat, de sociaal-culturele context van religies en de integratie in de verschillende zorgorganisaties. Ik licht deze drie uitdagingen toe.

Het functioneren op het breukvlak van kerk en staat verschaft geestelijk verzorgers een even autonome als controversiële status. De autonomie ligt bijvoorbeeld vervat in de vrijplaatspositie die geestelijk verzorgers hebben. De vrijplaats heeft betrekking op het recht en het gebruik om op grond van religieuze of kerkelijke motieven de cliëntèle buiten de gangbare verwijzingsverbanden te benaderen en zorg te verlenen. Enerzijds biedt de vrijplaats zo legitimiteit en autonomie voor het beroep. Anderzijds marginaliseert ze de positie van de geestelijk verzorger juist in het multidisciplinaire samenwerkingverband vanwege het feit dat men in dat geval - parallel optreedt. Het recht op geestelijke verzorging verschaft geestelijk verzorgers in dat geval een zelfstandige status die in feite losstaat van de inhoud- en effectbepaling van het werk; behalve dan waar dit privilege gekoppeld wordt aan een confessionele volume- en behoeftebepaling. De overheid faciliteert geestelijk verzorgers, maar trekt zich terug als het gaat om de omschrijving, regulering en borging van de werkinhoud van geestelijk verzorgers en verwijst door naar de verantwoordelijkheid hiervoor bij de achtergrondgenootschappen. ${ }^{14}$ Deze hebben wel een sterke juridische band met de overheid (zij het een van non-interventie), maar voeren in professioneel opzicht nauwelijks werkinhoudelijk of flankerend beleid tegenover geestelijk verzorgers. ${ }^{15} \mathrm{Ze}$ vertonen de neiging om op lokaalkerkelijke modellen van pastoraat en rituele zorg terug te vallen in de beoordeling van ontwikkelingen in de geestelijke verzorging. Dat levert soms risico's op waarbij de formeel vereiste zendingsopdrachten vanuit de kerken in het kader van conflictogene ambtsdiscussies komen te staan. ${ }^{6}$ Vooralsnog moet geconstateerd worden dat er over de professionele status van het ambt in de beroepsgroep weinig eenstemmigheid bestaat. ${ }^{17}$

Naast dergelijke structurele uitdagingen zijn er ook conjuncturele kwesties zoals die met de veranderende sociaal-culturele context van religies samenhangen. Uit beschikbaar onderzoek blijkt dat de cliëntèle van geestelijke verzorging doorgaans gebruik maakt van de geboden zorg en daarover (zeer) tevreden is. Zo waardeert men in het kader van de ziekenhuiszorg in het bijzonder de bejegening, de aansluiting van de hulp en het effect ervan (Loo, Jabaaij en Goudriaan 1998). Men moet daarbij in aanmerking nemen dat de traditionele cliëntèle van geestelijk verzorgers in de zorg gemiddeld wat ouder is en daarom grotendeels nog een religieuze en kerkelijke socialisatie kent. In de komende jaren zullen nieuwe cohorten een verder geëmancipeerde generatie te zien geven die ook wat betreft de geestelijke zorg eigen eisen zullen stellen. Deze groepen zullen meer divers 
van samenstelling zijn, geseculariseerd en moeilijker identificeerbaar op grond van gedeelde godsdienstige en levensovertuigingen. Door de multiculturalisering van Nederland treden bovendien nieuwe religieuze groepen voor het voetlicht, onder wie Turkse en Marokkaanse islamieten die wat betreft hun religieuze betrokkenheid sterker bepaald worden door etnische en familiale conventies (Phalet en Ter Wal 2004). Ze hebben eigen vragen waarbij ze conform de overheidsfaciliteiten een beroep doen op eigen geestelijk verzorgers. ${ }^{18} \mathrm{De}$ individualisering en secularisering van religieuze behoeften enerzijds en de opkomst van traditionele niet-christelijke zorgvragen anderzijds, roept de vraag op met welk aanbod geestelijk verzorgers hierop moeten inspelen. Blijft een min of meer traditioneel kerkelijk model maatgevend; is een multi- of interreligieus aanbod noodzakelijk; of is een areligieus aanbod gewenst? Op alle terreinen doen zich ontwikkelingen voor. Een van de meest markante is de opkomst van vrij gevestigde geestelijk verzorgers die zonder band met een genootschap tegen marktprijzen hulpverlenende en rituele begeleiding aanbieden, waarbij ingespeeld wordt op de individualiserende vraag en een uitwaaiering van het aanbod. ${ }^{19}$ Dergelijke ontwikkelingen zijn vooralsnog kleinschalig maar hebben grote potentie. Zo moet bijvoorbeeld de invloed niet onderschat worden van het verdwijnen van kerkelijke begrafenissen in de nabije toekomst op de vraagontwikkeling naar professionele afscheidsriten die beter aansluiten op moderne leefstijlen.

Ten slotte valt nog te wijzen op de integratie van geestelijk verzorgers in de zorgsector. De tendens naar extramuralisering kan grote consequenties hebben voor de geestelijke verzorging. Geestelijk verzorgers zijn sterk vertegenwoordigd in de residentiële zorg waarbij cliënten langer verblijven en dus ook een sociaal leven onderhouden binnen de instelling. De tendens in de zorg is er echter een naar 'short-stay' waarbij een duidelijker 'cure'-bijdrage gevraagd wordt van zorgverleners en een strikte oriëntatie op de problematiek van de cliëntèle. ${ }^{20}$ Daarbij volstaat het voor de legitimiteit van geestelijke verzorging wellicht niet meer om naar gevestigde rechten te verwijzen en zal afgewogen moeten worden of men een duidelijkere professionalisering richting 'cure' wenst dan wel een taak ziet in vermaatschappelijking van de zorg. Een en ander impliceert een groeiende beweging van de geestelijke verzorging als discipline richting de begripsvorming en hulpverleningspraktijken van de (geestelijke) gezondheidszorg waarbij kan worden aangesloten op de innovatieve tendensen die zich in de gezondheidszorg voordoen. In het bijzonder kan daarbij aandacht gevraagd worden voor het belang van 'empowerment', een zorgbeleid dat cliënten minder medicaliseert, maar hen motiveert ('remoralization') en op eigen hulpbronnen afstemt waardoor zij minder afhankelijk raken van de professionele regimes en de dure zorgtrajecten in de (geestelijke) gezondheidszorg. ${ }^{21}$ In dat verband kan tevens gewezen worden op het opkomende wetenschappelijk specialisme 'geestelijke verzorging' dat een vrucht is van een groeiende academische belangstelling. ${ }^{22}$ 


\subsection{SCENARIO'S VAN GEESTELIJKE VERZORGING}

In deze bijdrage ben ik gestart met de vaststelling dat de afstemming van het constitutionele beginsel van de scheiding van kerk en staat op dat van de godsdienstvrijheid ideologiegevoelig is, wat het risico meebrengt dat de maatschappelijke betekenis van religies aan het oog onttrokken wordt. Dat geldt eens te meer waar blijkt dat religies aan institutionele veranderingsprocessen blootstaan die een innovatie vergen van religieus kapitaal, in het bijzonder buiten de kerkmuren. De zorg vertegenwoordigt een van de domeinen waarin een dergelijke herinvestering in het kader van geestelijke verzorging professioneel gestalte kan krijgen. Ik beschrijf in dat verband een viertal modellen van geestelijke verzorging: een vertegenwoordigingsmodel, een servicemodel, een 'cure'-model en een 'care'-model waarin de eerder geschetste functies van religie verschillende professionele configuraties laten zien.

Een eerste scenario weerspiegelt het meest de huidige stand van zaken: die van vertegenwoordiging door een zendend achtergrondgenootschap. Geestelijk verzorgers vertegenwoordigen achtergrondkerken en bieden - min of meer op basis van een afspiegeling van het kerkelijk takenpakket - de cliëntèle van zorginstellingen hun diensten aan. De juridische basis van dit model is sterk en er is een institutionele band tussen kerk en overheid aanwezig die in het maatschappelijke domein ook een sociaal-culturele betekenis en feitelijke invloed heeft op grond van een eeuwenoude traditie van religieuze overtuigingen. 'Vertegenwoordiging' betekent hier dan ook dat religieus kapitaal sociaal geherinvesteerd wordt. Voorop staat het verschaffen van identiteit door het eigen religieuze erfgoed centraal te stellen en nieuwe verbindingen te zoeken tussen kerkelijke en zorgnetwerken. Sociaal-rituele integratie is een van de professionele prioriteiten om de eigen identiteit te profileren en kerkelijke gemeenschapsbanden aan te halen in moderne organisaties van de zorg. Bij de realisering van dergelijke functies doen zich ten minste twee problemen voor. Allereerst moet opgemerkt worden dat het religieuze landschap snel verandert. Te wijzen valt op de terugloop in het lidmaatschap van christelijke kerken, een ontwikkeling die in dit model onvermijdelijk negatieve consequenties heeft voor de formatietoewijzing aan christelijke geestelijk verzorgers. Het omgekeerde is het geval bij islamitische geestelijke bedienaren waarvan de formatie in dit model sterk in omvang zal toenemen. ${ }^{23}$ Bovendien zullen zich steeds vaker andere religieuze genootschappen aandienen met aanspraken op overheidsfinanciering van geestelijke verzorging, waaronder assertieve kerken met soms controversiële overtuigingen of praktijken. ${ }^{24}$ Met andere woorden: het vertegenwoordigingsmodel zal in de toekomst de religieuze pluraliteit institutionaliseren, waarbij men zich kan afvragen of dat de beoogde functie van identiteit en integratie bevordert. Ten tweede moet opgemerkt worden dat het model haaks staat op het proces van functionele differentiatie. In een verzuild tijdsgewricht valt legitimiteit voor het vertegenwoordigingsmodel te vinden op grond van gevestigde 'religieuze monopolies' van kerken die gebaseerd zijn op sociaal-culturele conventies. Met de mate waarin die evidentie terugloopt, zal nieuwe legitimiteit moeten worden gezocht in de aard en wijze 
waarop men in de functies van de zorg vertegenwoordigd is. Centraal daarbij staat de vraag of en hoe religieus kapitaal in de zorg geïnvesteerd kan worden op een wijze die de functies van de zorg zelf bevordert. Dit is een van de cruciale kwesties die in de professionele ontwikkeling van de geestelijke verzorging gethematiseerd moet worden.

Een volgend model is een servicemodel waar geestelijk verzorgers op een vrije markt diensten aanbieden op maat van de overtuigingen van cliënten of cliëntgroepen. Hier is de dienstverlening aangepast aan de religieuze deïnstitutionalisering en individualisering. De kwaliteit van geestelijke verzorging heeft zich hier te bewijzen in een succesvolle afstemming van religieuze of levensbeschouwelijke vraag en geestelijk aanbod. Voor zover expliciet zorg geboden wordt is financiering op grond van het verzekeringsstelsel geïndiceerd; voor ritueel en coaching wordt per dienst privé of op grond van afspraken met organisaties betaald. Hier zijn typisch niet de gemeenschapstichtende of morele functies van religie aan de orde, maar de betekenissen die - weliswaar geïndividualiseerd of geseculariseerd - transcendentie beklemtonen zoals kosmische en ritueel integrerende functies. In dit model krijgt religieus kapitaal voor individuele personen pas relevantie op het moment dat 'important life events' de levensregie ondermijnen en geestelijke hulp voorziet in zowel 'zorg op tijd' als 'zorg op maat'. Er zijn argumenten te geven om een dergelijk 'marktmodel' als prototype van functioneel gespecialiseerde religie aan te duiden. Zo valt het model zowel behoefteals domeinspecifiek te omschrijven en is het gestript van 'accidentele' betekenissen die in traditie of gemeenschap met de religieuze kern verbonden zijn geraakt. Anderzijds kan men een dergelijke 'freischwebende Religiosität' juist daarom ook afwijzen, door bijvoorbeeld te argumenteren dat religieus kapitaal zo ieder gedeelde vocabulaire of collectieve symboliek mist en slechts relevant is voor paraculturele 'niches' in de markt van welzijn en geluk. Een prangend probleem is hier welke functionele band de geestelijke verzorging met de (geestelijke) gezondheidszorg heeft en of er überhaupt een beroep gedaan kan worden op particuliere of collectieve verzekeringsgelden. Daarbij kan sterk betwijfeld worden of geestelijke verzorging in dat geval nog als een kerkelijke activiteit aangemerkt kan worden. In feite wordt immers met gevestigde kerken geconcurreerd waardoor de constitutioneel verankerde religieuze vrijheden een geheel andere betekenis krijgen. Men kan zich daarbij - naar analogie van vergelijkbare ontwikkelingen in andere instituties - afvragen welke invloed marktsturing heeft op de traditionele functies van religies. De overheid staat dan voor de vraag welke betekenis religie in een kerkelijk gedereguleerde markt heeft, en of zij instrumenten heeft om hier überhaupt constitutionele borging van religieuze vrijheid te garanderen of daarop politieke invloed uit te oefenen.

Dan is er het 'cure'-model van geestelijke verzorging waarbij geestelijke verzorging als zorgdiscipline in de gezondheidszorg geïntegreerd wordt. Vanwege specialisering en voortgaande professionalisering worden de diensten van geestelijk verzorgers afgestemd op de conceptuele en instrumentele kaders van de (geestelijke) gezondheidszorg. De banden met de achtergrondgenootschappen 
worden gaandeweg verbroken. Geestelijke verzorging ontwikkelt zich tot "professionele zorg voor levensbeschouwelijke overtuigingen" die - volgens welke financieringssystematiek dan ook - onderdeel wordt van integrale zorg. De geestelijk verzorger is de 'levensbeschouwelijk specialist' waarvan de diensten niet per denominatie of naar geloofsovertuiging van de cliënt, maar op grond van (religieus-)wetenschappelijke vakkennis ingeroepen worden, telkens waar daarvoor indicaties en verwijzingen bestaan binnen de zorgketens of in het multidisciplinaire zorgverband. De geestelijk verzorger staat zelf op afstand van specifieke overtuigingen en kan door een seculier en meer abstract begrippenapparaat te hanteren (zingeving, betekenisverlening, levensbeschouwing) 'meer objectief' handelen. Ook hier staat een profilerende functie van religie centraal, namelijk de zorg voor contingentie-erkenning. De geestelijk verzorger vertegenwoordigt in de zorg een 'last resort'; een gatenvuller van uiteindelijke deficiënties van sociale zorg en medische technologie. Op het moment dat de specialist de handen aftrekt van een patiënt treedt de geestelijk verzorger naar voren. Cynisme is hier echter misplaatst: er zijn immers evidente mogelijkheden om de geestelijke verzorging juist hier te profileren binnen de kernfuncties van de zorg. Althans, dat is het geval indien de beroepsgroep zich op dit punt professionaliseert en zich kan meten met opkomende disciplines als bijvoorbeeld palliatieve zorg of de nieuwe vormen van gespecialiseerde kwaliteitszorg. Hoe dan ook ligt de klemtoon in dit 'cure'-model niet langer op een specifieke overtuiging, en verschuift de cliëntrol van geestelijk verzorger van de ambtelijke presentie van religieus kapitaal in het publieke domein naar een gespecialiseerde patiëntenzorg in het private domein. De taak van de overheid is hier slechts die van toezichthouder op de kwaliteit van zorg, waarvoor ze overigens over eigen expertise moet beschikken op religieuswetenschappelijk vlak.

Ten slotte valt een 'care'-model van geestelijke verzorging te onderscheiden. Daarin wordt de klemtoon op de lokale gemeenschap gelegd. Op grond van subsidiaire maatregelen wordt de bekostiging van zorg, waaronder geestelijke verzorging, gelegd bij een zo laag mogelijk regieniveau als effectief is. De landelijke overheid treedt terug, terwijl lokale overheden verantwoordelijkheid dragen voor bekostiging en toezicht. In dit model komt ook de verantwoordelijkheid voor geestelijke verzorging te liggen bij lokale stichtingen waarin cliëntnetwerken, lokale overheden en kerkelijke vrijwilligersorganisaties vertegenwoordigd zijn. Zij bieden een draagvlak voor informele en mantelzorg waarbinnen professioneel werkzame geestelijk verzorgers coördinerende en uitvoerende taken verrichten. Financiering wordt mede gemeten aan het vermogen om de cliëntèle uit de dure en gespecialiseerde tweedelijnszorg te houden, bij te dragen tot preventie en zorg te dragen voor reïntegratie van cliënten in de thuissituatie. Typisch is hier een functionele klemtoon op het morele en mobiliserende karakter van religie. Lokale netwerken voor wederzijds zorgbetoon kunnen niet zonder aandacht voor morele oriëntaties en kritische zorg; ze ontlenen er immers hun motivatie en feitelijke inzet aan. Daarbij valt overigens het eenrichtingsverkeer uit te sluiten waarbij de overheid achtergrondgenootschappen slechts inschakelt om te voorzien in de zorg voor maatschappelijke noden. Subsidiaire maatregelen 
versterken het maatschappelijke middenveld en mobiliseren zo de emancipatie van lokaal op bovenlokaal gezag. Het is dus niet onaannemelijk dat religieus kapitaal in dat geval lokaal een politieke lading zal krijgen op grond waarvan ervaren lokale nood ook bovenlokaal aangeklaagd zal worden. Aldus kan een professionalisering van de diaconale en charitatieve taak van kerken (opnieuw) gestalte krijgen. Bij een dergelijk model kan men enerzijds de vraag stellen in hoeverre het wenselijk is dat de overheid op instrumentele gronden aan kerken een takenpakket toewijst waarvan betwijfeld moet worden of het wel beantwoordt aan het primaire proces van kerken en of het voldoende aansluit op de overtuigingen van de -immers seculariserende - cliëntèle. Anderzijds is het religieuze kapitaal juist vanwege het kenmerkende onderscheid van religieuze en seculiere domeinen voldoende doordrongen van motieven die bijdragen aan een sociale emancipatie van de zorg.

Kan religieus kapitaal ook buiten de kerkmuren zinvol geïnvesteerd worden, zo valt de vraag van deze bijdrage te omschrijven. Met bovenstaande vier ideaaltypische scenario's van geestelijke verzorging kan deze vraag positief, zij het hypothetisch en verschillend beantwoord worden. Dergelijke scenario's veronderstellen nieuwe allocaties van religieuze functies die in het beste geval in bepaalde combinaties enig inzicht in de toekomst opleveren. De discussie erover staat of valt met de vraag of de geestelijke verzorging voldoende professioneel ontwikkelingspotentieel heeft om dergelijke functies in de zorg van alledag vorm te geven. Daarbij doen zich tal van 'opportunities' maar ook 'threats' voor om religieus kapitaal opnieuw te investeren. Voor een taxatie van de mogelijkheden is het inzicht van belang dat de scheiding van kerk en staat niet slechts om staatsrechtelijke demarcaties vraagt, maar wellicht ook proactief en faciliterend overheidsbeleid vergt om in het kader van de vrijheid van godsdienst en levensovertuiging waar mogelijk bij te dragen aan een professionele behartiging van de maatschappelijke investeringsmogelijkheden van religieus kapitaal in het publieke domein van moderne zorgvoorzieningen. 


\section{NOTEN}

Zie ook het eerste mandement op de Constitutie van de Verenigde Staten waarbij enerzijds een 'establishment clause' staatsgodsdienst verbiedt evenals overheidspreferentie van de ene religieuze overtuiging boven de andere of boven niet-religieuze overtuigingen; en anderzijds een 'free exercise clause' die bepaalt dat er een absolute vrijheid bestaat om te geloven wat men wil en een gelimiteerde vrijheid om die overtuiging ook in publiek handelen vorm te geven.

Dergelijke functies van religie vat ik op als ideaaltypen, dat wil zeggen hypothetische constructen samengesteld uit profielkenmerken van religies. Ideaaltypen sluiten in empirische zin zowel 'eu'-functies als disfuncties van sociale fenomenen in. De pretentie is dus juist om empirische afwijkingen van het logisch construct inzichtelijk te maken. Zie M. Weber (1922) Grundriss der Sozialökonomik, Tübingen: Mohr. I i 3.

3 Zie o.a. R. Stark and R. Finke (200o) Acts of Faith. Explaining the human side of religion, Berkely, CA: University of California Press 120.

$4 \quad$ Zie de areligieuze argumentatielijnen in de dagelijkse politieke discussies in de media over het bijzonder onderwijs, de genderlading van het ministerieel handen schudden, het homohuwelijk, 'family values', het evolutiegeloof, de hoofddoekkwestie, het euthanasiedebat, de condoomcontroverse en tal van andere 'religion-fuelled' discussies.

Voor een meer fundamentele discussie zie: T. Asad (2003) Formations of the Secular. Christianity, Islam, Modernity, Stanford CA: Stanford University Press.

Zie als voorbeeld in de zorg kwesties in verband met levensbegin en levenseinde. Zorgdisciplines als 'genetic counseling' en 'palliatieve zorg' illustreren zowel een dergelijk medische vocabulaire als een geprivatiseerde oriëntatie op de morele problematiek van abortus en euthanasie.

Onderzoek naar de psychische en sociale consequenties van moreel controversiële besluiten en de betekenis van hulpverlening daarbij staat nog in de kinderschoenen. Zie bijvoorbeeld de recent in kaart gebrachte omvang van posttraumatische stress en ernstige psychische problematiek na zwangerschapsafbreking. M. Korenromp (2006) Parental Adaptation to Termination of Pregnancy for Fetal Anomalies, UMC Utrecht: Utrecht.

Beroepsstandaard voor de geestelijk verzorger in zorginstellingen (VGVZ 2002).

9 De auteurs van het advies zien af van de formulering van inhoudelijke of functionele criteria voor geestelijke verzorging vanwege de grote verschillen tussen organisatie en financiering van de verschillende categoriale settings enerzijds en de aanwezige levensbeschouwelijke en religieuze pluraliteit anderzijds.

Kamerstukken II 1989-1990, 20 868, nr. 2. In het kabinetsstandpunt (blz. 11-13) wordt de steunvoorwaarde toegespitst op de 'bijzondere omstandigheid' waarin personen (leden en belangstellenden) door hun opname in instellingen waar overheidsgezag geldt zich bevinden en die hen minder bereikbaar maken voor normale geestelijke verzorging vanuit de genootschappen.

Artikel 3: 'Voor zover het betreft zorgverlening die verblijf van de patiënt of cliënt in de instelling gedurende tenminste het etmaal met zich brengt, draagt de zorg- 
aanbieder er tevens zorg voor dat in de instelling geestelijke verzorging beschikbaar is, die zoveel mogelijk aansluit bij de godsdienst of levensovertuiging van de patiënten of cliënten.' Verder ligt er een plicht tot jaarlijks verslag rond het gevoerde beleid inzake geestelijke verzorging bij de zorginstellingen (artikel 5) en een bevoegdheid bij de overheid tot ingrijpen indien aan kwaliteitnormen niet voldaan wordt (artikel 7 ). Artikel 6: '1. Ieder heeft het recht zijn godsdienst of levensovertuiging, individueel of in gemeenschap met anderen, vrij te belijden, behoudens ieders verantwoordelijkheid volgens de wet.' Schattingen op basis van VGVZ-indicaties en W. Smeets (2006) Spiritual Care in a Hospital Setting. An Empirical-theological exploration, Leiden: Brill. Men kan zich afvragen of in die opvatting eigenlijk niet van een impliciet kerkelijk detacheringmodel sprake is dat juist op gespannen voet staat met het beginsel van scheiding van kerk en staat en uiteindelijk de wettelijk vastgestelde structurele bekostigingstructuur van geestelijke verzorging in gevaar brengt. Pas recent ontstaat bredere aandacht voor het grensgebied van kerk en professionele zorg. Zo werd onlangs het Landelijk Platform Kerk \& Zorg opgericht, mede op grond van het onderzoeksrapport van de sow-kerken Geestelijke verzorging in de gezondheidszorg en de kerken (2000). Het LPK\&z beoogt zorgberaad,zorginformatie en zorgmonitoring. Een van de concrete initiatieven (2006) is het vademecum Camillus Almanac (www.camillus-almanak.nl) waarin veel relevante informatie over geestelijke verzorging bijeen wordt gebracht. Soms zijn er overigens op dit punt juist innovatieve voorstellen voor oplossingen: zie bijvoorbeeld voor de R-K: R. Huysmans (2006) 'Naar een uitsplitsing tussen pastoraat en geestelijke verzorging?!' In: VGVZ 'Daarom Mijnheer, noem ik mij katholiek!'. Het zelfuerstaan van de katholieke geestelijk verzorger. Syllabus Landdag Katholieke Sector, 20 maart 2006, 25-35.

17 Dat althans blijkt uit de discussie over de opzet van een registratiesysteem voor geestelijk verzorgers door de beroepsverenging vGVZ, waarbij de vraag centraal staat of het ambt al dan niet als professionele voorwaarde geldt. Ook na zeven jaar voorbereiding blijkt hierover vooralsnog geen overeenstemming mogelijk. Zie het verslag in Trouw, 14 juni 2006 naar aanleiding van een symposium over deze kwestie: 'Symposium van geestelijk verzorgers eindigt in crisis'. Zie voor het werkveld van de zorg bijvoorbeeld: McGv (1999) Geestelijke verzorging in de gezondheidszorg in multicultureel perspectief, Utrecht: Universitair Medisch Centrum. P. van den Akker, S. van Wersch (2003) Naar meer pluriformiteit in de geestelijke verzorging in zorginstellingen, Tilburg: IVA 2003, 7-29. Zie nieuwe organisaties als 'rent-a-priest' (www.rentapriest.nl/rentapriest.htm) of particuliere initiatieven als www.moederoverste.nl; dan wel het koepelaanbod van vrij gevestigde geestelijk verzorgers door het Humanistische Verbond: www.humanistischverbond.nl/diensten/geestelijk_nw_telefoonlijst.html. Daarbij dient verdisconteerd te worden dat geestelijke verzorging volgens de huidige kwaliteitswet alleen ingeroepen kan worden bij een verblijf langer dan 24 uur.

21 Voor een oriëntatie op deze laatste ontwikkeling van het nieuwe professionaliseringsparadigma in de geestelijke gezondheidszorg zie: G. Hutschemaekers, 
B. Tiemens en A. Smit (2006) Weg van professionalisering. Paradoxale bewegingen in de geestelijke gezondheidszorg, Wolfheze: GRIP.

22 Dat is althans een van de conclusies die men kan trekken uit de explosieve groei van opleidingen geestelijke verzorging.

23 De islam zal zich tot een gelijkwaardige religie ontwikkelen, in aanmerking nemend dat in 2050 20-25\% van de Europese bevolking islamiet zal zijn: T. Savage (2004), 'Europe and Islam: Crescent Waxing, Cultures Clashing', Washington Quarterly 27-3, 25-50.

24 Zie bijvoorbeeld de discussie over de politieke en economische erkenning van de 'scientology-church' als officiële kerk in de Verenigde Staten, en hun nationale beleid als kerkelijke organisatie (www.scientology.nl/html/parto6/index.html). 


\section{LITERATUUR}

Becker, J., J. en J. De Hart De Wit (2006) Godsdienstige veranderingen in Nederland. Verschuivingen in de binding met de kerken en de christelijke traditie, Den Haag SCP.

Bruce, S. (2002) God is dead. Secularization in the West, Blackwell: Oxford.

Boer, A. de (red.) (2005) Kijk op informele zorg, Den Haag: SCP.

Dalferth, I.H., Ph. Stoellger (Hrsg.) (200o) Vernunft, Kontingenz und Gott. Konstellationen eines offenen Problems, Religion in Philosophy and Theology 1, Tübingen: Mohr Siebeck.

Dekker, P., J. de Hart, M. Leijenaar, K. Niemöller en E. Uslaner (1999) Vrijwilligerswerk vergeleken. Civil society en vrijwilligerswerk III, Den Haag: SCP.

Durkheim, E. (1912) Les formes élémentaires de la vie religieuse; le système totémique en Australie, Paris: Alcan.

Furbey, R. et al. (2006) Faith as social capital. Connecting or dividing? Bristol: Policy Press.

Gameren van E., J.J. Jonker, T. Marx (2006) Liever uit dan thuis, Den Haag: SCP.

Geertz C. (200o) Available Light. Anthropological Reflections on Philosophical Topics, Princeton: Princeton University Press.

Geertz, C. (1993) The Interpretation of Cultures. Selected Essays, New York: Fontana Press.

Gehlen, A. (1975) Urmensch und Spätkultur. Philosophische Ergebnisse end Aussagen, Frankfurt am Main: Athenaion.

Hirsch Ballin, E. (1988) Overheid, godsdienst en levensovertuiging, eindrapport van de Commissie van advies inzake de criteria voor steunverlening aan kerkgenootschappen en andere genootschappen op geestelijke grondslag, Den Haag: Ministerie van Binnenlandse Zaken, Stafafdeling Constitutionele Zaken en Wetgeving.

Kaufmann, F.X. (1989) Religion und Modernität. Sozialwissenschaftliche Perspektiven.

Koops, H., R. Kwekkeboom (2005) Vermaatschappelijking in de zorg. Ervaringen en verwachtingen van aanbieders en gebruikers in vijf gemeenten, Den Haag: SCP.

Loo, D. van der, L. Jabaaij, I. Goudriaan (1998) De geestelijk verzorger in het algemeen ziekenhuis. Een praktijkstudie naar functie-uitvoering van geestelijk verzorgers en waardering daarvan door patiënten, Utrecht: Trimbos-instituut.

Lübbe, H. (1986) Religion nach der Aufklärung. Graz: Styria.

Phalet, K. en J. ter Wal (2004) Moslim In Nederland. Diversiteit en verandering in religieuze betrokkenheid: Turken en Marokkanen in Nederland 1998-2002, Den Haag: SCP.

Pollack D. (2000) 'Was ist Religion?', blz. 55-81 in: W. Schreiber (Hrsg.) Die religiöse Dimension im Geschichtsunterricht an Europas Schulen. Ein interdisziplinäres Forschungsprojekt. Neuried: Ars Una.

Ricoeur, P. (1992) Oneself as another, Chicago: Chicago University Press.

Schilderman, H. (2006) Kwalificaties van geestelijke verzorging. (Facultair studierapport Radboud Universiteit Nijmegen).

Schilderman, H. (2005) Religion as a Profession, Leiden: Brill.

Stark, R., W. Bainbridge (200o) A theory of religion. New York [etc.]: Peter Lang.

Stark, R., R. Finke. Acts of faith. Explaining the human side of religion. Berkeley: University of California Press.

Swaan, A. de (1988) In Care of the State. Health care, Education and Welfare in Europe and the USA in the Modern Era, Cambridge: Polity Press. 
Timmermans J., A. de Boer, J. Idema (2005) De mantelval. Den Haag: SCP.

Ven, J.A. van der (1998) Formation of the Moral Self, Grand Rapids: William B. Eerdmans Publishing Company.

Vincken, L. (2004) Werkboek FWG 3.0/2004; Teksten, Toelichting, Den Haag: CNV Publieke Zaak.

Weber, M. (1947) Gesammelte Aufsätze zur Religionssoziologie, Tübingen: Mohr. 


\title{
16 DE MIGRATIE VAN HET GODDELIJKE. OVER GELOOF EN KERK IN DE MODERNE MAATSCHAPPIJ ${ }^{1}$
}

\author{
Gabriël van den Brink
}

Tegen de zomer van 2005 besefte ik dat de belangstelling voor geestelijke cultuur weer aan het groeien was. In het tijdsbestek van een half jaar was ik van diverse kanten benaderd met de vraag wat de betekenis van godsdienst of geloof in de moderne tijd zou kunnen zijn. Eind november sprak ik in het katholieke Nijmegen over de rol van religie bij het cultiveren van waarden en normen. Eind december vroeg de Amsterdamse hoofdcommissaris van politie welke houding men het beste tegenover moslimjongeren kan aannemen. Begin januari hield ik een korte voordracht over welzijnswerk en zingeving. Medio januari was er in Rotterdam een bijeenkomst over de relatie van islam en burgerschap. Eind februari organiseerden twee linkse politieke partijen in Utrecht een symposium over morele vraagstukken. Op 1 april sprak ik in Naarden de Comeniuslezing over religieuze tolerantie uit. Eind april werd mij verzocht om iets te zeggen over de opdracht van christelijke kerken in deze tijd. Midden mei schreef ik een tekst over de plaats van vrijmetselaren in de geschiedenis. Een dergelijk patroon roept bij de cultuursocioloog vanzelfsprekend vragen op. Het kan geen toeval zijn dat vragen rond geloof in het sterk geseculariseerde Nederland zoveel belangstelling oproepen. Zou er toch een tijdgeest zijn die in verschillende milieus tot eenzelfde gedachte leidt? En als een dergelijke geest bestaat, hoe kan het dan dat 75 procent van de bevolking bij geen enkele kerk aangesloten is? Over deze vragen wil ik hieronder nadenken. Daarbij zal ik eerst aangeven wat ik onder het goddelijke versta en wat ik denk over bestaande godsdiensten. Vervolgens zeg ik iets over de crisis die wij nu doormaken en over de plaats van het geloof in dat verband. Er blijkt een fundamentele spanning te bestaan tussen de morele of spirituele traditie van het christendom en de wijze waarop het moderne leven vorm krijgt. Ik eindig bij de manieren waarop men die spanning zou kunnen oplossen en zal tevens aangeven welke oplossing mijn voorkeur heeft.

\subsection{TWEE GRONDBEGRIPPEN}

Laat ik beginnen met het onmogelijke en een korte typering geven van de twee kernbegrippen waar het in deze beschouwing om gaat: de moderniteit en het goddelijke. Zo'n typering komt eigenlijk op een vorm van hoogmoed neer. 'Moderniteit' is een containerbegrip dat op de meest uiteenlopende manieren wordt gebruikt en geen vaste betekenis bezit. Dat geldt a fortiori voor een term als het goddelijke. Maar om elkaar te begrijpen moeten we soms het onmogelijke doen. Vandaar.

Op filosofisch niveau omschrijf ik moderniteit als een bestaan dat zich rekenschap geeft van de vier grote omwentelingen die zich in het Europese verleden 
voltrokken: de wetenschappelijke revolutie (zeventiende eeuw), de democratische revolutie (eind achttiende eeuw), de industriële revolutie (eind negentiende eeuw) en de seksuele revolutie (laatste kwart twintigste eeuw). Een van de voornaamste gevolgen van deze veelvoudige omwenteling is dat we het moderne bestaan niet langer zien als een zinvolle en samenhangende totaliteit. Moderne mensen hebben met diverse domeinen van doen die veelal een eigen ontwikkeling kennen en zich niet laten samenvoegen tot een harmonieus geheel. In die zin is het moderne leven altijd een gebroken bestaan. Als het geen paradox was zou men kunnen zeggen dat de essentie van moderniteit juist in conflicten, strijdigheden, coördinatieproblemen, breuken, fragmentatie en heterogeniteit gelegen is. Tegelijkertijd is moderniteit - anders dan de postmodernisten menen - veel méér dan een vorm van willekeur, relativisme, diversiteit of 'melting pot'. Het heterogene karakter van de moderne wereld vertoont wel degelijk structuur. We leven in domeinen die elk een eigen 'sfeer' of 'wereld' vormen, waar specifieke regels gelden en waar een eigen dynamiek tot ontplooiing komt. Niet voor niets spreekt men van de medische wereld, het domein van de economie, de sfeer van het recht, het publieke domein enz. Op het niveau van de samenleving vormen deze domeinen een gestructureerd geheel, maar daaruit volgt niet dat er veel samenhang op het niveau van de individuele levens is. Op dat niveau staat het moderne leven juist in het teken van meervoudigheid en diversiteit. En dat moet ook wel, omdat moderne mensen voortdurend heen en weer gaan van het ene domein naar het andere.

Voor het tweede containerbegrip grijp ik terug op de formule die ik een jaar geleden heb bedacht. In een opstel over de positie van de islam omschreef ik het goddelijke als een kracht die (tijdelijk) de verdeeldheid van het menselijk bestaan opheft (Van den Brink 2004b). Ik denk dat deze formele omschrijving voor uiteenlopende geloofspraktijken te gebruiken is. Tegelijkertijd is het een positieve typering die iets verwoordt waar ik zelf in geloof. Ik doel op het moment waarop we geraakt worden door een vorm van eenwording, verzoening of betrokkenheid. Die ervaring wordt meestal niet bewust gezocht, zij dient zich vaak op een onverwachte wijze aan. Zij kan op de meest uiteenlopende manieren benoemd worden en vloeit niet altijd voort uit een geloof in de gebruikelijke zin. Zij kan schuilen in de ontroering die ons overvalt als het verdriet van anderen ons raakt. Maar ook in de vreugde wanneer er een einde komt aan vijandschap en het vrede wordt. Zij kan schuil gaan in de muziek (die niet toevallig met harmonie te maken heeft), in een heftige vrijpartij van twee geliefden (die niet toevallig hun grenzen loslaten) of in het moment dat men anderen vergeeft (wat niet toevallig op het gebaar van geven wijst). Gemeenschappelijk aan al die ervaringen is dat men het besef van strijd, gemis of vijandschap te boven komt en voor een moment aan de eenheid van het leven proeft. Dit soort ervaringen is vele mensen bekend, maar ze zullen het niet altijd zien als een werking van het goddelijke. Vaak beseft men niet eens dat die ervaring een spirituele dimensie bezit. Niettemin is het duiden en bevorderen van deze eenheidservaring de kern waar het in vrijwel elke religieuze traditie om draait. ${ }^{2}$ 
De lezer begrijpt dat er twee complementaire definities aan de orde zijn. Terwijl het moderne leven in het teken staat van de gebrokenheid, wordt het goddelijke als de ervaring van eenheid opgevat. Dat is minder tegenstrijdig dan men wellicht denkt, want het gaat om twee verschillende niveaus. Het begrip moderniteit verwijst naar de manier waarop samenlevingen vandaag de dag georganiseerd worden, het goddelijke naar een individuele ervaring die nauwelijks te organiseren is. Dat heeft gevolgen voor de vraag hoe men de taak van de kerk ziet. Volgens mij moeten kerken zich niet in dienst van de moderne maatschappij stellen. Dat zou neerkomen op een reductie à la Durkheim waarbij de betekenis van kerk en geloof tot hun sociale functie wordt herleid. Kerken hebben niet zozeer een functie als wel een opgave en ik denk - overigens geheel in lijn met de traditie - dat die opgave vooral in het bevorderen van heil of heelheid ligt. Wat dat betreft spreekt het motto van de kerkenactie uit $2004 \mathrm{mij}$ wel aan. Ik beschouw 'heel maken van datgene wat gebroken is' niet als een wereldvreemd ideaal, maar als een noodzakelijk werk waar de moderne wereld elke dag opnieuw om vraagt. De kerken kunnen dat werk doen op verschillende niveaus, waarvan ik er vier met name noem. Zij moeten zich op het mondiale niveau voor rechtvaardigheid en vrede inzetten en daarbij in het bijzonder de samenwerking zoeken met andere wereldgodsdiensten. Zij moeten zich op het niveau van de nationale politiek sterk maken voor respect en fatsoen in het publieke domein. Zij moeten op het sociale niveau voor de nodige geborgenheid zorgen en voorkomen dat mensen geestelijk of fysiek alleen komen te staan. En zij moeten op het individuele niveau de heiligheid van het leven en de liefde vormgeven. Daarmee is veel gezegd maar tegelijkertijd ook ontzettend weinig. Want de grote vraag is natuurlijk: hoe zou men dat in een moderne context kunnen doen? Moet men ten strijde trekken tegen de moderniteit? Of kan de spanning van geloof en wereld op een of andere manier vruchtbaar worden gemaakt? Hieronder schets ik vier mogelijke houdingen, maar eerst zeg ik iets over de crisis die we momenteel doormaken. Want voor je het weet is ook de term 'crisis' een containerbegrip dat weliswaar op een bepaalde stemming duidt, maar waar vervolgens iedereen het zijne onder verstaat.

\subsection{EEN MEERVOUDIGE CRISIS}

De huidige crisis brengt vier problemen aan het licht die elkaar weliswaar versterken, maar niet dezelfde bron hebben en zich ook niet op dezelfde wijze laten oplossen. Het eerste probleem ligt in de wijze waarop de westerse wereld zichzelf ziet. Dat zelfbeeld leek stabiel en duidelijk zolang er nog een tegenstander was. Sinds de Tweede Wereldoorlog kon het Westen zich als verdediger van vrijheid en democratie opwerpen, maar dat ideaal maakte vanaf 1989 steeds minder enthousiasme los. Pogingen van de vs om gewapenderhand dictaturen te ontmantelen, leidden in Europa tot twijfel en kritiek en zelfs bij de strijd tegen het internationale terrorisme lijkt er een aarzeling. Het Westen beschikt niet langer over een ijzersterk verhaal en ziet met zorg de confrontatie met opkomende wereldmachten als India en China tegemoet. Binnen Europa is het eenheidsideaal bleker dan ooit en veel Europeanen keren voor hun heilsverwachtingen naar de nationale staat terug. Het is opmerkelijk dat het zoeken naar eigen- 
heid vooral in ruimtelijke termen wordt gesteld. Men denkt als het ware dat elke regio een eigen identiteit bezit met als gevolg dat de nadruk op de onderlinge verschillen ligt. Men zou de identiteit van het Westen ook in temporele termen kunnen zien, door te wijzen op de weg die de moderne samenleving de afgelopen decennia heeft afgelegd. Dat zou niet alleen een relativering van de regionale verschillen met zich meebrengen, maar ook een duidelijker beeld van de manier waarop we onze toekomst (kunnen) vormgeven. Bovendien kan men zo afstand nemen van het onjuiste idee dat het Westen een monopolie op modernisering heeft (Eisenstadt 2002). Maar vooralsnog tekent een dergelijk historiserend zelfbeeld van het Westen zich niet af en interpreteren de meeste Europeanen hun identiteit in territoriale termen.

Toch zal het beroep op de nationale staat niet veel oplossen, want ook op dat niveau dient zich een crisis aan. Daarbij zijn vooral de omgangsvormen in het geding. Het gaat om de houding die burgers aannemen wanneer ze in het publieke domein met elkaar van doen hebben. Openbaar fatsoen is een belangrijk aspect van burgerschap en voor het vreedzaam samenleven even wezenlijk als goede wetgeving. Niettemin wordt er meer en meer over het ontbreken van dat soort fatsoen geklaagd. De beschikbare cijfers stellen deze klagers in het gelijk. Een groeiend aantal personen maakt zich aan gewelddadig, agressief, bedreigend, overlast gevend of gewoon asociaal gedrag schuldig. De oorzaken daarvan liggen volgens mij in de levensstijl die zich de afgelopen decennia ontwikkeld heeft. Kenmerkend is dat burgers zich op alle terreinen van het leven zeer assertief opstellen. Maar het verschil tussen assertief en agressief is niet erg groot. Bijgevolg zien we vaak dat mensen op een egocentrische en ruwe manier aan het maatschappelijk verkeer deelnemen. Ze letten niet op hun medeburgers en hebben weinig moeite met het overtreden van de verkeersregels. Om dat op te lossen pleit ik voor een beschavingsoffensief. De bedoeling daarvan is dat burgers een aantal elementaire normen in acht nemen zodat het maatschappelijk verkeer op een min of meer vreedzame manier verloopt. Het gaat er niet om dat alle Nederlanders elkaar liefhebben, dezelfde waarden aanhangen of dezelfde idealen nastreven. Op dat punt bestaat nu eenmaal grote diversiteit en dat moet je in een democratie niet willen veranderen. Wat je wel mag nastreven is dat burgers, juist omdat ze in moreel of levensbeschouwelijk opzicht zo verschillend zijn, in het onderlinge verkeer een elementaire beschaving aan de dag leggen (Van den Brink 2004a). Ik zou het toejuichen als de overheid hieraan wil bijdragen, maar ik zie niets in het idee van een nationale gemeenschap waarin burgers dezelfde waarden of idealen aanhangen.

Dit betekent niet dat waarden onbelangrijk zijn of dat het gemeenschapsleven er niet toe doet. Mensen ontlenen hun betekenis voor een belangrijk deel aan anderen en daarom is de vraag bij welke groep(en) zij (willen) horen van groot belang. Maar in de aard van die groepen hebben zich wel veranderingen voorgedaan. Vroeger ging het vooral om 'zware gemeenschappen': een collectief waarvoor men zelf meestal niet gekozen heeft en waarvan een grote druk uitgaat. Voorbeelden zijn het dorpsleven, kerkgenootschappen, politieke bewegingen of het fami- 
lieleven in vroeger tijd. Zij boden het individu weliswaar gedeelde waarden en geborgenheid maar legden ook veel beperking op. De tijd van dat soort collectiviteit is eigenlijk voorbij, omdat moderne burgers hun individuele keuzen en voorkeuren vooropstellen. Dit neemt niet weg dat ze vaak zoeken naar anderen met wie ze religieuze idealen, politieke denkbeelden, muzikale voorkeuren of een sportieve belangstelling gemeen hebben maar nu op vrijwillige basis. Ik denk dat de behoefte aan dit soort 'lichte gemeenschappen' inderdaad is toegenomen (Duyvendak 2004). Vanaf de jaren zeventig zien we in Nederland een ontwikkeling waarbij veel mensen zich tegen gedwongen banden afzetten en de eigen bewegingsvrijheid vooropstellen. Dat heeft in alle opzichten tot een sterk individualistische en mobiele maatschappij geleid. Maar het is ook vaak een maatschappij van eenzamen. Veel mensen willen meer met elkaar delen, maar de structuren die daar vroeger vanzelf voor zorgden - de eigen wijk, de kerk, de vakbond, de sportvereniging enzovoorts - zijn in verval en het maken van nieuwe contacten valt niet iedereen gemakkelijk. Ook in geestelijk opzicht dient zich een lacune aan. We worden overspoeld door een diversiteit aan waarden of levenswijzen en zoeken de geborgenheid van mensen die ongeveer hetzelfde in het leven staan, dezelfde dingen van belang vinden, zich aan dezelfde zaken ergeren of dezelfde idealen najagen. Zo'n gemeenschap geeft steun en richting aan het eigen levenspad en zou zeker in een behoefte kunnen voorzien. Hoewel de Nederlandse staat zelf geen gemeenschap is, zou hij - wetend dat gemeenschappen in het leven van burgers belangrijk zijn - het opzetten en onderhouden van die gedeelde ruimte wel kunnen bevorderen. Vooralsnog worden er meer gemeenschappen afgebroken dan bijgebouwd en ook dat draagt ontegenzeggelijk tot een gevoel van crisis bij.

Ten slotte heeft de huidige crisis nog een vierde component die veeleer te maken heeft met de wijze waarop het individu zich tot zijn eigen lot verhoudt. De moderne mens wordt voortdurend opgeroepen tot zelfstandigheid en het is van groot belang dat dit voor steeds meer mensen en op steeds meer gebieden van het leven daadwerkelijk gestalte krijgt. Toch is dit maar de helft van het verhaal. Er is in het moderne mensbeeld weinig aandacht voor datgene waarin wij mensen niet zelfstandig (kunnen) zijn, voor datgene wat ons - ten goede en ten kwade - gegeven wordt zonder dat we erom gevraagd hebben. Het begint al met het leven zelf waarin een fundamentele afhankelijkheid zichtbaar wordt: niet alleen jegens onze ouders en voorouders maar ook jegens de natuur en alle andere levende wezens die bijdragen tot ons voortbestaan. Moderne mensen hebben weinig middelen waarmee ze bijvoorbeeld hun dankbaarheid kunnen vormgeven, terwijl dat juist een klassiek element in de oude religieuze tradities en rituelen was. Dat geldt evengoed voor de kwade kanten van het bestaan. Alle mensen worden vroeg of laat getroffen door ziekte en gebrek, door verdriet of dood, door eigen tekortkomingen en het kwaad van anderen. Hoe daarmee om te gaan? Op dat soort vragen geeft de moderniteit bitter weinig antwoorden en het is daarom geen wonder dat vele burgers gaan zoeken naar vormen van wijsheid, troost of zingeving. Het merkwaardige is dat men zelden terugkeert naar de spirituele bronnen die het Westen zo lang gevoed hebben. Het lijkt wel alsof de kerken niet 
in deze vraag kunnen voorzien met als gevolg dat veel burgers in het geval van blijdschap en verdriet liever naar de meest exotische symbolentaal grijpen dan naar de kerk of dominee die wat verderop in de straat zo geduldig op hen wacht (Aupers 2004). Met andere woorden: er is ook een crisis die verder dan het gemeenschapsleven reikt en samenhangt met de manier waarop mensen als individu een verhouding zoeken tot het goddelijke. We ervaren een spirituele leegte die niet door de gezelligheid van medemensen wordt opgelost, een stilte die ermee te maken heeft dat de geestelijke bronnen van het Westen opgedroogd, geblokkeerd of veronachtzaamd zijn en waar desondanks veel vraag naar is.

\subsection{DRIE MOGELIJKE HOUDINGEN}

In de huidige crisis komen dus vier tekorten bij elkaar. We missen een helder verhaal over de rol van het Westen op mondiaal niveau of in elk geval een verhaal waarin het verleden en de toekomst van Europa op een zinvolle manier verbonden zijn. Het ontbreekt ons op nationaal niveau aan burgerschap. We slagen er onvoldoende in onze verschillen in levensstijl of morele opvattingen op een fatsoenlijke manier te regelen. Op sociaal niveau is in toenemende mate een gebrek aan geborgenheid merkbaar. Het sociale weefsel waarin mensen op een min of meer natuurlijke wijze hun plaats innemen, staat onder druk. En op individueel niveau zien we een tekort aan zingeving, omdat steeds minder mensen kunnen aangeven waar het bij hun werk en hun privéleven nu eigenlijk om gaat. Met andere woorden: het gebroken karakter van de moderne wereld dringt zich aan alle kanten op en er is meer dan genoeg te doen voor kerken, gelovigen of anderen die de heelheid willen bevorderen. Maar de grote vraag is - zoals gezegd op welke wijze men daarbij te werk zou moeten gaan. Hoe kan men de spanning tussen geloof en wereld opheffen of, als zij niet op te heffen is, tenminste productief maken? In feite dienen zich twee vragen aan. Ten eerste de vraag hoe men tegenover de moderne wereld staat waarbij men (extreem gezegd) kan kiezen tussen aanvaarding en verwerping. Ten tweede de vraag of men al dan niet aan de belofte van het goddelijke wil vasthouden. Uit de combinatie van deze mogelijkheden kan men vier houdingen afleiden waarbij de kwestie van de moderniteit en het goddelijke op een specifieke wijze wordt belicht.

In de eerste plaats kan men de spanning tussen geloof en wereld oplossen door zich geestelijk terug te trekken in het eigen geloofsleven en de wereld als een goddeloos domein te zien. Het komt mij voor dat veel moslims in het Westen een dergelijke houding aannemen (Ramadan 2004). Ze leven weliswaar in Nederland, maar brengen weinig loyaliteit voor de Nederlandse rechtsstaat op. Hun burgerschap blijft vaak een formele aangelegenheid. Velen maken gebruik van sociale voorzieningen, maar voor het algemeen belang zetten slechts enkelen zich in. Er is een bescheiden deelname aan de publieke meningsvorming, voornamelijk als het gaat om zaken die de islam raken. In sociaal opzicht beperken de meeste moslims zich tot hun eigen milieu. Ze spreken onvoldoende Nederlands en komen zelden in aanraking met autochtone burgers. Dit sociaal-culturele isolement is sterker naarmate men zich meer op de islam oriënteert. Het omge- 
keerde geldt eveneens: men ontwikkelt meer belangstelling voor de islam naarmate men sterker het slachtoffer van uitsluiting en discriminatie is. Deze terugtrekkende beweging beperkt zich niet tot de sociale sfeer. Zij raakt ook het eigenlijke geloofsleven. De voorkeur gaat veelal naar een orthodoxe interpretatie uit. Aan de status van de Koran mag niet getornd worden en voor de moderne wetenschap heeft men geen belangstelling. Ten slotte koesteren veel moslims het nodige ressentiment over de verhoudingen op wereldschaal. Ze beschouwen Israël, de Verenigde Staten en andere westerse landen als vijanden, terwijl de gebreken van een groot aantal islamitische landen met de mantel van de broederliefde bedekt worden. Met andere woorden: op al deze punten wordt geloof als afweermechanisme ingezet. We hebben geen reden om eraan te twijfelen dat de spiritualiteit in eigen kring gestalte krijgt, maar tegelijkertijd zien we dat men uit naam van die spiritualiteit de moderne wereld zoveel mogelijk op afstand houdt, als men die wereld niet als een duistere en boze macht beschouwt (Van den Brink 2004b). Het spreekt voor zich dat men deze houding niet alleen bij moslims vindt. $\mathrm{Zij}$ komt evengoed voor bij bepaalde orthodoxe christenen en men kan zich zelfs een verfijnde burgerij voorstellen die uit naam van humanistische idealen hetzelfde doet.

In de tweede plaats kan men de spanning tussen wereld en geloof verminderen door vast te houden aan het geloof en uit naam daarvan de wereld te veranderen. Dat vergt een radicale houding waar in de geschiedenis van het monotheïsme al vele malen voor gekozen is. Men neemt de belofte van een komende bevrijding of verlossing zo serieus dat compromissen met de wereld uitgesloten zijn (Walzer 1985). Zelf heb ik dat gedaan toen ik in de jaren zeventig samen met vele andere studenten in Nijmegen zeer linkse opvattingen verkondigde. Teruggrijpend op de vier niveaus die zojuist genoemd werden, kan men het profiel van deze houding als volgt tekenen. Om te beginnen was daar op wereldschaal de 'keuze' die wij maakten tegen het imperialisme van de vs en alle dictaturen die door de vs gesteund werden. Even vanzelfsprekend was de keuze vóór de bevolking in Vietnam en alle andere volkeren die door het Westen onderdrukt werden. Ofschoon wij voor de Sovjet-Unie en andere socialistische regimes weinig sympathie hadden, is het wel opmerkelijk dat hún slachtoffers minder mededogen opriepen. Vervolgens was er de afwijzing van alles wat aan de burgerlijke orde herinnerde zoals zakelijkheid, parlementaire omgangsvormen, academische vrijheid, respect voor hoogleraren enz. In plaats daarvan eisten wij als studenten medezeggenschap, gingen meedoen aan de klassenstrijd, pleitten voor maatschappelijk engagement en gingen tot het bezetten van de universiteit over. Een derde aspect is dat deze radicale studenten - die veelal afkomstig waren uit de lagere middenklassen en een (klein)stedelijk milieu - de geborgenheid van een collectieve beweging opzochten. Zij kozen niet voor de hardheid van de echte maatschappij maar schuilden in woongemeenschappen waar aandacht voor hun persoonlijke problemen was. Ten slotte werden zij overtuigde aanhangers van een socialistische ideologie die weliswaar met het katholicisme van hun ouders brak, maar waarin zij toch hun betrokkenheid bij slachtoffers van geweld en onderdrukking konden vasthouden. In feite namen zij hun religieuze idealen zeer 
ernstig en losten zij de spanning met de wereld op een nieuwe wijze op. Namelijk door die wereld te verwerpen, respectievelijk te streven naar een andere wereld waarin gelijkheid en solidariteit meer dan een vage belofte zouden zijn.

Ten derde kan men de spanning tussen geloof en wereld oplossen met een houding die in elk opzicht het tegendeel van de zojuist geschetste is. Daarbij wordt de wereld met al haar hardheid en cynisme als realiteit geaccepteerd, terwijl het spirituele engagement als een private aangelegenheid wordt opgevat. Die houding zou men als een vorm van resignatie kunnen betitelen. Ik wil het Christen-democratisch Appel niet voor de voeten werpen dat het steeds voor deze houding kiest. Toch komt het bij herhaling voor dat CDA-politici oog in oog met onverenigbaarheid van moraal en politiek kiezen voor het prijsgeven van de moraal. Daar kunnen politiek gesproken heel valide redenen voor zijn, maar we moeten dan wel vaststellen dat de spanning tussen geloof en wereld in het nadeel van de eerste pool is opgelost. Ik noem een viertal voorbeelden. Op nationaal niveau biedt de christen-democratie onvoldoende weerwerk tegen de neoliberale strategie die VVD en D66 volgen. Zij verwacht alle heil van marktwerking, langer werken en een sanering van de verzorgingsstaat, terwijl een aanzienlijk deel van de bevolking juist de andere kant op wil (SCP 2004). Ik neem aan dat economen de juistheid van die agenda kunnen aantonen, maar de kwestie is welke betekenis men hecht aan een louter economische benadering. In elk geval hebben christendemocraten de afgelopen eeuw naast economische altijd normatieve en morele argumenten gehanteerd waarbij hun maatschappelijke betrokkenheid naar voren kwam. Op dat punt is het huidige kabinet zorgwekkend stil. Een vergelijkbare moeilijkheid dient zich in de sociale en semi-publieke sector aan waar professionals al jarenlang gebukt gaan onder bezuinigingen en reorganisaties die vanuit Den Haag aan hen worden opgelegd. Dat ondermijnt de motivatie van die professionals en haalt de status van hun beroep omlaag. Er worden in de praktijk korte metten gemaakt met de betrokkenheid, deskundigheid en zorgzaamheid van deze beroepskrachten en daarmee wordt de kwaliteit van de zorg aangetast (Van den Brink 2005). Het is mij niet duidelijk hoe men dat vanuit een spiritueel engagement zou kunnen verdedigen. Een derde voorbeeld is het beleid met betrekking tot asielzoekers. Het is opmerkelijk dat talloze burgers zich het lot van deze vluchtelingen aantrekken en - geïnspireerd vanuit de christelijke traditie of anderszins - een praktische vorm van naastenliefde beoefenen. Die houding staat haaks op de harde houding waarmee de regering deze kwestie ter hand genomen heeft en illustreert dat de spanning tussen geloof en wereld ook op dit punt ten gunste van de laatste is opgelost. Ten slotte zouden christen-democratische politici zich op internationaal niveau meer voor een dialoog met de islamitische wereld kunnen inspannen. De strijd tegen het terrorisme is onvermijdelijk en moet hard gevoerd worden, maar daaruit volgt niet dat het aanhalen van de religieuze band een heilloze opgave zou zijn. En ook op dat punt wint de realpolitik het van de geestelijke betrokkenheid. Met andere woorden: veel politici zijn als privépersoon ongetwijfeld brave christenen, maar daarvan is weinig te merken in hun politieke handelen. De wereld heeft het laatste woord en de idealen hebben het nakijken. 


\subsection{EEN ANDERE OPLOSSING?}

Het zal de lezer duidelijk zijn dat mijn eigen voorkeur niet naar een van deze drie houdingen uitgaat. Ik verwacht persoonlijk meer van de laatste combinatie die overblijft en die neerkomt op het aanvaarden van een dubbele opgave. Het is enerzijds noodzakelijk de moderne wereld te nemen zoals zij is en dus te erkennen dat er voortdurend breuken optreden. Terwijl men anderzijds ook moet vasthouden aan de belofte van het goddelijke en bevorderen dat dit in het moderne bestaan gestalte krijgt. Dat kan echter alleen wanneer men de werking van het goddelijke in de meest gewone dingen zoekt en de eigen idealen in de meest alledaagse praktijken investeert. Anders gezegd: men kan alleen heilzaam werken wanneer men de vragen van de huidige crisis ter harte neemt om ze op een praktische, alledaagse en moderne manier van antwoorden te voorzien. Dat is ook de achterliggende gedachte van een aantal denkbeelden en voorstellen die ik de afgelopen jaren naar voren heb gebracht en die ik kort wil toelichten.

In de eerste plaats zou men de plaats van het Westen in de wereldgeschiedenis moeten herzien. Er was de afgelopen halve eeuw veel aandacht voor onze eigen fouten en tekortkomingen. Velen hebben zelfs het gevoel dat het Westen zich met zijn economische rijkdom schuldig maakt aan onrechtvaardigheid en uitbuiting. Ik zal de laatste zijn om te ontkennen dat wij problemen in de wereld veroorzaken en ik ben als modernist een voorstander van permanente zelfkritiek. Tegelijkertijd roept de breed gedragen neiging tot zelfkritiek een paar vragen op. Is het waar dat het Westen de wereld vooral ellende heeft gebracht? Waarop berust die taaie neiging tot zelfbeschuldiging? En als het inderdaad om een oude neiging gaat, hoe kunnen wij haar dan productief maken? Er is met andere woorden wel aanleiding om ons gekwetste zelfbeeld met enig mededogen te bezien. ${ }^{3}$ Een nieuw verhaal over de plaats van het Westen in de wereldgeschiedenis kan daarbij helpen. Dat verhaal zou ten minste twee vragen moeten beantwoorden. Ten eerste de vraag wat de specifieke bijdrage van het Westen aan de wereld is geweest vanaf het moment dat de modernisering zich ontwikkelde. Ten tweede de vraag wat de rol van de christelijke traditie is die niet alleen de voorgeschiedenis van de moderne tijd bepaalt, maar als onderstroom tot op heden werkzaam is en soms op een onverwacht moment naar buiten treedt. Om dit laatste van één voorbeeld te voorzien verwijs ik naar de brede respons die de tsunami in Zuidoost-Azië teweegbracht. Veel commentatoren laten zich daar graag cynisch over uit en zeggen dat het weinig moeite kost om een bedrag over te schrijven op de gemeenschappelijke hulpactie. Maar volgens mij slaan ze de plank mis als ze denken dat onze betrokkenheid bij de slachtoffers misplaatst of oppervlakkig is. Zelf denk ik dat er een continuïteit bestaat tussen naastenliefde die in de christelijke traditie werd gecultiveerd en de 'spontane' neiging van velen om iets voor hun medemensen aan het andere einde van de wereld te willen doen. Ik zie eigenlijk weinig reden waarom deze vrijgevigheid een aanleiding tot zelfkritiek zou moeten zijn. Tenzij de christelijke traditie ook qua schuldgevoel veel sterker doorwerkt dan wij gewoonlijk aannemen. In elk geval zou ik het Westen op dit gebied meer zelfkennis toewensen. 
Op het nationale niveau pleit ik voor een opwaardering van het burgerschap. Ik geloof niet dat het mogelijk is om de bewoners van hetzelfde land samen te smeden tot een hechte gemeenschap waar allen dezelfde waarden aanhangen. Daarvoor is de diversiteit juist op het punt van idealen en doeleinden veel te groot. Maar dat betekent niet dat de verruwing van het openbare leven een noodzakelijk kwaad zou zijn, een aspect van het moderne leven waaraan men niets kan doen. Burgerschap houdt in dat de bewoners van een land zich meer betrokken voelen bij de publieke zaak en uit naam daarvan een aantal elementaire fatsoensregels met elkaar afspreken. Die gedachte heb ik uiteengezet in mijn boek over het beschavingsoffensief. Dat vooronderstelt een antwoord op de vraag welke gedragingen in de Nederlandse maatschappij als normaal gelden. Maar het vooronderstelt ook een gerichte inspanning voor die situaties of groeperingen die op het punt van de normaliteit sterk afwijken. Het vergt een elementaire eerlijkheid over die normen, codes en verwachtingen die door een meerderheid van de Nederlanders gehanteerd worden en die bindend werken. De vraag is: mogen we dat laatste wel als een gestalte van het goddelijke zien? In mijn definitie is dat het geval, ook al geef ik toe dat het op een heel alledaags niveau gebeurt. Maar het gaat wel degelijk om het helen van een breuk en het overwinnen van onenigheid. Bijvoorbeeld de kloof tussen allochtoon en autochtoon, tussen rijke en minder rijke burgers of tussen Nederlanders die veel en weinig opleiding gevolgd hebben. Momenteel dreigen er tussen al deze groepen forse scheidslijnen te ontstaan en treedt een verharding van het publieke leven op die men door middel van een meer ontwikkeld burgerschap zou kunnen verminderen.

Op sociaal niveau bepleit ik meer ruimte en waardering voor de professionals die op verschillende plaatsen in de (semi-)publieke sector werken. Ik denk aan artsen in het ziekenhuis, aan leerkrachten in het onderwijs, aan degenen die bij justitie en politie werken, aan de bestuurders in het openbaar vervoer, aan de ambtenaren die zorgen voor uitkeringen enzovoorts. Zij moeten zich dag in dag uit voor kwetsbare groepen inzetten (patiënten, jongeren, slachtoffers, werklozen enz.) en de kwaliteit van de zorg hangt sterk af van de wijze waarop zij hun werk doen. We hebben evenwel gezien dat er de afgelopen decennia in deze sector enorme tekorten zijn ontstaan, niet alleen in kwantitatief opzicht (bezuinigingen enz.) maar ook in kwalitatief opzicht. Er is een schrijnend tekort aan persoonlijke aandacht, geduld en menselijke betrokkenheid en dat kan niet alleen door meer budget of personeel hersteld worden. Nodig is eveneens een andere beroepsethiek waarbij de professionals enerzijds meer ruimte krijgen om hun werk zo goed mogelijk te doen en anderzijds beseffen dat hun werk méér omvat dan het verdienen van een inkomen. Zij kunnen met hun werk veel pijn of verdriet wegnemen, troost bieden, conflicten oplossen en het onderlinge begrip versterken. Een belangrijke voorwaarde daartoe is dat beleidsmakers en managers zich beperken tot het scheppen van de beste voorwaarden en de details overlaten aan degenen die het eigenlijke werk doen. Alleen dan kan het idealisme van de moderne professional tot zijn recht komen en heilzaam uitwerken. ${ }^{4}$ 
Ten slotte zouden we ook op individueel niveau het heil kunnen bevorderen. Daarbij is onder meer een herwaardering van het lichaam en de lichamelijke liefde wenselijk. Al te lang heeft het Westen een scheiding tussen lichaam en geest gecultiveerd waarbij ons lichaam als het lagere en onze geest als het hogere werd opgevat. Die zienswijze lijkt mij achterhaald al was het maar omdat de levenswetenschappen steeds meer bewijzen voor de samenhang van het leven aantonen. Zij nemen afscheid van het oude idee dat er een diepe kloof tussen mens en dier bestaat en laten in toenemende mate zien dat wij mensen enorm veel met hogere zoogdieren gemeen hebben. Onder andere onze behoefte aan onderlinge zorg en lichamelijke warmte (De Waal 1996). De wetenschap neemt eveneens afscheid van het oude idee dat er een kloof tussen lichaam en geest bestaat. Ze laat juist zien dat deze twee voortdurend op elkaar inwerken en dat heelheid of gezondheid uit een evenwicht tussen deze twee bestaat. En toch is er op dat punt nog het nodige te doen. Velen hebben inmiddels afscheid genomen van een geestelijk ideaal, terwijl ze hun heil alleen op materieel gebied zoeken. Dat is wellicht begrijpelijk als reactie op een cultuur die het lichamelijke minachtte, maar op termijn leidt dat tot een affectief, moreel en spiritueel tekort. Dat probleem kunnen we alleen oplossen wanneer we onderkennen dat in het hogere ook het lagere aanwezig is, dat seks en liefde niet hetzelfde zijn maar wel elkaar versterken, dat lichamelijke en geestelijke gezondheid heel dicht bij elkaar liggen en dat wij ons moeten inspannen voor het bereiken van een zeker evenwicht.

Langs deze lijnen kan men aan de belofte van het goddelijke vasthouden en tegelijkertijd midden in het moderne leven staan. ${ }^{5}$ Het betekent dat spiritualiteit niet als kritiek op of een alternatief voor de wereld wordt gezien, maar als een poging om op de meest praktische manier aan heelheid en betrokkenheid te werken. De kerken hebben daarin volgens mij een voorname taak, maar ze zijn zeker niet de enigen. In feite kan elk mens van goede wil een dergelijke opgave ter hand nemen.

\subsection{DE WERKING VAN HET IDEAAL}

$\mathrm{Nu}$ zijn er ongetwijfeld lezers die deze zienswijze met enig cynisme tegemoet treden. Wat is dat voor een wereldvreemd verhaal waarbij de problemen van het moderne leven met idealisme worden opgelost? Hebben de grote denkers ons niet geleerd dat al die idealen uit platvloerse belangen voortkomen? Zijn we dan vergeten dat het geld (Marx), de wil tot macht (Nietzsche), de geslachtsdrift (Freud) of de techniek (Heidegger) zich altijd mooier voorstellen dan ze zijn? Met andere woorden: waarin verschilt het pleidooi dat ik hier houd van een simpele geloofsbelijdenis en wie zegt dat een dergelijk streven in de moderne wereld kans van slagen maakt? Die vragen zijn volkomen op hun plaats binnen de gangbare opvatting van onze geschiedenis. Mijn punt is evenwel dat ik die opvatting als zodanig niet langer geloofwaardig acht. Ik wil daarom afsluiten met enkele vermoedens waarvan ik de speculatieve aard erken, maar waarmee $\mathrm{ik}$ me toch tegen het verwijt van een ondoordacht idealisme wil verdedigen. 
Om te beginnen vermoed ik dat onze voorstelling van het goddelijke de afgelopen eeuwen aanmerkelijk verschoven is. Dat blijkt uit de manier waarop men het heil 'lokaliseert'. Oorspronkelijk stelde men God als een bovennatuurlijke instantie voor, een kracht die niet onderhevig was aan natuurlijke of historische beperkingen. Het heil werd gelokaliseerd in een sacrale sfeer die op grote afstand van het gewone leven stond. Dat veranderde in de loop van de achttiende en negentiende eeuw. In West-Europa begon men de realisatie van het heil langzaam maar zeker in historische termen te zien. Het opheffen van scheidslijnen of de verwerkelijking van broederschap zou gestalte krijgen in de menselijke geschiedenis. Sommigen hielden aan de belofte van een heilstaat vast en verwachtten dat er in de toekomst een totaal nieuwe maatschappij zou zijn. Anderen gaven die verwachting op maar vonden het wel noodzakelijk om aan een meer rechtvaardige samenleving te werken. In die zin werd de realisatie van het goddelijke niet langer als een sacraal maar als een sociaal project gezien. Inmiddels maken we een volgende verschuiving door. Veel burgers geloven niet langer dat je menselijke idealen kunt realiseren via staat of politiek en zoeken nieuwe kanalen of actie-vormen op. Dat heeft tot het succes van organisaties als Artsen zonder Grenzen of Amnesty International geleid. Daarbij valt op dat het accent steeds meer op het vitale register wordt gelegd. Deze verschuiving typeer ik als de migratie van het goddelijke. De droom van eenheid en betrokkenheid bevindt zich niet altijd op dezelfde plaats en het lijkt erop dat zij zich op een steeds 'lager' niveau manifesteert. We lokaliseren het heil niet langer in de hemel of een sacrale sfeer en ook niet in de verre toekomst of een ideale maatschappij, maar in het concrete handelen van mensen en hun onderlinge betrekkingen. Met andere woorden: het idealisme is in de loop der eeuwen niet verdwenen maar het werd aardser, praktischer en meer alledaags van aard (Ferry 1998). Overigens betekent dit dat het goddelijke zich niet beperkt tot mensen die een bepaald geloof aanhangen. In mijn opvatting kunnen ongelovigen evengoed het heil belichamen.

Een tweede vermoeden betreft de wijze waarop de moderniteit sinds een eeuw gestalte krijgt. Ik wees er al op dat modernisering geen vorm van vooruitgang is maar een proces dat zowel zon- als schaduwzijden kent. Daarom komen bij elke nieuwe etappe van dat proces voorstanders en tegenstanders tegenover elkaar te staan. Het debat gaat meestal om de vraag in welk tempo de veranderingen optreden. Voorstanders vinden dat de verandering niet snel genoeg verloopt: ze klagen over zaken uit het verleden die remmend werken zoals religieuze opvattingen, tradities, oude technieken of achterhaalde wetgeving. Voor tegenstanders gaat de verandering juist veel te hard: zij wijzen op waardevolle zaken die bedreigd worden of verloren gaan zoals huwelijkstrouw, historisch besef, typische gebruiken of sociale gemeenschappen. In werkelijkheid gaat modernisering altijd met debat, onenigheid en strijd gepaard. Daarbij zijn waarden of idealen van enorme betekenis. Men zou zelfs een stap verder kunnen gaan en de moderniteit definiëren als een samenleving waar idealen er echt toe doen. Zoals bekend verdedigden Marx en Engels in het midden van de negentiende eeuw de omgekeerde opvatting (Marx 1972). Zij kenden aan het zijn veel meer gewicht dan aan het bewustzijn toe en formuleerden daarmee een leer die als historisch materialisme te boek staat. 
Volgens mij geldt deze leer voor grote delen van de westerse geschiedenis tot... het midden van de negentiende eeuw! Het bewijs daarvoor wordt geleverd door het enorme succes dat het denken van Marx en Engels in heel Europa en ver daarbuiten had. Het illustreert dat een volslagen idealistische gedachte zoals het idee van een klasseloze maatschappij niet alleen door grote massa's werd aanvaard, maar ook tot een tastbare historische kracht geworden is. En dat voorbeeld staat niet op zich. In de hele twintigste eeuw zijn geestelijke entiteiten zoals denkbeelden, utopieën, waarden of idealen de inzet geweest van een gevecht dat misschien wel in de politiek, via de markt of op het slagveld werd beslist maar dat óók een ideële component bezat. In die zin horen moderniteit en (de strijd om) idealen bij elkaar.

Deze verbintenis geldt - en dat is mijn derde vermoeden - in extra mate voor de periode die volgde op de jaren zestig. Tot die tijd was de ambitie voor grote delen van de bevolking gericht op bestaanszekerheid en veiligheid. Daardoor bleef de ruimte om eigen idealen na te jagen aan de bescheiden kant. Vanaf de jaren zestig zou dat evenwel veranderen. Zo kwam de afgelopen decennia een vorm van postmaterialisme tot ontwikkeling waarbij andere doeleinden dan veiligheid of een goed inkomen werden nagestreefd (Inglehart 1977). Het gaat voor een deel om ambities in de publieke sfeer zoals meer openbaarheid of medezeggenschap. Voor een ander deel gaat het om particuliere verwachtingen zoals een goede gezondheid, een aantrekkelijke partner of zelfstandige kinderen. En voor weer een ander deel gaat het om de verwachtingen die men heeft van het werk of het bedrijfsleven. Een toenemend aantal mensen werkt niet alleen voor een inkomen maar ook om zich te ontplooien of iets te kunnen betekenen voor anderen. Bij het bedrijfsleven wordt niet alleen gelet op winstcijfers maar ook op zaken als publieke verantwoordelijkheid of milieu. Met andere woorden: over de hele breedte van het maatschappelijk leven hebben denkbeelden en idealen tegenwoordig méér gewicht dan in de periode vóór 1970. Er is discussie mogelijk over de effecten van dit idealisme en ik erken direct dat er ook nadelen aan vast zitten. Maar intussen zijn idealen wel overal werkzaam. En niet alleen als het om verheven thema's gaat (mensenrechten, politieke vrijheden enz.) maar ook bij de vraag hoe wij tegen ons alledaagse leven en werken aankijken. Daarbij doen zich uiteraard conflicten voor maar evengoed situaties waarbij mensen elkaar de hand reiken. In feite is de door mij bepleite visie niet zo wereldvreemd. Ze sluit in hoge mate op de aard van het moderne leven aan en het zijn vooral de intellectuelen, journalisten of wetenschappers die - steunend op een oude gedachtegang - de aard van dat leven onvoldoende onder ogen zien.

Op grond van dit alles geloof ik niet dat het goddelijke zich geheel uit de moderne wereld teruggetrokken heeft. En daar komt nog een laatste vermoeden bij. De cultuurgeschiedenis van de afgelopen eeuwen vertoont een opmerkelijke golfbeweging waardoor morele en spirituele gevoeligheid een cyclus van ongeveer honderd jaren kent. Het beschavingsoffensief waar ik sinds het einde van de jaren negentig voor pleit, verwijst naar een vergelijkbare impuls aan het einde van de negentiende eeuw (Van den Brink 1996). En die beweging werd voorafgegaan 
door een golf aan het einde van de achttiende eeuw toen - niet alleen in het kerkelijk leven maar ook in kringen van de burgerij - met grote inzet aan maatschappelijke en morele verheffing gewerkt werd. Dat kwam onder meer in de oprichting van de Maatschappij tot Nut van 't Algemeen tot uitdrukking (Kruithof 1982). Een vergelijkbaar engagement is in het laatste kwart van de zeventiende eeuw te zien, ofschoon het toen ging om een kerkelijk offensief dat zich vooral richtte op een verinnerlijking van het geloofsleven (Van Deursen 1986; Frijhoff 1986).

Volgens sommige auteurs zou zich aan het einde van de zestiende eeuw eenzelfde beweging hebben voorgedaan. Zo stuiten we op het even raadselachtige als hoopgevende verschijnsel dat zich eens per eeuw een streven naar uitzuivering en verinnerlijking manifesteert zonder dat het uit economische of politieke motieven te verklaren is (Clemens 1988). Ik heb daar geen verklaring voor en zou er graag een nader onderzoek naar doen. In afwachting daarvan stel ik vast dat Gods wegen nog veel ondoorgrondelijker zijn dan het geloof beweert. We weten dat de werking van het goddelijke zich soms aan het oog van de gelovigen onttrekt, maar nu blijkt dat het goddelijke juist in werking treedt zodra het zich aan het oog van de gelovigen onttrokken heeft. 


\section{NOTEN}

1 Eerder verschenen in G. Buijs \& T. van der Ploeg (red.) En plein publique. De samenleving van morgen en de kerk van nu, ICS Cahiers 43, Zoetermeer: Boekencentrum.

2 Daarom is het mogelijk om onderzoek te doen naar religieuze verschijnselen zonder zich uit te laten over dogmatische vraagstukken. Zie bijvoorbeeld Staal 1978, p. 225-235; Firth 1996, p. 50; Winkelaar 2005, p. 184.

3 Vgl. het gepassioneerde opstel dat kardinaal Ratzinger in 2001 hierover schreef en dat op 30 april 2005 in het dagblad Trouw opnieuw werd afgedrukt.

$4 \quad$ Overigens sta ik met dit pleidooi allerminst alleen, zoals blijkt uit een recente uitgave van Christen Democratische Verkenningen.

$5 \quad$ Overigens heeft deze houding in de Lage Landen al een lange geschiedenis. Zie bijvoorbeeld de wijze waarop de Moderne Devotie in de veertiende eeuw gestalte kreeg (Los 1984, p. 7-32). 


\section{LITERATUUR}

Aupers, S. (2004) In de ban van de moderniteit. Sacralisering van het zelf en computertechnologie, Amsterdam: Aksant.

Brink, G. van den (1996) De grote overgang. Een lokaal onderzoek naar de modernisering van het bestaan, Woensel 1670-1920, Nijmegen: SUN.

Brink, G. van den (2004a) Schets van een beschavingsoffensief. Over normen, normaliteit en normalisatie in Nederland, Amsterdam: Amsterdam University Press.

Brink, G. van den (2004b) Tekst, traditie of terreur? Naar een moderne visie op de Islam in Nederland, Utrecht: Forum.

Brink, G. van den, T. Jansen, D. Pessers (red.) (2005) Beroepszeer. Waarom Nederland niet goed werkt, Amsterdam: Boom.

Buijs G. \& T. van der Ploeg (red.) (2005) En plein publique. De samenleving van morgen en de kerk van nu, ICS Cahiers 43, Zoetermeer: Boekencentrum.

Deursen, A. van (1986) 'Volkscultuur in wisselwerking met de elitecultuur in de vroegmoderne tijd', blz. 54-70 in G. Rooijakkers \& T. van der Zee (red.), Religieuze volkscultuur. De spanning tussen de voorgeschreven orde en de geleefde praktijk, Nijmegen: SUN.

Duyvendak J., M. Hurenkamp (red.) (2004) Kiezen voor de kudde. Lichte gemeenschappen en de nieuwe meerderheid, Amsterdam: Van Gennep.

Eisenstadt, S. (ed.) (2002) Multiple Modernities, New Brunswick: Transaction Publishers.

Ferry, L. (1998) De god-mens of de zin van het leven, Amsterdam: Ambo.

Firth, R. (1996) Religion: A Humanist Interpretation, London: Routlegde.

Frijhoff, W. (1986) 'Vraagtekens bij het vroegmoderne kersteningoffensief', blz. 71-98 in: G. Rooijakkers \& T. van der Zee (red.), Religieuze volkscultuur. De spanning tussen de voorgeschreven orde en de geleefde praktijk, Nijmegen: SUN.

Inglehart R. (1977) The silent revolution. Changing values and political styles among western publics, Princeton: Princeton University Press.

Kruithof, B. (1982) 'De deugdzame natie. Het burgerlijk beschavingsoffensief van de Maatschappij tot Nut van 't Algemeen tussen 1784 en 1860', blz. 363-377 in: B. Kruihof, J. Noordman, P. de Rooy (red.) (1982) Geschiedenis van opvoeding en onderwijs. Inleiding, bronnen, onderzoek, Nijmegen: SUN.

Lans, J. van der (1998) Kernervaring, esthetische emotie en religieuze betekenisgeving, Nijmegen: Katholieke Universiteit Nijmegen.

Los, C. (1984) Van Geert Groote tot Erasmus. De Broeders des gemenen levens en de navolging van Christus, Zeist: Uitgeverij Christofoor.

Marx, K., F. Engels (1972) De Duitse Ideologie, Nijmegen: SUN.

Ramadan, T. (2004) Western Muslims and the future of Islam, Oxford: Oxford University Press.

Rooijakkers, G., T. van der Zee, red. (1986) Religieuze volkscultuur. De spanning tussen de voorgeschreven orde en de geleefde praktijk, Nijmegen: SUN.

SCP (2004) Sociaal en Cultureel Rapport 2004. In het zicht van de toekomst, Den Haan: SCP. Staal, F. (1978) Het wetenschappelijk onderzoek van de mystiek, Utrecht: Het Spectrum.

Waal, F. de (1996) Van nature goed. Over de oorsprong van goed en kwaad in mensen en andere dieren, Amsterdam: Contact. 
Walzer, M. (1985) Exodus and Revolution, New York: Basic Books.

Winkelaar, P. (2005) Anders dan we denken. Een geseculariseerde benadering van het religieuze, Amsterdam: Uitgeverij swP. 


\title{
17 RELIGIE EN HET MORELE DISPUUT
}

\author{
Jean-Pierre Wils
}

\begin{abstract}
“De mensen moeten de broers (en zusters) liefhebben, die zij kennen, en in die aangelegenheden hun interesses nagaan, die zich in het bereik van hun horizon bevinden; en zij moeten hierbij hun religieuze overtuigingen - $i k$ wil niet zeggen een secundair maar toch een omvattender en meer algemeen gevoel laten zijn." (Peirce 1995: 201)
\end{abstract}

\subsection{RELIGIE EN HAAR DUBBELZINNIGHEID}

Religie is terug op de culturele agenda. Over de 'toekomst van religie' te spreken is onder intellectuelen geen taboethema mee (Rorty 2004). Religie is tevens terug op de politieke agenda. 'Fundamentalisme' is een formule geworden waarmee de verontrustende en radicaliserende invloed van religie op politieke vraagstukken wordt bezworen (Deuser 2005). De 'onttovering' van de wereld (Gauchet 1997) als het resultaat van een rechtlijnig proces van de secularisatie heeft niet het laatste woord. Inmiddels is er overal sprake van een 'desecularization of the world' (Berger 1999). Maar ook op het vlak van de morele disputen waar onze cultuur niet arm aan is, kan er sprake zijn van een terugkeer van religie. De bijdrage van religies aan morele kwesties is echter onderhevig aan een sterke ambivalentie. Enerzijds gelden zij als hoeders van de morele cultuur (Heirman 2006), als advocaten van de persoonlijke verantwoordelijkheid en als de wakende instanties over 'normen en waarden'. Sinds de Verlichting is er een beeld ontstaan dat de kern van religie - haar essentie - uit een soort 'natuurlijke' of 'universele' moraal zou bestaan. Religie wordt dan ontdaan van haar rituele, dogmatische en institutionele aspecten (en van grote delen van haar geschiedenis) en gereduceerd tot een soort 'moraalproductie'. Religie is vanuit dit perspectief waardevol, omdat zij voorziet in de belangrijkste factor van de stabiliteit van een maatschappij - de moraal (Van der Burg 2005).

Anderzijds kan men zich niet aan de indruk onttrekken dat deze visie op z'n minst kortzichtig is. De productie van moraal is historisch gezien slechts één van de vele functies die religie heeft gehad. En voor het christendom geldt dat de belangrijke ethische paradigma's die in het verloop van de geschiedenis werden ontwikkeld steeds in ruime mate op de leest van filosofische - en dus niet-religieuze - moraaltheorieën waren geschoeid. Maar los daarvan kan men tegelijkertijd empirisch vaststellen dat de invloed van religie op morele overtuigingen en praktijken niet slechts constructief maar vaak verstorend en destructief is geweest (Manenschijn 2005). Het is dus steeds de vraag welke ethiek door religie wordt bevestigd of genegeerd en of deze bevestiging of negatie wel terecht plaatsvindt. Niet iedere door religie bevestigde moraal hoeft een verstandige moraal te zijn en niet iedere door religie genegeerde moraal hoeft een slechte moraal te zijn. En natuurlijk geldt evenzeer dat niet iedere door religie bevestigde moraal een 
onverstandige moraal moet zijn. De verhouding tussen 'religie' en 'moraal' is in principe een open relatie. In de moderniteit hebben wij wel geleerd dat er een autonomie van de moraal bestaat. Dat betekent dat moraal ook zonder religie kan, en dat morele kwesties ook buiten religieuze taalspellen zinvol kunnen worden gearticuleerd.

Religieus geïnspireerde commentaren op moreel complexe casuïstiek geven momenteel echter steeds vaker aanleiding tot een radicalisering van het publieke debat. Voorzichtig geformuleerd: de 'common sense' in morele kwesties staat sterk onder de druk van religieuze interventies en commentaren. Daarmee is natuurlijk niet gezegd dat deze 'common sense' bij voorbaat het gelijk aan zijn kant heeft. Dit is slechts een feitelijke uitspraak over de groeiende spanningen tussen religie respectievelijk religieus gemotiveerde interventies in ethische (en politieke) discussies enerzijds en 'common sense'-opvattingen over morele kwesties anderzijds.

Men zou deze twee verschillende uitingen van religie - de moraal-bevorderende en de moraal-verstorende - met de volgende predicaten kunnen typeren. De stelling dat religie een wezenlijk positieve invloed op moraal heeft, zou men een uitspraak over religie als 'zachte' religie kunnen noemen. Het vermoeden dat religie in dit geval echter gehalveerd wordt en in tal van gevallen een nefaste invloed op morele 'basics' uitoefent, zou men met Rudolf Otto een uitspraak over 'diepe' religie kunnen noemen - over religie 'aan de andere kant van de moraal'. In zijn befaamde boek Das Heilige (1917) had Otto de stelling verdedigd dat religie vaak ook zonder morele restricties moet worden begrepen: religie is dan 'jenseits von Gut und Böse' (Friedrich Nietzsche). Het 'goede' stelt dan geen grens aan de uitingsvormen van religie. Soms wordt in dit verband religie een soort van 'moreel nihilisme' (Schröder 2002) verweten, dat over de limieten van het menselijke zelfbehoud en de meest elementaire morele normen heen gaat. Morele grensoverschrijding is in ieder geval niet vreemd aan religie. Ik geef kort drie voorbeelden.

De discussie omtrent de Amerikaanse Terry Shiavo, een vrouw met een apalisch syndroom die meerdere jaren in een irreversibel coma lag, staat ons nog voor ogen: ethische deliberatie was hier nog nauwelijks mogelijk, nadat politieke belangen maar vooral religieuze stellingnamen zich van de casus meester hadden gemaakt. Het conflict over het stopzetten van de behandeling onderging door de religieuze commentaren een regelrechte fanatisering, die de meningsvorming in het publieke domein deels vergiftigde. Plotseling hebben wij niet meer te maken met een moreel dispuut maar met een politiek-religieus gevecht. Gebruikmakend van de autoriteit van God werd het standpunt van de ander aangevallen. Het resultaat was een geëmotioneerde en diep verstoorde publieke opinie, die zich niet bekommerde om degelijke geneeskundige informatie of om een begrijpelijke ethische argumentatie.

In april van dit jaar werd in Berlijn een rechterlijke uitspraak gedaan in een proces over een zogenaamde 'eermoord'. Drie Turkse broers hadden hun gescheiden 
zuster, moeder van een kind, op straat vermoord, omdat zij vonden dat haar stijl van leven niet paste bij een islamitische cultuur. De jongere zuster van de vermoorde vrouw verlangde het zorgrecht voor de kleine jongen, die in een pleegfamilie was opgenomen. In een interview gaf ze te kennen dat ze de hele opschudding rondom deze brutale moord niet begreep, want - zo letterlijk - 'mijn zus is toch in het paradijs?'. De religieuze duiding en legitimatie van de moord verhinderden blijkbaar ieder (on)rechtsbewustzijn. Ook de twee vrijgesproken broers hadden geen enkel schuldgevoel; zij onderschreven de daad van hun jongste broer ten volle. Iedere vorm van emancipatie of zelfbeschikking stond hier blijkbaar haaks op een religieus gelegitimeerde cultuur van onderdrukking van vrouwen.

Begin juni van dit jaar deed de 'Pauselijke raad voor de familie' uitspraken over onder andere homoseksualiteit. Dit gebeurde tegen de achtergrond van groeiende Europese discussies en politieke besluitvormingen over het zogenaamde 'homohuwelijk'. In scherpe formuleringen spreekt deze raad over de 'verduistering' van de westerse cultuur, die tot uitdrukking zou komen in een permanente aanval op de waarden (en de realiteiten) van de familie. Andere formuleringen die tegen deze achtergrond vaker worden gehoord luiden 'cultuur van de dood' en 'dictatuur van het relativisme'. Mij interesseert hier niet het ethisch debat over homoseksualiteit. Waar ik wel op wil wijzen is het feit dat de metaforen die in de discussie worden geworpen de ethische argumentatie dreigen te verstoren. Wanneer de gesprekspartner in een 'cultuur van de dood' leeft, is een zinvol dispuut onmogelijk geworden. Wie in 'duisternis' leeft, kan geen betrouwbare of geldige argumenten ontwikkelen. Nog verontrustender is de constatering dat op deze manier niet slechts de 'cultuur van argumenteren' wordt verlaten, maar dat de ethische tegenstander tot een morele vijand wordt gemaakt. Niet enkel het argument maar ook de argumenterende moet feitelijk worden bestreden.

De genoemde voorbeelden zijn aan actuele westerse situaties ontleend. Zij vinden plaats in een maatschappij die over een 'publieke ruimte' beschikt waarin morele geschillen gearticuleerd (kunnen) worden in de gedaante van ethische disputen. De stem van religies is een stem in deze publieke ruimte naast andere stemmen. Maar toch leek deze stem afgelopen jaren steeds schriller en scherper te worden. Religieus geïnspireerde interventies in morele conflicten schijnen een redelijke discussie dus veelal te blokkeren. De religieuze legitimatie of delegitimatie van leefvormen leidt steeds vaker tot een verharding van de standpunten en tot een houding die - omwille van de 'heilspraktische rechtzinnigheid' van de aanhangers - ieder zinvol debat onmogelijk dreigt te maken. 'Rechtzinnigheid' die niet tot zelfcorrecties in staat is, is vanzelfsprekend geen privilege van religies. $\mathrm{Zij}$ bestaat ook ten overvloede in seculiere contexten. Maar men kan moeilijk ontkennen dat de inbreng van religieuze standpunten momenteel nauwelijks een positieve invloed heeft op de discussiecultuur en deze 'cultuur van argumenteren' dreigt te ondermijnen.

Deze morele voorbeelden staan niet los van de politieke invloed die religies uitoefenen. In hun lijvige empirisch-sociaal-wetenschappelijke studie met de titel 
Krieg der Religionen. Politik, Glaube und Terror im Zeichen der Apokalypse (2006) hebben Victor en Victoria Trimondi onlangs een verontrustend beeld geschetst van het wereldwijd toenemend religieuze radicalisme en fundamentalisme. $\mathrm{Zij}$ gaan ervan uit dat momenteel in alle wereldreligies een apocalyptisch denken groeit dat onheilspellende gevolgen heeft voor de samenlevingen die de gevolgen van dit denken moeten ondergaan. De 'apocalyptische matrix' die in de meest uiteenlopende godsdiensten wordt gehanteerd, heeft verschillende kenmerken, waarvan ik slechts de voor onze thematiek meest relevante noem: de oorlog tussen 'goed' en 'kwaad'; de radicale verwerping van de maatschappelijke 'status-quo', die als decadent, vervallen en losbandig wordt ondervonden; 'absoluutheidsdenken' of de macht van het eigen gelijk; een 'zondeboksyndroom'; intolerantie tegenover andersdenkenden (en anderslevenden). Politiek en moraal gaan in dit verband sterke allianties aan: het morele gelijk wordt niet onderscheiden van het politieke en religieuze gelijk. De legitimiteit van de democratie wordt gekoppeld aan een morele code: wijken politieke beslissingen van het absolute, religieus verankerde normenpatroon af, dan verliezen de instituties en procedures die deze beslissingen genereren, hun recht van bestaan.

Op deze manier wordt echter een basispremisse van de liberale, democratische rechtsstaat ontkend. Weliswaar is de rechtsstaat gebaseerd op een aantal 'normen en waarden', en garandeert deze staat basale rechtsgoederen, die in hoge mate met de code van de mensenrechten compatibel zijn, de toepassing van deze morele grondtekst is een object van voortdurende besluitvorming en wettelijke aanpassing. De sedert jaren in alle westerse landen omstreden 'embryowetten' laten goed zien hoe democratische besluitvorming 'in rebus morum' - in morele kwesties - tot stand komt. Deze wetten worden aangepast, gemodificeerd, versoepeld of verengd in een continu proces van wikken en wegen - in een proces van politieke en morele deliberatie. Het resultaat van deze deliberatie - de modificatie van een toepassing - kan nooit alle burgers bevredigen. Maar het zou noodlottig zijn wanneer iedere modificatie, die op (democratisch) verzet of op de gearticuleerde dissensus van een minderheid stoot, ertoe leidt dat deze minderheid de legitimiteit van de rechtsstaat als dusdanig ontkent. In religieuze kringen is dit echter steeds vaker het geval.

\subsection{TEgEN DE METAFysica VAN 'GOED' EN 'KWAAD'}

Het is van belang te onderscheiden tussen een analytisch en een empirisch begrip van religie. Analytisch gezien betekent religie een 'ensemble van overtuigingen, praktijken en riten, gebaseerd op een instantie die de immanentie te buiten gaat'. Vanzelfsprekend is deze definitie betwistbaar. Maar de opvatting dat in religies een elementair onderscheid wordt gehanteerd, dat men met de begrippen 'immanentie' en 'transcendentie' kan omschrijven, is vatbaar voor een zekere overeenstemming. 'Transcendentie' betekent dan "het gevoel dat er buiten mijzelf nog iets bestaat dat groter is", om Charles Taylor (2002: 55) te citeren. Deze analytische benadering is in zekere mate leeg. $\mathrm{Zij}$ verstrekt geen substantiële informatie. Zij moet als een soort model worden beschouwd waarmee men religie van niet- 
religie kan onderscheiden, ofschoon dit onderscheid in nogal wat gevallen niet zo simpel te maken valt.

Empirisch gezien is religie een culturele realiteit die van dit verschil tussen immanentie en transcendentie op talloze manieren gebruikmaakt. De realiteit van religie kan redelijke en onredelijke, humane en inhumane gevolgen van dit verschil laten zien. Menselijke handelingen kunnen door religie in hoge mate humaniteit winnen, maar zij kunnen ook humaniteit verliezen. De verleiding is in ieder geval niet gering om zich door religie gelegitimeerd aan het 'wikken en wegen van argumenten' te willen onttrekken en een soort idiosyncratisch moreel denken te koesteren. Ik wil dat vanuit een tweevoudig perspectief - een empirisch-politiek en een filosofisch ingekleurd perspectief - toelichten.

Op 18 oktober 2000 zei Simon Peres in een interview met NRC Handelsblad over de situatie in het Midden-Oosten: "Waar religie begint, helpt een compromis niet. Waar heiligheid begint, eindigt de rede." Peres wees op het ongebreideld religieus fanatisme dat in Israël aan beide zijden van het politieke spectrum een zinvol compromis doet mislukken. Wie argumenteert en zijn rede gebruikt, is gevoelig voor het relatieve gelijk van de ander en in staat tot een compromis. Wie echter vindt dat zijn 'heil' op het spel staat en de ander in een toestand van 'onheil', 'decadentie' of 'verdoemenis' verkeert, moet iedere onderhandeling met haar typische sfeer van geven en nemen afkeuren. In een kleine collegereeks die de befaamde joodse auteur Amos $\mathrm{Oz}$ aan de universiteit van Tübingen gaf onder de titel 'Wie man Fanatiker kuriert', stelde hij het volgende:

\footnotetext{
"Ik vind een compromis. Ik geloof stellig in compromissen. Ik weet dat het woord 'compromis' in de idealistische kringen van Europa een slechte reputatie heeft, vooral bij jonge mensen. Compromissen worden beschouwd als een tekort aan integriteit, als een tekort aan morele ruggengraat, als een tekort aan volharding, aan eerlijkheid. Compromissen stinken, zij berusten op leugens. Maar niet in mijn woordgebruik. In mijn wereld zijn compromissen een synoniem voor het woord 'leven'. En waar leven is, daar zijn compromissen. Het tegendeel van compromissen is niet integriteit, en het tegendeel van compromissen is niet idealisme en vastberadenheid. Het tegendeel van compromissen is fanatisme en dood. (...) Ik spreek hier over het tegemoet treden van de ander halverwege. Er bestaan geen gelukkige compromissen. Een gelukkig compromis is een tegenspraak, een oxymoron." (Oz 2004: 28)
}

Oz pleit dus voor de kunst van het sluiten van een compromis en voor een grote voorzichtigheid bij het gebruik van verheven en abstracte begrippen. In politieke maar ook in morele contexten doen zulke begrippen vaak verwarring ontstaan of laten zij discussies ontsporen. Ik voeg hier onmiddellijk een tweede belangrijk citaat aan toe dat het model dat Oz voor ogen staat goed markeert en dat tegelijkertijd het filosofische probleem toont. 
"Er bestaat geen strijd tussen goed en kwaad. Ik beschouw deze strijd eerder als een tragedie in de klassieke en meest nauwkeurige betekenis van het woord tragedie: een botsing tussen 'juist' en 'juist', een conflict tussen een zeer sterke, zeer duurzame en zeer overtuigende eis en een andere, zeer verschillende, maar niet minder overtuigende, niet minder sterke, niet minder menselijke eis.” (Oz 2004: 62)

Ik wil hier de aandacht vooral vestigen op slechts één enkele zin, op de zin: "Er bestaat geen strijd tussen goed en kwaad." Deze zin staat diametraal tegenover de reeds genoemde 'apocalyptische matrix', want die beweert juist dat die strijd een beslissende betekenis heeft. Wellicht kan deze 'relativering' van de begrippen 'goed' en 'kwaad' op het eerste gezicht vreemd aandoen. Zijn 'goed' en 'kwaad' geen essentiële categorieën van het morele taalgebruik en daarmee ook van de morele 'werkelijkheden'? Kunnen wij zonder deze begrippen morele vraagstukken articuleren, en leidt de relativering van hun functie niet tot een 'waardeverlies' in de politiek of tot een moreel relativisme? Het zou inderdaad dwaas zijn om deze begrippen overboord te werpen. Maar de geciteerde zin van $\mathrm{Oz}$ articuleert geen scepsis over de begrippen van 'goed' en 'kwaad', maar wil vermijden dat deze predicaten met kosmische of politieke machten of realiteiten worden vereenzelvigd. 'Goed' en 'kwaad' zijn predicaten, die in de taal van de moraal onvermijdelijk zijn, maar zij zijn geen entiteiten. Wie over een 'strijd' tussen 'goed' en 'kwaad' spreekt, suggereert niet enkel dat wij met zulke entiteiten ook daadwerkelijk te doen hebben, maar verlangt ook dat men moet kiezen aan welke kant men zich opstelt. Uit predicaten die in het morele discours hun thuishaven bezitten, zijn nu namen geworden waarmee blijkbaar duidelijke zaken in de realiteit corresponderen. Maar abstracties zoals 'het goede' en 'het kwaad' doen vergeten dat het niet evident is waaraan zij refereren. Omdat realiteitstoetsen hier nauwelijks wenselijk zijn, ontstaan effecten die slechts moeilijk voor correcties toegankelijk zijn. Lee Harris spreekt in deze samenhang over 'the Fanatism of abstract Thought' (Harris 2004: 147). Het abstracte denken is weinig of niet geïnteresseerd in de complexiteit van de reële verhoudingen, het voelt zich veilig in de omgeving van algemeenheden en vermijdt de lastige taak van de precieze analyse en van de deliberatieve toepassing van regels en principes. Wij worden hier met het fanatisme van de realiteitsnegatie geconfronteerd.

Ik wil bij deze bevindingen nog even stilstaan. In de zogenaamde 'meta-ethiek' de analyse van de betekenis van morele begrippen - is met veel aandacht naar de semantiek van het predicaat 'goed' gekeken. Het meest befaamde commentaar werd door Georg Edward Moore in zijn Principia Ethica gegeven. Volgens Moore is 'goed' uiteindelijk ondefinieerbaar. Het is een niet nader te analyseren kwaliteit. Wij bezitten weliswaar tal van intuïties over de betekenis van 'goed', maar wat het eigenlijk betekent blijft onhelder. Men kan dit als een waarschuwing voor een te volmondig en zelfverzekerd gebruik van 'goed' interpreteren. Ik wil nog op een ander probleem attenderen. Dikwijls wordt 'goed' als vertrekpunt in een moreel dispuut beschouwd. In dit verband gaat men er dan van uit dat wij over substantiele inzichten omtrent 'het goede' beschikken die van meet af aan de morele 
kwestie bepalen. Maar dit is in talrijke gevallen een drogreden. Het predicaat 'goed' gebruiken wij in werkelijkheid als een soort eindpunt, als een luisterrijk slot van de reflectie en van het debat. Wanneer de morele casus degelijk geanalyseerd is en de moeilijke oordeelsvorming, waarbinnen wij algemene regels in het licht van de concrete vraagstelling moeten verbijzonderen, tot een voorlopig einde is gekomen, vatten wij het oordeel vaak samen door te zeggen dat deze of gene handeling 'goed' is. 'Goed' is dus het gevolg van een genese in het morele discours, het is het resultaat van een reflexief en deliberatief proces. Het kan dit proces in ieder geval niet vervangen. Wie steeds weer terugvalt op abstracties en substantiële beweringen en zich daarbij onttrekt aan argumentatieve strategieën die moeten aantonen hoe de vermoedelijke juistheid van onze stellingen reflexief kan overtuigen, trekt zich terug in de afgesloten ruimte van de ideologie.

Voor het gelijk van het 'substantieel goede', van 'het goede' werden en worden echter oorlogen gevoerd. Men zou dit de polemologische component van een metafysica van het goede kunnen noemen. Onder 'metafysica' versta ik hier twee verschillende maar toch samenhangende dingen. Ten eerste: een metafysisch betoog lijdt vaak aan een abstracte nominalisering van predicaten. Wat dit voor 'goed' betekent hebben wij zojuist laten zien. 'Goed' wordt een naam voor een entiteit, voor een 'ding'. Ten tweede: de metafysica gaat over 'laatste vragen', over vragen omtrent de 'zin van het leven', over de 'beginselen van de werkelijkheid'. Morele vraagstukken hebben weliswaar voeling met dit soort 'laatste vragen', maar zij betreffen uiteindelijk 'voorlaatste' vragen. Om het concreet te maken: een van de belangrijke inzichten en verworvenheden van de vroege moderniteit betreft de ontkoppeling van de metafysica en de ethiek. Ook wanneer wij het niet eens zijn over 'laatste vragen', zijn wij toch in staat om over morele kwesties te delibereren. Een variant van deze stelling luidt: Ook wanneer wij verschillende religies belijden, is het toch mogelijk een zinvol ethisch debat te voeren. Men spreekt in dit verband vaak over de 'autonomie van de ethiek'. Achter deze formulering schuilt een dramatische ervaring en een even dramatisch inzicht: wie 'morele' inzichten afhankelijk maakt van 'metafysische' overtuigingen, of wie deze 'morele' inzichten strikt aan religieus gelijk koppelt, maakt ethisch overleg in een pluriconfessionele en plurireligieuze samenleving onmogelijk. De Europese samenleving heeft in de 16de en 17de eeuw ervaren wat het betekent wanneer de grenzen tussen 'metafysica' en 'ethica' en hun weerspiegeling in 'religie' en 'politiek' niet worden of niet kunnen worden getrokken.

\subsection{DE PRIORITEIT VAN HET 'JUISTE' OVER Het 'GOEDE' - Een MODERNE UITVINDING}

De Europese moderniteit is in hoge mate getekend door de successievelijke ontkoppeling van 'religie', 'moraal' en 'politiek'. Sociologisch wordt deze langdurige ontwikkeling vaak beschreven als 'proces van de differentiëring'. De 'autonomie' van deze drie bereiken of subsystemen van de maatschappij wil niet zeggen dat deze geen enkel verband met elkaar hebben, maar betekent dat het ene systeem niet bestaat bij de 'gratie' van het ander. De 'politiek' behoeft geen reli- 
gieuze legitimatie om te kunnen bestaan en functioneren (alhoewel religieuze overtuigingen de cohesie van de 'polis' kunnen - maar niet moeten - verhogen) en kan niet iedere morele praktijk willen regelen. De 'moraal' behoeft geen politieke sancties om haar autoriteit te kunnen uitoefenen (alhoewel het 'recht' morele goederen kan beschermen en immorele handelingen kan sanctioneren) en religieuze opvattingen hebben geen a priori aanspraak op beter inzicht in morele kwesties. De 'religie' is niet afhankelijk van haar politieke opportuniteit (alhoewel zij in hoge mate profiteert van de bescherming die zij in politieke contexten kan genieten) en haar erkenning valt en staat niet met de kwaliteit van de morele inzichten die zij genereert.

De subtiliteit van deze verhoudingen maakt op een dermate vanzelfsprekende manier deel uit van onze alledaagse manier van leven dat wij nauwelijks nog waarnemen hoe weinig vanzelfsprekend deze autonomie in drievoud is. Wij hoeven maar even te kijken naar de talloze samenlevingen die deze autonomie niet kennen, om onmiddellijk te begrijpen dat strikte allianties tussen 'religie', 'moraal' en 'politiek' respect voor de meest elementaire burgerrechten onmogelijk maken. Ik wijs er uitdrukkelijk op dat deze 'autonomie' geenszins tot gevolg heeft dat de drie genoemde systemen niet met elkaar communiceren. Er bestaat wel degelijk een 'inter-penetratie' (Münch 1986). 'Moraal' kan commentaar geven op 'politiek' en 'religie', en dit 'recht op becommentariëring' betreft natuurlijk ook de twee andere systemen. Maar deze kritische of bevestigde commentaren zijn slechts denkbaar omdat de genoemde systemen ook afstand houden van elkaar.

Ik wil dit opnieuw illustreren met de casus omtrent 'goed' en 'kwaad'. Deze predicaten zijn van morele afkomst. Maar tegelijkertijd worden zij ook in metafysische of religieuze taalspellen gehanteerd waar zij naast hun morele betekenis nog een andere dimensie verkrijgen. Het volgende citaat van Susan Neiman gebruik ik als toegang tot dit probleem:

"Wat namelijk een verklaring nodig heeft", zo zegt Neiman, "is niet, hoe morele oordelen (en praktijken, JPW) gefundeerd kunnen worden, maar wel waarom die oordelen, die blijkbaar zo degelijk gefundeerd zijn in het verleden, zo vaak werden overtreden.” (Neiman 2004: 29)

Wat Neiman hier bedoelt is dat er twee niveaus zijn waarop wij de predicaten gebruiken - het niveau van de morele handelingen (niveau 1) en het niveau van de wereldinterpretatie (niveau 2). Ik concentreer mij op het laatste. Morele handelingen hebben een achtergrond die breder is dan die van de moraal. Zij vinden in een wereld plaats die wij op een bepaalde manier ervaren, interpreteren en benoemen. Wanneer wij zeggen dat de wereld 'goed' of 'kwaad' is, doen wij geen directe uitspraak over morele handelingen, maar wel over de kwaliteit van de wereld als geheel, waarin deze handelingen gebeuren of mislukken. Wie zegt dat de wereld 'goed' is, beweert dat wereldvertrouwen terecht bestaat. Wie zegt dat de wereld 'kwaad' is, stelt dat er geen reden is om de wereld te vertrouwen. Beide 
uitspraken zijn 'laatste' oordelen en dus van metafysische aard. Natuurlijk zullen deze uitspraken onze handelingsmotieven beïnvloeden. Zij zullen ons bevestigen bij de poging de wereld door onze handelingen positief te veranderen of zullen ons doen aarzelen of zelfs diep doen twijfelen of morele handelingen uiteindelijk zin hebben. Uiteenzettingen op het niveau van de wereldinterpretatie zijn niet enkel buitengewoon controversieel, maar slechts in zeer beperkte mate communiceerbaar. Metafysische en/of religieuze wereldduidingen hebben vaak een absoluut karakter en zijn daarom geen onderwerp van discursieve oordeels- en besluitvorming. Zij zijn in hoge mate dus onbeslisbaar.

Maar op niveau 1, het niveau van de reële morele handelingen en het niveau van de ethische deliberatie, geldt dit niet. Onze morele handelingen kunnen wij niet opschorten en evenmin kunnen wij stoppen met onze ethische deliberatie en als gevolg daarvan morele handelingen voor onbeslisbaar verklaren. Ook wanneer wij op niveau 2 geen overeenstemming kunnen bereiken, moeten wij op niveau 1 steeds weer tot (voorlopige) regelvorming overgaan. En terwijl men zich op niveau 2, dus op het gebied van de metafysische en/of religieuze wereldinterpretatie, moeilijk de betekenis van een compromis kan voorstellen, is de zoektocht naar zinvolle compromissen op niveau 1 essentieel. Dit heeft overigens niet tot gevolg dat wij bij de ethische deliberatie gedoemd zijn tot een radicaal relativisme. Niets is minder waar dan dit. Maar de 'juistheid' van morele handelingen is altijd het resultaat van een 'wikken en wegen', van een deliberatie waarin nauwelijks iemand het absolute gelijk ooit aan zijn kant heeft. Ethische funderingen zijn steeds voorlopig en baseren zich niet op absolute inzichten of onbespreekbare evidente principes, hoewel zij soms deze indruk (pogen te) wekken. Vooral in samenlevingen waarin een betrekkelijk moreel pluralisme aanwezig is en men het over funderingen niet gemakkelijk eens zal zijn, neemt de betekenis van zinvolle - redelijke - compromissen alleen maar toe.

Religieuze wereldinterpretaties neigen van oudsher echter tot een vermenging van deze twee niveaus. Dat is ook niet verrassend, want zij zijn bijna allemaal ontstaan in culturen die het 'proces van de differentiëring' nog niet hadden ondergaan. Slechts uiterst langzaam is in religies het inzicht gerezen dat 'wereldinterpretatie' en 'handelingsfundering' niet identiek zijn. De 'legitimiteit van de Nieuwe Tijd' (Hans Blumenberg) heeft namelijk essentieel met het eigen recht van de 'handelingsfundering' tegenover de 'wereldinterpretatie' te maken. Het behoeft geen indringend betoog om te begrijpen dat dit verschil in culturen die niet meer over een homogene wereldinterpretatie beschikken, van het grootste belang is. Ik herhaal: de (relatieve) scheiding tussen ethische vraagstukken en metafysisch-religieuze wereldinterpretaties is typisch modern. In religieus en wereldbeschouwelijk heterogene samenlevingen zoals de onze heeft deze scheiding niet te onderschatten pacificerende gevolgen. Maar daarom geldt ook omgekeerd: de herroeping van dit verschil leidt tot de moralisering van 'goed' en 'kwaad' als categorieën van de wereldinterpretatie enerzijds en tot de metafysisch-religieuze radicalisering van 'goed' en 'kwaad' als categorieën van de 'handelingsfundering' anderzijds. 
Vooral in omstreden ethische kwesties worden de relevantie en de urgentie van dit verschil al snel duidelijk: 'wereldinterpretaties' hebben een holistisch profiel. $\mathrm{Zij}$ gaan over het geheel van de dingen. $\mathrm{Zij}$ zijn in slechts zeer beperkte mate object van argumentatie. Zij worden beleden of geloofd, zij berusten op intuïties en op persoonlijke ervaringen. De 'handelingsfundering' daarentegen is primair het resultaat van een deliberatief proces. Hier domineert het 'geven van en verlangen naar redenen' (Brandom 2004: 71). Aan het einde van een dergelijke deliberatie staat vaak een 'nobel compromis'. In metafysische of religieuze aangelegenheden zijn compromissen in de strikte zin van het woord echter misplaatst. Zij zijn daar ook niet nodig. Op niveau 1 , het niveau van de morele handelingen en hun funderingen, moeten wij in complexe en niet-homogene samenlevingen onze standpunten bij gelegenheid flexibiliseren. Wij ervaren hier bijna dagelijks dat morele zekerheid in tal van kwesties niet of nauwelijks haalbaar is. Onze oordelen hebben steeds een voorlopig karakter. Zij zijn onderhevig aan een principieel fallibilisme: het zou kunnen dat wij het soms verkeerd hebben. Zekerheid is slechts gradueel mogelijk. Maar wat hier een deugd is - op niveau 1 - kan op het niveau van de wereldinterpretatie (niveau 2) bij wijze van spreken een last zijn. Iemand die zijn geloof belijdt, kan niet tegelijkertijd zeggen dat hij het misschien verkeerd heeft.

\subsection{IN HET PUBLIEKE DOMEIN}

Ethische vraagstukken zijn echter in de huidige - westerse - maatschappij object van controversiële stellingnamen. Daarmee is het volgende bedoeld: het debat over nieuwe morele kwesties (bijv. genetica, embryo-onderzoek, intraculturele diversiteit van leefwijzen en leefvormen) wordt niet langer door de feitelijke hegemonie van één traditie gedomineerd. De maatschappelijke ruimte waarin zulke debatten plaatsvinden, wordt niet meer op een prominente manier door religieus-levensbeschouwelijke instituties ingenomen. Moraaldisputen vormen een wezenlijk onderdeel van het 'publieke domein' en komen pas terecht in het 'politieke systeem', wanneer een strafrechtelijke relevante reguleringsbehoefte is ontstaan. Maar ook in het politieke systeem en dus principieel niet anders dan in het 'publieke domein' hebben zulke moreel ingekleurde kwesties een pluralistische en democratisch getinte signatuur. Het publieke domein of de 'Öffentlichkeit' (Jürgen Habermas 1962) is opnieuw een moderne verworvenheid. Zij kan als de discursieve ruimte worden beschouwd, waarin burgers - gevrijwaard van de directe invloed van politieke instituties maar wel door deze beschermd - onder andere hun morele en politieke opvattingen kunnen genereren. Zij doen dit in het kader van 'vrije associaties', die onder de voorwaarden van een mediaal doordesemde informatiemaatschappij over deze opvattingen controversieel en concurrentieel debatteren.

Deze constatering is aldus geformuleerd relatief simpel. Zij laat echter een veeleisende vooronderstelling onzichtbaar, namelijk de noodzaak om ethische (en politieke) argumenten 'coram publico' te vertalen. Wie zich in het 'publieke domein' ethisch engageert respectievelijk zijn ethische argumenten ter discussie stelt en 
wil verdedigen, wordt met de noodzaak geconfronteerd om deze ethische argumenten aanzienlijk te transformeren. Hij spreekt 'per definitie' niet in het midden van en voor zijns gelijken. Hij moet dus aan een voortdurende vertaalslag doen. Zijn argumenten moeten ook voor andersdenkenden - letterlijk gesproken - redelijk toegankelijk zijn. De 'publieke rede' valt of staat met het vermogen om op het gepaste moment idiosyncratische beweringen en taalspellen ten gunste van openbaar toegankelijke redeneringen open te breken.

Dit wil ik graag met het verschil tussen 'first-order justifications' en 'second-order justifications' verduidelijken - een verschil dat geïnspireerd is door de late filosofie van John Rawls. 'Rechtvaardigingen van de eerste orde' ontstaan in de context van eigen (religieuze, levensbeschouwelijke en/of morele) overtuigingen. Deze zijn groeps- en/of cultuurgebonden en hebben tegen de achtergrond van een gepluraliseerde samenleving een particularistisch aanzien. De 'rechtvaardigingen van de tweede orde' zijn daarentegen ontstaan op basis van de cognitief dissonante ervaring dat 'mijn' rechtvaardiging niet noodzakelijk door iedereen gedeeld wordt en dat het risico bestaat dat rechtvaardigingsconflicten het winnen van de rechtvaardigingsconsensus. 'Rechtvaardigingen van de tweede orde' houden op een positieve manier rekening met de dissensus die in de publieke ruimte feitelijk aanwezig is: Rawls spreekt in dit verband over de noodzaak van een 'public justification'. Argumentatieve 'fairness' in het publieke domein veronderstelt dat wij bereid zijn om onze 'first-order justifications' te transformeren in argumenten die publiekelijk toegankelijkzijn. Flankerend spreekt Rawls ook over het zoeken naar een 'overlapping consensus' en over het belang van een 'reflective equilibrium', waarin voortdurend een nieuw argumentatief evenwicht tussen de standpunten van de partijen wordt gezocht. Wat dan ontstaat zijn precies de 'second-order justifications'.

Hier rijst natuurlijk de vraag of religies dit wel kunnen. Religies beschikken over scherp afgebakende morele overtuigingen respectievelijk morele overtuigingssystemen. Deze zijn vaak verankerd in autoriteitsargumenten (openbaring, religieus gelegitimeerde instanties met onbeperkte 'ethische' bevoegdheid, culturele particularismen enz.), die het buitengewoon moeilijk maken zich te verzoenen met de 'logica' van het publieke domein met zijn latent 'revisionisme', met de dwangloze dwang van het betere (maar niet het absolute) argument, met de redelijke compromissen en de voorlopigheid van de beslissingen, die in dit domein tot stand komen. Op het eerste gezicht zijn religies in hoge mate resistent tegen de vertaalslag die in het 'publieke domein' moet worden voltrokken - de vertaalslag tussen 'argumenten van de eerste orde' en 'argumenten van de tweede orde'. Waar deze publieke ruimte echter al geruime tijd bestaat, zijn religies in zekere mate in staat tot zulke vertaalstrategieën. 'Westerse' religies - religies in maatschappijen met een 'publieke ruimte' - beschikken (over het algemeen) over een relatieve vertaalcompetentie die ontstaan is als gevolg van de noodzaak zich in deze 'publieke ruimte' gehoor te verschaffen. In toenemende mate trekken religies zich echter terug uit deze ruimte of zijn ze zelfs van mening dat het 'publieke domein' ze noopt tot een onacceptabele zelfverloochening: het compromis schijnt te compromitteren. Maar niets is minder waar dan dit. Het compromis eert. 


\section{LITERATUUR}

Berger, P. L. (1999) The Desecularization of the World. Resurgent Religion and World Politics, Grand Rapids: William B. Eerdmans Publishing Company.

Blumenberg, H. (1966) Die Legitimität der Neuzeit, Frankfurt a. Main: Suhrkamp.

Brandom, R. (2004) Begründen und Begreifen. Eine Einführung in den Inferentialismus, Frankfurt a. Main: Suhrkamp.

Burg, W. van der (2005) Over religie, moraal en politiek. Een vrijzinnig alternatief, Kampen: Ten Have.

Deuser, H. (2005) 'Religion und Politik - Zur theologischen Kritik des religiösen Fundamemtalismus', blz. 1-11 in: S. Alkier e.a., Religiöser Fundamentalismus. Analysen und Kritiken, Tübingen: Franke Verlag.

Gauchet, M. (1999) The Desenchantment of the World. A Political History of Religion, Princeton: Princeton University Press.

Habermas, J. (1962) Strukturwandel der Öffentlichkeit. Untersuchungen zu einer Kategorie der bürgerlichen Gesellschaft, Darmstadt/Neuwied: Luchterhand Verlag.

Harris, L. (2004) Civilization and its Enemies. The next Stage of History, New York, London, Toronto, Sydney: Free Press.

Hierman, M. (2006) Beschavingen botsen niet. In de tang tussen religie $\&$ cultuur, Antwerpen: Houtekiet.

Manenschijn, G. (2005) Religie en haat. Over religieus gemotiveerd terrorisme, Kampen: Ten Have.

Otto, R. (1917) Das Heilige. Über das Irrationale in der Idee des Göttlichen und sein Verhältnis zum Rationalen, München: Beck.

Oz, A. (2004) Wie man Fanatiker kuriert, Frankfurt a. Main: Suhrkamp.

Moore, G. E. (1970) Principia Ethica, Stuttgart: Reclam.

Münch, R. (1986) Die Struktur der Moderne, Frankfurt a. Main: Suhrkamp.

Neiman, S. (2002) Evil in Modern Thought, Princeton: Princeton University Press.

Peirce, Ch. S. (1995) Religionsphilosophische Schriften, Hamburg: Meiner.

Rawls, J. (2001) Justice as Fairness. A Restatement, Cambridge (Mass.)/London: Cambridge University Press.

Rorty, R./Vattimo, G. (2004) Il futuro della religione, Milaan : Garzanti Libri.

Schröder, L. (2002) Moralischer Nihilismus. Typen radikaler Moralkritik von den Sophisten bis Nietzsche, Stuttgart-Bad Cannstatt: Fromann-Holzboog.

Taylor, Ch. (2002) Die Formen des Religiösen in der Gegenwart, Frankfurt a. Main: Suhrkamp.

Trimondi, V. en V. (2006) Krieg der Religionen. Politik, Glaube und Terror im Zeichen der Apokalypse, München: Fink. 


\title{
18 RELIGION AND MEDIA: A POLITICAL THEOLOGICAL PROBLEM
}

\author{
Hent de Vries
}

\subsection{INTRODUCTION: UNDERSTANDING AMBIVALENT (PUBLIC) RELIGIONS IN A GLOBAL ERA}

It remains to be examined what constitutes the exact interrelationship between the political, economic, and cultural characteristics of the "age of globalization," on the one hand, and the vision of society and structures of governance developed over millennia by major faith traditions as well as by supposedly less systematized indigenous traditions, on the other. That such an undertaking has about it an element of urgency cannot be doubted, in view not only of $9 / 11$ and subsequent attacks in Madrid and London but also - more broadly and perhaps, in a longer view, more importantly - of religiously informed resistances and responses to pressures to secularize and to assimilate in cultural and political terms. These resistances and responses are implicit in the continuing sources of tension and conflict between the self-proclaimed secularism of the West and its allies, on the one hand, and the selfperception of developing, often postcolonial, societies with their state-sponsored, popular, or alienated fringe political movements, on the other.

The West still imagines developing societies and underprivileged communities and individuals to be inevitable beneficiaries of globalization, of its markets no less than its cultural goods, its constitutional democracy as well as its interpretation of human rights. In the end, if somewhat indirectly, they very well may be. But these societies' present place in a hegemonic world ruled by imbalances in power, news, money, and markets is a source of permanent frustration, indeed, of humiliation and contention. This has repercussions for internal relationships in Western nations, with their significant immigrant communities, no less than for the establishment and maintenance of international law. The recent dramatic difficulties with policies of integration and accommodation in European countries (for example, in France and the Netherlands), as well as the recent escalation in the Middle East of hostilities between Israel and the Palestinian authority (Hamas) and Hezbollah in Lebanon are just some examples of these tensions. So is the immobility, not to say paralysis, of European governance in dealing with its internal affairs, to say nothing of the inability or unwillingness of the international community to enforce an immediate end to reiterated acts and crimes of war or to guarantee minimal assurances for security, justice, and peace for all.

To illustrate this, let me refer to the example of "political Islam," especially the much-debated danger represented by dispersed militant movements. Having emerged in the wake of globalization, after the failure of so many of its state-based and "secular" nationalist projects, these groups are at times merely virtual, then again all too real in their operation as "cells" and informal, ad hoc, "networks." 
What has emerged in some of the more careful scholarly and journalistic analyses of this phenomenon is the need for a theoretical matrix that also has relevance for engagements of religion with politics (or vice versa) in major religions other than Islam, such as Christianity, Judaism, Hinduism, and Buddhism. Since many of the current troubles have little to do with Islam per se - other major and minor religious and nonreligious traditions and sensibilities are potentially just as entangled with the question of politics as it presents itself globally today - we might expect such a theoretical matrix also to illuminate some of the developments and prospects of secularism. The phenomenon of secularism constitutes more than a modern public religion in disguise, which some have accused of being, but its implication in our conception of the political and in our formulation of policies follows a logic similar to that of political, public religions in the modern world. The theoretical matrix we are seeking should thus be able to encompass religious and nonreligious or secular systems of thought, practices, and other modes of expression. Its central concepts and insights should hold for religious communities or groups that are numerically smaller than the major religions, just as it should offer indirect lessons, if not for the policies of governments and international institutions or nongovernmental organizations as such, then at least for the intellectual and affective dispositions with which their representatives approach religions in a post-secular world. This being said, let me now turn to our example and discuss some of its implications.

The Western fixation on political Islam is unfortunate but consequential, not least since it is echoed and amplified in the United States, where in some influential circles a caricature has taken hold, that of an emerging "Eurabia" or "Londonistan," the mirage of an "ever-growing Muslim-Europe-within-Europe - poor, unassimilated, and hostile to the United States." In this hyperbolic view - which in the words of a respected European journal, The Economist, looks very like "scaremongering" - a fatal process would seem to be unfolding: "Stagnant Europe, goes the argument, cannot offer immigrants jobs; appeasing Europe will not clamp down on Islamofascist extremism; secular Europe cannot deal with religiosity (in some cities more people go to mosques than to churches). Europe needs to study America's melting pot, where Muslims fare better." ${ }^{2}$ Just as it downplayed the Soviet threat during the Cold War and let ethnic cleansing rage in the Balkans, Europe this time around lacks both the socio-political flexibility and the moral stamina to "either give the newcomers a decent economic life or to confront extremism successfully." 3 In the final analysis, so the narrative concludes, this political-cultural weakness runs aground not only in "a godless continent's failure to understand the depth of other people's faith" but in an apparent inability or unwillingness to give quite the same public space to the culture of free speech is characteristic of the United States. ${ }^{4}$

Demographically, economically, and culturally these negative and slightly resentful assessment may soon prove false. The Muslim inhabitants of the European Union constitute an estimated 15 million, or 4 percent of the total population, a figure that is expected to rise to 30 million, or 10 percent, by 2025 , not taking into 
account Turkey's eventually joining the E.U. By contrast, the current estimated figures for the U.S. and Canada are 1.7 percent and 2.3 percent, respectively. Moreover, the fear of an emerging "Eurabia" ignores the vast economic and cultural differences between immigrant populations in the different European countries and between these and the U.S. In addition, references to "Eurabia" simultaneously overestimate and underestimate the present force of the political elements and forms of Islam - and other major and minor religions. The fact that religions constitute both an integrative and a potentially disintegrating or even violent aspect of modern societies has to do less with persistent or newly emerging ties to nation and traditional doctrine and law than with a novel configuration of post-secular identities, whose volatile dynamics contain as much promise as potential for political havoc. To begin to acknowledge and then interpret this built-in ambivalence of religion in relation to the very definition of the political, as well as to concrete politics or policies, may well be a key to the understanding and mitigation, if not anticipation or prevention, of religion's most pernicious effects.

\subsection{THE DYNAMIC RELATIONSHIP BETWEEN THE 'THEOLOGICAL' AND THE 'POLITICAL': THE NEED FOR NEW CONCEPTS AND METHODOLOGIES}

If there is any lesson to be drawn from the more extreme - and heavily mediatized - phenomena of violence inspired or framed by religion, it is that the relationship between the theological and the political is no longer obvious, let alone direct. Previously limited to problems of national sovereignty (pitting the Holy Roman Empire against the princes, stipulating religious allegiance based upon one's belonging to a given territory) or of constitutional law (the separation of church and state, the ban on "ostentatious religious signs" in public schools in France and Turkey), the most interesting and troubling cases of religion's continuing and renewed role at present are more elusive, more delocalized and hence difficult to grasp, both conceptually and empirically. We are left with blanks and dots (that is to say, words, things, gestures, and powers) - the very stuff of utterances and affects (both passive and active, destructive and salutary) - which we continue to attribute to "religion", (as if we know what that means). The ways these disarticulate and reconstellate themselves as the elementary forms of political life in the twenty-first century are no longer transparent, nor can they be reduced to simple empirical (naturalistic or, philosophically speaking, immanent) terms. Rather, for all their this-worldly, indeed, down-to-earth impact, they place great demand on our theoretical skill, even our speculative imagination and sensibilities. New concepts need to be coined, novel practices of research attempted, even though they may turn out to be - may even need to be - out of sync with the phenomena in question (and hence untimely in their intended timeliness).

The contemporary political and public presence of "religion" seems no longer dependent upon - or especially effective through - broad popular, let alone democratic support (although this is, of course, not excluded either, as is 
witnessed by the victory of Hamas in the January 2006 Palestinian elections, just as it is further illustrated by the success of ideological-nationalist, left- and rightwing populist movements, in Venezuela, Poland, and elsewhere). The journalistic and scholarly debate concerning the exact meaning and impact of public religions in the post-secular world (of the theologico-political, that is) has remained fragmentary and disoriented. The reasons for this impasse are not difficult to determine. For one thing, it seems as if the more challenging issues raised by these public religions address a multi-dimensional space and time before, around, and beyond the theologico-political, at least in its ancient, medieval, and modern definition, even though no plausible account of current transformations can ignore the historical archive for which this term, with its many semantic connotations, visual associations, rhetoric, and affects, still stands. That the most burning political issues are not so much directly but indirectly - some would say, tangentially or negatively - related to the "theological" can already be glimpsed in the unforeseen ways in which the subject of "religion" has entered the contemporary public domain and debate, nationally and internationally.

Religion, in its more concrete and abstract, local and global determinations is perceived as a problem to which policy-and opinion-makers, social and political scientists, cultural critics and philosophers, media theorists and economists tend to direct their attention with either increasing fascination or barely veiled irritation. Yet the phenomenon manifests itself in more and more ethereal ways elusive and absolute, but then also quite visceral. It is upon this paradox, if not aporia, that the contemporary presence and often virulence of religion (of its words, things, gestures, and powers) is premised. No longer a given, it cannot simply be given up, either, not even by the most persistent - and supposedly enlightened - of its detractors. The post-secular condition and its corresponding intellectual stance consist precisely in acknowledging this living-on of religion beyond its prematurely announced and celebrated deaths. While it increasingly escapes pre-established contexts and concepts, horizons and expectations, it nonetheless takes on an ever more ghostly appearance. In order to track its movements, new methodological tools and sensibilities are needed.

\subsection{IN SEARCH FOR ADEQUATE STRATEGIES: HOW TO CONFRONT THE MANIFESTATIONS AND AMBIGUITIES OF RELIGION IN A POST-SECULAR AGE?}

For this retreat yet permanence of religion and the theologico-political (to echo titles coined by Jean-Luc Nancy, Philippe Lacoue-Labarthe and Claude Lefort (1983), 5 several complementary explanations could be given. They include the fate of metaphysics in the philosophical and cultural discourse of modernity, especially the critical onslaughts on metaphysica specialis or theologia naturalis, the overcoming of "onto-theology" on which Heidegger mused, and the symbolic interpretation of the "popular metaphysics" with which Schopenhauer, not unlike Spinoza, equated historical and revealed or positive religion (that is to say, superstition). More material trends, having to do with the development of 
markets and the fortune or failure of nation-states, have contributed to the deterritorialization, delocalization, mediatization, and even virtualization of religion, together with the invention of new forms of agency and community. No unified theory is currently available to hold these trends together in a compelling explanatory account or historical narrative. No political theology, in the singular, ever will. But several building blocks can be discerned along the road leading up to the post-secular condition. The geographical and demographic-sociological base of physical struggle inspired or at least verbally legitimated by religion - no religion without (at least some) violence, no violence without (at least some) religion - is characterized by an increasingly delocalized, deterritorialized, and volatile mobility (De Vries 2002). The beliefs and theological rationalizations that motivate spectacular forms of violence against states and civilians need no longer take hold in the minds and hearts of whole groups and generations - and general stoicism, if not resignation, may well be the dominant public response. Yet the elusive effects of such militant religious manifestations and the terror associated with them have come to permeate the life of all institutions and come to affect the substance of legal systems, political hopes, and cultural sensibilities, well beyond the borders in which they are committed and out of all proportion. How should we explain this discrepancy? And how can citizens, nongovernmental organizations, and nations respond to it in a responsible and effective way? Is there a policy of and for the unpredictable and the disproportional?

Clearly, the "war on terror"- or any other version of military preemption and judiciary, let alone para- or extra-legal, repression - cannot be it. Sweeping gestures invoking labels such "global terrorism" (or "terrorists of global reach") and a "global war on terror" are no more helpful, since they cling to an outdated concept, "war," and fail to specify the - often "local"-conditions and special effects to which the adjective "global" refers (Shane 2006). Other approaches are required, ones that can engage local issues of legal, political, economic, and cultural integration or dialogue, though without any certainty, whatever other ills they may undo, that they can identify a single, now moving, now immobile in any case, invisible, inaudible, ungraspable, and often unintelligible - target. Can such approaches be learned and taught, let alone be planned or institutionalized? Where the proclaimed "enemy" has no clear strategy other than inflicting terror and provoking wrath, can one develop strategies? And without them, what would the political be? Where the perceived threat turns out to elude the state apparatus' horizon of expectation, is there anything left to do? Or is acting and reacting no longer the proper modality of response? Where diplomacy is not an option, is one condemned to respond either too little, too late, or in a disproportionate way? A whole new art of conducting war and establishing peace - something other than war and warfare, peace and peacefulness in their traditional definitions, based upon the existence of and dealings among states and sovereigns seems needed, together with a different attunement to nonstate actors and actions whose sensibilities, passions, and affects obey a logic and rhythm that eludes the modern understanding of data, numbers, cause, and effect. 
Has the theologico-political tradition prepared us for that task? Has the time come for it to release its critical potential? Or is its legacy part of the problem, merely symptomatic of the present difficulty in thinking about the political, politics, and policies in altogether different terms, perhaps by turning toward what lies beyond, before, and around them? This task may be more challenging than the appeal to what recent "progressive realists," in search of an alternative to the impasses of American liberalism, on the one hand, and neoconservatism, on the other, have called "moral imagination," putting oneself in the shoes of the other political actor (Wright 2006). ${ }^{6}$

More often than not, we now realize, minimal, seemingly negligible differences and differentiations, whether ideational, sociological, or organizational, can cause maximal effects (whether enormous havoc, countless blessings, or both), whereas, conversely, maximal investments in, say, lofty ideas or excessive economic or military power too often result in minimal or virtually no effects at all. Indeed, these maximal investments may very well, in their expansion and promulgation, revive or provoke the minimal differences whose larger - but structurally elusive - effects unsettle the distribution of forces and resources that state-regulated social and cultural policies, market-inspired measures, or hightech military strategies had sought to bring about in a comprehensive and controlled manner, whether by piecemeal engineering or in a single stroke.

This paradoxical tendency obeys a logic that one may be tempted to analyze as a "dialectic of Enlightenment" (as Theodor W. Adorno and Max Horkheimer argued), as the paradox of Western rationalization (as Jürgen Habermas, following Max Weber, added), or as the performative contradiction of universalism (as Judith Butler, Ernesto Laclau, and Slavoj Žižek have insisted in more psychoanalytically informed ways). The difference matters little for present purposes. What remains important is to rethink and, as it were, reframe these paradoxes and aporetics in terms that are suitable for the novel problems and challenges that face us at present. How is one to ponder the imponderable, manage the unmanageable? And what experiences or sensibilities are most likely to prepare us for this increasingly difficult - and, we might add, eminently political, perhaps quintessentially theologico-political - task?

This question has become all the more difficult to answer because in the present, post-secular domain the inspiration, motivation, and effectuation of political theologies no longer lie within the cultural and institutional, ecclesial or communal heritage of the major religions or within the modern forms of political sovereignty with which their theologically (or cynically) driven politics were, historically, geographically, empirically, and conceptually linked. Instead, their authority (to the extent that it still, or once again, exists) resides in infinitely mediated and refracted forms of "make believe" (call them special effects), which are in many ways elements of "belief in the making." Indeed, they, more than anything else, are the wonders and miracles - sometimes the "shock and awe" of the contemporary world. 
The very shrinkage and evaporation of the doctrinal substance of historical religion may propel the remainder of its believers into rhetorical overdrive - a whistling in the dark that becomes shriller as fewer and fewer give heed - just as the staunch defense of self-proclaimed Western Enlightenment values (whether in the name of a "clash of civilizations," laïcité, tolerance, militant humanism, or political liberalism - the difference, here again, matters little), may find itself adopting a no less troublingly devout and often even "apocalyptic tone" (irrespective of its professed atheism, humanism, materialism, naturalism, skepticism, or immanentism). ${ }^{7}$ In a latest twist of the dialectic of Enlightenment, of the paradox of universalism, secularism might find itself to have become sacral - and, as "secular fundamentalism," even parochial - while the so-called religious fundamentalists of the world continue to express and further the very disenchantment of the modern world against whose vehicles (global markets, media, hegemonic political models, economic liberalization, and cultural liberties) they believe they protest. Religion, in its most dramatic and terrifying, even terrorist, forms could thus be seen as the flipside of modernity, not just in the "age of extremes," but, in this century, in the hyperbolic effects of exponential growth, the expansion and displacement of populations, the movement of capital and ideas, the spread of democratic ideals - in short, of openings and closures alike.

Olivier Roy sees one consequence of "deterritorialization" as being a paradoxical "congruence between contemporary Islam and Christianity," which lose nothing of their potential for conflict and confrontation even as they disarticulate and reconstellate themselves in the same geographical spaces, becoming contemporaries and cohabitants in an increasingly global realm. ${ }^{8}$ On the contrary, he writes, even as they "become closer" they "become more antagonistic, precisely because they are no longer separated by linguistic and territorial borders" (Roy 2004:39). In other words, "globalization does not necessarily imply moderation" (2004:39). Where we are all more or less the same, the need to manufacture differences, to create and stigmatize "others," may become a temptation, one easily susceptible to political exploitation. The psycho-sociological, possibly even biological mechanisms of mimetic rivalry, aggression, and a death drive, visible in larger groups and nations, may well first emerge in small disaffected factions and cells that can seem to constitute themselves out of the blue, parting ways with the familial, parental, and religious-cultural environments into which they had heretofore blended, gray on gray.

\subsection{BEYOND FUNDAMENTALISM: IS VIOLENT JIHADISM A MERE POLITICAL PRODUCT OF GLOBALIZATION AND SOCIETAL ALIENATION?}

A case in point is violent jihadism, which, as international investigations and polls repeatedly demonstrate, ${ }^{9}$ finds little overall support among Muslim populations in predominantly Muslim countries and entertains a complicated relationship with the internal colonies of immigrant communities in the West. The special report "Muslim Extremism in Europe," published in the aftermath of the 
July 7, 2005, London attacks, which killed fifty-two victims (and the four bombers) and which, while not unexpected, struck the intelligence community, political elites, and the general public because of their home-grown, suburban origins, ${ }^{10}$ gives important indications of how jihadism is a product of globalization and its vehicles (markets, modern secularism, and media). ${ }^{11}$ The report makes two related claims, both of which illustrate the changing meaning of national sovereignty and the redefinition - one is tempted to say, the virtualization and perhaps even profanization - of the theologico-political. First, it suggests that "in an age of globalized communication and porous borders, there is no real distinction between domestic and foreign threats." Indeed, it continues:

"Even if everyone involved in terrorizing London turns out to have been British-born [as turned out to be the case], it is clear that the bombers had access to sophisticated explosives, not easily available in suburban Yorkshire; and, more important, that they were influenced by ideas, images, and interpretations of Islam that would continue to circulate electronically, even if every extremist who tried to enter Britain were intercepted."

Second, profiling the suspects of the London attacks revealed a pattern: disaffection with the home country, familial authority, local community, and mosque often preceded petty criminalization, conversion, and reterritorialization, as it were, in what is often a merely virtual group of like-minded, radicalized individuals, which establishes itself through the Internet and which - when effective guidance by experienced veterans from actual battlegrounds is finally found may or may not coalesce into an ad hoc death squad that dissolves (through suicide, arrest, or flight) after the fateful action has been undertaken.

In “The Ideology of Terror” Roy (2005a) observes that what inspires this religious violence has, in the end, little to do with circumscribed local conflicts, often of a postcolonial nature (say, Israel/Palestine, Bosnia, Chechnya, Kashmir, Afghanistan, Iraq, Indonesia, or Somalia). Rather, it is characterized by a process he calls the "delinking of Islam as a religion from a given culture - from any given culture" (Roy 2004:33). He stresses the striking modernity -including the increasing irreality - of the ideological outlook of Islamic militancy. It cannot, he suggests, be adequately captured in terms of "fundamentalism," "Islamism" that is, the "movement that conceives of Islam as a political ideology" (Roy 1994:ix) - or intégrisme, but instead acquires near-phantasmatic features, which are increasingly difficult to read, let alone respond to. Not mechanistically linked to such causes as geopolitics in the Middle East or the publication, on September 30, 2005, of cartoons of the Prophet Muhammad by the conservative Danish journal Jyllands Posten, ${ }^{12}$ these relatively spontaneous acts of violent rebellion lack a political aim that could merit the title of a strategy, an agenda, or a concerted effort to change or reform anything in and of this world. If there is any communitarian aspiration in militant jihadism or Islamism, it is, Roy suggests, one of virtual belonging, a belonging without belonging, an identitarianism without identity, a communality without community. 
Pointing out that the $9 / 11$, Madrid, and London bombers were not from regions directly affected by the conflict in the Middle East and were often "Western-born converts to Islam," Roy makes a further observation: "What was true for the first generation of Al Qaeda is also relevant for the present generation: even if these young men are from Middle Eastern or South Asian families, they are for the most part Westernized Muslims living in or even born in Europe who turn to radical Islam" (Roy 2005a). ${ }^{13}$ Their imagination of belonging to a worldwide community of believers finds its ground not in deeply ingrained participation in the daily life of traditional families, groups, or mosques in the West, let alone in their countries and cultures of origin but in their increasing alienation from both. Roy compares their "dream of a virtual, universal ummah," not with Muslim history in general (as historians such as Bernard Lewis had somewhat ominously suggested) but rather with the fantasies of a "world proletariat" and "Revolution" that inspired the terrorist movement of the ultra-left in the 1970s, notably the Baader-Meinhof Group in the Federal Republic of Germany, the Red Brigades in Italy, and the Japanese Red Army (Roy 2004: 42ff). ${ }^{14}$ Like the jihadists, these groups had no clear (or particularly effective) strategy other than acting out what they perceived to be a universal - a global and near-cosmic conflict, to which their response was one of theatrical or almost ritual behavior (acting out or "performance violence"). As Roy notes: “The real genesis of Al Qaeda violence has more to do with a Western tradition of individual and pessimistic revolt for an elusive ideal world than with the Koranic conception of martyrdom" (2004:43). It is not even the case, he adds, that "most present-day conflicts involve Muslims"; rather, it would be more appropriate to say that "most conflicts that are of interest to the West involve Muslims. (...) But clearly few of these conflicts involve Islam as such, even if the reference to Islam contributes in the aftermath to reshaping these conflicts in ideological terms" $(2004: 43) \cdot{ }^{15}$

Roy's position is ultimately based upon the assumption that "politics" prevails over the religious - as well as over its metaphysical understanding and inflection of "the political" - so that political Islam must necessarily fail. Roy calls this its "becoming commonplace," "being integrated into politics," and suggests that political Islam has "'social-democratized' itself." Indeed, in its very appeal to Muslim law or sharia, it does not invent "new political forms" but is "condemned to serving as a mere cover for a political logic that eludes it - a logic in which we ultimately find the traditional ethnic, tribal, or communal divisions, ever ready to change their discourse of legitimization, hidden beneath the new social categories and regimes" (1994:ix). Roy goes so far as to claim that political Islam or Islamism "is no longer a geostratic factor; it is at most a societal phenomenon" (1994:x). The "illusion" of its supposed fundamentalism, that of a "return" to a purer origin, is, like such movements in all religions, above all a reaction to the failure of other models. Roy singles out three: secularism, Marxism, and nationalism, all of which reflect a broader spectrum of "symptoms of state crises": "Islam is not a "cause" (1994:xi). With the revolutionary moment gone, Roy draws a sober conclusion: "Only the rhetoric remains" (1994:xi). Yet this dimin- 
ished role of religion in its ontological - or onto-theological - weight does not exclude its continued appeal as a semantic, axiological, figural, and, indeed, theologico-political archive and resource. Roy sees in this circumstance the reduction of political Islam to a culturalized and individualized - a marketed and mediatized - notion of religiosity.

But other interpretations might be possible. Might religion, precisely in its minimal remainder - despite or thanks to being elusive, erratic, volatile, and virulent be all the more able to produce maximal effect? And to do so for good and for ill, as historical circumstance, fate, and luck allow?

Political Islam shares its "failure" - in a sense, due to the success of its accommodation - with other claims to political authority, indeed, with the theologicopolitical concept of sovereignty as such. Wherever it engages in down-to-earth concerns of governance and policy, law and order, it cannot but secularize - that is to say, ultimately render profane - its ways. The ways of politics are the ways of the world. One cannot but be of this world, that is, come to belong to this world, as soon or as long as one is in this world, in other words, as soon or as long as history and human finitude follow their course. The Economist's special report gives a concrete example:

\footnotetext{
"In the municipal politics of Britain and the Netherlands, some radical Muslims quite often find themselves doing political business with other anti-establishment groups on the secular left, to the dismay of older immigrants. During a recent contest in east London, the candidate for the new Respect party-a young Muslim lawyer-was chided by his co-religionists for sharing a platform with homosexuals. But Abdurahman Jafar held his ground: 'We want equality for Muslims and we would seem insincere if we didn't stand together with other minorities who face discrimination.' The rhetoric that emerges from this sort of politics in a variety of European countries is not always attractive to American ears, since one of the few common denominators between angry Muslims and secular leftists is hostility to America. But, given a choice between pious self-segregation and plunging into public affairs, many European Muslims are choosing the latter. (...) A process of political assimilation is, hesitantly but visibly, taking place. This will change the politics of Europe. It may affect Europe's relations with the outside world. But, in the process, Muslims also change - and perhaps settle into their homelands as comfortably as most American Muslims have done." 16
}

In also assuming this general trend, Roy approaches Gauchet (1997) who, in The Disenchantment of the World, albeit from a different genealogical and a more philosophically based perspective, claims that the role played by religion proper (in Roy's formulation: "Islam as such") is, in the modern world, basically over. While Christianity, for Gauchet, is instrumental in its own demise - being "the religion of the end of religion" - Islam, or at least political Islam, undermines its own stature the more successful, that is to say, the more globalized and mediatized it becomes. 
Roy draws another conclusion that seems at once to exculpate and to implicate religion (and hence the theologico-political) as a determining factor. He takes his observation to imply that

"the key to understanding the contemporary 'territorial' struggle is nationalism and ethnicity, not religion. Two factors give Islam a post hoc importance: the reciprocal rationalization of some conflicts in religious or civilizational terms, and the growing deterritorialization of Islam, which leads to the political reformulation of an imaginary ummah" (Gauchet 1997:44).17

In this view, radical jihadism is merely the contemporary successor form of an internationalist struggle, taken up by marginalized youths from Muslim immigrant communities (or, in a few cases, by converts) for whom the old leftist movement - or, for that matter, present-day antiglobalization movements - are no longer available options. We are thus dealing with "a 'modern' coalition of 'negative' and radical forces whose roots are not in the Koran but in a Western tradition of a 'red-brown' confusion, which has recently been given some green brushstrokes by Islamic radicals" (Roy 2004:49). This conjunction has everything to do with the influence of popular culture and the role of media:

\footnotetext{
"The fault-line between Europe and the Third World goes through Muslim countries, and former spaces of social exclusion in Western Europe are partly inhabited by Muslims at a time when the radical Marxist Left has disappeared from them. But a closer look shows that these antagonistic identities are less entrenched in the actors than "played" by them. The Islamization of the French suburbs is largely a myth: youngsters are fascinated by Western urban youth subculture (baseball caps, hamburgers, rap or hip hop, fashionable dress, consumerism)" (Roy 2004:50).
}

Indeed, he notes, we should understand that in the outburst of rioting in fall 2005 in destitute neighborhoods and slum-suburbs (cités or banlieus) of Paris and other French cities there was "nothing particularly Muslim or even French," and that the phenomenon was merely "the temporary rising up of one small part of a Western underclass culture that reaches from Paris to London to Los Angeles and beyond" (Roy 2005b). The insight that those involved were second-generation immigrant (and male) youth of French citizenship who were burning property (cars, schools, gymnasiums, etc.) belonging to their own communities in a selfdestructive response to unemployment and racism, economic and social exclusion, with a counter- or subcultural gusto, whose model stems from Western urban centers rather than from the rioters' Arab or African countries and communities of origin, inspired New York Times columnist David Brooks to see in it a tragic paradox of global hegemony: the fact that the pop- or counterculture of gangsta rap and hip hop, with its accompanying "poses of exaggerated manhood," by now defines "how to be anti-American" (Brooks 2005).

This being said, the local detail of the events in France and their context in the everyday lifeworld were barely reported by the media (an exception being the 
work done by the blogger-reporters on location in Bondy for the Swiss journal L'Hebdo and by a new generation of scholars in France who align themselves under the ambitious title "La Nouvelle Critique Sociale"). ${ }^{18}$ What apparently stuck in viewers' and readers' minds was yet another instance of a seemingly inevitable clash of religions (or, rather, of religion, notably Islam, on the one hand, and the "religion of secularism, or laïcité," on the other). This perception, however, is largely a media-induced effect. ${ }^{19}$

If deterritorialization and de-culturalization are keys to understanding urban unrest, well-intended appeals to multiculturalism are not of much use in addressing contemporary religious violence. In Roy's words: “In the end, we are dealing here with problems found in any culture in which inequities and cultural differences come in conflict with high ideals (...) - the struggle to integrate an angry underclass is one shared across the Western world" (Roy 2005b). This is not to say that jihadists are not recruited under such conditions. But other forms of violent destructiveness - aptly documented, long before the events of 2005, in Mathieu Kassovitz's 1995 film La Haine - may be more prominent (not least of them sexual violence against women within the suburban communities themselves).

\subsection{THE IMPORTANCE OF (NEW) MEDIA FOR THE (RE)EMERGENCE OF RELIGIOUS IDENTITIES}

As in the case of the Bondy blog, the role of new media, notably the Internet, in this constitution of contemporary identities is not exclusively that of social and psychological isolation, compensated by a merely virtual, phantasmatic, and disembodied community of likeminded souls. Another and more surprising tendency can be observed.

Shortly after the beginning, on July 12, 2006, of new hostilities between Hezbollah and Israel, which soon involved missile launches into Israeli cities and relentless bombardments by Tsahal on southern Lebanon and Beirut, it was widely reported that Israeli and Lebanese bloggers established or kept open lines of communication with personal observations and video images concerning events and developments on the ground that largely escaped the official media of television and the printed press, to say nothing of official channels of diplomatic exchange and military propaganda. Not for the first time, though in a significant international conflict - and for worldwide Internet users to witness directly citizens refused to play by the rules laid down by states and semipolitical factions, armies, and ideological movements. They are helped by an informational network (the Internet) that is decentralized and allows no (simple or direct) control. Israelis consulted Lebanese blogs and vice versa, and both sides expressed themselves - for example, on the blog of a certain Ramzi ("Ramzi blah blah") - thus maintaining a dialogue, finding mutual sympathy otherwise frustrated, and preventing the war and its victims (most of them civilians) from being anonymous. But would attempts to personalize or singularize the effects of war- 
rendering them visible, audible, palpable through media that are no longer simple instruments of propaganda in the hands of governments and organizations (as happened during the Balkan wars, as well) - make it easier one day to interrupt or mitigate its violence (Manach 2006) ${ }^{20}$ It is clear that in affluent societies and emerging economies (China, India, and several countries in Southeast Asia and Latin America) new technological media - the Internet and the relatively recent phenomenon of personal participatory media such as blogging, text and instant mobile phone messaging - are already dramatically transforming the mass media industry, as well as the socio-cultural and political landscape as a whole, albeit not everywhere with the same intensity, pace, and consequences (Crampton 2006). ${ }^{21}$ Time will tell whether and how this process will shape Third World regions. Could cheap and easily maintainable computers, laptops with instant access to the Internet - which are currently being designed by MIT's Media Lab under the direction of Nicholas Negroponte (the brother of John Negroponte, former ambassador to the U.N. and at present the national director of U.S. intelligence) change the face of the earth, with its inequalities in income, health, education, and democratic powers? ${ }^{22}$ Or can this dream - some twenty-five years after the invention of the personal computer (of which approximately one billion are currently in use around the world, albeit unequally distributed) - be fully realized only with newer, cheaper, and more easily accessible digital technologies, such as "pocket computers" in the form of, say, mobile phones or "handsets with simple web-browsers, calculators and other computing functions"? ${ }^{23}$

We might be witnessing a transition paralleling that from the technology of movable type introduced in 1448 by Gutenberg, via mass media production, through the Internet and beyond (the blogs, etc.), whose general features will be those of generalization, intensification, and trivialization: a transition from undivided sovereignty ("one nation under God,” Garber and Walkowitz 1999) to a multiplication and diversification of the theologico-political, which simultaneously echoes, produces, and expresses not only transformations in the so-called First, Second, and Third worlds but also the remarkably swift shift from the bipolar world of the second half of the twentieth century, through the unipolar episode of American supremacy after the fall of the Berlin Wall in 1989, to a more complicated and volatile twenty-first-century multipolar world, characterized by the rise of non-Western nations, international corporations, nongovernmental organizations, regional and ethnic movements, the emergence and multiplication of new countries, and, increasingly, nonstate actors, networks, and so on - most, if not all of them invoking "religion" as a referent. The undeniable promises of this development, given the unprecedented sharing of power and information, communication tools and publicly heard opinions it implies, are overshadowed only by its perils: 
London underground, or squirting sarin gas into the Tokyo subway. Developments in information technology and globalized media mean that the most powerful military in the history of the world can lose a war, not on the battlefield of dust and blood, but on the battlefield of world opinion. (...) The net effect of these very disparate trends is to reduce the relative power of established Western states, above all the U.S” (Ash 2006).

The British journal The Economist, in its yearly outlook, predicts changes in the multipolar world in these terms:

\footnotetext{
“By 2026, China's economy will be bigger than America's, and India's will be much larger than that of any individual European country (Russia, Brazil, and Indonesia will not be far behind). The press will be full of articles about "Asian values" and the "Beijing consensus." As these countries develop, so will their voracious appetite for natural resources and human capital. (...) But even the biggest powers will be vulnerable. The privatization of destruction - with computer nerds able to wreak havoc from the bedroom and terrorists able to buy weapons of mass destruction in a global market - will allow groups of individuals to take on nation states. This vulnerability may encourage "defensive imperialism": powerful countries taking over states to prevent them from serving as bases or breeding grounds for hostile groups. As economic might shifts from the north and west to south and east, so will cultural power. The rise of al-Jazeera and Bollywood already means that the world no longer looks at things overwhelmingly through American eyes. Ancient civilizations like China and India will become more self-confident and will project their own ideas onto concepts such as democracy, freedom, and the rule of law" (Leonard 2006). ${ }^{24}$
}

The introduction of more and more actors on the geopolitical stage seems to clash with an international order whose ideals and institutions, forms of cooperation and conflict, dreams of peace and declarations of war, were for at least a century premised upon the primacy of nation-states and the explicit formulation and official guaranteeing of their bi- or multilateral agreements. In short, the rules of the game have dramatically changed, and all drawn into it to make up the rules as they go along.

Recent surveys suggest that online identities succeed in reaching out to members of different faith-based or ethnic groups more often and more easily than was previously assumed. So-called allochthonous and autochthonous youth, a Dutch report claims, overcome social and cultural segregation in virtual forums, in which religion, the relation between the sexes, and homosexuality - all subjects on which they are likely to disagree with their parents or educators - are the topics of the day. "The Internet is good for integration," a Dutch newspaper quipped on its front page, noting that more than 80 percent of Turkish, Moroccan, Antillean, and Surinam youths communicate - albeit it virtually - with peers from different ethnic backgrounds, whereas only 20 percent limit themselves to their own groups, shunning kaaskoppen ("cheese heads," as Dutch autochthonous people are unflatteringly called). ${ }^{25}$ 
The reports in question also find that more than half of those interviewed present themselves as someone different on the Internet from who they are in "real" life. And one might argue that integrating verbally, perhaps even visually (through webcams, etc.) is not quite the same - or at least not as demanding and promising - as integrating as bodies in space that do or do not "get along." Is virtual coexistence, being mindful of others, who may still be other than one thinks (and not necessarily present themselves in their true identity) a way of coming to terms with the otherness of others, a way of learning to live with the skepticism concerning "other minds," as Stanley Cavell might say? But it should not be forgotten that the medium in question also gives rise to more disturbing phenomena, such as mob "Internet hunting” and "Internet wars" (French 2006).

\subsection{MARKETS, ELECTRONIC NETWORKS AND CIVIL SOCIETY: NEW DOMAINS FOR THE THEOLOGICO-POLITICAL}

In his recent book Market Islam, Patrick Haenni claims that, since the second half of the 199os, political Islam and radical jihadism are slowly but steadily being overcome by strategies of engagement and accommodation centered less on the state (the nation, the ummah), let alone on violence and terror, than on more subtle promises of economic achievement. The ensuing "'theology of prosperity" announces a new muslim pride, which no longer passes through armed confrontation or affirmation of an ostentatious piety, but via performance and competitiveness" (Haenni 2005:10). Haenni observes that a management- and bourgeois-like individualistic culture of "free riders" of islamization, an emphasis on the powers of "positive thinking," is emerging, to be substituted for past disappointments concerning the restitution of the Caliphate and the general introduction of sharia - in short, a "neo-liberal politicization of Islam," which, ironically, resembles the agenda of "faith-based initiatives" and "compassionate conversation" of the American Republican Party more than anything else (2005: 8-12). ${ }^{26}$ No longer focused on acquiring power in the nation-state and shunning the Jacobin (but also Marxist and Keynesian) models of interventionist policies in state-sponsored socialist and welfare states, the new practice of "market Islam" puts its money on reforming mores in "civil society."

This development goes hand in hand with tendencies in recent Islamic global investment and private banking in the Middle East and in Malaysia, Singapore, and Indonesia, operating in compliance with the requirements of sharia (which bans usury, the charging of interest on loans, and all commercial transactions having to do with alcohol, tobacco, and gambling), while attempting to provide competitive returns (such as sukuk, or non-interest rent on revenue). Since February 2006, the Singapore stock exchange lists a "Shariah 10o Index," which covers Asian banking and trading indexes that comply with traditional law (Kolesnikov-Jessop 2006).

Tracking the disillusionment of former Muslim Brotherhood militants, notably in Egypt, both in conversations and on the Web site www.islamonline, Haenni 
sees an aspiration to turn away from pyramidical hierarchies toward "operating in networks" (2005:17). Its result will be a "multipositioned" engagement, which no longer aspires to a global political agenda for Islam but opts instead for a variety of managerial (antiglobalist, ecological, feminist, cybercultural, etc.) local interventions, whose overall effect will be that of a "new mental universe," basedupon "bricolage" (2005:18)." Again, this new agenda would seem to be carried out by individuals rather than movements, brotherhoods, or small groups and cells. They are typically well integrated, oriented toward self-realization, and weary of great global causes. Its guiding concepts are that of a nonviolent "civil jihad" or even an "electronic jihad" (or "hacktivism," also meaning, it should be added, taking out anti-Islamist sites) (2005: 18-19).

While this process takes shape, other tendencies and potentialities may emerge, presenting threats that must be assessed and politically addressed. Jihadists, in Roy's view, share a tendency with other religious terrorists (such as the Hindu Tamil Tigers) and also some Third-Worldist movements, to engage in what Mark Juergensmeyer, in his seminal Terror in the Mind of God, calls "performance violence," an acting out in which political calculation is less prominent than the desire to make a statement in the eyes of the world and to draw perceived enemies into a conflict of "cosmic" proportions. As Roy aptly notes: "Osama Bin Laden has no strategy in the true sense of the word. (...) His aim is simply to destroy Babylon" (Roy 2004: 55-56). ${ }^{27}$

Rather than being merely retrograde or reactive, the jihadists' expressions of religious extremism are thus, Roy concludes, ways of mimicking and superlatively outbidding - and, in that sense, directly getting back at - what are perceived to be hegemonic Western economic, political, and cultural principles and trends: "The Western-based Islamic terrorists are not the militant vanguard of the Muslim community; they are a lost generation, unmoored from traditional societies and cultures, frustrated by a Western society that does not need their expectations. And their vision of a global ummah is both a mirror of and a form of revenge against the globalization that has made them what they are" (Roy 2005a).

It has been suggested that - fueled by repeated and nightmarish Western lapses, which can be indicated by such proper names as Guantánamo Bay, Abu Ghraib, Hadhita, and now Qana - jihad is becoming a "global fad," which, like other counter-cultural expressions, "feeds" on the lurid images readily provided by the Western media (as well as al-Jazeera, the Internet, etc.), shaping a generation whose fascination seems increasingly that of "making war, not love" (Stern 2006). Jessica Stern argues that "among many Muslim youth, especially in Europe, jihad is a cool way of expressing dissatisfaction with a power elite that is real or imagined; whether power is held by totalitarian monarchs or by liberal parliamentarians" (Stern). In other words, jihad is in the process of becoming "a millenarian movement with mass appeal," whose narratively constructed "identity of victimhood" is constantly being reinforced by damaging images, that is to say, by "facts, or at least pictures that appear to be facts" (Stern). Beyond real-life 
issues in Europe and the Middle East (i.e., immigration, occupation, and terror), the conflicts in question express - and require - a battle for an "idea, not a state": "Military action minimally visible and carefully planned and implemented may be necessary to win today's battles. But the tools required in the long run to win the war are neither bombs nor torture chambers. They are ideas and stories that counter the terrorist narrative - and draw potential recruits away from the lure of jihad" (Stern).

After the dismantling of its traditional geographical bases in Afghanistan and Pakistan through the U.S.-led military intervention, Al Qaeda has virtually regrouped in the intractable realm of the Internet. Its members are dispersed in some four thousand different Web sites, leaving Western intelligence communities with the dilemma of either targeting and, where possible, destroying them or leaving them intact in order to monitor them and so pick up possible announcements of things to come or learn to discern nuances of "disagreement" and "inner cleavages" (e.g., concerning the legitimacy, from the viewpoint of Islam, of violence against Muslims or "noncombatant non-Muslims") that might help efforts to "broaden gaps" within these Internet communities (Weimann 2006).

As with all technological monitoring, there are structural - logical-mathematical difficulties in doing so, even beyond the question of allocating financial and other resources. ${ }^{28}$

Whereas the U.S. seeks to contain the war on terror by localizing it abroad in specific territories (first Afghanistan, then Iraq)- thereby, paradoxically, producing the very territorial base for terror that, in the case of Iraq, was previously lackingthe online jihadists dream of unleashing or at least staging a global, indeed, cosmic conflict, which would have no geographical boundaries or concretely envisioned terms of political (let alone diplomatic) resolution. In fact, it now seems just as unlikely that the Bush administration will stop identifying, taking on, and thereby unintentionally creating potential geopolitical threats against its perceived economic interests, democratic ideals, and cultural values as it is unrealistic to assume that militant jihadism will tone down its rhetoric (and put down its arms) the moment that Western forces were to withdraw from Islamic holy grounds. In the meantime, inflammatory and inflated words and gestures, along with a brandishing of things and powers, continue unabated. There is no end to conflicts that one does not and, for identitarian reasons cannot - want to end or whose possible victor one cannot realistically imagine oneself to be one day. ${ }^{29}$

These processes in which on all sides the "masters of war" (Bob Dylan) get the upper hand, and obey a relentless logic of "escalation," which Le Monde, in a telling editorial concerning the most recent war in Lebanon, summarized as follows: "It is tempting to believe that military logic, when it reaches a certain level of escalation, has become a fatality. Nonetheless, nothing in this conflict is uncontrollable. Israel like Hezbollah, acts in a considered and determined manner, even though both might have been surprised by the amplitude of the enemy's reaction." 30 


\subsection{NEW CHALLENGES FOR POLITICAL THEOLOGY IN A DiGITAL AGE}

Political theology might well become the discipline of studying and eventually mastering such "escalation," that is, the excesses of sovereignty and their violence, as well as the rhetorical overdrive with which they are accompanied, ideologically justified, and irresponsibly spiced up. To suggest this means rewriting a certain idea of transcendence (the notions, dimensions, or experiences with which "religion" and the "theologico-political" are most often identified) in the language of immanence, associated with the history of atomism, materialism, naturalism, and pantheism. The latter traverses the history of thought as a heretical countercurrent, of sorts. Yet this rewriting also implies interrogating the historical and systematic pertinence of the very distinction and opposition between transcendence and immanence, the sacred and the secular, as well.

Beyond this ontological - and, ultimately, metaphysical - hypothesis, one could return to the original theologico-political question and ask: Where and how did this fatal dualism, if not Manicheism, of two supposedly separate and antagonistic realms - an opposition that contains the seeds of its better alternative, first enter the historical world in its theologico-political guise? In antiquity, the Middle Ages, or modernity, including today's uni- and multipolar worlds? And what are its perils and chances for contemporary and future democracy, for an openness associated with tolerance and hospitality, with the flourishing of human rights as well as novel possibilities for the living together of bodies and minds, peoples and cultures, animals and things? 


\section{NOTEN}

The notion is aptly demystified in "Islam, America, and Europe," in The Economist, June 24, 2006.

Ibid.

Ibid.

Ibid.

See also Sparks, S. (1997) (ed.) Retreating the Political London: Routledge. Wright attributes this view to Hans Morgenthau.

See my concluding chapter in Hent de Vries 1999.

For deterritorialization, see Oliver Roy, Globalized Islam: The Search for the New Ummah (New York: Columbia University Press 2004), 38. This book is a revised edition of L'Islam mondialisé (Paris: Seuil 2002). Roy is hardly defending a present-day version of "Orientalism," which he defines as "the prevailing discourse among Islamic intellectuals" and its "mirror vision that still dominates a part of Western Islamic studies," namely, "the perception of Islam and of Muslim societies as one global, timeless cultural system" (Roy, The Failure of Political Islam, trans. Carol Volk [Cambridge: Harvard University Press, 1994], vii). On the meaning of Orientalism, see my lemma "Orientalism," in Encyclopedia of Religion, $2 \mathrm{~d}$ ed., ed. Lindsay Jones (New York: Macmillan, 2005).

See the Global Attitudes Project of the Pew Research Center, reported in Le Monde, July 18, 2005, and in "Muslims and Europe: Surprisingly Positive. Pew Finds Changes in Attitudes," in The International Herald Tribune, July 7, 2006. See http://pewglobal.org/

The Economist, July 16, 2005. A year after the attack, a video was broadcast by the Quatar-based news channel al-Jazeera in which one of the purported suicide bombers, Shezad Tanweer, announces that "what you have witnessed now is only the beginning," along with separate footage showing Ayman al-Zawahiri, Al Qaeda's number two in command, who thus sought to take credit for the attacks (see The International Herald Tribune, July 7, 2006).

Recruitment of volunteers in the targeted country by means of video appeals such as the one referenced in $\mathrm{n} .2 \mathrm{O}$ may inaugurate a next phase in the logic of terrorism's de- and re-territorialization. See Jessica Stern, "Marketing Jihad: Al Quaeda Changes Its Pitch," in The International Herald Tribune, July 17, 2006. Stern refers to Adam Gadahn, a young American who invokes the widely mediatized abuses of prisoners and the increasing number of civil victims in Iraq to impute responsibility to American citizens, addressing himself to prospective local recruits.

The Danish prime minister Anders Fogh Rasmussen was taken to task in the appendix to a recent report by scholars of the Center for Middle Eastern Studies at the University of South Denmark for not receiving a delegation that in October 2005 had requested an audition to protest against "discriminatory tendencies" and "the abuse of Islam in the name of democracy, freedom of expression, and human rights." This blockage of dialogue, the researchers conclude, constituted "the real offense" in the whole affair, that is to say, "not the fact that the Prophet 
was insulted, but the fact that the insult was not recognized as such" (see Le Monde, June 6, 2006). A comment by scholars, made in a personal communication in Copenhagen in June 2006, was as simple as it was insightful: what the whole affair taught us, they said, was that "there is no longer a local public sphere."

See also Roy's “La Communauté virtuelle: L'Internet et la déterritorialisation de l'islam," in Réseaux (Paris: CENT/Hermes Science Publications, 200o). There is an element of autocritique in this comment, if we consider it against the background of Roy's pre-9/11 statement that "aside from the Iranian revolution, Islamism has not significantly altered the political landscape of the Middle East. Political Islam does not pass the test of power. In the early 1990 os the regimes of 1980 are still in place, and the Gulf War has established American hegemony. A strange Islamic threat indeed, which waged war only against other Muslims (Iran/Iraq) or against the Soviets (Afghanistan) and caused less terrorist damage than the Baader-Meinhof gang, the Red Brigade, the Irish Republican Army, and the Basque separatist ETA, whose small-group actions have been features of the European political landscape longer than hizbullahs and other jihad movements" (The Failure of Political Islam, ix). For a discussion of the cultural representation of the RAF, see Thomas Elsaesser, "Antigone Agonistes: Urban Guerilla or Guerilla Urbanism? The RAF, Germany in Autumn and Death Game," in Giving Ground: The Politics of Propinquity, ed. Joan Copjec and Michael Sorkin (London: Verso, 1999). Mutatis mutandis, this might even hold true for the changes in the balance of power within the Middle East itself, where an almost cynical calculation seems to hold sway over ideologico-religious considerations (cf. Olivier Roy, "L'Iran fait monter les enchères: La stratégie de tension que Téhéran organise hors de ses frontières inquiète ses voisins arabes," Le Monde, July 21, 2006).

16 The Economist, June 24th, 2006.

17 See also Faisal Devji, Landscapes of the Jihad: Militancy, Morality, Modernity (Ithaca: Cornell University Press 2005).

See The New York Times, January 30, 2006, and the "BondyBlog," to be found at www.hebdo.ch/indexBlogs.cfm and the corresponding volume edited by L'Hebdo, together with Serge Michel, Bondy Blog: des journalistes suisses dans le 9-3 (Paris: Seuil, 2006). The word blog comes from "weblog," then the pun "we blog." On the "new social critique" and "La République des idées," inspired by the work of Pierre Rosanvallon, see the dossier in Le Monde, May 20, 2006, and the volume La nouvelle critique sociale (Paris: Seuil, Le Monde, 2006). See also David Lepoutre, Cour de banlieue: Codes, rites et langages (Paris: Odile Jacob, 2001) and Loïc Wacquant, Parias Urbains: Ghetto, banlieus, état (Paris: Éditions La Découverte: 2006), and idem, "Burn Baby Burn, French Style? Roots of the Riots in the French City," an interview to be found on http://sociology.berkeley.edu/faculty/wacquant/. Positive. Pew finds changes in attitudes," in: The International Herald Tribune, Jule 7, 2007. 
"Anne Frank 2006: Web-savvy Youths Record Suffering in Mideast," in The International Herald Tribune, July 25, 2006. For the blog and video Galya Daube, a 15-year old inhabitant of Haifa, see www.snipurl.com/Galya. The article reflects on the intensity of blogging of users in France, where, interestingly, a far greater percentage (and, indeed, a majority) of Internet users visits blogs, "the personal and public journals of the Internet age." See also the survey of new media in The Economist, April 22, 2006, which details in what ways the "era of mass media is giving way to one of personal and participatory media," notably blogs, including photo- and video blogs (or "vlogs"). See for a report of the "One Laptop per child” (OLPC) project, Éric Leser, “À 100 dollars, l'ordinateur des pauvres," in Le Monde 2, June 17, 2006, and Nicholas Negroponte, “One Laptop Per Child," in The World in 20o6, The Economist, 2006.

23 See The Economist, July 29, 2006, which leaves no doubt to the answer of this question: "Mobile phones are cheaper, simpler and more reliable than PC's, and market forces - in particular, the combination of pre-paid billing plans and microcredit schemes - are already putting them into the hands of even the world's poorest people. Initiatives to spread PC's in the developing world, in contrast, rely on top-down funding from governments or aid agencies, rather than bottom-up adoption by consumers.... There is no question that the PC has democratized computing and unleashed innovation: but it is the mobile phone that now seems most likely to carry the dream of the "personal computer" to its conclusion." For the history of the personal computer, including its links to countercultural dreams of utopian social engineering in the sixties, see Thierry Bardini, Bootstrapping: Douglas Engelbart, Coevolution, and the Origins of Personal Computing (Stanford: Stanford University Press 200o); the topic has recently also been taken up by Fred Turner, in From Counterculture to Cyberculture: Stewart Brand, The Whole Earth Network, and the Rise of Digital Utopianism (Chicago: University of Chicago Press 2006).

24 Leonard also sees a limited future role for what he - with a somewhat unhelpful expression - calls a "Faith Zone," that is to say, a consortium of Muslim countries, tied in with the global economic market, but distinguished from the supposedly secular (and expanding) "Eurosphere."

25 Trouw, May 15, 2006. For the report, see Jos de Haan and Christian van 't Hof, ed., Jaarboek ICT en samenleving. De digitale generatie, published under the auspices of the Sociaal en Cultureel Planbureau and the Rathenau Instituut (Amsterdam: Boom, 2006). On the general trends in the integration of young migrants, see Dirk Vlasblom, "Het beste van twee werelden: internationale studie wijst uit dat de meeste jonge immigranten voor integratie kiezen," in NRC Handelsblad, January 8, 2006, which reviews a recent study by John W. Berry, Jean S. Phinney, David L. Sam, and Paul Vedder, entitled Immigrant Youth in Transition: Acculturation, Identity, and Adaptation Across National Contexts (Mahwah N.J.: Lawrence Erlbaum Associates 2006). In addition, see the contested report by the Dutch Scientific Council for Government Policy (WRR), entitled Dynamiek in islamitisch activisme: Aanknopingspunten voor democratisering en mensenrechten (The Hague, Amsterdam: WRR, Amsterdam University Press 2006), and to the report 
by the Netherlands General Intelligence and Security Service (AIVD) of the Ministry of the Interior, De geweldadige Jihad in Nederland. Actuele trends in de islamitisch-terroristische dreiging (Den Haag: Algemene Inlichtingen- en Veiligheidsdienst, March 2006). See also Samantha M. Shapiro, "Ministering to the Upwardly Mobile Muslim," The New York Times Magazine, April 30, 2006, on the media empire of Amr Khaled, a former accountant, whose website received 26 million hits in 2005 and is the third most visited Arabic website after Al Jazeera. Of course, one might point to a host of semi-official declarations that have now been assembled, translated, and interpreted. See Bruce Lawrence, ed., Messages to the World: The Statements of Osama bin Laden (London: Verso, 2005); Gilles Kepel and Jean-Pierre Milelli, eds., Al-Qaida dans le texte: Écrits d'Oussama ben Laden, Abdallah Azzam, Ayman al-Zawahiri et Abou Moussab al-Zarqawi (Paris: PUF, 2005). See also the widely acclaimed book by Jason Burke, Al Quaeda: The True Story of Radical Islam (London: Penguin Books, 2003, 2004). These documents demonstrate a considerable heterodoxy and adaptability in discourse and strategy. In a recent public video statement, broadcast by Al-Jazeera on July 27 , 2006, Ayman Al-Zawahiri, the second most important ideologue of Al Quaeda, responding to the crisis in Lebanon, went so far as to call on all the peoples who are the "disinherited of the world" and the "victims of oppressors" to solidarize themselves with Muslim jihadists. This was the first time Al Quaeda directly appealed to non-Muslims to join its struggle (see Le Monde, July 29, 2006). This rhetoric may also have been a response to the fact that the perceived "success" Hezbollah, a Shiite organization sponsored by Iran, seemed to tickle the mimetic rivalry - and downright conspiracy theory - of the Al Quaeda leadership, whose Sunni orientation considers Shiities as heretics. Al Quaeda has found it more easy to solidarize itself with Hamas, which is a Sunni and Muslim Brotherhood organization. And, conversely, Hezbollah has always disapproved of Al Quaeda's tactics, to say nothing of the latter's justification of violence against Shiite populations in Iraq. Uncannily, the "accidental war" (cf. the editorial of The Economist, July $22^{\text {nd }}, 2006$ ), which broke out over a (miscalculated?) action of Hezbollah on Israeli territory, may have the unintended effect of $\mathrm{Al}$ Quaeda desiring to reassert itself as "true defender" of Islam through spectacular actions in Iraq and the West (see Bernard Haykel, "Al Quaeda takes a Back Seat," in The International Herald Tribune, July 27, 2006).

To be aware of such tragic ironies and nasty subtleties is important, as Roger Cohen insists in a comment, entitled "Sacrificing a Democracy While Supporting an Ally," contributed to The International Herald Tribune, July 29-30, 2006: "“"Everyone understands that a victory for Hezbollah is a victory for world terror," said Haim Ramon, the Israeli justice minister. Not so: a victory for Hezbollah is a victory for Hezbollah, which is not Al Qaeda, which is not the Palestinian national movement, which is not the Iraqi insurgency, which is not homegrown European Muslim suicide bombers. Trying to turn the problems of the world into a single undifferentiated issue - the war on Islamic terror - does nobody any good."

An important source and study concerning the influential Muslim Brotherhood 
can be found in Olivier Carré, Mystique et politique: le coran des islamistes (lecture du Coran par Sayyid Qutb, Frère musulman radical (19o6-1966) (Paris: Les Éditions du Cerf 2004); Mysticism and Politics: A Critical Reading of Fi Zilal al-Qu'ran by Sayyid Qutb (19o6-1966), ed. by Reinhard Schulze (Leiden, Boston: E. J. Brill 2003). For a view taken from everyday life on the streets and schools among the mullahs in Pakistan, the Taliban in Afghanistan, and the mujahideen in Irak, see Anne Nivat, Islamistes: Comment ils nous voient (Paris: Fayard 2006).

28 See Le Monde, August 6, 2005. That the very concept, let alone practice, of electronic monitoring - as in the uncanny cooperation between the American National Security Agency (NSA), the most powerful technological information agency in the world, and phone companies such as AT\&T, Verizon, and BellSouth - is problematic not just for legal and moral but for logistical or mathematical reasons, is convincingly argued by Jonathan David Farley in his article "Getting the Terrorists on the Phone: The NSA's Math Problem," in The International Herald Tribune, May 17, 2006. See also the informative article "National Security Agency: Les oreilles de l'Amérique," in Le Monde, June 1, 2006. Farley, in his article, argues that so-called graph theorists and social network analysis specialists have the greatest difficulty determining the exact factual patterns of communication, with its "central players" and hierarchies, based a drawn "chart with dots or 'nodes' representing individuals and lines between nodes if one person has called another." An unimportant person in the chain of command may take most calls; a crucial person in the chain of events may show up only once.

The problem is hardly solved by the fact that, in addition to government agencies such as the NSA and CIA, also private security companies, such as the Search for International Terrorist Entities (SITE), are either contracted for or volunteer information they track on Jihadist websites. See Benjamin Wallace-Wells, "Private Jihad: How Rita Katz got into the spying business,” The New Yorker, May 29, 2006.

And, lest we forget, private internet companies such as Yahoo and its Chinese partner Alibaba.com, Microsoft, Cisco Systems, and Google have not hesitated to "monitor" on their turn the access to sites deemed "obscene" or "politically subversive" by Chinese authorities which currently employ some 30.000 online monitors (according to international human rights groups such as Amnesty International). The affected sites express critique of the regime, support of Taiwan's or Tibet's independence, news about labor unrests, etc. Asked to respond, Google declared to indicate such restriction to users explicitly (stating that it had taken place "in response to local laws and regulations") and to avoid offering access when privacy for individual users would not be fully guaranteed. The reasons for this collaboration in surveillance and filtering (limiting access to certain sites upon the government's request while, supposedly, protecting citizens' further freedom) are obvious. China has the second largest group of internet users after the USA and hence constitutes an enormous growing market, even though it has its own - censured - search engines (such as baidu.com, which exploits approximately $56 \%$ of the available market). And the companies in ques- 
tion justify themselves on the grounds that even limited access to the net for mainly economic uses has a net positive result on everyday live (see The International Herald Tribune, July 20, 2006, and also the special report on "China and the Internet: The Party, the People and the Power of Cyber-Talk," in The Economist, April 29, 2006, which cites Bill Clinton's insightfull comment that China's attempts to curtail internet access and guide its use is "sort of like trying to nail Jell-O to the wall," indicates that the set up firewalls are in fact quite "porous," and also reports on the congressional hearing, in February 2006, on American companies involved in internet business in China).

Nonetheless, the organization Reporters sans frontiers (Reporters Without Borders) took Google to task for indirectly being responsible for the arrest of some internet journalists. Indeed, of the 58 online journalists that, according to some sources, are currently jailed, some 50 are in China. But the collaboration of Western internet providers with the Chinese authorities is nothing exceptional. Telecom Italia owns a large portion of the Cuban internet, and the French company Wanadoo offers broad band services in Tunesia (see Elda Dorren, "Online vrijheid in gevaar," in NRC Handelsblad, June 12, 2006). According to Reporters sans frontières (www.rfs.org) in the year 2005 there were some fifteen countries which censured the web. The organization urged Western countries to develop legislation for those multinational internet companies which offer services in countries with human rights violations.

One might argue that something similar is happening in the Israeli-Palestinian conflict in Lebanon. See Steven Erlanger, “How 'Winning' Might Be Defined by Israel and Hezbollah," in The International Herald Tribune, August 3, 2006. Erlanger sketches a "battle of perceptions" based upon a dialectic of maximal force with minimal impact and the reverse, which perpetuates itself interminably: "Prime Minister Ehud Olmert wants to ensure that when a cease-fire is finally arranged, Israel is seen as having won a decisive victory over Hezbollah. Israel wants to send a clear message to the Palestinians and to the Lebanese, as well as to Hezbollah and its sponsors, Syria and Iran, that attacks will be met once again with overwhelming force, and that the cost is not worth the adventure... For Hezbollah, however, victory means simply avoiding defeat. Hezbollah and its leader, Sheik Hassan Nasrallah, will be perceived by many Muslims to have won by surviving the war and keeping the capacity to fire even short-range rockets into Israel." The article, citing a former Israeli negotiator, calls this the "9o-10 paradox": "Israel can eliminate 90 percent of Hezbollah's fighting capacity, but Hezbollah can still declare victory and claim to have fought the mighty Israeli Army to a draw." See also Martin van Creveld, "In This War, Too, Victory Is Unlikely," in The International Herald Tribune, August 3, 2006, and Robert A. Pape, "The Imagined Enemy, and the Real One," in The International Herald Tribune, August 4, 2006.

Conceding a predicament concerning perceptions at a time when top military commanders (General John Abizaid, Commander of the the U.S. forces in the Middle East, and General Peter Pace, Chairman of the Joint Chiefs of Staff), had expressed fear of an all-out civil war in Iraq, U.S. Secretary of Defense Donald Rumsfeld, at a hearing of the Senate Armed Services Committee, noted that "it 
was difficult to gauge the ideal number of troops the United States and its allies should have in Iraq. Too many troops, and the Iraqis would see them as occupiers, leading to more unrest. Too few, and the violence could spiral out of control" (David Stout, "U.S. Generals See Growing Threat of Iraq Civil War," in The International Herald Tribune, August 4, 2006).

"Moderate and secular" Muslim countries have expressed concern about the effects of the media images from the conflict in Lebanon on their populations. At an emergency meeting of the fifty-seven-nation Organization of the Islamic Conference in Kuala Lumpur, the president of Indonesia, Susilo Bambang Yudhoyono, echoing Samuel Huntington's much-decried thesis, was quoted as saying: "This war must stop or it will radicalize the Muslim world, even those of us who are moderate today. From there, it will be just one step away to that ultimate nightmare: a clash of civilizations" (Thomas Fuller, "Terrorism Could Grow, Leaders Say: Muslim Nations Warn of Lebanon Fallout,” The International Herald Tribune, August 4, 2006). 


\section{LITERATURE}

Ash, T.G. (2006) 'New World Disorder', The Guardian Weekly, July 28-August 3.

Brooks, D. (2005) 'Gangsta, in French', The New York Times, November 10.

Crampton, T. (2006) 'France's Mysterious Embrace of Blogs', The International Herald Tribune, July 28.

French, H.W. (2006) 'Mob Rule on China’s Internet: The Keyboard As Weapon', The International Herald Tribune, June 1.

Garber, M., R. L. Walkowitz (1999) (eds.) One Nation Under God: Religion and American Culture, New York: Routledge.

Marcel Gauchet (1985) Le désenchantement du monde: Une histoire politique de la religion, Paris: Gallimard.

Patrick Haenni (2005) L'Islam de marché: L’autre revolution conservatrice Paris: Seuil, 2005.

Kolesnikov-Jessop, S. (2006) 'Islamic Banking Seeks New Customers as Wealth Expands', International Herald Tribune, May 24.

Lacoue-Labarthe, P. and Nancy, J.-L.(eds.) (1983) Le Retrait du politique: Travaux du centre de recherches philosophiques sur le politique, Paris: Galilée.

Leonard, M. (2006) 'The Geopolitics of 2026', The World in 2006, The Economist.

Manach, J.-M (2006) 'Échos de la guerre sur la blogosphère', Le Monde, July 29.

Roy, O. (2005b) 'Get French or Die Trying', The New York Times, November 9.

Roy, O. (2005a) 'The Ideology of Terror', The International Herald Tribune, July 23-24.

Roy, O. (2004) Globalized Islam: The Search for the New Ummah, New York: Columbia University Press.

Roy, O. (1994) The Failure of Political Islam (trans. Carol Volk), Cambridge: Harvard University Press.

Shane, S. (2006) 'Terrorism Has a Global Impact but Is Often Rooted in Local

Disputes', The International Herald Tribune, July 17.

Sparks, S. (1997) (ed.) Retreating the Political London: Routledge.

Stern, J. (2006) 'Terrorism: Jihad Is A Global Fad', in The International Herald Tribune, August 2.

Vries, H. (2002) de Religion and Violence: Philosophical Reflections from Derrida to Kant, Baltimore: The Johns Hopkins University Press.

Vries, H. de (1999) Philosophy and the Turn to Religion, Baltimore: The Johns Hopkins University Press.

Weimann, G. (2006) 'Deadly Conversations: Terrorists on the Web', in The International Herald Tribune, July 21. 


\title{
19 HOE ZAL DE RECHTER DAT OPLOSSEN? LASTIGE KWESTIES ROND GODSDIENST ${ }^{1}$
}

\author{
Petra Jonkers
}

\subsection{INLEIDING}

Tijdens hoogoplopende conflicten waarbij godsdienst in het spel is, wordt de gang naar de rechter wel als de ultieme oplossing voorgesteld. Na de moord op Van Gogh is gesteld dat beledigde partijen hun recht om naar de rechter te stappen (eerder) hadden moeten aangrijpen. Een dergelijke oproep klonk ook tijdens de discussies na de publicatie van de Deense cartoons over de profeet Mohammed. De aanmoediging om een rechtsgang te overwegen lijkt dus in conflicten over als beledigend ervaren uitlatingen vooral bedoeld ter voorkoming van escalatie en geweld. Natuurlijk moet de rechtsgang daarbij in eerste instantie leiden tot een op de situatie toegespitste uitspraak. Tegelijkertijd kan het inzetten van of laten aankomen op een rechtszaak ook juist al of niet bedoeld tot effect hebben dat het grotere publiek kennis van het conflict neemt. De rechtspraak geeft soms verhelderend inzicht in (nieuwe) conflicten die zich rond godsdienst afspelen: zo leverde in augustus 2006 een zaak over een reformatorische school die een jongen weigerde vanwege zijn ouders' opvattingen over medezeggenschap, televisie en het wel eens dragen van een broek door zijn zus, grote verbazing en ergernis op en voorstellen om dit in de toekomst met wetgeving te verhinderen.

De toegenomen gevoeligheid rond religie en de daaruit voortvloeiende botsingen kunnen aan verschillende factoren worden toegeschreven. Vaak wordt gewezen op de toename in religieus pluralisme, onder meer door migratie en meer recentelijk door de manifestatie van de orthodoxe islam in Nederland. Nieuw daarbij is dat in tegenstelling tot het begin van die manifestatie in Nederland, nieuwe religieuze minderheden niet meer vooral 'slachtoffer' zijn van discriminatie, maar vaker zelf als de onderscheid makende partij worden beschouwd (Loenen 2003: 267). De pregnantere manifestatie vindt bovendien plaats op een moment dat de 'oude omgang' met religieus pluralisme door middel van de verzuiling min of meer verdwenen is. Dat pluralisme manifesteert zich bovendien in een maatschappij waarin steeds meer nadruk ligt op de ontwikkeling van het individu, diens autonomie en authenticiteit. Experimenten met leefstijlen en zelf samengestelde levensbeschouwingen nemen de plaats in van religieuze en culturele tradities (nota Grondrechten 2004; Kronjee en Lampert 2006). Het grotere belang van de persoonlijke ontwikkeling en autonomie uit zich volgens Pessers ook in een grotere rol van 'het persoonlijke' in het publieke domein én in het doen van rechtsaanspraken, de zogenaamde 'juridische emancipatie van het individu' (2003: 5). ${ }^{2}$ Het beroep op de vrijheid van godsdienst is daarin niet uniek, maar valt in de huidige context wel bijzonder op. Dit leidt gemakkelijker tot wrijvingen met en tegenreacties van aanhangers van (meer traditionele) religies waarin de autonomie en persoonlijke beleving van het individu minder centraal staan of 
zelfs van ondergeschikt belang worden geacht. Het religieus pluralisme dat tot botsingen leidt, is daarom niet alleen tot de manifestatie van de islam te herleiden, maar ook in 'hernieuwde' botsingen met vooral orthodoxen uit in Nederland langer bestaande religieuze tradities. Volgens de burgemeester van Amsterdam Cohen is met het toegenomen pluralisme ook de afgenomen vaardigheid om met verschillen om te gaan een oorzaak van (dreiging met) rechtszaken. Dit komt - constateert hij in navolging van Kennedy - niet door het vaak gehoorde ontbreken van een gemeenschappelijke identiteit, maar juist door de nieuw ontstane mogelijkheid een meer uniforme seculiere identiteit te construeren, wat in het verzuilde Nederland eerder onmogelijk was. De acceptatie van verschillen en de waardering voor de vrijheid van godsdienst lijken daarmee af te nemen. ${ }^{3}$

De oproep om maar naar de rechter te stappen, is vooral te horen als een persoon of groep zich door een ander beledigd voelt. Echter juist in die zaken pleiten velen voor een tegenreactie in het publieke debat zonder naar de rechter te gaan. Daarvoor worden echter uiteenlopende argumenten aangedragen. Volgens Dommering (2003) wordt de discussie verpest door het beroep op de rechter van iemand die een strafklacht bij het OM indient over belediging. Dat zo'n strafklacht in de praktijk vaak niet tot vervolging leidt, doet daar volgens hem niet aan af. ${ }^{4}$ Hoewel Cohen (2005) een positieve kant ziet in de rechtsgang van moslims - daarmee laten ze zien gebruik te willen maken van de mogelijkheden die de rechtsstaat biedt - vindt hij een rechtsgang negatief wanneer die (intolerant) slechts gericht is op het beteugelen van andermans gedrag omwille van de eigen vrijheid, zonder daarvoor met de ander te hoeven overleggen. Anderen vinden het onwenselijk dat beledigende partijen de ander tot een rechtsgang uitnodigen, omdat ze zich daarmee tot de uitspraak van de rechter een vrijbrief zouden verschaffen om zelf geen grenzen te hoeven trekken (Berger 2006; Zeeman 2006).

Het kabinet en de Tweede Kamer lieten zich (in respectievelijk 2004 en 2005) eveneens dubbelzinnig uit over de rechtsgang na belediging. ${ }^{5} \mathrm{Zij}$ onderstrepen vooral het belang van de rechter in het geval twee partijen zich tegenover elkaar op hun grondrechten beroepen. Omdat de wetgever totnogtoe zelf steeds een vaste hiërarchie tussen grondrechten heeft afgewezen, moet de rechter deze afweging in specifieke gevallen maken. Niettemin bepleiten kabinet en Tweede Kamer ook terughoudendheid in de gang naar de rechter. Het kabinet gaat nadrukkelijk uit van het belang van verantwoordelijkheid, weerbaarheid, tolerantie, tegenspraak en wederkerigheid en 'het vermogen tot dialoog' van personen in het publieke debat. Liever tegenspreken dan 'onmiddellijk de weg naar het OM te volgen' (kabinet in de nota Grondrechten 2004: 20). Wanneer een zaak uiteindelijk wel geschikt is voor de rechter, laten kabinet en Kamer in het midden.

Ondanks deze dubbelzinnige visie op de rechter, beperkt het kabinet zich in de nota Grondrechten tot voornamelijk een beschrijving van de jurisprudentie die 'nuttige richtsnoeren' oplevert. Het ontbreken van een kritische reflectie op de oordelen van de rechter van kabinet en later ook de Tweede Kamer in het debat over de nota veronderstelt min of meer instemming met de afwegingen van de rechter (zie Sam- 
kalden 2006: 48; Dales 2006). Over het algemeen worden de oordelen van de rechter 'adequaat' genoemd (nota Grondrechten 2004: 10) Hoewel het kabinet stelt dat er 'steeds kritischer geluiden in het maatschappelijk debat waarneembaar zijn naar aanleiding van rechterlijke uitspraken', wil het zich beperken tot meer inzicht geven in 'het vervolgingsbeleid en te communiceren over de afwegingen tussen grondrechten door rechter of CGB om te voorkomen dat de geloofwaardigheid van de (straf)rechtspleging in het geding zou komen' (2004: 10).

Kortom, in het publieke en politieke debat wordt de rol van de rechter door sommigen gewaardeerd waar het gaat om de afweging tussen grondrechten. Tegelijkertijd wordt zeer veel waarde gehecht aan het in de openbaarheid bediscussiëren van de waarden die in het geding zijn. Bovendien wordt de nadruk op het buiten de rechter om 'oplossen van geschillen' mogelijk ook nog gevoed door bezwaren tegen de feitelijke uitspraken van de rechter. Soms bestaat twijfel over de vraag in hoeverre de rechter, gezien de jurisprudentie, wel zo geschikt is voor het oplossen van conflicten rond religie. Er rijzen daarbij eigenlijk twee vragen: is de rechtbank het meest geschikte forum voor conflictbeslechting rond religie en, als de rechter zich over een dergelijke zaak buigt, weet hij dan tot een bevredigende oplossing te komen? Om daarover iets zinvols te kunnen zeggen zullen we in dit essay aan de hand van een selectie uit de jurisprudentie inzicht verwerven in een aantal casusoverstijgende lastige kwesties voor de rechter. ${ }^{6}$ De teneur van dit hoofdstuk zal zijn: ten eerste dat de ontwikkeling van individuele vormen van religie het voor de rechter ingewikkeld maakt om godsdienst überhaupt nog goed als zodanig te identificeren. Ten tweede komt het probleem van de vaak te beperkt onderbouwde oordelen van de rechter aan bod. De jurisprudentie is afkomstig van zowel de Nederlandse rechter, de Commissie Gelijke Behandeling (CGB) als het Europese Hof voor de Rechten van de Mens (EHRM). Het essay sluit af met een beschouwing over mogelijke alternatieven.

\subsection{INSTITUTIONALISERING EN HORIZONTALE WERKING VAN GRONDRECHTEN}

Voorafgaand aan de bespreking van de jurisprudentie geven we inzicht in een belangrijk aspect van de juridische context waarin conflicten zich voordoen. ${ }^{7}$ Het is een relatief nieuw verschijnsel in de grondrechtsgeschiedenis dat burgers ten opzichte van elkaar een beroep kunnen doen op hun grondrechten (horizontale werking). Europees recht versterkt deze ontwikkeling.

In de aanloop naar oudere versies van de Nederlandse grondwet dan die van 1983, maar bijvoorbeeld ook bij de opstelling van de Universele Verklaring voor de Rechten van de Mens is niet of heel beperkt aandacht besteed aan vrijheidsaanspraken tussen burgers onderling (horizontale werking) en de daaruit voortvloeiende mogelijkheid van botsing tussen die grondrechten. Aanvankelijk ging het 'slechts' om vrijheidsrechten die burgers tegen (verticale) staatsinmenging moesten beschermen en die de staat in beginsel tegelijkertijd aan alle burgers kon garanderen. Overigens noemen sommigen de beperking van bescherming tot 
overheidshandelen kunstmatig omdat, wanneer grondrechten de mens 'van nature toekomen', ze in zekere zin ook bescherming moeten bieden tegen anderen dan de overheid (Akkermans et al. 1993: 168). Hoewel van concrete botsing tussen grondrechten eerder niet expliciet gesproken werd, werd het beginsel erkend dat de uitoefening van een grondrecht niet ten koste van de uitoefening van grondrechten door anderen mocht leiden. Ook speelden al eerder kwesties over de vraag welk grondrecht in een concrete kwestie de meeste bescherming kon leveren (grondrechtenconcurrentie). ${ }^{8}$ Beperkingen op grondrechten zoals op de vrijheid van meningsuiting door beperking van de drukpersvrijheid door de strafbaarstelling van belediging en godslastering bestonden al langer, neergelegd in specifieke wettelijke voorschriften. De overheid kreeg gaandeweg meer een taak in de 'verzekering van het genot van grondrechten' die zij steeds nauwkeuriger ter hand nam. De subsidiëring van persorganen en onderwijsinstellingen zijn hier een voorbeeld van. Van der Hoeven (1983: 184) noemt dit de nadere 'institutionalisering' van grondrechten, die echter ook steeds meer invloed had op de inhoud van die rechten zelf. De nadere vormgeving van grondrechten - in bijvoorbeeld strafwetgeving - werd bovendien vereist door internationale verdragen die na de Tweede Wereldoorlog ook door Nederland werden geratificeerd. De ondertekenaars verplichtten zich bijvoorbeeld tot het opnemen van een verbod op rassendiscriminatie in de strafwet.

Bij de grondwetswijziging van 1983 werd ook de beperking op de vrijheid van godsdienst verruimd van 'behoudens de bescherming van de maatschappij en harer leden tegen de overtreding van de strafwet', naar 'behoudens ieders verantwoordelijkheid voor de wet'. Ook werd aan het grondrecht de vrijheid van belijden van levensovertuiging toegevoegd. Sindsdien kunnen naast de strafwet ook het burgerlijk en bestuurlijk recht de vrijheid van godsdienst inperken.

Bij de grondwetswijziging van 1983 werd de grondrechtencatalogus aanzienlijk uitgebreid en werd bepaald dat burgers ook grondrechtaanspraken in onderlinge rechtsverhoudingen konden laten gelden, zij het niet bij alle grondrechten. ${ }^{9}$ Inmiddels nam het belang van horizontale werking ook toe door de groeiende invloed van en machtsconcentraties in de particuliere sector. Door verdergaande vervaging tussen rechtsgebieden werd bovendien meer aanvaard dat gemeenschappelijke fundamentele rechtsbeginselen aan zowel het publiek als het privaatrecht ten grondslag liggen (Akkermans 1993: 168).

De wetgever verwachtte veel van de ontwikkeling van de horizontale werking van grondrechten door de jurisprudentie die hierover meer duidelijkheid zou kunnen verschaffen. In het burgerlijk recht, waar al veel beroep was gedaan op onrechtmatige daad, kon voor die afweging gebruik worden gemaakt van het steeds uitbreidende rechtersrecht (de jurisprudentie) waarin criteria als betamelijkheid in het maatschappelijke verkeer en redelijkheid en billijkheid sturend kunnen zijn. Van der Hoeven (1983) wees erop dat een dergelijke afweging veel moeilijker zou liggen op het moment dat burgers zich bij de rechter rechtstreeks op hun grondrechten zouden beroepen. De rechter zou namelijk niet met aan de 
onrechtmatige daad ontleende jurisprudentie afwegingen kunnen maken, maar zou zelf de grondwet moeten gaan interpreteren voor de onderlinge afweging tussen botsende positieve grondrechtsaanspraken.

De verdere invulling van grondrechten in Nederland heeft veel invloed ondergaan van dwingende bepalingen uit het EG-recht. Nederlandse burgers kunnen zowel in uiterste instantie hun zaak aan het Europese Hof voor de Rechten van de Mens voorleggen als direct voor de Nederlandse rechter een beroep doen op bepaalde internationale bepalingen, zoals het EVRM. In tegenstelling tot (sommige) andere landen in Europa, worden veel internationale verdragen in Nederland direct van toepassing verklaard, waardoor geen nadere uitwerking in wetgeving vereist is. Bovendien geldt ook voor eenieder verbindende verdragsbepalingen dat ze in Nederland horizontale werking kunnen hebben. Bij de herziening van de Nederlandse grondwet in 1983 is bovendien al sterk rekening gehouden met de dominantie van het EVRM waardoor bepaalde cruciale waarden die wel in het EVRM (en in grondwetten van andere Europese landen) zijn opgenomen (bijvoorbeeld over de menselijke waardigheid) ontbreken in de Nederlandse grondwet (Heringa 2003). Bovengenoemde ontwikkelingen verruimden de mogelijkheid voor rechtsvorming door rechters in Nederland en daarmee ook voor verdere horizontale uitwerking van fundamentele rechten. Zo is in Nederland de socialezekerheidswetgeving in reactie op dit rechtersrecht in overeenstemming gebracht met internationale non-discriminatiebeginselen. ${ }^{10}$ Het interpreteren en toepassen van Europees recht in Nederland is nog versterkt doordat de Nederlandse rechter geen wetgeving mag toetsen aan de Nederlandse grondwet, maar wel aan internationale verdragen. De grote 'macht' die Nederlandse rechters hierdoor hebben, laat zich niet eenvoudig door de nationale wetgever corrigeren, omdat internationale verdragen zich moeilijk door de Nederlandse wetgever laten veranderen (Loenen 2006: 19). Het EVRM biedt echter ook de wetgever een normatief kader en stelt juridische grenzen voor de landen die bij het EVRM zijn aangesloten (Loenen 2006: 41).

\section{Ontwikkeling van horizontale werking van het non-discriminatiebeginsel}

Aan sommige grondrechten uit de Nederlandse grondwet is heel nadrukkelijk horizontale werking 'verleend', door ze in gewone wetgeving expliciet als zodanig uit te werken. Dit geldt bijvoorbeeld voor de uitwerking van artikel 1 van de grondwet (non-discriminatiebeginsel) in de Algemene Wet Gelijke Behandeling (AWGB) die in 1994 van kracht werd. De AWGB stelt dat burgers elkaar onderling (vooral rechtspersonen tegenover burgers) in bepaalde situaties gelijk moeten behandelen, dat wil zeggen dat in het handelen en het nemen van besluiten bepaalde argumenten en overwegingen (subjectieve, niet-zakelijke gronden) zijn verboden (Gerards 2004: 103). De AWGB verbiedt onderscheid bij het aanbieden van werk, goederen en diensten op grond van godsdienst, levensovertuiging, politieke gezindheid, ras, geslacht, nationaliteit, hetero- of homoseksuele gerichtheid of burgerlijke staat. ${ }^{11}$ Verondersteld is dat hiermee een opsomming is gemaakt van de persoonskenmerken waarvan niet of alleen met grote moeite afstand kan worden gedaan. Direct onderscheid op een van deze gronden leidt altijd tot het oor- 
deel verboden onderscheid, tenzij er sprake is van een in de wet genoemde uitzondering. Bij schijnbaar neutrale maatregelen die een bepaalde groep meer treffen dan andere groepen en daarmee tot indirect onderscheid leiden, zal moeten worden aangetoond of de betreffende maatregel objectief te rechtvaardigen valt.

De AWGB is lastig als uitsluitend een uitwerking van artikel 1 op te vatten, hoewel sommigen stellen dat artikel 1 van de grondwet juist door de uitwerking in de AWGB al feitelijk voorrang heeft gekregen op andere grondrechten (Akkermans e.a. 1993: 186). Het feit dat de AWGB voornamelijk horizontale werking verleent aan artikel 1 en daarmee onvermijdelijk botst met andere grondrechten, dwong de wetgever zelf al om in de wet een afweging tussen grondrechten te maken. Dat laat de lange en roerige voorgeschiedenis van de wet zien waarin vooral van confessionele zijde weerstand bestond tegen een definitieve onderschikking van de vrijheid van godsdienst aan het gelijkheidsbeginsel. De in de wet opgenomen uitzonderingen voor instellingen en politieke partijen die zich op een religieuze of ideologische grondslag kunnen beroepen - die wetstechnisch gezien ook een uitzondering zijn - hoeven echter niet slechts als uitzonderingen op het beginsel van de gelijke behandeling gezien te worden, maar kunnen ook als bewuste afweging tegen de andere grondrechten worden opgevat.

\section{Godsdienst in het Europees Verdrag voor de Rechten van de Mens}

Van de internationale verdragen die relevant kunnen zijn voor de Nederlandse rechter en burger, wordt hier alleen kort het godsdienstartikel uit het EVRM besproken, om daarna aandacht te schenken aan jurisprudentie van het Europese Hof. Het negende artikel van het EVRM, dat gewijd is aan godsdienst, is uitgebreider dan het Nederlandse grondwetsartikel. Dit geldt zowel de inhoud van de opgesomde rechten als de beperkingen die daaraan door de overheid kunnen worden gesteld. Het artikel heeft betrekking op de vrijheid van zowel gedachte, geweten en godsdienst alsook de vrijheid om van godsdienst of overtuiging te veranderen. In jurisprudentie heeft het Hof hier nog uitdrukkelijk de vrijheid om geen godsdienst te belijden aan toegevoegd. De vrijheid is er ook voor atheïsten, agnosten en onverschilligen (Loenen 2006: 25). Verder garandeert het artikel aan ieder de vrijheid om alleen of met anderen, zowel in het openbaar als privé zijn godsdienst of overtuiging te belijden en tot uitdrukking te brengen in erediensten, in onderricht - hierin is ook een Europees equivalent te lezen van recht op religieus onderwijs, niet automatisch van bekostiging -, in praktische toepassing en in het onderhouden van geboden en voorschriften. Beperkingen zijn mogelijk wanneer ze bij wet zijn voorzien en in een democratische samenleving noodzakelijk zijn in het belang van de openbare veiligheid, voor de bescherming van de openbare orde, gezondheid of goede zeden of voor de bescherming van de rechten en vrijheden van anderen. De uitvoerige beperkingen op diverse fundamentele rechten in het EVRM zijn te begrijpen uit de overeenstemming die heel diverse landen voor het sluiten van het verdrag moesten bereiken (Van der Hoeven 1983). Het Hof houdt bovendien rekening met de specifieke context van de diverse landen (de 'margin of appreciation'). Het EVRM dwingt niet tot één specifiek kerk-staatmodel (Loenen 2006). 


\subsection{BESCHRIJVING JURISPRUDENTIE EN TOETSINGSKADER}

De volgende paragrafen geven door middel van een selectie van jurisprudentie inzicht in belangrijke afwegingen van het Europese Hof, de Nederlandse rechter en de CGB. De besproken jurisprudentie biedt geenszins een totaaloverzicht, maar is gekozen ter verheldering van de in dit essay te bespreken lastige kwesties. De instanties hanteren alle drie een bepaald toetsingskader, dat grofweg bestaat uit de volgende vragen:

- wat betreft de definitie en identificatie van godsdienst: is er in het concrete geval wel sprake van (een manifestatie van) godsdienst, zodanig dat betrokkenen zich met recht op de vrijheid van godsdienst kunnen beroepen?

- wat betreft de aantasting of beperking van de vrijheid van godsdienst:

1. is er in het concrete geval werkelijk sprake van een inbreuk op de uitoefening van het recht?

2. en is er een rechtvaardiging voor die inbreuk, bijvoorbeeld vanwege een zwaarder wegend grondrecht (botsing van grondrechten) of omdat die inbreuk noodzakelijk is voor een te rechtvaardigen doel?

Deze vragen zijn niet in alle gevallen voor de genoemde rechterlijke instanties volledig hetzelfde vanwege de verschillen in de aard van de zaken en regelgeving die de rechterlijke instanties in hun oordelen betrekken. De CGB toetst bijvoorbeeld niet direct of de vrijheid van godsdienst in het geding is, maar of er sprake is van ongelijke behandeling van personen die (g)een bepaalde godsdienst aanhangen. Daarbij zijn ook aard en gewicht van de zaken die de diverse instanties bespreken heel verschillend. Het Europese Hof oordeelt doorgaans over meer fundamentele zaken dan de CGB, alhoewel beide zich ook over vergelijkbare zaken buigen, zoals het dragen van hoofddoeken.

\subsubsection{JURISPRUDENTIE EHRM ${ }^{12}$}

In de jurisprudentie zijn afwegingen rondom het zogenoemde forum internum en forum externum te onderscheiden. Het EHRM erkent niet alleen het belijden van godsdienst, maar ook het ernaar handelen. Het forum internum heeft betrekking op respectievelijk de vrijheid van gedachten, geloof en geweten of het hebben en belijden van een godsdienst, die min of meer absoluut beschermd zijn (Labuschange 1994: 143). Daar is bijvoorbeeld uit afgeleid dat een staat niet alleen zelf burgers niet mag dwingen tot een kerklidmaatschap of tot (verplicht) godsdienstonderwijs op openbare scholen, ${ }^{13}$ maar er ook zorg voor moet dragen dat personen uit een kerkgenootschap mogen uittreden, ook als een genootschap zelf niet in die mogelijkheid voorziet. ${ }^{14}$ Het forum externum betreft de vrijheid om uitdrukking te geven aan de godsdienst, zoals het bijwonen van religieuze bijeenkomsten en riten en het verrichten van bepaalde handelingen. Dit laatste kent geen absolute bescherming, alleen al omdat hier de rechten van anderen in het geding kunnen komen. Daarom slaagt ook niet elk beroep op de vrijheid van godsdienst. 
Het Hof heeft bepaalde criteria ontwikkeld om vast te stellen of er in een concreet geval sprake is van een te beschermen religieuze manifestatie. Volgens het Hof valt een religie of overtuiging te identificeren als er sprake is van 'thought and conscience'. Het moet grofweg gaan om een geheel van opvattingen die onderling en met het geweten samenhangen (Labuschange 1994: 49). Daarbij moeten er aanwijzingen zijn dat het een (religie)praxis in een 'generally recognised form' betreft. Daarmee wordt aangesloten bij wat in algemene zin als een kenmerk van de betreffende religie wordt opgevat. De term religieuze praktijk zoals genoemd in art. 9 EVRM en in het bijzonder de daar gehanteerde term 'belijden' dekt daarom niet alle handelingen die ingegeven zijn of beïnvloed door een godsdienst (Thomassen 2004: 127). Daarbij moet het bovendien ook nog gaan om uit religie voortvloeiende noodzakelijke uitingen. Religieuze handelingen die niet als verplicht hoeven te worden opgevat, hoeven niet beschermd te worden. Dit ondervond een islamitische docent die graag op vrijdag een langere pauze wilde om de recent in de buurt gevestigde moskee te kunnen bezoeken. ${ }^{15} \mathrm{Hij}$ zag het moskeebezoek als 'een verplichting waaraan hij als het enigszins mogelijk was zou moeten voldoen' (Loenen 2006: 37). Volgens het Hof betrof het echter geen noodzakelijke uiting van godsdienst, onder meer omdat de man voorafgaand aan de vestiging van de moskee geen beroep had gedaan op zijn recht zijn godsdienst te belijden. Ten slotte moet in elke zaak worden vastgesteld of de betrokkene weet wat onder het belijden van zijn godsdienst moet worden verstaan, zijn overtuiging ernstig neemt en daarvan blijk geeft (Labuschange 1994: 49-50). Zo kon een pacifiste zich beroepen op de vrijheid van godsdienst, omdat haar overtuiging was te herleiden in de onderdelen denken en geweten en omdat de ernst waarmee de vrouw het pacifisme was toegedaan, buiten twijfel was. ${ }^{16}$

\section{Beperking van de vrijheid van godsdienst}

Voor de vaststelling of sprake is van een aantasting of beperking van de vrijheid van godsdienst zijn minder eenduidige criteria af te leiden. Vaak beantwoordt het Hof die vraag gelijktijdig met de vraag naar de rechtvaardiging van de beperking. Hiervan is een aantal voorbeelden te geven. Griekse Jehova's getuigen wilden hun kinderen niet laten deelnemen aan een parade ter ere van een Griekse feestdag, omdat zij die vanwege het militaristische kader in strijd achtten met hun geloofsopvatting. ${ }^{17}$ Het Hof vond de parade niet militaristisch en constateerde daarmee dat er geen sprake was van een inbreuk op hun vrijheid van godsdienst. Het feit 'dat de ouders daar zelf anders over denken is dus niet relevant' (Loenen 2006: 38). Ook in het geval van een zevendedagsadventist die niet tussen vrijdag- en zaterdagavond wilde werken, constateerde het Hof dat het conflict feitelijk arbeidsomstandigheden betrof waarbij de vrijheid van godsdienst niet zou zijn beperkt. ${ }^{18}$ Bovendien stelde het Hof dat de man de vrijheid had een andere baan te zoeken (Loenen 2006a: 305). Een soortgelijke redenering maakte het Hof in een zaak van apothekers die omwille van geweten geen anticonceptiva wensten te verkopen. ${ }^{19}$ Het Hof constateerde dat de apothekers hun opvattingen ook elders konden uitdragen en dat niet ook nog in hun apotheek hoefden te doen (Loenen 2006: 39). Opmerkelijk is dat het Hof hier het willen handelen volgens het (godsdienstig gevormde) geweten kennelijk op één lijn stelt met het 
willen verkondigen van de eigen godsdienst, terwijl er redenen zijn om die uit elkaar te trekken. De CGB maakt hier in vergelijkbare gevallen wel een nauwkeurig onderscheid, zonder vanzelfsprekend elk gewetensbezwaar te honoreren.

\section{Rechtvaardiging van beperking van godsdienst}

Om te bepalen of in een concreet geval een beperking - wanneer die eenmaal als zodanig is erkend - valt te rechtvaardigen, onderzoekt het Hof of de beperking (vaak de door de eiser bestreden beslissing) aan bepaalde eisen voldoet: de beperking moet proportioneel zijn aan het nagestreefde en in de wet beschreven doel. In de praktijk wordt daarbij onderzocht of de betreffende beperking noodzakelijk is voor de bescherming van de menselijke waardigheid en vrijheid of voor het respect voor democratische waarden. Volgens Thomassen (2004) leidt de vraag of de menselijke waardigheid niet in het geding is, relatief eenvoudig tot het verlenen van voorrang door het Hof aan bijvoorbeeld rechten van kinderen boven de vrijheid van godsdienst. In de hieronder beschreven jurisprudentie is dit geillustreerd.

Allereerst een zaak waarbij ouders die behoren tot de zevendedagsadventisten geen ontheffing kregen van de Luxemburgse autoriteiten om hun kind tijdens de periode van hun sabbatsverplichtingen van vrijdag- tot zaterdagavond niet te laten deelnemen aan verplichte onderdelen van het schoolcurriculum. ${ }^{20}$ In het onderwijsreglement was alleen voorzien in een ontheffing voor religieuze feestdagen en bepaalde erediensten, niet in een 'generieke ontheffing' (Loenen 20o6: 29). Volgens het Hof ging het recht van het kind voor de godsdienstvrijheid van de ouders. Ditzelfde oordeelde het Hof in een zaak waar ouders bezwaar hadden aangetekend tegen een Zweedse wet die lichaamsstraffen verbood, wat volgens die ouders in strijd was met hun godsdienstige overtuiging. ${ }^{21}$ 'Het belang van de staat om zwakken te beschermen vormt een rechtvaardiging voor het inperken van het recht van ouders' (29). Hoewel in beide gevallen het recht van het kind boven dat van de ouders gaat, kunnen ze niet eenvoudig op één lijn gesteld worden. In het eerste geval is het zelfs de vraag of er eigenlijk geen sprake is van een botsing tussen de vrijheid van ouders om kinderen religieus op te voeden en de wettelijke verplichting tot deelname aan het schoolcurriculum. In het tweede geval is het recht van het kind - geen fysieke straf - duidelijker.

In twee hoofddoekzaken in twee verschillende landen (Zwitserland en Turkije) is de vrijheid van godsdienst tegen andere belangen afgewogen. De zaak-Dahlab tegen Zwitserland ging over de vraag of een docente een hoofddoek mocht dragen. ${ }^{22}$ De vrouw was al enkele jaren op de school werkzaam voordat zij zich tot de islam bekeerde. Pas enkele jaren nadat ze begonnen was een hoofddoek te dragen, betwistte de directeur het recht om een hoofddoek te dragen omdat de neutraliteit van het onderwijs in het geding zou zijn. Van de Zwitserse rechter kreeg de vrouw ongelijk, omdat het recht op 'religieus neutraal' onderwijs van kinderen op een openbare school voorrang kreeg op haar recht om haar godsdienstige overtuiging uit te drukken. De Zwitserse rechtbank erkende op zichzelf het dragen van een hoofddoek als een mogelijk te beschermen godsdienstige uitdrukking, hoewel de 
beperking in dit geval te rechtvaardigen was. Het Hof stemde in met het oordeel van de Zwitserse rechter, omdat de invloed van het uitgesproken religieuze symbool (de hoofddoek) op de vrijheid van geweten en religie van de kinderen moeilijk was vast te stellen, zeker gezien de jonge leeftijd van de kinderen. Het Hof voegde daar zelf nog aan toe dat het dragen van een hoofddoek - gebaseerd op een voorschrift in de Koran - moeilijk was te verenigen met seksegelijkheid en 'met de boodschap van tolerantie of verdraagzaamheid, gelijkheid en non-discriminatie en respect voor anderen die docenten in een democratische samenleving aan leerlingen dienen over te dragen' (Loenen 2006: 30). In de zaak-Sahin (tegen Turkije) ageerde een studente tegen het beleid van een universiteit die religieuze uitingen, zoals het dragen van een hoofddoek, verbood vanwege strijd met het Turkse beginsel van secularisme. ${ }^{23}$ Naast de (herhaalde) constatering dat de gelijkheid van mannen en vrouwen en de tolerantie in een democratische samenleving in het geding waren, voegde het Hof een aspect uit de bijzondere context van de Turkse staat toe. Een verbod op het dragen van hoofddoeken was te rechtvaardigen vanwege de intrede van extremistische groeperingen die de Turkse seculiere staat mogelijk bedreigden, binnen welke context de dracht van hoofddoeken een sterke politieke betekenis krijgt (Loenen 2006: 32).

De Turkse hoofddoekzaak valt beter te begrijpen in de algemene lijn van het Hof om het seculiere karakter van de Turkse staat te beschermen. In die context is ook de zaak over de Turkse Refah Partisi (Welvaartspartij) behandeld. ${ }^{24}$ De partij die in 1995 de Turkse verkiezingen won, werd door de Turkse rechter verboden. De partij zou onder meer streven naar een pluralistische rechtsorde, waarbij moslims aan een ander (islamitisch) rechtsregime zouden worden onderworpen dan christenen en joden. Het Hof rechtvaardigde het verbod van de Turkse rechter, omdat de staat zijn verantwoordelijkheid voor de rechten van individuele burgers niet kan overdragen en individuen niet kan onderwerpen aan de statische regels van een godsdienst (Loenen 2006: 26). De staat mag geen afstand doen van zijn positieve verplichtingen om individuele rechten te garanderen. Daarbij oordeelde het Hof alvast dat de sharia in zichzelf in strijd is met de waarden van het EVRM, vanwege de benadering van het strafrecht, de juridische positie van vrouwen en de wijze waarop zij in alle onderdelen van het openbare en privéleven doordringt. Loenen (2006: 27-28) concludeert hieruit dat de staat volgens het EHRM niet hoeft toe te staan dat mensen naar eigen, op religie geïnspireerde waarden leven als die in strijd zijn met het EVRM.

Voordat we tot een afronding komen, besteden we nog aandacht aan jurisprudentie die vanwege de vergelijkbaarheid interessant is met de hierna beschreven Nederlandse jurisprudentie over botsing tussen godsdienst en vrijheid van meningsuiting. Het Hof laat uitlatingen die geïnspireerd zijn door religie niet vallen onder de vrijheid van godsdienst, maar onder de vrijheid van meningsuiting (art. 10 EVRM; Thomassen 2004: 133). Volgens Thomassen, zelf rechter bij het Europese Hof, valt uit de jurisprudentie niet op te maken dat vanuit een godsdienstige overtuiging minder respect hoeft te worden betoond aan anderen dan de vrijheid van meningsuiting vergt. Het grof beledigen van iemand vanwege zijn 
homoseksualiteit kan geen bescherming vinden in de vrijheid van godsdienst. Dit betekent volgens Thomassen geenszins dat de vrijheid om vanuit persoonlijke of religieuze overtuiging te discussiëren over homoseksualiteit verloren zou gaan. Deze blijft immers in essentie bestaan als alleen grove belediging daarbij verboden is. Iets soortgelijks geldt de bescherming van godsdienst. Directe aanvallen op godsdienst zijn niet beschermd, maar kritiek op instituties en leerstellingen wel (Dommering 2006: 166).

De bescherming van religieuze gevoelens uitte zich onder meer daarin dat het Hof preventieve censuur aanvaardde van de Oostenrijkse staat - censuur is in Nederland bij wet verboden - zonder dat op te vatten als schending van de vrijheid van meningsuiting. ${ }^{25}$ De censuur betrof een door katholieken als sterk blasfemisch ervaren film. Dit oordeel is opmerkelijk omdat het Hof zeer ruime grenzen stelt waar het de vrijheid van meningsuiting in het publieke debat betreft: daar zijn juist voor anderen uitermate onwelgevallige uitspraken beschermd vanwege de cruciale functie van het debat voor de democratie.

Uit de jurisprudentie valt af te leiden dat het EHRM de vrijheid van godsdienst als een van de grondslagen van de democratische samenleving ziet en als onontbeerlijk voor het pluralisme, maar geen bijzonder royale vrijheid van godsdienst garandeert (Loenen 2006: 24). De gewetensvrijheid is bijna absoluut, maar dat geldt zeker niet voor daarop gebaseerde gedragingen. Er wordt vrij makkelijk een noodzaak tot het beperken van de handelingsvrijheid aanvaard waarmee het beroep op de vrijheid van godsdienst vervalt.

\subsubsection{JURISPRUDENTIE VAN DE NEDERLANDSE RECHTER}

Het is lastig een overzicht te geven van de afwegingen van de rechter vanwege het grote scala aan typen zaken die zowel het strafrecht als het civiele en bestuursrecht beslaan. ${ }^{26}$ De Nederlandse rechter heeft een veel breder toetsingskader vergeleken met het EHRM en de CGB, die zich voornamelijk beperken tot respectievelijk het EVRM en de AWGB. ${ }^{27}$ De oordelen van de rechterlijke instanties geven tentatief inzicht in typen conflicten waarbij godsdienst een rol speelt. ${ }^{28}$ Het type conflicten voor de rechter is in de loop der tijd echter veranderd. Deze verschuiving is te verklaren door nieuwe wetgeving, de (andere) manifestatie van nieuwere godsdiensten in Nederland, de ontwikkeling van de horizontale werking van grondrechten en de instelling van de CGB. Het lijkt aannemelijk dat de oprichting van de CGB het aantal zaken voor de rechter heeft gereduceerd. Ook is veel jurisprudentie in bepaalde opzichten gedateerd geraakt. Dit geldt bijvoorbeeld voor oudere jurisprudentie rond aanhangers van voorheen 'niet-gevestigde' religies in Nederland als islam en hindoeïsme waarbij net als bij de van oudsher gevestigde religies een zekere kristallisatie in regelgeving heeft plaatsgevonden. Het betreft vaak een zekere accommodatie om aan religieuze verplichtingen te voldoen, zoals tot uitdrukking is gekomen in regelgeving rond (ritueel) slachten en de wet op de lijkbezorging (Labuschange 1994: 194). 


\section{Definitie en identificatie in de jurisprudentie van de rechter}

De Hoge Raad hanteert ten eerste het criterium dat de mogelijk te beschermen uiting 'naar haar aard, dus naar objectieve maatstaven gemeten, als godsdienstige handeling kan gelden'. Of elders, handelingen die 'naar hun aard in enigerlei vorm uitdrukking geven aan godsdienst of levensovertuiging' (zie De Boer 2004). Een zeer controversiële zaak in dit opzicht betrof de Kloosterorde der Zusters van St. Walburga, die naar eigen zeggen zwarte rituelen uit de cultus van het satanisme uitvoerden. ${ }^{29} \mathrm{Zij}$ beriepen zich dan ook op de vrijheid van godsdienst en het daaruit voortvloeiende recht van kerkgenootschappen op ongestoorde religieuze bijeenkomsten. Door een inval zou de politie dat recht hebben overtreden. Volgens de politie betrof het echter een seksclub waar 'zusters' seksuele diensten aanboden. Het Gerechtshof in Den Haag deelde dit oordeel, omdat de activiteiten van de zusters zich niet lieten onderscheiden van die in een gewone seksclub. Wel stelde het Hof in dat arrest dat het in de multiculturele samenleving moeilijker zou kunnen worden om duidelijke oordelen over godsdienst te vellen (De Winter 1996).

In vergelijking met het Europese Hof is de Nederlandse rechter veel voorzichtiger in het zelf beoordelen van bronnen en voorschriften van religie. Dit is te verklaren uit het zogenoemde leerstuk van de interpretatieve terughoudendheid, dat zijn oorsprong vindt in een arrest uit 1957. Daarin constateerde de Hoge Raad in een twist tussen kerkgenootschappen dat het niet aan de rechter is te treden of partij te kiezen in theologische geschillen: de interpretatie van heilige boeken laat de rechter zoveel mogelijk over aan gelovigen zelf. ${ }^{30}$ Dit leerstuk wordt door de Hoge Raad nog steeds vrij strikt gehanteerd. Bijna steeds wanneer een lagere rechter een beroep op de vrijheid van godsdienst afwijst vanwege alternatieve mogelijkheden om de Bijbel of Koran te interpreteren - welke badkleding staat de Koran bijvoorbeeld toe - volgt daarop een correctie van een hogere rechter. ${ }^{31}$

De individuele gelovige krijgt andersom niet alle ruimte zich op de vrijheid van godsdienst te beroepen. In het bekende Aow-arrest over een man die om godsdienstige redenen geen AOW-premie wenste af te dragen, stelde de Hoge Raad dat de vrijheid van godsdienst niet inhoudt dat ieder wettelijke voorschriften aan zijn godsdienstige opvattingen of overtuiging mag toetsen..$^{32}$ Vermeulen (2005: 246) stelt dat de terughoudende interpretatie van de rechter daaruit moet worden begrepen dat het individu binnen zekere marges zelf mag bepalen of zijn handelen ook een religieuze handeling vormt. Aan de andere kant kan er geen recht bestaan als ieder volledig individueel zijn eigen handelen juridisch zou kunnen definiëren. In sommige gevallen kan de rechter daarom een oplossing vinden door aan te sluiten bij de interpretatie van het volgens de religie zelf bevoegde gezagsorgaan. Het ontbreken van centraal leergezag (bijvoorbeeld in de islam) maakt dit lastig. Om die reden schakelt de rechter soms deskundigen in om de interpretatie van de betrokkenen te beoordelen. Dit was bijvoorbeeld het geval in de verderop te beschrijven zaak waarin de vraag rees of de imam El Moumni zich met zijn uitspraken over homoseksuelen op de Koran kon baseren. Voor sommigen is de noodzaak om soms deskundigen in te schakelen om een mogelijke interpretatie van een heilig boek te beoordelen al een teken dat de interpretatieve 
terughoudendheid wordt doorbroken: de deskundige doet immers precies wat de rechter zich niet wil veroorloven (Galenkamp 2005: 254).

Een vrij recent vonnis laat zien dat de rechter zijn weg zoekt in niet alleen het identificeren maar ook het waarderen van godsdienst, los van de belangenafweging die daarop volgt. Het is nog niet duidelijk of dit een te verwachten algemenere lijn is, maar het past wel binnen wetenschappelijke kritieken op jurisprudentie over religie in het algemeen. In het betreffende vonnis stelde de rechter dat een gelovige ook de risico's zal moeten dragen die voortvloeien uit de botsing tussen de eigen gedragingen en de belangen van anderen. In 2003 diende de zaak tussen een vrouw en haar ex-man om een verzoekschrift voor een omgangsregeling met hun beider kind te laten vaststellen. 33 De rechter ontzegde echter voorafgaand aan de zitting de vrouw de toegang tot de rechtszaal, omdat ze had aangekondigd een nikaab te zullen dragen. De rechter liet haar uitsluitend tot de zitting toe als ze ten minste haar gelaat en gezichtsexpressie toonde, bijvoorbeeld door haar nikaab voor een hoofddoek in te wisselen. De rechter baseerde zijn oordeel op de afweging dat 'een onderzoek naar feiten op basis van waarheidsvinding en een zorgvuldige belangenafweging' vraagt om zodanig duidelijke communicatie dat hij ook kennis kan nemen van houding en lichaamstaal van de procespartijen. ${ }^{34} \mathrm{Om}$ die reden is het dragen van een nikaab niet toegestaan, 'ook niet als dit kennelijk voortvloeit uit geloofsovertuiging en/of levensopvatting'. Volgens de rechter moet voorkomen worden dat een van beide procespartijen de rechter in de vervulling van zijn taak en de regels voor zorgvuldige procesvoering onder druk zet, 'omdat deze door partijen in plaats van door de rechter zelf naar believen zouden kunnen worden ingevuld'. Daarbij stelt de rechter dat art. 6 EVRM (recht op een eerlijk proces) niet is overtreden, omdat 'het de vrouw zelf (is) die door haar keuze de toegang tot de rechter blokkeert, althans de rechter wil dwingen tot een houding die zich niet verdraagt met zijn taakstelling'. 'Het risico dat zij hiermee creëert' is, volgens de rechter, dan ook voor haar eigen rekening. In deze afweging is cruciaal dat de rechter haar religie en de daaruit voortvloeiende gevolgen tot (slechts) een eigen keuze reduceert.

\section{Aantasting door godsdienst of niet}

$\mathrm{Bij}$ de bespreking van casus rond het thema godsdienst kan een rechterlijke uitspraak over de afweging van de vrijheid van godsdienst tegen de vrijheid van meningsuiting haast niet ontbreken. ${ }^{35}$ Er zijn diverse rechterlijke uitspraken die de nodige aandacht hebben gekregen, waarbij uitingen op grond van godsdienst op enigerlei wijze een rol speelden. Zo zijn de nodige zaken te noemen waarbij de vraag speelde of uitingen over godsdienst of gelovigen in strijd waren met diverse bepalingen van het Wetboek van Strafrecht. Hier is vooral de ontwikkeling in de jurisprudentie van belang. Daarin is cruciaal of 'mensen met een heilig boek onder de arm' meer beschermd worden dan anderen..$^{36}$

De Hoge Raad heeft zich enkele malen uitgesproken over de vraag wanneer beledigende uitlatingen over joden (door het christelijke echtpaar Goeree) en homoseksuelen (door diversen) strafbaar waren. Steeds onderzocht de rechter of de 
uitlatingen hun beledigende karakter en strafbaarheid konden verliezen door de aanwezigheid van 'disculpatiegronden', waaronder een succesvol beroep op de vrijheid van godsdienst. De rechter moest daarom altijd vaststellen of de concrete uitlating op een godsdienstige opvatting herleidbaar was. De Hoge Raad trad ook hier niet in theologische leerstelligheden, zodat de vaststelling dat iemand zich op Bijbel of Koran kon beroepen, kon volstaan. ${ }^{77}$ Daarbij was soms wel aan de orde of de wijze waarop iemand zich uitdrukte - bijvoorbeeld een Hengelose dominee die homoseksualiteit een vieze en vuile zonde noemde - voldoende dicht bij het heilige boek (hier de Bijbel) van de betreffende persoon lag om daaraan potentieel een disculpatiegrond te ontlenen. ${ }^{8}$ Daarnaast weegt de Hoge Raad ook nog mee (tweede mogelijke disculpatiegrond) of een uitlating misschien een bijdrage aan het maatschappelijke debat is. Precies op dit punt is de Hoge Raad bekritiseerd, omdat hij gelovigen daarmee dubbel zou beschermen, namelijk ook door de vrijheid van meningsuiting. Nadat eenmaal een uiting als bijdrage aan het maatschappelijke debat is opgevat, antwoordt de Hoge Raad zelden bevestigend op de vraag of de bijdrage misschien onnodig grievend was.

Zowel het EHRM als de Hoge Raad stelt weinig eisen aan een bijdrage aan het maatschappelijke debat, vanwege de grote betekenis van het vrije maatschappelijke debat voor de democratie. Voor de Hoge Raad is vooral van belang of de uitlatingen voor de verdachte van betekenis voor het maatschappelijk debat waren. 39 Daarvoor moet de uitlating kunnen worden opgevat als reactie op andere uitlatingen of in elk geval een context die de uitlating op enigerlei wijze begrijpelijk maakt. De Hoge Raad vatte de krasse uitspraken over homoseksuelen van de Hengelose dominee in reactie op een televisie-uitzending uit de vs op als een poging van de verdachte 'vanuit zijn geloof de mensheid te beschermen' en daarmee als een bijdrage aan het maatschappelijke debat. Tevens kwam daarmee de vrijheid van godsdienst als 'zelfstandige disculpatiegrond' voor belediging te vervallen.

De Hoge Raad stelt steeds prominenter de vraag voorop of een godsdienstige uiting zelf als een bijdrage aan het debat kan worden opgevat. Daarmee worden ongeveer dezelfde eisen gesteld aan de godsdienstige uiting als aan de meningsuiting. De 'dubbele' bescherming van religieuzen lijkt daarmee te vervallen, hoewel Nieuwenhuis (2003) de religieuzen nog steeds als extra beschermd ziet: alle geloofs- en moraaluitspraken kunnen wel opgevat worden als bijdrage aan het maatschappelijke debat. Volgens Mevis is nu juist de ultieme gelijkstelling bereikt tussen wel en niet op geloof geïnspireerde bijdragen aan het maatschappelijke debat.

Wanneer deze jurisprudentielijn wordt doorgezet hoeft de rechter in het vervolg mogelijk niet meer de lastige vraag te beantwoorden welke uitlatingen werkelijk uit godsdienst voortvloeien. Het probleem van de interpretatieve terughoudendheid lijkt daarmee gedeeltelijk opgelost. Nadelig blijft dat er nog weinig criteria zijn vast te stellen of werkelijk sprake is van (van een poging tot) een bijdrage aan het maatschappelijk debat. Zo is, volgens Mevis in de noot bij het arrest over de Hengelose dominee, kennelijk geen 'bepaald niveau van sereniteit' nodig voordat 
een uiting beschermwaardig is. Daarbij lijkt ook de strafrechtelijke bescherming van kwetsbare groepen als homoseksuelen tegen discriminatoire uitlatingen te verdwijnen, tenzij ze onnodig grievend zijn of oproepen tot haat of geweld. In de discussie over de nota Grondrechten van het kabinet stemde het merendeel van de Tweede Kamer in met deze jurisprudentie waarin gelijke ruimte wordt geboden aan godsdienstigen en niet-godsdienstigen om vrijuit te spreken. Een rechtsgang lijkt voor de klager alleen succesvol te kunnen zijn bij beledigingen die niet bijdragen aan het maatschappelijke debat, onnodig grievend zijn of aanzetten tot haat of geweld.

Overigens verleent de rechter zelden bescherming aan mensen die diverse uitingen als godslastering opvatten. Zo wees de rechter bij voorbeeld een eis van tienduizenden hindoes tegen een pornobedrijf dat de meisjesnaam Shiva (ook de hoogste hindoegod) als handelsnaam had gekozen af, onder meer omdat het een algemene meisjesnaam betrof die al eerder - zonder op bezwaren te stuiten - als handelsnaam was gekozen. $4^{\circ}$ Volgens Vermeulen (2007) is het correct te stellen dat belediging (van goden) niemand belemmert in zijn eigen godsdienstoefening. Zoals we zagen oordeelde het Europese Hof hier anders over. Het Hof achtte het wel een schending van de mogelijkheid de godsdienst te belijden op het moment dat mensen ernstig gegriefd werden.

\subsection{3 “JURISPRUDENTIE" (OORDELENPRAKTIJK) VAN DE CGB}

De Commissie Gelijke Behandeling (CGB) is naast de rechter aangesteld om het beleid en gedrag van rechtspersonen als werkgevers en aanbieders van goederen en diensten te toetsen aan de AWGB en enkele andere wetten die een nadere uitwerking zijn van artikel 1 Grondwet. De kern van de AWGB is in paragraaf 2 besproken. De wetgever gaf de CGB in de Memorie van Toelichting bij de AWGB uitdrukkelijk de opdracht de gelijkebehandelingsnorm nader te ontwikkelen en zorg te dragen voor continuïteit en juridische consistentie in de uitleg van de wet. De CGB zelf noemt zich een 'gespecialiseerd handhavingsorgaan', wat misschien een betere kwalificatie is dan de CGB als 'rechterlijke instantie' aan te duiden (oodeel 2001/150). Niettemin heeft de wetgever via de CGB vooral een laagdrempelige rechtsgang willen creëren voor hen die weliswaar ook naar de rechter kunnen stappen, maar op die weg in de praktijk allerlei barrières zien opgeworpen.

Sinds 1994 heeft de CGB een keur aan zaken - zij het beperkter dan de rechter over gelijke behandeling en godsdienst voorgelegd gekregen over onder meer: directe afwijzing van werknemers wanneer zij een (andere) godsdienst belijden of homoseksueel zijn, kleding die aan godsdienst uitdrukking geeft (hoofddoeken en bedekkende gymkleding), gewetensbezwaren tegen het verrichten van bepaalde handelingen en het werken op religieuze feest- of rustdagen, de vraag of (van oorsprong confessionele) instellingen IVF-behandelingen mogen onthouden aan alleenstaanden en lesbische paren, selectie van leerlingen en een trouwambtenaar die bezwaar aantekent tegen het sluiten van 'het homohuwelijk' ${ }^{41}$ 
Achter de oordelen van de CGB gaat een strikt stappenplan (de term is van de CGB zelf) c.q. toetsingssystematiek schuil waarin het eerder in paragraaf 19.3 beschreven algemene toetsingskader herkenbaar is. Dit stappenplan is deels in de AWGB voorgeschreven en door de CGB verder ontwikkeld. De oordelen van de CGB zijn altijd gericht op het constateren of er sprake is van strijd met de AWGB (verbonden onderscheid) of niet. We bespreken het strikte stappenplan waarbij enkele casussen als illustratie dienen.

Ook de CGB hanteert deels eigen criteria om de vrijheid van godsdienst af te bakenen. De CGB stelt vast tot welke godsdienst de klager zich rekent en of hij consistent is in zijn uitleg van die godsdienst. Vervolgens kijkt de CGB ook naar de godsdienstbeleving van de betrokkenen en niet alleen naar de officiële leer van een religieuze stroming. Bij de concrete toetsing aan haar criteria kijkt de CGB niet of de beleving van de benadeelde 'alom gedeeld wordt' binnen de religieuze stroming. Het feit dat de meeste islamitische vrouwen geen nikaab dragen, hoeft voor hen die dat wel doen geen belemmering te zijn om zich te beroepen op de vrijheid van godsdienst. ${ }^{42}$ De CGB beoordeelt net als de Nederlandse rechter geen theologische leerstellingen.

De precieze criteria (en ook het onderscheid tussen levensovertuiging en godsdienst) worden helder in een recent oordeel over de vraag of iemand met dreadlocks zich kan beroepen op de grond godsdienst (oordeel 2005/162). Volgens de CGB staat in een godsdienst een opperwezen centraal, waar deze in een levensovertuiging ontbreekt. Deze laatste kenmerkt zich door 'een min of meer coherent stelsel van ideeën, waarbij sprake is van fundamentele opvattingen over het menselijk bestaan'. 'Noodzakelijk is dat deze opvattingen niet slechts individueel worden gehuldigd, maar dat sprake is van gemeenschappelijke opvattingen.' De verzoeker in dit oordeel stelde dat hij dreadlocks droeg - om die reden was hij binnen zijn bedrijf niet bevorderd - vanwege het nazireeërschap waarmee hij uitdrukking gaf aan het rastafarigeloof. Hoewel sommige aanhangers van rastafari eerder spreken over een levensstijl, zijn er ook die Haile Selassie (keizer van Ethiopië) opvatten als goddelijke entiteit. Op grond daarvan constateert de CGB - in navolging van het constitutionele hof van Zuid-Afrika - dat er sprake is van een godsdienst.

Gedragingen genieten volgens de CGB dezelfde mate van bescherming als de overtuiging zelf. De wet beschermt niet alleen het huldigen van godsdienstige opvattingen, maar stelt mensen ook in staat zich ernaar te kunnen gedragen. Wel moeten gedragingen om bescherming te genieten 'mede gelet op de betekenis van godsdienstige voorschriften en regels, rechtstreeks uitdrukking geven aan een godsdienstige overtuiging' (Den Boer 2004: 154), waardoor niet elk religieus gedrag beschermd is door de wet. ${ }^{43}$ De CGB hanteert in tegenstelling tot de rechter ook een 'individueel gewetensmotief', omdat de CGB stelt dat 'het (...) eigen (is) aan een geloofsovertuiging dat betrokkenen hieraan veel gewicht toekennen, waarvan niet, dan wel ten koste van de eigen persoonlijkheid, zomaar kan worden afgeweken'.44 


\section{Ongelijke behandeling op grond van godsdienst}

In veel zaken uit de beginjaren van de Commissie constateerde zij zonder veel moeite direct onderscheid op grond van godsdienst. Het ging vaak over vrouwen die vanwege hun hoofddoek werden geweigerd in een algemeen bedrijf of openbare school. Andersom werd soms ten onrechte naar godsdienst gevraagd voor een functie waarvoor dit niet relevant was. Zo mocht een werkgever voor de functie meubelmaker geen christelijke medewerker zoeken.

Het is lastiger om te constateren of er sprake is van strijd met de AWGB wanneer een specifieke maar op zich neutrale maatregel ten grondslag ligt aan de ongelijke behandeling. In dat geval moet de CGB beoordelen of voor die maatregel een objectieve rechtvaardiging valt te geven, bijvoorbeeld omdat die noodzakelijk is voor het gestelde (zwaarwegende) doel van de betreffende instelling. De interpretatievrijheid van de CGB illustreren we hieronder met twee oordelen over situaties waarin respectievelijk een islamitische man en vrouw weigerden iemand van het andere geslacht een hand te geven. De man die uit geloofsoverwegingen vrouwen geen hand wilde schudden, solliciteerde naar een baan als reproductiemedewerker bij een school. De CGB erkende dat het hier ging om een rechtstreekse uitdrukking van een godsdienstige overtuiging die daarmee in principe bescherming verdient van de AWGB (oordeel 2002/22). De school wees de kandidaat echter af, omdat zijn gedrag in strijd zou zijn met haar richtlijnen over het in acht nemen van algemene fatsoensnormen die nodig zijn voor representatie en gelijke behandeling van mannen en vrouwen. Het was denkbaar dat de man in situaties zou belanden waarin het schudden van een hand wenselijk was. Volgens de CGB maakte de school geen direct onderscheid, omdat de functie-eis niet direct mensen met een specifieke godsdienstige opvatting ongeschikt zou verklaren. Er was sprake van indirect onderscheid, omdat deze op het oog neutrale regel in het bijzonder mensen treft die vanwege hun geloof geen handen mogen schudden. Echter, door de objectief te rechtvaardigen richtlijnen van de school kon niet van verboden onderscheid worden gesproken. 'Het niet geven van een hand (kan) opgevat (...) worden als een ontkenning van de gelijkwaardigheid van mannen en vrouwen (welk beginsel evenzeer bescherming vindt in de AWGB).' Elders stelt de CGB over deze zaak dat de aanspraak van de sollicitant op gelijke behandeling moet 'worden afgewogen tegen de aanspraak van zijn nieuwe vrouwelijke collega's op een respectvolle bejegening' (CGB 2005: 17). Opmerkelijk is dat de CGB in 2006 op haar eerdere wijze van oordelen terugkwam. Ze stelde dat een islamitische vrouw die mannen geen hand wil geven er ook voor kan kiezen om zowel mannen als vrouwen op dezelfde respectvolle wijze, maar zonder handen schudden te begroeten (oordeel 2006/51).45 De instelling die de betreffende vrouw voor haar opleiding tot onderwijsassistent weigerde zou ook niet hard kunnen maken dat 'handen schudden' een essentieel deel van de opleiding was. Daarmee verviel de noodzaak en rechtvaardiging van de onderscheid makende regel.

In een ander veelbesproken oordeel stelde de CGB dat een gezichtsbedekkende sluier moet worden opgevat als een rechtstreekse uiting van een godsdienstige opvatting. De school die leerlingen het dragen van de sluier in school verbood, 
beriep zich ter rechtvaardiging van het verbod op een 'drieledig doel, te weten het bevorderen van de onderlinge communicatie, het kunnen vaststellen van de identiteit van de deelnemers aan de opleiding en de naleving van de op verweerder rustende wettelijke taken' (oordeel 2003/40). De commissie achtte deze doelstelling voldoende zwaarwegend om te constateren dat geen sprake was van discriminatie en dat een verbod op een gezichtsbedekkende sluier passend en noodzakelijk was. Eerder beoordeelde de CGB het verbod van een school op het dragen van een chador in de klas nog als ongerechtvaardigd, omdat het verbod niet werkelijk in een behoefte zou voorzien. Er waren leraren die de leerlinge met chador wel onderwijs wilden geven, de chador kwam niet veel voor en de nonverbale communicatie zou ondanks beperkingen nog wel mogelijk zijn (oordeel $2000 / 63)$.

\section{Gewetensbezwaren en gelijke behandeling}

Hoewel bepaalde gewetensbezwaren zijn beschermd onder de grond godsdienst, zijn inbreuken daarop toch te rechtvaardigen. De mogelijkheid om zich te beroepen op gewetensbezwaren geldt ook voor wie zich op een levensovertuiging of (naar het zich laat aanzien, aldus de CGB) politieke gezindheid beroept (2005: 21). Bezwaren tegen het zelf moeten verrichten van bepaalde handelingen of werken op bepaalde feest- of rustdagen zijn op zich beschermd, maar dat geldt niet voor gewetensbezwaren tegen gedragingen van anderen. Dit betekende dat de weigering van een orthodox gereformeerde verpleegkundige om zelf ingeënt te worden of om bij te dragen aan een medische handeling als abortus wel onder bescherming van de AWGB valt, maar dat dit niet geldt voor de weigering een patiënt te verzorgen die zojuist een abortus heeft ondergaan (2000/13). De bescherming betreft alleen handelingen die direct met (voorbereidingen op) een medische ingreep te maken hebben. De vraag of een gewetensbezwaar valt te honoreren hangt bovendien sterk af van de belangen van andere partijen en de mogelijkheden om een organisatie ondanks de gewetensbezwaarde goed te laten functioneren. Zo mocht een niet-ingeënte verpleegkundige niet als werknemer op een consultatiebureau worden geweigerd, omdat de kans op besmetting van kinderen gering werd geacht (oordeel 2001/89). In plaats van de sluiswachter die niet op zondag wilde werken - maar alleen in noodsituaties beschikbaar wilde zijn zouden voldoende collega's ingeroosterd kunnen worden (oordeel 2006/147). Het bezwaar van een Jehova's getuige die als leerling-verpleegkundige geen bloed wilde toedienen, werd door de Commissie niet gehonoreerd vanwege roostertechnische problemen met nachtdiensten (oordeel 97/46).

\section{Beperking door rechten van anderen}

In deze paragraaf bespreken we een specifiek geval dat eveneens betrekking heeft op het honoreren van gewetensbezwaren, maar waar ook heel duidelijke rechten van anderen in het geding zijn. De CGB moest oordelen over de zeer lastige kwestie van de trouwambtenaar die gewetensbezwaar had tegen het sluiten van homohuwelijken en van wie het arbeidscontract niet verlengd werd. De CGB redeneerde - strikt volgens haar stappenplan - dat er sprake was van een gewetensbezwaar dat voortvloeide uit godsdienstige overtuiging en dat er bovendien 
in de gemeente voldoende ambtenaren waren om in de trouwbehoefte van paren van gelijk geslacht te kunnen voorzien. De CGB constateert op opmerkelijke wijze dat het hier om indirect onderscheid gaat. Ze stelt dat de maatregel van de gemeente dat iedereen alle paren moet trouwen vooral die mensen treft die bezwaren hebben tegen het homohuwelijk. Omdat dat nu eenmaal meestal godsdienstige bezwaren zijn, heeft de gemeente indirect onderscheid gemaakt: een neutrale maatregel die tot specifieke achterstelling van godsdienstigen leidt. Voor dat indirecte onderscheid is volgens de Commissie geen rechtvaardiging te vinden. Niet alleen de CGB zelf was eigenlijk ongelukkig met de uitkomst van het strikte stappenplan. Later stelde de CGB (2005) in het algemeen ook voor niet te moeten willen oordelen in zaken waarbij een breder toetsingskader tot een heel ander oordeel zou leiden. Loenen (2004: 146) bekritiseerde de uitspraak, omdat 'het niet zo kan zijn dat een beroep om bij de uitoefening van een openbare functie naar eigen godsdienstige overtuigingen te handelen, leidt tot discriminatie van andere burgers'. Ook zou de CGB veel meer vrijheid hebben dan ze deed voorkomen. Zo had de CGB niet hoeven te oordelen dat er sprake was van indirect onderscheid, waarvoor dan een objectieve rechtvaardiging gegeven zou moeten worden. In andere zaken blijkt het juist een bewuste keuze van de CGB te stellen dat er sprake is van indirect in plaats van direct onderscheid, omdat ze daarmee meer ruimte heeft om tot een genuanceerde afweging te komen (Gerards 2002: 611).

\section{Wettelijke rechtvaardigingen van beperkingen op gelijke behandeling}

Uitzonderingen die op het beginsel van gelijke behandeling kunnen worden gemaakt vloeien voort uit andere grondrechten, zoals de vrijheid van onderwijs en de vrijheid van vereniging. De CGB legt de toegestane beperkingen op de plicht tot gelijke behandeling, die voortvloeien uit andere grondrechten, zo restrictief mogelijk uit. Op deze wijze geeft de CGB zoveel mogelijk voorrang aan gelijke behandeling (en art. 1 van de grondwet), wat niet vanzelfsprekend is voor de 'gewone' rechter. Instellingen op politieke, godsdienstige of levensbeschouwelijke grondslag (waaronder het bijzonder onderwijs) hebben het recht uitdrukking te geven aan hun grondslag. $\mathrm{Zij}$ mogen bijzondere eisen stellen als die nodig zijn voor het vervullen van een functie in hun instelling, mits zij geen onderscheid maken op grond van het enkele feit van politieke gezindheid, ras, geslacht, nationaliteit, hetero- of homoseksuele gerichtheid of burgerlijke staat. Deze constructie kreeg veel bekendheid, omdat het instellingen op bijzondere grondslag, onder condities, de mogelijkheid biedt om bijvoorbeeld homoseksuele leraren te weigeren. In aanloop naar de wet werden met name op dit vlak veel zaken verwacht. In de praktijk werden twee zaken aan de CGB voorgelegd, ${ }^{46}$ waarvan eenmaal op verzoek van een school zelf (oordeel 1999/38). Omdat de school een leraar had afgewezen om het enkele feit dat hij homoseksueel was, oordeelde de CGB dat sprake was van direct en niet te rechtvaardigen onderscheid. In het geval waar een reformatorische school alle sollicitanten een formulier voorlegde met vragen naar opvattingen over levenswijzen en huwelijk was volgens de Commissie geen sprake van 'enkele feit'-discriminatie van homoseksuelen (oordeel 1996/39). 
De instellingen mogen echter geen bijzondere eisen stellen voor functies waarin werknemers geen bijdrage hoeven te leveren aan het realiseren van de grondslag, zoals de schoonmaker of roostermaker. Een beroep op de grondslag wordt door de CGB bovendien alleen gehonoreerd indien het beleid van de instelling berust op de grondslag en ook in de praktijk gestalte krijgt, de gestelde eisen nodig zijn voor het realiseren van de grondslag en de instelling ook consistent is in de handhaving. Zo onderzoekt de CGB of er geen aanwijzingen zijn dat de instelling de eigen grondslag niet zo serieus neemt. De vraag of het beleid ook daadwerkelijk nodig is voor het realiseren van de grondslag wordt slechts marginaal getoetst: kan de instelling in redelijkheid beslissen zoals ze heeft gedaan?

De uitzonderingsbepalingen gelden niet voor openbare scholen. Zij mogen geen eisen stellen aan docenten en leerlingen die in de AWGB zijn verboden ter verwezenlijking van hun niet-religieuze grondslag. Alle levensovertuigingen dienen op een openbare, niet-bijzondere school geëerbiedigd te worden. Bijzonder-neutrale scholen, die in hun statuten expliciet uiterlijke kenmerken van religie in hun school niet toestaan, mogen hier hun personeel op selecteren. Ook een leraar uit het openbaar onderwijs hoefde zijn overplaatsing naar het 'christelijke deel' van een (samenwerkings)school niet te aanvaarden (oordeel 2003/114). Hiermee is aansluiting gezocht bij het EVRM (en de uitleg daarvan) waarin onder de vrijheid van godsdienst ook het niet hebben of belijden van een godsdienst is beschermd.

Is de eis van neutraliteit van bijzondere ambtenaren een te rechtvaardigen beperking? De oordelen van de CGB zijn niet alleen te begrijpen uit haar strikte stappenplan, maar ook uit de specifieke uitleg die zij geeft aan bepaalde begrippen, zoals het begrip neutraliteit. De CGB heeft hierover een andere opvatting dan de nog te publiceren, langverwachte kledingrichtlijn van het ministerie van Justitie over religieuze kentekenen tijdens rechtszittingen. De CGB uit haar kritiek door uit te gaan van haar toetsingskader, waarbij steeds onderzocht moet worden of ongelijk behandeld wordt ten opzichte van de 'maatmens'. Deze 'maatmens' moet op een aantal relevante punten gelijk zijn aan degene die betwist gelijk behandeld te zijn. Als maatmens voor de 'neutrale rechter' wordt volgens de CGB de 'blootshoofds opererende' functionaris gekozen. Deze norm voor neutraliteit door het niet bedekken van het hoofd is echter een cultureel bepaalde waar op af te dingen valt. De maatmens verwijst volgens de CGB te veel naar een dominante maar 'onzichtbare standaard' die bovendien is ontstaan in een 'religieus, sociaal en cultureel bepaalde context', die nu aan het veranderen is. 'Tot voor kort kon iedereen eenvoudig voldoen aan deze norm, zonder te botsen met de eigen overtuiging' (CGB 2005: 38). Bovendien sluit blootshoofdheid ook niet uit dat de rechter toch een orthodoxe godsdienstige of politieke overtuiging huldigt. De CGB stelt daar tegenover dat neutraliteit ook kan worden bereikt door het personeelsbestand pluriform te laten zijn waarbij de godsdienst van mensen niet ter zake doet. De CGB zoekt in haar oordelen expliciet naar alternatieve oplossingen om nadere doorwerking te verlenen aan de AWGB volgens haar perspectief. Door aan een oordeel een dergelijke aanbeveling toe te voegen, gaat de CGB verder 'dan wat bij rechtsprekende colleges gebruikelijk is' (Den Boer 2004: 159).47 


\subsection{LASTIGE KWESTIES EN NIEUWE VRAGEN}

Ondanks aanbevelingen naar de rechter te gaan, bestaat er onenigheid over de wenselijkheid dat ook werkelijk te doen. Dit hangt niet alleen samen met de voorkeur voor het publieke debat, maar ook met kritiek op de oordelen van de rechter. Deze kritiek hangt samen met de lastige kwesties van het moeilijk kunnen identificeren van godsdienst en het niet scherp beargumenteren waarom en hoe belangen precies tegen elkaar zijn afgewogen. Er is kortom kritiek op de wijze waarop rechterlijke instanties alle drie toetsingsvragen (begin paragraaf 19.3) die bij conflicten rond godsdienst spelen, beantwoorden. Na een korte reflectie op enkele alternatieven voor conflictoplossing rond godsdienst sluit deze bijdrage af met een pleidooi voor het voorlopig eerst verbeteren van de argumentatie van de rechter.

\section{Identificatie van godsdienst}

Dit hoofdstuk laat zien dat de discussie over de begrippen religie, godsdienst en neutraliteit, zoals naar voren kwam in de bijdrage van Van de Donk en Plum in het eerste luik van deze bundel, niet slechts een theoretische is maar levendig speelt in de juridische praktijk. Daarbij vallen twee aspecten in het bijzonder op.

Ten eerste is het niet eenvoudig het eens te worden over de vraag of er überhaupt wel sprake is van een godsdienstige uiting. Dit is zowel ingegeven door onbekende (of soms al weer door het grote publiek vergeten) manifestaties van meer gevestigde godsdiensten, als door de ontwikkeling van individueel vormgegeven godsdienst (van 'aanhangen' kan lastig gesproken worden). Voor de rechter zullen deze vormen van religie lastiger worden - als de 'nieuwe religieuzen' al een beroep op de vrijheid van godsdienst doen - omdat ze mogelijk geen vaste 'heilige teksten' en gebruiken, noch een aanwijsbare gemeenschap kennen.

Ten tweede leiden de consequenties van de identificatie van bepaalde uitingen en handelingen als godsdienst tot steeds scherpere kritiek. Het gaat dan niet zozeer om de identificatie an sich, maar om de bescherming die in principe zou moeten worden geboden aan gedragingen en uitlatingen die als niet (meer) beschermwaardig of zelfs verwerpelijk worden beschouwd. Hoewel de rechter altijd nog moet oordelen of bepaalde godsdienstige uitingen dan wel beperkingen daarop zijn te rechtvaardigen, kan hij dit vermijden door striktere criteria voor de identificatie van godsdienst te hanteren. Dit valt te illustreren met de al besproken oordelen van de CGB over bezwaren van sommige moslims om personen van het andere geslacht een hand te geven. Oud-commissielid Den Boer vraagt zich echter af of - in tegenstelling tot de uitspraak van de CGB - de weigering een hand te schudden niet buiten de reikwijdte van het begrip godsdienst had moeten worden verklaard, vanwege het feit dat dit in Nederland volgens '(tamelijk) algemeen aanvaarde omgangsvormen onfatsoenlijk (...)' is. Hij verwijst naar een recent etiquetteboek (Den Boer 2004: 160). Het zou misschien wel als religieus gefundeerd gewetensbezwaar of als 'indirect daaruit voortkomend maatschappelijk handelen' kunnen worden gezien, maar daardoor had het minder bescherming van de AWGB gekregen. De CGB zou volgens hem nauwer moeten aanslui- 
ten bij de volgens het Europese Hof alleen te erkennen religiepraxis in een 'generally recognised form' (Den Boer 2004) en zich minder interpretatievrijheid moeten veroorloven. We zagen al dat het Europese Hof in concrete gevallen inderdaad gemakkelijker dan de Nederlandse rechter en de CGB constateert dat er geen sprake is van godsdienst, waardoor het ook minder vaak de afweging hoeft te maken of een beperking kan worden gerechtvaardigd of niet. Het Hof heeft ook 'minder last' van het leerstuk van de interpretatieve terughoudendheid zoals dat in Nederland is ontwikkeld. Op verschillende plaatsen stelde het Hof zelfs dat godsdienst niet in het geding was, terwijl door de Nederlandse rechter vermoedelijk meer ruimte zou worden gelaten aan het individu om dat te beoordelen. Zo stelde het Hof dat een militaristisch ogende manifestatie niet in strijd was met de pacifistische overtuiging van Jehova's getuigen.

De beschreven jurisprudentie rond de vrijheid van meningsuiting en de enorme aandacht voor de Deense cartoonrel is in het bijzonder een katalysator geweest voor de discussie over de (on)mogelijkheid van de identificatie van godsdienst door de rechter die nog versterkt wordt door de ervaring van ongelijke grondwettelijke bescherming tussen godsdienstigen en niet-godsdienstigen. Een van de oplossingen die genoemd worden voor de kennelijke impasse waarin de identificatie van godsdienst lijkt te zijn beland, is het minder dogmatisch hanteren van de interpretatieve terughoudendheid (Galenkamp 2005). De rechter zou afzijdig kunnen blijven in geschillen tussen gelovigen onderling, maar wel degelijk kunnen oordelen wanneer een gelovige zich ten opzichte van een ander op zijn specifieke interpretatie beroept. Dit geldt bijvoorbeeld wanneer gelovigen met hun uitspraken over homoseksuelen de grenzen van het betamelijke overschrijden. Uiteindelijk zou de rechter moeten toetsen of mogelijk het wederzijds respect en de menselijke waardigheid - waar gelovigen en ongelovigen zich in kunnen herkennen - in het geding is. Daarmee is al een belangrijk deel van wat de vrijheid van godsdienst wil beschermen, beschermd. Opmerkelijk is dat 'lagere' rechters in Nederland vaak al veel verder gingen in het interpreteren van godsdienst - overigens net als het Europese Hof - maar daarin steeds (bijvoorbeeld door de Hoge Raad) gecorrigeerd werden. Het verschil tussen Nederlandse rechters en het Europese Hof zit hierin dat de Nederlandse rechters vaak beredeneren waarom ze een alternatieve interpretatie van de bronnen waarop een gelovige zich beriep, soms juister achten, terwijl het Europese Hof er vaker voor kiest om (slechts) te stellen dat een beroep op de vrijheid van godsdienst in het concrete geval niet gehonoreerd kan worden.

Naast het pleidooi om de teugels van de interpretatieve terughoudendheid te laten vieren, richten velen zich meer op het aanpakken van nog bestaande 'privileges' van godsdienstigen, die zich op een 'extra grondrecht' zouden kunnen beroepen (De Winter 1996). In die context is ook het nut en de rechtvaardigheid betwist van bijzondere bescherming van groepen godsdienstigen tegen belediging in art. 137 Sr. Cruciaal daarbij is de stelling dat alleen die kenmerken bescherming verdienen die onlosmakelijk met de persoon verbonden zijn en waarvan iemand ook geen afstand kan doen (geslacht, ras, seksuele geaardheid en eventu- 
eel ook handicap) (Dales 20o6). Zelfgekozen kenmerken, zoals godsdienst, zouden geen vergelijkbare bescherming verdienen. Overigens is de stellingname dat godsdienst een eigen keuze is en om die reden niet zomaar bescherming verdient ook te zien in de zaak over de vrouw met nikaab die in de rechtszaal werd geweigerd. Hoewel haar gedrag als godsdienstig werd erkend, zou zij toch zelf de rechtsgang blokkeren. Volgens Van der Burg (2003) reduceert deze redenering godsdienst gemakkelijk tot louter subjectieve keuze, terwijl de vrijheid van godsdienst is gebaseerd op de overtuiging dat van een godsdienstige overtuiging niet gemakkelijk afstand gedaan kan worden. Een uiterste optie betreft de afschaffing van het grondwetsartikel van de vrijheid van godsdienst, wat deels in het verlengde ligt van het gelijkstellen van een godsdienstige overtuiging met een mening. Aspecten van de vrijheid van godsdienst zouden ook zijn gedekt met de vrijheid van meningsuiting, het recht op vereniging en vergadering en het recht op een privéleven (zie bijvoorbeeld Van Schie 2006). $4^{8}$

\section{Gebrekkige argumentatie}

De tweede lastige kwestie betreft de argumentatie van de rechter bij de afweging van botsende belangen. In de jurisprudentie zijn we een aantal oordelen tegengekomen waarbij onduidelijk is hoe precies tot de afweging gekomen is, welke criteria zijn gehanteerd en hoe het gewicht van de verwikkelde belangen bepaald is. Verschillende auteurs wijzen erop dat bij het toekennen van gewicht van in het geding zijnde belangen en zeker bij fundamentele waarden, eventueel persoonlijke opvattingen van de rechter of in elk geval diens intuïtie een rol kunnen spelen (Gerards 2006: 4). Dit geldt zeker in een open systeem waarin de rechter bij zijn interpretatie ook rekening moet houden met maatschappelijke gevoelens. Vooral bij (botsende) grondrechten is dit lastig, omdat deze bij uitstek 'tegen de verdrukking in functioneren' (Mevis in annotatie) en juist bescherming bieden tegen die handelingen en uitlatingen die door anderen - mogelijk zelfs velen in de maatschappij - onbegrijpelijk zijn en tegen de borst stuiten. Zowel ten aanzien van de vrije meningsuiting als bij geloofsverkondiging is wel gesteld dat die nu juist grievend en heftig appellerend mogen zijn, omdat ze juist bedoeld kunnen zijn om anderen van hun ideeën af te brengen. ${ }^{49}$ De rechter moet dus rekening houden met wat als maatschappelijk aanvaardbaar moet worden opgevat, maar ook weer zodanig dat het recht om af te wijken van het gangbare niet te veel wordt aangetast. De Blois (2004: 200) vraagt zich echter af wat nog 'common ground' is voor de rechtsvorming als het pluralisme toeneemt. Op grond van welke bevindingen constateert de rechter wat als geldend wordt beschouwd? Zie bijvoorbeeld de suggestie dat het niet schudden van handen botst met algemene fatsoensnormen. En welke maatstaven hanteert de rechter om het gewicht van diverse belangen te bepalen? Volgens Holtmaat is het in elk geval onmogelijk 'zuiver' juridisch te blijven bij de vorming van een waardeoordeel (2004: 11).

Een illustratie bij bovengenoemde is de al besproken zaak-Dahlab tegen Zwitserland waarin het Europese Hof veel waarde hechtte aan de erkenning van gelijke behandeling tussen mannen en vrouwen. De aanleiding voor de zaak was echter 
de afweging tussen het belang van neutraal onderwijs voor kinderen en de vrijheid van godsdienst van de docente. In deze zaak valt vooral op dat het Hof maar beperkt aan belangenafweging toekomt. Zo besteedde het Hof geen enkele aandacht aan de persoonlijke opvattingen van de vrouw en de vraag of deze specifieke vrouw ondanks haar hoofddoek niet toch respect aan kinderen zou kunnen bijbrengen. Het Hof diskwalificeert volgens Loenen (2006a: 308) dan ook het dragen van een hoofddoek, omdat die per definitie in strijd met seksegelijkheid en tolerantie wordt geacht. Daarmee verleent het Hof eenvoudig slechts één betekenis aan het dragen van een hoofddoek, daarmee voorbijgaand aan (Duits) onderzoek waaruit blijkt dat veel jonge vrouwen uit andere overwegingen dan een dwingende eis van de Koran een hoofddoek dragen.

In de besproken jurisprudentie werd bovendien duidelijk hoezeer verschillende perspectieven en referentiekaders - zoals van het Europese Hof en de CGB - tot uiteenlopende argumentaties en rechtsbescherming leiden. Zo valt een vrij helder perspectief in de oordelenpraktijk van de CGB te achterhalen. Het uitgangspunt van de CGB is: 'het bieden van ruimte voor pluriformiteit en eigenheid (zijn) een wezenlijk aspect van het recht op gelijke behandeling. De menselijke waardigheid beschermen, achterstelling van verschillende mensen tegengaan en tolerantie en participatie van personen die "anders" zijn bevorderen, zijn onlosmakelijk met elkaar verbonden. Mensen moeten de ruimte hebben om in vrijheid eigen keuzes te maken en naar eigen inzicht invulling te geven aan het leven, zonder daarbij te worden belemmerd door (voor)oordelen op grond van kenmerken die onlosmakelijk verbonden zijn met hun innerlijke en uiterlijke identiteit' (2005: 17). De CGB is sterk gericht op het bijdragen aan een praktijk waarin mensen zoveel mogelijk kunnen participeren, wat ook blijkt uit de keuze om neutraliteit expliciet door religieus pluralisme vorm te willen geven. Bovendien gaat de Commissie ver in het beoordelen of voor maatregelen die tot ongelijke behandeling leiden, geen minder vergaande alternatieven bestaan (Gerards 2002: 620621). Wanneer de CGB bepaalt of een bepaalde maatregel noodzakelijk is, houdt ze rekening met onderzoek, verklaringen van getuigen-deskundigen en algemene feiten en omstandigheden. De Commissie beoordeelt bijna altijd inhoudelijk het doel en de noodzaak van een maatregel om dat doel te bereiken, terwijl de (Europese) rechter daarin veel terughoudender is (Gerards 2002: 634). Het perspectief van de CGB verklaart mede het feit dat en de mate waarin haar oordelen afwijken van bijvoorbeeld het Europese Hof, uiteraard voor zover het enigszins vergelijkbare kwesties betreft. ${ }^{\circ}$ Overigens kan de mate waarin de Commissie zoekt naar accommodatie en 'compromissen', veel meer dan de Europese rechter doet, ook worden toegeschreven aan het vaak praktischer karakter van de zaken waarover zij oordeelt. Bij de vraag of een politieke partij verboden kan worden valt minder te accommoderen dan bij een geschil op de werkvloer.

\subsection{SLOTREFLECTIE}

Veel botsingen rond religie laten zich verklaren door de scherpere manifestatie van godsdienst en van het persoonlijke in het publieke domein in een periode 
waarin de horizontale werking van grondrechten sterk is uitgebreid. In het publieke debat rijzen daarbij twijfels over de geschiktheid van de rechter bij het oordelen over geschillen rond het moeilijk te definiëren fenomeen religie.

De wens naar alternatieven voor de rechter laat zich deels begrijpen uit de context van de in deze bundel beschreven ontwikkeling van secularisatie. De Amerikaanse jurist en theoloog W.F. Sullivan zegt hierover - met instemming James Beckford citerend - dat het de ironie van de secularisatie is dat religie van iedereen wordt, met allerlei opvattingen gecombineerd kan worden en vooral 'gedereguleerd' wordt (1994: 26). De problemen die dat voor de rechtspraktijk oplevert zijn in Amerika vergelijkbaar met Nederland: de identificatie van godsdienst wordt steeds lastiger. Volgens Sullivan is het recht van de vrijheid van godsdienst in die zin problematisch dat het recht in de praktijk haast onmogelijk godsdienst kan beschermen. Godsdienst kan weliswaar de moeite van het beschermen waard zijn, maar het recht - bij uitstek een talige aangelegenheid neigt ertoe eerder in leerstellingen vastgelegde (orthodoxe) religie te beschermen dan levende, 'gedereguleerde' religie. Door definitieproblemen is het immers juist de grillige religieuze praktijk die sneller bescherming ontbeert (2006: 10). Ook op een ander niveau botsen recht en religie, wanneer recht wordt opgevat als de opvolger van religie waar het gaat om een gemeenschappelijke moraal (1994: 37). Volgens Sullivan wringen recht en religie in die zin dat het recht ruimte creëert voor religie (door grondrechten) om zich potentieel weer aan dat recht (in wetgeving en gewoonterecht vastgelegde moraal) te onttrekken (zie ook Samkalden 2006). Sullivans beschouwing wijst op de in de rechtspraak maar ook in het publieke debat steeds oplevende vraag hoe, maar zeker ook door wie, religie geïdentificeerd mag worden. Dat is ook te herkennen in de alternatieven voor de conflictbeslechting door de rechter, zij het dat die vaak meer gericht zijn op het grondig beïnvloeden van de belangenafweging van de rechter dan op het geheel weghouden van de conflictbeslechting bij de rechter. Zo zijn er voorstellen om met nieuwe wetgeving bepaald religieus gedrag expliciet te verbieden - of om kritiek op religie expliciet toe te staan - waarmee door de wetgever al een afweging tussen belangen wordt gemaakt: dit geldt bijvoorbeeld het nu door de Tweede Kamer op aanvaardbaarheid onderzochte algemene burkaverbod. Alternatieven die de afwegingsruimte van de rechter sterker beïnvloeden betreffen het instellen van een hiërarchie tussen grondrechten, met de vrijheid van meningsuiting of het non-discriminatieartikel op de eerste plaats of zelfs afschaffing van de vrijheid van godsdienst.

Hieronder ga ik kort in op deze alternatieven, te beginnen bij de laatste. De afschaffing van de vrijheid van godsdienst zou een radicale oplossing zijn, die echter niet op voorhand moet worden afgewezen gezien de fundamentele transformatie van de manifestatie van religie in de samenleving (zie Kronjee en Lampert in deze bundel). Deze oplossing zou zowel betrekking hebben op de lastige kwestie van de identificatie van godsdienst als op de belangenafweging: godsdienst wordt dan immers niet meer als een potentieel te beschermen belang meegewogen. Identificatieproblemen over bijvoorbeeld hoe en waar de mense- 
lijke waardigheid en daarbij wederzijds respect precies in het geding zijn, zoals in de vorige paragraaf besproken, komen daarvoor mogelijk in de plaats. Een interessant bezwaar tegen dit alternatief is gelegen in de eis van neutraliteit van de staat (samenhangend met het beginsel van de scheiding tussen kerk en staat) dat wordt afgeleid van of zelfs uitgedrukt met behulp van het begrip godsdienst. Hoe moet de staat 'neutraal' zijn als het begrip godsdienst zelf onduidelijk is geworden? Vraagt dat ook niet om herformulering van het domein en de waarden waartoe de overheid afstand moet bewaren? Om de ongelijkheid tussen religieuzen en niet-religieuzen op te heffen, zonder af te doen aan de bescherming van burgers tegen dominantie van een meerderheid (inclusief de staat) ligt het dan nog meer voor de hand het oude grondwetsartikel te 'hervormen' tot een artikel waarin fundamentele opvattingen over de betekenis en wenselijke inrichting van het leven beschermd worden. Van de huidige vrijheid van godsdienst en levensovertuiging zou in elk geval de vrijheid van levensovertuiging gehandhaafd moeten blijven, afgezien van de vraag welke identificatieproblemen dat met zich mee kan brengen. Op die manier kan de grondwet ook in dit opzicht blijvend bescherming bieden tegen de wetgever zelf. Burgers zijn door de vrijheid van godsdienst immers ook expliciet beschermd tegen het opleggen van een godsdienst door anderen, inclusief de overheid. Dat is mogelijk vergeten in de ophef die recentelijk ontstond na suggesties over een - theoretisch mogelijke - ontwikkeling van een politieke meerderheid voor een versie van de sharia in Nederland. Vrijheid van godsdienst beschermt overigens niet tegen religieuze moraal.

Het alternatief van het instellen van voorrang tussen grondrechten heeft recentelijk veel aandacht gekregen. Hoewel vaak is benadrukt dat een rangorde tussen grondrechten weinig zinvol zou zijn vanwege het Europees Verdrag voor de Rechten van de Mens (EVRM), dat niet in een dergelijke hiërarchie voorziet, blijkt het Europese Hof in de praktijk al wel degelijk vaak voorrang te verlenen aan het gelijkheidsbeginsel tussen man en vrouw en de rechten van kinderen (Thomassen 2004). ${ }^{51}$ Ook de Hoge Raad geeft al vaker bescherming aan de vrijheid van meningsuiting boven de vrijheid van godsdienst. In het Liberaal Manifest uit 2005 en opnieuw door Dales (2006) is voorgesteld het non-discriminatierecht (art. 1) bovenaan de hiërarchie te plaatsen, met niet te veranderen kenmerken bovenaan. Te veranderen kenmerken, waaronder godsdienst, zijn daaraan ondergeschikt. Een vaste volgorde tussen grondrechten vergroot echter niet zozeer de nauwkeurigheid van de belangenafweging door de rechter, maar vermijdt deze. De argumentatie van het EHRM waarbij een bepaalde hiërarchie impliciet wordt aangehouden laat vaak nu al te wensen over. Vaak ontbreekt een nadere rechtvaardiging van een vooronderstelling op basis waarvan een belang wordt vastgesteld. Dit gold bijvoorbeeld de betekenisverlening van het EHRM aan hoofddoeken als vrouwonderdrukkend. Principiëler is het bezwaar dat met een vaste voorrang wordt afgedaan aan de mogelijkheid van de rechter - waarvoor hij bij uitstek geschikt is - om in concrete gevallen de grondwet anders uit te leggen. Overigens is het goed mogelijk dat de rechter zich in de toekomst inderdaad meer zal laten leiden door de door Dales genoemde wenselijke voorrang van en binnen artikel 1. Maar juist op grond van argumenten zou van die 'vaste jurisprudentie' moeten kunnen worden afgeweken. 
Ten slotte besteed ik aandacht aan de mogelijkheid om de rechtsvorming door de rechters in de praktijk te verbeteren. Het niet optimaal functioneren van de rechter - en dat volgens Sullivan ook niet kunnen - in zaken rond religie doet niet af aan het blijvend grote belang van individuele en contextbepaalde belangenafweging. Maar het alternatief om de belangenafweging te laten zoals die nu is, is weinig aanlokkelijk gezien de in dit essay beschreven lastige kwesties. Het door de rechter expliciet of impliciet gehanteerde perspectief blijkt zeer relevant voor zijn eindoordeel, waardoor cruciaal is dat de rechter daar ten minste inzicht in geeft. Het belang van een nauwkeuriger argumentatie wordt breed gedeeld en heeft de aandacht van zowel rechters als wetenschappers. Gerards (2006) ontwikkelt in lijn met haar proefschrift over de rechterlijke toetsing aan het gelijkheidsbeginsel in haar onderzoeksprogramma een systematiek waarin de rechter nauwkeuriger belangen kan (af)wegen, zodanig dat een 'objectievere' en meer uniforme interpretatie kan ontstaan. In andere landen wordt een gezaghebbende grondrechten- en grondwetuitlegger (zoals het Bundesverfassungsgericht in Duitsland) onder meer gewaardeerd vanwege het grote belang van inzicht in de totstandkoming van een interpretatie, waardoor de acceptatie van moeilijke keuzes wordt vergroot (Heringa 2003: 288). Hoewel religie mogelijk een nog persoonlijker zaak wordt, kan de rechter met zijn belangenafweging daar in elk geval nauwkeuriger bij aansluiten dan de (grond)wetgever zou kunnen. In de strijd om de vraag wie mag definiëren wat onder religie moet worden verstaan, kan de rechter daarin bemiddelen. Dit is niet alleen van groot belang voor de aanvaardbaarheid van een oordeel, maar juist ook voor de publieke discussie. Rechtspraak kan immers als onderdeel van de publieke discussie worden opgevat. De rechter kan met nauwkeurige argumentatie het debat verrijken, verdiepen en mogelijk nuanceren, omdat helder wordt hoe in concrete gevallen onder precies welke voorwaarden welk belang het zwaarst weegt. 


\section{NOTEN}

Voor dit essay zijn gesprekken gevoerd met mevrouw prof. mr. T. Loenen en enkele (oud)leden van de CGB en de rechterlijke macht.

Raes spreekt zelfs van de tirannie van het persoonlijke, geciteerd in Pessers (2003: 15).

Dit valt te illustreren met de waarneming van de CGB dat sommige werkgevers zich in één keer van allerlei problemen willen ontdoen door richtlijnen voor 'neutraal' werknemersbeleid in te voeren en elke verwijzing naar godsdienst uit hun bedrijf te weren. Volgens de CGB leidt neutraliteit die alleen geloofsovertuigingen uitsluit, echter tot onderscheid tussen mensen die wel of geen geloofsovertuiging hebben (CGB 2005). Ook het feit dat na de aanslagen in de vs van 11 september 2001 moslims vaker klachten indienden bij de CGB naar aanleiding van grievende opmerkingen op de werkvloer, illustreert de hiergenoemde ontwikkeling.

4 De Zeister advocaat Steijnen kondigde in de periode van de cartoonkwestie namens een zestal grote moslimorganisaties en een groep particulieren aan systematisch klachten in te zullen dienen tegen alle Kamerleden, hoofdredacteuren en journalisten die zouden aanzetten tot haat en discriminatie van moslims, juist naar aanleiding van de uitspraak dat moslims maar naar de rechter moeten stappen als ze boos zijn over de cartoons. De advocaat diende in elk geval een klacht in bij het Amsterdamse OM in tegen Wilders en Broertjes, de hoofdredacteur van de Volkskrant (Algemeen Dagblad, 22 februari 2006). Nota Grondrechten in een pluriforme samenleving (2004) en Handelingen TK 50 en 52, 22 en 24 februari 2005.

6 In haar boek Geloof in het geding, juridische grenzen van religieus pluralisme in het perspectief van mensenrechten bespreekt $\mathrm{T}$. Loenen de belangrijkste recente jurisprudentie van de rechter, de CGB en het EHRM inzake godsdienst. Het boek geeft een overzicht van wat de burger van de rechter kan verwachten bij het belijden dan wel bestrijden van godsdienst. Wat onbesproken blijft in dit essay, maar wel van belang voor de context, is de discussie over het mogelijk honoreren van eigen religieus of cultureel bepaald familie- of erfrecht. In de (strafrechts)praktijk gaat het vaak om de vraag of een cultureel verweer kan leiden tot het aannemen van verzachtende omstandigheden bij de beoordeling van een misdrijf.

$8 \quad$ Was het verspreiden van een aankondiging van een lezing bij Jehova's getuigen beschermd door de vrijheid van drukpers of door de vrijheid van godsdienst? Deze vraag speelde in 1951 (zie Van der Hoeven 1983: 184).

9 Sommigen spraken daarom over de terugtred van de grondwetgever, omdat er veel aan de beoordeling van de rechter (en de gewone wetgever) wordt overgelaten (Akkermans 1993: 175). Onder invloed van bepalingen in internationale verdragen over gelijke behandeling van met name vrouwen en door inzet van (ook buitenlandse) mensenrechtenorganisaties, heeft dit zeker ook consequenties gehad voor de rechtsverhoudingen binnen Nederland. Zo leidde de toepassing van het 'recht op respect voor 
gezinsleven' uit het EVRM in Nederland ertoe dat niet gehuwde biologische en juridische vaders een sterkere positie kregen ten opzichte van hun kinderen (in niet-huwelijkse relaties). Ook de gelijkstelling van gehuwde vrouwen en kostwinners en tussen weduwen en weduwnaars was een gevolg van de toetsing van Nederlandse regelingen door de Nederlandse rechter aan internationale verdragen (Loenen 2006). Instellingen kunnen de CGB ook verzoeken om een oordeel omtrent eigen handelen. De CGB brengt ook (on)gevraagd adviezen uit aan regering en Tweede Kamer. De CGB oordeelt niet over eenzijdig overheidshandelen. Het betreft hier strikt genomen niet alleen jurisprudentie van het Hof, maar ook de niet-bindende oordelen van de Europese Commissie voor de Rechten van de Mens (ECRM) die tot 1998 klachten van individuen behandelde en kon doorverwijzen naar het Hof (Loenen 2006: 17).

Dit geldt niet voor kennisoverdracht in tegenstelling tot overdracht van bepaalde leer of leefwijze (Loenen 2006: 36). Zie Labuschange 1994: 81. Van Dijk en Van Hoof stellen dat burgers ook niet onderworpen zouden mogen worden aan een behandeling die is gericht op het wijzigen van een denkproces en dat ook wijziging van godsdienst op geen enkele wijze mag zijn gesanctioneerd (in Labuschange 1994: 80). ECRM 12 maart 1981, Ahmed t. het Verenigd Koninkrijk. ECRM 12 oktober 1978, Arrowsmith t. Verenigd Koninkrijk. Labuschange merkt op dat pacifisme internationaal wordt erkend als overtuiging en nationaal als levensovertuiging (1994:49). Volgens de ECRM waren de gewraakte folders van de vrouw overigens te weinig duidelijk pacifistisch om bescherming onder de vrijheid van godsdienst en levensovertuiging te genieten (Vermeulen 2007). EHRM 18 december 1996, Valsamis t. Griekenland en Estratiou t. Griekenland. ECRM 3 december 1996, Konttinen t. Finland. ECRM 2 oktober 2001, Pichon en Sajouw t. Frankrijk. EHRM 27 april 1999, Martins Casimiro en Cerveira Ferreira t. Luxemburg. ECRM 13 mei 1982, Zeven Individuen t. Zweden. EHRM 15 februari 2001, Dahlab t. Zwitserland. EHRM 10 november 2005, Sahin t. Turkije. EHRM 31 juli 2001, Refah Partisi t. Turkije. EHRM 20 september 1994, Otto-Preminger-instituut t. Oostenrijk. Zie voor uitgebreide overzichten van de jurisprudentie Labuschange (1994), Vermeulen (2005) en Loenen (2006).

In tegenstelling tot de CGB en het EHRM is de Nederlandse rechter bovendien functioneel en geografisch verspreid.

De zaken voor de Nederlandse rechter betreffen ook een keur aan conflicten over onder meer discriminatie en belediging met godsdienst als bron en doelwit, godslastering, godsdienstoefening op openbare plaatsen (processies, evangelisatie, gebedsoproepen en kerkklokken), subsidieverlening van instellingen op godsdienstige of levensbeschouwelijke grondslag, erkenning van richtingen in het bijzonder onderwijs, toelating leerlingen en bekostiging leerlingenvervoer naar bijzondere scholen, vragen over familierecht waaronder de erkenning van buitenslands gesloten huwelijken en de grenzen van de ouderlijke vrijheid om 
naar eigen godsdienst op te voeden en voor kinderen te beslissen, rechtspersonen- en kerkrecht, vluchtelingen- en asielrecht, met name vragen over bescherming van om godsdienst gevluchte asielzoekers, statusverlening aan en arbeidspositie van godsdienstleraren uit het buitenland, ruimtelijke ordening en bestemmingsplannen, bescherming van 'heilige plaatsen' als monument, politiek-religieuze besluiten van gemeenten, gewetensbezwaren in de verhouding tussen overheid en burger (leger, sociale verzekeringen). Hierover speelden twee zaken: HR, NJ 1987, 173 en HR, NJ 1989 BNB 1990, 161. HR 15 februari 1957.

Dit gaat volgens Galenkamp (2005) ook weer zo ver dat er sprake is van een dogma (ook een religieuze term) waardoor de rechter steeds moeilijker uit de voeten kan. Daarentegen neemt De Winter (2006:3) toch diverse uitspraken waar, waarbij de rechter zich kennelijk als 'supertheoloog' manifesteert door toch uit te spreken dat bepaalde gewetensbezwaren niet te zwaar gewogen moeten worden. HR 13 april 1960, NJ 1960, 436. Rechtbank Zwolle, 10 oktober 2003, NJB 2003,31.

De rechter kan haar gezichtsuitdrukking overigens ook niet waarnemen als haar advocaat haar vertegenwoordigt.

Art. 7 van de grondwet beschrijft het recht op de vrijheid van meningsuiting en een verbod op censuur: niemand heeft voorafgaande aan publicaties verlof nodig om gedachten en/of gevoelens te openbaren. In het EVRM worden meer mogelijke beperkingen van het recht op vrijheid van meningsuiting genoemd, hoewel de jurisprudentie veel ruimhartiger is. 'De vrijheid van meningsuiting eindigt (formeel) waar het strafrecht geschonden wordt' (Nieuwboer 2002: 872) .

36 Zie bijvoorbeeld Ellian (2003) of Dommering (2003).

37 Nieuwenhuis (2003) constateert dat de Hoge Raad uitspraken van de Goerees over joden aanvaardde vanwege de referentie naar de Bijbel. Dat gold niet voor uitspraken over een verband tussen homoseksualiteit en aids. De Hoge Raad stelde dat de onjuistheid daarvan wetenschappelijk was bewezen. Nieuwenhuis concludeert daaruit dat, wanneer afgeweken wordt van de traditionele geloofswaarheden, geloofsuitingen aan de wetenschap getoetst mogen worden. HR 14 januari 2003, NJ 2003, 261, met noot Mevis.

39 Andersom is bij de vraag of sprake is van godslastering de intentie van de persoon van belang, terwijl bij belediging van een groep de intentie geen rol speelt (Berger 2006).

40 Rechtbank Amsterdam, 2 augustus 2001, KG o1/1331 (LJN: AB306).

41 Alle oordelen van de CGB zijn terug te vinden in de jaarlijkse oordelenbundels van de CGB en op www.cgb.nl. Eind augustus 2006 waren op deze site ongeveer 145 oordelen te vinden waarbij de grond godsdienst in het geding was geweest. Dit gold volgens de CGB ook in de zaak waar een islamitische stagiaire (verpleegkundige) problemen kreeg, omdat ze bewoners van een verpleeghuis alcohol moest schenken. De CGB constateert dat het een feit van algemene bekendheid is dat de islam het gebruik van alcohol verbiedt. Het feit dat de leerlinge andere voorschriften niet naleefde, deed volgens de CGB niet af aan het feit dat ze voor deze handeling wel beroep kon doen op de grond godsdienst van de AWGB (oordeel 2000/75). 
Zoals zingen van religieuze liederen op het werk of het verzoek om een schoollokaal voor gebed te kunnen gebruiken.

Volgens Vermeulen en Zoethout (2003) wijkt de CGB hier af van de rechter. Een individueel gewetensmotief is volgens hen niet nodig om een beroep te doen op de vrijheid van godsdienst.

De oplossing dat vrouwen die weigeren mannen een hand te geven ook ervoor kunnen kiezen dan maar beide geslachten geen hand te schudden wordt wel 'levelling down' genoemd, omdat aanvaard zou worden dat 'even slecht ook gelijk is'.

6 Uit het feit dat weinig van de CGB gebruik wordt gemaakt in dergelijke gevallen maakt de CGB op dat betrokkenen de oplossing van het probleem niet in de juridische sfeer zoeken. Overigens betekent dit geenszins dat discriminatoire bejegening van homoseksuelen daarmee zou zijn afgenomen.

Inmiddels adviseerde de Commissie in een oordeel (2006/30) over het kledingbeleid bij de politie aan het ministerie van Justitie om met de Commissie te komen praten alvorens een kledingbeleid daadwerkelijk vast te stellen. In het oordeel over een studente die solliciteert naar de functie van waarnemend griffier (2001/53) stelt de commissie dat gezien de ontwikkelingen de behoefte aan een kledingbeleid betrekkelijk is.

Overigens is het de vraag of met de afschaffing van het grondwetsartikel van de vrijheid van godsdienst ook bepaalde uitingen beschermd blijven die nu over het algemeen wel als beschermwaardig worden geacht (Vermeulen 2007).

In de zaak Kokkinakis tegen Griekenland erkende het Europese Hof het recht om anderen te proberen te bekeren - waarmee het is beschermd onder de vrijheid van godsdienst - mits niet de vrijheid van godsdienst van anderen wordt verstoord, EHRM 25 mei 1993, Kokkinakis t. Griekenland.

O Vanuit haar visie op de AWGB, houding bij oordelen en proactieve taak komt de CGB bovendien tot expliciete aanbevelingen aan de wetgever over wetswijzigingen. De CGB spreekt zich bijvoorbeeld duidelijk uit voor bepaalde gewenste (maatschappelijke) ontwikkelingen en zoekt naar mogelijkheden om haar eigen bevoegdheden en de wetgeving op grond waarvan zij oordeelt zodanig te veranderen dat ze zelf aan die ontwikkelingen kan bijdragen. Heel duidelijk is dit waarneembaar waar de CGB zich uitspreekt over het zodanig wijzigen van de wet dat zij ook de bevoegdheid krijgt om intern verenigingsrecht te toetsen, zodat bijvoorbeeld ook een zaak tegen de SGP over haar toelatingsbeleid in behandeling zou kunnen worden genomen.

Overigens neemt dit niet weg dat het kabinet in de Nota Grondrechten (2004) waarneemt dat er als gevolg van de jurisprudentie van de rechter een zekere 'voorrangsregeling van grondrechten' valt waar te nemen: zolang uitlatingen beogen een bijdrage aan het publieke debat te zijn, is er 'betrekkelijk weinig ruimte voor een strafrechtelijke veroordeling'. De ruimte om de vrijheid van meningsuiting in te beperken is zeer gering en zal daarom in een afweging tussen grondrechten mogelijk vaak een zwaarder gewicht krijgen toegekend. 


\section{LITERATUUR}

Akkermans, P.W.C., C.J. Bax, L.F.M. Verhey (1993) Grondrechten en grondrechtsbescherming in Nederland, Heerlen: Wolters-Noordhoff.

Berger, M. (2006) 'Religieuze grenzen aan de vrijheid van meningsuiting, de Deense spotprenten voor de Nederlandse rechter', NJCM-Bulletin, jrg. 31, 5: 664-675.

Bijsterveld, S.C. (2003) 'De controversiële godsdienst- en meningsuiting', Ars Aequi 52, 7/8: 533-540.

Boer, den R. (2004) ‘Een open doekje voor de Commissie Gelijke Behandeling?’ blz. 149161 in: R. Holtmaat (red.), Gelijkheid en (andere) grondrechten, Deventer: Kluwer.

Blois, de M. (2004) 'Gelijkheid en grondrechten: internationaal-rechtelijk kader' blz. 187203 in: R. Holtmaat (red.), Gelijkheid en (andere) grondrechten, Deventer: Kluwer.

Cohen, J. Multatulilezing 2005.

Commissie Gelijke Behandeling (2005) Het verschil gemaakt, evaluatie AWG B en werkzaamheden CG B 1999-2004, Utrecht.

Commissie Gelijke Behandeling (2006) Gelijke Behandeling: oordelen en commentaar 2005, Nijmegen: Wolf Legal Publishers.

Dales, G. (2006) 'Artikel $\mathrm{I}$ is terecht artikel 1 maar moet wel anders luiden', in: W.P.S. Bierens, C.L.C. Richert en P.G.C. van Schie (red.), Grondrechten gewogen, enkele constitutionele waarden in het actuele politieke debat, Den Haag: Prof. mr. B.M. Telderstichting.

Dommering, E. (2006) 'De extreem afwijkende mening' (boekbespreking), Mediaforum, 6:162-172.

Dommering, E.J. (2003) ‘Tolerantie, de Vrijheid van Meningsuiting en de Islam', blz. 89-108 in: A.W. Hins en A.J. Nieuwenhuis (red.), Van ontvanger naar zender, Opstellen aangeboden aan prof. mr. J.M. de Meij, Amsterdam.

Ellian, A. (2003) 'Van Janmaat tot El Moumni, de discriminatie tussen gewone en heilige meningen', Justitiële Verkenningen, jrg. 29, 3: 26-36.

Galenkamp, M. (2005) 'Religieuze overtuigingen en het discriminatieverbod. Enkele bedenkingen bij het leerstuk van interpretatieve terughoudendheid', Trema, mei 2005 (Themanummer 'Ieder z'n recht, magistraat in een pluriforme samenleving'), 251-256.

Gerards, J.H. (2006) Belangenafweging bij rechterlijke toetsing aan fundamentele rechten, oratie Leiden.

Gerards, J. H. Rechterlijke toetsing aan het gelijkheidsbeginsel (dissertatie Maastricht), SDU Uitgevers: Den Haag.

Heringa, A. (2003) 'Grondrechten in de Grondwet. Een evaluatie na twintig jaar in het licht van het toetsingsrecht en verdragsontwikkelingen', Grondwet-special NJCM-bulletin, 276-288.

Hoeven, J. van der (1983) ‘Botsing van Grondrechten', Mededelingen der Koninklijke Nederlandse Akademie van Wetenschappen, afd. Letterkunde, Nieuwe Reeks, deel 46, 7: 183-204, Amsterdam: BV Noord-Hollandse Uitgevers Maatschappij.

Holtmaat, R. 'Gelijkheid en (andere) grondrechten, naar een nieuw evenwicht tussen vrijheid, gelijkheid en solidariteit', blz. 3-22 in: R. Holtmaat (red.), Gelijkheid en (andere) grondrechten, Deventer: Kluwer. 
Labuschagne, B. C. (1994) Godsdienstvrijheid en niet-gevestigde religies, een grondrechtelijk-rechtsfilosofische studie naar de betekenis en grenzen van religieuze tolerantie, (Diss. Groningen) Groningen: Wolters-Noordhoff.

Loenen, T (2004) 'Naar een ander toetsingskader voor de AWGB?', blz. 138-148 in:

R. Holtmaat (red.), Gelijkheid en (andere) grondrechten, Deventer: Kluwer.

Loenen, T. (2003) 'Het gelijkheidsbeginsel en andere grondrechten in de multiculturele samenleving: ontwikkelingen sinds 1983', Grondwet-special NJCM-bulletin, 259-276.

Loenen, T. (2006) Geloof in het geding, juridische grenzen van religieus pluralisme in het perspectiefvan mensenrechten (serie Infoplus Minderheden), Den Haag: Sdu Uitgevers.

Loenen, T. (2006a) 'Het EHRM en de grenzen van religieus pluralisme' NJB, afl. 2006/o6, jrg. 81: 304-310.

Loenen, T. en A. Terlouw (2006) 'De ondraaglijke zwaarte van de hoofddoek: het EVRM bevestigt dat een hoofddoekverbod aan de Turkse universiteiten geoorloofd is', NJCM-bulletin, Nederlands Tijdschrift voor Mensenrechten, 31 (2006), 2 (maart), 213-233.

Nieuwboer, J.W. (2002) 'Vrijheid van meningsuiting vs. discriminatieverboden', A A (Ars Aequi) 51, 12, 868-873.

Nieuwenhuis, A. J. 'Godsdienstvrijheid en bijdragen aan het maatschappelijk debat', NJCM-bulletin, 154-166.

Nota Grondrechten in een pluriforme samenleving (2004) Den Haag.

Pessers, D. (2003) Big Mother, Over de personalisering van de publieke sfeer (oratie vu Amsterdam), Den Haag: Boom Juridische Uitgevers.

Samkalden, C. (2005) 'Pluriforme gedachten over de nota grondrechten', NJCM-Bulletin, jrg. 30 1: 44-59.

Schie, P. van (2006) 'Liberalen: tijd voor afschaffing religieuze privileges', Christen Democratische Verkenningen, Boom Tijdschriften, 264-270.

Sullivan, W. F. (2006) The Impossibility of Religious Freedom, Princeton University Press: Princeton and Oxford.

Sullivan, W. F. (1994) Paying the words extra, Religious Discours in the Supreme Court of the United States, Harvard University Press: Cambridge, Massachusetts.

Thomassen, W. (2004) 'Samenleven met verschillen', blz. 121-137 in: R. Holtmaat (red.), Gelijkheid en (andere) grondrechten, Deventer: Kluwer.

Vermeulen, B. (2005) 'Religieus pluralisme als uitdaging aan de "neutrale” rechter', Trema, mei (Themanummer 'Ieder z'n recht, magistraat in een pluriforme samenleving') 243-250.

Vermeulen, B.P. (2007) The freedom of religion in Article 9 of the European Convention on Human Rights: historical roots and today's dilemma's, Leiden.

Vermeulen, B.P. en C.M. Zoethout (2003) 'Godsdienst, levensovertuiging en politieke gezindheid’, blz. 71-76, in: D.J.B. de Wolff e.a. (red.), Gelijke behandeling: oordelen en commentaar 2002 (oordelenbundel CGB) Deventer: Kluwer.

Winter, R. E. 'Godsdienst als alibi', NJB, 5 januari 1996, 1: 1-8.

Zeeman, M. 'De nieuwe wereld vraagt om nieuwe omgangsvormen', de Volkskrant, 11 februari 2006. 


\section{OVER DE AUTEURS}

Dr. T. Bernts is directeur van het Kaski in Nijmegen. Hij is als adviseur verbonden aan diverse kerkelijke en interkerkelijke commissies.

Dr. E.P.N.M. Borgman is theoloog en directeur van het Heyendaal Instituut in Nijmegen.

Prof. dr. G.J.M. van den Brink is hoogleraar Maatschappelijke Bestuurskunde aan de Tilburgse School voor Politiek en Bestuur van de Universiteit van Tilburg en lector Gemeenschappelijke Veiligheidskunde aan de politieacacademie in Apeldoorn.

Dr. mr. S.C. van Bijsterveld is als universitair hoofddocent Europees en Internationaal Publiekrecht verbonden aan de Universiteit van Tilburg.

Prof. dr. P. Dekker is hoofd van de onderzoeksgroep Participatie en Bestuur van het Sociaal en Cultureel Planbureau en deeltijd-hoogleraar Civil Society aan de Universiteit van Tilburg.

Prof.dr. W.B.H.J. van de Donk is voorzitter van de Wetenschappelijke Raad voor het Regeringsbeleid en deeltijd-hoogleraar Maatschappelijke Bestuurskunde aan de Tilburgse school voor Politiek en Bestuur, Faculteit der Rechtsgeleerdheid aan de Universiteit van Tilburg.

Dr. J.J.M. de Hart is als senior onderzoeker verbonden aan het Sociaal Cultureel Planbureau, daarnaast is hij associate member van het Leiden Institute for the Study of Religions.

Dr. H.Y.M. Jansen is als NWO-postdoc onderzoeker verbonden aan de afdeling wijsbegeerte van de Universiteit van Amsterdam.

Prof. dr. H. Joas is als hoogleraar (godsdienst-)sociologie verbonden aan het Max Webercollege van de Universiteit van Erfurt en aan de Universiteit van Chicago. Hij is lid van de Berlijn-Brandenburgse Academie der Wetenschappen.

Drs. G. de Jong is wetenschappelijk medewerker van het Kaski in Nijmegen.

Dr. A.P. Jonkers is als wetenschappelijk medewerker verbonden aan de Wetenschappelijke Raad voor het Regeringsbeleid.

Prof. dr. J.C. Kennedy is hoogleraar moderne geschiedenis aan de Vrije Universiteit in Amsterdam.

Dr. G.M.J.B. Koolen was tot zijn pensionering senior beleidsmedewerker van het Ministerie van Justitie. 
Dr. G.J. Kronjee is als wetenschappelijk medewerker verbonden aan de Wetenschappelijke Raad voor het Regeringsbeleid.

Prof. dr H.P. Kunneman is hoogleraar sociale en politieke theorie aan de Universiteit voor Humanistiek in Utrecht en tevens voorzitter van de Humanistische Alliantie.

Drs. M. Lampert is als hoofd van het Mentality team- en onderzoeksprogramma verbonden aan Motivaction International in Amsterdam.

Dr. R.J.J.M. Plum is als onderzoeker verbonden aan het Heyendaal Instituut in Nijmegen en als wetenschappelijk medewerker aan de Wetenschappelijke Raad voor het Regeringsbeleid.

Dr. J.B.A.M. Schilderman is als universitair hoofddocent empirische religiewetenschappen verbonden aan de Radboud Universiteit in Nijmegen.

Dr. M.G. Valenta is als wetenschappelijk medewerker verbonden aan de faculteit der Letteren van de Vrije Universiteit in Amsterdam.

Prof. mr. drs. B.P. Vermeulen is hoogleraar staats- en bestuursrecht inclusief onderwijsrecht aan de Vrije Universiteit in Amsterdam en hoogleraar onderwijsrecht aan de Radboud Universiteit Nijmegen. Vermeulen is tevens lid van de Onderwijsraad.

Prof. dr. H. de Vries is deeltijd hoogleraar aan de Universiteit van Amsterdam en hoogleraar Humanities \& Philosophy aan de Zanvyl Krieger School of Arts and Sciences van de Johns Hopkins University in Baltimore.

Prof. dr. H. Vroom is hoogleraar Godgeleerdheid aan de Vrije Universiteit in Amsterdam en voorzitter van de nationale raad voor religies.

Prof. dr. J.-P. Wils is hoogleraar theologische ethiek aan de Radboud universiteit in Nijmegen en directeur van het Centrum voor Ethiek.

Prof. dr. A. Wolfe is hoogleraar politicologie en sociologie aan het Boston College. Hij is tevens directeur van het 'Boisi Center for Religion and American Public Life' van het Boston College in Massachusetts. Wolfe maakt deel uit van de task force 'Religie en Democratie in the United States' van de 'American Political Science Association'.

Drs. H. Yar is directeur van IHSAN, het Islamitisch Instituut voor Maatschappelijke Activering in 's-Hertogenbosch. Hij is tevens als docent verbonden aan de opleiding theologie van de School of Education aan de Hogeschool InHolland in Amsterdam/Diemen. 


\section{RAPPORTEN AAN DE REGERING}

\section{Eerste raadsperiode (1972-1977)}

1 Europese Unie

2 Structuur van de Nederlandse economie

3 Energiebeleid

Gebundeld in één publicatie (1974)

4 Milieubeleid (1974)

5 Bevolkingsgroei (1974)

6 De organisatie van het openbaar bestuur (1975)

7 Buitenlandse invloeden op Nederland: Internationale migratie (1976)

8 Buitenlandse invloeden op Nederland: Beschikbaarheid van wetenschappelijke en technische kennis (1976)

9 Commentaar op de Discussienota Sectorraden (1976)

10 Commentaar op de nota Contouren van een toekomstig onderwijsbestel (1976)

11 Overzicht externe adviesorganen van de centrale overheid (1976)

12 Externe adviesorganen van de centrale overheid (1976)

13 Maken wij er werk van? Verkenningen omtrent de verhouding tussen actieven en niet-actieven (1977)

14 Interne adviesorganen van de centrale overheid (1977)

15 De komende vijfentwintig jaar - Een toekomstverkenning voor Nederland (1977)

16 Over sociale ongelijkheid - Een beleidsgerichte probleemverkenning (1977)

Tweede raadsperiode (1978-1982)

Etnische minderheden (1979)

A. Rapport aan de Regering

B. Naar een algemeen etnisch minderhedenbeleid?

Plaats en toekomst van de Nederlandse industrie (1980)

Beleidsgerichte toekomstverkenning

Deel 1: Een poging tot uitlokking (1980)

Democratie en geweld. Probleemanalyse naar aanleiding van de gebeurtenissen in Amsterdam op 30 april 1980

Vernieuwingen in het arbeidsbestel (1981)

Herwaardering van welzijnsbeleid (1982)

Onder invloed van Duitsland. Een onderzoek naar gevoeligheid en kwetsbaarheid in de betrekkingen tussen Nederland en de Bondsrepubliek (1982)

Samenhangend mediabeleid (1982)

\section{Derde raadsperiode (1983-1987)}

Beleidsgerichte toekomstverkenning

Deel 2: Een verruiming van perspectief (1983)

Waarborgen voor zekerheid. Een nieuw stelsel van sociale zekerheid in hoofdlijnen (1985)

Basisvorming in het onderwijs (1986)

De onvoltooide Europese integratie (1986)

Ruimte voor groei. Kansen en bedreigingen voor de Nederlandse economie in de komende tien jaar (1987)

Op maat van het midden- en kleinbedrijf (1987)

Deel 1: Rapport aan de Regering

Deel 2: Pre-adviezen 


\section{Vierde raadsperiode (1988-1992)}

Activerend arbeidsmarktbeleid (1987)

Rechtshandhaving (1988)

Allochtonenbeleid (1989)

Van de stad en de rand (1990)

Technologie en overheid (1990)

De onderwijsverzorging in de toekomst (1991)

\section{Vijfde raadsperiode (1993-1997)}

Duurzame risico's. Een blijvend gegeven (1994)

Besluiten over grote projecten (1994)

47 Hoger onderwijs in fasen (1995)

De financiering van de Europese Gemeenschap. Een interimrapport (1987)

Overheid en toekomstonderzoek. Een inventarisatie (1988)

Een werkend perspectief. Arbeidsparticipatie in de jaren '90 (1990)

Milieubeleid. Strategie, instrumenten en handhaafbaarheid (1992)

Grond voor keuzen. Vier perspectieven voor de landelijke gebieden in de Europese Gemeenschap (1992)

Ouderen voor ouderen. Demografische ontwikkelingen en beleid (1993)

Belang en beleid. Naar een verantwoorde uitvoering van de werknemersverzekeringen (1994)

48 Stabiliteit en veiligheid in Europa. Het veranderende krachtenveld voor het buitenlands beleid (1995)

Orde in het binnenlands bestuur (1995)

$50 \quad$ Tweedeling in perspectief (1996)

51 Van verdelen naar verdienen. Afwegingen voor de sociale zekerheid in de 21e eeuw (1997)

52 Volksgezondheidszorg (1997)

53 Ruimtelijke-ontwikkelingspolitiek (1998)

54 Staat zonder land. Een verkenning van bestuurlijke gevolgen van informatie- en communicatietechnologie (1998)

\section{Zesde raadsperiode (1998-2002)}

Generatiebewust beleid (1999)

Doorgroei van arbeidsparticipatie (2000)

Ontwikkelingsbeleid en goed bestuur (2001)

59 Naar een Europabrede Unie (2001)

60 Nederland als immigratiesamenleving (2001)

61 Van oude en nieuwe kennis. De gevolgen van ICT voor het kennisbeleid (2002)

62 Duurzame ontwikkeling. Bestuurlijke voorwaarden voor een mobiliserend beleid (2002)

63 De toekomst van de nationale rechtsstaat (2002)

64 Beslissen over biotechnologie (2003)

65 Slagvaardigheid in de Europabrede Unie (2003)

66 Nederland handelsland. Het perspectief van de transactiekosten (2003)

67 Naar nieuwe wegen in het milieubeleid (2003) 


\section{Zevende raadsperiode (2003-2007)}

Waarden, normen en de last van het gedrag (2003)

De Europese Unie, Turkije en de islam (2004)

Bewijzen van goede dienstverlening (2004)

Focus op functies. Uitdagingen voor een toekomstbestendig mediabeleid (2005)

Vertrouwen in de buurt (2005)

Dynamiek in islamitisch activisme. Aanknopingspunten voor democratisering en mensenrechten (2006)

Klimaatstrategie - tussen ambitie en realisme (2006)

Lerende overheid. Een pleidooi voor probleemgerichte politiek (2006)

De verzorgingsstaat herwogen. Over verzorgen, verzekeren, verheffen en verbinden (2006)

Rapporten aan de Regering nrs $1 \mathrm{t} / \mathrm{m} 67$ en publicaties in de reeks Voorstudies en achtergronden zijn niet meer leverbaar. Alle studies van de WRR zijn beschikbaar via de website www.wrr.nl.

Rapporten aan de Regering nrs $68 \mathrm{t} / \mathrm{m} 76$ zijn verkrijgbaar in de boekhandel of via Amsterdam University Press, Prinsengracht 747-751, 1017 JX Amsterdam (www.aup.nl).

\section{WEBPUBLICATIES}

\section{Zevende raadsperiode (2003-2007)}

WP 01 Opvoeding, onderwijs en jeugdbeleid in het algemeen belang Ruimte voor goed bestuur: tussen prestatie, proces en principe Lessen uit corporate governance en maatschappelijk verantwoord ondernemen Regulering van het bestuur van maatschappelijke dienstverlening: eenheid in verscheidenheid Een schets van het Europese mediabeleid De regulering van media in internationaal perspectief Beleid inzake media, cultuur en kwaliteit: enkele overwegingen Geschiedenis van het Nederlands inhoudelijk mediabeleid Buurtinitiatieven en buurtbeleid in Nederland anno 2004: analyse van een veldonderzoek van 28 casussen

WP 10 Geestelijke gezondheid van adolescenten: een voorstudie

WP11 De transitie naar volwassenheid en de rol van het overheidsbeleid: een vergelijking van insitutionele arrangementen in Nederland, Zweden, Groot-Brittannië en Spanje

WP 12 Klassieke sharia en vernieuwing

WP 13 Sharia en nationaal recht in twaalf moslimlanden 


\section{VERKENNINGEN}

\section{Zevende raadsperiode (2003-2007)}

1 Jacques Pelkmans, Monika Sie Dhian Ho en Bas Limonard (red.) (2003) Nederland en de Europese grondwet

2 P.T. de Beer en C.J.M. Schuyt (red.) (2004) Bijdragen aan waarden en normen

3 G. van den Brink (2004) Schets van een beschavingsoffensief. Over normen, normaliteit en normalisatie in Nederland

4 E.R. Engelen en M. Sie Dhian Ho (red.) (2004) De staat van de democratie. Democratie voorbij de staat

5 P.A. van der Duin, C.A. Hazeu, P. Rademaker en I.J. Schoonenboom (red.) (2004) Vijfentwintig jaar later. De Toekomstverkenning van de WRR uit 1977 als leerproces

6 H. Dijstelbloem, P.L. Meurs en E.K. Schrijvers (red.) (2004) Maatschappelijke dienstverlening. Een onderzoek naar vijf sectoren

7 W.B.H.J. van de Donk, D.W.J. Broeders en F.J.P. Hoefnagel (red.) (2005) Trends in het medialandschap. Vier verkenningen

8 G. Engbersen, E. Snel en A. Weltevrede (2005) Sociale herovering in Amsterdam en Rotterdam. Eén verhaal over twee wijken

9 D.J. Wolfson (2005) Transactie als bestuurlijke vernieuwing. Op zoek naar samenhang in beleid en uitvoering

10 Nasr Abu Zayd (2006) Reformation of Islamic Thought. A Critical Historical Analysis

11 J.M. Otto (2006) Sharia en nationaal recht. Rechtssystemen in moslimlanden tussen traditie, politiek en rechtsstaat

12 P.L. Meurs, E.K. Schrijver en G.H. de Vries (red.) (2006) Leren van de praktijk. Gebruik van lokale kennis en ervaring voor beleid 


\section{Geloven in het publieke domein}

Het fenomeen religie mag zich recentelijk verheugen in een oplevende belangstelling, zowel in wetenschappelijke als maatschappelijke debatten. In het wetenschappelijke debat is de secularisatiethese ter discussie gesteld vanwege de 'terugkeer' van religie. Het in deze bundel gepresenteerde empirisch onderzoek laat zien dat het niet zozeer gaat om een heropleving van 'klassieke godsdienst', maar veeleer om een ingrijpende transformatie naar nieuwe vormen. Veelal is nog onduidelijk wat er precies aan de hand is, maar duidelijk is wel dat die veranderingen ook voor beleidsmakers en bestuurders in het publieke domein relevant zijn. In Geloven in het publieke domein presenteert de wRR een serie bijdragen van uiteenlopende auteurs over de transformatie van zowel religie als het publieke domein. Hiermee wordt beoogd een bijdrage te leveren aan het onderzoek naar de vraag of deze ontwikkelingen aanleiding zijn voor nieuwe oriëntatiekaders voor een overheid die zich in kwesties van religie en publiek domein tot op heden vooral moet verlaten op het principe van de scheiding van kerk en staat. Als normatief principe zal dat niet gauw ter discussie worden gesteld, maar het lijkt wel nuttig te onderzoeken of met de verwijzing naar dat beginsel de complexe relaties tussen religie en publiek domein adequaat in beeld zijn gebracht.

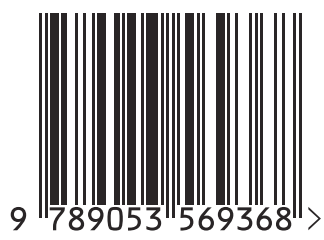

